


$$
\text { 응 }
$$






\section{HISTORY OF THE SAN FRANCISCO COMMITTEE OF VIGILANCE OF 1851}

A THESIS ACCEPTED IN PARTIAL SATISFACTION OF THE REQUIREMENTS FOR THE DEGREE OF DOCTOR OF PHILOSOPHY AT THE UNIVERSITY OF CALIFORNIA

MARY FLOYD WILLIAIIS 


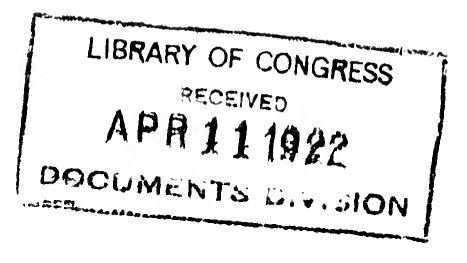




\title{
HISTORY OF THE SAN FRANCISCO COMMITTEE OF VIGILANCE OF 1851
}

\author{
$\mathrm{BY}$ \\ MARY FLOYD WILLIAMS, Ph.D.
}

University of California Publications in History Volume XII 


\section{9
$83 W_{12}$}

\section{UNIVERSITY OF CALIFORNIA PUBLICATIONS IN HISTORY}

Herbert Eugene Bolton, Editor

V01. 1. Studies in American History.

1. Colonial Opposition to Imperial Authority during the French and Indian

Wars, by Eugene Irving McCormac. Pp. 1-98.

2. The Viceroy of New Spain, by Donald E. Smith. Pp. 99-293.

3. The Beginnings of Spanish Settiement in the El Paso District, by Anne

E. Hughes. Pp. 295-392. In paper cover, \$2.75; cloth, \$3.00.

Index, pp. 393-406.

Vol. 2. A History of the Western Boundary of the Louisiana Purchase, 1819-1841, by Thomas Maitland Marshall. Pp. xdii + 266, 30 maps. December, 1914. In paper cover, $\$ 1.75$; cloth, $\$ 2.00$.

Vol 3. Texas in the Middle Eighteenth Century, by Herbert Eugene Bolton. Pp. $\mathrm{x}+501,11$ plates and map. December, 1915 . In paper cover, $\$ 3.25$; cloth, $\$ 3.50$.

Vol. 4. 1. The Influence of Anthropology on the Course of Political Science, by John Iinton Myres. Pp. 1-81. February, 1916. In paper cover, $\$ 0.75$.

2. The Reorganization of Spain by Augustus, by John James Van Nostrand, Jr. Pp. 83-154. October, 1916. In paper cover, $\$ 0.75$.

3. Prolegomena to History: The Relation of History to Literature, Philosophy, and Science, by Frederick J. Teggart. Pp. 155-292. August, 1916. In paper cover, $\$ 1.50$.

4. California: the Name, by Ruth Putnam, with the collaboration of Herbert I. Priestley, Ph.D., Assistant Professor of History, University of California. Pp. 293-365. One map. December, 1917. In paper cover, $\$ 0.75$.

Vol. 5. José de Gálvez, Visitor-General of New Spain, 1765-1771, by. Herbert Ingram Priestley. Pp. $x v+449,7$ plates and map. November, 1916. In paper cover, $\$ 2.75$; cloth, $\$ 3.00$.

Vol. 6. The Formation of the State of Oklahoma, 1803-1906, by Roy Gittinger. Pp. Xil $+256,5$ maps. November, 1917. In paper cover, $\$ 1.75$; cloth, $\$ 2.00$.

Vo1. 7. The Northwest Company, by Gordon Charles Davidson. Pp. 1-349, 5 maps. November, 1918. Cloth, $\$ 3.00$.

Vol. 8. Catalogue of Materials in the Archivo General de Indias for the History of the Pacific Coast and the American Southwest, by Charles E. Chapman. Pp. $\nabla+755$. January, 1919 . Cloth, $\$ 5.50$.

Vo1. 8. The Audiencia in the Spanish Colonies as Illustrated by the Audiencia of Manila (1583-1800), by Charles Henry Cunningham. Pp. $v+1 \times+463$. November, 1919.' Cloth, $\$ 4.00$.

Vo1. 10. The Constitutional History of the Louisiana Purchase, 1803-1812, by Everett S. Brown. Pp. xii + 248. April, 1920. Cloth, $\$ 2.50$.

Vol. 11. Official Explorations for Pacific Railroads, by George Leslie Albright. Pp. vii + 187. October, 1921. In paper cover, $\$ 1.50$.

Vol.12 History of the San Francisco Committee of Vigdlance of 1851, by Mary Floyd Williams. Pp. xii $+543,4$ plates. November, 1921. Cloth, $\$ 5.00$. 


\title{
UNIVERSITY OF CALIFORNIA PUBLICATIONS IN HISTORY
}

\author{
HERBERT E. BOLTON \\ EDITOR
}

VOLUME XII 


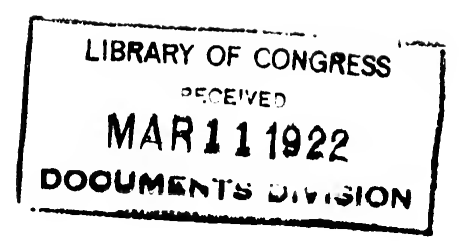




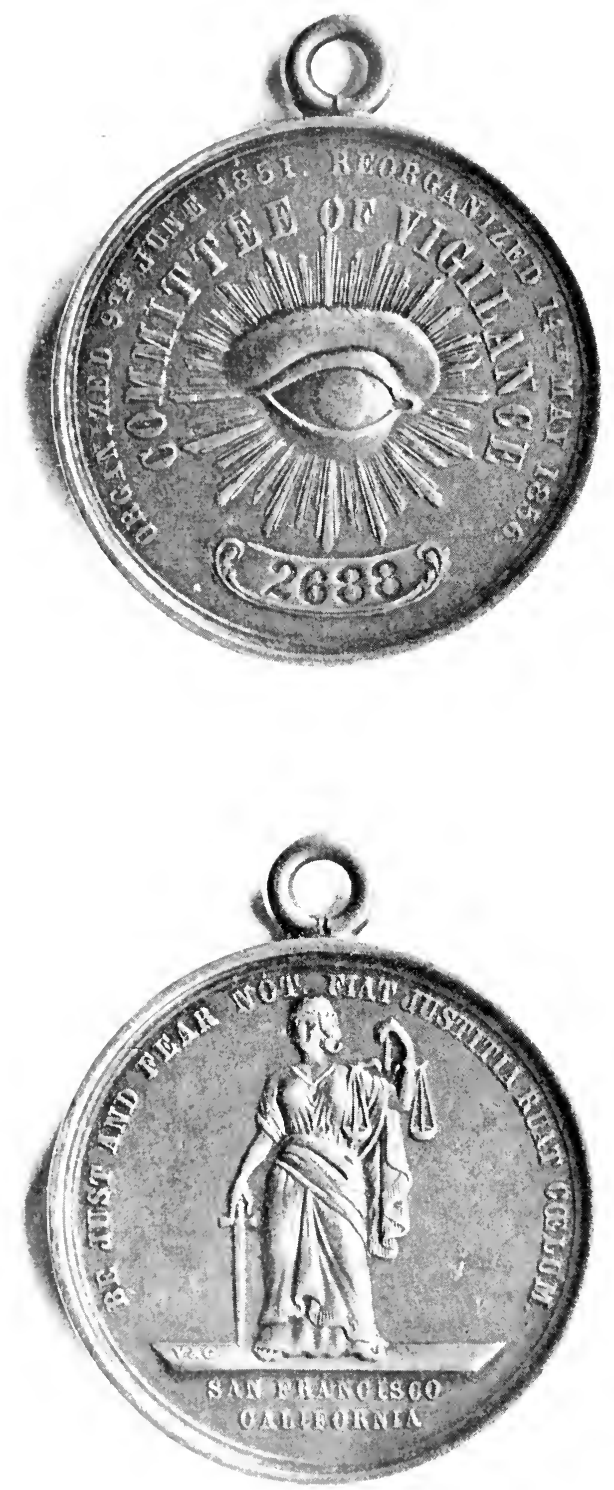

Merlal of the San Francisen ('ommittee of Vigilance of 18.56. "Organized 9th June 18.51. Reorganized 14th May, 18.56." "From the collection of Mr. Charles B. Turrill. 


\section{HISTORY OF THE SAN FRANCISCO COMMITTEE OF VIGILANCE OF 1851}

A STUDY OF SOCIAL CONTROL ON THE CALIFORNIA FRONTIER IN THE DAYS OF THE GOLD RUSH

BY

MARY FLOYD WILLIAMS, Ph.D.

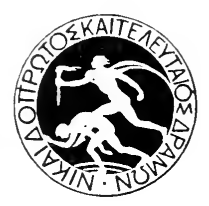

UNIVERSITY OF CALIFORNIA PRESS

BERKELEY, CALIFORNIA 
Copyrighted, I92I

BY

Mary Floyd Williams

All rights reserved 
TO THE MEMORY OF MY FATHER

\section{EDWARDS C. WILLIAMS}

A LiEUtenant IN STEVENSON'S REgIMENT

AND

A LOYAL CITIZEN OF CALIFORNIA

FROM 1947 TO 1913 



\section{CONTENTS}

Acknowledgments.

PAGES

$\mathrm{ix}-\mathrm{x}$

Abbreviations Used in Footnotes .............................................. xii

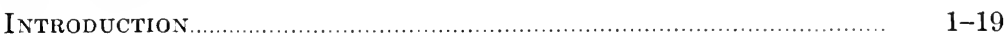

PART

The California Frontier, 1846-1851

CHAPTER I

The Spanish Inheritance and the American Conquest.

CHAPTER II

Colonel Richard B. Mason, Military Governor.

CHAPTER III

El Dorado

CHAPTER IV

Vox Populi in the Mines of California

$66-87$

CHAPTER V

The Struggle for Organization..

$88-115$

CHAP'TER VI

The Fabrication of the Commonwealth.

116-135

CHAPTER VII

The Failure to Establish Social Control. $136-159$

\section{PART II}

The San Francisco Committee of Vigilance of 1851 CHAPTER VIII

The Prelude to the Committee of Vigilance $162-185$

CHAPTER IX

The Organization of the Committee of Vigilance. 1S6-207

CHAPTER $\mathrm{X}$

The Committee at Work. 
The Records for June $227-251$

\section{CHAPTER XII}

James Stuart, Outlaw $252-274$

CHAPTER XIII

On the Trail of Stuart's Companions. 275-304

CHAPTER XIV

Adventures in Crime. $305-322$

\section{CHAPTER XV}

Politics and Reorianization. 323-337

CHAPTER XVI

The Closing Months 338-35.5

CHAPTER XVII

A Sumary of Methods 356-387

CHAPTER XVIII

'51 то '77. $388-408$

CHAPTER XIX

Lynch Law as a National Problem $409-427$

CHAPTER XX

In Retrospect. $428-440$

Biographical Notes. 441-452

Documentary Appendix $453-473$

BibliografHy 474-518

INDEX 519-5 43

\section{LIST OF ILLUSTRATIONS}

Medal of Commttee of Vigilance of 1856 Frontispiece TO FACE PAGE

Portrait of William T. Coleman. 190

Portrait of Samuel Brannan. 212

Facsimle of Proclamation by Governor John McDougal Relative to the Committee of Vigilance of 1851 


\section{ACKNOWLEDGMENTS}

It is pleasant to work in libraries, and in acknowledging a debt of gratitude that I owe to many friends, I would mention, first, the librarians who have made this work of research possible, Professor Herbert I. Priestley and Mr. Joseph J. Hill, of the Bancroft Library, Miss Eudora Garoutte, of the California State Library, and Dr. George Watson Cole, of the Henry E. Huntington Library, at San Gabriel, California.

I would record, with sincere appreciation, the kindness of President David P. Barrows, of the University of California, and that of Professors William Carey Jones, Walter M. Hart, Thomas H. Reed, Harold L. Bruce, and Charles E. Chapmanbusy men who have taken the time to read this volume in advance of publication, and have given me the benefit of their criticisms. Professor Edward Channing, of Harvard University, was also kind enough to read the manuscript in an early form, and to offer me advice that proved exceedingly valuable. Dr. Owen C. Coy, secretary of the California Historical Survey Commission, has directed me to important state records, and Mr. R. S. Kuykendall has placed at my disposal his notes on the history of California newspapers. Mr. Robert E. Cowan, an authority on Califormiana, has examined the proof of the bibliography, and suggested some interesting additions to the entries relating to the Committees of Vigilance.

Especial thanks are due to Professor Frederick J. Teggart, who directed my graduate work in its early stages, and to Professor Eugene McCormac, who has given me counsel and encouragement on many occasions when they were sorely needed.

I am much indebted to Professor Herbert E. Bolton for assistance in investigating the fronticr problems that developed in California. In addition to this service, Professor Bolton has 
devoted eareful attention to the many details of form and printing that have eome to his attention as editor of the University series of Publications in History.

I must name another-Professor Henry Morse Stephenswhose suggestion first led me to undertake this study, and whose unfailing interest in its progress furnished the strongest ineentive that earried it forward to completion. Professor Stephens died in April, 1919, and it is a cause of infinite regret to me that the book was then only in manuseript, and that my tribute to the inspiration of a remarkable teacher comes too late to fall beneath his eyes.

Mary Floyd Williams. 



\section{ABBREVIATIONS USED IN FOOTNOTES}

The footnotes of this volume cite Congressional Documents in a somewhat unusual manner. No mention is made of the title of the session of Congress, nor of the legislative body (Senate or House) that may be considered as author. The various papers are eited solely by the "Serial Number" and the "Document Number", under which they appear in the bound series of documents and the official check list. This method affords a concise but definite guide to the original authority, while the expanded entry in the Classified List of Material gives full details of publication.

Owing to the dearth of official documents relating to the early history of California, the local newspapers are of unusual importance, and references to them give not only the date, but also the exact position of the statement quoted, page and column being indicated by figures separated by an oblique line. Thus, Alta, 1851, April $1 \%$, refers to page two, column three, of the issue named.

The other abbreviations employed are quite obvious, and bibliographical information omitted from the footnotes will be found in the Classified List of Material. 


\section{INTRODUCTION}

When James Bryce wrote The American Commonwealth he remarked with surprise that little attention had then been paid to the individual histories of the separate states. ${ }^{1}$ Since that time the neglected subject has received a great deal of careful investigation: there has been much study and writing of local history, and sources of every kind have been carefully collected and published.

For the American period of California, however, little real progress has been made during the last thirty years, for, with the exception of a few students of special subjects, later writers have been content to reassemble material already in print, and to give it fresh vitality by fluency of style or touches of picturesque color. Bancroft's works, in particular, have been quoted most freely, and it cannot be denied that his analysis of the sources of California history was extraordinarily minute, and that the references in his voluminous footnotes are invaluable guides for nearly every line of research. But the synthesis of his text is less reliable, and it is dangerous to accept it as an adequate presentation of any specific period or event.

Fortunately nearly all of Bancroft's sources are still accessible to the student, for his large collection of books and manuscripts has remained intact, and in 1905 it became the property of the University of California. The purchase of this important library was due, in great measure, to the efforts of the late Henry Morse Stephens, who was then the head of the Department of History in the University. Professor Stephens had an especial enthusiasm for the publication of documentary sources of history, and he was ambitious that many of the unique treasures

\footnotetext{
1 James Bryce, American Commonuealth, ed. of 1914, I, 412 (ed. 1, 1888).
} 
of the Bancroft Library should be edited and printed as fast as funds could be procured for the purpose. The Academy of Pacific Coast History, with its interesting series of publications, has been a practical expression of his efforts in this direction.

One of the items in the Bancroft Library which strongly appealed to Professor Stephens' sense of historical values was the file of the archires of the San Francisco Committee of Vigilance of 1851 .

The stories of that remarkable association, and of its successor of 1856 , have been told more than once. Probably every reader of these pages already knows that the men who organized them were respectable and influential members of the body politic; that for brief periods they assumed unlawful control over criminal matters in their city; that they arrested and confined prisoners at their own discretion, hanged whom they would, and banished from the state citizens and aliens whose presence they deemed a menace to public order, while the community not only tolerated their usurpation of power, but supported them in the infliction of the most condign punishments. But it is not so generally known that these societies which defied the law regulated their conduct by the ordinary practices of parliamentary procedure, and kept careful records of their daily actions.

When Bancroft was preparing his Popular Tribunals he had access to the papers of both Committees, and those of 1851 were finally given to him outright by the former secretary, Mr. Isaac Bluxome, Jr. ${ }^{2}$ They include the roll of the signers of the constitution, lists of names proposed for membership, minutes, reports, and financial accounts and vouchers. Professor Stephens was convinced that these archives had great value as a contribution to local history, and as a documentary record of unusual human interest, and as soon as the Bancroft Library was transferred to the University he planned for the publication in full

2 H. H. Bancroft, Litcrary Industries, 1890, pp. 658-660. 
of the Papers of the Committee of Vigilance. In 1910 the List of Members, edited by Mr. Porter Garnett, appeared as a contribution to the first volume of the publications of the Academy of Pacific Coast History. Mr. Garnett also edited Part II of the Papers, the List of Names Approved by the Committee on Qualification, and the pamphlet was included in the second volume published by the Academy. But the labor involved in arranging and annotating the mass of minutes and miscellaneous papers promised to be very great, and it was not definitely commenced until Professor Stephens asked me to undertake it as graduate work in the Department of History. As the plans for publication were first outlined, it was intended that the documents should be given a preface that would furnish a necessary background of local conditions, and that both preface and documents should be printed together in two consecutive volumes of the Academy series.

The task of editing the documents advanced very slowly, and various puzzling questions arose as to the method of arranging them for the press, and of reproducing their characteristic style and atmosphere. The larger portion consists of loose pages of manuscript, and it was decided to group them in accordance with the chronological system adopted by Secretary Bluxome in filing the records committed to his care. ${ }^{3}$ This necessitated the wide separation of many pages that were closely connected in subject; consequently the documents, as printed, do not form a coherent history of the events they describe, although they provide a reliable source from which most of that history can be compiled.

It was an important and fascinating part of the editorial work to unravel the separate threads of this tangled skein, to trace the development of official policies, to gather together

3 See San Francisco Committee of Vigilance, Papers, III, 1919, pp. viii-ix. (Hereafter cited as Papers.) 
scattered but related references, and to explain obscure allusions by research in old newspapers and in the reminiscences of pioneers. This process finally resulted in a very definite reconstruction of the history of the Committee of Vigilance of 1851, based upon hundreds of original records, and verified by the testimony of actors and spectators. And this account differed materially from other narratives of the work of the Committee; for the secondary historians had over-emphasized a few melodramatic and crucial incidents, and had practically ignored the most distinguishing characteristics of the organization-the sincere conviction on the part of its members that they were justified in usurping temporary jurisdiction over the criminal problems of the city, and their conscientious and laborious efforts to exercise this self-assumed office with justice as well as with courage. The Vigilantes were never oblivious of the fact that their actions were open to the most serious objections, and the care taken to preserve their papers was largely due to their desire that future criticism should be based on exact knowledge of the course they had pursued. ${ }^{4}$

As progress was made in arranging the archives, it became more and more apparent that a detailed story of the Committee should also be published for the use of those who had neither the inclination nor the time to decipher the confused pages of the volume of documents. It was therefore decided that the archives should be bound by themselves for the special convenience of the research worker, and that, in place of the contemplated preface, the editor should embody the results of her study of the entire subject in a separate volume.

A most perplexing problem developed in seeking an appropriate point of departure for the narrative as a whole. It was comparatively simple to name and describe the members of the Committee, since many of them were distinguished by years of

\footnotetext{
4 See Papers, 639, 683-684.
} 
civic and commercial usefulness. It was equally simple to recount their actions during 1851 and 1852, for the records spoke for themselves. But when all that was done, there arose an inevitable and insistent question: "Why did such men do such things?" The answer could not be elicited solely from the archives of the Committee, nor did the general histories of California afford an adequate and satisfactory explanation.

As Professor Stephens has said in a brief introduction to the documents of the Committee, the significance of any historical event is a matter of interpretation, every generation regards the past from a different angle, and the emphasis in interpretation shifts with the shifting standpoints of historical criticism. ${ }^{5}$ Seventy years have passed since the organization of the Committee of Vigilance of 1851, and already one can recognize a succession of interpretations of that particular society and of its allied institutions, the miners' courts of California and the other popular tribunals of the entire western area.

The contemporary observer usually formed his judgment on the basis of efficiency. To him the protection of life and property was a matter of vital importance. When he found that criminals were terrified into unwilling docility by lynch law and vigilance committees, he commended such social expedients, although he might lament their incidental cruelty and deprecate their defiance of the principles of representative government.

The writers of the next generation, comfortably remote from the dangers that confronted the pioneer, showed a marked inclination to discuss the history of the earlier decades in uncompromising terms of right and wrong. Three important studies of the social life of California during the crisis of the gold fever appeared with singular sequence in three successive years: Charles Howard Shinn's Mining Camps in 1885, Josiah Royce's California in 1886, and Bancroft's Popular Tribunals in 1887.

\footnotetext{
5 Papers, iii.
} 
In preparing his interesting monograph on the mining camps, Shinn took pains to familiarize himself with books already in print, and with the local records and the newspapers of the period. He also had much conversation and correspondence with surviving Argonauts, who were then, however, removed more than a quarter of a century from the period they were asked to describe. The material thus collected is picturesque, vivid, and of great value, although deficient in exactness of reference. It has been freely quoted by all later writers, but it is evident that the author's wide acquaintance with the makers of California history and his sincere admiration of their sterling qualities led him to adopt their point of view as his own, for his book reflects only the most favorable and optimistic of contemporary impressions. ${ }^{6}$

Professor Royce, on the other hand, while he used some of the same documentary material as did Shinn, based much of his criticism of early social conditions on the diary and recollections of his mother, and on the letters of "Dame Shirley," a homesick New Englander, who spent some unhappy months in a California mining town. Both these women had keen powers of observation and scrupulous convictions as to righteousness and evil. Their influence no doubt accentuated the philosopher's tendency to judge the California pioneer by absolute standards of ideal citizenship, to attribute his failures to a sinful neglect of all personal and communal responsibilities, and to describe the resultant confusion as a time of retribution when the "restless and suffering social order" purged itself through struggle and penance. ${ }^{7}$

When H. H. Bancroft undertook to cover a part of the same field in his Popular Tribunals he obtained direct access to the archives of the Committees of Vigilance of 1851 and 1856. These

6 See Josiah Royce, California, 1886, pp. 279, 314-316.

7 Ibid., 344-356, 402, 406. "Shirley"' was a pseudonym for Mrs. Louise A. K. Clappe. 
afforded a new and reliable source of information on two important incidents that were typical of the spirit of the people of the state in the first decade of the commonwealth. The historian also supplemented these official records by obtaining interviews with some of the more prominent members, and securing from them dictated statements of their personal recollections. But Mr. Bancroft was always an out and out champion of the Vigilantes, and he was so eager to show their lofty ideals and heroic personalities that although his reconstruction of the history of the Committee of 1851 was drawn from original documents and personal reminiscences it neglected all the prosaic groundwork of painstaking detail, and often sacrificed exactness to melodrama.

Different as are these three interpretations in their conclusions, they have in common a distinctly moral point of view, and the writers commend or condemn, firm in the conviction of the inherent righteousness or wickedness of their segregated groups of good citizens and bad. The historical student of today is less inclined to pose as a dispenser of halos and of gridirons. He plucks the angels and he dehorns the devils whom he costumes for his historical pageant; and seeing in them men and women little better and little worse than those he knows in the intimacy of daily life, he seeks to explain their deeds by an understanding of the social conditions that impelled them to action.

The "Days of ' 49 "' has become a name to conjure with; in the popular imagination the real significance of the period has largely been obscured by the dominating figure of the bearded miner, with his pickaxe, his pistol, his strange oaths, and his sanguinary device of a rogue pendent. Although that miner was a product of the stout and virile life of the whole American frontier, the historians of 1885 had not awakened to the important influence of the frontier as a constant force in the development of our nation during the entire period when the tide of 
pioneer life was sweeping forward from the fall line of the Atlantic streams towards the placers of the Rio de los Americanos. They wrote of the Californian as of an American in unique circumstances, who faced his own peculiar problems with eertain racial predispositions. But in 1921 the historian no longer depiets the Californian as a foundling of the gold mines, with the shadow of the Sierra Nevadas east like a bar sinister across the escutcheon of his American paternity. The Argonaut is recognized as the legitimate offspring of an honorable race of pioneers, who were everywhere audacious and conservative, suspieious and optimistie, ready to grapple immensity with their naked hands, competent to build in the wilderness states based on the traditions of their Puritan forefathers, jealous of every measure put forth to restrain their arrogant individualism, and sublimely confident that the common sense of the majority would save any community, small or large, from the one unpardonable $\sin$ of self-destruction.

The frontier has ever been the laboratory of Ameriean demoeraey, where fearless men lay hold of the elemental forces that construct and destroy human society. After them have come the theorists, lamenting the catastrophes, explaining the triumphs, and formulating from the litter of the workshop generalizations and warnings for artisans of a more cautious régime. The frontiersman in California dealt with conditions and special problems unlike those developed in the Trans-Alleghany valleys and the Mississippi watershed, but his equipment to meet the new environment corresponded very closely with that of Ameriean frontiersmen of every generation. As a necessary introduction, therefore, to the study of the California pioneer, we must restate here certain essential characteristics and tendencies of the American national spirit. 
The long succession of social experiments which had accompanied the extension of the frontier diverged widely in individual features; but they were all founded on a common acceptance of the theory that the state was created by a voluntary compact between contracting parties who possessed various inherent rights. The theory included the conception of a period when society was still unorganized, and when men lived in simple enjoyment of all their natural rights, subject only to certain laws of God and of Nature. It was conceded that under particular circumstances, such as the violation of the contract by one of the subscribers, or the migration of a special group beyond the area in which an existing compact was binding, the organized people might resolve themselves into their original elements, and in their primary capacity resume the exercise of their natural rights, or form a new compact suited to changed conditions. ${ }^{8}$

This theory was preached by theologians and expounded by statesmen until it became an integral part of the national thought; it was the essence of the doctrine of the consent of the governed, it was the underlying force that impelled the Pilgrims of the Mayflower to pledge to each other mutual support and loyalty when they were obliged to establish their colony outside of the territory in which their patent rights were valid. From that day forward covenants of various kinds became the resource of the American settlers whenever they found themselves without the formal bonds and safeguards of constitutional government or in a situation where normal institutions failed to fulfill their legitimate functions. Many a New England town inaugurated its

8 The following references are useful in tracing the effect of the theory of the social contract on the establishment of institutions in American communities: A. C. McLaughlin, "Social Compact and Constitutional Construction," American Historical Review, V (1900), 467-490; A. B. Hart, "Growth of American Theories of Popular Government," American Political Science Review, I (1907), 531-560; Charles Borgeaud, Rise of Modern Democracy in Old and New England, 1894, pp. 77-90, 105-168; H. L. Osgood, "Political Ideas of the Puritans," Political Science Quarterly. Y'I (1891), 1-28; C. E. Merriam, History of American Political Theories, 1903, chaps. 2, 4; F. A. Cleveland, Organized Dcmocracy, 1913, pp. 34-45; C. S. Lobingier, The People's Law, 1909, chaps. 5-7. 
civic life with a compact modeled on the Mayflower document ${ }^{9}$ the Scotch-Irish of the Alleghanies also understood how to associate themselves for mutual protection; $;^{10}$ and as the frontier pushed westward there was constant illustration of the tendency to crystallize the public opinion of the scattered communities into a practical medium of government under the form of compacts, especially as to the preservation of order and the occupation of land.

Such agreements were written and signed in pre-Revolutionary times by the people of North and South Carolina, who formed societies of "Regulators" to punish crime and to check the extortion practiced by dishonest officials. In South Carolina, where the associations appeared as early as 1764, they were suppressed with difficulty. In North Carolina the Regulation was active from 1768 to 1771 , and persisted until the tragic battle of the Alamance dispersed the insurgents, and subsequent trials resulted in the execution of some of the leaders. ${ }^{11}$ In 1772 the settlers at Watauga, beyond the pale of colonial organization, signed the first written constitution adopted by men of American birth, a compact which made the will of the majority practically supreme, and which remained in force for the six

9 See Lois K. Mathews, "The Mayflower Compact and Its Descendants," Mississippi Valley Historical Association, Proceedings, VI (1912-1913; $79-106$; F. J. Turner, "Western State-Making in the Revolutionary Era,', American Historical Review, I (1895-1896), especially pp. 70-87; Allen Johnson, "Genesis of Popular Sovereignty,' Iowa Journal of History and Politics, III (1905), 3-19.

10 See Theodore Roosevelt, Winning of the West, 1889-1896, I, 101-133.

11 See North Carolina, Colonial Records, 1886-1890, Introductions to VII, VIII. The agreements of the Regulators, accessible through the Index of this series, are very suggestive of the records of the Committee of Vigilance. The Regulation movement may be further studied in J. E. Cutler, LynchLax, 1905, chaps. 2-3; David Ramsay, History of South-Carolina, 1809, I, 211-215: J. H. Wheeler, Historical Sketches of North Carolina, 1851, I, 48-60 ; II, 10-20, 301-331; J. S. Bassett, "Regulators of North Carolina,", American Historical Association, Annual Report, 1894, pp. 141-212; M. DeL. Haywood, Governor William Tryon, 1903, pp. 77-194; S. A'C. Ashe, History of North Carolina, 1908, I, 336-376; Archibald Henderson, "Origin of the Regulation in North Carolina,' American Historical Review, XXI (1916), 320-332. 
years that elapsed before the neighborhood was incorporated as Washington County in the state of North Carolina. ${ }^{12}$

Immediately after the Revolution many western settlements took the initial steps in local organization without waiting for action of the Continental Congress. In one case, indeed, the state of Franklin sustained itself in isolated democracy for several years. ${ }^{13}$ The land clubs and claim associations of the Old Northwest applied the same principle of voluntary alliance to the mutual protection of homesteaders' rights, and were based on written agreements that furnish some of the most characteristic documents of American local history. ${ }^{14}$ " All through these compacts," wrote Professor F. J. Turner, "runs the doctrine that the people in an unoccupied land have the right to determine their own political institutions," and he cited a declaration made by a committee reporting to the legislature of Wisconsin as late as 1843 , in which it was stated that all "political communities have the right of governing themselves in their own way within their lawful boundaries." ${ }^{15}$

12 See J. G. M. Ramsey, Annals of Tennessee, 1853, pp. 106-140; Roosevelt, Winning of the West, I, chap. 7 .

13 See Ramsey, Annals of Tennessee, 283-444; G. H. Alden, New Governments West of the Alleghanies before 1780, 1897; and his "State of Franklin," American Historical Review, VIII (1903), 271-289; "Petition for a Western State,' Mississippi Valley Historical Review, I (1914), 265-269; Roosevelt, Winning of the West, II, 32t-369; III, 153-202; A. W. Putnam, History of Middle Tennessee, 1859, pp. 89-103; Arehibald Henderson, Richard Henderson: the Authorship of the Cumberland Compact and the Founding of Nashville, 1916; C. S. Lobingier, The People's Law, chap. 8. Citizen committees did useful work in Mississippi in 1797 and 1798, see F. L. Riley, "Transition from Spanish to American Rule in Mississippi,', Mississippi Historical Society, Publications, III (1900), 275-311.

14 See B. F. Shambaugh, "Frontier Land Clubs or Claim Associations," American Historical Association, Annual Report, 1900, I, 67-84; and his Constitution and Records of the Claim Association of Johnson County, Iowa, 1894; Jesse Macy, Institutional Beginnings in a Western State [Iowa], 1884; Brigham Johnson, "Frontier Life in Iowa in the Forties," Magazine of History, XVIII (1914), 23-28; G. E. Howard, Introduction to the Local Constitutional History of the United States, 1889, I, 411-412.

15 Turner, "Western State-Making," American Historical Revicw, I (1895-1896), 265-266. The characteristics of the frontier as a form of society rather than as a geographic area are further discussed by Professor 
The American precedent of voluntary association was followed by the revolutionists in Texas when they sought independence from Mexico. In 1835 they formed local "committees of safety," primarily to provide protection against Indians, and these became the nucleus for the general representative Council of Safety which for a time constituted the central government. ${ }^{16}$ The provisional government of the people of Oregon, one of the most successful experiments in frontier organization, was another striking example of social agreement. It is said that the very term "compact" was preferred to "constitution" by some of the leaders of the movement, ${ }^{17}$ and provision was made for the voluntary withdrawal of anyone who might desire to revert to the unsocial state of nature by discontinuing his financial contributions to the common cause.

Successive experiments and expanding national life have modified the theory of the social compact. Our people have learned that even in a democracy changes in adopted contracts must be made in orderly ways, and that, if we are to have a government of law rather than of caprice, there must be some "machinery short of revolution", to determine whether the compact has been observed. But it has been necessary to recognize here the powerful influence exerted upon American thought

Turner in various articles collected in his The Frontier in American History, 1920. See also his List of References on the History of the West, ed. of 1913; Justin Winsor, Westward Movement, 1r63-1r98, 1897; R. T. Hill, The Public Domain and Democracy, 1910; the opening chapters of W. E. Weyl, The New Democracy, 1912.

${ }^{16} \mathrm{H}$. K. Yoakum, History of Texas, 1856, I, 337, 355-379, passim; H. H. Bancroft, History of the North Mexican States and Texas, II (1889), 155 et seq.; H. S. Foote, Texas and the Texans, 1841, II, 83-86, 128 et seq.; " Journal of the Permanent Council (October 11-27, 1835),"' Texas State Historical Association, Quarterly, VII (1904), 250-278.

17 See J. R. Robertson, "Genesis of Popular Government in Oregon," Oregon Historical Society, Quarterly, I (1900), 1-59; W. H. Gray, History of Oregon, 1870 , p. 336 et seq.; H. H. Bancroft, History of Oregon, 1886-1888, I, chaps. 12, 16, 18; H. S. Lyman, History of Oregon, 1903, III, 274 et seq.; W. C. Woorward, Rise and Early History of Political Parties in Oregon, 1913, pp. 13-34; Oregon Archives, 1853.

18 A. B. Hart, National Ideals Historically Traced, 1907, p. 100. 
by this theory of the state, because it found enduring expression in many of the institutions of the frontier, and asserted itself very definitely in California during all the period under our especial consideration.

Closely linked with the conception of a state based on a voluntary compact was the distrust of a centralized form of government which profoundly influenced the men who inaugurated the social life of our nation. The utmost liberty of action in domestic affairs was demanded by all the local groups and they subordinated their individual rights with reluctance to any superior authority. One result of this attitude was the development of a loose system of state government in which there was a marked sacrifice of efficiency in conducting matters that pertained to the common welfare. But self-government, not efficiency, was the passion of the first American colonists, and that passion they transmitted to the sons and grandsons who continued their work. Fathers and sons, alike, dared to be inefficient and to make mistakes, if in that way they could learn for themselves how the self-governed might perform those social tasks which had previously been centralized under kings and ministers of state.

One of the most difficult problems that arose under the decentralized system of American local government was the suppression of disorder in the outer line of settlements that constantly advanced beyond the convenient operation of the law, and from a very early period the frontiersmen exereised a self-assumed criminal jurisdiction which was commonly sustained by the mutual consent of the neighborhood immediately concerned. Professor Turner said : ${ }^{19}$

It was the multiplicity of revolutionary associations, and the ease with which they might run into the form taken by the Vigilance Committees of the far West, that led even so ardent a follower of revolutionary principles

19 Turner, "Western State-Making," American Historical Review, I (1895-1896), 265-266. 
as Patrick Henry to declare in 1786 regarding the defenseless condition of the western frontier, "that protection which is the best and general object of social compact is withdrawn, and the people, thus consigned to destruction, will naturally form associations, disgraceful as they are destructive of government.",

Even before Patrick Henry uttered his warning, the possibility of which he spoke had already become a reality. The Regulators of Colonial days had bound themselves to make common cause against horse thieves and other criminals, and they had subsequently arrested such undesirable neighbors, tried them in a summary fashion, and chastised the guilty by stripes deemed appropriate to their misdeeds. The general excitement and disorder incident to the Revolution stimulated the tendency towards the punishment of criminals or unpopular persons by groups which assumed a quasi-representative function. The famous Boston Tea Party was a manifestation of such an impulse, and the numerous committees of safety throughout the colonies constituted an efficient force for the pursuit and punishment of suspected Tories. ${ }^{20}$ An interesting summary of these Colonial and Revolutionary movements is given in the opening chapters of J. E. Cutler's Lynch-Law. In the opinion of that author, the much disputed origin of the term "lynch law" may be traced to a self-appointed court of Revolutionary days in Virginia, where Charles Lynch, William Preston, Robert Adams, Jr., and James Callaway disciplined the rogues and the Tories of Bedford County. ${ }^{21}$ After the war was ended, damages were sought

20 See E. D. Collins, "Committees of Correspondence of the American Revolution,' American Historical Association, Report, 1901, I, 245-271; Agnes Hunt, Provincial Committees of Safety of the American Revolution, 1904; J. M. Leake, The Virginia Committee System and the American Revolution, 1917. Handbills printed in Philadelphia and New York, 1773 and 1774, suggest notices issued by the San Francisco Committee of Vigilance of 1851 (see E. M. Avery, History of the United States, 1904-1910, V, 168-169).

21 Cutler, Lynch-Law, 13-40. See also H. H. Bancroft, Popular Tribunals, 1887, I, 6-7; The Grecn Bag, IV (1892), 561-562. Before the Revolution Lynch had acted as a justice of the peace (Lyneh-Law, 25 note) and Preston and Callaway had also represented the colonial government as lieutenants of the county (Green Bag, V [1893], 116). 
for some of the penalties inflicted, but the General Assembly of Virginia decided that the proceedings, while not strictly warranted by law, were justified by the imminence of the danger.

A like necessity constantly existed all along the line of the westward advance where there was always a definite element of dangerous eriminals. The same impulse towards organization that moved the pioneers to combine in land claim associations led them to seek protection from lawlessness by concerted effort to secure the punishment of crime. It became a general custom to improvise a kind of pseudo court wherever and whenever a flagrant offender incurred public censure. ${ }^{22}$ There was also a marked tendency to increase the severity of punishment; while discipline prior to 1830 was seldom more severe than whipping, the frequent executions of a later date made the term "to lynch" almost synonymous with "to hang." 23

A popular trial destined to attract wide attention was that of a murderer named Patrick O'Conner, convicted in May, 1834, by the people of Dubuque's Mines, in unorganized country north of Missouri. The courts of Illinois had no jurisdiction in the region, and during the month that elapsed before the sentence was executed the governor of Missouri refused to interfere, while an appeal to President Jackson elicited the reply that even he had no authority in the case, as the laws of the United States had not been extended over that part of the Louisiana Purchase. O'Conner was finally hanged with the solemnity befitting a legal execution. In commenting on the case the Niles Register said : ${ }^{24}$

22 The Green Mountain boys of Vermont protected their land titles by lynch law (the use of the birch) in the days of early settlement (Turner, "The Old West," in his Frontier in American History, 78). See also Roosevelt, Winning of the West, I, 132 note 1,187 note 1 ; J. L. McConnel, Western Characteristics, 1853 , pp. 171-245 passim.

23 Cutler, Lynch-Law, 116 et seq.

24 See also Eliphalet Price, "Trial and Execution of Patrick O'Conner," Annals of Iowa, ser. I, III (1865), 566-574; Jesse Nacy, Institutional Beginnings in a Western State, 7-8; Cutler, Lynch-Law, 86-88; Niles Register, XLVI (1834), 352; Des Moines Register and Leader, 1910, Sept. 25. 
As law, in every country, emanates from the people, and is, in fact, whether written or not, nothing more nor less than certain rules of action by which a people agree to be governed, the unanimous agreement among that people to put a man to death for the crime of murder, rendered the act legal to all intents and purposes.... They have taught the world that the people are the basis of law, even where no written law can be applied.

Turner has said that the Westerner, impatient of restraint, placed himself under influences destructive to many of the gains of civilization, but that he knew how to preserve order even in the absence of legal authority. "If there were cattle thieves, lynch law was sudden and effective: the regulators of the Carolinas were the predecessors of the claims associations of Iowa and the vigilance committees of California.... If the thing was one proper to be done, then the most immediate, rough and ready, effective way was the best way.', 25

Bancroft called these extra-legal courts "popular tribunals." The term describes them well and at the same time it relates the popular trials of the American frontier to the protective measures adopted by European communities in periods or crises when central governments were not strong enough to preserve order. Popular committees and associations for the suppression of crime have been of importance in the social development of many nations. Trial by popular assembly was a recognized practice in the Athenian democracy, as well as in the Teutonic tribes before the development of the jury system. ${ }^{26}$ The Vemgericht of Germany and the Santa Hermandad of Spain and the Spanish colonies were not only supported by the people at large but were tolerated and sometimes fostered by the authorities when justice could not be administered by due process of law. The medieval towns of France had their defensive

25 Turner, "The Problem of the West," in his Frontier in American History, 209-212, passim.

26 See Victor Duruy, History of Greece, tr. by M. M. Ripley, 1890, I, 538 et seq.; Sir H. S. Maine, Early Law and Custom, 1886, chap. 6. 
confréries. The local history of England and the Scottish border recounts many acts of extra-legal retribution. ${ }^{27}$

The inter-relation of these various tribunals and of the many secret societies which are allied to them is a subject far more inclusive than the study of any particular local committee, and generalizations can have little value unless they are based on exact knowledge of the many associations involved. ${ }^{28}$

No attempt has been made in this volume to cover so wide a field, or to question how far the popular tribunals of this century were indigenous and spontaneous, and how far they were influenced by European tradition and inheritance. ${ }^{29}$ The social emergencies of the American frontier were very different from the social emergencies of medieval Europe, whatever may have been the kinship between the sturdy pioneers of the West and the resolute brotherhoods of earlier centuries.

For more than two centuries, and under many varying circumstances, the American pioneers experimented in empire building from the Atlantic Ocean to the shores of the Pacific.

27 See L. J. Paetow, Guide to the Study of Medieval History, 1917, "Vemgerichte," p. 292, "Hermandadas," p. 321; Lavisse and Rambaud, Histoire générale, II (1893), 466; Lynn Thorndike, History of Medieval Europe [1917], 534 et seq.; R. B. Merriman, Rise of the Spanish Empire, I (1918), 191-194; II, 99 et seq.; C. E. Chapman, History of Spain, 1918, pp. $155-156$.

28 Allied associations are discussed in Cutler, Lynch-Law, 5-12; Bancroft, Popular Tribunals, I, chaps. 1, 3.

29 In California there was a definite point of contact between AngloSaxon and Spanish precedents as the Santa Hermandad had been highly developed in certain parts of Mexico (see Bancroft, History of Mexico, 1883-1888, III, 272-276). J. W. Dwinelle said that twenty years before the American occupation of California parties of reputable colonists were obliged to pursue outlaw soldiers and kill them like wild beasts. "The Vigilance Committees in Califormia are therefore a tradition of the MexicoCalifornian régime', (Colonial History of the City of San Francisco, ed. 3, 1866, p. 87 ). In 1836 there was a deliberate execution by a popular tribunal, when the people of Los Angeles tried and executed a man and woman guilty of an atrocious murder. As no constitutional courts had inflicted punishments for homicide this act was approved by the community and condoned by the authorities (Popular Tribunals, I, 62-66; J. S. Hittell, History of San Francisco, 1878, pp. 79-81; Tigilantes de Los Angeles, 1836, MS in the Bancroft Library; Vigilance Committee [of Los Angeles, 1836], MS in the Bancroft Library; Alta California, 1865, March 30 1/1). 
In California they encountered conditions and emergeneies that were radieally different from those that had appeared elsewhere, and that taxed to the utmost all their eapacity for self-control. None the less the development of California was an integral part of pioneer history, and the successes and the failures that attended the settlement and upbuilding of the state have a permanent value far transcending their sectional interest.

One of the most notable episodes in the history of California was the organization of the Committee of Vigilance of San Francisco, an organization which is invested with abiding signifieance when it is regarded as a demonstration of national life and thought, rather than as a singular episode in an isolated community. But to make clear this significance it is not enough to relate the Committee vaguely to general tendencies in American society. It is imperative to perceive, as well, the special problems of California, and the exigencies which distinguished the entire interval that had elapsed since the date of the Ameriean oecupation. To be explieit, we camnot understand the Committee of Vigilance of 1851 until we understand the failure of the courts to punish crime, and the consequent survival of the resort to popular tribunals. Nor can we discern the initial need of such popular tribunals and their recognized place in the life of 1848 and 1849 until we realize the extraordinary problems that developed when a hundred thousand gold seekers swarmed into a mining region that was destitute of any form of eivil govermment. For an explanation of this strange lack of the ordinary bulwarks of Ameriean soeiety, we must look still deeper into the unusual status of California while it was held as a military possession of the United States during the war with Mexieo, and at the changes that followed the conelusion of hostilities. Finally, in order to comprehend all the obvious and the subtle influences that called the committee into being, we must be able to appreciate how these years of uncontrolled, tumultuous, and intensely 
practical life, developed in the men of California an enormous self-reliance, and so accustomed them to improvise political and judicial organization that they tended to idealize the sovereign attributes of the "people assembled in their primary capacity" at the expense of legitimate, representative government.

Here is a group of problems which must be formulated, first of all, in the exact and simple terms of local history. Some of them receive adequate consideration in the standard works on California, but others of vital importance have been strangely neglected, or have been overlaid and confused with a mass of distracting detail. As a result, the studies already in print do not give a broad and well balanced picture of community life in California during the gold rush. It has, therefore, proved impossible to introduce the history of the Committee of Vigilance by any brief summary of familiar material, and it has been necessary to devote several chapters to a consideration of certain phases of California history that directed public action and molded private thought during the period prior to 1851 . 



\section{PART I}

THE CALIFORNIA FRONTIER

1848 TO 1851 



\section{THE SPANISH INHERITANCE AND THE AMERICAN CONQUEST}

The Committee of Vigilance of San Francisco was organized on the ninth of June, 1851. California had been a recognized commonwealth of the Federal Union exactly nine months; for nearly five years she had been under the flag of the United States; and for three-quarters of a century before the American occupation she had been a part of the great colonial system which Spain had planted upon the Western Hemisphere.

There had been only a brief clash of arms when the country passed from the control of one government to that of the other. California was nevertheless a field of conflict between two ideals of social order-the ideal of the Spanish-American colonists based on the civil law of Rome, and the ideal of their American successors based on the common law of England. Further, these distinct ideals, formulated by centuries of national life in the Old World, had been constantly modified by the problems of life in the New, as men of different races pushed their frontiers northward from Mexico, and westward from the Atlantic seaboard, to meet on the plains of the Southwest, and on the shores of the Pacific Ocean.

Until the close of Spanish rule in 1822, the military and ecclesiastical authorities had dominated California. Thenceforth the ecclesiastical influence declined, sinking to almost nothing after the secularization decree of 1833. At the same time the civil organization increased in importance until it vied with the military, and the Mexican system cannot be ignored in any study of the early American period, since it was perpetuated 
as the vehicle of local administration from the date of the occupation until the full establishment of state government in 1850 . It has been summarized as follows by one of the American military-civil governors : ${ }^{1}$

It consists, first, of a governor, appointed by the supreme government: in default of such appointment, the office is temporarily vested in the commanding military officer of the department.... Second, a secretary.... Third, a territorial or departmental legislature, with limited powers to pass laws of a local character. Fourth, a superior court (tribunal superior) of the Territory, consisting of four judges and a fiscal. Fifth, a prefect and subprefects for each district, who are charged with the preservation of public order and the execution of the laws: their duties correspond, in a great measure, with those of district marshals and sheriffs. Sixth, a judge of first instance for each district: this office is, by a custom not inconsistent with the laws, vested in the first alcalde of the district. Seventh, alcaldes, who have concurrent jurisdiction among themselves in the same district, but are subordinate to the higher judicial tribunals. Eighth, local justices of the peace. Ninth, ayuntamientos, or town councils. The powers and functions of all these officers are fully defined in the laws of this country, and are almost identical with those of the corresponding officers in the Atlantic and western States.

California, one would conclude, was provided with an adequate and nicely balanced government; and so she was, by statute. But it is necessary to accept such an obvious conclusion with extreme caution, as the Mexican officials had a genius for writing out organizations on paper, and for nullifying their statutes in actual practice. For this reason the "laws" and the "usages" of a given community often exhibit notable discrepancies, and accounts of conditions based on a study of national regulations may differ greatly from other accounts based on the personal experiences of residents and visitors. In California the variations between law and custom offer an interesting field for careful comparison of documentary sources and of contemporary observations. Pending such a

1 Cong. Docs., Ser. No. 573, Doc. 17, p. 778. 
thorough investigation one must speak with reservation of the exact condition at any particular time.

The unit of civic life in the Spanish colonial system was the town or pueblo, and this was the form of organization established in California after the secularization of the missions. ${ }^{2}$ Nunicipal control was vested in the ayuntamientos or town councils. The executive officers were the alcaldes, sometimes two in number, who exercised judicial and even legislative powers of great scope. The first alcalde of each district also acted as judge of first instance in considering cases of major importance. The statutes provided for higher tribunals to entertain appeals from these lower courts, but while superior judges may have been appointed in California, they seem never to have performed any important functions. ${ }^{3}$ In consequence the local officers exercised a greater authority than was actually bestowed upon them by legislative enactment.

In the course of a general movement towards centralization under President Santa Anna, the Mexican Congress, in 1837, enacted laws which deprived small towns of their elected ayuntamientos, and substituted for the alcaldes justices of the peace, appointed by the prefect of the district, and subordinate to the sub-prefect." These justices exercised certain of the "faculties and obligations" of the alcaldes and ayuntamientos, and their authority varied according to the size of the town. As none of the settlements in California had a population that entitled it

2 See T. H. Hittell, History of California, 1885-1897, II, 181-214; H. H. Bancroft, History of California, 1884-1890, III, 301-362 ; F. W. Blackmar, Spanish Institutions of the Southwest, 1891, pp. 153-191. General reference on Mexican organization may also be made to I. B. Richman, California under Spain and Mexico, 1911. It is unnecessary to consider here the exact number of legally constituted pueblos, although the question was very important in the settlement of land titles after the American occupation.

3 Baneroft, California, IV, 531; Frederic Hall, History of San José, 1871 , p. 169 ; W. H. Davis, Sixty Years in California, 1889 , p. 105.

${ }^{4}$ See the Digest of the laws of 1837, by H. W. Halleck, in J. Ross Browne, Report of the Debates in the Convention of California on the Formation of a State Constitution, 1850, Appendix, pp. xxxi-xxxiv. 
to an elective council, Governor Alvarado, in November, 1839, issued an order dissolving the ayuntamientos and displacing the alcaldes, with the probable exception of the officials of the capital town of Monterey. ${ }^{5}$

Radical changes in the Mexican system were again made in 1843 when Santa Ana was at the height of his power. ${ }^{6}$ In California the offices of prefects and sub-prefects were abolished, and in January, 1844, Governor Micheltorena reinstated ayuntamientos and alcaldes in several of the larger towns. ${ }^{7}$ Bancroft said that this change left little trace in the archives of the period, for in the summer of 1845, after the overthrow of both Micheltorena and Santa Anna, the legislative assembly of California reorganized the administration on the old basis of the laws of 1837. ${ }^{8}$ Alta California was divided into the districts of Los Angeles and Monterey, and these were again subdivided into partidos. The partido of Monterey was given a prefect, the others had sub-prefects. The town of Monterey, which had been the former capital, was also allowed an ayuntamiento and alcaldes, and so was Los Angeles, to which the seat of government had been removed early in $1845 .^{9}$ Elsewhere the justices of the peace were reëstablished, as prescribed in the laws of 1837, although there was a general tendency to persist in the use of the term alcalde, instead of juez de paz. Contemporary travelers commonly followed that custom, and old residents found it difficult

\footnotetext{
5 Bancroft, California, III, 586. Alvarado said in 1840: "There is no Ayuntamiento whatever in the Department, for there being no competent number of inhabitants in any of the towns as provided by the Constitution, those then existing had to be dissolved; and only in the Capital there ought to be one of such bodies' (Dwinelle, Colonial History of the City of San Francisco, Addenda L., p. 70). The varying local regulations are illustrated in Bernard Moses, Establishment of Municipal Government in San Francisco, 1889 , pp. $12-26$.
}

6 Bancroft, History of Mexico, V, 226-287.

7 Baneroft, California, IV, 358--359.

8 Ibid., 533.

9 Ibid., 519. 
to distinguish between the two classes of magistrates when called to testify in the American courts. ${ }^{10}$

Thus it happened that Spain's judicial legacy to California is for the popular mind embodied in the symbolic figure of the alcalde-the presiding officer of the town council, the dignified, paternal autocrat; so prominent in local affairs, and so impressed upon history and fiction, that the term "alcalde system" has frequently been applied to the whole elaborate and centralized organization in which the alcalde's legitimate position was actually that of a minor unit. ${ }^{11}$

During the last decade of Mexican rule a changing order affected many of the characteristic features of the earlier epoch. The neglected presidios and the rifled missions still formed a chain of little settlements from San Diego to Sonoma, but many of the more important residents lived in patriarchal fashion on great ranchos which had been granted from time to time to private individuals. Despite hampering restrictions, hundreds of foreigners had made themselves at home in California, and some had even acquired positions of distinction through marriage with influential families. Life was pastoral and indolent, little disturbed by commercial aspirations, but enlivened by constant political intrigue. The keener minds, both native and foreign,

10 See testimony in the case of the United States vs. José Y. Limantour, Transcript, 1857-1858, I, Case No. 424, pp. 140, 145, 153, 155, 163; IV, Exhibit O, pp. 9, 13-17. The changes in system are outlined, II, 753-754. Many extracts from this evidence are reprinted in Dwinelle, San Franciseo, and a list of Mexican officials of San Francisco is given in Addenda LXXVII, p. 111. See also B. S. Brooks, "Alealde Grants in the City of San Francisco,' The Pioneer, I, II (1854).

11 See R. A. Wilson, "The Alcalde System of California," First California Reports, 559 et seq. (in ed. 1, 1852, and annotated ed., 1906); C. H. Shinn, Mining Camps, 1885, especially chap. 8; Willoughby Rodman, History of the Bench and Bar of Southern California, 1909, pp. 28-36; J. R. Robertson, From Alcalde to Mayor, 1908, a MS doctoral dissertation in the University of California Library. Some court decisions ruled that the status of the alcaldes as defined in the laws of 1843 held over to the American régime, see “Mena vs. Le Roy,"'First California Reports, 220; "Cohas vs. Raisin,', Third California Reports, 449 ; “'Hart vs. Burnett,' Fifteenth California Reports, 530. 
were aware of impending change, for statesmen more energetic than those of Mexico were bestirring themselves to gain control of the Pacific Coast; and while the Californians were absorbed in their local problems and discords the toils of international ambition and diplomacy were drawing closer about them.

The various episodes that immediately preceded the change in government are some of the best known incidents in local history. A few words will recall the services of Thomas 0 . Larkin as United States consul at Monterey; the exploring expeditions of Captain John C. Frémont, of the United States Topographical Engineers; the protests made by the Mexican authorities when his large party lingered in California during the spring of 1846; the arrival, in May, of Lieutenant A. H. Gillespie, with secret orders from Washington for Larkin and Frémont; and the belligerent attitude immediately assumed by the latter. In June the American settlers at Sonoma, abetted by Frémont, attempted the establishment of an independent government, and while their Bear Flag was still flying, Commodore John D. Sloat appeared upon the Coast, announced the outbreak of hostilities between the United States and Mexico, and, on the seventh of July raised the Stars and Stripes above the little port of Monterey. ${ }^{12}$

The months that followed were filled with interesting events, and while most of them may pass unnoticed in these pages, a few require mention because they produced conditions that permanently affected the institutions of California. The expansion of the United States by the military occupation of Mexican territory created problems for which the officers in command could not be prepared by specific instructions issued long prior to the event. The development of a policy in regard to the

\footnotetext{
12 General reference on this period may be made to the histories of Bancroft, Hittell, and Royce; G. L. Rives, The United States and Mexico, 18211848, 1913, II; J. H. Smith, The War with Mexico, 1919, especially chaps. $14,16,17$, with their notes.
} 
administration of the acquired country was a series of experiments, in which the burden of responsibility was laid upon the local executives. The orders under which Sloat took possession of Monterey were dated June 24, August 5, and October 17, 1845 , and they vaguely directed him to preserve friendly relations with the people of California in case the declaration of war gave him an opportunity to seize the ports of the Pacific Coast. Letters which were dispatched after the outbreak of hostilities ordered him to encourage the people to "neutrality, self-government and friendship." They anticipated that it might be necessary for him to establish some form of civil government, but details of administration were left to his discretion. ${ }^{13}$

It is a recognized principle of international law that during the military occupation of conquered territory the native municipal laws shall continue in force except as the new commander may make specific changes. ${ }^{14}$ In accordance with the spirit of this regulation Commodore Sloat issued a proclamation on the day he occupied Monterey in which he promised that peaceable inhabitants should enjoy their native rights and privileges, as well as greater liberties assured to those who lived under the flag of the United States. ${ }^{15}$ At the same time he asked the judges, alcaldes, and other civil officers to retain their positions

13 For orders of this period see Cong. Docs., Ser. No. 499, Doc. 19, pp. 75, 79-84; Cong. Globe, 29 Cong., 2 Sess., Appendix, pp. 44-47; J. C. Frémont, Memoirs, 1887, I, 537; Richman, California under Spain and Mexico, pp. 528-529.

14 For discussion of the status of California at this time see R. D. Hunt, "Legal Status of California, 1846-49," American Academy of Political and Social Science, Annals, XII (1898), 387-408; C. E. Magoon, Reports on the Law of Civil Government in Territory Subject to Military Occupation by the Military Forces of the United Statcs, 1902, Index under "California"'; D. Y. Thomas, History of Military Government in Newly Acquired Territory of the United States, 1904, pp. 159-275; W. E. Birkhimer, Military Government and Martial Law, ed. 3, 1914, pp. 53-137.

15 Cong. Docs., Ser. No. 493, Doc. 1, pp. 644-645. Reprinted in Soulé, Gihon and Nisbet, Annals of San Francisco, 1855, pp. 98-100. 
until the government should be more definitely organized, but only a few of the native incumbents consented to continue in office.

Monterey, the first port occupied, was entitled to an ayuntamiento and alcaldes, ${ }^{16}$ and elsewhere common parlance clung to the term "alcalde." Therefore it is not surprising that the Americans, who were unfamiliar with the Mexican laws, immediately assumed that alcaldes were the constitutional magistrates in all the settlements that had so suddenly been transferred from the authority of one nation to that of another. Alcaldes, therefore, were appointed to fill the more important vacancies, ${ }^{17}$ and the safety of the little army of occupation required that in many places Americans should replace Californians of doubtful adherence to the new régime. Perhaps the most conspicuous of these magistrates was the Reverend Walter Colton, alcalde of Monterey, for his interesting diary is one of the most familiar sources of information on the events of the period. ${ }^{18}$

Commodore Sloat left California three weeks after his momentous action of July 7 . He was succeeded in command by Commodore Robert F. Stockton, who acted as executive for about six months-a brief administration which was disturbed by various uprisings of native malcontents. In the suppression of these outbreaks the Commodore was greatly assisted by Frémont and Gillespie, and the California Battalion of Mounted Riflemen, which they had organized from members of Frémont's

16 An election for the ayuntamiento had been held in Monterey, Dec. 10, 1845 (Baneroft, California, IV, 655 note).

17 Bancroft, California, V, 637 note, 648 notc. Commodore Sloat, however, appointed a justice of the peace at San José, and recommended the appointment of two more to try minor cases in San Francisco (Cong. Docs., Ser. No. 493, Doc. 1, pp. 641, 667). Henry D. Fitch was spoken of as justice of the peace in San Diego, April 16, 1847 (Archives of California, "Unbound Docs., 1846-1850," p. 118), and Robert Cliff as justice in the same place on Oct. 5, 1847 (ibid., 121).

1s Walter Colton, Three Tears in California, 1850. Colton had been chaplain of the frigate Congress. 
exploring expedition and from adherents of the Bear Flag forces. ${ }^{19}$

Stockton undoubtedly considered himself authorized to install an adequate form of civil government. He called for popular elections to fill the positions vacated by the old magistrates, and directed that the new officers should administer the law according to former usages until the departments of state could be rearranged. ${ }^{20}$ He publicly announced the probability of speedy territorial organization, and on his own initiative drew up a brief constitution which formally declared California to be a territory of the United States, provided for a governor, a secretary, and a legislative council, and continued the existing municipal institutions. This was forwarded to Washington, accompanied by the statement that he expected soon to resume his duty at sea, and would appoint Frémont governor, and Gillespie secretary. ${ }^{21}$

Long before this communication reached the East, other plans had been matured for California. Soon after the outbreak of the war Brigadier General Stephen W. Kearny had been sent westward upon a dual mission. He was ordered first to occupy New Mexico and to establish civil govermment there, and then to proceed overland to coöperate with the naval forces on the Pacific Coast, to assume command of all troops mobilized there, and to establish civil govermment as soon as possible. It was admitted that in both localities the work of administration might be difficult and unpleasant, and he was instructed to rely on his own judgment when necessary.22

19 See Bancroft, California, V, chaps. 12-15.

20 Cong. Docs., Ser. No. 493, Doc. 1, pp. 669-670. Stockton called for the local election at San José in a letter dated August 24, 1846, that is still preserved in the office of the clerk of that city.

21 Reports of Sept. 18 and 19, 1846, Cong. Docs., Ser. No. 521, Doc. 70, pp. 38-40, 45-46. For Stockton's plan of organization see Cong. Docs., Ser. No. 493, Doc. 1, pp. 669, 671-672, 675; Bancroft, California, V. 28t285.

22 Cong. Docs., Ser. No. 573, Doc. 17, pp. 236-240; Baneroft, California, V. $334-336$. 
To reinforce the troops that marched overland, the First Regiment of New York Volunteers was dispatched via Cape Horn, under the command of Colonel Jonathan D. Stevenson. It was composed of young men who enlisted for the duration of the war, with the understanding that they should be mustered out in California. The fact that many remained there as permanent settlers made the expedition famous in local annals under the familiar title of Stevenson's Regiment. ${ }^{23}$

Another body of volunteers was raised in Missouri, where Kearny recruited a battalion from a party of Mormons. These men were already on their way to California, where they expected to join a number of their fellow believers who had sailed from New York with the intention of procuring grants of land from the Mexican authorities. The seafarers arrived in San Francisco only to find that the American flag had preceded them. Although the personal force of their leader, Samuel Brannan, held them together for a while, they soon separated, and the majority gravitated naturally towards Salt Lake. ${ }^{24}$ Brannan stayed in San Francisco, became a conspicuous figure in local history, and was the first president of the Committee of Vigilance of 1851.

General Kearny experienced little difficulty in fulfilling the first portion of his instructions, for the occupation of New Mexico was quickly accomplished. The conqueror immediately announced the annexation of the territory to the United States, promulgated an elaborate organic law, and appointed a full staff of civil executives. ${ }^{25}$ When the report of the proclamation

23 See infra, p. 39.

24 See Daniel Tyler, Concise History of the Mormon Battalion in the Mexican War, 1881; Baneroft, California, V, pp. 469-498, 544-554; Sacramento Union, 1866, Sept. 11 6/1-4; James O'Meara, “A Chapter of California History,' Overland Monthly, ser. 2, XIV (1889), 625-630; B. H. Roberts, The Mormon Battalion, 1919.

${ }_{25}$ Cong. Docs., Ser. No. 499, Doc. 19, pp. 20, 26-73. See also R. E. Twitchell, History of the Military Occupation of New Mexico, 1909, pp. 84-94, 147-199; J. T. Hughes, Doniphan's Expedition, reprint by W. E. Connelley, 1907, pp. 201-202, 238-242 ; Thomas, Military Government, 101; 149; Birkhimer, Military Government and Martial Law, 62-63, 137. 
of annexation was received in Washington, Kearny was promptly informed that he should not repeat such a declaration in California, since incorporation of the acquired territory would depend upon governmental action. ${ }^{26}$

It may be inferred that President Polk was ready to allow much freedom to the commandants of New Mexico and of California, for in his Message of December 8, 1846, he stated with approval that the former civil government had been superseded in the conquered provinces, and that in some of them the military and naval commanders had established temporary governments, which conformed as far as practicable to the free institutions of the United States. ${ }^{2 \pi}$ But Congress proved jealously alert to any infringement of the legislative prerogative, and requested full information as to the affairs of the occupied territory. ${ }^{28}$ The President responded by transmitting the relevant documents, including the text of the laws for New Mexico, which had come to his attention after the delivery of his previous Message. He also stated that while he should approve of necessary regulations for the safety of the army of occupation, he should not approve such portions of the code as purported to establish a permanent territorial government, or confer political rights which could be enjoyed only by citizens. ${ }^{29}$

To Kearny himself a communication was sent under date of January 11, 1847, designed to guide him and his successor in the administration of California. After reference had been made to the obvious faults of the code for New Mexico, he was informed that the law of nations allowed a conquering power to establish a civil govermment for the purpose of preserving order,

26 Orders of Nov. 3, 1846, Cong. Docs., Ser. No. 499, Doc. 19, p. 15.

27 Cong. Docs., Ser. No. 493, Doc. 1, pp. 22-23. See also commendation of the Secretary of the Navy, ibid., 379.

28 Cong. Globe, 29 Cong., 2 Sess., p. 12 et seq.; Appendix, p. 43 et seq.

29 Message, Dec. 22, 1846, J. D. Richardson, compiler, Messagts and Papers of the Presidents, 1899, IV, 506-507. 
and that he was expected to exercise such an authority in a firm and judicious manner. But it was distinctly stated that the Federal Constitution had not been extended over the conquered people, and that the temporary regulations of the military régime could not be continued beyond the duration of a state of war without the authority of a treaty or a definite act of Congress. $^{30}$ When this letter was written General Kearny was already in California, and was confronted with difficulties which the Department of War had never foreseen. Learning of the rapidity and ease with which the ports had been occupied, he took scarcely more than a hundred men upon the long and difficult march from Santa Fé. ${ }^{31}$ Early in December the exhausted and hungry company reached the vicinity of San Diego, to find the Californians in arms against the Americans, and to engage the insurgents in a disastrous encounter at San Pasqual. ${ }^{32}$ Reinforcements sent by Stockton relieved a desperate situation, and the overland expedition arrived in time to participate in the final days of the insurrection. Its general, however, waited to assume command of the combined forces until more of his own troops should appear.

After peace with the belligerents was obtained by the Treaty of Cahuenga, negotiated by Frémont on January 13, 1847, Kearny felt that the time had arrived to take his place as military and civil executive. But Stockton was unwilling to relinquish his position and was determined to carry out his plan of installing Frémont as governor. He pursued this course in spite of protests; issued the civil commissions he thought necessary; appointed a legislative council to meet in March, invested the

30 Cong. Docs., Ser. No. 573, Doc. 17, pp. 244-247.

31 Baneroft, California, V, 336-339.

32 Bancroft, California, V, 339-356; V. M. Porter, "General Stephen W. Kearny and the Conquest of California,' Historical Society of Southern California, Annual Publications, VIII (1911), 95-127. 
new government with control on January 19, and departed for San Diego. ${ }^{33}$

Kearny did not endeavor to enforce his authority by arms, but proceeded quietly to the north. There he found a company of artillery, lately arrived from the East, and also Colonel Richard B. Mason, who had been sent to the Coast to relieve him. ${ }^{34}$ Commodore W. B. Shubrick, Stockton's successor, was at Monterey, and was quick to discountenance the claims made by Stockton and Frémont. Between the commanders of the land and naval forces was now established that cordial coöperation desired by the national authorities. On March 1, 1847, they made public a joint circular which announced Kearny's appointment as governor and fixed the capital at Monterey. At the same time Kearny issued a proclamation of a conciliatory character, ${ }^{35}$ but in accordance with the instructions of November 3, received by the hands of Mason, ${ }^{36}$ he forbore to declare formal annexation, as he had done in New Mexico. During the controversy with Stockton he had ordered the latter to cease all further proceedings relating to the formation of a civil government, ${ }^{37}$ and he now ignored Stockton's entire scheme. He confined himself to holding out the hope of speedy territorial organization by action of the United States government, and to amouncing that until changes could be accomplished by competent authority the existing laws would be continued in so far as they harmonized with the Federal Constitution. The principle thus stated was accepted

33 See Bancroft, California, V, 411-468; Proceedings of the General Court Martial in the Case of Lieutenant-Colonel Frémont, 1847 (Cong. Docs., Ser. No. 507, Doe. 33); John Bigelow, Memoir of Frémont, 1856, p. 222 et seq.; F. S. Dellenbaugh, Frémont and '49, 1914, pp. 355-380.

34 Bancroft, California, $\mathrm{T}, 436,518$.

35 Circular and proclamation in Cong. Docs., Ser. No. 573, Doe. 17, pp. 288-289. The latter was made public March 4 (ibid., 28t).

36 See supra, p. 33. Dates of the reception of Kearny's orders are given in Court Martial of Frémont, 48-55. The orders were reaffirmed June 11, 1847 (Cong. Docs., Ser. No. 521, Doc. 70, p. 29).

37 Cong. Docs., Ser. No. 557, Doc. 18, pp. 267, 268. 
as conforming with the orders of January 11, which shortly arrived. $^{38}$ It became from that time the basis of administration in California, but the anticipated civil organization proved illusive, and no competent authority effected changes in the organic law of the country until the people themselves adopted the state constitution of 1849 .

While Kearny was thus employed in the north, Frémont was still acting as governor in Los Angeles, but after many stormy days he was obliged to yield to the general's superior authority, and to return to Washington, where he was tried and convicted of insubordination. The court martial recommended his dismissal from the army, and although the President remitted the sentence, Frémont resigned and continued his career in the West as a private citizen.

The discord created by the disputes between the American officers reacted most unfortunately on conditions in California. Not only was the work of organization seriously delayed, but the conflict of authority produced a question as to the validity of the obligations assumed by Stockton and Frémont in raising forces and requisitioning supplies. They had promised to pay the California Battalion more than the rates allowed by Congress, and the members of that company refused to be mustered into the volunteer service. Their status therefore remained irregular, and their claims, as also those of civilians who had furnished food and horses, were a matter for tedious and unsatisfactory Congressional action. ${ }^{39}$ A most natural resentment was thus created against the authorities and serious antagonism engendered among the defrauded Californians, while many Americans felt that Stockton and Frémont had tried to give them a satisfactory govermment, but that the succeding military commandants were indifferent to their needs.

38 See supra, p. 34. The orders were received April 23 (Cong. Docs., Ser. No. 573 , Doc. 17 , p. 286 ).

39 Cong. Docs., Ser. No. 573, Doc. 17, pp. 287, 315; Bancroft, California, $\mathrm{V}, 462-468$. 
Frequent complaints of this sort were registered in the first newspaper that appeared in San Francisco, the California Star, published by Samuel Brannan. The initial issue, ${ }^{40}$ dated January 9, 1847, expressed the hope that an immediate acceptance of Stockton's scheme for a temporary government might end the confusion that existed as to the laws in force in California. On February 6 the Star gave the names of the governor, the secretary, and the members of the legislative council, as appointed by Stockton. On the thirteenth it printed a long editorial, rejoicing over the anticipated meeting of the council, and urging it to call a convention which should draw up a territorial constitution and so put a stop to the irregularities of the alcaldes, who were "all over the country, assuming the power of legislatures, issuing and promulgating their bandos and laws and orders and oppressing the people." Subsequent issues told of the selection of delegates to the proposed legislative council from San Francisco, ${ }^{41}$ Sonoma, ${ }^{42}$ and Santa Clara. ${ }^{43}$ When reports of these proceedings were sent to Kearny, he replied that no such council would then be convened. ${ }^{44}$ This fact was published in the Star, with the announcement that a call for a legislative assembly might be made within a short time. ${ }^{45}$ In the issue of March 13, 1847, there was an article setting forth the imperative need of land laws. On March 27 the editor wrote: "We have not been able to discover any traces of written law particularly.

40 The Monterey Californian, started August 15, 1846, by Walter Colton and Doctor Robert Semple, was friendly to the military authorities. The California Star was started as an organ of protest against their arbitrary methods. See E. C. Kemble, "History of California Newspapers," Sacramento Union, 1858, Dec. $25 \%$. An “Extra in Arlvance of the California Star', had been printed about the first of November, 1846 (Hittell, San Francisco, 109).

41 California Star, 1847, March 6 1/1.

42 California Star, 1847, March $6 \% 3 / 1$.

43 California Star, 1847, March $6 \% 1$.

44 Letters, March 3, 4, 1847, Cong. Docs., Ser. No. 573, Doe. 17. p. 290.

Kearny's official correspondence is given, ibid.. 283-313.

45 California Star, 1847, Mareh $20 \% 1$. 
applicable to this territory except the Bandos of the Alcaldes,", and remarked that, in the absence of formal statutes, "some contend that there are really no laws in force here, but the divine law, and the law of nature."

There was other evidence of hostility to the administration. Edwin Bryant, the alcalde of San Francisco, resigned in May, and two parties were then formed, which respectively petitioned the governor for the appointment of George Hyde and John Townsend. ${ }^{46}$ Hyde was given the position, and a meeting for protest was summoned by the following handbill $:^{47}$

\section{The People's Voice Stifled by Intrigue}

People of San Francisco, rally for your rights!!! A majority of your number have petitioned the Govr of this Territory to appoint John Townsend Esq. to succeed Edwin Bryant Esq., as Alealde of this district. Intrigue has defeated this voice of the people-George Hyde is appointed!!! Will you submit to this? The unrevoked Proclamation of Govr Stockton gives you the privilege of electing Alcaldes for yourselves. - The laws of California guarantee the same Right.

Assemble at Brown's Hotel at seven o'clock this evening, and assert your Rights.

San Franco, May 30th, 1847.

Many of the People.

Major James A. Hardie, who attended the meeting in his official capacity, as commander of the northern military district, put a stop to proceedings by announcing that any attempt to elect an alcalde in the place of the governor's appointee would be repressed by military authority. ${ }^{48}$ This incident is scarcely noted, even by Bancroft, but it derives significance from the appeal to Stockton's "unrevoked proclamation," and from the comment upon it made by William A. Leidesdorff, who wrote

46 Archives, "Unbound Does.,", 114-115.

47 Arclives, "Unbound Docs.," 110.

4 4 Hardie to Mason, May 30, 1847, Archives, "Unbound Docs.," 109 110. Reply, Cong. Docs., Ser. No. 573, Doc. 17, p. 325. 
that the party opposed to Hyde was an "open advocate of California being an independent government and not a territory of the United States.", 49

Fortunately at this time Kearny's position had been greatly strengthened by the arrival of Stevenson's Regiment, which landed early in March. This put at his command a force sufficient to quell any dangerous tendency towards insubordination. The volunteers were assigned to garrison duty, chiefly in the recently disaffected southern area, where they rendered excellent service. The roster of the regiment contains the names of many men who became leading citizens of the state, and of others who achieved unenviable notoriety as New York rowdies, quickly acclimated to the welcome license of conditions in California, and potent for evil in city and mining camp. ${ }^{50}$

49 Leidesdorff to Mason, May 30, 1847, Archives, "Unbound Does.," 68. 50 See F. D. Clark, The First Regiment of New York Volunteers, 1882; Bancroft, California, V, chap. $19 ; \mathrm{Z}$. S. Eldredge, Beginnings of San Francisco, 1912, II, 552-556. It was sometimes called the Seventh Regiment. 


\section{COLONEL RICHARD B. MASON, MILITARY GOVERNOR}

Kearny acted as governor for three months only. On May 31, 1847 , he was succeeded by Colonel Richard B. Mason, who filled the position for nearly two years.

California was fully pacified when Mason assumed his office, but past conflicts had left a heritage of bitterness between the Americans and the Californians, and the discord in the ranks of the victors had prevented any constructive work for the improvement of local conditions.

The little towns, both north and south, were still under the rule of their alcaldes, some of whom had been elected according to Stockton's instructions, while some had been appointed by Kearny. One can realize from the hasty sketch of early affairs given in the foregoing chapter that the American alcaldes inherited not only the traditional institutions of the Spanish system but also the confusion resulting from the years of turmoil in Mexico and California, during which acts had been passed and repealed and renewed until their real meaning was lost in a maze of contradictions.

The laws in force at the time of the seizure were held to be those of 1837 , but they were practically inaccessible in printed form. One pioneer explained that under the Mexican system laws were transmitted in writing to the alcaldes, and promulgated to the people by word of mouth. ${ }^{1}$ Such a method would account for the almost total lack of written statutes. Edwin Bryant, alcalde of San Francisco in February, 1847, could find

1 R. F. Peckham, San José Pioneer, 1877, July 7 (Serapbook in the Bancroft Library, Eventful Life, p. 19). 
no law books except a digest of the Laws of the Indies, published in Spain a century earlier, and a small pamphlet that defined the powers of judicial officers of the Mexican republic. ${ }^{2}$

It was a common impression that the former magistrates had administered the laws "in accordance with the principles of natural right and justice,"'3 and in one of his earliest despatches Colonel Mason wrote to the alcalde of Sonoma :

Having been only two days in office as governor, I am not at this time prepared to say what are the extent of your powers and jurisdiction as alcalde; you must, for the time being, be governed by the customs and laws of the country as far as you can ascertain them, and by your own good sense and sound discretion.

Such, indeed, had been the only guides for the conduct of the American alcaldes during the whole of their official existence, and some of them had developed very liberal conceptions of their responsibilities. The best known interpretation of the alcalde s office may be found in the diary of Alcalde Colton, of Monterey. Its pages give a vivid impression of the authority assumed by that paternal magistrate. He wrote on different occasions:"

My jurisdiction extends over an immense extent of territory, and over a most heterogeneous population.... All have come here with the expectation of finding but little work and less law. 'Through this discordant mass I am to maintain order, punish crime, and redress injuries. * * *

It devolves upon me duties similar to those of mayor of one of our cities, without any of those judicial aids which he enjoys. It involves every breach of the peace, every case of crime, every business obligation, and every disputed land-title within a space of three hundred miles. From every other

2 See Browne, Debates, Appendix, p. xxv; Edwin Bryant, What I Saw in California, 1848, p. 436; T. B. King. California, 1850, p. 3. By July, 1848 , Colton was familiar with more satisfactory Mexican codes (Three Years, 249).

3 Edwin Bryant, What I Saw in California, 436; Charles Wilkes, Narrative of the United States Exploring Expedition, 1844, V, 222.

4 Letter, June 2, 1847, Cong. Docs., Ser. No. 573, Doc. 17, p. 317 . A letter dated May 27 harl asked a definition of the alcalde's duties (Archives. “'Unbound Does.,' 110-111).

5 Colton, Three Years, 19, 55. 
alcalde's court in this jurisdiction there is an appeal to this, and none from this to any higher tribunal. Such an absolute disposal of questions affecting property and personal liberty, never ought to be confided to one man. There is not a judge on any bench in England or the United States, whose power is so absolute as that of the alcalde of Monterey.

Bancroft declared that these oft quoted paragraphs in reality described the duties of a Mexican prefect, but those officers were not installed during the first years of the American occupation. In the absence of higher authorities, the first alcalde of each district was recognized as ex-officio judge of first instance, with jurisdiction in criminal cases, and other alcaldes of the district were subordinate to him. ${ }^{6}$ Colton, however, made no distinction between the functions of the first alcalde of a district, and those of an ordinary municipal magistrate, and since he is often cited as an authority on the position of California alcaldes this characterization has tended to exaggerate the popular conception of their constitutional status.

As a matter of fact, Mr. Colton was never very exactly informed as to the Mexican precedents. In such an important matter as land laws he stated that the former authorities had been governed solely by

"The simple plan,

That they shall take who have the power,

And they shall keep who can.' 7

It is not surprising that his own disposition of public land was irregular, and his records carelessly preserved!

Colonel Mason proved himself well fitted to cope with the difficult situation in which he was placed. His choice of

6 See Bancroft, California, VI, 258 note 8; Cong. Docs., Ser. No. 573, Doc. 17, pp. 675,762 . Colton's exaggerated conception of an alcalde's position is noted in O. K. MeMurray, "Beginnings of Community Property System in California,' California Law Review, III (1915), 360-361.

${ }^{7}$ Cong. Docs., Ser. No. 573, Doc. 17, p. 170. Colton's methods were criticized (ibid., 761). In spite of this, his work as a whole was so valuable that he was not recalled to naval duty (Shubrick to Mason, Sept. 15, 1847, Archives, "'Unbound Does.,"' 127). 
assistants was particularly fortunate. Lieutenant William T. Sherman, the assistant adjutant general, was an efficient aid in military affairs, and Lieutenant Henry W. Halleck, the secretary of state, had an excellent understanding of civil and international law. ${ }^{8}$ The work of administration was greatly hampered by the lack of legal treatises, both Mexican and American. Mason and Halleck had a few American works, but as late as April, 1849, the senior military officer on the Coast was unable to procure in California a copy of the laws of the United States. ${ }^{9}$ The little staff at headquarters made sincere efforts to become familiar with the Mexican statutes, and it was Mason's purpose to prepare an English digest as a guide for the officials in California. This was completed in the course of a year, but before it could be printed, the conclusion of the war led the governor to believe that its publication would be unnecessary.

The best source of information on the events of the period is the collection of official letters accompanying President Taylor's Message on California and New Mexico, January 21, 1850. ${ }^{10}$ This is supplemented by a manuseript volume in the Bancroft Library which contains copies or summaries of many letters from citizens and alcaldes, received by the governors from 1846 to 1850. ${ }^{11}$ This correspondence shows that Colonel Mason was a strict disciplinarian in his interpretation of the subordination of municipal executives to military authority. Instead of allowing the freedom of election sanctioned by Stockton, he insisted

$8 \mathrm{~A}$ useful study of this period has been made by Flora A. Wright, in a master's thesis, Richard Barnes Mason, 1919, MS in the University of California Library. See also S. H. Willey, "Recollections of General Halleck,' Overland Monthly, IX (1872), 9-17; W. T. Sherman, Memoirs, $1875, \mathrm{I}$.

9 See Cong. Docs., Ser. No. 573, Doc. 17, pp. 263-264, 453, 722. It was impossible to procure some needed legal books except from visiting ships of war (H. W. Halleck, International Law, 1861, Preface.)

${ }_{10}$ Cong. Docs., Ser. No. 573, Doc. 17. A slightly different arrangement is given in Ser. No. 557, Doc. 18.

11 Cited here as Archives, "Unbound Docs." 
that it was the governor's prerogative to appoint the alcaldes, or to issue special permission for their election. He also kept a sharp watch over their actions, and demanded reports on matters of importance. They often appealed to him for advice and direction, and in so far as he was able he responded with precedents drawn from Mexican usage, and gave instructions to cover individual cases. Other appeals were made by contestants dissatisfied with the decisions of alcaldes. These were sometimes entertained, although more often they were dismissed on the ground that there was no higher tribunal to which an appeal might be carried. But when it was necessary, Colonel Mason exereised the governor's power of overruling the alcaldes, reversed decisions as he thought fit, and removed at least one alcalde from office. ${ }^{12}$

The eivil authority of the alcaldes did not give them jurisdiction over offenses committed by or upon soldiers; crimes of that sort were subject to punishment by a court martial or by a military commission. But difficulties attended even the administration of martial law. Lieutenant Sherman was obliged to inform the judge advocate of a military commission in Los Angeles that he could not send proceedings of other commissions to serve as precedents in a trial for burglary; that the best he could do was to forward extracts from the statutes of Missouri, and a digest of the laws of Texas-the only law books to which he had access which treated the crime. He also instructed his correspondent that the commission must revise the sentence that had already been pronounced-a term of imprisonment in a state prison-since there was not such a penitentiary within thousands of miles. ${ }^{13}$

12 Letters respecting appointments are found in Cong. Docs., Ser. No. 573, Doc. 17 , pp. $433,443,451,473,511,564$; appeals, 391,412 ; sentences, 410 , $445,475-476,487,488$; removal of Alcalde Nash, of Sonoma, 295, 318, 320, 344, 375, also A rchives, "Unbound Docs." 112, 118-119, 145. See also Baneroft, California, V, 606-611.

13 See Cong. Docs., Ser. No. 573, Doc. 17, pp. 351-354, 402-403. 
The total lack of prison facilities gave rise to most perplexing problems. Under the Mexican system the punishment of white culprits had usually taken the form of a fine, while Indians had been whipped. In consequence the jails were not constructed for other than temporary confinement, and when a guard was necessary it was furnished by the citizens. ${ }^{14}$ The inventory of prison equipment in Yerba Buena, January, 1846, consisted of

1 serviceable padlock.

2 ehairs.

1 pair of shackles which are missing and should be searched for in passing. 15

It is said that a hungry prisoner of that town called on one of the first American alcaldes with the door of the calaboose on his back, and demanded his breakfast. ${ }^{16}$

In spite of Mason's efforts to adhere to local usage, radical changes were gradually introduced. The most striking innovation was the adoption of the jury system. Under the Mexican practice, certain classes of disputes might be adjusted by "trials of conciliation," conducted before three arbitrators, who rendered a decision by vote of the majority. While these hombres buenos exercised some of the functions of the American juryman, the impartial jury of common law, rendering a unanimous and binding verdict, was not known in California. ${ }^{17}$ Nevertheless Alcalde Colton had not been in office six weeks before he

14 Stevenson to Mason, from Los Angeles, July 11, 1848, Archives, "Unbound Does.,', 164. Mason planned to erect some secure prisons (Cong. Docs., Ser. No. 573, Doc. 17, p. 558), but apparently the plan was not carried out (ibid., 790).

15 Case of U.S. vs. Limantour, Transeript, IV, Exhibit O, p. 35.

16 J. H. Brown, Reminiscences and Incidents of "The Early Days" of San Francisco [1886], p. [30]. See also Eldredge, San Francisco, II, 545.

17 "'There was nothing like trial by jury known to the Mexican system; and there was no law authorizing anything of the kind"' (Hittell, California, II, 663). Bryant spoke of the function of these courts as being similar to that of the American jury (What I Sav in California, 436). 
introduced it into his court, where, in spite of the novelty of the method and an overwhelming confusion of tongues, the verdict was cheerfully accepted by the plaintiff, the defendant, and the assembled inhabitants of Monterey. The alcalde closed his account of the trial with the words: "If there is anything on earth besides religion for which I would die, it is the right of trial by jury." 18

Our historians have treated as a matter of course this fitting of the Anglo-Saxon jury into the court of the California alcalde. Yet it was a step of profound revolutionary significance in that it waited not at all for treaties or statutes or even for a popular demand, but in order to meet the emergencies of a moment it altered the institutions of centuries by the sole initiative of a petty alcalde. The history of the state provides no example more typical of the serenity and self-confidence with which Americans confronted the exigencies of their daily life.

The example set in Monterey was soon followed in San Francisco, ${ }^{19}$ and it presently received official sanction when Colonel Mason gave orders that juries of six or more should decide all civil cases involving amounts exceeding one hundred dollars, and all criminal cases of a grave character. It was expressly stipulated, however, that the records of criminal convictions should be reviewed by the governor before the infliction of any punishment. ${ }^{20}$ The method was not entirely successful,

\footnotetext{
18 Colton, Three Years, 47-48.

19 Bryant said that the second jury trial was held in San Francisco before "judge", [alcalde] Bartlett (What I Saw in California, 328). Samuel Brannan was then tried for mismanaging the Mormon funds. The Annals, p. 186, called this the first jury trial in California, and so did Franklin Tuthill (History of California, 1866, 214-215), but the priority of the jury trial at Monterey is more often acknowledged. By January, 1817, Americans expected juries to be called, and the California Star, Jan. $9 \%$, noted with indignation a case in which that privilege had been denied.

20 Cong. Docs., Ser. No. 573, Doc. 17, pp. 384, 413-414, 419--422, 439$440,452,487,494,763$.
} 
as native Californians were reluctant to sentence their fellow countrymen, ${ }^{21}$ and the alcaldes did not always await official sanction of their sentences. William Blackburn, of Santa Cruz, for instance, executed a murderer convicted by a jury, and afterwards reported the case for Mason's approval, explaining his haste on the ground that it was difficult, with volunteer guards, to confine the prisoner securely. ${ }^{22}$

Other modifications of Mexican usage soon appeared. The alcaldes often obeyed the direction to administer justice with "good sense and sound discretion" by turning to American statutes in the absence of books of Mexican law, and they were quite content if any stray volume could give a hint of precedent in the cases that eame before them. ${ }^{23}$ In the southern region where society was more firmly established there was closer adherence to Mexican traditions, but in the new towns of the North, where the Americans soon predominated, there was a greater tendency to ignore old customs. ${ }^{24}$

21 Archives, "Unbound Does.," 122. See also the experience in Louisiana, infra, p. 420 .

22 Archives, "Unbound Does.," 108; California Star, 1847, Sept. 11 \%; W. F. Swasey, Early Days and Men of California, 1891, p. 180 ; History of Fresno County, 1882 , pp. 50-51. It was also reported that while under the influence of liquor Blackburn ordered a horse thief executed, and when sober wished to go on with the trial. The sheriff, who had concealed his prisoner, pretended for a time that the penalty had been inflicted. "Nerer mind," responded Blackburn, "proceed with the trial. All orders and judgments of this court must be justified by due and legal proceedings had.', The culprit was then brought into court, tried and executed (Sacramento Union, 1871, Dec. $2 \%$ ).

23 The California Star, 1847, Jan. $23 \% 1$, reported that the alcalde at Sonoma had adopted the whole volume of the statutes of Missouri, and the issue of July $33 \frac{2}{2}$, printed a notice of the court. conched in the formal terms of American jurisprudence. See also Cong. Docs., Ser. No. 573, Doc. 17, p. 762 .

2* In his thesis From Alcalde to Mayor, p. 198, Robertson studied the official personnel of the different districts, 1846 to 1850 . He concluded that in San Francisco and Sonoma only Americans held office, in Santa Barbara only Californians; in Los Angeles all were natives at first, but they gradually gave way to Americans, while in other towns offices were divided between the two nationalities. 
While the theory of beneficent military government under the ancient statutes was both useful and ornamental in official proclamations, the control of California by the native regulations became increasingly difficult with every month. The correspondence of the authorities shows that they discountenanced such an exaggerated ideal of the alcaldes' authority as was expressed by Colton, but we are forced to conclude that in spite of this many of the loeal magistrates greatly exceeded the limits contemplated by the laws of Mexico or the orders of the American officers. ${ }^{25}$ The neweomers from the United States found this arbitrary authority intolerably galling. The California Star kept up a constant fusillade of complaints and demands for civil organization. The editor gradually acquired some knowledge of the Mexican institutions presumably in force, but he continued to deplore that their imperfect establishment virtually left the alcaldes in supreme control, and he expressed the earnest hope that Colonel Mason would quickly promulgate some form of eivil government.

Week by week the hope of assistance from headquarters grew less, and on July 28 the alcalde of San Franciseo, George Hyde, took the first step toward improvement by selecting six gentlemen to act as a council until the governor should think fit to sanction an election. Colonel Mason had already realized the need for such a body, and had drawn up a plan for the town government of San Francisco, but its transmission had been delayed, and it was not forwarded to Alealde Hyde until the

25 C. E. Pickett wrote to Kearny, March 23, 1847, that the alcaldes throughout California were "but a mockery to law and justice, assuming and exereising prerogatives and powers far beyond any clothed [sic] then by the Mexican or United States' laws"' (Archives, "Unbound Does.,", $149)$. J. S. Ruckel, on Dee. 28, 1847, described a deplorable state in San José (ibid., 132). On July 11, 1848, Colonel Stevenson reported that the alcalde of Santa Barbara assumed more authority than belonged to the President of the United States (ibid., 24). See also Bancroft, California, VI, 268 note 31 ; California Star, 1847, June $19 \% 1$. 
latter had announced the appointment of his council.. ${ }^{26}$ The initiative, therefore, came from the citizens, not from the central authority, a characteristic California precedent, but in this case the governor did not consider the movement insubordinate, and gave permission for an election, which was held on September 13. A few simple regulations were quickly formulated, a constable was appointed, and the members of the council were also authorized to act as conservators of the peace. ${ }^{27}$

Unfortunately, the creation of the council did not greatly better affairs in San Francisco. Hyde was under constant charges of incompetency and irregularity of conduct, and, although Mason did not think his removal necessary, he finally resigned after a year of wrangling and disorder. ${ }^{2 s}$ Town councils were elected in some other places, but little information as to their services can be found in the correspondence of the governor. ${ }^{29}$

More serious even than the despotism of the alcaldes was the confusion and uncertainty that complicated every question relative to the ownership of real estate. The former laws had permitted the governors and pueblo authorities to make grants of land to private parties, and nearly all the desirable coast country

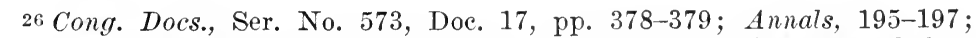
Baneroft, California, V, 648-650; Moses, Establishment of Municipal Government, 30-36. Councilmen W. D. M. Howard, E. P. Jones, and R. A. Parker became members of the Committee of Vigilance of 1851.

27 Laws of the Town of San Francisco, 1847, pp. 4, 8. Two constables were appointed at first, then one who was to give his entire time at a salary of fifty dollars a month.

28 Official correspondence in Cong. Docs., Ser. No. 573, Doc. 17, pp. 361362, 494, 499-500; Archives, "Unbound Docs.,"' 7, 27-42, 106-107. Hyde defended himself in his Statement of Historical Facts, 1878, MS in the Baneroft Library. See also Baneroft, Califormia, $\mathrm{T}, 649-652$; and his Chronicles of the Builders of the Commonwealth, 1891-1892, II, 286-294.

29 See notes to Bancroft, Califomia, V, chaps. 23, 24; Cong. Docs., Ser. No. 573, Doc. 17 , pp. 417, 431, 446, 498. Allusions to councils oceur in Archives, "Unbound Docs.," 117, 121, 122, 339-340. A few papers of the "Junta or Council"' of San José, dated May 24 to Nov. 5, 1847, are preserved in the office of the city clerk. 
south of Sonoma was claimed by virtue of such grants, sometimes by three or four alleged owners. Under the obligations of international law the new régime was bound to recognize titles which were valid under the old; but until documentary records could be investigated, and boundaries corrected by accurate survey, it was impossible to ascertain what land was legally in private hands, and what might be considered public property. In the meantime private conveyances could carry only doubtful rights, and the public tracts were closed to settlers, as the Federal Government had issued no regulations concerning them, and Colonel Mason refused to make grants that might ultimately be declared invalid. ${ }^{30}$ At the same time the Americans who had participated in the bitter, if insignificant, struggle of the "Conquest", felt themselves to be victors on conquered soil, ${ }^{31}$ and the immigrants who had arrived later supposed that the country was open for homesteads as had been other parts of the frontier. Many sturdy pioneers reached California at great risk and hardship, only to find that it was impossible to preëmpt land from the public domain, or even to purchase it under any satisfactory guaranty. ${ }^{32}$ This situation transformed them into an army of squatters, hostile alike to Mexican landholders and to Federal authorities, and inclined, in a later decade, to defend their squatter's holdings with the rifle, as well as with endless litigation.

In order to clear the way for intelligent action in the matter of titles, Colonel Mason directed Halleck to collect and examine the archives, which were scattered up and down the state. The latter could not make a report on the subject until March, 1849, and he then expressed the opinion that many of the old deeds

30 Cong. Docs., Ser. No. 573, Doe. 17, p. 321.

31 See Colton, Three Years, p. 228.

32 The California star, 1847, Feb. $27 \% 1$, noted the desperate plight of American immigrants who had exhausted their resources and could not secure the anticipated homes. 
were invalid, either from fraud or from technical imperfections. ${ }^{33}$ Meanwhile Colonel Mason acted with extreme caution. He construed the Mexican regulations as permitting the sale of town lots by the alcaldes for municipal expenses, but he held that the governor had no authority either to rent or to sell the public land. ${ }^{34}$ In the case of disputed titles he advised rival claimants to arbitrate their differences until such time as proper courts could be established. ${ }^{35}$ In the interim he prepared for future adjustments by appointing surveyors to begin the work of defining boundaries.

There were many other perplexities that confronted the governor of California in 1847: questions of revenue, of military equipment, of the control of Indians, of the restraint of lawlessness on the part of insurgent natives and restless immigrants. Yet it seems safe to say that during the period of the war social order was fairly well preserved. The governor commanded the respect and obedience of the people, and kept a close watch over local affairs; there was constant communication between headquarters and the scattered posts and settlements, and military aid was ready to sustain the alcaldes in the discharge of their duties; $;^{36}$ there were supervision, and accountability, and discipline, and there was a fundamental element of definite law behind the "good sense and sound descretion" that guided the untrained officials in their judicial capacity. There was, to be sure, constant complaint in the newspaper, with unceasing demand for a more adequate system of govermment, but

33 Cong. Docs., Ser. No. 573, Doc. 17, pp. 118-133. See also W. C. Jones, Report on the Subject of Land Titles in California (Cong. Docs., Ser. No. 589, Doc. 18) ; Dwinelle, Colonial History of San Francisco; Baneroft, California, VI, 529-581; Hittell, California, II, 739-755; Rodman, History of the Bench and Bar of Southern California, 52-85; William Kelly, Excursion to California, 1851, I, 199-213.

34 Cong. Docs., Ser. No. 573, Doc. 17, pp. 321, 440.

35 Cong. Docs., Ser. No. 573, Doc. 17, pp. 380, 389, $435,440$.

36 Cong. Docs., Ser. No. 573, Doc. 17, pp. 340, 349-350. 
there was no actual defiance or insurrection, and the Americans awaited improvement with what patience they might command. In retrospect we can see that the governor was helpless to effect any permanent reforms, but the insurmountable difficulties of the situation were not fully appreciated by the men who naturally resented a policy that neglected their pressing need for civil organization. ${ }^{37}$

37 The California Star became constantly more emphatic in its condemnation of existing conditions. On Dec. 25, 1847, it presented a most gloomy picture of eriminal conditions, and on Jan. 22, 1848, it printed a violent protest against a state of affairs that allowed the alcaldes to "exercise authority far greater than any officer in our Republic-the President not excepted." Again, on Jan. 29: "They [the governors] had no power to allow the people to form a government... but yet they have the right to appoint and continue Alcaldes in office, for an indefinite period, of notoriously inefficient, unprincipled and dishonest characters, and to permit their assuming unprecedented, unwarrantable and anti-republican powers." 


\section{EL DORADO}

It must be remembered in making a study of this situation that the statesmen who had advocated the acquisition of California by the United States desired the territory because of its strategic advantage in the development of commercial relations with countries bordering on the Pacific Ocean. Farsighted men anticipated a day when the natural advance of population would build American cities beside the harbors of the Coast to command the great trade routes, and to stand guard over the western portals of the nation. But in their vision that day was sufficiently remote to allow a gradual development of the Federal policies, and a deliberate adjustment of the local problems that might arise from the conflict between Spanish and American institutions.

Since the earliest pioneers had turned their faces toward the western wilderness, the American frontiersman had exhibited an amazing capacity for taking care of himself. Hardly had the explorer and the trapper threaded the most distant forests and traced their hidden waters before a creaking van lumbered behind them, bearing the household gear of some intrepid settler who was ready to transplant into virgin soil the life of an older group from which he had detached himself. His wife sat beside the driver, with a baby in her arms, while older boys and girls trudged along the uncleared track. When the animals were finally unyoked the first task undertaken was the building of a rough log house that was to become a unit in the social organization of a new community. And slowly or rapidly the new community formed itself, always out of the elements of the older 
commonwealths, reproducing with more or less modification the institutions of the parent society, until an increased population gave evidence of an accomplished novitiate, and warranted full admission into the sisterhood of states. There had been every reason to expect that the familiar sequences of the western frontier would be repeated with slight variation on the Pacific Coast, and in spite of the hardships of the overland journey the usual type of settlers, men, women, and children, quickly appeared beyond the Sierra Nevada Mountains.

A treaty of peace with Mexico was signed at Guadalupe Hidalgo, February 2, 1848. On that day no human wisdom could foresee that in California all precedents of westward emigration would be shattered by an overwhelming local emergency, and the coincident development of a tremendous national crisis. Gold had been discovered in January; by midsummer the state was in a frenzy of excitement, and at the close of 1849 the population was increased by approximately eighty thousand new arrivals. ${ }^{1}$ There was instant need for the establishment of a strong government, and yet Congress could take no action on the subject without precipitating a dangerous quarrel between the advocates and the opponents of the extension of slaveholding territory. As a result the history of California was for a time inextricably bound up with the struggle over an institution that was already forbidden on Mexican soil, ${ }^{2}$ was repugnant to a majority of the American settlers, and was unsuited to every industry likely to develop on the Pacific Coast.

1 There are no accurate statisties of the influx. The Memorial presented to Congress at the time of the application for admission, estimated the white population, Jan. 1, 1849, at 26,000-Native Californians, 13,000; Americans, 8000 ; other nationalities, 5000: Jan. 1, 1850, total 107,000-Californians, 13,000; Americans, 76,000; other nationalities, 18,000 (Browne, Debates, Appendix, pp. xxii-xxiii). Some allowance should be made for exaggeration (see Bancroft, California, VI, 158-159; Hittell, California, II, 700; J. S. Hittell, San Francisco, 139-140).

2 Slavery was abolished in Mexico by a decree of Sept. 15, 1829 (Hittell, California, II, 115-116). 
The situation in Washington may be summarized very briefly. On August 8, 1846, a month and a day after the occupation of Monterey, a bill was introduced into the House of Representatives asking for an appropriation to negotiate the adjustment of boundaries with Mexico. To that bill an amendment was offered by David Wilmot, of Pennsylvania, providing: "That as an express and fundamental condition to the acquisition of any territory from the Republic of Mexico by the United States... neither slavery nor involuntary servitude shall ever exist in any part of said territory, except for crime, whereof the party shall first be duly convicted.',3 The resolution was not an expression of extreme abolition sentiment, but rather of the determination of a large number of Northern men to prevent the further extension of slaveholding territory. They controlled a majority in the House, and the bill passed, as amended, but defeat was predicted in the Senate, where the measure was still under discussion when the session adjourned. The essentials of the Wilmot proviso subsequently reappeared in various forms and always met with ultimate failure; but the discussions crystallized the sectional discord of North and South into two opposing groups, equally determined in purpose, and so equally divided in power that neither could dominate the situation.

The hostile attitude assumed by some members of Congress when they criticized the steps towards civil organization taken by Stockton and Kearny was a direct outcome of this discord, for neither party was willing to tolerate a delegation of Congressional power that might result in establishing a precedent for the future. So long as the war continued it was possible to insist upon the temporary and military nature of the rule extended over the conquered territory, and Congress refrained from action. The President suggested formal organization as

\footnotetext{
3 Cong. Globe, 29 Cong., 1 Sess., p. 1217. It is unnecessary to discuss here the history of the discord over slavery. Its existence, not its origin, was the fact that affected conditions in California.
} 
soon as he was convinced that the acquisition of California and New Mexico would be made permanent. ${ }^{4}$ When he announced the ratification of the treaty of peace he again urged that the people of the annexed areas should be given civil institutions, ${ }^{5}$ but Congress adjourned on August 14, 1848, without adopting any constructive measures for California and New Mexico.

It is probable that in the spring of 1848 Colonel Mason had determined to initiate some new methods in the civil organization of California. In May he sent to the printer the manuscript of a digest of the Mexican laws, and in anticipating its early publication he announced that it would provide for the organization of a higher court, and also for the appropriation of funds for constructing jails. The press, however, was deserted before the laws were printed, and after the termination of the period of the war Mason felt that the changed status of California rendered his compilation out of date. ${ }^{6}$

The ratification of the treaty with Mexico was proclaimed in California by Governor Mason on August 7, 1848. ${ }^{7}$ He then acknowledged with regret that California had not been placed upon a territorial basis before his dispatches left Washington, although he hoped that Congress had subsequently passed the requisite acts, and that the representatives of civil government would presently appear. Meanwhile he was greatly embarrassed by the absence of any orders covering the emergency except a brief note, dated nearly five months earlier, which had directed

\footnotetext{
4 Richardson, Messages, IV, 542.

5 Richardson, Messages, IV, 589-590.

6 See Cong. Docs., Ser. No. 573, Doc. 17, pp. 489, 555, 558, 559, 586, 677; Browne, Debates, Appendix, p. xv. The Alta California, 1849, June $14 \%$, said that a book of "laws for the better government of California"' had come from the press a few days before the news of peace was received, and that in consequence of the changed status of California Governor Mason never published nor attempted to enforce those laws. Bancroft spoke of the code as if it had been promulgated (California, VI, 263), but Hunt corrected the statement ('Legal Status of California,', as eited, 396).

${ }_{7}$ Cong. Does., Ser. No. 573, Doe. 17, pp. 590-591. See also the comment of G. W. Crawford, secretary of war, ibid., 233.
} 
him to take proper measures for the permanent occupation of Upper California as soon as he should receive official news of the ratification of the treaty of peace. ${ }^{8}$ Thus thrown upon his own judgment, he shaped his conduct by the broad principles of international law. Decisions in other cases had established the point that until changes could be made by competent authority, a ceded territory should retain its prior local laws, or should revert to them if they had been modified by the temporary authority of a military commander. ${ }^{9}$ It was therefore announced that the existing laws would remain in force although greater freedom would be allowed in the matter of local elections.

It seems incomprehensible that definite instructions were not sent to Colonel Mason as soon as peace was declared, but no such official message was written until as late as October, 1848, when the Secretary of State and the Secretary of War, under circumstances that will be narrated hereafter, sent out letters which embodied the theory of the administration as to the status of the country. Secretary Buchanan then wrote $:^{10}$

By the conclusion of the treaty of peace, the military government which was established over them [the people of California] under the laws of war...has ceased to derive its authority from this source of power.... The termination of the war left an existing government, a government de facto, in full operation; and this will continue, with the presumed consent of the people, until Congress shall provide for them a territorial government. The great law of necessity justifies this conclusion. The consent of the people is irresistibly inferred from the fact that no civilized community could possibly desire to abrogate an existing government when the alternative presented would be to place themselves in a state of anarchy, beyond the protection of all law, and reduce them to the unhappy necessity of submitting to the dominion of the strongest.

s Orders of March 15, 1848, Cong. Docs., Ser. No. 573, Doc. 17, p. 255.

9 See Browne, Debatcs, remarks of C. T. Botts, pp. 274-28t, and Halleck's statement of the situation, Appendix, p. xxir; Julius Klein, The Mating of the Treaty of Guadaloupe Hidalgo, 1905, pp. 36-46; Hunt. "Legal Status,' as eited, 398-408; Birkhimer, Military Government and Martial Law, 361-369; Hittell, California, II, 701.

10 Cong. Docs., Ser. No. 573, Doe. 17, pp. 7-8. Repeated almost exactly by Secretary Marcy to Colonel Mason (ibid., 258-259). See also infra, p. 90 . 
It was further stated, by Secretary Marey, that it was the duty of the commander of the military force to recognize the government de facto, and to lend the aid of the military power to protect the persons and the property of the inhabitants of the territory. They, on their part, were urged to live peaceably and quietly under the existing government, but long before these admonitions were received in California all thoughts of peace and quietness had been driven from men's minds.

The failure to establish a permanent form of civil government immediately upon the final acquisition of the new territory was a greater trial to Colonel Mason than to the most querulous citizen under his charge. He realized more plainly than anyone else that the treaty of peace greatly weakened his authority as governor, required the discharge of the volunteer troops enlisted only for the duration of war, and left him in a position where he was responsible for maintaining order, but was deprived of the means of enforcing a single regulation.

The mining region was quite without any equipment for civil or military control. It lay along the western slope of the Sierra Nevada Mountains, and was separated from the original line of the missions by the hills of the Coast Range and the sun-scorched plain of the central valley. Some grants of land had been made by the former government to adventurous colonists from abroad, notably to Captain John A. Sutter, who had been a commissioned officer, sometimes called an alcalde, under the old régime, ${ }^{11}$ and whose fort at New Helvetia had been an outpost of patriarchal civilization. In February, 1848, John Sinclair was appointed alcalde "for and in the district of country on the Sacramento river, near New Helvetia." ${ }_{12}$ In March a large district in the

11 Bancroft, California, IV, 137, 226; History of Sacramento County, 1880 , p. 58. On Dee. 20,1847 , Sutter estimated the white population east of the San Joaquin and Sacramento rivers as 218 men and 71 women; Indians, 22,362 (Archives, "'Unbound Docs.,' 306).

12 Cong. Docs., Ser. No. 573, Doc. 17, pp. 486-487. Sinclair was mentioned as alcalde as early as Feb. 15, 1848, in Archives, "Unbound Does.," $8,15,405$. 
Contra Costa and San Joaquin regions was cut off from the jurisdiction of San José, ${ }^{13}$ and Elam Brown was appointed its alcalde. These two appointments appear to represent the civil staff of the entire mining area.

The earliest news of the gold discovery was received doubtfully, but about the twelfth of May Sam Brannan roused San Francisco to hysterical excitement as he passed through the streets waving aloft a bottle filled with dust, swinging his hat, and shouting: "Gold! Gold! Gold from the American River!" The town was quickly deserted. In June the California Star suspended publication, the school closed, workmen abandoned their employment, officials left their posts. Soldiers and sailors joined the general stampede. In Monterey the officers were without servants, and even Colonel Mason was forced to take his turn at cooking. ${ }^{14}$

The governor quickly realized that there would be need of new methods of enforcing order. On May 23, 1848, he asked Major J. R. Snyder, who was about to visit the mines, to draw up an outline of desirable regulations, but nothing resulted from the effort. ${ }^{15}$ In June and July Colonel Mason himself made a tour of the mining district, and reported his observations to Washington. ${ }^{16}$ Finding that crime of any kind was very infrequent, and conscious of his inability to enforce a questionable authority, he did not try to establish there any general control. But he threatened to concentrate his forces in the field and to exclude unlicensed miners unless soldiers ceased to desert from

13 Shinn, Mining Camps, 96; Archives, "Unbound Does.," 8, 42.

14 See Bancroft, California, VI, 52-81; Fayette Robinson, California and Its Gold Regions, 1849, Appendix, p. 135. The disastrous consequences of the desertions of soldiers and civil authorities are noted in Cong. Docs., Ser. No. 573 , Doc. 17 , pp. 603, 612, 613, 648, 650, 667, 677. Sutter's entire retinue deserted him, and his property was left at the mercy of dishonest miners (J. A. Sutter, Personal Reminiscences, 1876, pp. 195-196, MS in the Bancroft Library).

15 Cong. Docs., Ser. No. 573, Doc. 17, pp. 555-556.

16 Cong. Docs., Ser. No. 573, Doc. 17, pp. 528-536. 
the army, and unless civilians made provision for their families before seeking the placers. ${ }^{17}$

On August 7, 1848, the same day on which he proclaimed the ratification of the treaty with Mexico, Mason directed John Sinclair, the "First Alcalde, Sacramento district," to call for an election of four subordinate alcaldes to serve at the four most prominent places in his district, which included the whole country west and northwest of the district of Sonoma. ${ }^{18}$ I have found no documentary record that the election was held, nor that Sinclair exercised any jurisdiction over the more remote stretches of his district, although later in the year Mason expected him to take charge of a murderer whose arrest was in prospect. ${ }^{19}$ That the governor attempted to inaugurate some more effective system of judicial control may be inferred from a letter dated at the "Upper Mines," September $3,1848,{ }^{20}$ in which L. W. Hastings accepted the "judgeship for the northern district" in order to establish law and government there, and to check the frequent robberies and murders. Later correspondence indicated that Mason abandoned such efforts in the expectation that news of territorial organization by Congress would be received before local improvements could be put in operation. ${ }^{21}$

But in spite of this anticipation the governor was exceedingly anxious over the situation in California. On August 19 he wrote to the adjutant general :22

For the past two years no eivil government has existed here, save that controlled by the senior military or naval officer; and no eivil officers exist in the country, save the alcaldes appointed or confirmed by myself. To

${ }_{17}$ Cong. Docs., Ser. No. 573, Doc. 17, p. 580.

18 Cong. Docs., Ser. No. 573, Doc. 17, p. 593.

19 Letter of Oct 24, 1848, Cong. Docs, Ser. No. 573, Doc. 17, p. 677.

20 Archives, "'Unbound Docs.,' 157.

21 Cong. Docs., Ser. No. 573, Doe. 17, p. 677.

22 Cong. Docs., Ser. No. 573, Doc. 17, pp. 597-598. This was in reply to orders of March 15, see supra, p. 57 note 8. 
throw off upon them or the people at large the civil management and control of the country, would most probably lead to endless confusions, if not to absolute anarchy; and yet what right or authority have I to exereise civil control in time of peace in a Territory of the United States? or, if sedition and rebellion should arise, where is my force to meet it? Two companies of regulars, every day diminishing by desertions, that cannot be prevented,23 will soon be the only military force in California.... Yet, unsustained by military force, or by any positive instructions, I feel compelled to exercise control over the alcaldes appointed, and to maintain order, if possible, in the country, until a civil governor arrive, armed with instructions and laws to guide his footsteps.... In the meantime, however, should the people refuse to obey the existing authorities... my force is inadequate to compel obedience.

This was the situation in midsummer, 1848, when the universal rush to the mining regions swept the men of the state away from their ordinary interests to seek their fortunes beneath the soil of the Sierra Nevada foothills.

First in the gold fields were the natives of the United States who were already in California, for the strenuous labor of the mines did not greatly attract the indolent Californians. ${ }^{24}$ Soon after came many who had settled in the neighboring territory of Oregon. ${ }^{25}$ Thus the nucleus of the mining population was composed of pioneers of the usual American type, and it was the universal verdict that even in the excitement and license of the mines they were not only hard working and self-reliant, but honest and generous in their attitude toward each other.

News of the richness of the placers spread quickly. among the ports of the Pacific, and the next gold seekers came from Mexico, South America, and the Sandwich Islands. They were quickly followed by parties from Australia, among whom were

23 "There will be fifty able-bodied soldiers fit for duty in California", (Report, Aug. 25, 1848, Cong. Docs., Ser. No. 573, Doc. 17, p. 603).

24 Hittell, California, III, 161-162.

25 "I think that at least two-thirds of the male population of Oregon. capable of bearing arms, started for California in the summer and fall of 1848' (Peter H. Burnett, Recollections and Opinions of an Old Pioneer, 1880, p. 254). 
numbers of discharged convicts and ticket-of-leave men. Such foreigners, unaccustomed to self-government and in some cases outlaws by instinct and experience, were undesirable additions to the ranks of the miners, and were much disliked as alien intruders who had no rights in the mineral wealth of the public lands. ${ }^{26}$ The eastern states received information of the mines so late in the autumn of 1848 that the season was unfavorable for undertaking the overland journey, but twenty thousand men assembled on the banks of the Missouri River, eager to start for the West as soon as the winter was over, and a fleet of vessels prepared to carry passengers to California by way of the Isthmus of Panama, and around Cape Horn. ${ }^{27}$ The real rush therefore reached the state early in 1849, when thousands of men poured over the Sierra Nevada Mountains, and other thousands sailed through the Golden Gate into the harbor of San Francisco.

The typical pioneer was no longer in the ascendant. Men came from every section of the land, and from every walk of life. Puritans and drunkards, clergymen and convicts, honest and dishonest, rich and poor-they strode side by side across the plains, crowded the decks of steamers, and worked shoulder to shoulder in the diggings. A little later came all the world, and the people of Europe and Asia and Africa brought to California every social inheritance entailed upon humanity since the dawn of history. ${ }^{28}$

26 The subject of foreign miners is discussed infra, pp. 121-126. J. S. Hittell spoke of the predominance of aliens during 1848 (San Francisco, 140). It is quite certain, however, that in 1849 the American arrivals greatly exceeded those of other nationalities.

27 See Bancroft, California, VI, 110-163.

28 On Nov. 1, 1849, the Alta reported in the harbor vessels flying the flags of England, France, Spain, Portugal, Italy, Hamburg, Bremen, Belgium, New Granada, Holland, Sweden, Oldenburg, Chili, Peru, Russia, Mexico, Ecuador, Hanover, Norway, Hawaii, and Tahiti (Steamer Ed., supplement $3 / 1$ ). The world-wide interest in California mines is attested by the great number of books on the subject, published in various European languages. 
They found a land of magnificent distanees, sparsely settled toward the south, and virgin wilderness from the mining region to the northern boundary. The genius of the country was an apparition of the Mexican law, invoked by a military-civil governor whose authority was unsupported by even a show of physical force, and rested precariously on the presumed consent of the governed. It is necessary for us to picture as vividly as possible the tremendous excitement of these first months of the gold rush, then to revert to Colonel Mason's report ${ }^{29}$ of August 19, and remind ourselves that he had neither the authority nor the equipment to impose any regulations upon these men, who were already miles removed from the jurisdiction of the alcaldes he had installed in office. Again we must visualize the thousands of gold seekers, constantly keyed to the highest pitch of excitement, gathered in mountain camps far from the nearest office of government, generally unaequainted with the customs prevailing in the older settlements, and perfectly aware that there was no executive strong enough to enforce order, no police empowered to make arrest, and no jails where the lawless could be confined.

The miners had, however, at least two pressing social necessities: every man wished to be assured that he could dig where he chose without displacement by an interloper, and that his life and his gold should be reasonably safe from the assaults of violence. Here were primitive elements of society: a man's relation to the soil, and his relation to his neighbor, in the restricted sense of the other man who might jump his claim, rob his tent, or shoot him in the back.

But the people called upon to adjust these primitive relations were not primitive people. They were the heirs of all the ages: their social reactions to their environment were not the reactions of inexperienced, unsophisticated men, groping through experi-

29 See supra, p. 60. 
ment and failure after methods that should meet their particular needs. Americans were the dominant spirits in ' 48 ; they formed a great majority of the miners of ' 49 , and the American tradition and experience hovered as a mighty influence over the inchoate groups that hurled themselves swiftly together, and as swiftly disintegrated, while anticipation and disappointment drove the eager miners restlessly from gulch to gulch. They carried with them no itinerant shrine of civic life, but rather the tools with which that shrine might be erected wherever their wandering feet should linger. For wherever three or four Americans gathered themselves together, they understood how to accomplish rapid but effective social organization by agreeing to ascertain and accept the wishes of the majority.

The popular imagination has been delighted by many pictures of the California miner of 1848 and 1849, with his uncouth virtues and his picturesque vices, his courage, his rough kindness, his swift and unsparing justice, and his simple standards of manliness and integrity. But the erucial moment of his adventurous life has been passed over with a light touch, possibly because he met it lightly and without melodrama. It was the moment when the secret strike of a prospector became public property. He had traveled far, perhaps quite alone, perhaps as a nember of some little company; he had carried on his own back tools and food and rifle aeross country still impassable for a pack animal; he had spent days in barren, heart-breaking toil, and nights at the mercy of murderous Indians, and at last he had "struck it rich!" But before his dream of fortune might be realized there came others who had spied on his movements, followed his trail, and overtaken him in time to divide the fruits of his suffering, his patience, and his skill. ${ }^{30}$ This was the danger

30 Such an incident was described by E. G. Buffum, who found a rich ravine and hoped to make a fortune from the location. Within twenty-four hours he was traced, and the gulch was over-run with other miners. About $\$ 10,000$ was taken in a few days, of which the discoverer realized only about $\$ 1000$ (Six Months in the Gold Mines, 1850, p. 91). 
point in California life-excited men, in a remote mountain gorge, with gold uncovered at their feet and loaded weapons in their hands. And this was the salvation of that life: they put their guns aside, sat down and talked things over, estimated the richness of the placer, and apportioned it fairly between them. In that action was displayed the fundamental characteristic of California existence in 1848 and 1849 : swift agreement by the will of the majority on matters of common interest, and cheerful loyalty to such decisions until they might be changed by another popular verdict. And by this token the Argonaut of ' 49 claims his honorable descent as a social being through two centuries of American pioneers, across three thousand miles of American frontier, from the Pilgrims of the Hayflower, the settlers of the Cumberland, and the explorers of the Old Northwest. Too little effort has been made to set him in his place as an American, in a large majority of cases born and bred east of the Mississippi, equipped with the traditions of his people, but thrust into circumstances unprecedented even amid the infinite variations developed during the conquest of the continent. 
CHAPTER IV

\section{VOX POPULI IN THE MINES OF CALIFORNIA}

The Argonaut of California unquestionably belonged to the great brotherhood of American frontiersmen, but it is equally true that his surroundings created problems which were entirely his own. A few of the fundamental differences that distinguished the American settlement of California from that of other parts of the frontier require particular emphasis here.

While the majority of the miners came from the United States, the mixture of men from every class and section of the nation and from all the nations of the earth destroyed that unity of descent and of social experience that had elsewhere blended pioneer communities into homogeneous groups. Moreover, in place of the gradual development of complex conditions accompanied by progressive adjustment of social mechanism, many of the problems of life became suddenly acute as throngs of new arrivals crowded into the congested towns and swarmed over the restricted area of the mining regions.

The advance into California, unlike the advance of the men of the western waters, was not the migration of a people, pushed westward by hereditary tendencies. It was more like the onrush of viking hordes lured by spoil to a foreign shore. The adventurers were nearly all men, ${ }^{1}$ nearly all young; they came with no thought of remaining beyond the time necessary to snatch a fortune from the placers; they had no purpose of reproducing accustomed institutions in a land of transient sojourn ; and they

\footnotetext{
1 From April 12 to Dec. 31, 1849, the arrivals by sea were 28,269 men and 800 women (Browne, Debates, Appendix, p. xxii). See also J. D. Borthwick, Theree Fears in California, 1857, pp. 381-383; Burnett, Recollections, 301; Alexandre Holinski, La Californie, ed. 2, 18.53, pp. 125-126.
} 
were utterly divorced from those ties of home and family which have ever been the center of community life.

Another radical difference arose from the circumstance that the earliest California miners formed no fixed attachment to the soil, and that they were interested in a given locality only so long as it yielded freely of surface gold. The greater part of the mining region was on the public domain of the United States. No statutes provided for its temporary or permanent occupation, as, before the discovery of gold was made public, Mason had abolished the laws relative to the denouncement of mines, he had never substituted regulations of his own, nor had Congress placed California under the laws that in other regions opened public land to private ownership. ${ }^{2}$ The miners, then, were simply trespassers on land belonging to the United States, but they serenely accepted their anomalous position as a sort of modus vivendi, applied to it the old idea of social control based on a more or less extemporaneous expression of the will of the majority, and by this appeal to mutual agreement rather than to the strong arm established their relation to the soil on an equitable basis. In commending the usual fairness of their regulations, however, one must not ignore their disregard of the prior rights of a few men who held private titles to property in the mining regions. Sutter, for instance, was despoiled of his live stock and equipment, and James W. Marshall, who discovered gold, had his own prospects ruined by miners who paid no attention to his claims as a legitimate land owner. ${ }^{3}$

2 See Cong. Docs., Ser. No. 573, Doc. 17, pp. 476, 532. Mason's successor, General Riley, continued the policy of non-interference (ibid., 789).

3 See E. E. Dunbar, The Romance of the Age. 1867 , p. 129 ; J. B. Landis, "Life and Work of General John A. Sutter," Lancaster County [Pennsylvania] Historical Society, Papers XVII (1913), 288; G. F. Parsons, Life and Adventures of James WT. Marshall, 1870; Hittell, California. III, 52-54. But compare a statement of H. I. Simpson, who said that a fine deposit on Sutter's property was not disturbed during the summer of 1818 (Emigrant's Guide, 1848, p. 6). 
The growth of every camp was merely an expansion, in varying terms, of the relation of the man first on the ground to the newcomer who was determined to work beside him. At first, while the placers were unexplored and miners were comparatively few, there was little need for organization. As early as June, 1848, however, one observer wrote: "It is curious how soon a set of rude regulations sprung into existence, which everybody seemed to abide by."', In many cases the initial steps towards association were taken before the miners reached the field. Parties of discharged volunteer soldiers who hastened to the mines as soon as they were mustered out in the early fall of 1848 , often adopted rules to enforce necessary concert of action. Larger companies from the East were usually bound together not only by commercial agreements, but also by pledges to follow certain lines of conduct and to accept the will of the majority as it might be expressed in future contingencies. ${ }^{5}$

Such companies tended to speedy dissolution, owing to conditions unforeseen at the moment of their formation. ${ }^{6}$ Nevertheless, they supplied elements of unity which asserted themselves in place after place, while the camp communities were so quickly assembled and so hastily dissolved that organization appeared only under the pressure of actual necessity. But whenever that necessity arose there was instant appeal to the American expedient of popular decision, and no question was too important or too trivial for an ultimatum by the vox populi. The little

\footnotetext{
4 J. T. Brooks, Four Months among the Gold-Finders, ed. 2, 1849, p. 77.

5 See Bancroft, California, VI, 144 et seq.; Hittell, California, III, 232250. Such an association is described in the Diary of Nelson Kingsley, 1914. Specimen rules may be found in W. R. Ryan, Personal Adventures in ... California, 1850, I, 211-214; A. J. MeCall, Great California Trail, 1882 , p. 17.

6 D. B. Woods, in Sixteen Months at the Gold Diggings, 1851, pp. 171-176, gave the following statisties of fourteen companies for 1849 and 1850: Number of members, 344; total days of labor, 35,876; value of gold extracted, $\$ 113,633$; average for each day's labor, $\$ 3.16$.
} 
companies voted where the camp should be pitched; who should be cook; who wash the dishes. In one instance it was decided by ballot how a particularly luxurious packing box should be enjoyed as a couch, in strictly fair rotation. ${ }^{7}$ If three prospectors discovered a promising placer they voted to assign a specified area to each one; if three hundred more invaded the gulch, claims were readjusted by another vote. ${ }^{8}$ If a dispute arose between individuals, their companions dropped their picks, listened to the controvery, rendered a decision, and saw to it that the verdict was enforced. In matters of greater moment the halloo was sounded from ridge to ridge, and a general gathering from a larger district was summoned for careful discussion and deliberation.

In the earlier months and in the smaller camps only the simplest regulations were required, and they were adopted by a verbal agreement, or sometimes even by silent assent to the obvious will of the entire group. As the number of miners increased, and the camps assumed more permanent character, the rules became more elaborate. Shim said that laws were formulated as early as the summer of 1848 . In the Annals of San Francisco it is stated that the first code was framed by Colonel J. D. Stevenson, and was adopted in the fall of that year by miners in the district above Mokelumne Hill. ${ }^{9}$ One of the best known of the early miners, who had been in the field from the first months of the gold excitement, wrote that he never heard of a specified miner's claim until the spring of $18 \pm 9$, when at Wood's Creek, in the southern mines, he saw the ground

7 Buffum, Six Months, 26-27.

$s$ One pioneer said that when the mines were opened around Nevada City a determined prospector claimed all the diggings as far as his rifle carried. The miners soon saw that more practical agreements were necessary (C. D. Ferguson, Experiences of a Forty-niner. 1858, p. 157). 788.

9 C. H. Shinn, Land Laws of Mining Districts, 1884, p. 236; Annals, 
measured off with tapes, under the direction of alcaldes, so as to prevent disputes. ${ }^{10}$ It is reported in the history of Colusa County that formal laws were adopted by a meeting at Rose Bar in April, 1849, and that "so far as then known" they were the earliest of their kind. ${ }^{11}$ It is evident, however, that by the spring of 1849 the custom had become so widespread that one writer humorously referred to the "lex diggerorum" which placed the strong and the weak upon a footing of equality, defined the claims that might be set apart, protected the tools left on the ground as an evidence of proprietorship, and permitted the adventurers to hold their rights as securely as if they were guaranteed by a charter from the government. ${ }^{12}$

Shinn stated that the smaller camps carried on most of their proceedings without written records. ${ }^{13}$ As the regulations still accessible are not dated earlier than 1850 , it is probable that meetings were called to adopt new codes, or amend old ones, when the organization of the state afforded an opportunity for permanent entry on the books of the county recorder.

The miners' laws usually dealt with the size of the individual claim, the signs by which ownership should be indicated, the amount of work necessary to establish and retain possession, the

10 J. H. Carson, Early Recollections of the Mines, ed. 2, 1852, p. 10. The two watersheds of the Sacramento and San Joaquin rivers were generally distinguished as the "northern" and "southern" mines.

11 Colusa County, 1880, p. 80.

12 Notes on California and the Placers [by James Delavan], 1850, pp. 64,66 . "A tool left in the hole in which a miner is working, is a sign that it is not abandoned yet, and that nobody has a right to intrude there, and this regulation. which is adopted by the silent consent of all, is generally complied with (F. P. Wierzbicki, Califormia as It Is, and as It May Be, 1849, p. 45). A few rears later H. R. Helper said: "Every Bar is governed by such laws as the majority of the miners see fit to enact, not by written or published documents, but by verbal understanding.... Almost every Bar is governed by a different code of laws... The discoverer of new diggings is awarded a double or triple share, or only an equal part, as a majority of those on the ground shall determine", (Land of Gold, 1855, p. 151). See also Kelly, Excursion to California, II, 24.

13 Shinn, Mining Camps, 168. 
title to water rights, and the adjustment of disputes. Speaking of them, in the broadest sense, H. W. Halleck said : ${ }^{14}$

The miners of California have generally adopted...the main principles of the mining laws of Spain and Mexico, by which the right of property in mines is made to depend upon diseovery and development; that is, discovery is made the source of title, and development, or working, the condition of the continuance of that title.

The strength of these regulations lay in the universal acceptance of the theory that the local group had a right to establish its own rules, and in the democratic practice that gave an equal voice in the open conference to every citizen of the United States, whether he spoke in the quaint phrases of the illiterate frontiersman, or in the polished tongue of a college graduate. One mar confidently say of the miners of California, as Albert Bushnell Hart has said of the New England colonists, that they practiced "that acceptance of the will of the majority which is the supreme test of popular self government." 15 One may also apply to them the words of James Bryce: "In nothing does the executive talent of the people better shine than in the promptitude wherewith the idea of an organization for a common object is taken up, [and]

14 See Gregory Yale, Legal Titles to Mining Claims and Tater Rights, in California, 1867. p. 71. On the subject of miners' laws, see also Shinn, Mining Camps, and his Land Laus of Wining Districts: Baneroft, California, III, chaps. 15-17; Hittell, California. III, 251-271; C. H. Lindley, Treatise on the American Law Relating to Vines and Mineral Lands within the Public Land, ed. 3, 1914, especially on Califormia. I. secs. 40-49, pp. 71-88; J. W. Thompson. Lnited States Mining Statutes. 1915, I. 635-643; Rodman, History of the Bench and Bar of Southern California. 85-92; C. L. Brace, The New Trest. 1869, pp. 128-129. Collections of miners' corles are given in J. Ross Browne, Reports upon the Lincral Resourees of the United States West of the Roeky Mountains [for 1866], 1867, especially pp. 226242 ; J. F. Davis, Historical Shetch of the Mining Law in California. 1902; Heckendorn \& Wilson, Miners \& Business Wen's Directory....1856... of Tuolumne. A special report prepared by Clarence King for the Tenth Census of the United States (Cong. Docs., Ser. No. 214t, Doe. 42, Pt. 1t), collected all the local mining laws and regulations of the nation that could then be obtained.

15 A. B. Hart, National Idtals Historieally Traecd. 93. 
in the instructive discipline that makes every one who joins in starting it fall into his place." ${ }^{16}$

The most interesting study of this phase of California life may be found in the works of Charles H. Shimn, but his treatment differentiated the pioneers of the Pacific Coast too sharply from those of the East and the Middle West. He felt that the latter" "melted away before the tides of civilization, without being forced by imperious necessity to the creation of any code of local laws, or to the organization of any form of permanent government," and that the mining camp was the "original contribution of the American pioneer to the art of self-government." ${ }_{17}$

This point of view led Shinn to trace the miners' dexterity in self-government directly to the racial genius of their Teutonic forbears, to connect the miners' meeting immediately with the Germanic folk moot, ${ }^{18}$ and to forget the long process of social education that had taken place in the Old World, in the American colonies, and on the Western frontier. Professor Royce also ignored the American heritage of the Califormia miners, and spoke of the result attained by their efforts at self-organization as in its nature unstable, since it had not been won as a prize of social devotion but only attained by a sudden feat of instinctive cleverness. ${ }^{19}$.Just as Shimn's admiration for the heroic qualities of his actors left them still umrelated to their forefathers of wilderness and inland valley, so did Royce's censure of their faults fail to relate their sins of citizenship to similar shortcomings elsewhere, and to recognize them as the product of a democracy that made haste to possess the continent before it perfected the vehicle of popular govermment.

\footnotetext{
16 Bryce, American Commonwealth, II, 282.

17 Shinn, Mining Camps, 4.

18 Shinn, Mining Camps, 2-3, 22-24, 125, 176. Reference to the New England town meeting and the settlers' associations of the West is made, however, in his Land Laws of Mining Districts, 50.

19 Royce, California, 281.
} 
The details of the miners' laws, interesting as they might be, need no long discussion here. It is only necessary to establish the fact that in circumstances where no exterior force could impose regulations, each little concourse of miners voluntarily imposed upon itself laws which determined the adjustment of claims in accordance with the will of the majority. ${ }^{20}$

It is very easy to concentrate attention upon the picturesque features of the miners' meeting: to visualize a firelit group of stalwart men, shut away from the world by a shadowy barrier of encircling forest, or to imagine the wild camp Sunday that was nevertheless a favorite day for the gatherings that decreed the laws for those roaring bravadoes of pick and pan. But neither the picturesque simplicity nor the mad disorder should obscure the significant fact that the camp-made laws were efficient. They met a temporary emergency, but they met it so well, with such stability of fundamental fairness, and such flexibility for local necessity, that for several years after the Federal control was asserted and the state organization was completed, the laws passed at those miners' meetings and at their successors of a gentler decade were accepted as the law of the land, were finally incorporated in the codes of California, and adopted in many other states. ${ }^{21}$ Again it must be borne in mind that while California was emerging from the chaos of the transition period, while a constitutional convention was at work and while successive legislatures were in session, the men of the Sierra mining camps still made their own mining laws with a

20 "No alcalde, no council, no justice of the peace, was ever forced upon a district by an outside power", (Shinn, Mining Camps, 177).

21 The miners of other districts followed California precedents, and developed some modifications and improvements which affected national legislation. See Beulah Hershiser, "Influence of Nevada on the National Mining Legislation of 1866,', Nevada Historical Society, Reports. III (1911-1912), 127-167; T. M. Marshall, "Miners' Laws of Coloralo," American Historical Review, XXV (1920), 426-439; and his Early Records of Gilpin County, 1920. 
direct popular sovereignty that left a profound impression on the spirit and institutions of the commonwealth. ${ }^{22}$

The miner's relation to his claim was thus adjusted with marked success, and with comparatively little disorder, but as much cannot be said of the establishment of the relations between man and man. The newcomers in California, even those who hailed from older states, were doubtless familiar with the usual features of popular tribunals. The precedent that had been tolerated as a matter of necessity in pioneer settlements had been followed in many better organized localities when courts had failed to punish crime, or when the bitterness engendered by the slavery question had given rise to acts of offensive partisanship. ${ }^{23}$ Trials by lynch law had occurred in several overland parties during the long course of the westward journey, and it is not at all surprising that, as soon as emergencies arose in the mines, the impromptu organization of the camp meeting transformed itself without hesitation into a criminal court.

22 The miners' rights were not confirmed by Federal authority until Congress passed the general lode mining law of 1866 (U. S. Statutes at Large, XIV, 251). The chairman of the Committee on Mines and Mining, urging the passage of the bill, said: "It will be readily seen how essential it is that this great system, established by the people in their primary capacities, and evidencing by the highest possible testimony the peculiar genius of the American people for founding empire and order, shall be preserved and affirmed. Popular sovereignty is here displayed in one of its grandest aspects, and simply invites us not to destroy, but to put upon it the stamp of national power and unquestioned authority', (Cong. Docs., Ser. No. 1240, Doc. 105, p. 2). It is significant of the spirit in which Royce reviewed this period that he said of the California miners: "They resist strenuously any legislative interference with their local self-government in these matters. They insist absolutely upon the autonomy of the miners' district, as regards the land; and for years, against all legislative schemes at home, and all congressional propositions at Washington, they actually maintained this autonomy', (California, 316).

23 Cutler, Lynch-Law, 91 et seq. Most of Cutler's examples for this period were from the Liberator, and record outrages upon abolitionists and Negroes rather than cases of frontier justice. See also P. W. Black, "Lynchings in Iowa,' Iowa Journal of History and Politics. X (1912), 151-254, and his "Attempted Lynchings in Iowa," Annals of Iowa, ser. 3, XI (1914), $260-285$. 
During the summer and early autumn of $18 \pm 8$ there was little need for severity of any kind as disorders were rare and some early observer's reported a period of almost Arcadian honesty that lasted well into the more strenuous days of ' $49 .{ }^{24}$ Bancroft recorded crimes in the region of San Franciseo and San José, but found only two instances of outrages in 1848 that incurred the punishment of popular tribunals in the mining regions. Carson wrote that honesty was the ruling passion among the miners of ' $t 5$ and recalled but one case of "high misdemeanor" in that rear. Of later months he said $:^{25}$

This honesty... was not to be found in the crowds that daily thickened around us in ' 49 . Hordes of pick-pockets, robbers, thieves and swindlers were mixed with men who had come with honest intentions.... Murders, thefts, and heary robberies soon became the order of the day.... Whipping on the bare back, cutting off ears, and hanging, soon became matters of as frequent occurrence as those of robbery, theft and murder.

These statements are in substantial accord with the experiences of a majority of the pioneers. The question of mining claims had been adjusted on a peaceful basis, but the camps now faced the more difficult problem of controlling without the customary aid of law a dangerous class of eriminals. ${ }^{26}$ Every fairly

24 See report of Mason, Aug. 17, 1848 (Cong. Docs., Ser. No. 573, Doc. 17, p. 532) ; Bancroft, California, VI, 8t; Brooks, Four Months, 67 ; Alonzo Delano, Life on the Plains and among the Diggings, ed. of 1857, p. 359; T. T. Johnson, California and Oregom. or Sights in the Gold Region, ed. 3. 1851, p. 146; James Neall, Jr., Statement. 4-5. MS in the Bancroft Library.

25 Carson, Early Recollections, 6, 11-12, 26. James Lynch, familiar with events in ' 48 and ' 49 , thought that the first jury trial in the mines was at Murphy's Diggings in the spring of ' 49 (With stevenson to California, 1896, p. 48).

26 'There was another branch of legislation soon called for to suppress a system of thieving that was fast spreading; but the code of the famous Judge Lynch was unanimously adopted. and under its oral provisions any person caught in 'flagrante delicto' was shot down without ceremony, or subjected to any other summary punishment the detector might prefer... While disapproving of the modicum of punishment, and the manner of putting it in force, I must almit that some rery stringent measures were necessary to keep in check the lawless and abandoned characters who flocked to the mines', (Kelly, Excursion to California. II, 24-25). 
successful miner collected gold dust in larger or smaller quantities which he was obliged to carry on his person or to leave about his tent, for there were no safes in the mines, and no banking or express agents ready to receive and forward treasure to the cities. As these accumulations of gold dust were a constant temptation to theft and murder, it became a vital necessity to make robbery umprofitable, even in a comntry that lacked the restraining influences of courts and jails. In the summer of 1848 Brooks said that every man guarded his gold dust with his own rifle, ${ }^{2 \pi}$ and the crimes of that season were doubtless avenged by the aggrieved party when detection was possible. As population increased united action became necessary. Then the miners almost universally adopted the custom of improvising courts for the immediate trial of suspected offenders, and it is important to realize that these trials were not a social retrogression towards anarchy, but an effort to protect society by elevating the punishment of crime above the primitive and dangerous plane of personal vengeance. ${ }^{2 s}$

The many anecdotes of miners' trials given by Shinn, Hittell, and Bancroft concur in describing the usual method as being the immediate trial of the suspect before an improvised court, with judge and jury, although sometimes the meeting as a whole voted on the verdict and sentence. Counsel were often assigned for prosecution and defense, evidence was always taken at its face value, and no technical evasions were allowed. The accounts that have been preserved indicate a large percentage of convictions. No doubt aequittals made less impression on the observer, and it must be remembered that the presumption of innocence

27 Brooks, Four Months, 177, 183-184, 206.

28 E. A. Ross, in his Social Control, 1901, pp. 41-52, used the development of the mining camps in California as an illustration of the progress of community action. "There are offences," he wrote, "that exasperate the group as well as offences that arouse the ire of the individual. In this common wrath and common vengeance lies the germ of a social control of the person."' 
was less than in ordinary courts, as arrest followed swiftly upon the discovery of crime, and many culprits were caught redhanded. ${ }^{29}$ Nevertheless conviction was dangerously easy, and some innocent men must have suffered cruel injustice. When guilt was once established it was considered imperative to rid the camp of the criminal, as there was no way of confining him pending a possible reformation. Immediate execution was the most effectual process of elimination and it was often employed. Sometimes a rough dignity solemnized such tragic occasions, but instances occurred of revolting ferocity and violence. If it was considered safe to give the guilty man another chance, he was punished, usually by whipping, and driven from camp with the warning that reappearance would mean death. Thirty-nine lashes on the bare back was a common sentence, but a hundred or even more, were not unknown.

Many of the Argonauts who participated in these trials always maintained the stern necessity for such prompt and severe penalties and pointed out the incontestable fact that in a country without penitentiaries whipping and execution were the only alternatives. ${ }^{30}$ Corporal punishment was not so repugnant to the standards of 1849 as it is to those of the present day. It had been rigorously employed everywhere upon the frontier, it was still legalized in some of the older states, and in others it had been abandoned but a short time. ${ }^{31}$ The pioneer journalist,

29 For incidents of acquittal, see Albert Lyman, Journal of a Voyage to California, 1852, pp. 121-122; Woods, Sixteen Months, 98.

30 General Riley attributed much of the lynching in 1849 to the lack of secure jails (Cong. Docs., Ser. No. 573, Doe. 17, p. 790).

31 Sherman cited the laws of Texas as a precedent for flogging a thief, and Mason recommended the penalty for rery aggravated cases (Cong. Docs., Ser. No. 573, Doc. 17 , pp. 403,445$)$. The sererity of frontier punishments was condemned by Howard, Introduction to Local Constitutional History, 416-423, and it was defended by Judge D. D. Banta, in "The Criminal Code of the Northwest Territory,' Indiana Magazine of History, IX (1913), 234-236. The following opinion was given by the Supreme Court of New Mexico: "In new countries, without jails... a pressing necessity for the adoption of the punishment of whipping for the offense 
Bayard Taylor, heartily approved of the miners' methods. Shinn defended them stoutly, and went so far as to say that "the miners' court was never wittingly cruel in its judgments, although it was liable to be swayed by prejudice or passion." ${ }_{32}$ Unfortunately, tales of cruelty cannot be denied. One of the most brutal scenes was the first lynching in the state, that of four Mexicans, at Dry Diggings (Placerville), which long thereafter bore the name of Hangtown. ${ }^{33}$ Josiah Royce spoke for a large group when he condemned all such punishments as barbarous, and in the end futile to reform the criminal. ${ }^{34}$

It is difficult to see, even in retrospect, how preventive and reformatory measures could have been adopted. Every camp faced dissolution at a moment's notice, and it could not suspend work to hew lumber, quarry stone, and erect a secure jail. Moreover, it was an isolated unit in its social existence, unable to establish srstematic coöperation with any other social unit, or to assist in devising a general policy for the preservation of order. In such an environment it was not to be expected that the young men of the mining region would develop a practical

of larceny exists. At some stage in the existence of almost every state and territory, they have resorted to this mode of punishment, and in no instance has its infliction been held to be unconstitutional ("Garcia vs. the Territory," First New Mexico Reports, 415-419).

32 Bayard Taylor, Eldorado, 1850, I, 92 ; Shinn, Mining Camps, 179-180. See also William Taylor, California Life Illustrated, ed. of 1858, pp. 295296 ; D. A. Shaw, Eldorado, 1900, pp. 139-144.

33 The lynching was in January, 1849. The Mexicans were first tried and whipped for robbery, then tried by a crowd of half-intoxicated miners on fresh charges of robbery and attempted murder. They endeavored to defend themselves in Spanish, but no interpreter was found, and they were immediately hanged from the branches of a tree in the center of the camp. See Buffum, Six Months, 83-85; Historical Souvenir of El Dorado County, 1883, pp. 148, 208; John Carr, Pioneer Days, 1891, p. 65; H. D. Jerrett, California's El Dorado, 1915, pp. 48-49; L. A. Norton, Life and Adventures, $1887, \mathrm{p} .293$. Other instances of excessive punishment may be found in J. W. Harlan, California ' 46 to ' 88,1888 , p. 140 . Anecdotes of trials extending over many years, are collected in Popular Tribunals, I, 142-178; Hittell, California, $272-309$.

34 See Royce, California, pp. 335-340. 
penology that should anticipate the advanced position of the present day, or even coincide with the most progressive standards of their own generation. It must be remembered also that the suppression of crime was their only aim, and their heavy-handed chastisement made life and property relatively safe, in spite of the presence in their midst of many men of the most desperate recklessness.

While the reader must turn to the pages of other authors for detailed pictures of the miners' trials, still a general grasp of local conditions is essential at this point, in order to understand that the widespread appeal to popular tribunals in 1849 was not due to a defiance of authorized government on the part of the populace, but to an utter lack of any system of control in the mining regions. Indeed, Colonel Mason acknowledged with regret that he was unable to initiate any measures for the relief of the emergency. On November 24, 1848, he wrote to Washington : ${ }^{35}$

I cannot too strongly recommend a territorial government to be organized in California at the earliest moment possible, if it has not already been done. There is no security here for life or property; and, unless a eiril government is speedily organized, anarehy and confusion will arise, and murder, robbery, and all sorts of crime will be committed with impunity in the heterogeneous and mixed community that now fills California.

Under such circumstances he was compelled to countenance the popular efforts to suppress crime, and when in December the

35 Cong. Docs., Ser. No. 573, Doe. 17, p. 648. When the military rule terminated in Santa Barbara it was necessary to release a convict, as there were no ciril anthorities and no jail (Archices, "Unbound Docs.," 10, 22, 25). Captain J. L. Folsom, assistant quartermaster at San Franciseo, wrote to Major General Jessup, Sept. 18, 1848: "I know of no section of the United States Territories which more imperatively requires strong garrisons. for the preservation of order. Without them I believe the whole country will sink into anarehy and the worst possible confusion', (New Tork Journal of Commerce, 18t8, Dec. 27, clipping in Francis Lieber's California Scrap-Book, p. 7, a collection of clippings in the Bancroft Library). See also another letter from Folsom, in Robinson, California and Its Gold Regions, Appendix, pp. 13t-137. 
alcalde of San José hanged three convicted highwaymen without waiting for official approval of the sentence, the Governor wrote $:^{36}$

I know, in this case, that necessity and circumstances, and the violent outrages of late so frequently committed upon society, compelled the good citizens of the pueblo to rise and promptly make a public example of those robbers, for the sake of their own safety and that of society in general. The country affording no means-jails or prisons-by which the persons of these lawless men could have been secured and society protected, it is not much to be wondered that, after the many atrocities so recently committed upon unoffending citizens, the strict bounds of legal proceedings should have been a little overstepped.

About the same time seven or more members of the Reed family were murdered at San Miguel, and three of the assailants were eaptured and taken to Santa Barbara for trial. Mason at once instructed the alcalde of that place to proceed to immediate trial and execution, and in reporting the two occurrences to Washington said $:^{37}$

You are perfectly aware that no competent civil courts exist. in this country, and that strictly speaking there is no legal power to execute the sentence of death; but the necessity of protecting their lives and property against the many lawless men at large in this country, compels the good eitizens to take the law into their own hands. I shall not disapprove of the course that has been taken in this instance, and shall only endeavor to restrain the people, so far as to insure to every man charged with a capital crime an open and fair trial by a jury of his countrymen.

Hittell felt that the resort to popular tribunals received an important impulse from the attitude Colonel Mason felt obliged to assume. "Under ordinary circumstances," he said, "nothing would have been more distasteful to Mason than this species of

36 Cong. Docs., Ser. No. 573, Doe. 17, p. 691; alcalde's report of the case, Archives, "Unbound Does,' 34, 340. See also Popular Tribunals, I, 68.

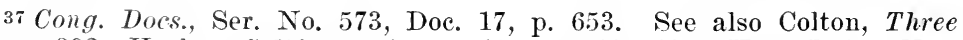
Years, 392 ; Harlan, California ' 46 to ' 48 , pp. 134-136; H. I. Dally, Narrative, $1878, \mathrm{pp} .53-63$, MS in the Bancroft Library. This was doubtless the crime mentioned by Senator Douglas as an awful result of refusing California the protection of adequate law (Cong. Globe., 30 Cong., 2 Sess., Appendix, pp. 275-276). 
lawless justice; but, in the condition of affairs as they were, he refused to interfere or stay the course of the popular vengeance that alone held lawlessness in some sort of check.", 38

As the population increased the miners' meetings became more formal in their procedure. The winter of 1848 to 1849 drove most men from the mountains, but a few Americans remained at the present site of Sonora, and a large party of Mexicans wintered at the same camp. It became necessary there to adopt some system more effective than impromptu meetings, and before the close of the year R. S. Ham was acting as alcalde. ${ }^{39}$ Shinn stated that Ham was elected at a meeting of the American miners of Jamestown, but H. O. Lang said that he assumed the office at Sonora without even a request from the inhabitants and was summarily deposed for .James Frazier (Frasier or Fraser) when a case arose that needed greater ability. My father, Edwards C. Williams, went to Jamestown in the autumn of 1848 , soon after he was mustered out of service with Stevenson's Regiment. He had not been there long when some excitement led the miners to desire an alcalde, and he was chosen for the position in compliment to a spectacular feat of horsemanship which he had performed when he arrived in camp. He resigned in two weeks, desiring to devote himself to business, but he always said that in the interval he wielded the power of life and death, although the only sentence he pronounced was a whipping imposed on a thieving Mexican. He remembered the administration of Alcalde Frazier, but the notes made of his recollections do not record which preceded the other in office.

When the cessation of the winter storms permitted the general resumption of mining, other camps followed the example set at Sonora, and elected alcaldes to administer the camp laws.

38 Hittell, California, II, 674.

39 See Shinn, Mining Camps, 127; History of Tuolumne County [by H. O. Lang], 1882 , p. 13 ; Baneroft, Califomia, VI, 469 : Hittell, California, III, 224. 
From the specimens of later rules that have been preserved it seems probable that the miners' laws adopted after the early months of 1849 made little distinction between the civil and the criminal departments of camp justice, and that the alcaldes not only supervised the allotment of mining claims but preserved order and presided at trials, ${ }^{40}$ although there were still many occasions when impromptu courts, with hastily chosen judges, conducted trials and imposed sentences.

These camp alcaldes were entirely independent of the supervision which the military-civil governor still exercised over the coast towns, and their election may be considered as an effort to provide the miners with a working substitute for the machinery of organized government. Their recommendation to office usually consisted in some accent of personality that caught the attention of the men about them; they derived their title from a Spanish inheritance, and their idea of law from their own inner consciousness; they were responsible to no central power, they were subordinated to no court of appeal, they were bound by no statute of legislation. Often they were well educated, often illiterate; sometimes they were sturdily honest, sometimes shamelessly venal; many drank and cursed with unchastened exuberance, many were thoroughly decent in speech and habits; some met untimely ends in drinking brawls and pistol duels, some spent long and honorable lives in the service of their adopted state. They were as far removed from the paternal dignity of the Spanish alcalde as they were from the well defined status of the American sheriff. Yet, because they perpetuated the title of the Mexican magistrate, there is a tendency to attach to the miners' alcalde a sort of retroactive significance, and to define in the terms of his arbitrary despotism the functions of the alcalde of the pre-American régime. The exact position of the latter was confused by conflicting statutes and shifting administrations,

40 See the code of Jacksonville, January, 1850, Thomas Donaldson, The Public Domain, 1881, pp. 317-318. 
but his authority reached back through centuries of Spanish law and custom; his successor of the transition period was very different from the Spanish model, but he still derived authority from well established usage; but the earliest alcaldes of the mines were detached from constitutions and precedents of any compelling force. As Buchanan said of the ultimate foundation of all order in California, the authority of the miners' alcaldes rested solely on the consent of the governed, who recognized the necessity of some form of social control, and gave voluntary obedience to these extraordinary magistrates.

Legal methods of the time may be illustrated as follows. In December, 1848 , C. E. Pickett, a merchant at Sutter's Fort, killed a man in self-defense. Sam Braman, who had a store at the same place, insisted that Pickett should be tried for murder. When the first and second alcaldes and the sheriff resigned to avoid conducting the prosecution, Bramnan called a mass meeting to elect new officers. Everyone who was suggested for alcalde declined and finally Brannan, himself, was chosen. The nomination for a prosecuting attorney likewise went through the circuit of the meeting, and was also finally accepted by Brannan. The prisoner then procured counsel, the sheriff pro tem. was ordered to bring drinks and cigars for all concerned, and arguments lasted far into the night, while Captain Sutter, one of the jury, wrapped in a Mexican serape, leaned against the wall fast asleep. Bramnan, as prosecuting attorney, summed up the evidence against the accused in spite of the fact that Brannan, as alcalde, was judge at the trial. The jury disagreed, and the sheriff was charged to hold the prisoner, but, as he had neither jail nor irons, it was decided to admit Pickett to bail, which was promptly furnished by the jurymen. "Thus ended the first criminal trial ever had at Sutter's Fort. At a subsequent and soberer trial Pickett was acquitted. ${ }^{\prime * 1}$

\footnotetext{
41 History of Sacramento County. 124-125; noted in Archives. "C'nbound Docs.,' 44.
} 
Another story tells us that in the spring of 1849 two Spaniards on the Mokelumne quarreled over the ownership of a mule worth about $\$ 20$, and availed themselves of the privileges of a jury trial. This resulted in fees amounting to $\$ 368$, and a verdict that they should draw lots for the disputed animal. The contestants cheerfully divided the costs and settled their quarrel by drawing straws. ${ }^{42}$ It is easy to understand why a pioneer should say : ${ }^{43}$

From the 7 th of July, $1846 \ldots$ the Government was a perfect nondescript-part military and part civil, and part no government at all.... The laws were most variant and variously conceived, the civil law, the Pike County code, the New York code, the common law, maritime law, the law on the plains, military law, and the miners' law, were all jumbled up together, and the Courts were as unique as the government and the laws; they were Americo-Mexican, military-civil, with a good degree of the vigilante.

In spite of their shortcomings and their eccentricities, however, the miners' laws and the miners' alcaldes prevented absolute anarchy in the camps. In the fall of 1848 the military authorities had anticipated a rapid increase in crime, but a year later the reports were much more cheerful. General Riley was then governor, and when he visited the mining region he was agreeably surprised to learn that order was preserved throughout almost the entire district. In each little settlement the miners had elected local alcaldes and constables, and sustained their official acts with loyalty and energy. ${ }^{44}$ A few months later, General Persifor F. Smith, commandant of the Pacific Division of the Army, wrote to the Adjutant General : ${ }^{45}$

42 Carson, Early Recollections, 27-28.

43 Lawrence Archer, "Oration," in Society of California Pioneers, Twenty-second Anniversary, 1877, p. 12.

44 Cong. Docs., Ser. No. 573, Doc. 17, p. 787.

45 P. T. Tyson, Geology and Industrial Resources of California, 1851, p. 79. General Smith was sometimes ealled the governor of California, but he took pains to state that he was not in charge of civil affairs. See Hittell, California, II, 676, 712; Cong. Docs., Ser. No. 573, Doc. 17, pp. 727,767 . 
I doubt whether any part of the United States has presented a community in which there has [sic] been so few erimes and even disorders committed. The public records of any of our largest eities will present more of these in one day, than have taken place in the whole of California since my arrival.... Many misrepresentations have been published on this point.

The best known and most enthusiastic contemporary account of conditions in California was written by Bayard Taylor. His letters to the New York Tribune have been the basis of many secondary accounts of mining life, and were the source of some of Shinn's important generalizations. ${ }^{46}$ Taylor spent some six weeks in the mines in the fall of 1849 , and reported that all the larger and older camps had elected alcaldes and adopted regulations which were faithfully obeyed, while crime was checked by just and deliberate punishments. ${ }^{47}$ It is quite possible that the places he visited were conducted as he described, but his inspection was hurried and superficial, and comparison with other observers leads one to think that he attributed to the entire extent of the mining region a good order which he found prevailing in the more accessible localities through which he traveled.

In spite of the optimistic reports of Riley and Smith and Taylor, it is incontestable that violence reached an alarming degree during 1849. Popular tribunals such as the miners' courts had developed as an emergency resource for small pioneer

46 Eldorado, 1850. Taylor made some very palpable errors, such as speaking of the Mexican ayuntamiento as a person "who was commissioned,' ete., ete. (I, 183), estimating the thousands of gold seekers from foreign parts as speedily outnumbering the American population (I, 100), and describing the harbor at Monterey as equal to any in California (I, 138). His optimistic statements should therefore be received with caution (see Royce, California, pp. 303-304).

47 Eldorado, I, 67 et seq. Henry De Groot said the miner of 1849 was far less disorderly than he was eurrently portrayed ("Six Months in ' 49 ,' Overland Monthly, XIV [1872], 316-329). E. G. Waite wrote: "In all my personal experience in mining camps from 1849 to 18.54 there was not a case of bloodshed, robbery, theft, or actual violence" ("Pioneer Mining in California,' Century, XLII [1891], 141). “For several years after the settlement of Nevada [City], in a society where little law had influence except that of moral restraint, but two homiciles oceurred "' (H. B. Thompson, Directory of the City of Nevuda and Grass Falley, 1861, p. 8). 
communities. They inevitably proved their inherent weakness and defects when called upon to control a population that in numbers and disposition required the restraints imposed by a highly developed social organization. It was not alone the avowedly outlaw element that needed to be curbed; men whose former habits of life had been orderly and well regulated learned in California to consume liquor in enormous quantities, and to gamble for enormous stakes. Disappointed greed and drunken passion sped many a knife thrust and bullet, and the frenzy of a mad debauch turned many a peaceable miner into an irresponsible enemy of mankind.

To attempt to gather and classify the accounts of California pioneers is like trying to classify the combinations of a kaleidoscope, for the components of the miners' society shifted and rearranged themselves and reflected the sunlight or caught the shadow with every turn of fortune's hand. We read, as it were in parallel columns, of bags of gold dust that lay safe in unguarded tents, and of merchandise piled high in the open streets; then of robbery and murder that went unnoticed in a community where a man might drop from sight without causing a ripple of comment among his self-absorbed neighbors. We read of the "lex diggerorum" to which men bowed in the swift adjustment of the most valuable claims, and of the groups which elected and obeyed their alcaldes in spite of the temptations of selfish individualism. We find, on the other hand, that there were many who opposed even the simplest forms of social restraint, and seized every opportunity to display their predatory instincts; again we find that there were many more whose habits of self-control gave way under the excitement and hardships of their life and the wild dissipation that was their only relaxation after days of feverish toil. Men of this sort committed crimes, sometimes in cold-blooded deliberation, more often in momentary passion. But drinking and gambling, even robbery and murder, 
were the accidents of an unorganized social condition, and beneath the confusion lay the force of a popular consent to the will of the majority, and to the essential spirit of law, as a solid foundation might lie beneath the disordered elements of an unfinished structure. ${ }^{\text {s }}$

48 This spirit was apparent to a critic of Bret Harte, who said: "Bret Harte's characters are amenable to no laws except the improvised laws of the camp; and the final arbiter is either the six-shooter or the rope of Judge Lynch. And yet underlying this apparent lawlessness there is that deep 'law-abidingness' which the late Grant Allen despised as being the 'Anglo-Saxon characteristic.' To my mind, indeed, there is nothing so new, fresh, and piquant in the fiction of my time as Bret Harte's pictures of the mixed race we call Anglo-Saxon finding itself right outside all the old sanctions, exercising nevertheless its own peculiar instinct for law-abidingness- of a kind" (Theodore Watts-Dunton, "Bret Harte," Athenaeum, May 24, 1902, p. 659). 


\section{THE STRUGGLE FOR ORGANIZATION}

The entire period of California history between 1848 and 1856 has sometimes been characterized as the era of the Struggle for Order. Writers have depicted the forces of law and of lawlessness as pitted against each other in open conflict, while a large element in the population was negligent of all social obligations, indifferent to all moral issues, and intent only upon the accumulation of wealth.

The significance of the years 1848 and 1849 may be much better expressed by calling them the era of the Struggle for Organization. In those years law was practically non-existent in much of the country, and the men who have been censured for neglecting the public welfare were actually deprived of the most elementary means through which their desires for order might find effective expression. Their response to the duties of citizenship under such unusual conditions should not be judged by their failure to regulate public morals, but rather by their demand for adequate laws, by their repeated efforts to formulate such laws, and by the final triumph of those efforts in the work of the constitutional convention of 1849 . When the historian, the reminiscent pioneer, and the writer of western fiction say, as they do in varying phrases, "There was no law in the land," they suggest a situation in which men took advantage of a temporary disorganization of justice to repudiate the usual bonds of community life. But the impression thus created is superficial and it has been necessary to linger over primary sources of history in order to show that the real menace to order was a lawlacking condition of society, rather than a law-defiant attitude on the part of the people. 
The spontaneous mass meeting of the mining camps had saved the country from absolute anarchy, but the mass meeting does not continue to be an efficient organ of government when the social group becomes very large, or loses its homogeneity of composition. Under such circumstances, as Ross pointed out, the ties of fellowship dissolve, and the "folk mass becomes a dangerous compound, ready to explode at a touch."' ${ }_{1}$ The need for some sort of representative system was usually recognized very quickly in the organization of the American frontier. It was especially necessary in the communities of California, where the preservation of order required a definite executive force to make effective the resolutions adopted by the popular assemblies. Without such a force, each individual act of discipline depended upon popular initiative, and upon the momentary temper of the meeting or mob that was stirred to action. Even in the camps where alcaldes had been elected, the constant shifting of the population deprived them of any permanent constituency to uphold them in carrying out a rule that had become unpopular. No lasting authority could be delegated to them until the community, as a whole, should be knit together by a bond of representative government. In the absence of such a bond even the political dexterity of the American citizen was powerless to stabilize social conditions. The large majority of the hundred thousand men in California desired that order should be established and that crime should be checked, but the will of this constructive majority could not be expressed in any organic law that would defend society from a minority that desired riot and license. On one day the peaceable miner might be a member of a congenial group, where life and property were protected by common consent. On the next, that group

1 Ross, Social Control, 52. See also A. B. Hart, in Cyclopedia of American Govermment, 1914, III, 543; Cleveland, Organizcd Demoeracy, 37, 45; Roosevelt, Winning of the West, I, 231-233; J. E. Young, "The Law as an Expression of Community Ideals,' Tale Law Journal. XXVII (1917), $1-33$. 
might be invaded by large numbers of gamblers and rowdies, who would defy every restraint of public opinion, and would yield only to the sheer force of physical constraint.

The continuance of this condition long after the increase in population demanded full civil equipment was not due to a lawless spirit inherent in the people, but to the situation at Washington. There sectional issues were asserting themselves with such vehemence that it was impossible to divorce the problem of territorial organization from the question of slavery, or to unite the hostile factions in establishing government in California and New Mexico.

While matters were in this condition Senator Thomas H. Benton, father-in-law of Colonel John C. Frémont, assumed the rôle of advisor to the Californians, and made public a letter in which he urged them to meet in convention, adopt a cheap and simple government, and take care of themselves until Congress could provide for them. ${ }^{2}$ His message was not published in California until January, 1849, when it had a certain effect in stimulating the people towards the course he advocated, but in the interim it caused grave uneasiness to President Polk, who feared that it would incite the settlers on the Pacific Coast to form an independent government, under the leadership of Colonel Frémont. ${ }^{3}$ To counteract the influence of Benton's letter the Secretary of State sent a communication to the people of California by the hands of Mr. William Van Voorhies, newly appointed postal agent, and in it he made the first official announcement of the status of the de facto government as it has been explained in an earlier chapter. ${ }^{4}$ Robert J. Walker, the

\footnotetext{
2 Printed in the New York Herald, 1848, Sept. 26, reprinted in Niles Register, LXXIV, 1848, Oct. 18, p. 244.

3 Benton had been "malignantly hostile" to Polk since the outcome

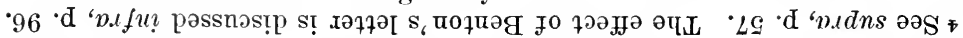

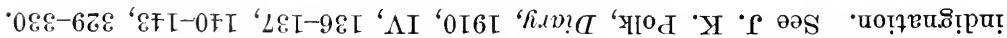

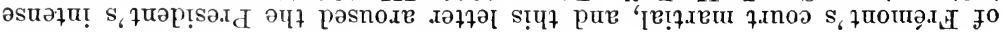


secretary of the treasury, issued a cireular at the same time, which announeed that by the treaty with Mexico the Constitution of the United States was extended over California, and which gave instructions as to the collection of customs duties, but ignored the question of local govermment. ${ }^{5}$ Secretary Buchanan urged the residents of California to await Congressional action with patience, but President Polk realized that they could not be expected to wait indefinitely, and at the opening of Congress in December, 1848, he made another appeal for immediate territorial organization. ${ }^{6}$ He pointed out that the entire question of the extension of slavery might be left to loeal determination, as it was not imperative for Congress to legislate on the subject, and in any case the ultimate decision would rest with the citizens of the acquired regions when they finally adopted state constitutions.

On the same day Senator Stephen A. Douglas announced that he should presently introduce a measure bearing on the subject of organization. On December 11 he presented a bill to authorize the immediate formation of a single state out of all the territory obtained from Mexico. As the area was far too large to form one commonwealth, Douglas later amended his bill to permit the people west of the Sierra Nevada Mountains to organize a state govermment at once, and the people of New Mexico to take the same action as soon as it should be justified by the increase of population. ${ }^{\top}$ The amendment empowered the acting governor of California to set the date for a constitutional convention, to call for an election of delegates, and to designate electoral districts; furthermore, when the state constitution and state govermment should have been established, and the president of the

5 Cong. Docs., Ser. No. 537, Doc. 1, p. 45. See also Magoon, Reports on the Law of Civil Government, 166-169.

6 Richardson, Messages, IV, 639-642.

7 Cong. Globe, 30 Cong., 2 Sess., 1, 21, 190-198, 381; Allen Johnson, Stephen A. Douglas, 1908, pp. 133-142; Polk, Diary, IV, 228-237; $254-257$. 
United States notified of the fact, the acting governor was directed to issue a proclamation declaring "the said State of California to be one of the States of this Union, upon an equal footing with the original States in all respects whatever." This bill was designed to hasten the local decision as to the prohibition of slavery, and although it was finally lost through postponements its tenor should be understood, because it apparently had an influence on subsequent events. ${ }^{8}$ When Congress adjourned, March 3, 1849, it had done nothing for the relief of California, except to extend over it the revenue laws of the United States. ${ }^{9}$

Throughout the dissensions of this session President Polk often recorded in his diary his apprehension lest California might be lost to the Union by the formation of a separate government. He felt that such an outcome might not be unwelcome to the coming Whig administration, as a relief from the embarrassments of the slavery conflict, ${ }^{10}$ and on the very day of the inauguration of Zachary Taylor, Polk's apprehensions were further excited when the new President expressed the opinion that both California and Oregon were too distant to become members of the Union, and that it would be better for them to be permanently independent. ${ }^{11}$

In less than a month President Taylor changed his point of view. Every despatch from the Coast confirmed the reports of the richness of the gold mines, enhanced the value of the new territory in the public estimation, and emphasized the need of

8 See infra, p. 103.

9 U. S., Statutes at Large, IX, 400. See also Hittell, California, II, 705-706; Polk, Diary, IV, 364-370.

10 Polk, Diary, IV, 231-233, 293-298. Eleven members of the House of Representatives voted to return all the territory obtained by the treaty with Mexico except the region about San Francisco Bay (Cong. Globe, 30 Cong., 2 Sess., 557-559).

11 Polk, Diary, IV, 375-376. Taylor had disapproved of the Mexican War, see his Letters from the Battle-Fields, 1908, pp. 28, 37, 39, 75, 117. 
providing an efficient government without waiting for another session of Congress. Early in April Thomas Butler King was appointed a special agent to the naval and military commanders in California, and was given instructions that distinetly advised the creation of civil organization by popular initiative. ${ }^{12}$ King had participated as a representative from Georgia in the last session of the House, and could inform the local authorities of the drift of opinion in Washington, but he did not reach San Francisco until June, by which time a movement for self-organization had already met with general endorsement.

The problems of California were not, by any means, limited to the preservation of order. There was constant difficulty in financing the civil department of the government, in enforcing revenue laws, and in regulating commercial affairs, but such questions do not require consideration here. ${ }^{13}$

It must not be thought that during the discussions that distracted Washington in the winter of 1848 to 1849 , the builders of the future commonwealth of California were indifferent or tolerant towards the disorder and confusion which reigned about them. On the contrary, they were fully and unhappily conscious of it, and resented their situation with outspoken bitterness. The papers attributed the rapid increase of crime to the fact that society was "held together without other law than had suggested itself in cases of emergency.", They pointed out the grave dangers that would attend the continuance of lynch law, which

12 Cong. Docs., Ser. No. 573, Doc. 17, pp. 9-11. King was later appointed collector of the port of San Francisco. He was disliked in California, but his Report on California, 1850, was a valuable document (Cong. Docs., Ser. No. 577, Doc. 59; reprinted under the title, California: the Tonder of the Age, 1850).

13 These subjects are discussed at length by Baneroft and Hittell, and more briefly by Thomas, Military Government, 218-228; and by W. C. Fankhauser, Financial History of California. 1913, pp. 109-116. An excellent summary was made in the Memorial to Congress (Browne, Debates, Appendix, pp. xiv-xix), and in King's report, Califormia, 3-t.

14 Placer Times, 1849, Nay $5 \%$. 
was "only worthy of barbarians," and was as likely to turn its destroying hands against the good as against the bad. ${ }^{15}$

Colonel Mason also viewed the situation with profound anxiety. As early as November 24, 1848, he had written to Washington:16 "The war being over, the soldiers nearly all deserted, and having now been from the States two years, I respectfully request to be ordered home." There was a grim acknowledgment of discouragement in the terse request, but the commandant did not abandon California to unchecked disorder even after he had asked to be relieved from his onerous position. On the evening of the very day on which he applied for a change of service he had an interview with E. C. Kemble, editor of the California Star and Califormian, ${ }^{17}$ and discussed with him the interests of the community. No record of their conference seems to have been preserved, but its tenor can be inferred from the following memorandum of a letter in the Archives of California, copied for the Bancroft collection $:^{18}$

1848 Nov. 2.5 Mont[erey]

Govr Mason to E. C. Kemble, on organizing Govt for Cal.

(a private letter)

It appears I did not convey to you my exact meaning in the conversation I had the pleasure to have with you last evening; what I wished to convey was this, that if on the receipt of the intelligence that Congress had adjournd last summer without organizing a territorial govt for Cala, that then the people should organize a temporary govt for themselves; that this intelligence (the adjournt of Congress) it was expected would be received by the St. Mary's now due and daily expected.

Although this letter is not ordinarily cited as a document of particular significance, it had a prompt and important influence

15 Alta, 1849, Jan. $4 \% 1$.

${ }_{16}$ Cong. Docs., Ser. No. 573, Doc. 17, p. 649.

1i The Monterey Californian had been transferred to San Franciseo in May, 1847. It was merged with the California Star in Norember, 1848, and Kemble was the editor. At the opening of the new year the old papers were succeeded by the Alta California, owned by Kemble, Edward Gilbert, and G. C. Hubbard. The paper was independent in polities, and opposer to the "high-handed measures", of the military authorities (Kemble in Sacramento Union, 1858, Dee. $25 \quad 3 \%$ ).

18 Archives, "Unbound Does.," $140-141$. It was r'umored that Mason and Commodore Jones had conferred on the subject of civil organization (Californian, 1848, Oet. 21 1/1). 
on public events, since the California Star and Califormian at once commenced a vigorous campaign for the formation of a provisional government. In the issue of December 2 the paper reported a particularly shocking murder in the mining regions, and under the caption, "Shall we have a Civil Government?" the editor urged the immediate organization of some form of social order that would restrain crime. He asserted that:

Our Military and Naval commandants recognize in the people a rightnay, enjoin it as a duty, to provide for themselves a government, recommending delay only until it be ascertained whether or not the Congress of the United States, at its last session, produced the long-awaited organization.

In the light of the letter from the governor, the reference to the military authorities becomes almost an official endorsement of the plan, but as Mason scrupulously refrained from any public utterance on the subject, his attitude towards organization has generally been interpreted as one of non-interference rather than of initiative. ${ }^{19}$

In quick response to the call for action a meeting was held in San José on December 11, and a eonvention for organization was suggested for January, 1849. The plan was ratified in San Francisco, December 21 and 22, with the proviso that the date should be advanced to Nareh 5. Other towns followed San Francisco's example, and when the proposed interval proved too brief to permit adequate representation from the South, it was again extended to Nay $6 .{ }^{20}$ Thus the movement for organization was well in progress before the letter of Senator Benton that had so agitated President Polk was published in the Alta California of January 11, 1849. The next issue of the paper, that

19 See Cardinal Goodwin, Establishiment of State Government in California, 1914, p. 71: Baneroft, Califormia, VI, 266-267.

20 Delegates were elected at Los Angeles, Monterey, San José, San Francisco, Sacramento, Benieia, and Sonoma. See Bancroft. Califormia. VI. 266-271; Browne, Debates, Appendix, pp. xri-xrii; Burnett, Recollections. $294-318$. 
of January 18, contained a sarcastic editorial expressing popular gratitude for the senator's parental solicitude, and characterizing the communication as a well-meaning document which quite mistook the caliber of the community. The letter entrusted to Mr. Van Voorhies, which had been designed to forestall Benton's, was printed without comment on March 15, although a copy of it was in the hands of the governor some time before that date. ${ }^{21}$

These two letters are often cited as expressions of opposing views on the status of California. The "administration theory", upheld the survival of the Mexican laws, subject to change only by act of Congress, and administrated by the highest military officer in the district as was provided for in the Mexican system when a civil governor was not in active service. Benton concurred with the administration in maintaining that the Mexican laws persisted until altered by the proper legislative authority, but he asserted that the American commanders had no power to administer those laws, and that in default of legitimate officials the people were left without government and had the right to provide organization for themselves. A third theory called the "Settler's theory" was held by some of the most prominent residents, who agreed with Benton that they had the right of selfgovernment, but based that claim on the assumption that the Constitution of the United States had superseded the Mexican laws as soon as the treaty was ratified. They acknowledged that the power to legislate for the acquired territory was primarily vested in Congress, but felt that since the Congressional prerogative had not been exercised the people might temporarily assume the right of legislating for themselves. They contended, also, that even in case President Polk and Secretary Buchanan were correct in their theory, the de facto government of which they talked rested entirely upon the presumed consent of the governed, and the inhabitants of California were at liberty to

21 Browne, Debates, 277. 
withhold their consent, and to adopt what laws they saw fit. Some historians identify the "Settlers' theory", with the "Benton theory," but as Benton opposed the doctrine of squatter sovereignty, and the "transmigratory function of the constitution," the two points of view were in fundamental disagreement. ${ }^{22} \mathrm{He}$ was never acknowledged as a popular influence in California, and his "patronizing letter" was again scored in the Alta of July 19.

The proposed convention was finally postponed until August that full reports of the session of Congress might be received. In view of the long delay the delegates resigned, recommending the election of new representatives who should be vested with full power to frame a state constitution and to submit it to the people for ratification. It is interesting to note that this suggestion as to state organization appeared in the same issue of the Alta California (March 22, 1849) that printed the bill which embodied Senator Douglas' first scheme for state government in the territory acquired from Mexico.

Coincident with the impulse towards general provisional government there was an effort on the part of some of the larger communities to apply the method of self-organization to their own local problems, for the existing Mexican system proved more and more inadequate to the needs of the increasing population.

This was particularly true of San Francisco, which had about two thousand inhabitants. ${ }^{23}$ It will be remembered that a town council had been instituted by the alcalde and confirmed by Colonel Mason in July, 1847. ${ }^{24}$ That body had been empowered

22 For the varying opinions on the status of California at this time, see J. F. Rhodes, History of the United States from the Compromise of 1850 , I (1893), 93 et seq.; T. H. Benton, Thirty Years' View, 1854-1856, II, 713; Burnett, Recollections, 311-317, 327-334; Browne, Debates, 274-284; Royce, California, 247-254; Hittell, California, II, 712; Hunt, "Legal Status of California', as cited, 80-82.

23 Annals, 219.

24 See supra, p. 49 . Even the alcaldes went to the mines in the summer of 1848. The council did not meet for five months, and special elections were called to fill the deserted posts (Cong. Docs., Ser. No. 573, Doc. 17, 593, 667; Annals, 205-207; Baneroft, California, V, 648-652). 
to serve until the close of the following year. An election for new officers took place in December, 1848, but the results were challenged on the ground that unqualified electors had been allowed to vote, and the old council refused to give place to the council elect. A second election was called in January, and for a time the three separate bodies wrangled over the control of town affairs. The alcalde, Doctor T. M. Leavenworth, also became a storm center of approval and dislike, and the arbitrary system in vogue grew so intolerable that a group of leading men resolved to wait no longer for constitutional authority, but to formulate for themselves a more efficient municipal government. Early in February they called a mass meeting to consider the difficulties between the rival councils, and in response about five hundred citizens gathered on the Plaza and adopted a new scheme of organization. ${ }^{25}$ They provided for the election of a legislative assembly with power to enact laws that harmonized with the Federal Constitution, and authorized three justices of the peace to try civil and criminal cases according to the common law as recognized in the United States. February 21 was set for the new election, and a committee was appointed to ask for the resignation of the members of the old contesting councils, who obligingly complied with the request.

Bancroft said that the assembly brought to the front a very respectable body of men, full of reform projects. One of their first acts was to appoint a committee to wait upon the senior military and naval commanders, and to ask their approval of the proceedings. Papers were sent them with particulars of the public meetings and minutes of the first session of the assembly, and in a clear and dignified letter the committee recounted the difficulties and hardships entailed upon San Francisco by a

25 See Annals, 208, 219-220; Burnett, Recollcctions, 306-310; Baneroft, California, VI, 209-211, 273; Moses, Establishment of Municipal Government, 36-46. A. J. Ellis, A. J. Grayson, and R. A. Parker (Vigilantes of 1851) were members of the Assembly. 
continuance of the arbitrary rule of an irresponsible alcalde. ${ }^{26}$ This document was one of the most interesting expositions of the popular mind at that period. It pointed out that nothing had been accomplished for eivil improvement; that even the old Mexican institutions had lapsed; that the American alcaldes had never understood or administered Mexican laws and had simply decided questions according to their personal bias; that the people, hitherto patient in the hope of speedy relief, were no longer willing to give that consent which was the indispensable support of the de facto government, and that, in such a situation, they had the right to gather in their primary capacity and to create a government to serve until it might be superseded by competent authority. It was the old resort to the reassembling of social elements by agreement among a particular group which felt that its previous organization was deficient or inoperative.

To the aggrieved citizens their position seemed unquestionably logical, but to the military commanders it was a menace to the integrity of the national authority and a possible step towards the establishment of the independent government decried by President Polk. In response to their petition for endorsement the citizens of San Francisco were therefore informed that as Congress alone had power to legislate for territories, the de facto government must persist until laws had been passed to replace it, and they were warned that "confusion and intricacy would inevitably result from establishing even the best government on a false basis." ${ }_{27}$ Undaunted by this disapproval, the assembly continued its work; held regular meetings, levied taxes, and enacted regulations. ${ }^{28}$ The office of alcalde was abolished, and the incumbent was asked to transfer his records to the senior justice of the peace. Leavenworth, however, appealed to the military authorities, who advised him to retain possession of his

${ }_{26}$ Cong. Docs., Ser. No. 573, Doc. 17, pp. 728-735.

27 Cong. Docs., Ser. No. 573, Doc. 17, pp. 735-737.

28 See The Minutes of the Proceedings of the Legislative Assembly of the District of San Francisco, 1860. 
office and papers. ${ }^{29}$ A little later formal charges of malfeasance were preferred against him, and the governor suspended him from duty pending an investigation. ${ }^{30}$ Even this did not satisfy the legislative assembly, which was determined to assert its authority. On May 31 its sheriff forcibly seized the papers in the alcalde's office. One of the books preserved in the recorder's office in San Francisco breaks off abruptly with the pencilled note in Leavenworth's handwriting and over his signature: "Here the Hounds entered the alcalde's office and seized the records. A. Patterson and others entering a [illegible] Tally ho." The interrupted entry was the copy of a deed dated April 6, 1849, but the intrusion referred to was probably the raid of May $31 .^{31}$ The next day the governor restored Leavenworth to the full exercise of his duties. ${ }^{32}$ His order to that effect did not mention the raid, and the interval was very brief for communication with Monterey. A few days later, however, he called public attention to the assault on the alcalde, asked for assistance in recovering the archives, and designated the "body of men styling themselves the Legislative Assembly of San Francisco" as an illegal organization which should not be supported by law-abiding citizens. ${ }^{33}$

29 Minutes, 16 ; Cong. Docs., Ser. No. 573, Doc. 17, p. 727.

30 Cong. Docs., Ser. No. 573, Doc. 17, pp. 758-760. Leavenworth tendered his resignation to take effect on May 15 (Archives, "Unbound Docs.," $56)$. He complained that the movement was one against the military government, and that the press was all on the side of the insurgents (letter, May 29, ibid., 64-66). Commodore Jones, Captain J. L. Folsom, and Rodman N. Price stated that Leavenworth was so unpopular that he could not give satisfaction in anything (ibid., 55).

31 See O. C. Coy, Guide to the County Archives of California, 1919, p. 413; Ryan, Personal Adventures, II, 251-254; Buffum, Six Months, 114-119; copy of the order issued by Myron Norton, directing Sheriff J. C. Pulis to seize the papers (Archives, "'Unbound Docs.,"' 320-321) ; Leavenworth's report of the raid (ibid., 319). A. A. Green mentioned the return of the town records to the alcalde after he was reinstated (Life and Adventures of $a$ ' $47-e r, 1878$, p. 24 , MS in the Bancroft Library). For the story of the Hounds, see infra, p. 105.

32 Cong. Docs., Ser. No. 573, Doc. 17, p. 771.

33 Cong. Docs., Ser. No. 573, Doc. 17, pp. 773-774. 
San Francisco was not the first nor the only community to experiment with local organization. When the residents upon the north side of the Bay of San Francisco met in Sonoma, February 5, 1849, for the purpose of electing delegates to the proposed constitutional convention, they adopted rules and regulations for the control of the district until a permanent govermment might be established. Nothing significant was accomplished by this association, which dissolved when the members found that their course was disapproved by the authorities. ${ }^{34}$ Sacramento, as the most convenient point of departure for the northern mines, also felt the need of some government more effective than that of the alcaldes at Sutter's Fort. An initial meeting was held April 30, 1849, and subsequently a legislature of eleven members was elected, but it was afterwards decided that elaborate organization was unnecessary, and an alcalde and sheriff were chosen to preserve order in a district extending from the Coast Range to the Sierra Nevada Mountains. ${ }^{35}$ Had such district associations been countenanced by the governor, it is probable that they would have been formed in other localities, but he felt called upon to suppress them. In consequence each community was obliged to shift for itself.

All through the early months of 1849 , while the Californians were hoping for favorable news from Washington, Colonel Mason maintained his official aloofness from the movement towards organization. By April 13, when Brevet-Brigadier General Bennet Riley arrived to relieve him, the scheme for provisional government had lapsed through postponement, although it was evident that resentment against existing conditions was fomenting

34 Alta, 1849, March 1 1/3; Cong. Docs., Ser. No. 573, Doc. 17, p. 749 .

35 The Placer Times, 1849, May 5, reported the organization. Burnett said the meeting was early in January (Recollections, 294), but in the History of Sacramento County, 47 , it is stated that there was no form of gorernment until the summer months. See also Sacramento Illustrated, Barber \& Baker, publishers, 1855 , p. 9 ; Bancroft, California, VI, 455. 
a spirit of aggressive self-assertion. ${ }^{36}$ The two officers reviewed the situation in careful consultation. They were not yet definitely informed of the plans of the Whig cabinet, but they were probably aware of the futile attempts made in the late session of Congress to pave the way towards state organization. They decided that it would be well for the new governor to summon a convention to draw up a state constitution as soon as he might learn that Congress had actually adjourned without passing any bills that would affect the situation. ${ }^{37}$

The administration of Mason closed without the establishment of the government for which he had sincerely hoped, but as his aid, William T. Sherman, pointed out he left matters in California so disposed that a civil system was a matter of easy adjustment. For nearly two years he had held his slender reins of government over the turbulent forces in California, and prevented utter catastrophe and ruin. His task had been discouraging and thankless, for his superiors had tacitly forbidden him to undertake any constructive work, while the people constantly blamed him for his failure to accomplish effective reforms. But he was not afraid of criticism, he was loyal to his idea of duty, and while all the world about him went mad over the pursuit of wealth, he never used his official position as a source of per-

36 The general discontent occasionally gave rise to rumors of a movement for independence. General Persifor F. Smith said that on his trip to California he encountered "some persons going out armed with Colonel Benton's letter to set up a government for themselves'' (Cong. Docs., Ser. No. 573 , Doc. 17 , p. 710$)$. E. O. Crosby said that an independent republic might have been attempted if California had not organized and been admitted (MS Statement, 1878, pp. 52, 57). The attitude of the newspapers has been analyzed in a MS master's thesis, Sentiment in California for a Pacific Republic, 1843-1861, 1919, by Joseph Ellison, in the University of California Library. See also Burnett, Recollections, 327-328; Baneroft, California, VI, 268 note 31; Hunt, "Legal Status," as eited, 73; Dorothy Hull, "'Morement in Oregon for the Establishment of a Pacific Coast Republic,", Oregon Historical Society, Quarterly, XVII (1916), 177-200; H. E. Bolton, "Admission of California," University of California Chronicle, XV (1913), 561.

37 Cong. Docs., Ser. No. 573, Doc. 17, p. 748. 
sonal profit. He left California shortly after his relief, and died of cholera, in St. Louis, in the summer of the same year. ${ }^{38}$

On or about the first of June Governor Riley received positive information that Congress had adjourned without creating a government for California. ${ }^{39}$ On June 3 he issued a proclamation that summoned a constitutional convention to meet at Monterey on the first day of September, designated the electoral districts, the number of delegates from each, and the time and mode of their selection. ${ }^{40}$ The measures proposed by Riley were so like those of the amended bill which Senator Douglas had offered in the Senate, that it seems safe to infer that they must have been formulated with exact knowledge and careful reproduction of the methods which had been considered at Washington. ${ }^{41}$ The document antedated by a day the arrival in San Francisco of Thomas Butler King, who for some unexplained reason did not communicate with the governor until about the middle of the month. ${ }^{42}$ It is therefore improbable that the presence of the President's special agent had any appreciable influence on the plans for the convention.

In this proclamation the governor also made public the first official summary of the Mexican system which had supposedly been in force from the time of the American occupation. ${ }^{43} \mathrm{He}$ announced that in view of the months that would elapse before

3s See Bancroft, California, VI, 27t; Hittell, California, II, 677; Sherman, Memoirs, I, 65.

39 Cong. Docs., Ser. No. 573, Doe. 17, p. 748 ; S. H. Willey, Transition Period, 1901, p. 85.

40 Cong. Docs., Ser. No. 573, Doc. 17, pp. 776-780.

41 Secretary of War Crawford wrote General Smith, April 3, 1849, that want of information on California conditions precluded the possibility of special instructions, although no plan for an independent government could be sanctioned (Cong. Docs., Ser. No. 549, Doc. 1, pp. 156-157). He wrote to Riley in a similar tenor, June 26, saying, at the same time, that it was the right of the people to form a plan of government, which might lead to their admission as a state (ibid., 160-161).

$42 \mathrm{King}$, California: the Wonder of the Age, 7 .

43 See supra, p. 24. 
any new government could be instituted, he would immediately put the native institutions into their "full vigor." To accomplish this purpose he ordered that when the people chose delegates for the constitutional convention they should also elect alcaldes, justices of the peace, and town councilmen, wherever such officials were not already installed, and should, in addition, elect the judges for the superior court, and the prefects and sub-prefects authorized by the Mexican statutes.

The call for a convention aroused unexpected opposition. Some of the advocates of immediate organization protested that the governor had no business to infringe upon their right of selfgovernment, even to the extent of setting a date for the convention, or allotting the number of delegates. This feeling was most loudly expressed in San Francisco, where there was much resentment over Riley's arraignment of the legislative assembly and his reinstatement of Alcalde Leavenworth; but after some discussion it was decided to accede to his suggestions, and to join in the general movement towards organization. ${ }^{44}$

Early in July the members of the legislative assembly, conscious of the governor's disapproval of their position, asked for an expression of popular opinion, and called for an election which should confirm or withdraw the authority that had been delegated to them. When this was held one hundred and sixtyseven votes were cast in their favor, and seven against them. The support was considered so inadequate that the assembly dissolved, leaving Leavenworth in possession of the field. ${ }^{45}$ The Annals of San Francisco, published in 1855, remarked of this situation : $:^{46}$

\footnotetext{
44 See Burnett, Recollections, 319-326; Hittell, California, II, 713-718; Baneroft, Califormia, VI, 277-280; Willey, Transition Period, 86-89; F. J. Lippitt, "The California Boundary Question in 1849," Century, XL (1890), 795 .

45 Annals, 223; Bancroft, California, VI, 211 note. Leavenworth again tendered his resignation on June 4 (Archives, "Unbound Docs.,' 228; Cong. Docs., Ser. No. 573, Doc. 17, p. 774).

46 Annals, p. 223.
} 
These various meetings and other proceedings narrated may possess little interest for the present inhabitants of San Francisco; but they certainly much excited those who dwelt in the town at the time of their occurrence.

And, indeed, for every student of California history they should have a profound interest as showing the strength of the current conviction that temporary organizations, adopted by the consent of the men immediately concerned, were legitimate forms of government in crises where other systems were non-existent or inefficient.

Another illustration of the spirit which appealed to popular initiative in public affairs is furnished by the episode of the suppression of the "Hounds," a company of San Francisco desperadoes who terrorized the city in the summer of 1849. More than one writer on the period noted that the adventure of the Mexican War had enlisted among the New York Volunteers numbers of rowdies, who flocked to the mines as soon as they were discharged, and there behaved so badly that in many places they were driven out of camp. Drifting back to San Francisco, they formed the nucleus of a criminal "gang," which adopted a semblance of military discipline, formulated rules, elected officers, and established so-called headquarters in a large tent known as Tammany Hall. ${ }^{47}$ They often paraded the streets with music and banners, and their commissary was provisioned by raids upon stores and restaurants, which were forced to supply their demands and "charge it to the Hounds," as the marauders marched away with insolent laughter. Later they adopted the more respectable name of the San Francisco Society of Regulators, and Bancroft stated that Alcalde Leavenworth employed

47 See Popular Tribunals, I, 76-102; Annals, 553-561. Stanislaus Grabowski, a German author with a penchant for historical novels, used the ineident for the theme of Die Regulatoren von San Francisco, a story which showed some familiarity with the eircumstances, but no personal acquaintance with San Francisco. It was also described in "La Californie lans les derniers mois de 1849,' an article by Patrice Dillon, in the Rerue des deux mondes, nouvelle periode, V (1850), 205-206. 
some of them in "carrying out the ends of justice." ${ }_{48}$ Be that as it may, they went far beyond any official sanction, and took advantage of the anti-alien sentiment of the community to make brutal attacks upon the foreigners of Latin American origin, many of whom lived under wretched and vicious conditions in the quarter known as Little Chili.

Hall McAllister, a distinguished lawyer of later days, has related the story in a dictation made at Bancroft's request. His account was in substantial agreement with that in the Annals of San Francisco, and with other original sources. He said $:^{49}$

During the months of June and July ' 49 there existed in San Francisco a band of men calling themselves "The Hounds," consisting principally of the refuse of Col. Stevenson's regiment. The leader of this band of men was named Samuel Roberts. They committed various outrages, particularly during the month of July. On one Sunday they were especially violent, going about and robbing all the Chilenos they could find... They ... beat them, and shot one of them very badly in the body.... Several of them, mounted on horseback, chased these Chilenos through the city and up Telegraph Hill, shooting at them as they ran.

On Monday afternoon, the following day, Sam Brannan, Frank Ward, A. J. Ellis, Sam Ward, and various others formed a meeting upon the Plaza, at which Sam Brannan and Frank Ward made speeches, from the top of the small buildings then existing at the S.W. Corner of Kearny and Washington Sts. After the speeches, an organization was immediately had, and Captain [W. E. Spofford] was appointed Chief Marshal; and A. J. Ellis, Hall McAllister, F. J. Lippitt and others were appointed Captains, to organize a force to arrest these Hounds. They immediately went to work that afternoon and secured quite a number [nineteen] of them, among whom were Samuel Roberts, the leader of the band, who was arrested on board a schooner in the harbor.... A number of them were taken at their rendezvous, which was then situated just where Commercial comes into Kearney St. now, in a tent which they had there... After the prisoners

48 Popular Tribunals, I, 78. J. H. Brown wrote that the Regulators originated with a group of about ten men who banded themselves together for the purpose of returning runaway sailors to their vessels (Reminiscences, [78]). Sam Roberts, the learler, had been a member of Stevenson's Regiment (Clark, First Regiment of New York Tolunteers, 37). At one time the alcalde of San Francisco had employed him to administer public corporal punishment to a mutinous sailor (Alta, 1849, Aug. 9 \% $/ 2$ ).

49 Vigilance Committees-Miscllany, 1877, pp. 14-16. 
were secured, there was a meeting of all the citizens, and a Court was organized, the Judges of which were Leavenworth, the Alcalde, Dr. William M. Gwin and James C. Ward. Horace Hawes, Francis J. Lippitt and Hall MeAllister were appointed attorneys to prosecute these men before this court. A Grand Jury was called, and they were regularly indicted, and charged with a conspiracy, to commit murder, robbery, ete. They were trier before these three judges and a jury, in a small building called the Court House, which was situated on the Plaza at the S. W. corner of what is now Portsmouth Square... The trials of the several men occupied many days, that of Roberts taking place first, and were conducted according to the ordinary legal form, witnesses being called on each side. The cases were summed up on behalf of the prosecution by Hawes and MeAllister, and on the part of the defendants by [P.] Barry and [Myron] Norton. [Eight of] the men were convicted. This organization of the people to put down these "Hounds", was called the Law and Order party. After the conviction of these men it became an important question how they should be punished. Some were for having them hung, others for having them whipped upon the public Plaza and banished, and others simply for having them banished and given to understand that if they returned they would be executed. That was the final disposition, and they were banished, with this warning. That ended the "Hounds" riot.

The outcome of the trials was characteristic of the time and place. Popular sentiment was contented with a reasonable number of convictions, and with the scattering of the gang. Since there was no jail in which sentences of imprisonment could be served, the actual pumishment of the offenders seemed to be of little importance in the public mind. ${ }^{50}$ There were, however, some permanent effects, for the impromptu military patrol was the initial step in the organization of a regular company of militia. ${ }^{51}$ More than this, MeAllister's referene to a "law and

50 The convicted men were confined for a time on board ressels in the naval service. See O. T. Shuck, Bench and Bar in Califormia. el. of 1889, p. 98; California Illustrated [by J. M. Letts], 1852, p. 53; S. C. Upham, Notes of a Voyage to California, 1878, p. 222 ; MSS in the Baneroft Library of Isaac Bluxome, Jr., Statement [1877?], 5, and of W. M. Gwin, Memoirs. 1878, p. 8 .

51 Isaac Bluxome, Jr., said: "After the conviction of some of the hounds, the gang was broken up, and the four companies were disbanded, and the California Guard was organized on the 27th of July, 1849 (MS Statement. 6). The list of members (Annals, 703), included the following men who became Vigilantes of 1851: H. M. Naglee, W. H. Tillinghast, W. D. M. 
order party" was confirmed by another participant, who said that the captains of the patrol acted as a nominating committee in the August election, and virtually secured the return of a reform ticket, and that the whole affair was the beginning of the vigilance committees of California. ${ }^{52}$ In view of that statement it is interesting to note that at least eleven of those who were prominent in the trial became members of the Committee of Vigilance of $1851 .{ }^{53}$

The story of the Hounds is important in this narrative not alone because of the personnel of the actors. It shows conclusively that the mass meetings and popular tribunals which were tolerated by necessity in the mining camps, had been widely accepted as legitimate means of social discipline, and that the men of San Francisco naturally resorted to them as an emergency organ of govermment. So strong was the force of the popular impulse that it obliged the alcalde to accept an invasion of his prerogative, and to conduct the trial in conference with the popularly appointed assistants. ${ }^{54}$ The people did not organize this extra-legal tribunal in any spirit of defiance of the ordinary safeguards of justice. On the contrary, they introduced for the

Howard, W. L. Hobson, H. F. Tesehemacher, A. J. Ellis, J. C. Ward, A. G. Randall, Benjamin Reynolds, E. A. King. The Constitution and By-Laws of the First California Guard was printed in 1850. This was not the first militia of San Francisco (see J. H. Brown, Reminiscences [36-38]; Bancroft, California, VI, 263 note 19).

52 "We detailed companies with captains to patrol and arrest these rioters... The companies were officered by the principal citizens. That was the commencement of the Vigilance Committee of California. After the affair of "the Hounds," the companies disbanded. Leavenworth was Alcalde, and acted as judge in the trial of the Hounds. He was giving away the town lands, and we had a great deal of trouble on that account. We petitioned the Governor to call an election for our protection. The captains of the companies acted as a nominating committee, and their ticket was elected almost unanimously', (C. V. Gillespie, MS Statement, 1875, pp. 5-6.)

53 Isaac Bluxome, Jr., Samuel Brannan, J. R. Curtis, A. J. Ellis, V. J. Fourgeaud, C. V. Gillespie, W. D. M. Howard, Benjamin Reynolds, Frederick Teschemacher, J. C. Ward, Hiram Webb (Annals, 558-559).

54 See Annals, 557-558; Shuck, Bench and Bar, 98. 
occasion the elaborate accessories of grand jury, associate judges, and counsel for prosecution and for defense, and they chose for the trial-jury men of established credit and importance. Even the two hundred and thirty volunteer constables ranged themselves from the start in ordered companies under the authority of officers, and conducted the search for the criminals without riot or undue violence. ${ }^{55}$

While the residents of San Francisco were settling their domestic concerns during the exciting summer of 1849 , the community at large made ready for the approaching election. ${ }^{56}$ Parties of speakers visited the mining regions to arouse interest in the convention, and Thomas Butler King did what he could to forward the movement. He stated afterwards that so far as he was informed, party and sectional affiliations did not figure in the selection of delegates, and that the only object seemed to be to find competent men who were willing to make the requisite sacrifice of time. Bayard Taylor confirmed that statement, but noted that in Sacramento and San Francisco political interests might have been influential. ${ }^{5 i}$

The elections took place on or near August 1. Any American citizen of twenty-one was allowed to vote, no matter how recent his arrival in California, and travelers paused en route to the mines to deposit their ballots at some chance polling place or in boxes nailed to convenient trees. ${ }^{58}$ The returns showed that all

55 Ernest Frignet called the trial an "Example mémorable, et que la Californie a donné plus d'une fois, de ce que peut le plus petit effort des honnêtes gens contre le désordre le mieux organisé et les malfacteurs les plus audacieux"' (La Californie, 1866, p. 125).

56 See Bancroft, California, VI, 279-283. Willey gave an interesting description of a typical meeting for the selection of delegates (Transition Period, 96). 147.

57 King, California: the Wonder of the Age, 7 ; Taylor, Eldorado, I,

58 See L. B. Patterson, Twelve Years in the Mines, 1862, p. 35; History of Placer County, 1882, p. 93; MS Statement of E. O. Crosby, prefect of the Sacramento district, pp. 52-56. 
the districts had chosen delegates, who prepared to meet in Monterey at the time appointed.

The attempt to put into full vigor the surviving Mexican law also met with a general response, and local officers were elected for the positions named in the governor's proclamation. This effected certain changes in the organization of California. District prefects were chosen as directed by the governor, who officially confirmed their selection. ${ }^{59}$ Alcaldes were elected wherever vacancies existed, and Riley commissioned one in each district to act as a judge of first instance. The election of judges of the superior tribunal at last created a court of appeal from the alcaldes' courts, but fees were so extortionate that contestants were not quick to take advantage of the privilege. ${ }^{60}$

The men who held office in the antumn of 1849 had the benefit of Halleck's Digest of the laws of 1837 , which was put into circulation about this time. ${ }^{61}$ Here, at last, was the complete scheme of organization which had, in theory, dominated California for three years, but which had been shorn in practice of all functions save those pertaining to the offices of the governor, his secretary, and the alcaldes. If promulgated earlier, it would have given the people a clearer realization of their subordination to a central authority, but that step had not been taken because of the constant anticipation that Congresisonal action would supersede the temporary government.

As soon as the alcaldes' courts were established on a more efficient basis they were fairly overwhelmed with cases. To relieve their congestion General Riley appointed additional judges of first instance, with civil jurisdiction only, for some

59 Commissions for the judges, prefects, and first alcaldes in Cong. Docs., Ser. No. 573, Doc. 17, pp. 797, 806-808, 811, 820-830, 865. Later appointments in Ser. No. 561, Doc. 52, pp. 22-39.

60 Burnett, Recollcctions, 346.

61 "The Laws of California"' were advertised in the Alta, 1849, Sept. 20 3/. Reprinted in Browne, Debates, Appendix, pp. xxiv-xl. 
of the larger towns. ${ }^{62}$ Among these judges was the eccentric William B. Almond, of San Francisco, who rose from the humble position of peanut vender on the public streets, to the tip-tilted chair of his crowded court room, where suits involving thousands of dollars were decided in half-hour hearings, with swift exchange of the "ounce of dust". that constituted his invariable fee. With his feet on the mantel, and his eyes and hands occupied with details of his toilet, he listened to counsel only so long as it took him to grasp the sense of the case, then pronounced a judgment from which immediate appeal was seldom taken, although there was a quick resort to the relief afforded by the establishment of the Supreme Court in $1850 .^{63}$

After this period of reorganization there was somewhat closer touch between the larger mining camps and the central authority. ${ }^{64}$ More effort was made in the new towns to keep records of proceedings, and men who had, perhaps, served as alcaldes in previous months, left as their earliest documents papers signed subsequent to the first of August, 1849. The dearth of public records from which to reconstruct the early history of California confronts every student of that period with an inexorable barrier. Since the military-civil governors made few, if any, appointments in the mining regions prior to August, 1849, they conducted little correspondence which referred to affairs in the mountains.

62 Appointments, Cong. Docs., Ser. No. 573, Doc. 17, pp. 832, 867, 871.

63 Amusing tales of Judge Almond are told in Hittell, California. II, 778-779, III, 223, 248; Burnett, Recollections, 343; Bancroft, California Inter Pocula, 1888, pp. 591-600; Annals, pp. 238-241. He sometimes said: "Gentlemen, I don't know just what the law of this case is, but I know what it ought to be (Memoirs of Cornelius Cole, 1908, p. 82). He allowed thirty minutes to each case, and during the winter rains jurors were often "corralled in the back yard" in default of a jury room, a situation which prompted them to make quick decisions (E. W. McKinstry, "Oration," in Society of California Pioneers, Twenty-first Anniversary, 1871, p. 7). The First California Reports included many cases appealed from his court.

64 Correspondence with alcaldes of Sonora Camp, Mormon Camp, and Willow Bar, September to November, 1849, in Archives, "Unbound Docs.," 13 , 50, 57; Cong. Docs., Ser. No. 561, Doc. 52, pp. 29-32; see also infra, p. 138 note. 5 . 
Each of the early camps was an independent body, unrelated to other bodies outside its immediate neighborhood, and without occasion for written communication of an official character. The domestic concerns of the camps were not matters of record except in the case of the regulations governing mining rights and the claims made thereunder, and whatever may have been written, much of it has been destroyed in the frequent fires that have swept the little towns. ${ }^{65}$

The August election gave the citizens of San Francisco an opportunity to make desirable reforms in their town government. John W. Geary, who had arrived in March to serve as the first postmaster of San Francisco, was chosen first alcalde, and several of the men who had taken part in the trial of the Hounds were elected to office. ${ }^{6}$ At the initial meeting of the new ayuntamiento $^{6 \tau}$ Geary presented an excellent address on the municipal situation, and described as follows the confusion that had arisen from the lack of civic equipment ${ }^{68}$

At this time we are without a dollar in the public treasury, and it is to be feared the eity is greatly in debt. You have neither an office for your magistrate, nor any other public edifice. You are without a single police officer or watchman, and have not the means of confining a prisoner for an hour; neither have you a place to shelter, while living, sick and unfortunate strangers who may be cast upon our shores, or to bury them when dead. Public improvements are unknown in San Francisco. In short, you are without a single requisite necessary for the promotion of prosperity, for the protection of property, or for the maintenance of order.

65 Some valuable pre-statehood records are mentioned in Coy, Guide to the County Archives, pp. 50-51.

66 Annals, 228-229.

67 Riley revived the use of the Spanish term, which had not been employed by Mason when he instituted the San Francisco council in 1847. Riley also encouraged the election of ayuntamientos in all towns entitled to such bodies (see Cong. Docs., Ser. No. 573, Doc. 17, pp. 761-769; Ser. No. 561, Doc. 52, p. 27).

68 See Annals, 229-234. The proceedings of the ayuntamiento were printed in separate parts, 1849-1850, and reprinted with the Minutes of the ... Legislative Assembly, 1860, pp. 47-296. 
He recommended that revenue should be raised by taxes and commercial licenses, and expressed his conviction that such a procedure would be approved by the governor, and by the first legislature that should assemble after permanent organization should be effected. On August 27 an ordinance was passed for raising a revenue according to his suggestions.

The work accomplished by this ayuntamiento was creditable and progressive. An old vessel, the Euphemia, was purchased and equipped to serve as a jail; a police force of thirty was organized, and order was preserved in the city with fair success. ${ }^{69}$ Improvements were begun on the wharves and on the muddy thoroughfares; and in recognition of the services of the members of the council, the city surveyor, W. M. Eddy, assigned their names to the streets which were laid out during their term of office. $^{70}$ Bancroft commended this administration, and said that at its close a balance of $\$ 40,000$ was left in the treasury, and that no blots stained the public character of the councilmen. ${ }^{11}$

On the third of September the constitutional convention at Monterey organized for business. Particulars of its work and of the constitution it framed need only our briefest consideration, since they have already been made the subject of special study. ${ }^{72}$ There were forty-eight delegates $:^{i 3}$ Doctor Robert Semple, of

69 A list of crimes, Sept. 4, 1849, to March 26, 1850, was given in the Alta, 1850, May $2 \%$. The total arrests were 741 , and included 170 cases of larceny, 70 of assault and battery, 10 attempted murders and 4 actual homicides. The summary indicated that violence in the eity was not of the alarming proportions sometimes attributed to the days of ' 49 .

To San Francisco Call, 1883, July 30 3\%s.

¿1 Baneroft, California, VI, 213-215.

i2 See Bancroft, California. VI, 284-303; Hittell, California, II, 756774; Royce, California, 259-270; Goodwin, Establishment of State Govermment; D. R. Hunt, Genesis of California's First Constitution, 1895 ; F. N. Thorpe, Constitutional History of the American People, 1898, II, 287-394; Browne, Report of the Debates in the Convention, 1850; Willer, Transition Period, 93-126; G. H. Fitch, "How California Came into the Union," Century, XL (1890), pp. 775-792.

is See Browne, Debates, 478; Goodwin, Establishment of State Governm.ent, 81-85. 
Benicia, one of the leaders in the Bear Flag revolt, acted as president, and he well expressed the task that lay before them when he said they had assembled to "make something out of nothing, to construct organization and form out of chaos.'

The convention was cautious in experimenting with original measures, and the debates show that the constitutions of several older states were consulted. That of Iowa served, in many respects, for the model finally adopted, although much was borrowed from the constitution of New York. Sentiment in California was so strong against permitting slavery that there was no dissent to the resolution that prohibited it within the limits of the state. ${ }^{75}$ Nevertheless the national conflict on the subject made itself apparent in a debate on a proposition to exclude free Negroes, and in the discussion of the demarkation of the eastern boundary, as the latter question had an important bearing on a future subdivision with the possibility of slave territory in a southern area. In the end, the exclusion of free Negroes was defeated, and the present boundary was adopted as the one least likely to lead to friction and delay when Congress should act on the application for admission to the Union.

General provisions were made for the legislative, executive, and judicial departments of the state, for the organization of counties, and for the establishment of courts, but wide discretionary powers were allowed to the coming legislature. In order to prevent inconvenience to the public service it was provided that no office should be "superseded, nor the law relative to the duties of the several officers changed, until the entering into office of the new officers to be appointed under this Constitution. ${ }^{76}$

74 Browne, Debates, 23.

75 In spite of this prohibition some slaves were imported into the state (see C. A. Duniway, "Slavery in California after 1848,' American Historical Association, Report, 1905, I, 243-248).

76 Schedule, Section 3. Browne, Debates, Appendix, p. xii. 
While the details of the constitution, like the details of the miners' laws, are not of importance here, there is great significance in the fact that in spite of the rapid creation of this framework of government it was eminently efficient and consistently liberal in its provisions. Hermann von Holst wrote of this accomplishment: $:^{i 7}$

And the population of California, swept together from all the states of the Union, gave the most magnificent illustration of the wonderful capacity of this people for self-government, by creating for themselves, of their own motion, and with the utmost coolness and deliberation, a political organization which proved itself viable under conditions to which many an old and firmly established government would have suceumbed.

The convention completed its labors on the afternoon of October 13. In suppressed excitement the delegates proceeded to affix their signatures to the completed instrument, and, as they wrote, the cannon of the fort broke forth in a national salute, announcing by its thirty-one guns that a new state presented her sons for citizenship in the Federal Union.

77 Hermann von Holst, Constitutional and Political History of the Cnited States, III (1881), 463. Hittell called the constitution "one of the best, if not the very best, of all the thirty-one that then existed (California. II, 783 ). 


\section{THE FABRICATION OF THE COMMONWEALTH}

A month after the constitution was signed at Monterey it was ratified by the people. ${ }^{1}$ At the same time an election was held for members of the first legislature and for representatives in Congress; Peter H. Burnett ${ }^{2}$ was chosen as governor, and John McDougal as lieutenant governor. For a second time party politics were disregarded in a state election, as most of the candidates made independent campaigns, and in many places they were practically unknown to their constituents. ${ }^{3}$

The first legislature assembled in San José on December 15, 1849. On December 20 Burnett was installed as governor, and General Riley issued his last proclamation, congratulating the people on the organization of their state government, and resigning the administration of civil affairs into the hands of the new authorities. $^{4}$

1 See Goodwin, Establishment of State Government, 251-254.

2 Burnett had served on the Oregon legislative committee of 1844 . He arrived in California in October, 1848, quickly assumed a leading position in Sacramento, and was later a member of the legislative assembly of San Francisco. He was prominent in the movement for state organization, and was elected judge of the superior court in August, 1849.

3 Bayard Taylor gave an amusing account of the haphazard manner in which the miners were forced "to go it blind"' in the choice of candidates (Eldorado, II, 6-8). See also A. J. MeCall, Pick and Pan, 1883, p. 35; Lyman, Journal of a Voyage to California, 129. It is usually stated that the first party organization in California was a Democratic gathering in San Francisco, Oct. 25 (Bancroft, California, VI, 304-305; Hittell, California. IV, 51-53; W. J. Davis, History of Political Conventions in California, 1849-1892, 1893, p. 1). A. J. Newman has called attention to a report in the Pacific News, Oct. $25 \% 1-3$, of a meeting in Portsmouth Square, Oct. 23, in the interests of T. Butler King, as a candidate for the United States Senate (Formation of the First Political Parties in California, 1918, MS master's thesis, University of California Library, Department of History).

4 See Browne, Debates, Appendix, p. xlvi. The constitutional convention had decided that the state government should go into operation, without waiting for Congressional approval (ibid., 274-288). Riley doubted the 
From that day the men of California took charge of their own destinies, and shaped their political institutions according to their own preferences. They clung closely to the precedents with which they were familiar. They transplanted to the vast and sparsely populated area of California the usual decentralized system of local organization. They replaced the civil law of Mexico by the English common law as received and modified in the United States, and they instituted the courts to which they had been accustomed elsewhere. ${ }^{5}$

All this new machinery of government could not be set in motion overnight. It was April or May of 1850 before the larger towns were incorporated and the counties and townships equipped with the necessary officials. ${ }^{6}$ In the meantime conditions in the state at large were even more confused than before. The alcaldes elected under the pre-statehood régime continued their legal services until their places could be filled by the new magistrates, but their unskilled interpretation of law and their arbitrary methods caused greater and greater complaint as the impatient citizens awaited the establishment of American institutions.

There was an increasing need for efficient officers in the mining regions where large investments of capital began to supersede the temporary claims of the individual miner. As the surface richness was skimmed from the placers, cradles or rockers took the place of the pan in which at first each miner washed out his own portion of gravel. Since such machines

legality of such a course, but acceded to the wishes of the people. For comment on the situation, see Cong. Docs., Ser. No. 573, Doc. 17, pp. 279282, 819; Richardson, Messages, V, 27; California Senate, Journal, 1850. pp. 32-33; Goodwin, Establishment of State Government, 220-223 ; Rodman, History of the Bench and Bar of Southern California, 21; von Holst, Constitutional History, III, 518.

5 The work of the first legislature was described and commended by Bancroft, Califormia, VI, 308-336; Hittell, California, II, 791-807; Goodwin, Establishment of State Government, chaps. 12-17.

6 County officers were elected the first Monday in April (California, Statutes, 1850, chap. 24, p. 81, sec. 3). 
required an adequate and regular supply of water, it became necessary to construct ditches and flumes, which immediately assumed value as a part of a miner's equity. ${ }^{7}$ This elaboration of industry naturally involved financial coöperation on a formal and permanent basis, and, as Professor Royce has emphasized, it had an important influence on the progress of social evolution in California. ${ }^{8}$ In consequence of General Riley's efforts to extend the operation of the Mexican system, the miners' alcaldes were by this time recognized civil authorities, ${ }^{9}$ and there was a growing tendency to refer mining disputes to them rather than to impromptu meetings, although legal forms were still set lightly aside in criminal matters.

The characteristics of the time are well illustrated by the experiences of Stephen J. Field, who became in later years chief justice of the state. ${ }^{10}$ He reached San Francisco at the close of December, 1849, and within three weeks moved inland to the present site of Marysville. The town, then known as Yubaville, had already attracted nearly a thousand people. A day or two after Field's arrival a civic organization was effected, and the young lawyer was elected first alcalde. He was sworn into office by the judge of the Court of First Instance in Sacramento, and in order to cover all contingencies that might arise under the impending change of laws, the prefect of the district obtained for him the governor's appointment as a justice of the peace.

‘ Bean's History and Directory of Nevada County, 1867, p. 65, stated that the first mining diteh in California was projected at Nevada City, March, 1850.

8 Royce, California, pp. 287-290, 301.

9 The old officers were retained until successors could be elected (California, Statutes, 1850 , cliap. 23 , p. 77 , sec. 2). Miners' alcaldes of this period are mentioned in Taylor, Eldorado, II, 17; A. B. Clarke, Travels in Mexico and California, 1852, p. 137. Many of Shinn's examples of eamp organization also belong to these months.

10 See S. J. Field, Personal Reminiscenees of Early Days in California, [1893], pp. 18-37, 243; Baneroft, California, VI, 463-464; Amy and Amy, Marysville Directory for $1856, \mathrm{p}$. 5. The Register of Suits before the First Alealde of Marysville, January to May, 1850, preserved in the archives of Yuba County, confirms Field's Reminiscences. 
The new magistrate was aware that the functions of the alcaldes were strictly defined by statutes, but he found that in the irregular conditions of the interregnum they exercised almost unlimited power. He therefore took jurisdiction over every case that was brought before him, and did his best to preserve order in spite of his ignorance of Mexican law. The lack of a jail forced him to sentence convicted criminals to corporal punishment, but this stern discipline was approved by the community, which exhibited an excellent understanding of the measures that were required for the administration of justice. The prompt methods of his court are shown by the proceedings in a case of burglary that occurred at four o'clock on an April morning. The alcalde issued warrants for the thieves, and they were pursued, arrested, indicted by a grand jury, convicted by a petit jury, sentenced, whipped, and turned out of town within twelve hours.

Various experiments in local organization were also products of the winter and spring of 1849 to 1850 . The residents of Stockton, for instance, tried to effect municipal organization, and elected a council that proved to be an illegal body. It hastily adjourned when the councilmen discovered that they were personally responsible for the obligations they had incurred. ${ }^{11}$

In November Sonora felt the need of a public hospital, and in order to raise funds for the purpose adopted a town government with a council of seven, and transferred the acting alcalde, C. F. Dodge, to the position of mayor. ${ }^{12}$ Sacramento, which had

11 History of San Joaquin County, 1879, p. 24. On Oct. 25, 1849, Thomas B. Van Buren, "prosecuting attorney of the District of San Joaquin," wrote to Halleck that as the citizens of Stockton had already contributed $\$ 7000$ for the prosecution of criminals, purchased a prison ship, and undertaken municipal improvements, they desired help from the government in defraying further expenses (Archives, "Unbound Docs.," 49 ).

12 On April 29, 1850, Major Sullivan was elected alealde, "without governmental authority and solely to meet an immediate emergency,' History of Tuolumne County [by Lang], 18, 25; Bancroft, California, VI, $469-470$. 
tried unsuccessfully to install a form of town government in the spring of 1849 , elected a council in July. It was, however, helpless to enforce order, as the people had failed to declare the boundaries of the eity, and to fix the duties of the councilmen. ${ }^{13}$ After a struggle with the disorderly element, which preferred the existing state of license, a charter was adopted in October; but the officials were unchecked by any wise limitations of power, and quickly accumulated a heavy debt. The situation was not relieved until the spring of 1850 , when a better charter was acquired from the legislature. The mountain camp known as Rough and Ready, near Nevada City, found itself with a large population early in 1850 , and the residents in mass meeting appointed a committee of three to settle disputes and to administer justice. Edward F. Bean, writing in 1867, spoke of this as a "Committee of Vigilance and Safety." As he did not quote from contemporary documents it is possible that the title was applied in retrospect after the committees of later days had made current the use of the term. ${ }^{14}$

The dangers that attended the unstable conditions of California society during the spring of 1850 were aggravated by certain changes for the worse in the population itself. These were due, in part, to the demoralization of large numbers of miners by hardships, excitement, and dissipations. Many were broken in health by the physical strain of their work, and by their constant exposure to fever and malaria, scurvy and dysentery, and many more whose physical strength permitted them to drink without drunkenness in '49 plainly showed the effects of such

13 Placer Times, 1849, Aug. 11 \%; Sept. 15 \%1. See also Bancroft, California, VI, 455-456; History of Sacramento County, 48-49.

14 Bean's History and Directory of Nevada County, 359-361; Shinn, Mining Camps, 180, 225; Hittell, California, III, 279-280. The committee was not mentioned in the early sketch by A. A. Sargent in Brown and Dallison's Nevada, Grass Valley and Rough and Ready Directory, for... 1856, pp. 44-45, but it was described in the History of Nevada County, 1880, pp. 89-91, and that volume also spoke of an attenipt to organize the independent "'State of Rough and Ready.', 
a habit after twelve or eighteen months of license. ${ }^{15}$ The ranks of desperate and ruined men were constantly recruited from the victims of the universal passion for gambling. Games of chance ran openly in the shabby barrooms that lined the main street of every camp, and in the gaudy saloons of the larger settlements. Hundreds of professional gamblers fleeced the unwary, and in many places formed an allied group that successfully opposed all efforts towards social improvement. ${ }^{16}$ The feverish and spectacular gambling of the mining days is often cited as an evidence of the toleration of evil permitted by an indifferent society. But in justice to the members of that society, it must be remembered that within five years of state organization gambling was forbidden by statute, and that laws of increasing stringency were subsequently enacted in the effort to suppress it effectively. ${ }^{17}$

Another and a more dangerous influence came from abroad, for soon after the announcement of the discovery of gold vessels from Australia began to bring large numbers of ex-convicts from the British penal colonies. These immigrants were the products of the wretched system of deportation which had shipped in the same vessels the most abandoned criminals, together with women,

15 On the hardships of California life, see Brooks, Four Months, 102108 ; J. L. Tyson, Diary of a Physician, 1850, pp. 62-64; Johnson, California and Oregon; or Sights in the Gold Region, 241-242; William Shaw, Golden Dreams and Waking Realities, 1851; Golden Dreams and Leaden Realities [by George Payson], 1853; Califormia and Its Gold Mines [by Thomas Allsop], 1853, pp. 73-77; Eliza W. Farnham, California, In-doors and Out, 1856, pp. 366-368; Hittell, California, III, 168-171; '“T. Turnbull's Travels...to California,', Wisconsin State Historical Society, Proceedings, 1913 , pp. 220-225. Taylor noted little drunkenness in 1849 (Eldorado, II, 66). An epidemic of cholera added to the troubles of 1850 (Annals, p. 305).

16 The gamblers in Sacramento defeated early attempts at organization (Baneroft, California, VI, 456).

17 The first eouncil of San Franciseo made an unsuceessful attempt to forbid gambling in January, 18t8 (Annals, 199). Games of chance were made illegal by the state legislature in 1855 (Statutes, chap. 103, p. 124). See also Hittell, California, II, 730, 805-806; IV, 69-70; and his General Laws of ... California, ed. 2, 1870, II, sees. 3322-3338; Royee, California. 425. Bothwick reported gambling on the wane in San Francisco in 18.52 (Three Years, 379). 
and even boys and girls as young as twelve years of age. The prison ships and settlements were disciplined with the lash, and were hotbeds of atrocious vice. Of the British convict it was truly said: "The heart of a man was taken from him and he was given the heart of a beast." 18 In Australia the prisoners were assigned to private masters, if such semi-liberty was considered safe. When the period of their sentence had expired, or when good behavior warranted an earlier release, they were granted either full liberty, or tickets of leave that allowed them freedom under official supervision. Conditional pardons were also issued which permitted the holder to go at large in any country except Great Britain. Thus dangerous men were sent away to be a menace to other lands.

The port of San Francisco stood open to all the ships of the world, and until 1875 it was unguarded by any national legislation that prevented the immigration of undesirable or criminal aliens. As early as 1838 a bill had been presented to Congress providing penalties for the master of a vessel who should transport to the United States convicts, lunaties, or passengers suffering from incurable diseases. The bill received no favorable consideration whatever, and as it was commonly supposed that individual states had power to regulate immigration into their own territory, some legislatures enacted statutes to prevent the landing of immigrants likely to become public charges. In 1849 , however, the Supreme Court declared that such laws of New York and Massachusetts were unconstitutional, as the Federal Government alone had power to regulate matters of commerce and immigration. ${ }^{19}$ Following the examples of Eastern states,

18 Encyclopedia Britannica, ed. 11, VIII, “Deportation," p. 58. See also Archbishop Richard Whately, "Remarks on Transportation," in his Introductory Lectures on Political Economy, ed. 4, 1855, p. 271; C. A. Browning, England's Exiles, 1842; Charles White, Early Australian History, 1889 ; C. H. Northeott, Australian Social Development, 1918, pp. 37-44.

19 See U. S. Immigration Commission, Immigration Legislation, 1911, pp. 12, 24-28 (Reports, XXXIX, Cong. Docs., Ser. No. 5879, Doc. 758). 
and perhaps unaware of the decision of 1849 , the first California legislature adopted a statute that made it a felony to bring into the state convicts from other countries. ${ }^{20}$ That law was nominally binding in California until as late as 1872, but it does not appear that there was an effective attempt to enforce it, and every vessel from Australia unloaded on the wharves of San Francisco men and women who had served their terms in the penal colonies, and gained freedom by means of conditional pardons, or escaped while still under sentence. ${ }^{21}$

One advantage accrued to the Sydney men from their common experience in dungeon and hold; they knew each other with the intimacy of the underworld of crime, and maintained in California associations that had begun in English byways, flourished in the plague spots of the Southern Seas, and ripened into bonds of mutual offense and defense in the steerage of the transPacific vessels. The gang organization quickly appeared among them, not in a highly developed form, as with the Hounds, but secret and evasive, yet none the less effective. Men and women from Sydney kept lodging houses in San Francisco, watermen from Sydney had boats to lend in time of need, blacksmiths were adept at cutting keys, bricklayers dropped useful hints about vaults and safes, clerks exchanged confidences as to the storage of coin and gold dust, even a warden of the port of San Francisco, sometime inmate of a British prison, outlined a tempting scheme for looting the Custom House. ${ }^{22}$ Instinctive obedience was given to the men who proved themselves best able to take advantage of local conditions; to those who could decide which offices might be robbed, and which should be avoided; who could

20 California, Statutes, 1850, chap. 82, p. 202; Penal Code, 1872, $\oint 173$.

21 Between March 31 and December 30, 1849, 842 passengers from Australia and Tasmania landed in San Franciseo, while 505 came from New Zealand. (See the "List of Passenger Arrivals," furnished by E. A. King, harbor master, in Society of California Pioneers, Twenty-fourth Anniversary, 1874, pp. 38, 47.)

22 Thomas Belcher Kay, see infra, p. 282. 
acceptably divide the spoils or provide bail and counsel for a hard-pressed subordinate; establish an alibi, or sit among the good men and true sworn to mete out justice to the prisoner at the bar.

Such leaders there were, and we shall presently make intimate acquaintance with them. But in the winter of 1850 and the early months of 1851 their identity was a mystery to the lawabiding citizens of California, although the community was fully aware of the menace to order that arose from the presence of the "Sydney Ducks," or "Sydney Coves," as the Australians were popularly styled. ${ }^{23}$ The existence of organized bands of criminals was suspected, and with each fresh outrage their power and complexity of organization were magnified. ${ }^{24}$ There was no agency, however, public or private, equipped to follow scattered clues to a common center.

There were in the state other aliens even more unpopular than the men from Sydney. From the days of the conquest there had survived a mutual dislike between Mexican and American. The American especially resented the presence in the mines of new arrivals from Mexico and from South America who expected to share with enfranchised citizens the benefit of the mineral treasure on the public land. Writing to the Secretary of War from Panama in January, 1849, General Persifor F. Smith had said: "I am informed that ships loaded with all the rabble of the Pacific ports are on their way to California,', and alluding to the "bands of plunderers organizing all along the coast for

23 Both terms gained early currency. The Alta, 1851, July $10 \%$, spoke of "'Sydney Ducks,' and the Annals of San Francisco, published in 1855, used the expression "Sydney Coves" (p. 257).

24 On Nov. 20, 1850, the Alta stated that convicts were in California "by thousands" and were making the state a pandemonium (see also ibid, Feb. $20 \% \frac{1}{1}$; April $11 \%$; infra, p. 233). The demoralizing effect of their presence was noted by Johnson, California and Oregon; or Sights in the Gold Region, 115; Delano, Life on the Plains and among the Diggings, 359 ; J. W. Revere, Keel and Saddle, 1873, p. 166; Burnett, Recollections, 342 . 
taking possession of the mines," he stated that he intended to enforce against aliens the laws that forbade trespassing on public lands. ${ }^{25}$

As we have seen, every miner in California was a trespasser, until the lode law of 1866 formally opened the mineral lands to private ownership. The agreements under the miners' laws were made possible by the expectation that the government would tolerate, and would eventually approve the exploitation of such lands by citizens of the country if their use of it conformed to existing practices as to the division of the public domain. This expectation was fulfilled. The law of 1866, however, restricted the right to take up mining claims to "citizens or those who have declared their intention to become such." ${ }_{26}$ Had this limitation been formulated in 1848 or 1849 and enforced through legitimate diplomatic and legal methods, California might have escaped the violence that was caused by the determination of the Americans to exclude the foreign miners from privileges in which aliens had no presumptive rights, and to prevent the spoliation of the placers by cheap competition, and by the contract labor of Indians, Negroes, Mexicans, Orientals, and Kanakas. ${ }^{27}$ As it was, the American miners were left to their own initiative in the matter, for General Smith did not order the arrest of foreigners, but contented himself with informing them that he could "not interfere to secure them in the infraction of

25 See Hittell, California, III, 705 note 2; Baneroft, California, VI, 403 ; Cong. Docs., Ser. No. 573, Doc. 17, pp. 708, 712. As early as December, 1847 , immigration from Sonora had been prohibited by Colonel Mason, because he considered the people of that province undesirable residents of California (ibid., 450). The order was not enforced after the discovery of gold, and nearly 8000 came overland from Mexico in 1849 (Browne, Debates, Appendix, p. xxiii).

26 See Lindley, Treatise on the American Law Relating to Mines, I, 493, 508-526; Thompson, U. S. Mining Statutes, I, 29-30; Yale, Legal Titles to Mining Claims, 34-42; J. S. Hittell, Resources of California, ed. 6, 1874, p. 424 (but compare his earlier statement, ibid., ed. 1, 1863, p. 354).

$2 \tau$ The natural resentment caused by the efforts to exploit extensive claims by cheap contract labor was noted by Katharine Coman in Economic Beginnings of the Far West, 1912, II, 282. 
the law.",2s His attitude, however, was generally understood, and the Americans took means of their own to oust unwelcome intruders.

The inevitable result was the development of constant friction, not only with undesirable immigrants, but also with inoffensive companies from France, Germany, and England. Some camps expelled foreign miners under threat of death, there was occasional retaliation and bloodshed, and much injustice was done by the miners' courts to prisoners of alien birth. The attack made by the Hounds on the Chilenos of San Francisco was an extreme example of anti-foreign sentiment. In that instance the community rose en masse to punish the outrage, but throughout the state, from the earliest days of American occupation, there was steady opposition to the immigration of large bodies of foreign laborers. Professor Royce denounced the attitude of the Californians in this respect as an example of narrow and unworthy prejudice. ${ }^{29}$ Their conduct, however, should not be dismissed with facile condemnation or palliation for this particular problem has proved most complicated and enduring in its perplexities. Indeed it should be related to the whole question of foreign immigration into the United States, as well as to the mingling of races on the Pacific Coast. For the purposes of this

28 Tyson, Geology and Industrial Resources, 75. General Riley, after touring the mines in 18.19 , reported that the current rumors of anti-foreign hostilities had been much exaggerated (Cong. Docs., Ser. No. 573, Doc. 17, p. 788). Holinski was enthusiastic over the "fraternité universelle" that united the many nationalities in the state (La Californie, 165-169), but Gerstäcker wrote that foreigners could not get justice in the remote regions (Travels, a translation from the German, 1854, p. 267). See also Édouard Auger, Voyage en Californie, 1854, pp. 112-113; Charles de Lambertie, Voyage pittoresque en Californie et au Chili, 1853, pp. 254-264; Kelly, Excursion to California, II, 23, 33-34; Johnson, California and Oregon; or Sights in the Gold Region, 225; Ryan, Personal Adventures, II, 296-299; Borthwick, Three Years, 74, 306, 363; Daniel Lévy, Les Français en Californie, 1884, pp. 88-105. The impressions of a traveler from Chili are given in Vicente Pérez Rosales, Recuerdos del pasado, 1910, pp. 259-370.

29 Royce, California, pp. 236-239, 356-368; Hittell treaterl the subject more calmly (Califormia, II, 736-737, III, 162-163, 262-264). 
study it has been necessary only to outline the situation and to show that it resulted in a marked increase of loeal disorders.

Another result was the passage by the first legislature of a bill which imposed a license of twenty dollars a month on miners who were not eitizens either by birth or by the provisions of the treaty of Guadalupe Hidalgo. ${ }^{30}$ The attempt to enforce that law provoked resistance on the part of the foreigners and actual riot in the southern mines. ${ }^{31}$ Some of the Latin Americans were driven from the camps to range the mountains as solitary outlaws, or in robber bands, that later gave much trouble to the authorities. $^{32}$

In reviewing the difficulties of the state during this time, we cannot ignore the hostility that constantly existed between the Indians and the white men. Long before Americans came to California the two races had lived in active eonflict and the Indians had attacked the Spaniards and suffered punishment for their raids even during the most suecessful period of the mission era. The coast region was fairly protected under the Mexican rule. but the interior valleys and the mountains had been left to the undisturbed possession of the savage tribes, yet in spite of this compromise Indian horse thieves eonstantly stampeded large bands of animals and slaughtered them for food.

With the advent of the Americans, hostilities grew more acute, for overland parties armed for self-proteetion and imbued with the hatred bred from centuries of frontier warfare, traversed

30 California, Statutes, 1850, chap. 97, p. 221 ; repealed, Statutes, 1851, chap. 108 , p. 424 .

31 See Shinn, Mining Camps, 212-218; History of Tuolumne County [by Lang], 28-34, 39-47; Hittell, Califormia, III, 128-131, 706-710. Sir Henry V. Huntley said that there would have been less objection to the tax or foreigners if the government had in return given them any protection (California, 1856, p. 218).

32 See Baneroft, California, VI, 469. Joaquin Murietta, a noted bandit, who was killed in 1853 , began his career in revenge for the mistreatment of his wife, and a whipping given him by miners in 1850. See Bancroft, California, VII, 203 note 13; Hittell, California, III, 712-726; J. M. Scanland, "Joaquin Murrieta," Overland Monthly, ser. 2, XXVI (189.5), 530-539; J. R. Ridge, Life and Adventures of Joaquin Murieta, ed. 3, 1871. 
mountain routes where the Indian considered himself master. During the first years of the gold excitement he was an ever present menace to the isolated miners, and the unprotected state of the country prompted an alert defense that often degenerated into wanton butchery.

On which side lay the initial aggression is a question for the expert in the special field of Indian affairs $;^{33}$ but no research can palliate the fact that for every overt act on the part of a thieving or murderous Indian, a deadly vengeance was levied upon the men, women, and children of the offender's race. Even in the neighborhood of the older settlements the most deplorable conditions prevailed, as military forces were insufficient to protect life and property, and Colonel Mason had been obliged to advise the residents to organize armed pursuit of Indian horse thieves and to kill them without compunction. ${ }^{34}$ On the other hand, when a friendly Indian appealed to the alcalde of San José for protection, he too was told that no aid could be given by government, and that he might defend his own life in case of attack. ${ }^{35}$ General Riley attributed Indian hostility in 1849 to the execution of certain chiefs in 1848, and to the barbarities of immigrants, especially of those from Oregon, who had brought to California the bitterness which resulted from the Indian massacres in that territory. ${ }^{36}$

33 See Bancroft, California, VII, 474-494, and Index under "Indian Hostilities', Hittell, California, III, 884-981. Early conflicts between Indians and Americans were noted in the California Star, 1847, March 13 1/1; April $10 \%$; Brooks, Four Months, 131-152; Kelly, Excursion to California, II, 141-148; S. Weston, Life in the Mountains... of Califormia, 1854, pp. 7-14; Biographical Slietch of William B. Ide [by Simeon Ide], 1880, pp. 224-230. The subject has been studied by W. H. Ellison, in a doctoral dissertation, The Unitcd States Indian Policy in Califormia, 1846-1860, 1918, MS in the University of California Library.

34 See Cong. Docs., Ser. No. 573, Doc. 17, pp. 355, 643, 645, 689.

35 Charles White, alcalde of San José, to Mason, April 29, 1848, Archives, " Unbound Docs.,', 43.

36 See Cong. Docs., Ser. No. 573, Doc. 17, p. 790; Tyson, Diary of a Physician, 62-63; Johnson, California and Oregon; or Sights in the Gold Region, 170-186. Governor Burnett, who came from Oregon, frankly said that the extermination of the Indians was practically inevitable (Journals of the California Legislature, 1851, p. 15). 
Even the elements seemed to conspire against the peace of California in the critical winter of 1849 to 1850 , for the rainy season was of unusual length and severity. Many miners were forced to remain idle until want stared them in the face, while loaded wagons, mired along the rough highways, offered irresistible temptation to the needy and the dishonest. ${ }^{37}$ Cattle thieves also began the most outrageous operations, ${ }^{38}$ and theft and violence became matters of daily occurrence.

The citizens at large were quite aware of the unfortunate tendencies of the period, but with the same optimism that had carried them through the discomforts of the interregnum they accepted their troubles as inevitable accompaniments of a transitional era, and hoped for. speedy improvement as soon as the new order could be established. Meanwhile the demands of commercial life were insistent and exacting, and they devoted themselves to their private business, leaving public matters to the men they had placed in office. The frontiersman, as a rule, is an out and out individualist, who awakens slowly to the importance of communal interests. ${ }^{39}$ This trait was a marked characteristic of the early Californian, for the state, as a field of social activity, did not quickly arouse the enthusiasm of the self-absorbed pioneer. It did, however, appeal with tremendous allurement to another type of American-the professional office seeker, of petty or magnificent aspirations, and many political pilgrims from the East had followed the star of empire in its westward course. ${ }^{40}$

37 Popular Tribunals, I, 73; Delano, Life on the Plains and among the Diggings, 268, 359-362.

3s By January, 1850, Sutter had been robbed of almost all his live stock (see supra, p. 67 note 3). A rancher near Stockton lost nearly $\$ 3000$ worth of cattle in a single night ( T. H. Hittell, Adventures of James Capen Adams, 1860, pp. 11-12).

39 The persistence of individualism in the West is discussed by Hill in his Public Domain and Democracy, 130-146.

40 William Carey Jones wrote to the Secretary of the Interior: "A number of persons seem to have come out during the summer of 1849 with no other view than to go back with four thousand miles of mileage in their pockets', (Cong. Docs., Ser. No. 573, Doc. 17, p. 118). 
Chief among them were William M. Gwin and David C. Broderick, both of whom reached San Francisco in June, 1849. Absolutely unlike in personality and experience, they were equally resolved on securing a political leadership that would win for them seats in the Senate of the United States. ${ }^{41}$ Gwin was a Southern man, genial, educated, experienced as a Congressman from Mississippi from 1841 to 1843, and with Southern views on the extension of slavery. Broderick was of Irish extraction, rugged and unpolished, without friends or fortune, selfeducated in matters intellectual, but thoroughly schooled in the practices of Tammany Hall and of the New York Fire Department. He was opposed to the involuntary servitude of the colored race, but unscrupulous in fastening upon a negligent public the shackles of political despotism.

Gwin won immediate popularity, participated in the trial of the Hounds, became a delegate to the constitutional convention, assumed a leading part in the discussion there, and promptly realized his ambitions by securing the election to the United States Senate. ${ }^{42}$ He held the office for two terms and secured the passage of important legislation for the benefit of the state, while annual visits to California enabled him to maintain a firm grip upon local politics.

Broderick's earliest opportunity for leadership in California developed after the first great fire in San Francisco, December 24, $1849,{ }^{43}$ when he was conspicuous in organizing the Empire

41 The long rivalry between the two Democratic leaders ended only with Broderick's death after a duel with Gwin's adherent, Judge David S. Terry, on Sept. 13, 1859. In addition to the references found in Bancroft and Hittell, see James O'Meara, Broderick and Gwin, 1881; Alonzo Phelps, Contemporary Biography of California's Representative Men, 1881-1882, I, Sketch of Gwin, 231-239; Jeremiah Lynch, A Senator of the Fifties [Broderick], 1911; E. R. Kennedy, The Contest for California in 1861, 1912, pp. 32-63; R. C. O'Connor, "David Colbert Broderick," American Irish Historical Society, Journal, XIII (1914), 132-162; sketch of Broderick, San Francisco Chronicle, 1876, June 16.

42 See Bancroft, California, VI, 311.

43See infra, p. 104. 
Engine Company, of which he became the first foreman. On January 8, $1850,{ }^{44}$ he was elected to a vacant seat in the state senate, immediately became prominent in the movement for organization of the Democratic party and within a year was recognized as a party leader. ${ }^{45} \mathrm{He}$ was always fearless and uncompromising in his affiliations and animosities, and believed in using heavy tools for rough work. His influence as foreman of the Empire Engine Company was an asset which stood him in good stead. In addition, he gathered for use in hours of need a band of followers who were ready to do his bidding at mass meeting, election, and secret rendezvous. His effective machine did not become fully apparent in San Francisco until a year or two later; some of his future henchmen, however, were already well known as manipulators at local elections, and the names of a few of them appear in the papers of the Committee of Vigilance. ${ }^{46}$

The gentleman from the South and the ward boss from the North, with their allies and rivals, had a curious constituency with which to deal. About sixty per cent of the American population had been born north of Mason and Dixon's line. ${ }^{4 i}$ The sentiment of the state was overwhelmingly opposed to the local introduction of slavery and therefore to the most cherished policy of many of the national leaders of the Democratic party. Nevertheless California emerged into political life as a

44 Annals, 266.

45 For the earliest Democratic organization, see supra, p. 116. The Whigs organized Feb. 9, 1850 (Davis, Political Conventions, 6-9 ; Annals, 267-269).

46 See C. of V., Papers, Index under "'Broderick," "Charles Duane,", and "Ira Cole." "Broderick is said to have defended his use of such men by the argument: "Your respectable people I can't depend on. You won't go down and face the revolvers of those fellows; and I have to take such material as I can get hold of. They stuff the ballot boxes and steal the tally-lists; and I have to keep these fellows to aid me' (Bancroft, California, VI, 678 note).

47 See analysis of census of 1850 , in H. E. Bolton, "The Obligation of Nevada Toward the Writing of Her Own History,' Nevada Historical Society, Reports, III (1911-1912), 71. 
Democratic state, basing party affiliations not on the fundamental question of slavery, but rather on the secondary issue of the Mexican War, which was more generally approved by the Democrats than by the Whigs. ${ }^{48}$ All intense questions of national politics and of personal convictions were thus eliminated from the local arena for a large number of these anti-slavery Democrats. As a result, an ambition for office became the sole incentive in the conduct of campaigns, and the astute Democratic politicians, willing to devote their best ability to a promising field, rapidly gained control of the situation. The men to whom they distributed the spoils of victory were not, as a rule, those builders of the commonwealth who had met the problems of the transition period. Useful adherents of the political machine were placed in office, and it became a matter of moment in the later history of the state that Gwin and his followers selected many of their protégés from Southern families who soon became a well defined social and political influence in the population. The ascendancy and arrogance of the "Southern Chivalry" is a theme on which Bancroft waxed bitterly eloquent. ${ }^{49}$ The day of their supremacy was somewhat later than the period of the first Committee of Vigilance, yet as early as 1850 the master mechanics of the political craft were assembling and coördinating the elements of their future structure.

During the months in which California was pushing forward her self-assumed task of organization, the national capitol was seething with the protracted conflict over the extension of slavery. When Congress reassembled in December, 1849, the question of the western lands might no longer be evaded. California asked for admission as a sovereign state and claimed the privilege of such a state in the adjustment of her domestic institutions. The question of her admission had a significance

48 Hittell, California, IV, 50.

49 Bancroft, California, VI, “Political History,' chaps. 23-24. 
far wider than the mere recognition of a new commonwealth. Fifteen of the thirty states of the Union had already prohibited slavery. While these states controlled a majority in the House of Representatives, the Senate was evenly divided on sectional lines and could nullify the action of the House. If California should be admitted there would be a free-state majority in the Senate and an end to the power of the South to control or delay legislation inimical to the slave-holding interests.

Other aspects of the abolitionist propaganda complicated the situation. The public slave trade had become an offense to many who might have ignored unseen evils, and there was a strong demand that, in the District of Columbia at least, it should be abolished by Congress. Moreover, throughout the Northern states, there was a disposition to obstruct the execution of laws that enforced the return of fugitive slaves, and their owners insisted upon more stringent regulations. There was also a dispute over the boundary between Texas and New Mexico. Slavery was permitted in Texas, and the South therefore felt that it was extremely important to extend that area as far as possible. In the face of all these questions the slave states still had the strength to delay any change in the existing balance of power, while the Northern states, not content to exclude slavery from California alone, continued to insist upon its prohibition in all of the territory acquired from Mexico, and to agitate for modifications in the matter of the slave trade.

The struggle that ensued was long and bitter. Bills and resolutions of opposing import indicated the futile effort of both parties to establish control of the situation. More than once in the endless disçussions a smouldering spirit of disunion flamed into open threats of secession. ${ }^{50}$ The political leaders of a passing

50 See G. P. Garrison, Westward Extension, 1906, pp. 294-333; W. H. Smith, Political History of Slavery, 1903, I, 113-129; Rhodes, History of the United States, I, 116-198; J. B. MeM.aster, History of the People of the United States, VIII (1913), 10-43. 
era met for the last time in the memorable debates of that session. Henry Clay strove to avert impending civil war by concessions important to both the contending factions, and Daniel Webster supported him with all the resources of his passionate eloquence, while John C. Calhoun, rising from his deathbed, stirred the Senate with ringing words of opposition, although his mortal weakness imposed the delivery of his message upon the voice of a colleague.

In the end the statemanship of Clay effected a compromise. He was the author of a series of eight resolutions, which contemplated the admission of California according to the terms of her constitution; the organization of territorial governments for New Mexico and Utah without restriction as to slavery, and their subsequent admission as states with such regulations as their people should determine; the adjustment of the boundary dispute in favor of New Mexico, with liberal remuneration to Texas; the abolition of the slave trade in the District of Columbia to placate Northern sentiment, and the imposition of more stringent fugitive slave laws to satisfy the demands of Southern slave owners. After seven months of discord and struggle, such provisions were finally adopted as separate measures. The act admitting California to statehood ${ }^{51}$ was signed by President Fillmore on September 9, 1850, and the Compromise of 1850 relieved for a time the tension in national affairs.

The Oregon, bearing the news of admission, steamed through the Golden Gate on October 18, 1850, firing preconcerted signals which heralded her long awaited message. At the sound of her first gun the men of San Francisco paused to listen in tense expectation. Then, as the recurrent detonations confirmed their hopes, the voices of exultant thousands broke out in a mighty shout of universal joy. Dressed in all the flags her lockers could boast, the Oregon rounded Clark's Point, and came to anchor

51 U. S., Statutes at Large, IX, 452. 
abreast of the city, while the city rushed shoreward to meet her-laborers from the streets, merchants from the stores, lawyers from the offices, judges from the bench-until a solid mass of humanity surged back and forth between the water front and the Plaza, repeating the news and devouring the editions of the papers that appeared as if by magic within an hour of the steamer's arrival. ${ }^{52}$

The four year interregnum was over, the military commandant was no more, the de facto government was buried in the graveyard of political theories, the constitutional convention was approved, the organization of the state, and the acts of the first legislature were validated. The commonwealth of California had come into her own!

52 See Annals, 293-295. 


\section{THE FAILURE TO ESTABLISH SOCIAL CONTROL}

By the time the welcome news of admission was received in California the organization of the state had made substantial progress, but, instead of the expected improvement in social order, it became more and more evident that the new government failed to control crime and to check the evils that had taken root in the country during the long period of the interregnum. The system which had been outlined in the state constitution and developed in the first session of the legislature, was modeled on the institutions of older states, where Americans were habituated to self-control, where there was ready communication between the centers and the outskirts of social life, where families had long been planted in permanent homes, and where mutual acquaintance had ripened during years or generations of neighborly contact. In California conditions were still far from normal.

It is quite true that there were more than a hundred thousand men in California in 1850, but the mere fact that they had incorporated themselves into a state did not instantly weld the heterogeneous mass into social unity. And one curious thing must be remembered : they were, in each other's eyes, a hundred thousand men without any past that antedated their arrival in California. No questions were asked as to a man's family or associations, his success or failure in any previous environment, or his influence for good or evil on any community east of the Sierra Nevada Mountains. The initiation into California existence was briefly described by the observant Frenchman, Saint-Amant, who wrote 
of the arrival in the port of San Francisco: " "Personne ne vous demande qui vous êtes, ni d'òu vous venez. Vous quittez votre numéro de bord, et vous prenez le nom qui vous convient." The virile democracy of California towns and mining camps has often been depicted with enthusiasm as a splendid example of American manhood, and such it truly was; but a man without a past, be he never so fearless and independent, is not always a citizen of the highest constructive ability.

Another circumstance exerted a profound influence on the men of California: there was a persistent feeling on the part of the large majority that they were on the Pacific Coast only for a short time, and that they would return to their former homes as soon as their fortunes would allow. The state did not at first seem very attractive as a place of continued residence. There was a general anticipation that the placers would quickly be exhausted, and agriculture was a doubtful venture on account of the long season of summer drought. ${ }^{2}$ Even the men who desired to make permanent homes in California were checked in their ambitions by the confusion over land titles which distracted the state for many years. Holders of Mexican grants still laid claim to most of the desirable agricultural tracts, and cautious settlers feared to invest funds in the purchase of their doubtful titles. The covetous on the other hand wished to set all former ownership aside, and to appropriate whatever they might desire. Squatters went so far as to attempt armed

1 Pierre Charles de Saint-Amant, Voyages en Californie et dans l'Oregon, 1854, p. 73.

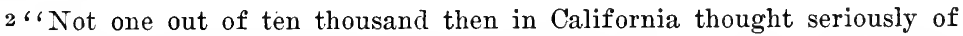
making the Pacific Coast his continual abiding place. All men were sojourners and everybody habitually talked about going home" (Memoirs of Cornelius Cole, 75). See also Buffum, Six Months, 136; Helper, Land of Gold, 17-18; Ryan, Personal Adventures, II, 184. Compare these conditions with the spirit of permanent settlers as portrayed by Esarey Logan, "The Pioneer Aristocracy," Indiana Magazine of History, XIII (1917), 270-287. 
violence, in Sacramento in the summer of $1850 .^{3}$ Such open efforts to steal private land were largely checked by public sentiment, although the original owners were in the end despoiled of most of their heritage by the tedious process of predatory laws. ${ }^{4}$

Aside from the gross injustice wrought against the Mexican proprietors, this condition greatly retarded the development of any class of small landholders, and seriously delayed the agricultural and industrial growth of the state. Mining was, therefore, the one important industry of California, and by its very nature imposed upon the people an abnormal excitement and restlessness. The mining camps were of necessity ephemeral in their existence, and shifting in their elements. Hundreds or thousands of men would flock to new diggings in a few weeks, only to desert the region as suddenly as they came. ${ }^{5}$ The towns were no less changeable in their composition. Burnett, a prominent member of the San Francisco legislative assembly, who had known nearly every one of his fellow-citizens in September, 1849 , could not recognize one in ten after an absence of six

3 See Royce, California, 467-491, and his "Squatter Riot of '50," Overland Monthly, ser. 2, VI (1885), 225-246; Bancroft, California, VI, 529-581; Hittell, California, III, 666-704; Upham, Notes of a Voyage to California, 333-351. The spirit of the times was illustrated by a card printed in the Sacramento Union, and copied in the San Francisco Herald, 1851, Sept. $172 / 4$, in which T. O. Selby warned whom it might concern that as trespassers had attacked his son, he would kill anyone repeating such an act.

4 The land bill (U. S. Statutes at Large, IX, 631), required the Mexican owners to prove their titles, with the United States in the position of a rival claimant. Decisions could be appealed to the United States District Court, and then to the Supreme Court, a process which ultimately impoverished even successful litigants. Their position is told with graphic pathos in a petition for relief, published by C. H. Shinn in the Magazine of American History, XXV (1891), 394-402.

5 A condition typical of several years was described by residents of Dry Diggings, when on Sept. 20, 1849, they petitioned for a special local election, as, at the regular date on the first of August, the settlement had been too small to need magistrates, while at the time of writing it was very large, and would swell to thousands by winter (Archives, "Unbound Docs.," 47-48, 325-326). The placers at Kennebec Hill were discovered in March, 1850 , and within thirteen days 8000 miners rushed to the camp (Shinn, Mining Camps, 244-245). 
weeks, and found himself such a stranger in November that he had grave doubts of securing his election as governor. ${ }^{6}$

As a result of these frequent and sudden migrations centers of population suddenly sprang up in remote and inaccessible places. There is much truth in Rudyard Kipling's aphorism: "Transportation is Civilization." "T The social order transplanted to California had grown up in regions where highroads were naturally extended as the population increased. But as yet California had no facilities for transportation. The larger towns were linked by rough stage roads, but many mountain settlements communicated with the outside world only by the most primitive trails, which were practically impassable at certain seasons of the year. Numbers of such scattered and isolated communities were associated in the political bonds of county organization, and all the administration of local affairs was in the hands of the officers elected by the voters of the several townships or the county at large.

Of late years the students of political science have investigated with interest the effect on our national life of the selfgoverning county. ${ }^{8}$ The political conscience of the state at large makes the laws for the general commonwealth, but the American distrust of centralized authority has developed a system that places the enforcement of those laws chiefly in the hands of officials who are chosen by relatively small groups of electors. In many matters of the utmost importance these officers are practically independent of any higher authority, and are responsible only to the vague master called "the public," which assumes

\footnotetext{
6 Burnett, Recollections, 347.

7 Rudyard Kipling, "With the Night Mail," in his Actions and Reactions (1910), 145.

8 See Howard, Introduction to the Local Constitutional History of the United States, I, 135-148; "County Government,' American Academy of Political and Social Science, Annals, XLVII (1913), 1-278, especially 271275 ; H. S. Gilbertson, The County, the "Dark Continent" of American Politics, 1917.
} 
tangible substance but once in two or three years, when the neighbors whom they have placated or antagonized slip printed papers into a ballot box. ${ }^{9}$ In consequence of this independence a local unit often nullifies unpopular statutes by the simple expedient of ignoring their infraction. If on the other hand the local officials are anxious to execute the laws promptly and effectively, they must rely entirely upon their own resources and expect no help from without. When a system such as this was applied to the conditions that prevailed in California it was inevitable that all its latent weakness should develop with startling abruptness.

In April or May of 1850 the people of nearly every community were called upon to fill a large number of elective offices. There was no requirement of pre-election registration although the law stipulated that a qualified elector must have resided thirty days in his county or district, and six months in the state. ${ }^{10}$ A voter of doubtful status might be challenged at the polls, but if he still affirmed under oath that he was entitled to the franchise he was permitted to cast a ballot, although subject to prosecution for perjury if he had sworn falsely. ${ }^{11}$ Such regulations fairly invited fraudulent voting, and at a later date the state became notorious for its wholesale corruption. At the earlier elections it is probable that the requirements as to residence were not strictly enforced, and that the wandering miners voted wherever they tarried over election day. Indeed, in November, 1851, William B. Ide, judge of the County Court of Colusa County, wrote $:^{12}$

9 See Bryce, American Commonwealth, I, 536 et seq.; J. A. Smith, Spirit of American Government, ed. of 1912, pp. 243-248; J. H. Mathews, Principles of American State Administration, 1917, pp. 401-473.

10 Calfornia, Statutes, 1850, chap. 38, p. 102, sec. 10.

11 See "The People vs. Gordon et al.,"' Fifth California Reports, 235. Large numbers of Sonorans were voted in squads by unscrupulous politicians in San José in the spring of 1851, and for years the native Mexican vote was manipulated in the same way (Peckham, in San José Pioneer, 1877, July 28, Scrapbook, p. 32). One of the Sydney men hanged by the Committee of Vigilance told of collecting a dozen ex-convicts to vote at a San Franciseo primary election for eity marshal (see infra, p. 292).

12 Letter in Biographical Sketch of William B. Ide, 231. 
Our population are like birds of passage, except their migrations are not exactly periodical.... At present ten individuals pay more than three-fourths of the taxes paid within the county, and comprise nearly all its permanent residents.... At the polls the non-residents (when they unite), have the elections as they please; and the usual result is, that transient, irresponsible persons are elected, and bonds of the like character are filed.

Even when the provisions of the Act to Regulate Elections were observed, the electors might have lived in a given locality but a month, and formed little acquaintance with their fellow-citizens. Often the candidates were almost unknown to their constituents. In such cases there was no way of securing reliable information as to their characters or past records, and any man ambitious for office could easily force himself upon the attention of the public. ${ }^{13}$

One of the best known political incidents of early days was the election of the sheriff of San Francisco, in May, 1850. ${ }^{14}$ The Democratic candidate was Colonel J. J. Bryant, owner of the best hotel in San Francisco. He spared no expense in winning votes, kept open house with a generosity that nearly proved his ruin, and stationed bands to play in a balcony for days before the election. His chief rival was Colonel John C. Hays, who had won celebrity by service with the Texas Rangers on the Mexican border. Hays had been a resident of San Francisco about two months, and ran as an independent candidate. This contest was the most exciting of the campaign and was conducted, on both sides, with enthusiastic meetings, music, and torchlight possessions. Animated electioneering was kept up as long as the polls were open, and the tide of popular favor was not decisively turned until Hays appeared, mounted on a magnificent

13 In August, 1849, Burnett accomplished the election of a friend from Missouri within forty-eight hours of the latter's arrival in Sacramento (Recollections, 335-336).

14 See Davis, Political Conventions, 10; Annals, 269-272. Hays announced himself as a candidate in the same issue of the paper that chronicled his arrival in San Francisco (Alta, 1850, Feb. 1). His adrentures as a Ranger are told in S. C. Reid, Jr., Scouting Expeditions of McCulloch's Texas Rangers, 1847, pp. 108-116. 
horse which he reined through the noisy streets with a skill that called forth the wildest applause. A throng surged around him, eager for recognition and the clasp of his hand, the music of his opponent was drowned in shouts of greeting, and when his excited steed finally dashed away through the cheering crowd the day was won for the Texas Ranger. The choice was most fortunate for the city. "Jack" Hays, always a popular and picturesque figure, proved an upright and efficient sheriff, and we shall hear much of him during the summer of 1851 . His election was typical of a condition of society where the choice of officials depended all too largely upon trivial accidents and the momentary impulses of the voters.

The men who were elected by these aggregations of comparative strangers were commissioned to control the local affairs of California for many months without fear of effective reproof or restraint. In many places the personnel of the community changed again and again before their terms expired, while standards of eitizenship shifted with equal rapidity. ${ }^{15}$ In such fluctuating conditions there was special need for sagacity and real executive ability on the part of those in authority, yet the small salaries of public office failed to attract the more able citizens who could win much larger rewards in commercial pursuits.

In California during the decade of the fifties there were men of every type and character in the major and minor offices of the state. A traveler wrote of one of the remote districts: ${ }^{16}$

One of the judges of this court is at the same time a justice of the peace, sign painter, postmaster, miner, engineer, carpenter, doctor, boarding-house keeper, and assistant surveyor of the district-having thus ten independent

15 "It was a common observation, until very large investments of capital necessitated permanency of residence, that there was not a mining town in California that did not have an almost entire change of population every three years", (Hittell, California, III, 108).

${ }_{16}$ California and Its Gold Mines [by Allsop], 124. Characteristic of 1850 , although written December, 1852 . 
functions, all of which he fills with eredit to himself and advantage to the community. You will often find a man on the bench one year, and in the middle of the river the next.

Another described as follows the magistrates of Murderer's Bar :

There is a justice of the peace (up to his arms in the river just at present), and there is a constable (who has been "prospecting"' a bag of earth from the hill, and been rewarded with a gold flake of the value of three cents); these two, one would suppose, could scarcely control two or three hundred men, with rude passions and quick tempers, each of whom, as you observe, carries his revolver even while at work. But these armed, rough-looking fellows themselves elected the judge and constable, and stand ever ready, as "specials," to support them.

But the same author also regretted that many judges had been elected who had hardly any knowledge of the law, and were subservient to the dishonest class from which they received their offices. ${ }^{17}$

Contemporary estimates of the public service were typified by the assertion made in the San Francisco Evening Picayune, that there was scarcely a legislative, executive, or judicial officer in the state who did not regard his position solely as a means of obtaining money for a speedy return to the East. ${ }^{18}$ In spite of such assertions, Bancroft wrote of the period: ${ }^{19}$

I may safely say that the judges on the whole were honest men.... On the Supreme bench, and presiding over the district and county courts, particularly in the cities and more thickly populated parts, have been from the first occupation of the territory by citizens of the United States until

17 See Frank Marryat, Mountains and Molehills, 1855, pp. 236, 389.

18 Picayune, 1850, Sept. 221 .

19 Baneroft, California Inter Pocula, 582. But contrast his statement: "In a few instances, before the year 1850 had expired, justices of the peace and judges had been impeached and driven from their seats by the people. But compared with those who at this time were accustomed, either openly or in secret, to take illegal fees, to extort, accept bribes, or otherwise violate their oath of office, the number punished was insignificant," (ibid., 590). 
the present day, as able and erudite jurists, men of as broad and enlightened intellects, as might be found elsewhere in Europe or America. Some were dissipated, but for the most part they were men of integrity.

Whatever may have been the personal characters of California's judges in 1850, the courts over which they presided quickly became notorious for their failure to convict and punish criminals, especially those who could pay for skilful defense. In the opinion of the contemporary public this immunity was almost universally attributed to flagrant corruption within professional circles, and later critics have found it very easy to make similar strictures. Corruption there was, for it was inevitable that many unworthy officials should find their way into positions of responsibility and time showed that not a few of them had past experiences of disreputable quality. Royce severely condemned the "persistently wicked neglect to choose good public officers" that made the mining society the "friend and upholder of the very roguery that it flogged and hanged.", 20 The student who desires to make a fair estimate of the situation, however, must take into account all the conditions that hampered the administration of justice, even when there was a righteous zeal on the part of the public servants.

Mention has already been made of the general result of the low ratio of salaries of public office to the ordinary profits of business, but particular attention must be called to its effect upon the selection of prosecuting attorneys. There were in California many men who had studied and practiced law before the gold rush attracted them to the Pacific Coast, and who were glad to return to their profession as soon as the courts were

20 Royce, California, 337. The difficulty of choosing suitable officials was clearly recognized by Saint-Amant (Voyages, 399). A striking example of California conditions is given by the story of Paul Geddes, of Pennsylvania, who under the alias Talbot $\mathrm{H}$. Green, was a leading candidate for mayor of San Francisco in 1851. His real identity and past irregularities of conduct were discovered on the eve of election (Bancroft, California, III, 765-766; Davis, Sixty Years, 325; Alta, 1851, April $16 \%$ ). 
established. Fees were so large in both civil and criminal cases that the private practice of a competent lawyer insured a large income while the small salaries of the prosecuting attorneys ${ }^{21}$ did not attract men who were fitted to cope with the counsel retained to defend the prisoners at the bar. In consequence, the criminal courts were quickly at the mercy of clever and well paid lawyers, who imposed upon them every possible technical evasion until the whole machinery of the law became a shield for the criminal rather than a safeguard to the community. ${ }^{22}$

Not only were the odds during the trial largely in favor of the defendant, but in cases of conviction he had an excellent chance to escape because of the total lack of secure jails. The failure of the various communities in California to provide adequate prisons even after five years of American occupation, has been severely censured ${ }^{23}$ as an evidence of a selfish reluctance to spend some of the common wealth in preserving and upbuilding the social order. As a matter of fact, public improvements had been out of the question in settlements that had no constitutional right to levy taxes, or to make contracts. ${ }^{24}$ San Francisco purchased a prison brig in 1849 ; Sacramento did the same in 1850, and smaller towns improvised places of confinement as best they might $;^{25}$ but before permanent structures could be commenced it was necessary to organize the counties, choose county seats, vote funds, and arrange many details of construction. ${ }^{25}$

21 The salary of a district attorney was $\$ 2000$ (California, Statutes, 1850 , chap. 25 , p. 83 ).

22 Prisoners were quite ready to pay their lawyers fees of $\$ 1000$ (P. A. Roach, Statement of Historical Facts on California, 1878, p. 8, MS in the Bancroft Library). The aneedotes told by L. A. Norton show how easily guilty men could be freed on technicalities (Life and Adventures, 279-290).

23 As by H. K. Norton, Story of California, 1913, p. 246.

24 See the experiments in Stockton, supra, p. 119.

25 The bark La Grange was bought for a jail at Sacramento (History of Sacramento County, 87-88). The early jail in Los Angeles was an old adobe residence, and prisoners were chained to a pine log for safe keeping (Horace Bell, Reminiscences of a Ranger, 1881, p. 51). The first public building of Contra Costa County was a stone jail, built in 1850, a poor affair 
An organic defect of the earliest statutes of California that has usually escaped the attention of historians was the provision that deprived local justices of the peace of any criminal jurisdiction beyond the office of examining magistrate, and referred trial for all petty misdemeanors to the Court of Sessions, which met at the county seat once in every two months. ${ }^{26}$ The effect of such a system upon criminal conditions in the mining regions was inevitably disastrous. It was the duty of the local justice of the peace to arrest suspected persons; if evidence justified their commitment for trial, he was then bound to deliver them to the sheriff of the county. ${ }^{27}$ This necessitated the transportation of the prisoner to the county seat, which was often far away from the scene of the offense, since some of the counties were as large as states on the Atlantic seaboard. ${ }^{28}$ In many cases the journey could be made only on horseback, and it afforded countless opportunities for escape or rescue.

Moreover, for the prosecution of such trivial misdemeanors as breach of the peace, assault and battery, and petty lareeny,

from which prisoners easily escaped (Illustrations of Contra Costa County, 12). In 18.51 Auburn had a log jail for a county prison (History of Placer County, 97). W. B. Ide, justice of the peace at Monroeville, Colusa County, in 1852, built an iron cage for the confinement of prisoners, and placed it out of doors in the shade of a tree (J. H. Rogers, Colusa County, 1891, pp. 77-78). In 1849 Riley had proposed to devote some funds to improving jails (Cong. Docs., Ser. No. 561, Doc. 52, pp. 19, 20, 37-38).

26 The Court of Sessions was composed of the county judge and two assistant justices of the peace. It was also entrusted with the duties which at present usually devolve upon a board of supervisors (California, Statutes, 1850, chap. 86, p. 210; Rodman, History of the Bench and Bar of Southern California, 38 ).

$2 \pi$ California, Statutes, 1850, chap. 44, p. 118, sec. 3. Some justices seem to have exercised criminal jurisdiction, as did the illiterate Richard $\mathrm{C}$. Barry, of Sonora, whose docket is a wonderful specimen of the public archives of 1850 (History of Tuolumne County [by Lang], 65-70; Bancroft, Califormia, VI, 470 ; and his Califomia Inter Pocula, 630-633). "The jurisdiction of justices of the peace in 1850 to 1851 , who were then the only judicial officers known in these diggings, was a little shadowy, or very substantial, as the reader pleases" (History of Nevada County, 99). See also the tales of Justice Bonner, of Butte County (Illustrated History of Plumas, Lassen and Sierra Counties, 1882, pp. 208-209).

28 Coy's Guide to the County Archives contains maps showing the boundaries of the original twenty-seven counties, and subsequent changes. 
it was necessary that the witnesses also should take the same journey, and remain in attendance upon the trial while counsel gained postponement after postponement. If the crime was of a serious nature it was tried in one of the District Courts, which also met at the county seats, and held from three to five terms a year. In such cases an indictment by the grand jury was a prerequisite to trial. ${ }^{29}$ All these vexatious delays not only burdened witnesses with the cost of living at wretched and expensive inns, but they involved the risk of forfeiting mining claims because of protracted absence and cessation of work. ${ }^{30}$ Under these circumstances it proved to be impossible to keep witnesses together for the slow progress of law, and any prisoner was almost sure of discharge if his lawyer could sufficiently retard the prosecution of his case.

In the mining regions, where improvement was most imperative, state control failed most signally to accomplish any immediate betterment. As soon as counties could be organized and local magistrates elected, all the offices peculiar to the Mexican system were discontinued. Justices of the peace and judges of the lower courts took the places of the alcaldes, who from that time had no legal status in California, although for some years they were occasionally chosen to supply the immediate needs of new and remote settlements. ${ }^{31}$

In 1850 Yuba County was so large, and the "trouble, expense and time required to send criminals to Marysville were so great, that many escaped the just punishments for their acts, while others were severely dealt with by Judge Lynch" (Illustrated History of Plumas, Lassen and Sierra Counties, 423).

29 See California, Statutes, 1850 , chap. 33, p. 93, chap. 119, p. 288, sec. 176. The District Courts took cognizance, also, of eivil and chancery cases. They superseded the Mexican Courts of First Instance (ibid., chap. 23, p. 80 , sec. 28$)$.

30 No fees were allowed witnesses in eriminal cases (California, Statutes, 1850 , chap. 138 , p. 421 , sec. 15). The Alta, 1851, Oct. $15 \%$, noted the impossibility of securing the attendance of witnesses under these circumstances.

31 See Shinn, Mining Camps, 187. The miners of Chinese Camp appointed an alcalde and a sheriff in September, 1850 (Heckendorn \& Wilson, Miners \& Business Men's Directory...1856 ... of Tuolumne, 83). John Carr spoke 
The old alcalde had usually been a fellow-worker among his constituents, with personal interests identical with theirs. The new justice often belonged to the class of political loafers. $\mathrm{He}$ had, moreover, an assurance in office that had not existed under a system that swiftly recalled unpopular alcaldes as soon as a majority of the camp might vote to do so. In consequence there was no longer the close accord between executive and community that had characterized the earlier organization.

Up to this time any given camp had enjoyed such security of life and property as the majority of its residents chose to enforce by the rules of mass meetings and the discipline of miners' courts. Now the exercise of criminal jurisdiction was removed from local control, for the justice of the peace could do no more than examine prisoners and if he saw fit hand them over to the sheriff of the county for arraignment in the proper court. This act of transfer immediately removed the criminal from the persons interested in his punishment, so that unless his offense had been particularly heinous, his fate became a matter of indifference to his former neighbors. In cases where popular indignation had been highly inflamed the notorious miscarriage of justice in the courts gave rise to a universal distrust of legal procedure, and incited the miners to administer retribution for themselves.

The increasing disorder aroused a spirit of resentment against the authorities that resembled the antagonism expressed during the period of the military control. The majority of the men of the mining camps in the fall of 1850 were of the same fiber as were the men of 1849 ; many of them were the same individuals who had conducted the popular trials which had

of a trial before a California alcalde, probably in February or March, 1851, and said that no one in Weaverville paid any attention to politics or law, until about June, 1851, when the camp was stirred to curiosity by the advent of a party of horsemen who looked too well dressed to be miners and too honest to be gamblers, and who proved to be candidates for the offices recently created for the new county of Trinity (Pioneer Days, 116, 128). 
preserved California from overwhelming anarchy and bloodshed. In their sovereign capacity, and out of the elements of chaos, they had formed a state, ordained laws, and appointed servants to execute the will of the people. Yet in spite of their labors they found the servants inefficient or unfaithful, and the laws so poorly adapted to the special needs of the community, and so poorly executed withal, that crime increased, while robbers and murderers laughed at statutes and courts, and at jails and jailers.

The ideals of popular sovereignty had not perished from the land when the cannon of Monterey announced the signing of the state constitution. History has shown that the conception of government as a social compact holds in itself the germ of potential secession. It is equally true that the conception of social order accomplished and preserved solely by the concurrent consent of the individual community contains the dormant menace of disorder. It is not only upon the unorganized frontier of American settlement that this dormant menace has been transformed into an active force. The tendency to deal with criminals through popular tribunals steadily accompanied what may be called the rearguard of the western advance, a zone of unstable conditions where the voluntary and temporary associations of the foremost pioneers were nominally superseded by a laggard civil organization. Here lingered competent and fearless men who had by their own swiftly spoken words evoked laws out of a cosmic void, and their social conscience gave fealty, not to the rules they had thus formulated, but to the purposes which had vitalized their rules-the preservation of life and property. When formal laws, once established, failed to accomplish these purposes, their impulse was quick to ignore the inefficient laws, and to revert to a direct and popular method of effecting the necessary results. 
Such an impulse was very apparent in California in the later months of 1850 . The people recognized the failure of the courts to restrain crime, and showed a strong tendency, especially in the mining regions, to adhere to the popular tribunals that had proved effective in the previous year. They came together as of old in the miners' meetings, to regulate their mining claims. They had never drawn any nice distinctions between the eivil and the criminal functions of such meetings; so they now desired to have suspected offenders still tried on the scene of their alleged guilt, and tried so promptly that honest men might go about their business without unreasonable delay, and they began to resent the interference of a sheriff whose duty it was to remove the criminals from their control. ${ }^{32}$

Conflicts over the possession of a prisoner became common and when they occurred the sheriff of the county faced a situation that tested him to the utmost, for he was obliged to decide, often at a moment's notice, whether he would attempt a rescue at the risk of several lives. In many instances he was convinced that the accused was a murderer who richly deserved death, and that those who contemplated immediate execution were stirred by the most righteous indignation. It then seemed like a mockery of justice to shoot men whom he knew and respected in order to place a cowardly assassin before a court which would probably condone his offense. In any ease, whether the prisoner were guilty or innocent, the sheriff was aware that the local community would never complain if he yielded to the mob, and that the state authorities could neither reprove him if he gave

32 In 1850 or 1851 the miners at Sandy Bar acquitted a suspected murderer, and then took advantage of the large gathering to decide on the disposition of mining débris (C. S. Abbott, Recollections of a California Pioneer, 1917, p. 104). For instances of popular trials at this time, see History of Nevada County, 98, 105; Carr, Pioneer Days, 60-67 ; Memoirs of Cornelius Cole, 85-91; William Downie, Hunting for Gold, 1893, pp. 111$113,145$. 
way nor help him if he chose to resist. ${ }^{33}$ Some sheriffs forfeited their lives in their determination to do their duty. Many carried off their men even when the odds were all against them. Many others gave way before the angry crowds and left the prisoners to trials by lynch law.

But a profound difference existed between the popular tribunals of the days of the commonwealth and those that had been held during the interregnum. The miners' trials of 1849 , conducted in sincere although uncouth emulation of the courts of justice, represented the popular adherence to the spirit of Law, to the principle of the trial by jury, and loyalty to the will of the majority. When the same men assembled in the autumn of 1850, arraigning, perhaps, the same culprits, for the same sort of crimes, they were no longer the symbol of the Lawthat was represented by the sheriff and the dilatory courts. Then the miners' tribunals, pitted against the constituted authorities, lost their dignity and their ideals of deliberate justice in conducting a struggle for the possession of a prisoner, and in making a hurried disposition of his fate. Inevitably they degenerated into angry mobs, that hastened to whip or to hang the accused before the sheriff could intervene, or that stormed a jail to recover a prisoner, and to forestall punishment or acquittal by the courts. ${ }^{34}$

33 When a sheriff in an American state was rebuked by the governor for permitting a lynching, the gorernor was bluntly told to mind his own business, as the sheriff was responsible only to the voters who had elected him (Woodrow Wilson, "Issues of Reform," in Initiative, Referendum and Recall, edited by W. B. Munro, 1912, p. 72). It is of interest to note here the following statement from the Herald, 1851, July $18 \% 1$ : "The Sheriffs throughout the country have been more true to the interests of the people, and more honest in the discharge of their duty than any other class of officials. We know of but two instances in the State in which the Sheriff has come under the ban of public censure."

34 The Alta recorded many murders and lynchings during the autumn of 1850. See also Popular Tribunals, I, 142-178; G. H. Tinkham, History of Stockton, 1880, pp. 155-158. The lynch law of this period forms the theme of The Volcano Diggings; a Tale of California Law [by Leonard Kip], 1851 . 
In the Alta California, September 16, 1850, a contrast was drawn between the comparative safety of life and property in the mines under the "prompt and substantial justice of 1849 ", and the frequent robberies and murders currently reported. The writer asserted that, although the better portion of the population had hailed with delight the advent of law as safer than the local practices which necessity had compelled, the statutes had proved so inefficient, and so poorly adapted to the migratory character of the community, that the courts failed to punish offenders and prevent crime; bail was habitually forfeited, rearrest was almost impossible, and trials could be postponed by technicalities until the absence of witnesses made acquittal inevitable. Throughout the state clever, premeditated robberies and murders formed a menace to security far more dangerous than the more impulsive crimes of an earlier period.

Peter H. Burnett made an excellent summary of the problems of the time when he said $:^{35}$

For some eight or ten years after the organization of our State government, the administration of the criminal laws was exceedingly defective and inefficient. This arose mainly from the following causes:

1. Defective laws and imperfect organization of the Courts; 2. The incompetency of the district attorneys, who were generally young men without an adequate knowledge of the law; 3 . The want of secure county prisons, there being no penitentiary during most of that time; 4 . The great expense of keeping prisoners and convicts in the county jails; 5 . The difficulty of enforcing the attendance of witnesses; 6 . The difficulty of securing good jurymen, there being so large a proportion of reckless, sour, disappointed, and unprincipled men then in the country; 7 . The unsettled state of our land-titles, which first induced so many men to squat upon the lands of the grantees of Spain and Mexico, and then to steal their cattle to live upon....

It was the extremely defective administration of criminal justice in California for some years that led to the organization of so many vigilance committees, and filled the courts of Judge Lynch with so many cases.

When the second legislature assembled in San José on January 6, 1851, Governor Burnett in his annual message alluded

35 Burnett, Recollections, 386, 390 . 
to many of the serious problems of the state, and proposed some desirable reforms, ${ }^{36}$ but he did not remain in office to assist in the work he had considered so important. He resigned January 9 , giving as his only excuse vague obligations of personal business. $^{37}$ No satisfactory explanation of the resignation has been made in the meager chronicles of the times. Judge E. O. Crosby, who was thoroughly familiar with the problems of the day, felt that Burnett lacked the self-confidence and assertiveness necessary to hold his own against the more astute demagogues. Alfred A. Green, another prominent San Franciscan, said plainly that the "Tammany" element was too powerful for the governor and was hostile to him on account of his honest opposition to land frauds in San Francisco. ${ }^{38}$ John McDougal, the lieutenantgovernor who succeeded Burnett, was somewhat skilful as a politician, but he lacked personal force in times of crisis, his habits were dissipated, and he became a tool in the hands of corrupt men. ${ }^{39}$ It was most unfortunate for the development of California that after its citizens had placed in office a man of honorable principles, any influence, either private or public, should have forced him to relinquish his important responsibilities into unscrupulous hands, and to abandon the entire machine of government to selfishness and ambition.

To fill the vacancy created by McDougal's promotion the senate elected as its president David C. Broderick, whose ability had already been recognized. From that time until his death Broderick was a dominant figure in the history of the state.

The legislature made some alterations in the statutes which may be noted here, although several of them did not become

36 Journals of the California Legislature, 1851, pp. 22-23.

37 Burnett, Recollections, 377.

38 See Crosby, MS Statement, 47-49, and Green, MS Life and Adventures, 25; Hittell, California, IV, 60-64, 87.

39 Bancroft said that in $1856 \mathrm{McDougal}$ was arrested for election frauds (Popular Tribunals, I, 130). 
effective until July, $1851 .^{40}$ Justices of the peace were given jurisdiction over minor offenses, and it was provided that their courts should be open continuously. ${ }^{41}$ This change permitted prompt trial of misdemeanors, and corrected one of the most flagrant defects in the earlier laws. Criminal cases might be appealed from the justice of the peace to the Court of Sessions, which also had jurisdiction over all more serious erimes, except murder, manslaughter, and arson. The last named offenses and all criminal cases not otherwise provided for were still under the jurisdiction of the District Court, which had, in addition, appellate jurisdiction over criminal judgments found by the Court of Sessions. These measures, generally designated as the Civil and Criminal Practice acts, proved so efficient that, with necessary modifications, they remained in force for many years, and served as models for other states and territories west of the Rocky Mountains. ${ }^{42}$

Acting on a recommendation of Governor Burnett, and on a petition from the citizens of El Dorado County, who prayed that horse stealing should be made a capital offense, ${ }^{43}$ the legislature passed an act that permitted a jury to impose the death penalty for robbery and grand larceny. ${ }^{44}$ The bill originated in the senate, where it was vigorously opposed by Broderick and three others, but passed by a vote of eight to four. It passed the assembly without delay, and a motion to reconsider it there was lost by a vote of seventeen to nine. ${ }^{45}$ The same bill per-

40 Especially an Act concerning the Courts of Justice of this State and Judicial Officers (California, Statutes, 1851, chap. 1, p. 9); an Act to regulate Proceedings in Civil Cases (ibid., chap. 5, p. 51); an Act to regulate Proceedings in Criminal Cases (ibid., chap. 29, p. 212).

41 California, Statutes, 1851 , chap. 1, p. 23, sec. 90 . The civil jurisdiction of justices' courts was also modified.

42 See Some Account of the Work of Stephen J. Field [edited by C. T. Black and S. B. Smith], 1881, pp. 19-20; Hittell, California, IV, 67.

43 Journals of the California Legislature, 1851, pp. 91, 101, 1412.

44 California, Statutes, 1851, chap. 95, p. 406.

45 See Journals of the California Legislature, 1851, pp. 286, 1422, 1426. 
mitted, at the discretion of the jury, a punishment of fifty lashes for petit larceny. The statute remained in force until $1856,{ }^{46}$ and several felons were executed under its provision. Professor Royce used the law as the text for this severe arraignment of the spirit of the lawmakers $:^{47}$

So far did this trust in hanging as a cure for theft go, that in the second legislature, that of 1851, an act was passed making hanging for grand larceny a penalty to be thenceforth regularly imposed at the pleasure of the convicting jury. So easy is it for men to sanction their blunders by the help of a little printers' ink, used for the publication of a statute.

Correcting an error of Shinn in regard to the date and duration of the statute, ${ }^{48}$ Royce continued:

The matter [of the date] . . . is of some importance, because it shows that the law did not first encourage the lynchers, but that only after the extravagances of popular justice had for some time flourished, it was found possible to load the statute book with an entirely useless and demoralizing penalty.

That criticism is hardly justified; a study of the measure reveals that it was suggested by the governor of the state as a temporary and deplorable substitute for the customary terms of imprisonment, that it was passed by large majorities in both houses, after full discussion, that it was seldom invoked by juries, and was repealed as soon as jails could be constructed and the emergency relieved..$^{49}$

46 See California, Statutes, 1856 , chap. 139 , p. 220.

47 Royce, California, 337-338.

48 Shinn, Mining Camps, 228. Perhaps copied from Tinkham, History of Stockton, 161.

49 See Hittell, California, IV, 70-71; and his General Laws of the State of California, I, secs. 1459-1461. The following executions under this statute have come to my attention. John Thompson and James Gibson, for highway robbery and assault, in Sacramento, Aug. 22, 1851. A companion named William Robinson or Heppard, sentenced for the same day, and reprieved by the governor, was hanged by a mob (History of Sacramento County, 126. See also infra, p. 378). James Wilson and Frederick Salkmyer, horse thieves, in San Joaquin County, November, 1851 (Herald, 1851, November 
One of the trials that took place under this law affords vivid illustration of the makeshifts imposed on the county courts. While William B. Ide was acting as a justice of the peace in Colusa County he examined and committed a man for the crime of horse stealing, and later, as county judge, presided at his trial. The prisoner had no counsel and no licensed attorney was procurable, so Ide volunteered to serve him in that capacity. The offer was accepted and in the absence of any prosecuting attorney Ide acted as counsel for the people, counsel for the defendant, and presiding judge. The verdict was guilty, with the penalty of death, which Ide solemnly pronounced, but the prisoner was subsequently pardoned by the governor. The anecdote was vouched for by Judge J. C. Huls, ${ }^{50}$ one of the associate justices, and it seems to be confirmed by the entries in the Minutes of the Court of Sessions in Criminal Business, October Term, 1851, which are preserved in the archives at Colusa. They contain this item in the record of the trial of one Joseph Wilson for grand larceny: $:^{51}$ "The prisoner having been informed of his wright to counsil there being no counsil the Court surved him as sutch." The case continues in accordance with the story as told by Huls.

30 2\%; Tinkham, History of Stockton, p. 162). José Corrales, for horse stealing, Sonora, Jan. 7, 1852 (History of Tuolumne County [by Lang], 149). Theodore Basquez, for horse stealing, San José, Jan. 30, 1852 (Hall, History of San José, 250). John Barrett, or Garrat, for robbery, Nevada County, July 16, 1852 (History of Nevada County, 107-108; Baneroft, California, VII, 195 note 3 ). George Tanner, for grand larceny, Marysville. July 23, 1852 (Herald, 1852, Mareh $233 / 7$; May $152 \%$; July 25 8/ ; San Francisco Chronicle, 1904, May 22, magazine p. 5 ; “The People vs. George Tanner,' Second California Reports, 257-261). A Mexican convicted of grand larceny at Martinez was sentenced to be hanged July 8, 1852 (Herald, May $12 \%$ ), but his execution is not recorded in the list given in the Illustrations of Contra Costa, 21.

50 History of Colusa County, 1880, pp. 46-47.

51 From a transeript of the Minutes in the collection of O. C. Coy. In November, 1851, Ide acted as judge of the County Court and Court of Sessions, as clerk of both, and of the District Court, as county recorder, and county auditor (Biographical Sketch, 230). 
The humorous reminiscence of the pioneer judge, and the grotesque souvenir of his court, must not divert our attention from the fact that just such men as Ide and the clerk of his court, by the sheer force of their common sense and their layman's acquaintance with American precedent, formed and vitalized a body politic out of the nebulous swarm of the hundred thousand independent atoms of 1849. The great majority of these hundred thousand men came to California to dig a fortune from the earth, but as incidental accessories of their miners' outfits they carried such a knowledge of political constitutions and of legal codes that they were able, by the close of the first legislature, to equip a state with the full mechanism of government, and by the close of the second to correct the defects most obvious in the hasty adjustment. ${ }^{52}$

In those early months of statehood the interests of the commonwealth were still, in a fashion, incidental accessories of mining and commercial life. The pioneer did not yet regard El Dorado as his permanent home. All local problems were but the responsibilities of a moment, to be met hastily, yet in a spirit that would secure his own rights and give fair play to his neighbor. The exercise of such a spirit was in itself a discipline in social life. One of the most interesting comments made on Californian influences was recorded by the artist Borthwick, who subsequent to a long visit in the state resided on the Isthmus of Nicaragua, and there had opportunity to observe that homeward bound miners "of the lower ranks of life" were far more orderly, more considerate, more alert to social obligations, and more amenable to the regulations of the voyage than

52 "It may be safely asserted that no new country ever received as suddenly, such a large population, so well fitted in every regard to found a great nation, as have poured into it [California] from the States", (Tyson, Geology and Industrial Resources of California, Introduction, xxxiii). "The conduct of the better portion of the inhabitants illustrates the force of American political ideas when displayed in a new land amid new conditions' ('Thorpe, Constitutional History of the American People, II, 289). 
were the same class of men from the rougher localities of the eastern interior who crossed the isthmus on their way to the mines. ${ }^{53}$

But the pioneer was still an individualist of the deepest dye. He did not visualize himself as the keeper of his weaker brother or the guardian and tutor of a future generation. Whatever might be his own habits of self-control, or of license, he tolerated in his associates any manner of life that was not absolutely destructive to the peace of the community, and the clergymen delivered sermons in the saloon and the barkeeper offered hospitality to the preacher with the same mutual allowance for personal liberty that had recognized the right of the whole camp to share in the deliberations of the miners' meeting. ${ }^{5 t}$ The pioneer left other men to set their own moral standards and to manage their own affairs, and in holding himself aloof from the personal life of his neighbor he detached himself, consciously or unconsciously, from the civic life of his community, except in the crises when public disorder became a menace to his individual interests.

The mining camps were always of such an unstable nature that the temporary residents had little incentive to make personal sacrifices for the improvement of general conditions, and the growing towns, with a more permanent total of population, were still so shifting in their units that any spirit of common enthusiasm and loyalty was a slow development. The incorporated cities-Sonora, Benicia, Monterey, San José, Sacramento,

53 Borthwick, Three Years, 149-150. H. J. Coke, an Englishman, wrote of one of his experiences in 1851: "I found myself about to pass a night in a small tent designated the 'miners' home,' in which over forty of these gentlemen were assembled to drink, board and lodge... only one unarmed. But strange to say, I never saw a more orderly congregation, or such good behaviour in such bad company", (Ride over the Rocky Mountains, 1852, pp. $359-360)$.

54 See Rev. William Taylor, California Life Illustrated, 300; Rev. James Woods, Recollections of Pioneer Work in California, 1878, p. 140. Borthwick said that California was a community of isolated individuals, each regardless of the opinion of his neighbor (Three Ycars, 67). 
and San Francisco-made definite efforts towards municipal improvement, but everywhere the mad rush of feverish speculation absorbed the men of the state in unremitting attention to business.

Even in San Francisco there were no citizens of assured incomes, much less of independent leisure, who could occupy themselves with altruistic social service. Every sunrise might be the herald of fortune or ruin, turning on the hazard of wind and tide, of fire or flood, and many merchants slept, like cats, in their tiny offices, that they might roll from their blankets with the dawn and profit by the added hours of commercial opportunity. ${ }^{55}$ They did not spend their overcrowded days waiting in the criminal courts to serve as jurymen in the trials of brawlers of the gambling house and thieves of the water front. They did not devote themselves to the petty polities of their city wards. With the long desired franchise of American citizens safely within their grasp, they forgot the dangers and clamors of the interregnum, and neglected to defend the court and ballot box from the manipulation of unworthy hands.

55 W. T. Sayward, of San Franciseo, who purchased gold dust from the miners arriving from Sacramento on the night boats, said that he often handled $\$ 5000$ or $\$ 10,000$ worth of dust before the banks opened at nine o'clock (Statement, [1877?], 13-14, MS in the Bancroft Library). A mason who built chimneys in San Francisco at $\$ 15$ a day, wrote home to Nantucket that time was so valuable he could not afford to dot his i's or cross his t's (B. H. Nye, "Letters," History Teachers' Magazine, VI [1915], 211). 

PART II

THE SAN FRANCISCO COMMITTEE OF VIGILANCE 



\section{THE PRELUDE TO THE COMMITTEE OF VIGILANCE}

San Francisco was always the center of life and interests in California. Very early in the months of 1851 it became the scene of exciting and disturbing events.

For some time after the suppression of the Hounds in July, 1849 , and the subsequent election of the reform ayuntamiento, the town had been free from political sensations and comparatively safe from acts of violence. ${ }^{1}$ Alcalde Geary and his council had given a conservative and honest administration, but their term was too brief to accomplish many improvements, for Riley's proclamation of June 4, 1849, provided that the officers elected in August should serve only until the close of that year. When the next election took place, January 8, 1850, the Mexican system was still in force; the first and second alcaldes were returned to office, five members of the ayuntamiento were re-elected and seven new members chosen. ${ }^{2}$

On April 15, 1850, San Francisco was incorporated by act of the legislature, ${ }^{3}$ and on May first the citizens approved the charter and elected the officers for which it called. Alcalde Geary was chosen mayor, and Frank Tilford, a member of the last ayuntamiento, was made recorder. ${ }^{4}$ All other positions were

1 G. E. Schenck, later a member of the Committee of Vigilance, said that from November, 1849, to February, 1850, everything seemed to be quiet in San Francisco, there was little robbery, and both life and property were safe, although personal quarrels between gamblers and their ilk were not uncommon. He recollected that a safe containing some $\$ 25,000$ or $\$ 30,000$ stood unmolested outside an office on Clay street, near Montgomery (Statement on the Vigilance Committee, 1877, pp. 22, 48, MS in the Baneroft Library). See also Johnson, California and Oregon; or Sights in the Gold Region, 215.

2 See Annals, 265--266. Great confusion attended the election.

3 California, Statutes, 1850, chap. 98, p. 223.

4 The recorder of a city had jurisdiction over violations of the city ordinances, and exercised other powers similar to those of a justice of the peace (California, Statutes, 1850, chap. 98, p. 225, secs. 11, 12). 
filled by new men.5 Three city elections in the space of ten months had obliterated the reform movement initiated at the time of the Hounds excitement. The rapid development of party and personal issues made the campaigns increasingly strenuous, and it was not possible for merchants whose business demanded the most alert attention to devote themselves so continuously to eity politics.

The men who were elected had unusual difficulties to face. San Francisco not only changed its officers with unprecedented frequency but during the period from December, 1849, to September, 1850, the city suffered four devastating fires, each of which swept away block after block from the center of the town and necessitated emergency measures of considerable magnitude. ${ }^{6}$ Heavy expenses were also incurred in improving streets and wharves, in acquiring public offices, and in commencing the erection of a county jail. Unfortunately, in all these departments city funds were spent lavishly and unwisely, while the official salaries were placed at an exorbitant figure.

The citizens were not indifferent to this mismanagement. They held large indignation meetings and adopted resolutions instructing the councilmen to revise their financial policy or to retire from office in compliance with the "sovereign will" of the people of the city. The fire of June 14, 1850, interrupted the work of a committee that had been charged with the delivery

5 See Annals, 273. The following future members of the Committee of Vigilance were elected: Charles Minturn, William Sharon, Robert B. Hampton, Francis C. Bennett, John P. Haff. John Middleton was subsequently elected to fill a vacancy.

6 The successive fires were described, as follows, in the Annals, 241, 275, 277, 290, 598-613. First, Dec. 24, 1849. Destroyed nearly all the buildings on the east side of the Plaza, and the south side of Washington Street, between Montgomery and Kearny. Damage over $\$ 1,000,000$. Second, May 4, 1850. Destroyed about three blocks, between Montgomery and Dupont, Clay and Jackson streets. Damage nearly $\$ 4,000,000$. Supposed to be incendiary. Third, June 14, 1850. Burned the whole space between Clay and California streets to the water's edge. Damage, nearly $\$ 5,000,000$. Fourth, Sept. 17, 1850. Swept the district between Dupont, Montgomery, Washington and Pacific streets. Damage about $\$ 300,000$. 
of the resolutions, but the obnoxious salaries were ultimately reduced. ${ }^{7}$ In spite of this the indebtedness of the city increased rapidly. Payments of accounts were made in scrip, which greatly depreciated in value and became a prolific source of scandal owing to the manipulation of speculators and of unscrupulous officials. ${ }^{8}$

San Francisco by this time had spread far beyond the limits of the little town over which the Stars and Stripes were raised in 1846. The old Plaza, where that ceremony took place, was thenceforth officially known as Portsmouth Square, though the Spanish name still lingered in common use. All the early buildings about it had been burned, with the exception of the "Old Adobe" on the northwest corner, which had formerly been used for public purposes and was subsequently rented for private business. ${ }^{9}$ This landmark of the past was elbowed by the frame structures of the hour: the postoffice, the city hall improvised from the old Graham House, and a host of saloons and gambling resorts, of which the El Dorado, on the corner of Kearny and Washington streets, was the most gaudy and notorious. In front of the Adobe rose a flagstaff, one hundred and eleven feet high, a gift from the people of Portland, Oregon. ${ }^{10}$ The unkempt and dusty space about it served as a rallying point for the mass meetings which for many years were a feature of the city.

North, east, and south of the Plaza ran the narrow strects of the business section, rescued from engulfing mud by wooden

7 See Annals, 278-281; Moses, Establishment of Municipal Government, 61-71; Baneroft, California, VI, 215-220; Hittell, California, III, 367-369.

8 By March, 1851, the liabilities of the eity were $\$ 1,099,577.56$, and on May 1, the legislature passed an act to authorize the funding of the floating debt of the eity of San Franciseo, and to provide for its payment (California, Statutes, 1851, chap. 88, p. 387). See also Hittell, California, III, 395-399; Annals, 327-328.

9 The Old Adobe was built in 1835, and was occupied by the Mexican officials. It was one of the three pre-' 49 buildings that survived the fire of May 4, 1851, and it met its end in the fire of June 22. See Alta, 1851, June $1 \%$; $27 \% 2$; Eldredge, San Francisco, II, 529.

10 Annals, 281. The eity was charged $\$ 100$ for digging the hole, and $\$ 200$ for rigging the halyards (Alta, 1851, March $251 / 3$ ). 
sidewalks from which the unwary might easily plunge waist deep into treacherous pools. On the eastern water front the streets reached out over the bay in wharves which bore lodging houses and offices, while other buildings, supported on piles, hovered above the unfilled water lots. Reclamation work was in vigorous progress. Behind the protection of the line of sand hills south of Market street, in a quarter known as Happy Valley, ${ }^{11}$ a dredger christened the Steam Paddy ${ }^{12}$ tore down the dunes. Cars impelled by gravity transported the sand through Battery Street and dumped it to fill the shallows of Yerba Buena Cove. Already the vessel Niantic, moored at Sansome and Clay streets, and converted into a large hotel, was well removed from high tide, and the hulks of other ships, deserted in the gold rush, lay forgotten beneath the new ground. ${ }^{13}$ Still others, moored near shore, served as store ships for the receipt of merchandise, or made more comfortable homes than could be found on land.

Telegraph Hill flanked the city on the north, and around its slopes clustered the wretched hovels of Little Chile and Sydney Valley, in which foregathered undesirable aliens from South America and Australia. ${ }^{14}$ On the other side of Telegraph Hill, towards the Presidio, lay North Beach, with a small wharf and planing mill owned by Williams \& Meiggs. About this

11 Poorer immigrants camped in Happy Valley to avoid exorbitant rents nearer the Plaza. Poverty, dirt, and dissipation rendered the place the scene of misery and disease. See Ryan, Personal Adventures, II, 270-275.

12 See Borthwick, Three Years, 80. The editor of the Alta, 1851, June $10 \%$, suggested that a medal be awarded this incorruptible assistant in civic improvement. In spite of its personal name it was solemnly assured by a jealous Irishman: "If you can do the work of a hundred men, you can't vote!' (J. R. Garniss, Early Days of San Francisco, 1877, p. 30, MS in the Bancroft Library).

13 See Eldredge, San Francisco, II, 578-580. Relies of such built-in vessels are still unearthed beneath the streets of the eity.

14 The Alta described the foreign quarters, 1851, June $29 \%$. The article did not tally exactly with the map in Popular Tribunals, I, which served as a guide for the map in the Committee of Vigilance Papers, III. 
point was another settlement of rough and dangerous characters. ${ }^{15}$ South of Market street rose Rincon Hill, soon to become the first fashionable residence district; starting from Market and Second streets, the Plank Road wound out to the Mission Dolores, affording the one comfortable driveway in the whole vicinity. ${ }^{16}$

The population at this time was about $23,000,{ }^{17}$ gathered from all the ends of the earth. ${ }^{18}$ To this number must be added a constant swarm of non-residents, rushing from their ships to the mines, and then back again to take passage to other ports. The streets were filled with hurrying men; with laborers who piled freight upon sidewalks and vacant lots; with auctioneers who sold it on the instant; and with purchasers who removed it before nightfall. Reckless drivers dashed through the streets, pack animals struggled and fell under heavy loads, horsemen with a touch of Mexican color rode splendidly through the busy crowd, Chinamen chattered and shuffled along the wooden walks, while every shade of black and brown humanity known to the tropic sun drifted in and out of the barrooms and worked along the wharves. Far into the night lights from auction houses, saloons, and gambling halls streamed into the murk of drifting

15 The mill owners were Edwards C. Williams and John G. Meiggs. The small wharf was later replaced by a larger one, projected by Meiggs' brother, Henry, a spectacular financier who became a fugitive from his commercial obligations.

16 See Annals, 296-298; J. S. Hittell, San Francisco, 151-153.

17 The statistics relative to the growth of San Franciseo are approximate, but the following references may be of interest.

1846, midsummer, over 200, Annals, 173.

1847, June, 459. Census taken by Lieutenant Edward Gilbert, J. S. Hittell, San Francisco, 117.

1848, Mareh, 812. School census, California Star, 1848, March 18. See also Annals, 174.

1849, Feb., about 2000, Annals, 219.

July, about 5000, constantly changing, Annals, 226.

1850, May, about 40,000, Johnson, Sights in the Gold Region, 210. Over 36,000 arrived by sea in 1850 , one half from foreign ports, Annals, 300 .

1851, Jan., 23,000, Alta, 1851, Feb. $7 \%$.

18 A cemetery on Russian Hill showed inscriptions in thirteen languages (Herald, 1852, Dee. $12 \%$ ). 
fog; otherwise the city lay in darkness, ${ }^{19}$ and evildoers crept unnoticed in the shadows or slipped noiselessly out over the Bay, where scarcely a beacon gleamed to direct or safeguard the shipping from a hundred ports.

Among the many descriptions of San Francisco, the picture presented by Édouard Auger, though little known today, deserves wider recognition. He spoke of it as $:^{20}$

Cette merveilleuse cité, bazar de toutes les nations du globe, création spontanée comme une de ces œuvres fantastiques des Mille et une Nuites * * * où les mineurs et les aventuriers de toutes sortes apportent sans cesse leur or, leurs passions, leur activité febrile et désordonnée. San-Francisco est la ville aux transformations brutales, aux changements de décors à vue; hier cité florissante, aujourd 'hui monceau de cendres. Repassez dans un mois, vous retrouverez à la même place une autre ville avec ses rues bien alignées, ses magasins regorgeant de marchandises, ses temples, ses théâtres, ses cafés, et une population affairée qui parle de tout, excepté d'une eatastrophe qui a déjà un mois de date.

In 1851 San Francisco had about half a dozen churches, ${ }^{21}$ and eight daily newspapers $;^{22}$ among the latter, the San Francisco Herald and the Alta California were the most important, with the Evening Picayune and the California Courier in the second rank.

There was, as yet, no public fire department. Volunteer companies had been formed after the first great fires, and had

19 The first street lights were installed by J. B. M. Crooks (Vigilante of 1851). The fire of May, 1851, destroyed them, and they were not replaced

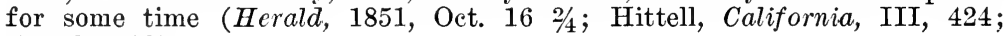
Annals, 518).

20 Auger, Voyage en Californie, 98, 173. For interesting descriptions of San Francisco at this period, see especially Annals, 243-321; T. A. Barry and A. B. Patten, Men and Memories of San Francisco in the "Spring of '50,' '1873 ; Borthwick, Three Years, 43-93 ; Baneroft, California, VI, 164220 ; Holinski, La Californie, 101-132 ; C. P. Kimball, Directory, Sept., 1850 ; J. M. Parker, Directory, 1852 . Excellent pictures can be found in J. P. Young, San Francisco, 1912; C. B. Turrill, "Life in San Francisco, 1856,' Overland Monthly, ser. 2, LXVIII (1916), 495-502.

21 Kimball's Directory, 1850, p. 127.

22 Six dailies were mentioned in Kimball's Directory, 1850, pp. 127-128; eight in the Alta, 1851, Jan. $23 \%$. 
been organized into serviceable coöperation by a city ordinance of July 1, 1850. The Empire Engine Company, one of the most active, was led by David C. Broderick, who used his experience in similar institutions in New York to mold the San Francisco company into a useful political tool. The California Engine Company, manned by residents of Happy Valley, had a house on the corner of Market and Bush streets; on the ground beside it stood a bell which was struck by hand in order to sound an alarm of fire. The Monumental Company, most famous of them all, was housed on Brenham place, facing the Plaza. From its belfry sounded a clear-toned bell which roused the citizens in many thrilling hours of conflagration and civic excitement. ${ }^{23}$ There were three more engine companies, the Protection, the Howard, and the Eureka, and two hook and ladder companies. All of them were influential in the social and political life of the city. The members drew no salaries, but in recognition of their services were exempt from jury duty. This privilege withdrew several hundred of the best men in San Francisco from that unwelcome but important attendance on the courts. ${ }^{24}$

To cope with all the criminal problems of the city, there was a force of about seventy-five policemen. ${ }^{25}$ From statements made before the Committee of Vigilance it is evident that some among them were confederates of thieves. ${ }^{26}$ The city station house was a disgraceful cellar, insecure and filthy. Although large funds had been expended on the preliminary work of constructing an adequate county jail, they had been so misapplied that the

23 The bells of the California and Monumental companies were used by the Committee of Vigilance. (See infra, p. 206.)

24 See California, Statutes, 1851, chap. 90, p. 401; Hittell, General Laus, secs. 3102-3124. For an account of the fire companies, see Annals, 614-625; Borthwick, Three Years, 87-90; Frignet, La Californie, 156-159; H. C. Pendleton, publisher, The Exempt Firemen of San Francisco, 1900.

25 Bancroft, California, VI, 214 note 68 ; Kimball's Directory, 1850, pp. 123-124.

26 See Papers, Index under "San Francisco-Police." 
building was far from complete. ${ }^{2 \tau}$ During this period criminal conditions grew steadily worse. The rogues who were driven out of the mining camps by the fear of lynch law showed an increasing tendency to concentrate in San Francisco. Crowded lodging houses and vicious resorts of the city offered shelter, without inconvenient curiosity, and any one might live at will beneath the scrub oaks and underbrush of the outlying sand hills. The ever shifting stream of transient sojourners diverted attention from particular individuals, and the few guardians of public safety had no way of identifying old offenders, whether they came from the other side of the Bay of San Francisco or the other side of the Pacific Ocean.

San Francisco citizens had asserted themselves once, in the affair of the Hounds. Since that occasion they had left the punishment of criminals in the hands of the authorities, ${ }^{28}$ although various mass meetings had voiced popular resentment at civic mismanagement, and had occasionally been heeded for the moment by those in authority. The expectation of improvement which had influenced men to adjust themselves to the inconveniences of the military-civil régime, now led them to hope that the state government would soon accomplish the establishment of social order. In fact, the toleration of the criminal situation of 1850 and 1851 was due in part to a patient acceptance of transitional conditions, and not wholly to a selfish indifference and a blunted civic conscience.

Nevertheless there was a limit to toleration, and that limit was reached on the night of February 19, 1851, when Mr. C. J. Jansen, a prominent merchant, was assaulted in his store and left for dead, while two men robbed his safe and escaped with nearly two thousand dollars. ${ }^{29}$ The crime, of itself, was no more

27 See infra, p. 247.

28 Annals, 314.

29 Full accounts were given in the papers of the day; Annals, 314-320; Popular Tribunals, I, 179-200; Royce, California, 407-417. The last is especially good. 
heinous than many that had passed unnoticed, but the victim was so well known and so popular that his misfortune roused unusual indignation. Within the next twenty-four hours the police arrested an Australian who was supposed to be James Stuart, a Sydney convict responsible for many robberies in California and for the cold-blooded murder of Charles Moore, near Foster's Bar, in Yuba County. ${ }^{30}$ Certain clues led to the suspicion that he was also guilty of the attack on Jansen, and he was immediately charged with that crime, although he protested his innocence most vehemently, and maintained that he was not Stuart at all, but a respectable British subject, honestly bearing the name of Thomas Berdue. Another Australian, Robert Windred, was arrested as an accomplice in the recent raid, and the general excitement rose to fever heat when the rumor became current that the desperado Stuart was actually in custody. while his latest victim hovered between life and death.

Stuart was, in truth, the murderer of Moore, the thief of common report, and the assailant of Jansen. Berdue's only fault was a strange resemblance to the notorious criminal. a resemblance which almost caused his death at the hands of a San Francisco mob, and imperiled his life and liberty in three successive trials for the crimes committed by another man.

Records of the evidence given at the different trials show that Stuart and Berdue were remarkably alike in height, figure, and complexion, in the color of their eyes and hair, in the English intonation of their voices, and in certain tattoo marks. Both of them had a stiff middle finger on the right hand and a scar on the right cheek. ${ }^{31}$ At one time or another men who had worked

30 See Herald, 1851, Feb. 21 3/1; $22 \% 2$; and infra, p. 253.

31 See Popular Tribunals, I, 194-196; Alta, 1851, Feb. 24; History of Fuba County, 1879, p. 125. Members of the Vigilance Committee had an opportunity to compare the two men, and Schenck said: "Berdue... was a man about five feet and $71 / 2$ inches in height, with full oral face. dark brown or auburn hair, a well built and good proportioned man, with rather a fair complexion, and I think grey or blue eyes. Stuart was a man full 
with Stuart, officers who had guarded him while under arrest, and judges who had tried him identified Berdue as the escaped murderer; other witnesses took the opposite position and were equally certain that Berdue was not responsible for the crimes of James Stuart, whatever share he might have taken in the attack on Jansen. It was not strange that the wounded man, himself, thought he recognized Berdue when the latter was taken to his bedside. When that fact was announced on the street an angry crowd tried to wrest the supposed Stuart from the police as the prisoners were being returned to the station house. When they were brought into court both men tried to establish an alibi. This device was the common resort of criminals, and their witnesses made a very unfavorable impression. The public irritation increased during the hearing and when the court adjourned on Saturday afternoon there was another attempt to seize the suspects and to hang them at once. With the help of the Washington Guards, who had been called out by the authorities, the crowd was again beaten off, and the prisoners lodged in a place of safety; but by evening several thousand people surrounded the city hall, some bent on violence, some anxious to prevent ill-advised action of any kind.

Popular restlessness was further increased by the radical expressions of the leading newspapers, and by the circulation of a handbill couched in the most inflammatory terms. ${ }^{32}$ After

five feet 9 or $91 / 2$ inches high, with sharp features, narrow chin, darker complexion than Berdue, and very dark brown or black hair, much darker than Berdue's, with longer arms, a slighter built man. There was really no strong resemblance between the two men, and there was no such distinguishing feature as the loss of a finger on the hand of each, as was mentioned in the public prints about six years ago"' (MS Statement, 30-31). G. W. Ryckman confirmed this view (Statement, 8, MS in the Bancroft Library), but A. M. Comstock found them remarkably alike (MS Vigilance Committees-Miscellany, 39). It was rumored that Berdue was an ex-convict (Papers, 506).

32 The handbill is printed infra, p. 453. On Feb. 21, the editor of the Alta severely criticized the failure of justice in the courts, and wrote: "We deprecate Lynch Law, but the outraged public will appeal to that soon unless some far more efficient measures be adopted in other quarters.' Similar sentiments were repeated on Feb. 23. 
listening to a number of speeches the assembly voted to appoint a committee to guard the prisoners during the night, and to consult with the authorities concerning the course to be pursued. Some of the actors in the Hounds' trial reappeared: W. D. M. Howard was chairman, Samuel Brannan took a leading part, and A. J. Ellis, H. F. Teschemacher, and T. H. Green were again chosen to represent the people. ${ }^{33}$ The committee held a long and stormy meeting, and their debates can still be read in the papers of February 23 and 24. A minority of four, led by Brannan, wished to recommend immediate execution, but the majority desired more deliberate action. In the end it was found impossible to make any unanimous report. ${ }^{34}$

On Sunday a still larger crowd collected in the Plaza, where both parties of the committee presented their views, ${ }^{35}$ while the mayor and other officials appeared on the balcony of the city hall and urged the citizens to disperse, promising that the prisoners should be tried without delay and promptly punished if their guilt were established.

The report in the Alta California stated that the five or six thousand persons present were as orderly and quiet as so large a body could be, but it is evident from the recollections of

33 The committeemen were: W. D. M. Howard, Samuel Brannan, A. J. Ellis, H. F. Teschemacher, W. H. Jones, Ralph Dorr, E. A. King, J. B. Huie, T. H. Green, Benjamin Ray, A. H. Sibley, J. L. Folsom, F. W. Macondray, Theodore Payne (Alta, 1851, Feb. 23 2\%). The first eight
became members of the Committee of Vigilance.

$34^{\prime \prime}$ "We are the mayor, and the recorder, the hang man and the laws!", cried Brannan, "The law and the courts never yet hung a man in California!', (Alta, 1851, Feb. $23 \%$ ).

35 The following report of the minority was distributed as a handbill, and printed in the papers of Feb. 24:

To The PEOPLE of SAN Francisco

The undersigned, the minority of the committee appointed by you, report as follows: That the prisoners, Stuart and Wildred [Windred] are both deserving of immediate punishment, as there is no question of their guiltiness of crime. The safety of life and property, as well as the name and credit of the city, demand prompt action on the part of the people.

[Signed] Samuel Brannan, Wm. H. Jones, E. A. King, J. B. Huie. 
spectators that the spirit of the crowd was one of intense excitement. There was a universal distrust of promises of reform, and a universal determination that this crime, at least, should be avenged; many were armed, and the issue of the day waited upon the appearance of some one able to dominate and unite the opposing elements. Such a leader was recognized when William T. Coleman, a man still under thirty years of age, pushed his way through the crowded balcony of the city hall, leaned far out over the railing, caught the attention of the impatient thousands with a dramatic arraignment of the intolerable miscarriage of justice in the city courts, and then proposed the formation of a peoples' court, which should give the prisoners a fair trial without an instant's delay, and either discharge or hang them before sunset. ${ }^{36}$ A shout of approval greeted his suggestion and a unanimous vote carried the motion that organization should immediately be effected. This was done. Judge, jury, and counsel were selected and they spent the afternoon and evening listening to evidence. The trial was held in the recorder's room in the city hall, but from motives of prudence the prisoners were not allowed to attend.

G. E. Schenck, who later became a member of the Committee of Vigilance, was one of the jury, and spoke of the trial as follows : ${ }^{37}$

The result of the trial was, from the testimony, that these men were decided to be guilty, and the verdict was about to be brought in accordingly, when I suggested that they should have a fair trial by the authorities, as we had not seen the prisoners, they not being before us, and as

36 For a biographical note on Mr. Coleman see infra, p. 190. The papers stated that he was the head of the committee, but they ignored the exact moment when he suggested organization. The details given in the text are from his MS Statement in the Bancroft Library. His recollections tallied so well with the printed reports that an extract is given, infra, p. 453. See also his "San Franciseo Vigilance Committees,' Century, XLIII (1891), 134-135.

37 MS Statement 25-26. Hall McAllister was also in substantial agreement with Coleman, Schenck, and the narrative presented by Royce. See MS Vigilance Committees-Miscellany, 16-17. 
Mr. Jansen had not fully identified them, there was room for doubt. Two others coincided with me in regard to it, and we agreed to bring a verdict that we could not agree; there were nine for conviction, and three had doubts. This was about nine o'clock at night. On our coming into the Court Room and announcing this fact, the outside crowd broke in the windows, and rushed in at the doors, and broke up the railing round the bar, and were about to make an attack on the jurors. The jury drew their revolvers, and rushed back into the jury room until the excitement subsided. The jury was then discharged. It was one o'clock before we got away. In the meantime, Mr. Wm. T. Coleman was haranguing the crowd, endeavoring to persuade them to disperse, while Brannan was urging them on, and was for hanging the prisoners anyway.

The disapproval of the waiting crowd was even more yiolent than Schenck depicted. During the evening several attempts had been made to seize the prisoners, but the police, assisted by some two hundred and fifty volunteers, had repulsed the attacks. When the disagreement was announced a rush was made for the jurymen, and there were loud cries of "Hang them, too!" An indignation meeting was held in the street and the excitement did not subside until after midnight, when it was voted to adjourn indefinitely, and the watchers quietly dispersed.

Windred and Berdue were tried about the middle of March and both were convicted. ${ }^{38}$ Windred was given a ten-year sentence, but he quickly escaped. ${ }^{39}$ Berdue, under a sentence of fourteen years, was sent to Marysville to stand trial for the murder of Moore. His case came up in June, and for the third time the prisoner made a fruitless effort to establish his innocence in spite of the fatal resemblance to his ill-reputed countryman. Judge B. F. Washington, who had tried Stuart in Sacramento, positively identified the accused as the fugitive, and some fifty other witnesses agreed with him. Judge O. P. Stidger, who had tried Stuart for robbery at Marysville, was equally definite on the other side. Several witnesses supported Judge

38 See the court reports in the Alta and the Herald, 1851, March 15-21. 39 See infra, p. 311. 
Stidger, but in spite of their evidence Berdue was pronounced guilty on July 4. By this time his funds were entirely exhausted, and his hopeless state of mind is clearly shown by a pathetic letter which he wrote to a friend, and which was later copied for the files of the Committee of Vigilance. ${ }^{40}$ There was, indeed, little chance of a reprieve, but a later chapter will show how Fate, which had played him such sorry tricks in the past, came to his rescue with incredible and dramatic caprice. ${ }^{41}$

In an effort to improve civic affairs the residents of San Francisco procured from the second session of the legislature a new charter that corrected some of the defects in the first. ${ }^{42}$ This necessitated a new election for local officers, which took place in April. Nearly six thousand votes were cast, and the majorities given to the Whig candidates made a sweeping change in the city administration. ${ }^{43}$ The editor of the Alta California interpreted this as a sign that the people were so tired of the corruption of the previous officials that they sought new men in the hope of securing reform. "They will be watched," he asserted, "and they will be held to a strict accountability for the manner in which they shall exercise the powers vested in them. . . . They will be watched by a vigilant party. They must be watched by a vigilant people." ${ }_{44}$ These were the men who served through the months of the activity of the Committee of Vigilance. The names of some of them are frequently mentioned in the archives of the society. Charles J. Brenham was

\footnotetext{
40 See letter to John Goff, Papers, 222-223.

41 See infra, pp. 257, 303.

42 California, Statutes, 1851, chap. 84, p. 357. The first months of municipal experiments in California had resulted in great waste of public funds in other places besides San Francisco, and during the second legislature several cities secured new charters. $302 \%$.

43 The Whig vote was about 3162, the Democrat, 2748, Alta, 1851, April 44 Alta, 1851, April 30 2/1.
} 
chosen mayor, R. H. Waller, recorder, Frank M. Pixley, city attorney, and Robert G. Crozier, marshal. ${ }^{45}$

The former county judge, R. M. Morrison, having resigned in April, the governor appointed Alexander Campbell to the vacant position. ${ }^{46}$ He was assisted in the Court of Sessions by Associate Justices Edward McGowan and H. S. Brown, who held over from the county election of 1850. Campbell's judicial integrity was never questioned, Judge Brown seems to have made no particular impression, either for good or evil, ${ }^{47}$ but "Ned" McGowan, friend of criminals and ward heelers, was an example of the worst sort of California magistrate. The Vigilance Committee of 1851 refrained from prosecuting him; the Committee of 1856 made strenuous though unsuccessful efforts to take him into custody. ${ }^{48}$

Another incumbent who remained in office was Judge Levi Parsons, who had been elected to the District Court by the first legislature. Parsons had no sympathy with efforts at reform, and he became so irritated with the constant agitation carried on by the press that he charged the grand jury to take measures against editors whose libelous publications might incite to acts of violence. At the same time he warned the jury not to return indictments against criminals except on evidence strong enough to insure conviction before a trial jury, an admonition which evoked the strongest censure from the San Francisco papers. The Herald was particularly emphatic, and remarked: "Thus the district court instructs the grand jury to aid the escape of criminals." This expression led Judge Parsons to cause the arrest of William Walker, the editor in charge, to try him for contempt, to fine him $\$ 500$, and to imprison him when payment

\footnotetext{
45 See Annals, 326.

46 Herald, 1851, May $17 \% 3$.

47 See note on his resignation, infra, p. 303.

48 See Papers, 332, 336, 349, also infra, p. 402.
} 
was refused. ${ }^{49}$ An indignation meeting was promptly held on the Plaza. Samuel Brannan presided and W. T. Coleman was one of the vice-presidents. Resolutions were passed condemning Judge Parsons' action, and a committee was appointed to procure his impeachment before the state legislature. Walker's case was immediately carried to the Superior Court on a writ of habeas corpus, and the prisoner was discharged. The effort to impeach Parsons was given up on the ground of insufficient evidence. ${ }^{\text {5o }}$

While discussing the personnel of the San Francisco bench in 1851, it is relevant to notice a serious handicap laid upon the lower court. The statutes of 1850 charged the county attorney with the duty of conducting criminal prosecutions before justices' courts, as well as in the County Court. ${ }^{51}$ That office was abolished in 1851, and the duties of the county attorney were transferred to the district attorney, who was charged with conducting prosecutions before lower magistrates when he was "not in attendance upon the District Court or Court of Sessions. " 52 This change imposed so many duties upon the district attorney of San Francisco that he entirely neglected any attendance on the recorder's court, which now exercised the larger powers given to lower magistrates by the revised statutes of 1851. The city recorder, obliged to act both as prosecuting attorney and as judge, petitioned in vain for a special prosecuting officer, since the common council had no power to create such an office. ${ }^{53}$ This condition placed criminals who employed able lawyers in a position of great advantage. Although repeated complaint was made against it, ${ }^{54}$ an appointment noted in the

49 See Annals, 322-324; Herald, 1851, Narch 4; 10; 15.

50 First California Reports (annotated ed.), 539-555.

51 California, Statutes, 1850 , chap. 39 , p. 112 , sec. 5 .

52 California, Statutes, 1851, chap. 21, p. 188, see. 6.

53 Alta, 18.51, Nov. $27 \% 4$.

54 See Herald, 18.52, March $22 \%$. The district attorney sometimes appeared, but was usually too busy. 
Alta California of April 5, 1856, seems to be the first special assignment of a prosecuting attorney to the lowest court. ${ }^{55}$

On May 4, 1851, San Francisco was devastated by a fifth great fire, which consumed more than three-quarters of the city and entailed a loss of several lives and of ten or twelve million dollars. ${ }^{56}$ This was by far the worst calamity that had yet overtaken the community. It oceurred on the anniversary of the fire of May 4, 1850, and in the excited public imagination it was generally believed that both were the work of incendiariesa belief strengthened by the discovery of about $\$ 10,000$ worth of booty in houses occupied by the Sydney immigrants. ${ }^{57}$

During the next four weeks San Francisco again justified the symbol of the phoenix upon the eity seal. Before the ruins had cooled rebuilding was under way. Within ten days nearly three hundred and fifty new structures were completed and occupied..$^{58}$ Men worked with indomitable energy to restore what had been destroyed, and with growing determination to protect the fruit of their toil from the outlaws whose plots had so often resulted in arson and death. The belief in the existence of a gang determined to burn the city for the purpose of plunder created an atmosphere of extreme nervous tension that especially affected the citizens of large financial interests. The pioneer merchants of San Francisco were cool of head and quick of hand, not afraid to carry their lives in their own keeping, although disinclined to seek trouble in the resorts of crime and violence. But single-handed courage was powerless to save either

55 A prosecuting attorney for the mayor's court had then been appointed.

56 See Annals, 329-333, 604-610; Bancroft, California, VI, 204-206; Popular Tribunals, I, 74. Interesting recollections of the eatastrophe were given by Schenk, MS Statement, 44-45; and by Alfred Wheeler, "Oration,' in Society of California Pioneers, Thirty-second Anniversary (1882), 19-23.

57 The fire was attributed to accident rather than to arson in Parker's Directory, 1852 , p. 19.

58 Herald, 1851, May $15 \%$. The slogan of the eity was said to be: "Go ahead, Young California! Who, the hell, eares for a fire!' (Gerstäcker, Gold ein Californisches Lebensbild, p. 111). 
life or fortune from the destruction of these recurrent fires, and the public officials were either unable or unwilling to ferret out the incendiaries.

On May 17 a movement was started to supplement the inadequate police force by organizing a volunteer night patrol. ${ }^{59}$. Residents of the Fifth and Seventh wards met at the California Engine House and formed an association which was duplicated, later, in the Third ward. The effort received not only the approval of the press but the sanction of the authorities. The patrol was authorized by a city ordinance, the mayor swore the volunteer police into office, and the city marshal assumed the direction of their work. ${ }^{60}$ Speaking of this organization Schenck said : ${ }^{61}$

Capt. F. W. Macondray was at the head of it, and there were about a hundred members. The members were assigned to different districts, and were on duty about eight hours. I was out four times per month in this way. This was a regular police organization, with proper officers, established by ourselves for our protection, and the members were expected to and did personally perform the duties required and not delegate them to any one else. This may be said to be the origin of the Vigilance Committee of 1851. The attack on Jansen and other outrages which had become so numerous as to excite the indignation of the people, together with the laxity of the laws and the difficulty of keeping witnesses here to give their evidence in cases brought to trial, led to the organization of this patrol, and ultimately to the formation of the Committee of Vigilance, which took place about the tenth of June, 1851. About a dozen members of the patrol casually met in the neighborhood of Macondray's building, about the middle of the day, and after some discussion, resolved themselves into a Committee of Vigilance, and procured Brannan's building to hold meetings in.

The last clause in Schenck's statement is not exactly substantiated by other accounts, but it indicates one of the influences which led to the formation of the Committee of Vigilance. Lists

59 Alta, 1851, May $19 \% ; 20 \% ; 21 \%$; $28 \%$.

60 See ordinance of May 26, 1851 (Manual of San Francisco, 1852, p. 49). Bancroft placed the organization of the patrol in February (Popular Tribunals, I, 205).

61 Schenck, MS Statement, 34-35. 
of the officers of the patrol were printed in the Herald. Of the thirty-four named, fourteen became members of the Committee, although they were not conspicuous in starting the movement. ${ }^{62}$ Occasional paragraphs in the papers suggested a decrease of violence after the demonstration of popular temper over the Jansen affair, and particularly after the formation of the volunteer patrol. Nevertheless, a long list of crimes can be compiled from the news items, and the more terrifying menace of arson oppressed the popular imagination with increasing apprehension. ${ }^{63}$

The cry of "Fire!' startled the town again on the night of the second of June. It proved to be but a small blaze, easily extinguished before it spread beyond a single room in a lodging house on Long Wharf. A smouldering heap of oil-soaked bedding seemed to incriminate the occupant, Benjamin Lewis, and he was arrested not far from the building and arraigned before the recorder. While the hearing was in progress hundreds of spectators thronged the court room and the street outside and

62 Herald, 1851, June $103 / 1$. In view of Schenck's statement it is interesting to record the names of future Vigilantes who served as officers of patrols, and to note their membership number in the Committee.

Third ward

James Murray, No. 345,

J. C. Hasson, No. 229,

J. F. Curtis, No. 31 ,

J. E. Dall, No. 80 ,

P. Markey, No. 393,

Thomas McCahill, No. 90,

W. F. Martin, No. 417 ,

P. W. Van Winkle, No. 554.
Fifth and Seventh wards.

G. M. Garwood, No. 46,

W. C. Graham, No. 152,

C. L. Case, No. 161,

Capt. E. Gorham, No. 3, R. S. Lammot, No. 49 ,

Frank Mahony, No. 6,

William Browne, No. 23.

63 An editorial in the Herald of June 4 reported a decided improvement, but the Courier of the next day lamented that there was no apparent decrease in crime. The Herald, July $4 \%$, gave a summary, showing that from April 30, 1850, to May 23, 1851, some 184 prisoners had been committed for trial before the District Court. Of these 68 had been discharged, 21 had escaped, 6 had died, 2 received pardons, and 9 were still in custody. Of the remaining 78, 40 had probably forfeited bail, and the rest were unaccounted for, although over 20 had been convicted and sentenced. For crimes of this period, see Popular Tribunals, I, 139, 162, 201-204. 
heard with growing excitement evidence that warranted holding the prisoner for trial before a higher court.

The rush of an engine responding to an alarm of fire nearly precipitated a riot late in the afternoon of the trial. When some one raised the cry that the prisoner's friends were creating a diversion in order to effect a rescue, the crowd began to clamor for immediate execution. Colonel Stevenson, owner of the house Lewis had fired, made a speech in which he urged all law-loving citizens to take into their own hands the administration of justice, since the authorities afforded no protection either for life or for property. Mayor Brenham and others succeeded in restoring order only when the people were convinced that Lewis had been removed from the building and placed in security beyond their reach. The papers of June 4 recounted the affair in detail. Their spirit is indicated by the following extract from an editorial in the Herald:

Although strongly opposed, as must be every lover of fair play, to the summary execution of even such a character as Lewis, without a patient and impartial trial-we yet must declare that we regard the demonstration of yesterday with the highest gratification; and we trust that, if the man be proved beyond a reasonable doubt to have committed the crime, the citizens will supply any deficiency that may exist in the law. We say this, fully alive to the expectation that we shall therefore be accused of advocating Lynch-law. If this man be guilty of setting fire to the house on Long Wharf, and if the law do not adjudge him the penalty of death therefor, we do most unquestionably advocate Lynchlaw.

Lewis was indicted by the grand jury on June 5, but Judge Parsons had the indictment quashed on the ground that the new judiciary act, effective May 1, eliminated May terms for the grand jury and for the District Court. The grand jury which had acted in the case of Lewis had been called on May 26 by a substitute, Judge Robinson, during Parsons' temporary absence from the bench. Parsons discharged it as being without 
standing in the eyes of the law. ${ }^{64}$ The prisoner was kept in custody to await the July term, when he was indicted, tried, convicted, and sentenced to two years' imprisonment, the heaviest penalty allowed for arson by the statutes in force at the time he committed the crime. ${ }^{65}$

Schenck said of the Lewis affair : ${ }^{66}$

This was one of the transactions which led immediately to the organization of the Vigilance Committee out of the volunteer patrol, their motive being to secure the conviction of Lewis. The first watchword of the Committee was "Lewis.', It was afterwards changed, partly owing to the fact that Rube Maloney got into the Committee, and he was not wanted there.

Schenck's statement is particularly valuable because it explains the presence among the papers of the Vigilance Committee of a document entitled "The People vs. Benjamin Lewis; Copy of Testimony before the Recorder." ${ }_{67}$ This is somewhat fuller than the reports which appeared in the newspapers, and it is evident that some one who was afterward connected with the Committee was at pains to secure a complete transcript of the record, perhaps in anticipation of the trial before the higher court. The case of Lewis thus occupies the opening pages of the Papers of the Committee, and it happens that a singularly vivid series of San Francisco pictures are given in the crisp, disjointed sentences which were caught by the recorder's clerk while the mob in the noisy street shouted for summary execution.

The same conditions that existed in San Francisco prevailed in lesser or greater degree in all the interior towns, and were arousing public efforts to combat organized crime. The residents

64 Herald, 1851, June $10 \% ; 12 \%$.

65 Herald, 1851, July $42 \%$; $23 \%$; $30 \%$.

66 Schenck, MS Statement, 51. He said that Lewis escaped, and was later connected with the murder of a Dr. Burdell in New York, and was also convicted of a murder in New Jersey. The incident of the watchword is considered, infra, p. 209.

67 Papers, 4-14. 
of Coloma gathered in mass meeting in the spring to devise some method to "ferret out and bring to punishment the villains who lurk about Sacramento city and who it seems have lately assaulted some citizens of Coloma." ${ }^{68}$ A little later the men of Sacramento made a vigorous protest against the crime that was rampant in their city. ${ }^{69}$ Just at the time of the excitement in San Francisco over the case of Lewis the people about Stockton were roused by the depredations of a band of horse thieves. Five of these were finally captured. One of them turned state's evidence, and disclosed concerted operations of very wide extent. His confession attracted much attention, and the papers began to advocate the formation of popular committees for the defense of society. In the San Francisco Herald of June 5 the editor recommended that a vessel should be chartered to deport all the criminals known to the police. ${ }^{70}$ The Stockton Journal went to greater extremes and demanded that the people should appoint a commission and proclaim martial law. ${ }^{71}$

The idea of a protective association was taking definite shape in many minds. On June 8 the Alta published a letter which outlined a general plan of organization. The writer proposed that a "committee of safety" should be established to prevent the landing of convicts from Sydney, and that each ward in San Francisco should have a "committee of vigilance" to hunt down criminals and warn them to keep out of the city. ${ }^{72}$ This communication was signed by "Justice," and Professor Royce identified the author as R. S. Watson, one of the first members of the Committee of Vigilance. ${ }^{73}$ The California Courier of

\footnotetext{
68 Alta, 1851, April $1 \%$.

69 Alta, 1851, April $16 \%$.

70 See infra, p. 454.

71 See infra, p. 455.

72 See infra, p. 456.

73 Royce, California, 418.
} 
June 10 printed another long article urging similar action on the ground that society was in a condition of revolution. ${ }^{74}$

The excitement attending the trial of Lewis, the disclosures at Stockton which confirmed the impressions of a widespread organization of the criminal element, and the publication of such editorials as those just quoted combined during several successive days to emphasize the imperative need of some new movement that should attempt the suppression of crime.

The effort to meet that need resulted in the formation of the Committee of Vigilance.

74 See infra, p. 456. 


\section{THE ORGANIZATION OF THE COMMITTEE OF VIGILANCE}

It has been the purpose of the preceding study of California to show the local problems and the local attitude of mind so clearly that the reader can understand, without further elaboration, why the citizens of San Francisco instinctively adopted some form of popular association when they believed that their lives and their property were at the mercy of a criminal organization. Whatever may be his interest in their work, his criticism of the motives that influenced them, or his judgment of the results they accomplished, his personal estimate of the Committee of Vigilance of 1851 must be grounded upon a realization of the historic fact that the men of California had obtained national citizenship through resolute self-determination, through audacious self-organization, and through vehement self-assertion within the halls of Congress. Determination, audacity, and selfassertion also obtained for them a representative state government and statute law, although they did not insure them against the consequences of haste and inexperience, nor protect them from political demoralization. The precedents set in the days of self-protection and self-organization long persisted as vital influences in the local consciousness and irresistibly directed the men of 1851 towards a protective emergency association.

The call for such an organization was widespread and insistent. The formation of a committee of safety or of a citizens' commission had been advocated in Stockton by the Journal and in San Francisco by the Herald and the Alta; it did not originate, as is sometimes presumed, in the imagination of hot-headed 
extremists who cowed the law-abiding community into temporary subjection. Extremists there were among the Vigilantes, but as we study the records of their work we shall see that passion and violence were restrained to a surprising extent.

The full list of members is printed in Part I of the Papers of the Committee, and is reprinted, with tables of officers, in the Appendix to Part III. The Index to the latter volume gives a guide to the activities of each one, but as no biographical data are included with the documents it seems necessary that this narrative should show the reader what sort of men the Vigilantes were, and what influence they exerted on the community, both before and after their connection with the Committee of Vigilance. It would be interesting to trace the previous life and the California experiences of all the 707 members, but such an enormous task has not even been attempted.

About one in ten of the entire membership have left biographical records that are easily accessible. Even that list is too long to be incorporated in this chapter, and only about a dozen whose names will constantly appear in the narrative of the Committee will be introduced to the reader at this point. Notices of many others will be found in the Biographical Appendix. None of these brief notes is an original contribution to the history of California, for they have been collected from newspapers and books already in print, without further verification by the present writer.

The roll of the Society of California Pioneers shows that more than a fourth of the committeemen reached the state prior to 1850 . Indeed that society was organized, in 1850, largely by men who joined the Committee of Vigilance in 1851. A dozen future Vigilantes were among its earliest officers, and seven served as presidents in the course of subsequent years. ${ }^{1}$

1 See Annals, 283-284. The first officers included W. D. M. Howard, president, J. R. Snyder and Samuel Brannan, vice-presidents, J. C. L. Wadsworth and A. J. Grayson, assistant secretaries, and J. C. Ward, Wil- 
It is not unlikely that many other members of the Committee arrived during the early months of the gold excitement, and were thoroughly imbued with the traditions and precedents of mining life. A number had already stamped their personality upon the community. Their names have already been mentioned in discussing the history of the state in 1847, the San Francisco town councils of 1848,1849 , and 1850 , the movement for state organization, the suppression of the Hounds, and the trial of Jansen's assailants. They constantly reappeared in connection with commercial and political affairs of more or less importance. ${ }^{2}$

The members of the Committee are often characterized as the "leading merchants of San Francisco." In 1851 about a score of them were reckoned among the wealthy men of the city, and others made comfortable or conspicuous fortunes in later years. $^{3}$ The majority, however, were clerks or small tradesmen, and are unknown to posterity except as sons and grandsons carry

liam Blackburn, J. D. Stevenson, Robert Wells, J. M. Huxley, Henry Gerke, R. A. Parker, directors. The list of later presidents included Brannan, Snyder, P. A. Roach, Dr. H. M. Gray, O. P. Sutton, and A. M. Ebbets (San Franciseo Call, 1890, Sept. 8, p. 3).

2 In July, 1848, W. D. M. Howard, C. V. Gillespie and J. C. Ward were appointed by a San Francisco mass meeting to petition Governor Mason to adjust important questions connected with the currency (Bancroft, California, VI, 268 note).

Future Vigilantes formed more than one-third of the signers of an early call for a Chamber of Commerce (Alta, 1849, Nov. $11 / 1$ ). The same merchants signed formal congratulations to the new collector of the port a few days later (Cong. Docs., Ser. No. 573, Doc. 17, pp. 28-29). J. L. Van Bokkelen, A. J. Ellis and G. M. Garwood were members of the Whig Convention, May 26, 1851 (Alta, May $27 \% 2$ ).

3 Contemporary ratings of the following members were given in $A$ Pile, 1851, which listed some 600 wealthy Californians:

\begin{tabular}{|c|c|c|c|}
\hline Felix Argenti & 000 & James King of Wm....... & $\$ 125,000$ \\
\hline Samuel Bramnan .................... & 275,000 & Charles Minturn. & 100,000 \\
\hline 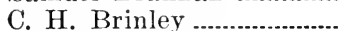 & 15,000 & John Middleton & 50,000 \\
\hline 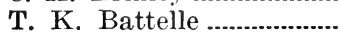 & 10,000 & A. B. Stout ....... & 20,000 \\
\hline A. J. Ellis . & 50,000 & J. D. Stevenson & 350,000 \\
\hline 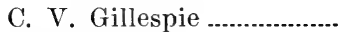 & 225,000 & H. F. Teschemacher & 50,000 \\
\hline Samuel Haight ...................... & 75,000 & J. T. $[\mathrm{J}$ ? ] Vioget & 50,000 \\
\hline J. B. Huie & 10,000 & Ferdinand Vassault & 60,000 \\
\hline W. D. M. Howard & 375,000 & J. C. L. Wadsworth ............ & 20,000 \\
\hline ........... & 10000 & & \\
\hline
\end{tabular}


on their names, or as the rolls of pioneer societies and brief obituary notices record their life and death.

It is probable that today no more than three men are generally remembered as leaders in the Committee of 1851: Samuel Brannan, the first president, Isaac Bluxome, Jr., the secretary, and William T. Coleman. Of these Bluxome is more widely known as "'33, Secretary,"' his official designation in the Committee of 1856, and Coleman, as president of that larger body. Brannan, therefore, has been accepted as the standard-bearer of the Committee of 1851, and since he was also a most notorious hot-head it is not surprising that his personal qualities have been embodied as the ruling spirit of the association.

Sam Brannan had been making history ever since July 31, 1846, when he landed in Yerba Buena at the head of his colony of Mormons.* $\mathrm{He}$ is said to have preached the first English sermon heard in the streets of the town, to have performed the first non-Catholic marriage ceremony, and to have been defendant at the first jury trial. He established the first San Francisco newspaper, the California Star, advocated the first public school, ${ }^{5}$ built the first flour mill, and made the first public announcement of the discovery of gold. He conducted a store at Sutter's Fort in 1847 and 1848, and engaged in land speculation at Sacramento, so that his name appears on many occasions in the annals of that neighborhood. He offered the first resolution against slavery at the Sacramento meeting which selected delegates to

4 Brannan was born in Saco, Maine, in 1819 , was a printer by trade, and became a Mormon in 1842. His career is discussed in Bancroft, California, II, 728; Popular Tribunals, especially II, 115-117; Annals, 748-753; O. T. Shuck, Representative and Leading Men of the Pacific, 1870, pp. 455-459, portrait; Davis, Sixty Years, 507; Burnett, Recollections, 298, 410 ; Brown, Reminiscences, [29]; Swasey, Early Days, 202-208; Eliredge, California, III, 118, portrait; Eldredge, San Francisco, II, 709-711; Ryckman, MS Statement, 4; San Francisco Call, 1890, Sept. $83 \%$. He received one rote for the Democratic nomination for governor in 1851, and as a presidential elector he cast his ballot for Lincoln and Johnson in 186t (Daris, Political Conventions, 11, 210, 212).

5 California Star, 1848, Feb. $53 / 1$. 
the constitutional convention proposed for March, 1849. He was a conspicnous leader in the trial of the San Francisco Hounds, and was elected to the ayuntamiento in the following August. He was also an advocate of the summary execution of Berdue and Windred when they were falsely accused of the attack on Jansen. The Committee of Vigilance was organized in his office, he was its second member and its first president, and appeared as its first spokesman before the San Francisco public. Much of the immediate success of the Committee was due to his fearless initiative and to his command over the temper of the general public, but his tendencies leaned too often towards summary punishment and his impetuous nature soon created intense friction that ultimately caused his resignation. Subsequent years found him still a leader in countless directions, always loyal in his support of the Union during the Civil War, and in local affairs active in promoting agriculture, in establishing banks, in organizing railway, telegraph, express, and insurance companies, in coöperating with literary and artistic movements, and in contributing to philanthropic efforts and the private relief of needy individuals. Misfortune overtook him in later life; his brilliant personality was clouded by dissipation. his wealth melted away, his position was lost, and he died in poverty and obscurity, in Escondido, San Diego County, May 5, 1889.

Enough has already been said of William T. Coleman to show that he had initiative and courage-the courage that could control excited men and check mob violence. ${ }^{6}$ He was born in Cynthiana, Kentucky, in 1824, lived for a time in St. Louis, and arrived in California in August, 1849. He was greatly surprised by the honesty and serenity of the country, and

6 See Bancroft, Chronicles of the Builders, I, 300-391, portrait; Popular Tribunals, especially II, 117-121; Swasey, Early Days, 345-354; Phelps, Contemporary Biography, I, 272-280; A. S. Hallidie, "William T. Coleman,' Overland Monthly, ser. 2, XXIII (1894), 71-75. 


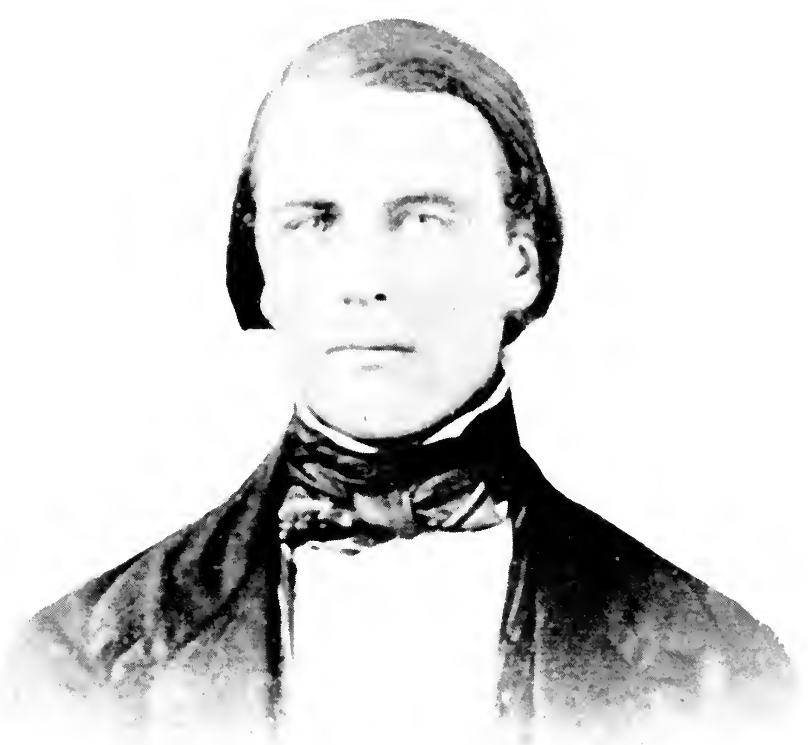

WILLIAM TELL COLEMAN IN $184 t$

From a daguerreotype in the possession of his son, Mr. Robert Lewis Coleman. 

attributed that condition to the stern lessons of lynch law. ${ }^{7} \mathrm{He}$ devoted himself to commercial interests in Placerville, Sacramento, and San Franciseo, but said that he was practically unknown in the latter town until he suggested the extra-legal trial that saved Berdue and Windred from the violence of the mob.

Coleman was number 96 on the roll of those who signed the constitution of the Committee of Vigilance, and he acted on the subcommittee that superintended the first execution. On that occasion his reputation for justice and caution must have done much to win the approval of the spectators. His hearty cooperation during the earlier weeks inevitably tended to instill order and method into the work of the Committee. The minutes and reports, however, make little reference to his part in the deliberations, and as early as August 9 he resigned from his position on the Executive Committee, excusing himself on the grounds of the demands of business. His interest in the society remained unabated, he was a member of the Committee of Thirteen that continued the organization after the cessation of open activities, and he led in the reorganization in 1856 . In spite of his Southern birth and of his adherence to the Democratic party, he was always staunchly loyal to the Union. In contrast to Brannan, Coleman stands for the pioneer of sound judgment and firm balance. successful not only in winning friends and fortune but in long maintaining his position of leadership in the financial and social development of his adopted state. His photograph taken in 1856 reveals a personality that inspires confidence. and admiration. ${ }^{8}$

Isaac Bluxome, Jr., ${ }^{9}$ was of Revolutionary stock, was born in New York in 1829, and educated in a private school in

7 Coleman, MS Statement, 2.

8 See Eldredge, California, III, 434.

9 See Popular Tribunals, especially I, 250-252; Phelps, Contemporary Biography, I, 269-271; description of the Bluxome Ranch, Alta, 187t, Aug. $241 / 3$; obituary, San Francisco Call, 1890, Nov. $11 \% / 6$. Bluxome was an influential Odd Fellow and a member of the Episcopal Church. 
Flushing, Long Island. He arrived in San Francisco in June, 1849, immediately engaged in the commission business, and was burned out in three successive fires. He was prominent in the arrest and trial of the Hounds, and in the military companies subsequently organized. "Bluxome's Battery' became one of the most dashing units of the California Guards. He joined the Committee as member number $71[67],{ }^{10}$ and acted as secretary throughout its activities and also during the reorganization in 1856. Bancroft, who knew him intimately, described him as a man of strong convictions and fearless spirit, although he was warm-hearted and genial in the ordinary relations of life. $\mathrm{He}$ led an honorable and successful business life in San Francisco, and owned for some years a large and beautiful ranch, known as Bluxomeville, near Cloverdale, Sonoma County. He died November 9, 1890.

Of these three men, only Bluxome kept up a long and active membership in the Committee of 1851, but the narrative of the Vigilantes will make us intimately acquainted with many others. As has been said, a few of the more important members will be introduced at this point. The names that follow are arranged in the order in which they were affixed to the constitution, as priority of membership has a definite significance in considering any man's importance in such a body.

The first who signed the roll was Selim E. Woodworth, ${ }^{11}$ in whom the urge of adventure had been so strong that at twelve years of age he shouldered a rifle and a knapsack and slipped away from his father's fireside in New York to look for big

10 The roll of members was copied by the sergeant-at-arms with a slight difference of arrangement. As his numbers were always used for purposes of identification they are included here in brackets, as they are in the lists printed in the Papers of the Committee.

11 Born in New York, 1815; died Jan. 29, 1871. See Annals, 794-798, portrait; Popular Tribunals, I, 247-248; Swasey, Early Days, 212-217; Eldredge, California, III, 134, portrait; Eldredge, San Francisco, II, 707708; Davis, Political Conventions, 8, 26; Alta, 1871, Jan. 30 3/4. 
game in the Rocky Mountains. He was intercepted and induced to return, and at a more mature age was able to gratify his tastes by exploring voyages in the South Seas, service in the United States Navy, and an adventurous trip across the continent to the Columbia River in 1846. From Oregon he came to California, and promptly distinguished himself by leading a party through the snowdrifts of the mountains to the relief of the ill-starred Donner camp. Resuming his naval duties he served on the Coast during the period of the war, but resigned in 1849 to accept a seat in the state senate, and held the position for two terms. While still a member of the legislature he was commissioned to raise a volunteer company and deal rigorously with horse thieves and Indians that were terrorizing Monterey County. ${ }^{12}$ He had the business acumen to build the first house above the unfilled water lots of San Francisco, and in consequence he and his partner for some time monopolized the lighterage of the port. His political affiliations were with the Whig party. He fought for the Union during the Civil War, resigning from the Navy after its close with the rank of commander.

A fellow Vigilante said that he was a man of great ability and honorable to a fault. ${ }^{13}$ He was made president of the General Committee a few weeks after its organization, held that office throughout the period of activity, and served as vice-president of the Executive Committee after reorganization in September.

Frederick A. Woodworth, ${ }^{14}$ number 4, a brother of Selim. arrived in May, 1849, and although his experiences have less notice in the records of the day he was widely known as an energetic and upright citizen. He was an Independent member

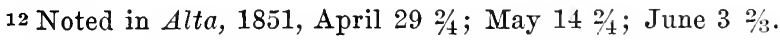

13 J. D. Farwell, Vigilance Committees in San Francisco, 18is. p. 10, MS in the Bancroft Library.

14 Mentioned in Alta, 1852, March 2 \%2; obituary, Alta, 1865, Feb. 3; 4 ; 7; 11; San Francisco Bulletin, Feb. $2 \frac{3}{6}$. 
of the state senate in 1857, and his death in 1865, at the age of forty-seven, was deeply regretted in the San Francisco press.

Colonel Jonathan D. Stevenson, ${ }^{15}$ former commander of the New York Volunteers, was number 18 [101]. He was a man of political experience in New York and Washington, and was the first grand master of the Free Masons in California. $\mathrm{He}$ had been somewhat successful in land speculations in San Francisco, but in 1851 his interests had been assigned to his creditors. He emerged from financial embarrassments with a comfortable fortune, and until his death, February 14, 1894, he was a center of interest and affection in the circle of California pioneers. It has been said that he tried to defend the Hounds on the ground of his responsibility to former members of his regiment, ${ }^{16}$ and if personal motives affected his attitude in 1849 they may have influenced him in 1851 to join the men who were determined to put down crime, for his office had been robbed earlier in the year, ${ }^{17}$ and the arson of Lewis had threatened the destruction of his property on Long Wharf.

Gerritt (or Garrett) W. Ryckman was number 57 [53], and although he was fifty-three years of age, and therefore much older than most of his colleagues, his magnetic but fearless personality made him one of the most influential members, and Bancroft paid a glowing tribute to his work. ${ }^{18} \mathrm{He}$ came to California in October, 1849, from Albany, New York, where he had been by turns a printer, a brewer, and a state inspector of hops. He was engaged in business at the time the Committee was formed, but during the summer of ' 51 devoted himself to its work, to the absolute neglect of personal affairs. His Statement dictated to Bancroft in 1877 or 1878 adds touches of real melodrama to the somber records of crime, trials, and executions,

15 See Annals, 784-789; Swasey, Early Days, 218-219.

16 Daniel Knower, Adventures of a Forty-niner, 1894, p. 86.

17 See infra, p. 307.

18 Popular Tribunals, I, 248-250. 
for he told of amateur detective expeditions under effective disguise, of dramatic episodes when the Vigilante revealed himself to dismayed antagonists, of threats against his own life, and of the moments when prisoners were moved to self-revelation. $\mathrm{He}$ became a member of the Executive Committee early in July, and was made the second vice-president in September. After that time he often acted as chairman, and was elected president in April, 1852. His attitude towards his companions was somewhat censorious and in 1856 he refused to join the reorganized Committee, asserting that their course was timid and vacillating. Ryckman became a friend of Broderick, and something of a power in the Democratic party. It was even said that he "carried Governor Bigler in his pocket." He was also a prominent Mason and when he died at the age of eighty-four the papers spoke of him with admiration and respect. ${ }^{19}$

If Ryckman was the Nestor of the Committee "little George Ward," number 62 [58], was the enfant terrible. He is affectionately described as brave as Caesar, a perfect fire-eater, a bit of a dandy, and a favorite with the ladies. He was so short that when he once lost his temper over a business dispute with Michael Reese he could barely reach to the latter's chest, but, nothing daunted, he thrust his pistol against his opponent's portly waistcoat and thundered: "Be careful, Sir, or by God, I'll blow your brains out!',20 At the first Vigilante execution he flourished his firearms so desperately that an older man begged: "Take that pistol away from that boy, or he will hurt somebody!',21 However, no tragedy was reported as a result of his impetuosity. He curbed his rash temper in indefatigable work, and acted as treasurer during the latter months of the Committee's activities. In 1856 he had a much greater scope

19 See Alta, 1881, Jan. 26 1/5; San Francisco Call, 1882, April 3 3/s.

20 San Francisco Bulletin, 1896, Nov. 21 13/\%.

21 Ryckman, MS Statement, 2. 
for his belligerent proclivities, and played a leading part in the more sensational adventures of that day. ${ }^{22}$

George E. Schenck, number 72 [68], came of a race of pioneers that had adventured in North America since one Schenck fitted out Hendrick Hudson's Half Moon, and another sailed upon her quarter-deck. ${ }^{23}$ He reached San Francisco in October, 1849, and immediately engaged in the exciting financial sport of buying cargos on invoice, sight unseen, and selling them for what the fluctuating market would allow. He had visited the mining regions but briefly, had attempted to stimulate public interest in the agricultural possibilities of the interior valleys, and had nearly lost his life in the fire of May, 1851. His long and interesting Statement is among the Bancroft manuscripts. It shows an accurate observation of the salient features of San Francisco business life, and also gives many important details of the work of the Committee of Vigilance, which he supported in the sincere conviction that the people had a right to displace their public servants when the latter proved unfaithful.

Captain Edgar Wakeman, number 95 [91], was a Yankee sailor typical of his generation. In 1851 he was tarrying awhile in the hospitable port of San Francisco, where he first cast anchor in July, 1850. Many of his adventures are recounted in a biography entitled The Log of an Ancient Mariner, but most unfortunately he made there but brief allusion to his services as chief of the water police of the Committee of Vigilance, leaving them for a later volume which was never completed.

The introduction to his reminiscences cites a letter from Mark Twain, who said of Wakeman $:^{24}$

22 See Popular Tribunals, I, 235; II, 64, 382, 387; obituary, Alta, 1861, Feb. $13 \% 1$.

23 Schenck, MS Statement, 57-59.

$24 \mathrm{Log}$ of an Ancient Mariner, 1878, p. 10. In 1872 Mark Twain made an appeal for a subscription for Captain Wakeman, who was helpless from paralysis (Alta, Dec. $141 / 3$; Dec. $221 / 2$ ). Obituary, Alta, 1875, May 9; $10 ; 12$. 
$\mathrm{He}$ is a burly, hairy, sunburned, stormy-voiced old salt, who mixes strange oaths with incomprehensible sailor-phraseology and the gentlest and most touching pathos, and is tattooed from head to foot like a Feejee Islander.... He never drinks a drop, never gambles, and never swears where a lady or child may chance to hear him.

James King of William, number 186, was destined by the tragedy of his death in 1856 to become one of the most famous men in California history. ${ }^{25} \mathrm{He}$ arrived in November, 1848, and in 1851 he was already widely known as a man of education and business ability, who had started for California before the news of gold stirred the eastern states. At first he made a brief but successful adventure in the camp known as Dry Diggings (Placerville), but in 1849 he established in San Francisco the banking house of James King of William, thus perpetuating in California the quaint patronymic he had assumed in Georgetown, District of Columbia, to distinguish himself from others of the same name. ${ }^{26}$ Earlier experience in an eastern bank gave him excellent equipment for the work, and his institution withstood a panic in 1850 . He was custodian of some of the funds of the Committee of Vigilance, and in the archives of the society is a passbook recording the account with this pioneer bank. Of his active work the minutes give little trace, but his standing is indicated by the fact that on August 26, 1851; he was considered as a candidate for the important position of chief of police. ${ }^{27}$ An unconfirmed anecdote relates that on one occasion he was so convinced of the innocence of an accused

$25 \mathrm{King}$ was born in Georgetown, District of Columbia, Jan. 28, 1822. Accounts of his life and death appear in all histories of California. See especially Shuck, Representative Men, 563-579; Phelps, Contemporary Biography, I, 202-206, portrait; Eldredge, California, IV, 62, portrait; Bancroft, California, IV, 700-701; Popular Tribunals, II, 22-68, passim.

26 As the son of William King, he assumed his father's given name; in place of the more usual designation of Junior.

$2 \pi$ Papers, 550. 
prisoner that he not only made strenuous intercession for his vindication but prepared to protect him by force of arms if such a course proved necessary. ${ }^{2 s}$ The story is entirely credible, for King always had the courage of his convictions, even to the supreme point of refusing to "defend his honor" when formally challenged according to the Southern code which still prevailed in California in spite of laws against dueling. ${ }^{29}$

In 1853 he was worth about $\$ 250,000$, but he became heavily involved in 1854, and his assets were transferred to Adams \& Co., with the agreement that they should assume all his liabilities. Unfortunately the subsequent failure of that firm involved some of King's creditors in a loss for which he felt that he was in no way to blame. In October, 1855, he started the Evening Bulletin, in a crusade of protest against the corruption existing in San Francisco, and his denunciation of crying evils led to his assassination in May, 1856, and to the reorganization of the Committee of Vigilance.

Jacob L. Van Bokkelen, number 173, a pioneer of 1849, was the first chief of the Vigilante police. In civic activities he was prominent in the volunteer fire department, and was an alderman of San Francisco in $1854 .^{30}$

Felix Argenti, number 187, was the senior member of a banking house established in 1850 . The curious episode which made him responsible for some of the most vexatious problems that troubled the Committee of Vigilance will be detailed in a later chapter. ${ }^{31}$

James R. Malony was number 250, and thereby hangs a tale, for Rube Malony had such a reputation for friendship with the undesirable element in San Francisco that his admission to the

2s Shuck, Representative Men, 563.

29 Shuck, Representative Men, 574.

30 Annals, 624; Herald, 1854, Nov. 10 2/.

31 Argenti is mentioned in Eldredge, California, V, 427 ; obituary, Alta, 1861, May $201 / 1$. See also infra, p. 243. 
ranks of the Committee of Vigilance was a matter of regret to some of the influential members. ${ }^{32}$ He was excluded from certain critical meetings by a change in the pass word, but he was never dropped from the rolls. In 1856 he took an open stand against the Vigilantes, was arrested by them, and banished from California. In retaliation Malony and Billy Mulligan, another exile, brought suit against Coleman and other committeemen while the latter were visiting New York. G. E. Schenck was in that city at the same time and appeared at a critical moment to testify that in 1851 Malony had participated in just such actions as he complained of in 1856. Schenck further maintained that "once a Committeeman, always a Committeeman." A non-suit was granted on the ground that the New York courts had no jurisdiction in the matter and Malony died while the case was under appeal.

David Earl, number 264, like Malony, was recognized after his admission as an undesirable member, and it was found that he was already under indictment in the courts for bigamy and other offenses. ${ }^{33}$ More serious charges were made against him by prisoners of the Committee, and he was finally expelled, arrested, and ordered out of the state.

John Sullivan, number 269, was a boatman along the San Francisco wharves. ${ }^{3+} \mathrm{He}$ was instrumental in arresting the first prisoner brought before the Committee and probably joined the organization immediately after that event. His wide acquaintance with the "bad characters" of the water front laid him under suspicion in the early days of investigation, but it proved an invaluable asset when it enabled him to recognize and to prevent the discharge of an important convict on presumption

32 Papers, 23 note 21; Schenck, MS Statement, 51-54; Popular Tribunals, Index under "Malony"; Alta, 1859, April 28 1/5.

33 See Papers, Index under "David Earl."

34 See infra, pp. 208, 257; Papers, 30; and Vouchers nos. 4 (p. 771), $86-88$. 
of innocence. One is compelled to note that as official boatman to the Committee he ran up accounts of appalling magnitude.

Eugene Delessert, number 439, was a prominent member of the French colony of San Francisco, and senior partner of the banking house of Delessert, Legieron \& Co. He was for some months the treasurer of the Committee. ${ }^{35}$

There were other men who did conspicuous service in the Committee but left little record in the works of contemporary biography. At the same time some of the less active members achieved great political or commercial distinction, as will be seen from the notices in the Appendix. Research among family records would doubtless reveal interesting particulars concerning many others, but it is improbable that it would in any degree change the composite type that is presented by the sketches already collected. The names of Vigilantes often appeared on public committees of importance. ${ }^{36}$ Some were prominent in the earliest efforts to develop a transcontinental railroad. Some were quick to respond when public calamities called for emergency measures of coöperative relief. One fact to their credit must be remarked. Of all their number only one or two attained unenviable distinction through political or financial misdeeds. Rube Malony was a notorious black sheep, and some half dozen members were dropped for various causes, among them being Captain Leonard Tuffs, who was convicted of forgery in $1852{ }^{37}$ A close scrutiny of the leading papers from 1851 to 1856 and

35 Delessert led in the organization of the French benevolent association, Herald, 1851, Dee. $15 \%$.

36 See, for instance, the railroad committees (Herald, 1851, Nov. 28 2/7; Dee. $5 \%$; 1852 , April $6 \%$ ), and measures for the relief of passengers on the wrecked North American (Herald, 1852, March $31 \%$ ).

$3 \pi$ See the Index to the Papers for the eases of J. B. M. Crooks, W. W. McLean, J. P. Muldoon, Thomas Norris, C. H. Welling. The trial of Tuff $\mathrm{s}$ is noted in the Herald, 1852, May $20 \%$; June 19, 1/1; $222 / 3$; July 25 $2 \%$; Alta, July $18 \% 3 ; 25 \%$. His name is annotated as expelled in the list of members (C. of V., Constitution, 24). W. H. Parker is also marked as expelled, but the entry is probably an error, and should have been referred to the name of Crooks. 
a search through the newspaper index in the State Library have failed to uncover any serious scandals comnected with the names that were conspicuous in the work of the Committee of Vigilance of 1851 .

It is a very curious circumstance that while so many of the members, even those of minor importance, have left behind them biographical records of more or less interest, little can now be learned of the man whose personality really dominated the most active months of the association. This was Stephen Payran, number 46 [42], who served as president of the Executive Committee from about July 4 to November 12, 1851, and who wrote a large number of the more important papers filed during the intervening period.

In August, 1851, Payran stated in the newspapers that he had then been in California nearly three years. ${ }^{38}$ Other committeemen have said that he was a professional copyist from Philadelphia, ${ }^{39}$ and the neatness and legibility of his handwriting testify to his skill in such an employment. More than any other member of the Committee he gave voice to the idea that the people had a right to assume direct control of public affairs, when their elected representatives failed to carry out their will. His sincere conviction, his quick imagination, and his ready pen gave him a power of expression that distinguished him as a sincere idealist from among the more practical merchants who did not extend their thoughts beyond the emergencies that confronted them. He was not always tactful, and evoked censure as an autocrat in administration. ${ }^{40}$ Ryckman, who was somewhat unsparing in his criticism, hinted that he became addicted to stimulants during the stress of his exacting duties, ${ }^{41}$ and

3s Alta, 1851, Aug. $31 \%$; Herald, Sept. $1 \%$.

39 Popular Tribunals, I, 246.

40 See infra, p. 336.

41 Ryckman, MS Statement, 4. 
Bluxome touched with exasperating vagueness upon an infatuation for a Sydney woman which ended his usefulness in the ranks of the Committee. ${ }^{42}$ Whatever may have been his romance or his tragedy, he was a respected resident of Petaluma in the decade of the sixties, where he acted as a justice of the peace, and as "Judge Payran" was much in demand as a public speaker. Mr. W. W. Carpenter, writing of him in 1874, described him as a man of seventy who looked twenty years younger, and who was still keenly interested in the Committee of 1851, of which, according to Carpenter, he was the real leader and hero. ${ }^{43}$ He lived on a ranch, then just east of the eity limits, and even now the Payran School and Payran Street commemorate his name. He died in Ukiah, on or about January 18, 1877 , and the county records show that his estate was settled by the public administrator, that it amounted to less than $\$ 600$, and that it was inherited by his brother Richard, then a resident of Illinois. A wife, from whom he had been for some time estranged, could not be found. ${ }^{44}$

Stephen Payran signed his name to more than a hundred documents in the archives of the Committee of Vigilance. $\mathrm{He}$ was also the author of a resolution designed to preserve the archives, so that the actions of the Committee might be shown in good faith to any representative body that at a future date should desire to investigate them. ${ }^{45}$ Perhaps it was to his foresight that we owe the survival of those records, and their final presentation to the students of the present time.

42 Bluxome, MS Statement, 16.

43 In Oakland Transcript, 1874, March 29 1/1. See also Royce, California, 419-420. Recollections of Payran were furnished to me in January, 1918, by Mr. Henry L. Weston, one of the oldest residents of Petaluma. "'Stephen Payran," a lawyer from Pennsylvania, was entered upon the Great Register of Sonoma County as a resident of Vallejo in 1866 .

44 Data obtained from the records of Mendocino County by Mr. F. L. Caughey of Ukiah.

45 Papers, 639. 
Had Payran lived a little longer it is probable that his personal recollections would have supplemented the official documents which he treasured with such solicitude, for it was in 1877 and 1878 that Bancroft secured the dictation of statements from many of the Vigilantes. Payran might have added much valuable material to those reminiscences, but his voice was silent too soon. The Bancroft manuscripts are of great service in reconstructing the work of the Committee, and they are often used in this volume to amplify more condensed and formal records. But they have not been quoted as absolutely authentic unless the archives or the contemporary press have afforded standards for careful verification. They are invaluable, however, for their accounts of the beginning of the Committee of 1851, since there are no official documents and no press reports that tell the steps that were taken to form the protective association that had been so widely advocated during the first week of June.

The clearest statement of the preliminaries of organization was given by James Neall, Jr. ${ }^{46}$ He said that on Sunday, June 8, he discussed the perilous condition of society with his neighbor, George Oakes. The latter suggested that they visit Sam Brannan and consult him as to the possibility of effecting improvement. Brannan was found in his office in company with his clerk, A. Wardwell, and the four men decided to summon a larger group to consider the situation of the city. A list was compiled without delay and notices were written asking various reliable men to invite other responsible citizens to meet on the following noon at the California Engine House. There was a most satisfactory response to this appeal, and after some debate on the course that should be followed the meeting adjourned, to reassemble in the evening at Brannan's building, on Sansome and Bush streets. There the plan of organization took definite shape,

\footnotetext{
-46 James Neall, Jr., MS Statement, 1-3. See extracts in Appendix, pp. $457-458$.
} 
and the name "Committee of Vigilance" was formally adopted. Previous to this the term had not been generally current in California, although it was by no means unknown. ${ }^{47}$ Both "Committee of Safety" and "Committee of Vigilance" had been used in the article by "Justice" in the Alta of June 8, and Baneroft said that after a discussion of various titles in the meeting on Monday night "Committee of Vigilance", was unanimously chosen. ${ }^{48}$ From that time it has acquired a significance based on the precedents set in San Francisco, and as used in this volume it connotes a group of responsible citizens, bound together by a permanent organization, with the declared purpose of protecting lives and property in emergencies where lawful means prove ineffective. ${ }^{49}$

No minutes have been preserved of this, the third meeting, but it is perfectly evident that the harassed citizens of San Francisco instinctively turned to the old American expedient of creating a social equipment by entering into a formal compact. They adopted a constitution-a brief and simple statement of

47 See supra, p. 120. The Alta, 1850, July $192 / 1$, announced that a "Vigilance Committee" of fifteen had been appointed in Stockton, to ask the state and military authorities to give aid in preserving order. During trouble between French and American miners at Mokelumne Hill, in April, 1851, a "Vigilance Committee" was appointed as an emergency organization (Alta, April 30 \%). "Cow Vigilantes"' who punished cattle thieves, also in the spring of 1851, are mentioned in the History of San Joaquin County, 130. "Councils of Safety," "Committees of Safety," and "Committees of Observation' 'were familiar associations of other American communities. In 1828 the Jackson party in Indiana formed precinct " $\mathrm{Com}$ mittees of Vigilance'" (Logan Esarey, History of Indiana, I [1915], 299). The same name was often employed by local organizations in Texas during the movement for independence from Mexico.

48 Popular Tribunals, I, 208.

49 J. M. Guinn, who compiled histories of several California counties, said that the name "Vigilance Committee" originated with the uprising in 1851, long after the tribunals of the people were generally established throughout the state (see his History of California, various county editions, p. 183 of general introduction). The Cyclopedia of American Government, III, 616, defines "Vigilance Committee" as "A term applied to committees formed in the North previous to the Civil War to aid in the escape of fugitive slaves. Also a name adopted by the voluntary organization for the purpose of keeping peace in California in the days of the great migration." 
their purposes, a solemn pledge of mutual good faith and loyalty. This document has already been printed in the series of Papers, but it is necessary that it should be repeated here, as a fitting introduction to the record of the subsequent months. ${ }^{50}$

\section{CONSTITUTION}

9 th June, 1851

Whereas it has become apparent to the Citizens of San Francisco that there is no security for life and property either under the regulations of Society as it at present exists or under the laws as now administered,-therefore, the Citizens whose names are hereunto attached do unite themselves into an association for the maintenance of the peace and good order of Society and the preservation of the lives and property of the Citizens of San Francisco and do bind ourselves each unto the other to do and perform every lawful act for the maintenance of law and order and to sustain the laws when faithfully and properly administered but we are determined that no thief burglar incendiary or assassin shall escape punishment, either by the quibbles of the law the insecurity of prisons the carelessness or corruption of the Police or a laxity of those who pretend to administer justice.

And to secure the objects of this association we do hereby agree;

First,- - that the name and style of the association shall be the Committee of Vigilance for the protection of the lives and property of the Citizens and residents of the City of San Francisco.

Secondly,-that, there shall be a room selected for the meetings and deliberations of the Committee at which there shall be some one or more members of the Committee appointed for that purpose in constant attendance at all hours of the day and night to receive the report of any member of the association or of any other person or persons whatsoever of any act of violence done to the person or property of any citizen of San Francisco and if in the judgment of the member or members of the Committee present it be such an act as justifies the interference of this Committee either in aiding in the execution of the laws or the prompt and summary punishment of the offender the Committee shall be at once assembled for the purpose of taking such action as a majority of the Committee when assembled shall determine upon.

50 This text of the constitution is that which is prefixed to the book of signatures, and may therefore be considered as the official copy (see C. of V., Constitution, 7-8). Another copy found among the miscellaneous documents and printed in the Papers, III, 1-3, is dated June 8, and Bancroft accepted that date for the definite institution of the Committee (Popular Tribunals, I, 210), but the official date of organization inseribed on the certificates of membership is plainly June 9 . 
Thirdly,-that, it shall be the duty of any member or members of the Committee on duty at the Committee room whenever a general assemblage of the Committee is deemed necessary to cause a call to be made by two strokes upon a bell situated ${ }^{51}$... [blank] which shall be repeated with a pause of one minute before each alarm.-The Alarm to be struck until ordered stopped.

Fourthly,-that when the Committee have assembled for action the decision of a majority present shall be binding upon the whole Committee and that those members of the Committee whose names are hereunto attached do pledge their honor and hereby bind themselves to defend and sustain each other in carrying out the determined action of this Committee at the hazard of their lives and their fortunes.

Fifthly,-that there shall be chosen monthly a President Secretary and Treasurer and it shall be the duty of the Secretary to detail the members required to be in daily attendance at the Committee room. A Sergeant at Arms shall be appointed whose duty it shall be to notify such members of their detail for duty.-The Sergeant at Arms shall reside at, and be in constant attendance at the Committee room.

There shall be a standing Committee of finance and qualification consisting of five each and no person shall be admitted a member of this association unless he be a respectable citizen and approved of by the Committee on qualification before admission.

The provisions of this agreement give unmistakable proof of the care and the deliberation with which the formation of the Vigilance Committee was undertaken, and disprove the assertion sometimes made that the organization was a sequel to the first execution. ${ }^{52}$ The associates in this cause of self-protection

51 The Committee had the use of the bells of the California and Monumental engine companies. Both were tapped when occasion required, but the Monumental bell, hung on the engine house on Brenham Place, facing the Plaza, was by far the more famous. It was finally presented to the museum of the Society of California Pioneers, and cuts of the relic were printed in the San Francisco Call, 1887, March $115 \%$, and in the Chronicle, 1896, Jan. $129 / 1$. The secretary of the Society of Pioneers las informed me that it was totally destroyed in the fire of 1906 . The Committee of 1856 installed a bell of its own on the roof of Fort Gunnybags, and at the sale of its effects it was purchased for $\$ 600$ by the citizens of Petaluma, who hung it in the belfry of the Baptist Church. Although badly cracked, it was rung on many occasions of public importance. See Popular Tribunals, II, 545; Alta, 1866, Jan. 15, 1/6 ; San Francisco Call, 1893, Dec. $18 \%$.

52 Popular Tribunals, I, 207. T. J. L. Smiley, number 573, said that Jenkins' trial “'was an impromptu meeting'" (Statement, 1877, p. 1, MS in the Bancroft Library). 
were not content to pledge themselves by word of mouth. They were ready to set their names to the compact they had adopted. A few may have signed the draft of the constitution on Monday evening, but it was later copied into a suitable book, and the Vigilantes met for a fourth time on Tuesday evening at the same place, to sign the roll and to perfect their plans.

Lois K. Mathews, in her "Mayflower Compact and Its Descendants," grouped quotations from the constitution of the Committee of Vigilance with other citations from pioneer associations, and said of it: "Here again one finds the absence of organized and effective government resulting in the union of a body of citizens along the lines of the compact idea." ${ }_{53}$ Its real significance lies in the fact that while the subscribers asserted that they associated themselves to maintain peace and good order, to preserve life and property, and to sustain the laws when properly and faithfully administered, they also made plain their determination to handle criminal matters themselves whenever the majority of the Committee should so resolve. The implication was obvious that in so doing they were ready to ignore or override police and courts and legal regulations, and to execute justice according to their own convictions! Neall said of this action :

They signed a form of agreement to do their duty when called upon, and to appear when needed. At this meeting ${ }^{5 t}$ there were of course many young men not largely experienced in the affairs of life, and who perhaps did not realize the responsibilities they were taking upon themselves, what it might lead to; but some of the older heads saw in it an incipient revolution, and that difficulties might arise, and among them was Col. J. D. Stevenson. Though he sympathized fully in the necessities of the movement, he felt its importance, and he got up and made a speech, in which he dwelt upon the responsibilities of the case, and called upon every man to do his full duty ete.,--putting on his severest military air as he spoke.

53 Mississippi Valley Historical Association, Proceedings, VI (19121913), 103-104.

54 Neall seems to refer to the meeting of Tuesday evening, but Bancroft placed Stevenson's address on Monday evening (Popular Tribunals, I, 207). 


\section{CHAPTER $\mathrm{X}$}

\section{THE COMMITTEE AT WORK}

The constitution of the Committee of Vigilance made a declaration of purpose. It outlined no programme beyond the provision that a subcommittee should constantly be on duty at a designated place to receive reports of deeds of violence, and to summon the General Committee for the consideration of cases that might need further action.

So matters stood when the meeting of Tuesday evening adjourned, after some hundred men had signed the roll. ${ }^{1}$ While a small group lingered in the room a startling knock beat upon the closed door, and when it was opened two or three members of the Committee entered, dragging between them a powerful and defiant prisoner. This was John Jenkins, who had that very evening entered the empty office of George W. Virgin on Long Wharf, seized a small safe, and dropped with it into a boat lying at the end of the pier. Virgin arrived in time to raise a hue and cry while the thief was still in sight. Seeing that capture was imminent Jenkins threw his booty overboard and surrendered to a boatman, John Sullivan, who had joined the chase as he was returning from a vessel lying out in the stream. David B. Arrowsmith and James F. Curtis, both members of the Committee, assisted Sullivan in securing his prisoner, and George E. Schenck, who encountered them as they emerged into Commercial Street, urged them to take Jenkins before the Committee, instead of to the police station, as had been their intention. ${ }^{2}$ The suggestion

\footnotetext{
1 Bluxome put the number at 100 (MS Statement, 9); Ryckman at 75 or 80 (MS Statement, 4).

2 Details of the capture were given by Schenck (MS Statement, 35-38); and by J. D. Farwell (MS Statement, 6).
} 
was adopted, and in a few minutes the newly pledged Vigilantes faced the first acute problem to arise under their self-assumed responsibilities.

In this case there was no doubt as to the overt act of violence nor as to the need for assembling the General Committee. Suddenly the bell of the California Engine Company struck a signal unfamiliar to the ears of San Francisco $:^{3}$ two measured taps, a pause, two taps, another interval, and again the two notes. until the attention of every man within its sound had been caught by the summons. Quickly the Monumental bell echoed the call : two strokes and silence; two, and two, and two! Then San Francisco swarmed into the humming streets, and as the initiated passed swiftly to the rendezvous at Brannan's building, a mystified crowd ran behind. Without there was excitement; men knocked at the guarded door. whispered a pass word, and gained admission, or asked in vain because they were ignorant of the countersign. $^{4}$ Within there was hasty consultation, initial confusion, and swiftly emerging order. There was a chairman. Brannan. and a secretary, Bluxome. An immediate trial was decreed. A jury was selected; Schenck was appointed prosecuting attorney : the particulars of the theft were rehearsed by witnesses. The evidence was conclusive; the verdict was "guilty."

3 Neall told Bancroft that the California bell was tapped some twent? times by George J. Oakes (Popular Tribunals, I, 229). The Monumental bell sounded a few minutes before ten o'clock (Herald, 1851, June 11 泣). Some reports said the signal was three taps.

4 Papers, 22-23. It may have been upon this occasion that "Lewis" was the countersign. See supra, p. 183.

5 Farwell, MS Statement, 6.

6 Schenck, MS Statement, 36.

i The theft of the safe was proved beyond question (Coleman, MS Statement, 19-21; Farwell, MS Statement, 7). J. C. L. Wadsworth said: "The doors were closed, and no one allowed in but those we knew, officers were chosen for the meeting, which being organized, we proceeded to the eridence. We heard the testimony, and after it was all in, a committee was appointed to step one side and deliberate upon it and bring in a rerdict. and say what should be done with the man. This committee went to a corner of the room, and after consultation for a while brought in a verdict of guilty, 
In the course of the trial it was shown that Jenkins hailed from Australia and was reputed to be an ex-convict. In San Francisco he had kept a vicious lodging house known as the Uncle Sam, which he had sold in May to fellow-Australians, Mr. and Mrs. Connolly, who had sought to change its reputation by renaming it The Shipman's Arms. It also appeared that Jenkins was regarded with growing aversion even by his own comrades, since Connolly had died suddenly soon after the transfer, and the widow had consoled herself all too quickly by a questionable intimacy with the former proprietor. ${ }^{8}$ The theft of the safe was not, in itself, very serious, as it had contained but little money, and had been successfully salvaged by a skilful use of oyster tongs. ${ }^{9} \quad$ But grand larceny rendered the thief liable to the death penalty of the statutes of 1851, his previous bad record told heavily against him, and he deliberately excited his captors to a dangerous pitch of resentment by cursing them vigorously and by boasting that he would quickly be rescued. In spite of all this, the members of the Committee hesitated to assume the responsibility of executioners. While they vacillated William A. Howard strode forward, threw his cap on the table. faced the meeting and said, briefly : "Gentlemen, as I understand it, we came here to hang somebody!',10 The effect was electric, and the meeting voted to hang Jenkins without delay.

A clergyman was summoned to confer with the condemned man, who gave no sign of penitence or of apprehension. In the interval that ensued William T. Coleman sought to obtain a postponement of execution until morning, urging that it was unmanly

and the sentence of death was pronounced on the man'" (MS Vigilance Committees-Miscellany, 23). At the coroner's investigation Brannan swore that the prisoner had a fair hearing before sixty or eighty persons, who gave a unanimous verdict of guilty (Papers, 24).

8 For the affair with Mrs. Connolly, see Papers, 45, 53-57.

9 Sehenck, MS Statement, 37; Herald, 1851, June $11 \%$.

10 Farwell, MS Statement, 7. Ryckman said that even Sam Brannan showed something of the white feather on this occasion (MS Statement, 4). 
to act under cover of darknes and secrecy. But the town was rousing to a high pitch of excitement, and the majority feared delay. Reports of the existence of a secret committee leagued for the protection of society had spread like wildfire, and even while the trial was in progress scores of the most prominent citizens were enrolling as members. ${ }^{11}$ It was rumored, at the same time, that the rougher element was no less active, that it was organizing for a rescue, and that David C. Broderick was out with all his strength to oppose any illegal steps that the Committee might contemplate. ${ }^{12}$

The Reverend Flavel S. Nines, rector of Trinity Church, presently arrived and was closeted long with the vindictive prisoner-so long that Ryckman finally intervened. "Mr. Mines," he said, "You have taken about three quarters of an hour. and I want you to bring this prayer business to a rapid close. I am going to hang this man in half an hour!",13 The clergyman reluctantly withdrew, admitting that Jenkins was incorrigible, ${ }^{14}$ and Mr. Ryckman encountered no further hindrances in the prosecution of his duties. A fair criticism of this first execution was made by him, much later, when he said $:^{15}$ "Every man who was convicted and sentenced to death signed his own confession, except Jenkins, who was somewhat hastily disposed of.'

It is very evident that there was haste and excitement and violent resentment against the defiant, surly attitude of the prisoner. Even Coleman was at last so antagonized by his insults that he no longer opposed immediate execution, and consented

11 Coleman, MS Statement, 19-20; and his "San Francisco Vigilance Committees," Century, XLIII (1891), 136. Schenck said that over eighty joined during the evening (MS Statement, 36).

12 Ryckman, MS Statement, 2.

13 Ryckman, MS Statement, 2.

14 See Papers, 309. When Jenkins was convinced that his fate was sealed, he asked only for a drink of liquor and a cigar, accepted these small favors coolly, and met his death without further protest (Herald, 1851, June 11 2/2).

15 Ryckman, MS Statement, 9. 
to serve with Wakeman, Schenck and probably James F. Curtis, as a subcommittee to make ready for the hanging. ${ }^{16}$ He said of the final decision:

The very circumstances of this crime having been committed in the teeth and at the moment of our organization, and in defiance of it, the defiant position of the prisoner, and the advices we had of threatened and certain resistance, not by law officers, but the abandoned criminals,-all tended to resolve the Committee to the most prompt action, and to the severest punishment of Jenkins.

While the majority of the Committee advocated summary action lest delay might defeat their plans, they felt that it was necessary to ascertain whether or not the community at large. would support them in their self-assumed office. Sam Brannan, therefore, was appointed to address the men without, and to ask for an expression of their sentiments. ${ }^{17}$ The events of the evening were thenceforth shifted to the open streets, and we can find full reports in the contemporary newspapers. ${ }^{18}$

At a quarter before one o'clock Brannan mounted a sand dune near the place of trial, the crowd closed in about him, and he told them of the formation of the Committee, the arrest of Jenkins, and his trial for grand larceny. He recounted the nature of the evidence, the clear proof of guilt, the conviction, and the sentence of death within an hour on the public square. Then he demanded that his auditors declare whether or not this action should be approved. The response was a tumultous cry of "Yes!" mingled with cheers and some dissenting "Noes!" Next came a voice from below: "Who is the speaker?" Mr. Brannan was named-and no name was more familiar than his. Another voice: "Who are the Committee?" But the prudent and

16 Coleman, MS Statement, 21; Schenck, MS Statement, 39 ; Wakeman, $\log , 139$. 24).

17 Wadsworth accompanied him (MS Vigilance Committees-Miscellany,

18 Especially in the Herald, 1851, June 11, and in the evidence before the coroner's inquest, printed in the newspapers and in the Papers, 14-27. 


$$
8
$$



sympathetic assemblage raised a warning cry: "No names! no names!' and then divided, some hurrying to the Plaza to watch developments there, and some remaining behind to await the appearance of Jenkins.

A little before two o'clock the Committee came from the building. The handcuffed prisoner and two guards walked within a circle of rope held by a watchful cordon. The rest of the Vigilantes surrounded them in solid ranks. All were armed, and little George Ward marched valiantly behind the towering Australian, flourishing his pistol and announcing that at the first hint of resistance he would shoot to kill. ${ }^{19}$ While the bells of the engine companies tolled a heavy dirge, the orderly procession moved through Sansome Street to California, thence to Montgomery and to Clay, and so towards Portsmouth Square. At Clay and Kearny streets a hostile group vainly attempted a rescue. The police also appeared, but faltered before the drawn pistols of the committeemen, and the Vigilantes swept irresistibly forward into the open Plaza. The subcommittee had arranged for the execution on the porch of the Old Adobe. Before that point was reached another hand rigged a block on the liberty pole, and the crowd was diverted in that direction, but a horrified cry of protest warned the hangmen from this unfitting gallows. The moments that followed were vividly described by Shenck: $:^{20}$

While some one was taking down the block, a rush was made by some of the friends of Jenkins, who attempted to rescue him. They got hold of his legs under the rope and pulled him down while the rope was being put around the beam of the old adobe building at the corner of the Plaza, the old Custom House. The other party pulled the rope, and he was really strangled before he was raised up. He was dragged from the Liberty Pole to the adobe building with the rope around his neck, a distance of about 125 feet, while his friends were hanging on to his legs, and he was really killed before he reached the latter place.

19 Bluxome, MS Statement, 10.

20 Schenck, MS Statement, 39. The attempted rescue was described at the inquest, and by Coleman (MS Statement, 22). 
It is a grewsome picture, showing a frenzied struggle in which the members of the Committee triumphed only through their physical ability to hold off the opposing forces at the point of the pistol. At the last erucial moment, in strange contradiction to the spirit of the hour, Sam Bramnan called out: "Every lover of liberty and good order lay hold of the rope!" and as many men as could do so put their hands to the tackle that lifted Jenkins to his death. ${ }^{21}$ With grim determination they held him there till life was absolutely extinct, while fitful moonlight pierced the drifting fog. and about the Plaza gleamed the lights of the gambling halls, where the games ran on, unchecked by the tragedy of the sterner game without. ${ }^{22}$

Bluxome, Ward, and perhaps others, stood guard over the body till morning. Then came Edward Gallagher, coroner, who cut it down and straightway impaneled a jury to make official inquiry into the cause of this violent death. Full reports of the testimony were printed in the San Francisco papers. As in the case of Lewis, transcripts of the evidence are preserved among the documents of the Committee. A few scraps of paper appear to be original records of the actual discussions of the jury in arriving at a verdict, and point to a very close connection between that body and some member of the Committee itself.

Among the manuscripts in the Bancroft Library is a dictation by A. M. Comstock, one of the jury, who said that at first there was great difficulty in determining anything respecting the cause of death, many witnesses refusing to give answers that might incriminate them, and others finding it impossible to identify

21 T. J. L. Smiley, MS Statement, 1877, p. 1.

22 A vivid picture of this scene is given in a MS entitled The Vigilance Committee of San Francisco, 1851, by T. G. Cary, now in the possession of Harvard University Library. Cary was not a member of the Committee. He watched the execution from the steps of the the Old Adobe, but remarked no appearance of riot. See also his "First San Francisco Vigilance Committee,' International Review, XI (1881), 78-88; Edward Bosqui, Memoirs, 1904 , pp. 55-56; illustration in Annals, 343 . 
more than one or two of the chief actors. ${ }^{23}$ Nembers of the police force testified as to the attempted rescue, and the violence with which it was repulsed. All were reluctant to name the citizens implicated, and Officer Noyce swore that he feared for his own life if he should tell what he had seen. The Herald stated that the court was cleared at his request even of reporters. Little of his evidence was printed, but the testimony in the Vigilance Committee Papers includes a fuller statement, although it does not mention the clearing of the room. It is thus evident that the Committee learned exactly what happened behind the closed doors of the court, and had immediate knowledge of the very facts the timid witness feared to divulge. ${ }^{24}$

Hall McAllister testified that he had watched people entering Bramnan's office after whispering a pass word to a guard at the door. He gave the names of several whom he recognized there and on the Plaza, but he asserted that he neither assisted in the trial, nor sympathized with those who held the rope. Broderick also identified several participants in the night's work, and related his own attempt to frustrate their efforts. Ira Cole, one of Broderick's followers, stated that a third of the crowd was in favor of releasing the prisoner. That significant sentence was omitted from the Committee's transcript of evidence. Unimportant testimony was given by five or six other citizens and by some half dozen members of the Committee, although most of the latter exhibited signs of partial or complete amnesia concerning the events in which they had been so actively engaged.

The inquiry occupied parts of three days. During its progress it became more and more certain that the community was prepared to give hearty support to the executioners of Jenkins. Secrecy, therefore, was less vital to the committeemen, and on the second day of the inquest Sam Brannan divulged more

23 Comstock, in MS Vigilance Committees-Miscellany, 38-39.

24 Papers, 18-20. 
information than any member had previously been willing to vouchsafe. He acknowledged the existence of the Committee, and its instrumentality in the trial and the lynching, but he still refused to give any names on the ground that threats had been made against the lives of those involved. But names were soon given. The papers of June 13 printed an official announcement of the organization and purposes of the Committee of Vigilance signed by the first hundred and eighty members, who informed the public that they were all equally responsible for the execution of Jenkins. The constitution was printed in full, and the citizens at large were invited to join the association, and to assist in establishing good order in San Francisco. ${ }^{25}$ At the inquest on the same day James C. Ward and F. A. Woodworth frankly avowed their connection with the Committee and swore that Jenkins had a full and fair trial and was justly condemned.

Early in the afternoon of June 13, the jury returned the following verdict:

We, the Jurors of a Jury of Inquest empanelled by the Coroner of the county of San Francisco to inquire into the cause of the death of one John Jenkins, alias Simpton,26 do find upon their oaths that the said Jenkins alias Simpton, eame to his death on the morning of the 11th of June, between the hours of two and three o'clock, by violent means, by strangulation, caused by being suspended by the neck with a rope attached to the [south] end of the adobe building on the Plaza, at the hands of, and in pursuance of a preconceived action on the part of an association of eitizens, styling themselves a Committee of Vigilance, of whom the following members are implicated by direct testimony, to wit: Capt. Edgar Wakeman, W. M. H. Jones, James C. Ward, Edward A. King, T. K. Battelle, Benj. Reynolds, J. S. Eagan, J. C. Derby, and Samuel Brannan; and the following members by their voluntary avowal of participation in the act: (Here follows a list of members of the Vigilance Committee published yesterday morning.) A unanimous verdict.

T. M. Leavenworth, Foreman.

25 See infra, p. 459.

26 See Papers, 72 note 2. 
The verdict appeared in the papers of the fourteenth, which also informed the public, over the same signatures that had been attached to the Vigilante communications of the previous day, that the Committee had

Resolved, That we, members of the Vigilance Committee, remark with surprise the invidious verdict rendered by the Coroner's Jury after their inquest upon the body of Jenkins, alias Simpton, after we have all notified the said jury and the public that we were all participators in the trial and execution of said Jenkins. We desire that the public will understand that Capt. E. Wakeman, W. H. Jones, James C. Ward, Edward A. King, T. K. Battelle, Benj. Reynolds, J. S. Eagan, J. C. Derby and Samuel Brannan, have been unnecessarily picked from our numbers, as the Coroner's jury have had full evidence of the fact, that all the undersigned have been equally implicated, and are equally responsible with their above named associates.

The members of the Committee thus kept their pledge to "defend and sustain each other in carrying out the determined action of the Committee at the hazard of their lives and fortunes." In this case the hazard incurred was not great. The ruling of Judge Parsons in the case of Lewis had prevented any session of the grand jury until the month of July, and there was no way in which the lynching could be brought promptly to the attention of the higher courts. Meanwhile the newspapers united in approving the work of the Committee, in condemning the verdict, and in pointing out the absurdity of prosecuting such a large number of the most prominent and respectable citizens. The general sentiment is well exemplified by the following excerpt from the Courier :27

All laws are based upon the law of nature and when they are incapable either from positive imperfection or from an inefficient administration of them to protect our lives and property from the assassin and robber, the people, from whom all power is derived, have the indefeasible right to

27 California Courier, 1851, June $14 \%$. Similar expressions were printed in the Herald and the Alta, June 11-14. Two clergymen, Mr. Wheeler and Timothy D. Hunt, preached sermons approving the execution (Courier, June 28 2/1). Hunt's address was printed in pamphlet form. 
fall back upon the first principles of government, and do all that may be necessary and proper to protect their lives and property. This right was asserted by our ancestors, and it is a doctrine peculiar to republicans. The people have done the deed complained of and are ready to shoulder the consequences.

Just at this time a committee representing the grand jury which Judge Parsons had declared illegal published a statement dealing with the condition of the local courts, the constant postponements of trials, the consequent escape of criminals, and the serious danger of a situation which for so long deprived the city of a legal body competent to take cognizance of felonies. This report was cited by the Herald as furnishing "a key to the enigma, why our most respectable citizens should be found at dead of night hanging a man with their own hands for larceny.", 28

While the press of the city and the public in general accepted the Committee with approval, it was bitterly opposed by Broderick. As Ryckman remarked, he "was out with all his strength" on the night of the hanging, and aided Jenkins' friends in their efforts to effect a rescue. Bluxome said : ${ }^{29}$

Although we were all friends to Broderick, he was against us as the Vigilance Committee; he did not think the people should take the law into their own hands. . . . I had nothing to say against Broderick in his position, because his theory was good enough, but there is a time when men should take the law into their own hands.

Broderick's evidence before the coroner's jury, as printed in the Horald, characterized the Committee as "very bad men." 30 He reiterated his convictions more forcibly in the course of a mass meeting held on the Plaza on the Thursday following the lynching. This was an adjournment from a meeting of Wednesday, when a crowd without any particular object or leader

28 Report and editorial, Herald, 1851, June 12.

29 Bluxome, MS Statement, 10.

30 Broderick stated that W. H. Jones was "in favor of hanging everybody not belonging to the Committee. He was very violent: he said 'To $\mathrm{h}-\mathrm{l}$ with all the courts, let's take care of ourselves', ' (Herald, 1851, June $12 \%$ ). 
boisterously commended the execution and handled with great roughness Mr. II. K. W. Clark, who ventured to express his disapproval. The meeting on Thursday afternoon was one of the largest that had ever been held in San Francisco. ${ }^{31}$ A Mr. Hoag offered a series of resolutions of the most radical nature. He maintained that the people had a "right to change their laws whenever they were nugatory and insufficient," and he proposed that they should then and there "resolve themselves back into their original elements, return to a state of nature, and commence again." He called for an immediate election where the people might adopt new eriminal regulations, and elect officials to administer "The Peoples' Law." In reporting the meeting the Herald used the caption "Revolution Advocated." In a later issue it spoke of Hoag's resolutions as presented in the nature of a jest. ${ }^{32}$ They were not received as a jest by the attendants at the mass meeting, however. Broderick forced his way to the side of the chairman and made a long speech against the entire proposition. When a vote was taken the division of sentiment was almost equal, and the senator hotly contested a ruling in favor of the adoption of the platform. Great confusion ensued, and a rush was made to drag Broderick from his position. He struggled fiercely to maintain his ground, while his friends were "fairly leaping through the crowd to get to his assistance." In the end, they seem to have held the steps of the Old Adobe against all comers. Broderick put a motion of adjournment and declared that it was carried, while officers of the city police. in the name

31 Herald, 1851, June 13, 2\%. The meetings were also reported in the issues of June 12 and 14. Ryckman said: "If our small numbers had been known, especially at the first, we should have been crushed by the force of the opposition. A great many men were opposed to us, and Broderick headed them; he was the main spring of the opposition, the head and front of the law and order party, and had hosts of friends. $\mathrm{He}$ was active in speaking against us, not only on the Plaza at the time Jenkins was hung, but at the Union Hotel, at the corner of Merchant St. which was a great rallying-place for politicians"' (MS Statement, 5-6).

32 Herald, 1851, June $13 \% 1 \%$. 
of the law, commanded the crowd to disperse. Later the other faction resumed control, but adjourned without further action.

This disorderly gathering deserves attention chiefly because it was one of the few occasions when public condemnation of the Committee was even attempted. Broderick may have felt that the moment was critical, but the crowd gave no indication of a temper ripe for revolution, and it seems more likely that the astute party leader hoped to check a movement that might initiate reforms dangerous to his methods of political control. In that he was entirely unsuccessful and apparently he then realized that San Francisco was resolved to support the new Committee, and that open resistance was practically useless. He was, however, an outspoken antagonist of the society, and some of his adherents, like Charles Duane and Ira Cole, did what they could to annoy and injure the individual members.

The Committee of Vigilance was thus fully launched upon its public eareer within a week of its initial gathering, and so strong was popular sentiment in its favor that the authorities took no steps to dissolve it. The verdict of the coroner's jury never resulted in any indictments, and the "association of citizens styling themselves the Committee of Vigilance" was unhampered in the prosecution of its work. Organization had progressed swiftly during the hours of the first arrest and trial. The need of responsible leadership was quickly realized, and sometime during the evening J. C. L. Wadsworth moved the appointment of an Executive Committee, ${ }^{33}$ which was immediately chosen. While Jenkins was still in custody, Isaac Bluxome, Jr., was elected to the post of secretary, ${ }^{3+}$ an office which he retained throughout all the activities of the Committees of 1851 and of 1856.

It has already been stated that the Vigilantes preserved written records of their work, signed by their names or identification

33 Wadsworth, in MS Vigilance Committees-Miscellany, 23.

34 Bluxome, MS Statement, 10. 
numbers. The Minutes and Miscellaneous Papers of the San Francisco Committee of Viligance fill eight hundred octavo pages, and represent hours of laborious and conscientious writing on the part of the officers and members. Even there the archives are not completely presented, for several items are most unfortunately lacking in the collection preserved in the Bancroft Library. The most notable of the missing records is a book of minutes of the Executive Committee from June 16 to July 4, 1851. Bancroft was familiar with this volume when he wrote Popular Tribunals, ${ }^{35}$ although he incorporated in that work no significant official information which is supplementary to the data on the loose sheets and in the statements dictated by the members. The book of minutes was never entered in the manuscript catalogue of his collection. no mention of it can be found among the documents transferred to the University of California, and the historian himself was unable to recollect its fate when questioned about it in 1914. The other missing items are not important, as they represent transcriptions of original drafts which are still preserved. One is a large volume in which was copied evidence concerning criminals $;^{36}$ the other is a minute book for the meetings of the General Committee, which was ordered by resolution but which may never have been prepared. ${ }^{37}$

No one can glance even casually through these unique documents without receiving a profound impression of the order and system prevailing in the work of the Committee. They have also an air of intense sincerity; the very haste and roughness of composition preclude the idea of evidence deliberately fabricated to conceal brutality or injustice, and careful comparison with the contemporary press and with the law reports there published

35 Popular Tribunals, I, 242.

36 "The testimony already collected fills a large volume, and has oceupied the exclusive attention of one man in transeribing', (Herald, 1851, June $212 / 1)$.

37 Papers, 247. 
establishes their accuracy so far as verification is now possible.

As retold from the records of its daily work, the proceedings of the Committee were not impetuous or reckless, but rather painstaking and cautious, both in seeking criminals and in controlling the activities of the more impulsive members. The methods adopted to accomplish these purposes are perhaps the clearest indication of the spirit which animated the organization. Let us therefore examine them in detail before a chronological narrative is presented.

The Executive Committee created on the night of Jenkins' arrest was composed of twenty members and became at once the center of administration. In that smaller circle matters of importance received their first consideration, ${ }^{38}$ work was outlined, prisoners were examined, and recommendations and reports were prepared for submission to the General Committee. The larger body ultimately enrolled 707 members. ${ }^{39}$ It met once or twice a week ${ }^{40}$ to review the work of the Executive Committee and to take action upon the final disposition of prisoners and such other questions as required decision by the society as a whole. During the period of greatest activity, that is, from June 26 to August 20, 1851, the Executive Committee met almost every day $;^{41}$ sixty-two meetings are recorded by minutes or roll call, with an average attendance of nine, and it is probable that some meetings are not registered. After the reorganization, September 17, 1851, there is an unbroken series of reports up to May 12, 1852 . showing thirty-four meetings, with an average attendance of eleven out of a membership increased to forty-five. A summary of the roll call is printed in the Papers. From it one can tell at a glance the members who gave most unremitting attention

38 See MS Statement of Ryckman, infra, p. 460.

39 C. of V., Constitution, 3 .

40 Papers, 300.

41 Papers, 62. 
to the business of the Executive Committee, and can gain an idea of the magnitude of the task which they assumed. ${ }^{42}$

For about a month Samuel Brannan acted as president both of the General and of the Executive bodies. When he resigned early in July, Selim E. Woodworth was elected general president, while Stephen Payran was chosen president of the Executive Committee, ${ }^{43}$ a modification of method which indicated an increasing differentiation between the functions of the two groups. There were also two secretaries, but only one general treasurer.

The disbursement of money for incidental expenses was at first in the hands of the sergeant-at-arms, who also collected initiation fees, and fines; but very soon all expenditures were made subject to approval by a standing Committee on Finance. which authorized payments by the general treasurer only. ${ }^{44}$ Another standing committee, the Committee on Qualification, was created by the constitution for the supervision of the admission of new members. ${ }^{45}$

A chief of police was appointed to investigate criminal conditions in the city and to make arrests when occasion required. He was sometimes called the chief of patrol, or the chief marshal, and five deputy marshals, with subordinate assistants, acted under his orders. ${ }^{46}$ Whenever necessary a much larger number were called to act on the police force. ${ }^{4 \tau}$ A separate group, assigned for duty as a water police, patrolled the Bay and visited vessels suspected of harboring Sydney convicts. Both branches of the police reported to the Executive meetings. and

42 Papers, Appendix C. Bluxome attended 74 meetings, Ryckman 65, and Payran 57.

43 See infra, p. 260. Appendix B of the Papers gives a list of officers. 44 Papers, 60, 91, and Index under "C. of V.-Finances." 1911.

45 C. of V., List of Names Approved by the Committee on Qualification,

46 Papers, 340, 356, and Index under "C. of V.-Police."

47 On June 19, the patrol was increased to one hundred (Papers, 58). 
often received instructions from that body, but on the whole they were left largely to their own initiative in making their investigations. ${ }^{48}$

The second article in the constitution provided for a room in which responsible members of the association should be in attendance day and night under direction of the sergeant-at-arms. From occasional reports it is apparent that five members were constantly on guard duty, in three hour shifts, and that every member was required to report daily so as to keep in touch with orders that might need his attention. ${ }^{49}$ The first headquarters were in the Brannan building, on the northwest corner of Sansome and Bush streets. On June 17 an agreement was made by which the firm of Bullitt, Patrick \& Dow, and H. A. Cheever, leased to five gentlemen (members of the Committee, but not so nominated in the bond) the second story of a frame building on the west side of Battery Street, betwen Clay and Pine. ${ }^{50}$

We have no accurate description of the permanent Vigilance headquarters. Contemporary illustrations ${ }^{51}$ showed that four windows and two upper doorways faced the Battery Street front, and the arrangement and furnishing of the interior may be partially reconstructed by reference to allusions scattered through the Papers. ${ }^{52}$ At the head of the stairway a door opened directly into a room large enough to accommodate a guard of forty or more men. It is possible that this apartment was sufficiently spacious to serve for the gatherings of the General

48"We systematized the thing, and formed our committees for different purposes. There was a water police. and other police. Captain Wakeman was Chief of the Water Police..... The city was districted, and there were committees for each district, and they patrolled the city day and night", (Ryckman, MS Statement, 3-4).

49 Papers, 97, and Index under "C. of V.-Headquarters-Police." Form of guard duty order, 136 ; lists of guards, 179, 531 .

50 Papers, 36, 42.

51 Annals, 562.

52 See reports on the escape of Whittaker and McKenzie, Papers, 528541 ; inventories, 654-656; disbursements for headquarters, 823. Remodeling the rooms cost about $\$ 650$, furnishing them about $\$ 700$. 
Committee. A sentinel stood watch over the door and members were expected to identify themselves by number as they entered. althoug the rule was sometimes relaxed, as for example at the time of the rescue of Whittaker and MIcKenzie. ${ }^{53}$ Another door, also guarded, led from the first room into another, where the prisoners were confined. The Executive Committee met in a separate chamber. This room, it is permissible to suppose. boasted of the more luxurious items of furniture-the armchair that cost sixty dollars, the two cushioned office chairs, the desk and writing accessories. Among the other fittings were a supply of smaller chairs, tables, two dozen straw mattresses, fifty-eight pairs of blankets, nineteen window curtains, a copper urn, cooking utensils, and tableware.

The earlier minutes do not indicate that there was much conflict of opinion over questions of policy. In view of the voluntary service given by the members, and of their emancipation from all the restraints that are imposed upon the lawful guardians of society, the harmony and coopperation that made the body efficient were remarkable. It is evident, however, that rival claims to authority produced moments of intense friction. After one such incident the Executive Committee was instructed to make a clear definition of the duties of the various officers. In response by-laws were framed, which dealt particularly with the responsibilities of the chief of police and of the sergeant-at-arms. and

53 "After the hanging of Jenkins, we had the room open day and night for the admission of members. Every man was called by his number, and admitted to the meetings by his number, the Sergeant at arms identifying him at the door. It was a good deal like a Free Mason's Lodge. At special times, when occasion required, a password was used. If the sergeant at arms was off duty at any time, the door keeper, if he dirl not recognize a man by his number when he came to the door, would ask his name also, and refer to his book" (Ryckman, MS Statement, 3). Mr. William M. Johnson, a member of the Committee of 1856 , informed me that in that body the members were pledged never to call each other by name while inside headquarters. No such rule was enforced in 1851, for many names are attached to reports and orders and embodied in the minutes. Bluxome sometimes signed published notices as “ '67, Secretary," but the full names of president and secretary were occasionally appended to such papers. 
with their subordination to the orders of the Executive and the General committees, and which provided that such orders were to be issued in writing. and returned, after fulfilment, endorsed with the report of the official who had executed them. ${ }^{5+}$ On July 23 the by-laws were adopted by the General Committee and sereral other important resolutions were also passed. One of these imposed obedience, as in a military company, to the orders of the chief of police; another required that all motions should be presented in writing, and should be signed by the number of the member who proposed them; wrangling and boisterous disputes were forbidden " after the hour of eleven P.Mr.," under the pain of fine, and the use of liquor in the Committee rooms was absolutely prohibited. .55

54 See Papers, 340-343, and infra, p. 278.

55 See Papers, 339-343, 397. Some resolutions were disregarded; comparatively few motions were presented in writing, if one can judge from the archives, and military discipline was not enforced (Smiley, MS Statement, 5). The use of intoxicants will be considered infra, p. 367 . 


\section{THE RECORDS FOR JUNE}

The activities of the Committee of Vigilance may conveniently be grouped in three periods.

First: From the hanging of Jenkins on Jume 11 to the arrest of James Stuart on July 1, an interval deroted to the investigation and apprehension of various suspicious characters who were unrelated to each other except as they were common members of the criminal community.

Second: From July 1 to September 16, a term which was occupied with events that developed as a result of Stuart's arrest. These included the identification of the prisoner as the assailant of Jansen, the murderer of Charles Moore, and the leader of a closely associated group of dangerous criminals; Stuart's betrayal of his confederates in the course of a long and important confession, his execution, the capture of many of his companions, their trials, the execution of Whittaker and IcKenzie by the Committee, the deportation of others, and the trial and imprisonment of several more by due process of law. During this time several of the Committee interested themselves in campaigning for the election of September 3, and secured results that promised improvement in the administration of local affairs.

Third: From the reorganization of the Committee on a less strenuous basis. September 17, 1851, to the final cessation of its activities. sometime subsequent to January, 1853.

Such a grouping affords a chronological framework into which may be fitted the hundreds of separate documents in the archives of the Committee. The succeeding chapters have been based upon it, and their construction has further been dictated by an 
effort to present the more important episodes of the Committee's existence in appropriate perspective, then to collect minor and picturesque incidents and to discuss certain special problems in such a way that they may supplement but not confuse the main course of the story.

The constitution of the Committee of Vigilance was adopted on the ninth of June; Jenkins was hanged on the eleventh, and by the fourteenth the Committee was deep in systematic and efficient work.

It must be remembered that its members felt that the safety of the community was threatened by an organized band of criminals, while the presence in the state of large numbers of ex-convicts from the British penal colonies provided a fertile field for the recruiting of just such a company of outlaws as was pictured by the popular imagination. It was against the Australian suspects, therefore, that the Committee exerted its earliest and most strenuous efforts, and it is apparent that the survey of criminal resorts proposed in the Alta of June 8 was adopted from the start as the step of primary necessity. This is indicated by a paper dated June 14, the first report preserved in the files. These rough notes of J. L. Van Bokkelen, the chief of patrol, give a key to the methods that accomplished rapid and effective results. The committeemen did not wait for other thieves to be apprehended with their spoils, nor for complaints to be lodged against suspected offenders: with methodical diligence they divided the city into districts, and inspected one by one the houses of questionable reputation. The report of the fourteenth recommended that eleven such houses should be watched for further information, and subsequent papers show that the suggestion was followed with such thoroughness that a mass of incriminating evidence was accumulated against five of the proprietors mentioned. ${ }^{1}$

\footnotetext{
1 See Papers, 27-28, and Index under cases of Henry Beck, Thomas Burns, James Hetherington, Crockstein and Ward, John Morris Morgan.
} 
One suspect was Thomas Burns, from Van Diemen's Land. He had been for a time host of the lodging house which, under the successive titles of the Uncle Sam and the Shipman's Arms, had been kept by Jenkins and sold to Mr. and Mrs. Connolly shortly before Mr. Connolly's mysterious death. A shadow still hung over the place and over the widow, who had comforted herself too promptly with the attentions of the unfortunate Jenkins, and again, after a second bereavement, had found another protector-a man known as "Jim" Burns, although in some places he seems to be identified with Thomas, who for a time took charge of her bar, but later moved to McManus' Welcome, on North Beach. His house was known to the authorities as one of the worst resorts of the Sydney thieves, and he had been heavily fined for keeping it open after midnight. ${ }^{2}$

Burns and another innkeeper, named James Hetherington, were considered especially dangerous residents and the secretary of the Committee was instructed to send them notices to leave town within five days. There is no copy of the communication. but the Herald of June 18 stated that Hetherington had appealed to the authorities for protection, exhibiting a letter which read somewhat as follows:

You are hereby warned to leave this city within five days.

By order of the Committee of Vigilance.

Here was a second warning issued to criminals by the Vigilance Committee; thieves should beware of the rope (vide Jenkins, deceased!) and the furtive abettors of crime should also expect punishment if they lingered within the city. Although the Herald had already urged the "Committee of Public Safety" to command the criminal element to leave the state under penalty of severe punishment, ${ }^{3}$ no one could anticipate how such orders would be received. Some of the Committee had grave scruples .

2 Alta, 1851, June $10 \%$.

3 Herald, 1851, June $12 \%$. 
as to the wisdom of enforcing them at the risk of doing personal injury to men against whom there were no charges for orert acts of violence. It was therefore decided that Burns, who had requested an opportunity to prove his innocence, should be allowed to appear in his own behalf, and that the same privilege should be offered to Hetherington. who had made no response to the notice. ${ }^{4}$

Burns came to headquarters, made a long, defensive statement, and called several witnesses to support him. The Committee, however, was dissatisfied with the testimony presented and continued his case, but further investigation failed to clear his reputation. 5

Hetherington responded to the notice by seeking protection from the city recorder, and the Committee voted to place him under guard until he could be shipped back to the British colonies. ${ }^{6}$ It was stated in the papers that two or three hundred Vigilantes marched in a body to North Beach, surrounded the house of the offender and carried him off to their headquarters. "despite his remonstrances and bluster." The report added that it seemed probable that such prompt and efficient action would have its effect upon others who had received orders to depart, and would induce them to give ready obedience to their instructions. ${ }^{\top}$

Once in the hands of the Committee, Hetherington made a statement in which he asserted that he was an American by birth. but had moved to Liverpool in childhood; that he had gone to Australia when he was thirty years of age. and had returned to the United States from Sydney with fellow-passengers who would vouch for his honesty. Several of these were called in his defense, ${ }^{8}$ but in the end the Committee decided that both Hetherington and Burns sheltered thieves and incendiaries, and that the safety of the city demanded their deportation.

\footnotetext{
4 Papers, 41, 43-44.

7 Herald, 1851, June $212 \%$.

5 Papers, 45-59, 66-68.

8 Papers, 60-73.

6 Papers, 59.
} 
While the two landlords were under investigation. other questionable characters were called upon to account for their past lives and associates. George Hopkins, from IIobart Town. may or may not have been an ex-convict, but his mode of life was undoubtedly suspicious. After various examinations a committee of eleven recommended his banishment on the ground that he was a "dangerous man." Their report is printed in facsimile in the documents. It is an interesting example of a case in which all the members of the subcommittee assumed responsibility for their action by attaching their signatures to the recommendations they submitted. ${ }^{9}$

Thomas Scott, a tailor, had crossed the Pacific in the same ressel with Hetherington, and had been in irons en route for theft, and assault upon the captain. There was also a rumor that in San Francisco he had poisoned a man named Russel. ${ }^{10}$ When examined by the Committee he assumed an air of great innocence, protested that he did not even know the location of North Beach. and was not acquainted with the ill-reputed Itetherington. The evidence is briefly annotated: "Here the two men were introduced to each other, and Mr. Scott finds he knows Mr. Hetherington." That acquaintance was destined to ripen upon another sea trip, undertaken at the command of the Committee of Vigilance, which finally decided to send all four of these objectionable aliens back to Australia. There may have been umrecorded information that established their guilt beyond question. The testimony in the documents proved little more than a close alliance between the prisoners and well-known members of the convict fraternity, and would not have carried conviction in any court of law.

The business interests of Hetherington and Scott were liquidated while they were in confinement. some of their personal effects were sold, and before they left the country they signed 
receipts for the proceeds, which in each case exceeded two hundred dollars. ${ }^{11}$ The undesirable quartette were probably deported on the Crescent City which sailed for Launceston on July 2.

Several other suspicious characters from Australia received the attention of the Committee during June. In this connection it is interesting to see how many permanent relationships had originated during the trans-Pacific voyage. For example, after a single trip of the Orator some thirty or more of her one hundred and fifty passengers maintained a loose association of unsavory fellowship. ${ }^{12}$

When commenting upon the notices of banishment sent to Burns and Hetherington, the San Francisco Herald, June 18, acknowledged the danger of such a weapon in unscrupulous hands, but expresed the belief that the Committee might be trusted to exercise eaution and honesty in issuing its decrees. On July 1 the paper said that some one was trying to create prejudice against the Committee by mailing, in its name, to men of unblemished reputation forged letters requiring them to leave town. The paper also made the positive statement that the Committee never dispatched notices of this kind by post. but always served them by the hands of a subcommittee of three. The Pacific star of the same date aserted that only two such notices had ever been issued. ${ }^{13}$

Only the orders to Burns and Hetherington, and another order sent to one Ryan, ${ }^{14}$ who evaded arrest, are mentioned in the

\footnotetext{
11 Papers, 151-153.

12 Papers, 63-73. Note the Reports $62-64$ as examples of the methods of investigation.

13 But the Herald, 1851, June 21, \%, had stated that many had "received notices to quit, and their good sense had induced them in almost every instance to obey.' Bancroft printed an example of such a notice, but no copy is preserved in the archives, and he may have paraphrased the notice given in the Herald in the ease of Hetherington. See Popular Tribunals, I, 260 .
}

14 Papers, 502. 
minutes or the reports. It is very possible, however, that the spurious letters to which the papers alluded are illustrated by a document in the files which warns Colonel James, a well-known criminal lawyer. to leave the city without delay. ${ }^{15}$ The fact that the minutes made no allusion to Colonel James and that he remained in town without incurring any censure from the Committee lends color to this supposition.

From the very first day of its existence the Committee recognized the importance of prevention as well as of cure in handling the criminal conditions that confronted the city. An attempt was therefore made to check the increase of the convict colony in Sydney Valley. The statute of 1850 which prohibited the immigration of criminals, ${ }^{16}$ although nominally in force, appears to have been ignored. perhaps because California officials realized that it was futile to attempt the exclusion of immigrants by local enactments after the Supreme Court had declared that similar legislation in New York and Massachusetts was unconstitutional. The Committee of Vigilance was undeterred by nice distinctions between state and Federal prerogatives. Therefore when it received a report that five hundred convicts were on their way to San Francisco, completely organized for crime, ${ }^{17}$ it undertook to send back, on its own responsibility, those who seemed to belong to a criminal class. ${ }^{18}$ It was announced in the California Courier

15 Papers, 69.

16 See supra, p. 123.

17 Papers, 30. Reference to the immigration from Sydney was constantly made in the papers, and the following quotation from the Alta, 1851, May $102 / 1$, is an example: "A vessel has arrived within a few days from Sydney, without her Port clearance. This is proof she was not searched by the Water Police before leaving. ... Some of the passengers on this ressel have their heads shaved, proving their infamous characters. They have evidently been smuggled away from Australia and smuggled into our community. The authors and abettors of this outrage deserve to be lynched without mercy for the villainy. Is there no authority which can look into and prevent such abuse of our generosity towards other nations?.... Our people must take this matter in hand.',

1s The Committee also considered taking legal steps against shipmasters who brought convict passengers to the state (Papers, 178, 291, 434, 440, $5 \pm 7)$. 
of . June 16 that arrangements had been made with the officers of the United States Revenue Department, by which the Committee would have access to incoming vessels, and would be given an opportunity to investigate the character of the passengers before the latter were allowed to land in San Francisco. Such an inspection had been made of the American bark Chief, which had arrived on the fourteenth, and "reliable persons, well acquainted with residents in the colonies" were employed to assist in the rork of identification. The chicf carried no mdesirable immigrants, and the only record of her inspection is contained in the bill for the hire of boats which carried the Vigilantes aboard. ${ }^{19}$

The statement that the revenue officers agreed to assist the Committee in this matter is confirmed by a note from Captain McGowan, of the revenue cutter Polk, conveying the information that the bark John Potter arrived from Sydney on July 2. This note was directed to "Mr. S. E. Woodworth, For "Vigilance Committee,', an address which proves that Captain McGowan desired to coöperate with the work of the Committee. ${ }^{20}$

Isaac Bluxome, Jr., thus described the methods employed in the examination of immigrants : ${ }^{21}$

The Committee sent a boat aboard every vessel that came in from Australia to look for convicts. We had a list, which we got from some Englishman here, of all the convict ships that went from England to Australia, alphabetically arranged, extending over several years. We examined all the passengers when the ship came in. They were all placed forward, and called into the Cabin one by one, and questions asked as to what year they arrived in Australia, and by what vessel, and so we identified them, and as fast as they were examined, they were sent aft. Those that were convicts we put into a boat alongside, and sent them ashore to the Committee rooms until there was a vessel going to Australia, when we paid their passage and sent them back. I recollect distinctly one old man that I put into the boat, who was probably eighty years old.

19 Papers, 770, Voucher no. 6.

20 Papers, 136.

21 Bluxome, MS Statement, 15. The "old man', may have been Lawrence Higgins, sixty-nine years of age (Papers, 517). 
Reports are preserved which cover the examination of passengers on eight vessels. They have not been printed with the other papers as the spelling of the names is very doubtful, and the facts recorded are of a strictly personal nature. ${ }^{22}$ The following extracts, however, illustrate the nature of the questionnaires :

George Starbuck, Mate of Bark John Potter. Joined ship at Sydney, 23 of December, 1850. Am an American, a native of Nantucket; have lived in Sydney for the last 20 years-have been an overseer in an oil establishment. My last employer was Chas. Chapman-I have an idea of the character of the passengers-and cannot say anything bad of any one-have been acquainted with many of them for years.

John Carney [on board John Potter], born in Ireland in 1840. Ship Elizabeth from Liverpool to Sydney-remained in Sydney 11 years-no certificate from Consul-Mr. Carney presents certificate from the parish in which he lived-countersigned at Emigrant office.

William Butt [on board Adirondack] - have lived in Sydney 34 yearsleft England in Lord Elden, a convict ship-was a laborer in Sydney-was a servant on Lord Elden-I know Capt. Patterson-on shore-

William Higgs [on board Adirondack]-An American-left London in the Somersetshire for Hobart Town about 9 years ago-She was a convict ship-was not a convict-has not followed the sea for eight years-has been in the tanning business since that time-knows of no convicts on board this ship-does not suspect any one as being a convict. Has a wife and three children on board-first came to Sydney in the Planter a convict ship (Doubtful).

Thomas Jones [on board Mary Catherine]-An Englishman-left England in 1838-in ship Parkfield for Sydney-a convict ship-was a servant on board-was a prisoner on board.

Emma Jones [on board Mary Catherine]-An Englishwoman-left Eng. in 1837-in ship John Renwick for Sydney-a convict ship for femaleswas a prisoner.

General Andrew Jackson [on board Mary Catherine], an American, from Honolulu.

22 The lists are summarized in the Papers, Appendix H. See also the Index under " Passengers examined by the C. of V.", Four other ressels arrived from the British colonies between June 8 and Sept. 17, 1851; the Sacramento on July 2, with 3 passengers; the Marmion. July 20, with 13 ; the Rosalind, July 23, with 8; the Titan, August 15, with 3; the Barette, August 22, with 5 . They are not mentioned in the records of the Committee. 
All the vessels inspected by the Committee were reported in the marine news under the date of their arrival at San Francisco, with mention in nearly every case of the number of passengers. Since it is possible thus to check the reports of the Committee by the records in the daily papers, it seems safe to conclude that the former are fairly accurate when they give the total number of passengers examined as 495 ont of about 865 arrivals. $^{23}$ of those examined some 25 were under suspicion as ex-convicts, but only 7 are on record as having been sent back to Sydney. ${ }^{24}$

The varied activities of the water police can best be estimated from a study of the bills presented on their account, as their chief, Captain Edgar Wakeman, submitted few reports of his proceedings. Writing of his connection with the Committee he said $:^{25}$

Of course, I joined the Vigilance Committee, and acted as sheriff at the hanging of Jenkins and Stewart. I have stood many and many a night's watch in the streets of San Francisco, and at one time had a large fleet of boats afloat on the Bay. At this time, I was sometimes called the Emperor of the Port, as all vessels coming in or going out were under my orders and subject to my inspection, the revenue cutter Polk being especially at my orders.

His accounts for June show an almost continuous service. There was a trip to Angel Island ${ }^{26}$ prior to June 19, conducted by ten committeemen, in search of deposits of stolen merchandise. Another trip was made to the Farallones, outside the Golden Gate, apparently on the order of the Committee, but for purposes unnamed in any report. ${ }^{27}$ Wakeman's Log tells of a launch party to those islands at about that time, but it gives no hint of his particular errand. ${ }^{28}$

23 These figures include the 15 passengers on the Chief reported in the California Courier, but not noted in the files of the Committee.

24 _ Alderson, William Barclay, Richard Garland, Thomas and Mary Jones, - Roach, Alexander Wright.

25 Wakeman, Log, 139.

27 Papers, 209, 771 Voucher no. 4.

26 Papers, 769 Voucher no. 4. 28 Wakeman, Log, 168-169. 
On July 31, 1851, Captain Wakeman assumed command of the passenger steamer Independence. His departure from San Francisco on his initial voyage to Panama was marked by the presentation of a large banner of crimson satin, made by the ladies of the city and emblazoned with the words "Vigilance" and "Eureka." The flag was given into his hands by F. A. Woodworth, and the occasion was considered a public acknowledgment of Wakeman's services to the community in connection with the Committee of Vigilance. The thanks of the association were conveyed to him in a letter very characteristic of Stephen Payran, who reviewed Wakeman's efforts to rescue the city from arson, murder, and burglary, and wished the bluff old salt a "long and prosperous life and in the end a safe anchorage in the Haven of Eternal rest." ${ }_{29}$ W. H. Clark, who succeeded to the post of chief of the water police, did his work so zealously that he brought upon himself censure for extravagance and an admonition to exercise greater caution in future. ${ }^{30}$

The constitution of the Committee of Vigilance declared that the members were determined to see to it that criminals no longer escaped punishment by the "quibbles of the law." In order to accomplish this purpose intelligently they kept themselves constantly informed of the proceedings in the local courts. In one of the first days of his presidential term Sam Bramnan wrote directly to Alexander Campbell, presiding justice of the Court of Sessions, and asked information relative to the effect of the recent revision of the criminal statutes. Judge Campbell replied in a courteous letter, dated June 17. He made no reference to Brannan's connection with the Committee of Vigilance, but assured him that the Court of Sessions would make every effort possible to expedite trials and to administer justice. ${ }^{31}$

29 Papers, 395-396; Wakeman, Log, 170; Herald, 1851, August $1 \%$.

30 Papers, 363 377, 824.

31 Papers, 38-39. 
The Committee watched with interest several cases which occupied the attention of the courts during the last fortnight of June. When Thomas Yates, or Wood. was arrested by the city police on suspicion of robbery and murder, Van Bokkelen immediately reported the case to the Committee. It was followed with attention in the hope that the evidence might assist in the discovery of the men who had stolen a large quantity of jewelry from a merchant named Robert. The Committee ultimately obtained information as to the identity of those thieves, but it was unable to recover the plunder. ${ }^{32}$

The Committee also took cognizance of charges of murder lodged against George Spires and Richard Hall, who were accused of poisoning Frank Brewer, and who, like Lewis, were awaiting investigation by the grand jury to be impaneled in July. Dr. MI. P. Burns, a physician entrusted with the post-mortem analysis, was a member of the Committee. A copy of his report was submitted to that body two days before it was made public in the Alta California of June $18 .^{33}$ The archives frequently refer to "The Brewer Case," although its conduct was left entirely to the courts. Both men were finally discharged.

The chief of the Vigilante police had a watchful eye for suspicious actions, wherever they might be observed. During the evening of June 15 Mr. Thomas Belcher Kay, late of Sydney and recently warden of the port of San Francisco, ${ }^{34}$ was seen on Powell Street in conference with a man who seemed to be under the influence of liquor. Kay became so uneasy when aware of surveillance that Van Bokkelen made a special report on the matter. ${ }^{35}$ His intuitions were fully justified by later revelations, which showed that the ex-warden was one of the most unscrupulous members of the Sydney gang. His successful attempts

32 Papers, 31 note 4.

33 Papers, 33--34.

34 Kay's resignation was noted in the Herald, 1851, May 15 2/.

35 Papers, 32, 232 note 26. See also infra, p. 282. 
to evade arrest by the Committee furnished an interesting episode in the records for July.

It has been said that few attempts were made to express public condemnation of the Committee of Vigilance. It is certain. however, that an element in the eity was anxious to find an opportunity to register its disapproval. On June 17 a handbill was distributed which called upon the lovers of law and order to meet on the Plaza on June 22 and take steps to suppress the "secret inquisition" and the "midnight murderers" that were disgracing the eity. ${ }^{36}$ The Committee investigated the origin of this broadside, found that it had been printed at the office of the Sunday Dispatch, that the original manuscript was signed by William French and George Stephens, and that the mayor in person had prohibited its further distribution. ${ }^{37}$

The meeting sumoned so passionately was never held. On Sunday, June 22. the citizens of San Francisco were struggling to check the ravages of another disastrous fire. The blaze started in the morning, at the corner of Pacific and Powell streets, and spread fiercely to the east and south, laying waste the whole, or parts, of sixteen blocks of buildings, and destroying property valued at three million dollars.

The Annals called the fire "unquestionably incendiary", it was so regarded at the moment. The crowds that swept through the scorching streets were ready for furious vengeance upon any one even suspected of the crime, and two men were beaten to death by mobs on suspicion of robbery and incendiarism. ${ }^{39}$ A like fate threatened Captain Harris, master of the bark

36 See infra, p. 460.

3r Papers, 37-38, 58. It was intimated in the California Courier, June 19 , that Broderick was instrumental in this publication, but the statement was retracted in the next issue.

3s Annals, 345, 611 .

39 Herald, 1851, June $24 \%$. Two men were also shot by the police for looting. Saint-Amant, who arrived shortly after this, found the city greatly in dread of another fire (Toyages, 124-125). 
Timandra, from Sydney, who indulged in such a violent dispute over the method that should be adopted to extinguish a blazing tar barrel that he was charged with an attempt to spread the fire. It was in vain that he protested his innocence-his Sydney connection was all to his discredit-and an angry mob began to raise cries of "'Hang him!' and to look about for a convenient scaffold. Realizing his peril, Harris shouted aloud the names of the agents of his vessel, Messrs. Davidson and Argenti, the latter a member of the Committee of Vigilance. Other Vigilantes, heeding this call, rushed to the captain's aid, and claimed the right to remove him under arrest to headquarters. A hand-tohand tussle ensued; the prisoner was badly bruised, his clothing was torn and his valuables were lost, but in the end a rescue was effected. Harris was glad enough to spend the night under safe shelter, and grew so friendly with his pseudo jailers that he signed the roll of members as number 468 . The irregularity of that proceeding is indicated by the annotations "Discharged" and "Not a member.", 40

This episode of Captain Harris has scant mention in the papers of the Committee. Theodore Dahlgrén, later under arrest, spoke of his efforts to assist at the rescue, and of the subsequent charge that he took advantage of the opportunity to pilfer a watch from the gentleman's pocket; and on July 14 there was filed a letter in which Harris claimed indemnity for the lost article. ${ }^{41}$ These allusions, however, are fully explained by reference to the Sydney (N.S.W.) Morning Herald, for the shipmaster returned to his home port seething with indignation at his treatment in San Francisco, and published a long letter on September 1 in which he accused the Committee of inciting the mob and of making the arrest in the hope of effecting a popular execution-a crime which motives of prudence alone prevented. He branded

40 Papers, 41.

41 Papers, 147, 279, 280. 
the members of the Committee as "bloodhounds" who "under the spurious name of Liberty and Order, roam continually in the good work of exterminating the Australian"; accused them of the loss of his valuable watch; and warned his countrymen to avoid the dangers of a sojourn on the California Coast. He further protested that the press of the state was so in fear of the influence of the Committee that no paper would publish the facts in his case. He especially blamed the editor of the Alta California for refusing to print a letter on the subject sent to him immediately after the fire.

Many of the papers published in Australia at this time reflected great indignation at the acts of the Vigilance Committee. hurled against them "tirades of abuse and slander," ${ }_{42}$ and denounced them as exhibitions of race hatred and jealousy against foreigners. That severe judgment was somewhat softened upon further information and several friendly articles were printed. On November 8 the Sydney Herald gave space to a long communication from Thomas Hinigan, a Sydney resident who had been in San Francisco for some eighteen months. during which time he had acted as marine reporter for one of the daily papers. Hinigan substantiated the main facts of the captain's story, but pointed out that the Committee actually rescued the prisoner from a mob that was on the point of lynching him. He especially refuted the statement that the press feared to offend the Committee of Vigilance, and said that the Alta was so reduced in size after the fire that it had space for only a brief paragraph regretting the unfortunate episode. ${ }^{* 3}$ Hinigan returned to San Francisco not long afterwards and offered his aid to the Committee in a letter that gave interesting comments on the public sentiments eurrent in Sydney. ${ }^{44}$

42 Papers, 746.

43 This notice appeared in the Alta, 1851, June $26 \%$ (Steamer Edition).

44 Papers, 746-747. The Alta, 1851, Oct. $5 \%$, quoted from the People's Adrocate, of Sydney, a letter in which W. M. Curtayne strongly commended the work of the Committee. 
The Sunday of the fire was a busy day for the Committee. Such squads as the one that rescued Captain Harris patrolled the streets constantly, on the watch for incendiaries and for thieves. While none of the former was detected, at least nine men were brought to headquarters charged with the possession of stolen goods. ${ }^{45}$ All of these except one Mexican succeeded in establishing their innocence and were discharged. The single conviction ${ }^{46}$ was followed by a public flogging of twenty-five lashes, mentioned with approval in the papers of June 25. The chastisement was not severe, as the knots on the cat had been removed. So far as the official records or the newspapers report, this was the only corporal punishment inflicted by the Committee of Vigilance of San Francisco. ${ }^{47}$ Emphasis should be laid on the difference between this fact and the popular imagination, which sometimes presents the Vigilantes of San Francisco as the administrators of merciless flagellations. Even Bancroft asserted that "many were publicly whipped," 48 but his statement is not corroborated by the records or by the daily papers.

While some of the Committee guarded the burning city on that Sunday in June, the water police watched the Bay for boats loaded with stolen plunder. One of the patrols tried to overhaul Captain Hammer, of the Medora, who was returning to his vessel after the excitements of the day. He indignantly refused to lie to, and the occupants of the two boats indulged in a struggle which threatened serious consequences before the cooler heads among them could restore peace. ${ }^{49}$

Two other incidents of June 22 must be noted. On that night a man named Samuel Gallagher stabbed to death one Lewis Pollock in a quarrel over an inmate of a vicious resort. Gallagher

45 See Papers, 74-83.

46 Papers, $75-76$.

47 A report on the case of Antonio Barsallio, arrested at this time, recommended a whipping, but it was annotated "Discharged"' (Papers, 82).

48 Popular Tribunals, I, 260.

49 Papers, 79-81. 
was immediately taken to Vigilance headquarters, but the Committee refused to assume jurisdiction over crimes of sudden passion, and the man was transferred to the city police before morning. The only allusion to the incident in the records is in an unimportant letter, but it was reported in the newspapers. It is of interest as an example of the Committee's policy of leaving the punishment of such offenses to the regular authorities. ${ }^{50}$

So far, the test of an exciting catastrophe had proved the Vigilantes to be men of calm judgment and self-control. They had inflicted no hasty discipline, shot no looters, and lynched no murderer, although the infectious spirit of violence was rife in the city. Yet that night, in an action comparatively trivial, they involved themselves in difficulties which permanently hampered their work and did much towards disrupting the ties that bound them together in a harmonious organization.

In a brief note, dated June 22, Felix Argenti, an Italian banker, complained that a man named Metcalf had purloined and secreted valuables which he had been hired to remove from the house of an unnamed "lady." 51 The plaintiff, known as Angelina Duclos, was the close friend and the reputed mistress of Argenti, whose name had been so potent to rescue Captain Harris early in the day. ${ }^{52}$ Argenti's friends rallied with equal staunchness to the aid of this second protégé. On the same night a party of ten or twelve accompanied her to the home of Metcalf, forcibly entered his house, threatened violence if resisted, and searched for the missing property even among the personal effects of his wife and daughter, who were roused from sleep to submit to the investigation. Several articles were claimed and appropriated

50 Four Vigilantes served on the jury that later convicted Gallagher of manslaughter. He was quickly pardoned by the governor. See Papers, 219; Alta, 1851, June $23 \% \frac{1}{\text {; Herald, June } 24 \% 1}$; Aug. $13 \%$; $14 \% 1$; Nov. $18 \%$; Dec. 6 2/4.

51 Papers, 78.

52 The relationship was scored in the arguments in court (R. A. Lockwood, Vigilance Committee of San Francisco, 1852, p. 20). 
by Mme. Duclos. Metcalf retaliated by bringing action for $\$ 25,000$ damages against Argenti and others who participated in the search, and the suit of Metcalf vs. Argenti et al. became one of the standing vexations during the entire period covered by the activities of the Committee. ${ }^{53}$ At the beginning, however, the threat of actions at law in no way daunted the courage of the committeemen. At a general meeting held July 5 they passed a resolution authorizing the publication of a notice in which they claimed the right to enter any premises where they had good reason to believe that they should find incriminating evidence " -and further, deeming ourselves engaged in a good and just cause-we INTEND TO MAINTAIN IT." ${ }_{54}$

Statements made at a later time indicated that the resolution did not reflect the sentiments of a majority of the Committee, ${ }^{55}$ but the course it advocated was a logical outcome of the whole spirit. of the Vigilance organization. The frankness of the avowal only emphasized anew the conflict between the claims of that self-appointed body and the ideals of American liberty. The announcement did not pass without challenge. Nayor Brenham, in an open letter to the citizens of San Francisco, ${ }^{56}$ specified among other wrongs laid at the door of the Committee that: "They claim and exercise the right of domiciliary visits, without any accountability, of a character not known under any other than inquisitorial governments." Judge Campbell, on another occasion, ${ }^{57}$ in a charge to the grand jury spoke of "unreasonable searches, without color of authority." The friends of the Committee, however, seem to have accepted its position without fear of any abuse of the license claimed, and their confidence was

53 See Papers, 156 note, and Index under "Metcalf"'; also infra, pp. 329,347 .

54 Papers, 178.

55 See infra, p. 330.

56 See infra, p. 271, and Brenham's proclamation, Appendix, p. 463.

57 See infra, p. 272, and Campbell's charge, Appendix, p. 464. 
clearly expressed in a leading editorial of the San Francisco Herald on July 17.

The Committee continued to exercise the "right of search" as necessity arose, but after the Metcalf incident more prudent methods were employed. Explicit instructions were issued in writing, and the men detailed for such service were required to return the orders with annotations showing the success or failure of each mission. Most of the premises entered were lodging houses, where the legal rights of tenants were of small importance to the proprietors. At least one landlord signed a formal permit for the investigation. ${ }^{58}$ No one except Metcalf sued the Committee for trespass and there is no record to indicate that in other instances threats of violence were employed by the committeemen.

The fire of June 22 reawakened the old fears of deliberate arson. Beginning June 26 and for some time thereafter the Committee advertised a reward of $\$ 5000$ for the capture and conviction of any one guilty of such a crime. ${ }^{59}$ A charge for posters and another for bill posting, paid at this date, ${ }^{60}$ lead to the inference that the reward was conspicuously advertised throughout the city, but it did not result in the apprehension and conviction of any incendiaries.

At one time a strong suspicion of arson rested upon a Negro known as Ben Robinson, who came into the hands of the Committee on June 30. In spite of the anti-slavery clause of the state constitution, Ben lived in abject subjection to a depraved white woman, Margaret Robinson, who was in the habit of beating him if he disregarded her wishes. He was arrested by the city police on suspicion of starting the fire of the twenty-second, and confessed that he did so in obedience to MIrs. Robinson. who

58 Papers, Index under "Search without warrant."

59 See infra, p. 461.

60 Papers, Vouchers nos. 29, 34. 
had a grudge against the man in whose house the fire originated. With strange negligence, he was allowed to escape from the officers, but members of the Committee of Vigilance immediately seized him, and took him to headquarters, where he repeated his story. Mr. and Mrs. Robinson were arrested the same night. When brought to the Committee rooms they made vigorous denials of the charge; thereupon Ben withdrew his whole confession and accused one of the police officers of bribing him to tell the story. The Vigilantes resolved to take no action in the case until they had investigated the cause of Ben's arrest and discharge. The subcommittee appointed to this duty reported a fortnight later that they were convinced that the whole thing was a plot to incite the Committee to take hasty action against Mrs. Robinson, whose evil life made credible any tale that might be told about her. The report was accepted, and the Negro and his mistress were discharged on or before July $12 .{ }^{61}$

It was during this period of activity that the Committee undertook a work of unquestioned value to the community at large-the completion of the county jail already in course of construction on Broadway between Kearny and Dupont streets. The building was under the supervision of the Court of Sessions, which controlled the administration of funds for county improvement. Large sums had been expended with small results, and the report of the grand jury for April contained charges of gross mismanagement against the officials responsible for the conduct of the work. ${ }^{62}$ The accusations in no way implicated the sheriff, Colonel Jack Hays, who had made vigorous efforts to hasten completion. He had tried without much success to raise a public subscription for that purpose, ${ }^{63}$ and had finally succeeded, by

61 See Papers, Index under "Ben Robinson." The possibility that Mrs. Robinson might be lynched was noted with horror in the Albany Knickerbocker (Alta, 1851, Oct. $16 \% 3$ ).

62 Alta, 1851, April $29 \%$.

63 Alta, 1851, May 20 \%1. 
the expenditure of personal funds, in preparing a part of the building for occupation.

Even with this addition the prison facilities of the city were still absolutely inadequate, and prisoners constantly escaped from the insecure buildings in which they were confined. For example, late in April eight men had broken out of the city prison, among them being Windred, of the Jansen affair, and George Adams and William Watkins, two notorious thieves. ${ }^{64}$ Watkins and Adams were quickly rearrested, and on May 6 Watkins made good a boast that he could escape from any jail ${ }^{65}$ by cutting a hole in the floor and departing in company with Adams and other friends known as Switzer, Welsh, and Gardner. ${ }^{66}$ The Alta of May 9 stated that twelve or fourteen more prisoners had broken from the station house, which was a wretched cellar under the city hall where as many as three dozen persons were tumbled together, without sanitary necessities, and fed on a scanty diet of bread and water. ${ }^{67}$ Adams, Welsh and Switzer were reincarcerated and on June 2 they escaped again with six others, this being the third escape made by Adams during a period of six weeks. ${ }^{68}$ Watkins was presently recaptured, ${ }^{69}$ but the others remained at large.

Such events constantly emphasized the need for a well constructed prison. The Herald of June 16 spoke of the unsatisfactory progress of the work on the county jail, stated that fourteen or fifteen hundred dollars were then owing to the sheriff, and suggested that the Committee of Vigilance should take the matter in hand. Four days later John Caperton, the under sheriff of the county, invited the Committee to send a delegation to examine the new building. ${ }^{70}$ A tour of inspection followed without delay. The visitors found seven cells occupied; the

\footnotetext{
64 Alta, 1851, April 24 2/3. 65 Alta, 1851, April $29 \%$.

66 Alta, 1851, May $7 \%$.

67 Alta, 1851, May $26 \%$.
}

68 Alta, 1851, June 3 \%2. 69 Alta, 1851, June $7 \%$.

70 Papers, 93. 
largest, twelve by fourteen feet, held fourteen prisoners, and the others, six by nine feet, held six each. ${ }^{71}$ The keeper's room was also finished; another tier of cells needed only doors to be habitable, although a part of the building was without a roof. ${ }^{72}$ The subcommittee recommended the raising of funds for the completion of the prison and at a General Meeting on July 5 it was resolved that each member should secure ten subscriptions of three dollars each. ${ }^{73}$

Suitable blanks were distributed within a few days, ${ }^{74}$ and the work of collection extended over a period of several weeks. In the meantime a further report was made on the condition of the jail. $^{75}$ This was transmitted to Sheriff Hays, as is evident from the following note, which is missing from the files of the archives, but may be found in Popular Tribunals $:^{76}$

\section{Executive Chamber of the Committee of Vigilance, San Francisco, August 11, 1851.}

To John C. Hays, Esq., High Sheriff for the City and

County of San Francisco:

\section{Dear Sir:}

Permit me, on behalf of the Committee of Vigilance, to offer you the annexed report, with the action thereon; and in their name $I$ offer, with the concurrence of my colleagues, the thanks of the Committee for your perseverance, skill, and assiduity in bringing the affairs of our county prison to so happy an issue. We regret much that you personally should have suffered any pecuniary inconvenience in the prosecution of its financial affairs, and earnestly hope that the pittance raised by us may

\footnotetext{
71 Papers, 157-162.

72 The unroofed condition was described in the Herald, 1851, Sept. 11 $2 / 3 ; 19 \%$.

73 Papers, 177.

74 Papers, 247 note 3 . Thirty-seven sheets, containing over 300 signatures, are preserved in the archives, but have not been printed, as the signatures are often illegible, and the list is incomplete.

75 Papers, 347-349.

76 Popular Tribunals, I, 401-402. The absence from the archives of several documents which were printed in that volume, and pencilled annotations upon others, indicate that Bancroft sent original papers to the printer, and that some were not returned to the files.
} 
serve to carry out your sanguine expectations and subserve the public safety. As a public servant we have much in you to commend, and at all times as citizens will lend our aid to assist you in your legitimate course of office.

May you long survive to serve the state of your adoption and receive the good wishes of your fellow-citizens.

Very truly, your obedient servant,

Stephen Payran,

President of the Executive Committee.

The raising of the fund was not completed until September. It finally amounted to about $\$ 4700$, and was placed at the disposal of Sheriff Hays, to be disbursed under his instructions by the treasurer of the society. ${ }^{77}$ The recorder's office of San Francisco still bears indirect testimony to this act of the Committee in two records showing that on February 6, and on Narch 30, 1852, B. D. Baxter and Sheriff J. C. Hays respectively acknowledged the satisfaction of liens on the county jail. ${ }^{78}$ It was proposed in the Committee that after these incumbrances upon the building were released, another lien should be executed in the name of the Vigilantes. In this way it was thought that the Committee might be reimbursed when the jail fund should be replenished from the county taxes. No record of such a lien has been found. ${ }^{79}$

The example set by the citizens of San Francisco when they banded together for mutual protection received the hearty approval of many of the smaller towns. As soon as the Committee felt assured of the support of its local community, it made a bold appeal for more extended coöperation by publishing the following open letter in the papers of San Francisco $:^{80}$

77 Papers, 622, 729, and Index under "County Jail of San Francisco." Facsimiles of interesting documents appear in Papers, 729; Popular Tribunals, I, 307.

${ }^{78}$ San Francisco-Recorder, General Index.

79 The lien is mentioned in the Papers, 157, 161, 602, 723, 729, 740 .

80 Herald, and Alta, 1851, June 14. 


\section{The Committee of Vigilance of San Francisco to the Citizens of Califor- nia:}

Should the order-loving portion of the citizens of Sacramento City, Stockton, the Pueblo de San Jose, Monterey, Marysville, and all other towns and cities of the State find it necessary, they are invited to form themselves into Committees of Vigilance, for the purposes set forth in the Constitution of the Committee of Vigilance of San Francisco.

The object of the formation of these committees is moreover for the purpose of corresponding with each other, so as to be able to mark and notice the movements of all disorderly or suspicious characters. By vigilance we may succeed in driving from our midst those who have become so baneful and obnoxious to our communities.

By ORDER OF THE COMMitTeE.

Friday, June 13, 1851.

The suggestion met with a cordial response. Before the end of June Committees were formed at Marysville, Santa Clara, and Sacramento, and in other neighborhoods as the summer went on. There was a constant interchange of correspondence between these independent associations, and mutual help was given in the detection of criminals. But the history of the out-of-town Committees is not an integral part of the narrative of the parent society, and it is considered by itself in a subsequent chapter. ${ }^{81}$

In San Francisco a gratifying decrease in crime marked the weeks that immediately succeeded the execution of Jenkins. No doubt this was partially due to the summer movement toward the mining regions. Both the Herald and the Alta credited it, however, to the influence exerted by the Committee of Vigilance, which by the end of June numbered between five and six hundred members. ${ }^{82}$ This created a large and effective force of private detectives, and since the uninitiated were ignorant of the extensive ramifications of the society, the rogues could never tell when one of the Committee might be at their elbows. ${ }^{83}$ With

81 See infra, p. 347 et seq.

82 Initiation fees for June were received from 477 members, and 71 remained delinquent (Papers, 764).

83 This fact was noted in the Herald, 1851, June 21 2/3. Ryckman related an amusing story of the horror with which a detractor of the Committee 
the exception of the names that had been printed after Jenkins' execution, the personnel of the association was shrouded in mystery. No secret, howeverr, was made of the aims and the methods adopted by the Vigilantes; the location of their headquarters was known to every one in the city, frequent notices were printed of their meetings, and many proceedings were reported so accurately in the leading papers that it is evident the Committee desired to keep the public informed of its policies and actions. ${ }^{84}$

The members of the Committee were still convinced of the existence in the community of some sort of organized band of criminals, recruited chiefly from the Sydney immigrants. From the investigations of the Vigilante police, and the testimony given by the witnesses in the cases of Burns, Hetherington, and other prisoners, they began to see definite traces of such a criminal brotherhood. Names appeared which were familiar on the dockets of the city courts-Adams, Beck, Edwards, Ainsworth, Ogdenand all seemed to be mutual friends and common habitués of the lodging houses kept by Sydney landlords. But the evidence was still so detached and indefinite that no one could unravel from it any clue to the band of outlaws who were supposed to haunt the nooks and corners of Sydney Valley.

learned that the friend to whom he complained was himself a member of the secret tribunal (MS Statement, 8).

84 See an excellent account of the work for June, from the Herald, infra, p. 462 . 


\section{JAMES STUART, OUTLAW}

With the opening of July the work of the Committee of Vigilance suddenly assumed a new and much more definite phase as a result of the capture of James Stuart, already mentioned in connection with the attack on C. J. Jansen and the arrest of Thomas Berdue.

This strange episode of mistaken identity seems almost incredible when one reads it among the tales of the California pioneers, but it loses none of its vividness when verified from the documents of the Committee of Vigilance and the court reports in the newspapers of the day.

Stuart, an ex-convict from Sydney who had been in California since November, $1849,{ }^{1}$ was widely and unfavorably known in the criminal records of the state under the aliases of Mason, Carlisle, Campbell, Long Jim, and English Jim. Early in October, 1850, he was tried by Judge O. P. Stidger, of Marysville, for the theft of four or five thousand dollars from Dodge and Company, of Foster's Bar. One attempt to lynch him was frustrated by the authorities, and he succeeded in breaking jail before the case was concluded. ${ }^{2}$ Two months later he was in the same region with two companions. As all three were out of funds, they "concluded that they might as well be dead as without money and agreed to go up to the mountains and rob every man they met, till each had $\$ 20,000 .{ }^{\prime}$ The first victim was Charles

1 See his statement, Papers, 139. A story was repeated by James O'Meara, who did not vouch for its truth, to the effect that Stuart, under the alias of Shaw, worked in the mines in Nevada County early in 1850, and honestly dispatched to England a very large sum of gold dust entrusted to his eare by an unsuspecting comrade (Sacramento Bee, 1881, Dec. 31, p. 1).
2 Papers, 169, 227.
3 Papers, 256. 
Moore, who was on his way to Marysville to make purchases for his store in the little camp of Winslow Bar, near the larger settlement of Foster's Bar. ${ }^{4}$ The bandits shot Moore in cold blood, secured a quantity of gold, and made their escape. Although Stuart's participation in the crime was generally suspected, he concealed himself for a time in Sacramento, where he drove a brisk trade in stolen horses and engaged in a profitable series of burglaries. He was several times under arrest for larceny, but was skilfully defended by Frank M. Pixley.

At one time while Stuart was confined on the prison brig $L a$ Grange, residents of Marysville recognized him and charged him with the murder of Moore. About the same time other men arrived from Auburn to see if the prisoner might be either of two brothers named Stewart, who had killed Sheriff Echols in Auburn, in June, 1850. ${ }^{5}$ With that murder Stuart had no connection whatever, but it was sometimes charged against him, and was often confused with the death of Moore, who was sometimes called "Sheriff Moore," or "Sheriff of Yuba." The people from Marysville were so sure of their man that they set about procuring the papers necessary for his removal. Before this could be accomplished the prisoner made his escape and went by a circuitous route to San Francisco, where he hid in various lodging houses of Sydney Valley. There he gathered to himself a band of kindred spirits and directed them in a series of daring robberies, including the assault on Jansen. ${ }^{6}$ In April he rode boldly down to Monterey, where four or five of his friends were on trial

4 History of Yuba County, 94, 124; Herald, 1851, March 28 \%. The murder was probably in December, and a footnote on p. 137 of the Papers should be corrected to that effect.

5 William and Samuel Stewart killed Echols on June 2, 1850. As the sheriff had been umpopular, the justice of the peace merely admitted the murderers to bail, to answer to the charge of assault with intent to kill. The county judge caused the rearrest of Samuel, but as he was allowed to exercise outside his place of confinement, he easily escaped, and neither culprit was brought to justice (Sacramento Daily Transcript, 1850, Aug. $131 / 5$ ).

6 See Stuart's confession, Papers, 231-23t. 
for robbing the Custom House of $\$ 14,000$ in the previous December. Assuming the alias of James Carlisle, he appeared as a witness in their behalf, and exerted himself in effective perjury. When the jury disagreed and the prisoners were remanded for another trial, Stuart again went to their rescue, broke open the jail, and then betook himself to the southern mines. ${ }^{7}$

Among the documents of the Committee of Vigilance is a stained and ragged sheet of letter paper, folded for mailing without an envelope, and once sealed with the convenient red wafer of business correspondence. Inscribed on the inner page is the following message $:^{8}$

Old Fellow

San Francisco June 19th 1851

Look out the Hawks are abroad and after you both here and down below, you had better keep in the upper Country at present, I can say no more at present

$$
\text { Yours S. W. }
$$

This was originally addressed to J. Taylor, Marysville, Yuba County, California, and consigned for delivery to Freeman's Express. The text and the address of this missive are neat and legible, but the cramped initials of the signature are the work of an awkward penman, and the same untrained hand has scrawled above the name of Taylor the further direction, "In eare of S. Stewart." The tattered sheet guards its secret to this day, but stimulates the imagination by suggesting that it was sent to Stuart by his companion, Sam Whittaker, as a warning to beware of trouble. In any case, we know from Stuart's own lips that he lingered in the mining region until near the end of June, then grew fearful of recognition there and returned to San Francisco to hide with an old friend and compatriot, Kitchen, the boatman. ${ }^{9}$

7 Papers, 237; infra, p. 309.

3 Papers, 62.
9 Papers, 237. 
Hearing before long of a Spaniard in the Mission whose house promised excellent plunder, he walked out there to meet an alleged cousin, called Stephens, and arranged with him the details of a raid. Assistants were necessary, and Stuart returned to town to obtain them. It is evident that the fear of detection was upon him, for on the morning of July 1 he was skulking in the underbrush of the sand hills, near the present corner of Powell and California streets, waiting for a safe moment to go upon his way, but retiring steathily as he spied approaching strangers. It was the old story of the fugitive betrayed by his own caution. It so happened that a house or tent in the neighborhood had just been robbed of a trunk containing clothing and valuables, and a party of men were beating the brush in search of the thief. They spied Stuart as he slipped furtively behind a bit of scrub oak and seized him before he could escape. ${ }^{10}$ His clean, light clothes, still creased from recent packing, led his captors to fancy that he might have discarded his own suit for garments appropriated from the missing chest. This he denied, insisting that he had not changed his clothes for some days, and that he was innocently walking back to San Francisco from the Mission. When they retorted that he had chosen a "damned pretty way to come from the Mission," he became confused, and it was determined to place him somewhere in safe keeping. The rooms of the Committee of Vigilance were suggested, as affording more security than the city lock-up. Stuart calmly acquiesced, remarking that he would go there with pleasure, since he was anxious to see the far-famed institution. ${ }^{11}$

At headquarters he made a favorable impression by reason of his apparent frankness and his attractive personality. He was

10 Papers, 140-143.

11 Ryckman, MS Statement, 9. 
a well proportioned man of medium height. One member of the Committee has described him as exceedingly handsome, and it was said that his features suggested the traditional pictures of Christ. ${ }^{12}$ His maner was always cool and confident, his courage equal to any emergency. When interrogated he gave his name as William Stevens (or Stephens), denied his connection with the theft for which he was arrested, and again tried to establish an alibi by stating that he had that morning walked from San Francisco to the Mission Dolores and back again, a story which may have been quite true. G. E. Schenck said that Stuart's answers were so prompt and his manner so open, that it was proposed to release him at once, in spite of the fact that he carried a pistol and a bowie knife fourteen inches long. His clean clothes, however, belied the assertion that he had worn them during the long and dusty walk from Sonora. This diserepancy aroused fresh suspicion, and it was decided to detain him over night. ${ }^{13}$

In his effort to account for his past life, Stuart went so far as to begin a written statement, which is still preserved among the archives, ${ }^{14}$ and is still potent to conjure up a vision of the clean-limbed Australian hiding his murderous past behind a mask of assumed frankness while inwardly alive to the deadly peril of his situation. He wrote but a few lines with his own hand, and the pencilled addenda indicate that Sam Brannan continued the statement from dictation, so that the pages become doubly interesting as relies of two vivid and historic personalities.

12 From a reporter's interview with an unnamed physician in Oakland, easily identified as Dr. Samuel Merritt (Oakland Tribune, 1881, April 5 $5 / 2)$. Stuart's attractive personality much impressed James Dows (MS Statement, 4).

13 Schenck, MS Statcment, 28. Other committeemen related the capture to Baneroft. They varied in slight details, but agreed as to the main facts.

14 Papers, 137-140. 
In the morning John Sullivan (he who assisted at the capture of Jenkins) went on guard duty. The events that followed are related by Schenck $:^{15}$

On taking his position, he naturally opened the door and looked in to see who was in his keeping, when he espied in a corner of the room, one whom he had formerly known, and he sung out to him "Halloo, Jim! How did you come here?", The person accosted pretended not to know him, and Sullivan said, "You needn't pretend not to know me; I know who you are. I worked for you six months at Foster's Bar." He then closed the door, and called to me, as I happened to be near, and said "Mr. Schenck, do you know who you have got here? . . . Why, you have got English Jim, or Jim Stuart, the man who murdered the Sheriff of Auburn [Charles Moore of Winslow Bar], and I was present when he was about to be lynched at Marysville, when the rope broke and he escaped.

In the first flush of exultation over the unexpected capture the thoughts of the Committee turned to the unhappy Berdue, whose trial at Marysville had been most fortunately delayed until the end of June. There was still a possibility of rescue, although not a moment could be lost. Schenck, assisted by R. S. Watson, ${ }^{16}$ raised funds the same afternoon to send a messenger to arrest proceedings. Captain Hartford Joy was entrusted with a letter from President Brannan to the Vigilance Committee of Marysville, asking assistance in gaining possession of "the person of Stewart, the assasin of Jansen." " 17 Two days later the Executive Committee instructed the secretary to ask the Marysville Committee to send to San Francisco several important witnesses to testify in the examination of the "Prisoner Stephens.", Both of these letters were acknowledged on June 6 by John H. Jewett, president of the Marysville Committee, ${ }^{19}$ who stated that "James Stuart, alias Thomas Berdue," had been found guilty on Friday, the fourth, and awaited sentence on Monday; that the local

15 Schenck, MS Statement, 29-30.

16 Schenck, MS Statement, 30. Watson had been foreman of the jury in the trial of Berdue in February and had used his influence to prevent Berdue's condemnation (Royce, California, 412).

17 Papers, 143.

18 Papers, 164.

19 Papers, 220-221. 
Committee was firmly convinced of his guilt, was determined to see due punishment inflicted, and was not at all inclined to allow a postponement on account of the capture just made in San Francisco. ${ }^{20}$

The witnesses, however, were sent as requested. In the meantime others had been found nearer at hand. ${ }^{21}$ On July 4 the prisoner was confronted by four men besides Sullivan, who positively identified him as the James Stuart of criminal notoriety. The accused was permitted to cross-question the witnesses, and Selim E. Woodworth acted as his advocate. During a part of the examination the British consul was present.22 Stuart still insisted that his name was Stevens, and repeated the story of the cousin in the suburbs of the city. In order to give him an opportunity to prove his tale he was driven out to the Mission with an armed guard and an escort of horsemen, but the elusive kinsman could not be discovered..$^{23}$ An effort was also made to identify the prisoner through the police of the city, and Officers W. A. Thorp, R. C. McIntire, and A. J. McCarty were called to headquarters. Thorp branded Stuart as a thief, but although McIntire and McCarty were well acquainted with the criminal, they stoutly maintained that he was unknown to them. Their staunchness was poorly repaid. When the rogue turned informer he included the two policemen in the long list of his confederates, and their names were often repeated by others of the gang. ${ }^{2+}$

In their search for competent witnesses the Committee turned to Frank Pixley, who had formerly acted as Stuart's attorney.

20 Details of the trial and testimony were given in the History of $Y u b a$ County, 124-125. See also Popular Tribunals, I, 194-196.

21 Papers, 165-170.

22 Papers, 176.

23 Papers, 165, 174. Curtis and Spence visited the Mission early in the course of the trial, and reported that they had been forestalled by someone who claimed to represent the Committee, and told "everything we knew!!!", (Papers, 169).

24 Papers, 176, 188, 234 note 31 . 
Pixley was now eity attorney of San Francisco, and he had previously sworn that Berdue was not the man he had defended at Sacramento. Bluxome related the interview with great zest:25

Stephen Payran, Jacob Van Bokkelen and myself were appointed a committee of three to examine those who came to the door. We went out and found Frank Pixley. Tan Bokkelen was the spokesman. Said he, "Pixley, will you say on your word of honor, if this man is the man whom you have defended time and again in the lower courts?" "I will, gentlemen,' said he. 'Van Bokkelen administered the oath, if it could be called an oath. We all went into the prisoner's room with Frank Pixley. The man was chained by his wrists and legs. He was sitting on a long bench, and the moment he saw Pixley, he thought his deliverer had come. He stood up, and we saw that they recognized each other, and Jake said to Pixley, "Is that Stuart or not?", Said he, "You have no authority to ask me any questions, you are an illegal body." The others heard what was going on through the thin partition, and when Pixley answered in this way called out, "Hang him! Hang him!" We had ropes and tackle all ready, and Jake just pushed him down the stairs, or he would have been hung. The people were angry with him because he defended all the thieves. Then we knew that the prisoner was the genuine Stuart.

The capture of James Stuart gave rise to a very serious situation in the affairs of the Committee of Vigilance. News of the arrest soon spread through the community, and the probable fate of the prisoner was discussed with the greatest interest. The Vigilantes knew that their action in this case would be taken as a test of their courage, sincerity, and self-control, and the early days of July were filled with hard work and strenuous meetings. The records for this period are evidently incomplete, as they fail to include some of the evidence in Stuart's case. ${ }^{26}$ They also omit all explanation of a very important change that occurred among the officers of the Committee, and which must be mentioned at this point although it may not have been connected with the excitement attending the trial.

25 Bluxome, MS Statement, 8-9. Pixley's connection with Stuart is further discussed, infra, p. 265.

26 Some of the missing evidence was published in the newspapers, and has been reprinted with the official documents. 
A day or two after the arrest of Stuart, Sam Brannan, hitherto the leading spirit of the association, relinquished all positions of importance. On July 2 he presided at a morning session of the Executive Committee, and wrote an official letter to Marysville. Another document that is mentioned in the minutes of that day he did not sign. It was signed instead by "Stephen Payran, President of Executive Committee," and Payran was definitely acting as chairman by July $4 .{ }^{27}$

A few days later Brannan considered himself so insulted by the sergeant-at-arms, A. J. McDuffee, that he wished to withdraw entirely from membership in the Executive Committee, and to give up the office he still held as general president. Explanations and apologies mollified him for a short time, but on July 8 he finally left the Executive Committee. On the next day the General Committee also accepted his resignation as president, tendered him a vote of thanks, and appointed Selim E. Woodworth in his place. ${ }^{28}$ In making these changes in the personnel of the leaders, the Committee of Vigilance gave an early illustration of its constant tendency to strengthen the power of the more conservative members. The trait is particularly worthy of attention because it diverges most radically from the inclination towards severity and violence that has marked the progress of many other extra-legal protective associations.

There are few records to show Woodworth's direct influence. He acted chiefly as a presiding officer, but his attendance at all meetings was regular and punctual, and under his guidance the General Committee was safeguarded from impetuous and ill-considered courses of action.

Stephen Payran on the other hand immediately and permanently imposed upon the proceedings of the Executive Committee the stamp of his own personality. He believed almost passionately in the legitimate function of the Committee as an expression

27 See Papers, 133, 143, 154, 164.

28 See Papers, 175, 179-182, 198, 202, 215, 246. 
of the will of the people at large, and as an agent to protect them from corrupt public servants; and he felt a solemn obligation to meet these responsibilities with integrity and justice, and to leave on record a careful history of the manner in which these duties were accomplished. Brannan was a wretched penman and an execrable speller, and few papers perpetuate his activities as president. Payran was indefatigable in preparing reports and wrote with his own hand many of the minutes of the Executive Committee. One may say that he never neglected any opportunity to attach his name to an official paper, and he signed and countersigned and attested and endorsed with supreme indifference to any personal punishment that the outraged law might ultimately inflict. He was painstaking, cautious, yet courageous - the antithesis of Brannan, who was all too ready to hang first and try afterwards. He assumed leadership in the Committee at a most critical time, when the archeriminal Stuart was handcuffed in the prisoner's room, and witnesses from all over the state were piling up against him a mass of damning evidence.

Stuart finally realized that further denials and evasions were useless, and all the members of the Committee seem to agree with a statement made by W. T. Coleman, that the culprit "conceived the idea of making a full confession, and asked the privilege of doing it." ${ }_{29}$ Bancroft portrayed the amount of selfrevelation as a dramatic climax to the breakdown of Stuart's incognito, ${ }^{30}$ but there is evidence to show that it was an audacious effort to evade a swift and righteous retribution. Before the Vigilante court technicalities and bravado availed him nothing, but he realized that his judges were eager to purge the state of the Sydney convicts. He therefore resolved to bargain to his own advantage, and at the sacrifice of his accomplices.

29 Coleman, MS Statement, 25.

30 Popular Tribunals, I, 281. It is possible that Bancroft often used verbal recollections of the Vigilantes as well as their dictated statements. 
We do not know to whom he made his first proposition, but in due time it was submitted to the Executive Committee. This we learn from a report ${ }^{31}$ which states that the prisoner was willing to make a full confession and to incriminate his various confederates, provided he should then be handed over to the courts for trial on the charge of the murder in Yuba County; if he failed to fulfill the stipulated terms, or to convict at least ten criminals, he was to remain in the hands of the Committee of Vigilance. Delivery to the constituted authorities would hold out an excellent chance of escape, and the prisoner was quite aware that an uncorroborated confession could easily be set aside in a legal trial. ${ }^{32}$ Stuart himself, using the alias of William Stephens, signed the report referred to, but although the document was endorsed as correct by President Payran, it was not countersigned by any other official and it is mentioned but once in the subsequent discussions of the prisoner's fate. It bears no date save the endorsed date of filing, July 9, but it affords a valuable clue to the impulse that prompted Stuart to unbosom himself to his jailers, and to lay bare not only his own crimes, but the guilty participation of many friends whose safety he had formerly guarded even at the risk of his own freedom.

On July 8 the General Committee met twice and the Executive Committee met three times. At the last gathering, held at half past ten in the evening, Mr. Spence was appointed to "conduct the examination of Prisoner Stephens," and it was ordered that questions should be put on paper and asked by Spence alone. ${ }^{33}$ Coleman said of the events of that night: $:^{34}$

I myself assisted, as one of the Executive Committee, in hearing and recording this confession, and sat up through the whole night, and until the morning sun shone in at the window, before it was completed. $\mathrm{He}$

31 Papers, 223-224.

32 The Vigilante (Dr. Merritt), who told of Stuart in the Oakland Tribunc, 1884, April $5 \frac{5}{2}$, said that the prisoner seemed to rely on this point of law.

33 Papers, 216. $\quad 34$ Coleman, MS Statement, 25. 
[Stuart] went through the whole range of his many rascalities, gave vivid descriptions of his adventures, entering with great zest into the details, and it was curious to see his eye brighten and twinkle, and a smile play round his facile countenance, when describing his kest successes, and recounting his best jobs. He threw off all restraint or reservation, and felt that he was bringing to light a brilliant record that had heretofore been necessarily kept in the dark.

The confession is dated, "Vigilance Committee Room, July 8th, 1850, 101/2 p.m.," and its length confirms Coleman's statement that it was not completed before daylight of the next morning. It did not reveal the prisoner's real name, and it touched but lightly on his early experiences, when as an English lad of sixteen he was transported for life to the penal colonies on a charge of forgery. Released after six years, he was free to drift first to South America, and later to San Francisco. Of his career in California he drew a startling picture. ${ }^{35}$

He gave details of more than a dozen robberies, and accounted for nearly $\$ 9000$ in money, beside much valuable plunder in tools, household furniture and horses. Many of the raids were accompanied by brutal violence. The speaker calmly acknowledged having dealt the blow that knocked Jansen senseless, and seemed to feel it was greatly to the credit of the real culprits that they resolved to burn the city again if the innocent Windred and Berdue suffered unmerited execution in consequence of that assault. Several abortive plots were also described, one of which entailed Stuart's devout attendance at mass at San José, while he kept his eyes alert for certain golden images reported as enshrined in the sanctuary. The bandit named about twentyfive accomplices ${ }^{36}$ but with all his apparent frankness he evaded betraying certain matters which he desired to conceal. So far

35 See Papers, 225-242. Schenck said of Stuart's trial: "Witnesses were sent for from all parts of the state, and whenever he suggested any witnesses, to prove an alibi, or for any other purpose, they were sent for, at a considerable expense to the Committee'" (MS Statement, 31).

36 Papers, 225 note 12. 
as we can learn, he never acknowledged his share in the murder of Charles Moore, ${ }^{37}$ although the trial of Berdue at Marysville seems clearly to have established his guilt on that charge. In the long list of companions whom he implicated in his misdeeds he made very inadequate allusion to Samuel Whittaker, who was second in leadership to himself, and shared in many of the most high-handed outrages.

Other sources of information, however, were available to the Committee. On July 8, the same day that Stuart made his confession, there was filed in the archives a written statement made by Joseph Hetherington, ${ }^{38}$ who was intimately acquainted with the Sydney men, especially with those who congregated at a boarding house kept by a Mrs. Hogan, where Stuart himself had sometimes lodged. This paper was dated July 7 , and if it was received prior to Stuart's examination it must have been of great assistance in drawing from him details as to his associates. Hetherington showed the importance of Whittaker's position among the desperadoes, and in a later statement asserted that Whittaker had plainly told him that Stuart had shot Moore and had afterwards exhibited a large gold nugget which had been taken from the body. ${ }^{39}$

In spite of the general knowledge of Stuart's arrest, ${ }^{40}$ no official protest was made except by the city attorney, Frank M. Pixley, whose personal convictions and whose public position placed him in open opposition to the course pursued by the

37 Schenck said the murder "was clearly proved against him at the trial"' (MS Statement, 43). Stuart alluded to the charge in exactly the same way that he mentioned the false accusation as to the murder at Auburn (Papers, 231), and the Reverend F. S. Mines, to whom he made a penitential confession, was ignorant that the charge of murder had even been laid against him (Papers, 311). It was said that at the time of execution he publicly acknowledged that his confession was true, but denied that he was guilty of murder (Sunday Dispatch, 1851, July $132 \% 4$ ).

38 Papers, 242-245. See also note on Hetherington, infra, p. 402.

39 See Papers, 256, 477, 480.

40 The capture of Stuart was announced in the daily papers, July 7 . 
Committee of Vigilance. The reports of proceedings in the Supreme Court on July 8 and 9 show his efforts to secure the person of Stuart by a writ which summoned W. H. Jones, A. J. McDuffee, J. L. Van Bokkelen, and Stephen Payran, to produce their captive in court. ${ }^{41}$ Issuance of the writ was promptly reported to the Committee, and the gentlemen named therein were given leave to retire from the rooms. ${ }^{42}$ Service was effected in the case of the three first mentioned, but President Payran "was not found, after diligent search." When the members of the Committee appeared in the Supreme Court on the ninth, they made affidavit that they did not have said Stuart in their possession, and had never had such custody as would have enabled them to comply with the order.

On the petition of Pixley another warrant was then issued, directing Sheriff Hays to obtain the body of James Stuart and bring him into court on the following day. Isaac Bluxome, Jr., thus described what followed $:^{43}$

Frank Pixley went to work and got out a writ of habeas corpus on us for the surrender of Stuart. We knew the writ was coming, and we did not want to refuse it, and so I borrowed a long cloak and slouched hat, and Oaks [Oakes] and I dressed Stuart up in them and took him to Endicott \& Oaks building on First St. between Market \& Mission. We showed him two pistols, and said to him, "If you attempt to run, we will shoot you." We put him down cellar there. When Endicott went home, we placed a guard over him. Endicott came back and said, "This won't do, I am a city official,44 and have taken the oath to support the government.', This was in his own building. Rube Maloney, who was also a member of the Committee said..."I will put him in my house." So we walked him up there to his house, to keep him clear of the habeas corpus. About 12 o'clock down came Maloney, and said he could not keep him any longer.... We sent a guard and took him to some other place, and he was shifted round to keep him away from the Sheriff.

\footnotetext{
41 Herald, 1851, July $9 \% 3 ; 10 \% \frac{4}{4}$ Alta, July $9 \% 3 ; 10 \%$.

42 Papers, 214.

43 Bluxome, MS Statement, 11-12. The committee in charge of Stuart was given a formal rote of thanks, July 10 (Papers, 254).

44 Endicott was an alderman (Annals, 326). He was not a Vigilante.
} 
The method was entirely successful. Hays was allowed to inspect headquarters, but he found no Stuart in the guardroom. He went into court empty-handed to report that he had searched the city in vain, and had even followed a carriage out as far as the Mission in the hope of securing the missing man. This ended all active attempts to effect a rescue. Broderick and others held a meeting on July 9 or 10 for the purpose of organizing a company to sustain the civil authorities and to prevent the infliction of punishment upon any citizen without due process of law, but it did not result in any noticeable public movement. ${ }^{45}$

Within a few days the city attorney had cause to feel that he was treacherously requited for the efforts he had made. The publication of Stuart's confession created the impression that Pixley undertook his defense in Sacramento in the face of positive evidence of guilt, and permitted perjured testimony to be presented. Stuart also claimed that the lawyer had appropriated the whole of a sum of $\$ 730$, confided to him for safe-keeping, of which only $\$ 230$ was due for professional services. He put in the hands of the Committee a statement of this alleged account, and an order for the balance of $\$ 500$. Pixley printed in the San Francisco papers a communication in which he most indignantly denied the charge that he was aware of his client's guilt, or had connived at perjury; and as for the $\$ 500$, he explained that he had kept it as a retaining fee in expectation of continuing the defense at Marysville. The letter is printed in full in the Papers as a footnote to Stuart's confession. ${ }^{46}$

Some of the members of the Committee entertained serious misgivings over their evasion of the time-honored provisions of the writ of habeas corpus, ${ }^{4 \pi}$ and the fact that the Alta California

${ }^{45}$ Reported in California Courier, 1851, July 11 \%2. See also. Popular Tribunals, I, 320.

46 Papers, 230-231, 242, 293.

47 "We thought it a terrible thing to deny the writ of habeas corpus" (Farwell, MS Statement, 9). 
had advised them to obey $i^{48}$ may have increased their uneasiness. Nevertheless, the precedent established in Stuart's case was followed a few days later when another prisoner was retained in defiance of a writ. ${ }^{49}$ The question was considered so important, however, that a subcommittee was appointed to "examine the question of the use and abuse of the writ of habeas corpus and report the same to this Committee with its opinion of the degree of respect which shall be accorded by the Vigilance Committee to that writ. ${ }_{50}$ Dr. A. B. Stout, W. L. Bromley, and C. H. Brinley were charged with this duty, and they soon submitted a paper that was an interesting exposition of the Vigilante point of view. ${ }^{51}$ They traced the origin of the writ of habeas corpus and acknowledged its great value when legitimately employed; but they asserted it became a menace to society when it was used to promote the escape of the guilty, and they concluded that the Committee of Vigilance was justified in refusing obedience to writs which sought to remove prisoners before their cases had been investigated. They said:

It is against the abuse of the Habeas Corpus that this people are called to raise their voice. And if the Vigilance Committee be the people, it is through the former that the latter may obtain justice and freedom from the ills which oppress and ruin our community.

As this report was not presented until August 2, the chronological narrative is somewhat dislocated by its introduction here. Yet it was so directly an outgrowth of the evasion in the case of Stuart that it should be closely related to that circumstance. The members of the Committee knew beyond peradventure that

48 Alta, 1851, July $92 \%$.

49 See case of LeBras (Papers, 281). Writs were also evaded in the cases of Arentrue, and of W. H. Hays (ibid., 414, 441), and subterfuge was employed when Bluxome was summoned to produce his records in court (ibid., 731).

50 Papers, 357. At the same time the General Committee laid on the table a motion giving the sergeant-at-arms and the chief of police diseretionary powers to admit civil officers to headquarters.

51 Papers, 404-407. 
delivery of their prisoner to the courts would result in his escape from punishment, and that defiance of the writ was the only way in which they could retain him, but with unconscious inconsistency they found it necessary to appoint a formal committee to consider the infraction of a minor constitutional privilege, while they contemplated without trepidation the far graver responsibility of inflicting the penalty of death!

That penalty for Stuart became more and more certain. Meetings of the General Committee were held on July 9 and 10, when reports were submitted touching the case, but no definite action was taken. About half past nine o'clock on the morning of Friday, July 11, San Francisco heard again the measured tapping on the bell of the Monumental Engine Company, and watched groups of well-known citizens hurrying, in open day, towards the headquarters of the Committee of Vigilance. ${ }^{52} \mathrm{~A}$ large majority of the entire membership assembled at that summons, and listened for three hours to the reading of Stuart's confession and the evidence of witnesses. Then for some time they debated the punishment, while the prisoner in an adjoining room complained that the slow trial was "damned tiresome," yawned indolently, and solaced himself with a quid of tobacco. The record of this long session is brevity itself. It reads $:^{53}$

\section{Minutes of General Meeting July 11, 1851}

Mr. Selim Woodworth in Chair

On Motion

Resolved-That Evidence in case Stuart be read. Questions by Dr. Stout and Mr. Dows 54

Has the prisoner performed his contract or not? No Unanimously-

Has the prisoner been guilty of crimes rendering him liable to the punishment of death-Yes-unanimously-

52 Full accounts of the trial and execution were given in the Alta and the Herald, July 12 to 14 .

53 Papers, 263-264.

54 Probably James Dows. John Dows was also a member, but his name appears nowhere in the minutes of the Committee. 


\section{On Motion}

Resolved That Prisoner Stuart be hung-unanimously carried-

Resolved that a Clergyman be sent for to remain with Prisoner until he is hung-

Resolved That Prisoner be hung at 2 o'clock

Resolved That Ex Com make necessary arrangements

Resolved That no person be allowed to leave the room

Resolved That Prisoner receive his sentence

Resolved That Col Stevenson inform the populace that at 2 o'clock the prisoner Stuart will be hung-

The Chair announced that the Clergyman was now in the room with prisoner On Motion

Resolved That a Committee be appointed to draft a form of the testimony to be published in the papers of tomorrow morning

\section{On Motion}

Resolved That the Com take a recess of half an hour

These minutes are in the handwriting of Secretary Bluxome, although he did not sign the page as usual. The allusion to the contract is the only direct reference ever made to the document which proposed to deliver Stuart to the authorities of Yuba County if he made a full confession, although at one time Stephen Payran favored sending him to Marysville in order to secure Berdue's release. ${ }^{55}$ Nowhere is there a discussion of the force of the agreement, nor any explanation of the decision that its provisions had not been met satisfactorily. The promise of immunity is not mentioned in the recollections of any of the Vigilantes; Bancroft did not speak of it; and no charge of treachery has been laid upon the Committee, even by the men who most opposed it. The minutes show that the matter of the contract was considered and decided by a unanimous vote. With the meager facts at our command it is futile to attempt to pass judgment on the point of honor, or to decide whether the failure to acknowledge the murder of Moore placed the murderer beyond the pale of clemency.

The convict received his sentence composedly. He was then allowed an interval for the ministrations of the Reverend Mr.

55 Papers, 224-225. 
Mines, who found him a more hopeful penitent than was his predecessor, Jenkins. In his youth Stuart had been a communicant of the Church of England, and in the last moments of his life he responded to the appeals made to his better instincts, acknowledged the justice of his sentence, and received the absolution of the Church. ${ }^{56}$

During the two hours consumed in these preparations "the four hundred members in the Committee Room sat like statues on their seats-not a word was uttered, not a sound was heard to break the solemn stillness." and as the silent moments slipped away each man who had affirmed the verdict must have felt a growing sense of personal responsibility for the approaching execution. In accordance with the precedent set on a previous occasion, Colonel Stevenson was appointed to refer the sentence to the approval of the populace. The crowd outside was large, but patient, and heard with attention an account of the trial, a resumé of the confession, and a report of the sentence. Then the question was put to the citizens: Would they sustain the action of the Committee? And the vote of endorsement was "almost unanimous." 58

About three o'clock a stream of silent men began to emerge from the headquarters of the Committee. In the street they formed into platoons, ten abreast, and with Stuart in the center swung eastward toward the water front. The condemned man "marched as erect and with as firm a tread as any innocent man and no one could see in his actions any indications of agitation." 59 When the ranks reached Market Street wharf they parted to the right and left, and gave passage to the bodyguard, then closed again, locked arms, and ranged themselves into a

56 See Mr. Mines' letter on the subject, Papers, 308-312.

57 Herald, 1851, July $14 \%$.

58 Herald, 1851, July $142 / 3$.

59 James Dows (MS Statement, 4). Stuart's composure was especially noted in the Sunday Dispatch, 1851, July 13. 
solid barrier. ${ }^{60}$ A derrick upon the pier had been selected for the place of execution, and there James Stuart, with unshrouded face and clasped hands, received the bitter punishment of his years of crime, while the multitude stood uncovered below him, hushed and motionless, and irresistibly moved by the fearless composure with which the outlaw met his doom.

When the coroner was allowed to take possession of the body $y^{61}$ he observed the formalities of his office, and impaneled a jury which promptly found :62 "That the deceased came to his death by strangulation by hanging at the hands of a body of men styling themselves the Vigilance Committee of San Francisco.'

In its deliberate and open defiance of the law the execution of Stuart far exceeded the hasty action in the case of Jenkins. The constituted authorities were in duty bound to take public cognizance of such an occurrence, and the mayor, Charles J. Brenham, immediately published an open letter addressed to the citizens of San Francisco, in which he pointed out the insurrectionary tendencies of the Committee of Vigilance and called upon the people to withdraw from its ranks and assist the authorities in supporting the laws. ${ }^{63}$

60 Smiley said that while there was no regular military organization in the Committee of ' 51 as there was in the Committee of ' 56 , military formation was adopted at the execution of Stuart. He remembered the company as about 380 men, and said he commanded the escorting squad, and stood within twenty feet of the seaffold (MS Statement, 5). A poor eut of the scene is reproduced in the Annals, 580 .

61 Herald, 1851, July $142 / 3$. Smiley said that while Stuart was dying "Ned Gallagher came along, stopped at my platoon with arms locked and said, 'I demand permission to pass.' Middleton said, 'Who are you?' $\mathrm{He}$ said, 'By God, Middleton, you know I am a coroner!' 'By God,' was the answer, 'you don't get through till that fellow's a fit subject for your administration' (MS Statement, 4-5). There was a report that life was not absolutely extinet when Stuart was eut down, although all efforts failed to revive him (Alta, 1851, July $13 \% \frac{1}{4}$; Herald. 1851, July $14 \%$; Ryekman, MS Statement, 16). J. W. Palmer wrote: "The first man hung by the San Francisco Vigilance Committee was dead before he was swung up. and the second... was alive after he was cut down' (The New and the Old, 1859, p. 73$)$.

62 Herald, 1851, July $14 \% 3$.

63 See infra, p. 463. Sections of the act covering the suppression of riots followed the mayor's letter, in the Alta, July 13-15. 
Thus Mayor Brenham discharged his duty, but Alexander Campbell, judge of the Court of Sessions, was made of sterner stuff. The assurances made in his letter to Sam Brannan had been no idle boast. In accordance with his determination to expedite justice he had impaneled a grand jury early in July, and that body immediately showed itself zealous in the performance of its duties. Calling this jury into court on the morning of the twelfth, Judge Campbell brought to its attention the event of the previous day. He declared that the people must decide without delay whether or not they were willing to throw away all safeguards of society, to declare that law was inconsistent with liberty, and to place life and property at the mercy of a secret organization. He denounced the execution as an inexcusable outrage, accused all who had abetted it of the crime of murder, and charged the jurymen that it was their sworn and solemn duty to bring the guilty to punishment. ${ }^{64}$

The Alta of July 13 stated that after the charge had been delivered Mr. C. L. Ross asked to be excused from further service, as he had friends belonging to the Vigilance Committee, and his feelings would not allow him to bring in a bill against any of them. The application was refused, Judge Campbell stating that his own position was similar, but that they were all sworn to perform their duty and no private feelings could be allowed to interfere with their oaths. Eight other members of the jury were in a position infinitely more difficult than that of Mr. Ross, being themselves members of the Committee, and thus under the "sworn and solemn duty" of bringing against themselves and their closest associates indictments for the crime of murder. ${ }^{65}$ It is probable that Judge Campbell was unaware of the subtle humor of the situation, although two of the jury, J. D. Farwell and W. B. Peake, had signed the list of members published immediately after the execution of Jenkins.

64 See infra, p. 464.

65 See names of the jurymen, infra, p. 467. 
In an editorial condemning Judge Campbell's attitude, the Herald pointed out the futility of any such attempt. It approved the hanging on the ground that the law, if properly executed, would have inflicted the same penalty long before, and concluded as follows :

What moral wrong, then, has been committed? The law has been violated, it is answered. Ay, the law; but the Sabbath was made for man, and not man for the Sabbath, and the citizen is not made for the law, but the law for the citizen; and whenever the law becomes an empty name, has not the citizen the right to supply its deficiency?

The California Courier of the same date expressed similar sentiments, blamed the inefficiency of the public officials for the prevalence of crime, and asserted that it would do little good for the coroner to investigate the deaths of criminals executed by the people while he neglected to take note of the victims of cold-blooded murder. ${ }^{67}$

The grand jury took no steps to indict the five or six hundred members of the Committee, but it alluded to Stuart's execution in its final report, and regretfully acknowledged that the deed was "unlawful." At the same time it deplored the situation in the District Court that had moved the Vigilantes to action, and urged the officials of the city to remedy the causes of complaint. ${ }^{68}$ Judge Parsons was so offended by the criticism of the District Court that he asked to have that portion of the report stricken from the records, but Judged Campbell overruled the motion. ${ }^{69}$

Following the precedent set by Mayor Brenham the governor of the state issued a proclamation that dealt with the dangers that attended the organization of Committees of Vigilance in various places. His arguments were much the same as those used by Brenham and Campbell, but he suggested that it would

${ }^{66}$ Herald, 1851, July $142 / 1$.

67 See infra, p. 465.

68 See infra, p. 466.

${ }^{69}$ Herald, 1851, August 9 2/2; $11 \%$. 
be quite legitimate to form protective associations if they would assist the officers of the law and the civil authorities in detecting and punishing crime. ${ }^{70}$ This message was not written until ten days after the execution of Stuart, and in the meantime the Committee of Vigilance of San Francisco greatly enlarged its sphere of activity. Stuart's confession provided the long-sought clue to the gang of criminals that had infested central California. The community at large gave unmistakable evidence that the Committee could depend upon the support of popular approval. The Vigilantes, therefore, resolved to search for the outlaws, one by one, and deal with them according to their deserts.

70 See infra, pp. 467-469. 


\section{CHAPTER XIII}

\section{ON THE TRAIL OF STUART'S COMPANIONS}

Stuart had named about twenty-five participants in the robberies he described. By order of the General Committee his confession, accompanied by the evidence in his case, was sent to the papers on the day of the execution. ${ }^{1}$ It was published immediately, with the omission of some names which at the time the Committee wished to conceal. It was republished a week later, and the suppressed portions inserted in full, that the community at large might assist in the apprehension of the criminals.

The most important members of the gang were known to be Sam Whittaker, George Adams, Robert McKenzie, James Burns (usually called Jimmy from Town), Joseph Turner, Richard Osman, Jim Briggs, John Edwards, and John Morris Morgan. T. Belcher Kay, late port warden, was a valuable confederate on account of his official knowledge ; Kitchen, a boatman, constantly served them when they were in need of transportation; and Big Brummy, Dab the horse thief, Billy Hughes, Long Charley, Ryan, and others were useful members of the company. The two policemen, McIntire and McCarty, were depended on to protect them from arrest, and to help in making

1 See Papers, 263 note 1 . The following note prefaced the testimony in an extra edition of the Herald, July 11:

"Editor San Francisco Herald:

The accompanying documents in the case of Stephens, alias Stuart, alias Campbell, alias English Jim, alias Carlisle, alias Mason, are handed you by order of the Committee of Vigilance for publication, your doing so will much oblige them and disabuse the public mind touching the affair.

Respectfully,

The Executive Comaititee,

Per Order of Committee of Vigilance.' 
escapes, and a boarding house kept by Michael Hogan and his wife, Mary Ann, was a safe and favorite place of meeting. The popular term "criminal organization" was scarcely applicable to the loosely knit band, but the Vigilantes realized that they had uncovered the trail of desperadoes who very seriously threatened the good order of society.

The most effective work of the Committee began at this point. Orders were immediately issued for the arrest of many of those implicated; searching parties were sent into the interior, and several important captures were made with little difficulty. The first member of the gang to be taken was Jimmy from Town, a small, clean-shaven, Irish sailorman, an adept in the peculiar patter of the thieves' jargon, and a burglar of celebrity. ${ }^{2}$ Jimmy would steal anything on which he could lay his hands-a trunk of clothes, an office safe, the wallet of his own pal, the earnings of a disreputable woman. When his Irish temper was aroused he would quarrel with his confederates and spoil their plans, so that the more cautious sometimes refused to work with him. But he was useful in many raids, was especially expert in executing daring jail deliveries, and had led in several of the breaks from the San Francisco station house. This light-fingered gentleman was caught in Marysville on July 16. Two days later representatives of the Committee secured George Adams, for whom they had been searching since the first days of their investigations.

Adams, who rejoiced in the flattering alias of Jack Dandy, was of English birth and recently from Sydney. While the stigma of penal servitude was not proved against him, he was known in California as a seasoned criminal and a chronic truant from disciplinary lodgings. He was also a useful member of Stuart's organization, since his trade of engineer or millwright

2 For a description of this notorious thief, see Papers, Index under "'James Burns.' 'His arrest was announced in the Herald, 1851, July 18 2/1. 
enabled him to design tools and keys for expert operations. ${ }^{3}$ Being at this time a refugee from justice, he had hidden himself in a lonely spot on the banks of the American River, where he was arrested by civil officers on July 17, but discharged for lack of positive identification. Members of the Vigilance Committee, more alert in their investigations, seized him before he could again conceal himself, and speedily transported him to the prisoners' room at San Franciseo.

Dab, the horse thief mentioned by Stuart, was delivered to the Committee by gentlemen from Marysville on July 17, but Sam Brannan, who had some hand in his capture, effected his release a few hours later for unexplained reasons, and to the great indignation of the entire association. The incident occurred on a night when there was evidence of unusual excitement and tension in the rooms of the Committee. Dab seems to have been at large in the outer apartment, but Van Bokkelen, the chief of police, had taken the precaution to forbid egress from headquarters to all except those who were provided with special permits. Brannan, then merely a private member of the General Committee, attempted to remove Dab from the room in defiance of Van Bokkelen's regulations, and finally succeeded in forcing him through the door when it was opened for some one who had the required pass. Before Brannan could follow the chief pulled him back, whereupon there ensued a general rush for the exit by others who had resented detention. Brannan struggled to release himself, threatening "in not very polite language" to use his pistol unless liberated. He was finally allowed to go, the room was cleared, and order restored.

Van Bokkelen reported the occurrence in an indignant note to the Executive Committee, and asked that it be decided whether or not his power was superior to that of a private member, and

3 See Papers, Index under "George Adams." His arrest was noted in the Herald, 1851, July $21 \%$. 
whether or not frivolous pleas should be allowed to frustrate the ends of the Committee. Many voluntary associations would have been disrupted by such a quarrel. In this instance the whole question of authority was referred to the Executive Committee, and was quickly settled by the formulation of adequate by-laws, which were passed a few days later. At the same time the General Committee adopted resolutions which pledged all members to implicit obedience to the orders of the chief of police. The incident left the Committee of Vigilance more efficiently organized than ever before. ${ }^{*}$ It also gives a valuable hint of the crises that must have developed in a body of determined and self-confident men when disputes arose that involved freedom of personal action. Only the bond of a sincere and common purpose could have held them together in irksome subjection to such control.

Brannan ceased to play a leading part in the Committee from this time. A week later he stated that he no longer had free access to headquarters, and was helpless to assist an acquaintance who was under suspicion. ${ }^{5}$

Determined to rid the country of the worst elements of Stuart's gang, the Committee continued the search for other fugitives, especially for Sam Whittaker and for Robert McKenzie. Both of these men were supposed to be in the vicinity of Sacramento or of Stockton. As early as July 10 a party was sent out to secure them, but the search was unavailing. ${ }^{6}$ The sergeant-at-arms headed another posse, summoned assistants from the Committees of Stockton and Sonora, and scoured the country about Stockton, Chinese Diggings, Georgetown, Jamestown, Shaw's Flat, and Sonora. ${ }^{7}$ That expedition cost the Committee nearly two hundred dollars. At its close the quest was

\footnotetext{
4 See Papers, 227 note 14, 294-296, 340-343; also supra, p. 226.

5 Alta, 1851, July $2+2 / 1$.

6 Papers, 253, 265, Voucher no. 12.

7 Papers, 282, 303, Voucher no. 10.
} 
given over to the Committee of Sonora, since it was thought that the fugitives were hiding somewhere in the neighborhood of the southern mines.

McKenzie was finally discovered in Sacramento, was arrested on July 29 at the instigation of J. G. Schultz, a member of the San Francisco Committee, and was safely incarcerated at headquarters by the first of August; ${ }^{8}$ Whittaker, however, still baffled the Vigilante detectives.

This man for whom they were searching through the highways and byways of California seems to have been the typical villain of melodrama. He was about thirty years of age, of medium height, courageous and manly in his bearing, exceptionally neat and particular in his habits of dress, and, according to Joseph Hetherington, the smartest thief in the whole group. ${ }^{9}$ Like Stuart, he had been transported from England in his early youth under a life sentence. He had been freed by a conditional pardon, and had come to California in $1849 .{ }^{10}$

After some vicissitudes he formed a partnership with an Australian named Teddy McCormac, and together they opened the Port Phillip House, which quickly became a rendezvous for thieves and ruffians. There the two men led a career of successful crime until they treacherously despoiled too intimate an acquaintance, one James Kelly, "the fighting man," who reimbursed himself by selling out the Port Phillip House while the senior partner was in Monterey committing perjury in the interests of the robbers of the Custom House. ${ }^{11}$ Whittaker, thus dispossessed, removed to the Hogans' establishment during Mr. Hogan's absence in the mines.

8 Papers, 402 note 3.

9 Papers, 243. Ryckman was much attracted by Whittaker's manly personality (MS Statement, 10).

10 Papers, 468-469.

11 Papers, 236, 468, 470. 
The new lodger was attractive and unfettered by scruples, his hostess was equally attractive, equally unscrupulous, and they quickly resigned themselves to an intimacy that became notorious. On Hogan's return from the country he forced the unwelcome guest to leave, but the sordid story had become a matter of common report, and Hetherington repeated it to the Executive Committee with a frankness that could not be misunderstood. It is not beyond the bounds of probability that the two leaders of the Sydney circle were rivals for the favor of the same mistress. Stuart had made no mention of Mrs. Hogan's fondness for Whittaker, but boasted that she wore a daguerreotype of himself; while Whittaker accused Stuart of plotting to shoot him, either for money or because of jealousy. ${ }^{12}$

The importance of Mrs. Hogan's position was quickly realized by the Committee, and she and her husband were taken to headquarters immediately after Stuart and Hetherington had first mentioned their names, but the woman cleverly evaded compromising questions and betrayed none of the secrets of her lodging house. She denied any relationship with Whittaker beyond that of innkeeper and guest, and when her place was searched she foiled the Committee by secreting his likeness. ${ }^{13} \mathrm{Mr}$. Hogan aired his grievances without reservation. While he contributed nothing of value to the records of the Committee, he must have derived much personal comfort from this opportunity to brand his supplanter as a roundshouldered person with a turned-up nose. ${ }^{14}$

After Stuart's confession was published Mrs. Hogan tried to avoid further embarrassment by leaving the country, and took passage on the Cameo for Sydney. The Committee sent on board the yessel and removed her to headquarters, then made further search to see if Whittaker had concealed himself on the same

12 Papers, 242, 474, 475.

13 Papers, 257-259, 458.
14 Papers, 260. 
boat. $^{15}$ Though the inspection was fruitless and the woman was quickly released, a watch was kept over her movements. When she presently went to Stockton, orders were sent there to have her followed in the hope of discovering Whittaker's hiding place. ${ }^{16}$ The surveillance proved futile, however, and another searching party was sent to Sacramento to examine thoroughly the sloughs and creeks of the marshy river. ${ }^{17}$ Quietly and unobserved Mrs. Hogan slipped southward from Stockton and made her way to San Diego, where, in fact, Whittaker expected to join her. He evidently took the coast route, for he was recognized on August 8 in Santa Barbara, where he was taken into custody by Sheriff V. W. Hearne, who at once embarked for San Francisco, intending to deliver him to the police of that city. ${ }^{18}$

Once again a strange chance placed the Vigilance Committee in possession of an important captive. While Hearne was looking for Sheriff Hays he entered the office of J. C. Palmer, to whom he mentioned his errand. J. C. L. Wadsworth, a member of the Committee, had a room in the same building. Palmer immediately told him that Whittaker was even then on board the steamer Ohio lying at Long Wharf. Wadsworth hurried to the water front, meeting J. F. Curtis on the way, and together they induced the captain to deliver the prisoner to them, and so transferred him without violence to the guard room of the Committee of Vigilance. Hearne was reimbursed for the expense of

15 Papers, 293, 298, 335. "The famous Mrs. Hogan... was seized on Saturday on board a ship in the harbor... and removed to the Committee Rooms..... She is about thirty-five years of age, quite genteel in appearance, and one who might safely keep a crib without ever being suspected. Her carriage, the most elegant in the city, was waiting on Saturday morning at the door of the Committee Rooms. For what cannot be said-certainly not for the interesting female within', (Herald, 1851, July $21 \%$ ). Voucher no. 15 in the Papers, shows that the carriage was hired by the Committee at an expense of $\$ 16$.

16 Papers, 363.

17 Papers, 414-416.

18 Papers, 435-436; Herald, 1851, Aug. $12 \%$. 
the trip from Santa Barbara, and he expressed no dissatisfaction with the final disposition of his eaptive. ${ }^{19}$

Both Whittaker and McKenzie proved difficult to handle, maintaining for some time such a stubborn silence that we may leave them, as it were, handeuffed in their prison, while we follow other events of July and August.

Much energy was consumed in pursuing other companions of Stuart. Thomas Quick and some of the lesser thieves were caught later, but the Committee was not always successful in securing the prisoners it desired. Thomas Belcher Kay, for instance, was followed in vain although he was in Sacramento when the early suspicions of his eriminal activities ${ }^{20}$ were confirmed by Stuart's confession. Officers were immediately dispatched to arrest him there. They actually had him in their hands on July 11, the day Stuart was hanged, but in view of the intense excitement prevailing at the time Kay persuaded them to allow him to remain at large, and although he then gave his word that he would accompany them voluntarily on the following day he promptly broke this parole and took advantage of his liberty to escape to San Francisco disguised as an old woman. ${ }^{21}$ With assumed frankness he wrote to the Committee, promised to surrender himself when desired, and requested that E. G. Austin should be retained as his counsel, but the office was indignantly refused by Mr. Austin, who more than once acted as legal adviser to the Vigilantes.

Mr. Kay, however, had some friends who were willing to appear in his behalf. One of them was William Thompson, Jr., who with commendable forethought sought to provide sanctuary for the fugitive in one of the crowded apartments of the county jail. On July 11, while Kay was still in Sacramento, Thompson

19 Wadsworth, in MS Vigilance Committees-Miscellany, 25-26; Papers, 454, Voucher no. 40.

20 See supra, p. 238.

21 Papers, 276-277; Herald, 1851, July 16 2/5; 17 2/4; Aug. 11 2/5. 
made affidavit in San Francisco that the former port warden was even then unlawfully restrained of his liberty on a steamer in the Bay, by "a great number of persons who styled themselves the Vigilance Committee." In that way he procured a writ that required the sheriff of San Francisco to produce the said Belcher Kay in court, in order to prevent his execution at the hands of his captors. Kay's counsel, Mr. McHenry, then placed his client in the sheriff's care, merely for the purpose of protecting him from the threatened violence of the Vigilance Committee. While he was in confinement the grand jury investigated his affairs, and in order to obtain all the information possible asked the Committee of Vigilance for whatever evidence it had, and even risited headquarters in a body to discuss the matter with the Executive Committee. ${ }^{22}$ Kay's case was called in court on the same day, but as no complaint had been lodged against the prisoner he was discharged on the ground that the county could not afford the expense of his maintenance or the risk of damages for unlawful detention. ${ }^{23}$ The grand jury immediately caused his rearrest. ${ }^{24}$ but after ten days of imprisomment he was again released. " the Grand Jury having represented to the court that they had no presentation to make against defendant." The Committee of Vigilance, learning of the order for his discharge. watched the jail and the outgoing Panama steamer in the hope of making an arrest, but Kay slipped through the guard and made good his escape. ${ }^{25}$

He was fortunate in departing just when he did, for in a few days Whittaker and McKenzie gave further details of his crimes.

22 Papers, 290, 298. "The Grand Jury and the Vigilance CommitteeThese two important bodies, the former of which is charged to bring in indictments for murder against the latter, had a free conference on Saturday at the Committee Rooms. The purpose and proceedings have not transpired', (Herald, 1851, July $21 \%$ ).

23 Herald, 1851, July 21, 2\%; $22 \%$.

24 Herald, 1851, July $21 \%$.

25 Herald, 1851, Aug. 2 2/4; Papers, 400. 
His real name, said Whittaker, was Gibson, and he was also known in England and Paris as Singing Billy and Count Peri. A checkered career had carried him from Europe to the penal colonies of Van Diemen's Land; thence he had escaped and made his way to California, and although he was so illiterate that he could scarcely read and write he became a leader in planning and executing many robberies, and was one of the principals in the attack on Jansen. His appointment to office illustrated the ease with which past records could be ignored in the new community. We have evidence, also, that he continued his interesting occupations in other climes. After a sojourn in the southern seas he reappeared to history in South America, and the papers of 1855 reported that he was prominent in a band of ruffians who were committing outrages in Valparaiso. ${ }^{26}$

While Kay was still in confinement the Committee instigated the grand jury to indict William Thompson, Jr., on the charge that he had perjured himself when he swore that his friend was under illegal restraint by the Vigilantes. The case was tried in August. Several witnesses described Kay's arrest in Sacramento and the crowd on the San Francisco wharf that awaited the arrival of his steamer. That "crowd" may have been the guard of twenty appointed to act as a "well armed" escort" and to protect the expected prisoner from possible violence. The evidence for the defense, however, characterized it as a large and threatening "mob" that gave vociferous applause to inflammatory speeches in which Sam Brannan promised that the former port warden should hang as "high as Haman within twenty-four

26 Papers, 472, 680 note 1; Alta, 1855, Aug. 7 2/. Kay's career was mentioned in the San Francisco Call, 1893, Feb. 5, p. 16; H. C. Merwin, Life of Bret Harte, 1911, p. III. He had been appointed port warden by Governor McDougal, and became popular in spite of his close association with the Sydney men. He was acquainted with Dr. Randall, of Monterey, and was suspected of complicity in the robbery of the Custom House. His name also appears in a lurid tale, Mysteries and Miseries of San Francisco [1853].

27 Papers, 265. 
hours." If we can accept these sworn statements at their face value, we must add another turbulent scene to the instances of disorder that accompanied some of the activities of the Committee of Vigilance. The trial resulted in Thompson's discharge; the jury "under the instruction of the court ... that the indictment was faulty . . returned a verdict of not guilty.",28

Messrs. Edwards, Osman, Briggs, Morgan, and Hughes, also evaded arrest by the Committee. Hughes had been tried and acquitted of the burglary of Robert's jewelry store early in June, ${ }^{29}$ but Whittaker finally said the charge was true and that the plunder had been entrusted to Morgan, who with Edwards, Osman, and Briggs was traced to San Diego, where the party boarded a steamer for Panama. Unsuccessful efforts were made to arrest them at Mazatlan, and again, in October, when it was reported that they had returned to the vicinity of San Francisco. ${ }^{30}$

The archives contain the names of eighty-six persons who were implicated by the statements of James Stuart and his confederates. Only twenty-one of these were positively designated as ex-convicts, although a much larger number undoubtedly hailed from the penal colonies. About forty-five of the entire group can be classed as minor rascals, but the remaining forty-one seem to have achieved unenviable prominence in the circle of outlaws. Fifteen members of this dangerous gang were incarcerated. first and 'last, within the prisoners' room of the Committee of Vigilance, and their trials were prosecuted with vigor. ${ }^{31}$

28 Papers, 300 note 3 ; Herald, 1851, July $24 \% 4$; Aug. $11 \%$.

29 See supra, p. 238.

30 Papers, 228 note 16, 444-445, 500, 506, 679 note 1 . In June the Committee received a letter which described the escape of a supposed thief, and the recovery of a watch that he had dropped in his flight. Two months later Whittaker identified the fugitive as Old Jack Morgan, a typical example of the interweaving of independent clues (ibid., 47, 476).

31 Compare Papers, Appendix E (list of prisoners), Appendix F (list of Stuart's confederates), and Index under "Convicts.", 
So far as Stuart's friends were concerned, his statement and that of Joseph Hetherington furnished a basis for examinations, and the accused, sometimes interrogated in private, sometimes confronted with old confederates, one by one admitted their guilt and told more or less of their past life and associations. T. J. L. Smiley said : ${ }^{2}$

The usual course was first to examine these men in relation to their antecedents, to make particular inquiries in relation to their present life, and to investigate any complaints or charges made against them. These examinations were conducted by Gerrit L. Ryckman and Stephen Payran, who reported the result to the Executive Committee. If the Executive Committee desired any further evidence in relation to the matter, they would either investigate themselves, or refer the matter to a sub-committee. As a general thing, before any definite action was taken, the prisoner was allowed the privilege of appearing before the Committee, and making whatever defence he might be able to in regard to any misdeeds charged against him. On the report of the Executive Committee, it was referred to the Committee at large, and, on being endorsed by them, was carried into effect. The sentence of the Committee, as a general thing, was banishment, or voluntary transportation, amounting to the same thing. In some few instances, opportunities were given for them to wind up their business and close their affairs, before taking their departure.

The great strength of the Committee of '51 lay in the wonderful faculties possessed by two members of the Executive Committee, Gerrit Ryckman and Stephen Payran. The part allotted to them was obtaining information in regard to the antecedents and present life and surroundings of the parties brought before them. They had a most wonderful faculty of impressing these parties with the fact that their only hope of safety lay in confession of crime. Gerrit Ryckman would talk to them like a father, and they would unbosom themselves fully, uncovering everything without any promise of reward, or special fear of punishment, except on the general principle that they had better make a clean breast of it. Nine times out of ten they confessed, and consented to transportation, glad to get away, particularly when their requests to wind up their affairs were acceded to. With the wonderful power of these men to get so many to confess there was very little for the mass of the Committee to do.

32 Smiley, MS Statement, 2-4. 
It was not always so easy as Smiley intimated to extort truthful confessions from those experts in perjury and evasion. A series of statements made by Adams, Jimmy from Town, Ainsworth, and others, shows how carefully the inquisitors conducted their investigations. ${ }^{33}$ Adams, for instance, began a plausible tale of honest industry. In the midst of his story he was confronted with William Hays, who was under suspicion as a raseal on his own account, and who hoped to win immunity by informing on his old friends. Adams denied any aequaintance with him, but Hays recounted various experiences which he claimed they had shared in common, especially one incident of an Indian celebration. "It was about the third of July. Wasn't it?" he queried, and Adams incautiously corrected "The Fourth!' The lying defense was broken down; a whining confession followed, and George Adams may well have trembled for his life as he realized how many scores were accumulating against him upon the records of the Vigilantes.

After the committeemen had played the rôles of detectives, police, prosecutors, and juries, they were called upon to act as judges and pronounce sentences upon these convicted or selfconfessed thieves. Here we mark another striking divergence of method between their course and that of other popular tribunals which have been noticed in the earlier pages of this volume. The people's courts of the unorganized frontier and of the mining camps of 1848 and 1849 considered themselves the legitimate representatives of law in regions physically beyond the reach of legal institutions; those that persisted in California in 1850 and 1851 frankly ignored or defied the constitutional authorities which they found powerless or unwilling to safeguard society. The Committee of Vigilance, however, acknowledged the supremacy of the existing government, and was

33 Papers, 314-327. 
pledged by its constitution to sustain the law when it was faithfully and properly administered. By the middle of July criminal conditions in San Francisco had changed decidedly for the better since the early days of June when Jenkins was given his short shrift: the revised statutes were in effect, one or two of the local judges showed themselves incorruptible in executing justice, the grand jury was zealous in returning indictments, the popular interest was aroused, the courtrooms were thronged with critical spectators, and verdicts inclined towards a salutary severity. The primary object of the Committee was not the punishment of criminals, but the protection of society. As soon as the courts gave promise of better efficiency the Committee turned to them as the most desirable source of discipline, and adopted the policy of delivering to the officers of the law those prisoners whose guilt was so clearly established that conviction might be expected, and whose crimes were not so heinous that the safety of the community demanded their execution.

The most significant illustration of this policy was the action in the cases of Stuart's confederates, Adams, Jimmy from Town, and Ainsworth, and in the case of George Arthur, a burglar who was under arrest at the same time. It had cost the Committee heavily both in time and money to capture these men and to bring them to the point where they acknowledged their crimes. All were confessed thieves, but no proof of murder had been obtained, although murder was strongly suspected. On July 23 the Executive Committee advised that they should be tried in the courts, where the documents obtained by the Committee might serve to convict at least one other prisoner then in the hands of the authorities. ${ }^{34}$ This recommendation was immediately adopted in regard to Jimmy, Ainsworth, and Arthur, but Adams was remanded for further examination. At the

34 Papers, 338, 345. 
next general meeting, July 28, action was again deferred. On August 3 he made a more satisfactory statement, which was submitted to the General Committee without recommendation. ${ }^{35}$ No minutes intimate that Adams' fate hung in the balance for several hours, but the San Francisco Herald stated that about ten o'clock on the morning of August 6 the Monumental bell tapped out the well-known call for a gathering of the General Committee, and that crowds collected about headquarters, greatly excited by a rumor that a sentence of death was under serious consideration. At last the prisoner was brought out, not on his way to the scaffold, but to the county jail, where he was handed over to the under sheriff, John Caperton, who acknowledged the delivery by a formal receipt. It is probable that Adams had a very narrow escape. The minutes show that the motion for his transfer to the authorities was made by "Mr. Malone," none other, we must think, than number 250, James R. Malony, commonly called Rube, who was himself in bad repute as too close a friend of rowdies and ballot-box stuffers. John Arentrue, another colleague of Stuart, was also delivered to Sheriff Hays on the same day.

The Committee pursued its policy of "vigilance" even after" placing its prisoners under legal control. In the case of Jimmy from Town it was voted to detain Hays and other important witnesses, and to produce them in court at the proper time. A committee of six was appointed to attend to this duty, and various allusions point to the existence of similar committees charged with the supervision of other trials. ${ }^{36}$ The presence in court of members of the society has been severely scored by some writers as an effort to overawe judge and juries. If such attempts were made, they are not reflected in the newspaper reports, or in the sentences pronounced, which in no case took

35 Papers, 375, 410-413, 418, 419, 424, 426.

36 Papers, 339. 
advantage of the statute allowing the penalty of death to be imposed for grand larceny. It is, however, apparent that the trials of these men were conducted with unusual promptness. Within a week Jimmy from Town was sentenced to ten years' imprisonment, and some time later Adams received a twentyyear sentence. The charges against Arentrue were dismissed, owing to technical defects in the indictment, and the old trouble of the departure of necessary witnesses. ${ }^{37}$

These notable rogues disappear at this point from the annals of the Committee of Vigilance, but the members of that body may have learned with interest that during the improvements on the county jail Sheriff Hays employed the facile Jimmy from Town in the mixing of mortar, while Adams delved some twentyseven feet under ground, and their old friend, Watkins, handled a plane. ${ }^{38}$ Unfortunately, honest toil did not reform their wandering impulses. In January of the next year Jimmy escaped again, and was again captured. In May he and Adams and Watkins attempted another sortie, but were detected, and were most unkindly flogged, Adams suffering an extra ten lashes in compliment to his leadership. ${ }^{39}$ Jimmy was later transferred to San Quentin, where the new state prison proved as frail a barrier as had his other jails. In October, 1854, he led five friends in a successful dash for liberty, ${ }^{40}$ and thereafter vanished from the attention of the public.

Schenck said that the Committee had been informed that the authorities had evidence to convict some. of the prisoners of murder, ${ }^{41}$ and it may be inferred that their surrender was prompted by the hope of severe and legal punishment. It is

37 See the Court reports in Herald, 1851, July 29; Aug. 7 ; 8; 14; 26-30; Sept. $3 ; 23$.

38 Herald, 1851, Sept. $19 \%$.

39 Herald, 1852, Jan. 21 2/4; May $21 \%$.

40 Herald, 1854, Oct. $26 \%$.

41 Schenck, MS Statement, 43. 
noteworthy that the Vigilantes did not attempt to recover the criminals when milder sentences were imposed. Nevertheless, it is not unlikely that the good fortune of Adams and Jimmy from Town sealed the fate of two more dangerous felons.

The records of Whittaker and McKenzie had been bared with pitiless detail by Stuart, Joseph Hetherington, and other informers. McKenzie, a brutal, coarse-fibered man, tried to save himself by sullen silence, or by prevarication, but finally made a confession that fully established his guilt as a member of Stuart's gang. ${ }^{42}$

Whittaker also attempted to conceal the truth, but the accusations against him were too explicit. In the end he spoke freely - of his past offenses. The circumstances attending his confession make it in some respects the most remarkable of all the documents preserved in the files of the Committee. Stuart may have dictated his statement in the hope of securing immunity by frankness, but Whittaker, with Stuart's fate in mind, could have cherished no vision of reprieve at the expense of others. Ryckman related a touching interview when kind words broke down the prisoner's reticence, and he offered to unburden his heavy conscience in the face of the warning that even honesty would not save him from the penalty of his sins. ${ }^{43}$ Once started, he confessed crime after crime with astonishing fluency. While Stuart's narrative was a plain recital of events, Whittaker's was interspersed with reflections on the men and the occurrences that he described. ${ }^{44}$ Like many other criminals he blamed society for his downfall: he gave instances of injustice to show that a thief had a better chance than an honest man; he sneered

42 Papers, 463-467, 506. A brief and unimportant addendum, missing from the files, was printed in the Alta, 1851, August $27 \%$.

43 Ryckman, MS Statement, 10-12. He stated that Payran had been drinking, and could not conduct the examination with his usual skill. Bancroft gave a somewhat garbled version of the episode in Popular Tribunals, I, $342-343$.

44 Papers, 468-488. 
at his own service on a jury which sentenced a prisoner to a term of imprisonment for the theft of a pistol, while greater offenders, skilfully defended, went scot-free $;^{45}$ he showed how his successful efforts to corrupt officials caused him to despise the authorities he defied; and he boasted of his influence as a politician, and of the dozen ex-convicts whom he led to the polls when called upon to assist in the election of Malachi Fallon, marshal of the city. ${ }^{46}$

He characterized his companions with critical appraisement: Kay was ignorant, and a dandy; others were bungling; the convicts from Van Diemen's Land were far worse than those from Sydney ; $;^{47}$ such a one was a convict without doubt, another might be an incendiary but the "report was rumor" ;4 John Darke was a thief "on his own hook"; Dick Smith, friend of convicts and of police, could be depended upon to provide straw bail. ${ }^{49}$ He described moral and physical qualities with equal facility, and little touches of personality bring these unknown rogues before our eyes with startling realism. The acme of his contempt he reserved for the unkempt, unclean, and physically repulsive. "Kitchen is a rough boatman-looking fellow; dirty, very dirty." "George", was roundshouldered, a dirty-looking fellow, a thief; one receiver of stolen goods at Sacramento was stigmatized as a "dirty looking little pock-marked Jew."

$\mathrm{He}$ did not hesitate to acknowledge his relations with Mrs. Hogan, told of lavish presents he had made her, and of her determination never to go back to her husband. He even repeated a rumor that she had been transported for crime, but admitted at last:51 "To do her justice, I must say that she done all in her power to break up my associations, and to lead a different life."

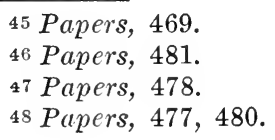

45 Papers, 469.

46 Papers, 481.

47 Papers, 478.

48 Papers, 477, 480.

49 Papers, 482, 483.

50 Papers, 480-482.

51 Papers, 473-476, 484. 
Mary Hogan was then recalled to headquarters, and the confession was read to her. Compelled by the man's frank avowals, she admitted the intimacy that had bound them together, but indignantly repudiated the insinuation that her affections had been won by the value of his gifts. She insisted that she had handled his money as might a wife, returning to him on various occasions such sums as he needed.52 We read that during her ordeal the "prisoner Whittaker was brought in and confronted with Mrs. Hogan." So far as we may know, they never met again. Sam Whittaker was held to meet the punishment of his misdeeds, and Mrs. Hogan was allowed to go at large subject to the order of the Committee. ${ }^{53}$ In closing her story it is perhaps fair to repeat the judgment of one of her own sisterhood who characterized Mrs. Hogan as "only guilty of loving a bad man." ${ }_{54}$

The examinations did not prove actual murder against either Whittaker or McKenzie, but the Executive Committee reported that both men were self-confessed robbers who did not hesitate at any violence, that they were a menace to the community, and that it would be unsafe to hand them over to the authorities. $^{55}$ It therefore recommended that they should suffer death at the hands of the Committee of Vigilance. These reports are in Stephen Payran's handwriting, and both contain a canceled paragraph which provided that execution should take place at one o'clock on the afternoon of August 18. In spite of the fact that there are no minutes and no annotations to prove that these recommendations were accepted, there is little doubt that

52 Papers, 488-490; Herald, 1851, Aug. $18 \% 1$.

53 Papers, 501.

54 Report of a conversation with "Harriet," probably Harriet Langmeade, in a brief paragraph in the Herald, 1851, August $4 \% 2$.

55 Papers, 462, 467. Smiley said: "The sentences of death in the cases of Whitaker and McKenzie were passed by the Committee at large, upon the cases coming before them"' (MS Statement, 4 ). 
they were, although with a postponement of the execution for forty-eight hours. On the nineteenth there are two unsigned orders, one in Payran's handwriting instructing the chief of police to remove the prisoners to a place of greater security, and another written by Bluxome, directing that the execution should take place on a vessel in the harbor in view of the crowds on shore. ${ }^{56}$

The plans of the Committee were not destined to be carried out, as the removal of the prisoners was not accomplished in time to frustrate a delivery executed under the personal supervision of the governor of the state. His proclamation of July 21 had concluded with the words: "It is my sworn duty to see that the laws are executed, and I feel assured that all good citizens will cordially coöperate with me in its discharge." For nearly a month Governor McDougal had rested content with this inner assurance of restored tranquility, and then his confidence in the good citizens of San Francisco was rudely shattered. On August 18 the papers published the full text of the examinations in the case of Whittaker and McKenzie. On August 19 the governor learned that the Committee of Vigilance intended to hang both prisoners on the following day. $\mathrm{He}$ at once hastened to San Francisco and about midnight he obtained confirmation of the rumor from two members (or former members) of the Committee whose names he never divulged. Summoning Mayor Brenham to his assistance, he searched the

56 Papers, 522, 523, 536. The following undated fragment may refer to some plan connected with the execution. The writing does not identify the author, and it was reserved for publication in this volume as an illustration of the problems that arose in arranging a portion of the archives:

"The prisoners will be moved this night with guard of ten-

At 8 o'clock a person will be sent to room for special detail of 25 who will come to such spot as may be designated-

When Comt. meets-report \& let the bells toll-then form \& proceed under direction of me without previous statement \& he who leads will wave his handkf-when the prisoners will run-,' Bancroft interpreted the concluding phrase as referring to the moment when the prisoners should be run up to the yard arm (Popular Tribunals, I, 359). 
city for a judge who could issue a warrant for immediate seizure. Having produced this from Judge Myron Norton, he aroused the sheriff and directed him to serve it without delay. ${ }^{57}$

Colonel Hays had no relish for the commission. As has been said, he sustained the most cordial relations with the volunteer police headquarters on Battery Street; he had invited members of the Committee to visit his own jail; they had commended his efforts to complete the building, and had promised substantial financial assistance towards defraying the expenses he had assumed. More than once they had delivered important prisoners into his keeping, and more than once they had frustrated his efforts to take from them men whom they were unwilling to relinquish. At first he thought it was not his duty, "and rather roughly declined, ${ }_{58}$ but the obligation could not well be evaded, and he reluctantly called his deputy, John Caperton, and accompanied the governor and the mayor to the rooms of the Committee.

Here there had been all through the night an atmosphere of suppressed excitement; members came and went, intent upon the stern work of the morrow, sometimes so absorbed and hurried that they passed the guard without the customary countersign. Payran, who had been indisposed during the day, ${ }^{59}$ had retired for sleep after a final consultation with Tan Bokkelen. The latter had nearly completed arrangements for transferring the condemned to the vessel selected as the place of execution and had stepped outside for a moment, when Hays and Caperton, taking advantage of their knowledge of the rooms and of the customs of admission, mounted the stairs and pushed past the guard at the door. Caperton rushed directly to the prisoner's room, crying: "Whittaker and McKenzie, I am an officer; I

57 The affidavit and the warrant are printed infra, pp. 469-470.

5 Papers, 530.

59 Papers, 520. 
come to save you!" The three locked arms and dashed back to the exit, where Hays held open the door in spite of all that the surprised guard could do to dislodge him. During this dramatic reseue there was great confusion, but no concerted resistance, and no resort to violence or firearms on either side. The whole thing occurred so quickly that Payran was not awakened until the scuffle was over. When Van Bokkelen returned he found his charges in the hands of the officers. He made such a feeble effort to regain them that he was severely censured by the Committee for neglect of duty, and temporarily relieved of his office as chief of the Vigilance police.

The General Committee met at eight o'clock the next morning to discuss the eircumstances of the rescue. ${ }^{60}$ Some of the members favored immediate retaliation. Payran's habitual deliberation gave way before his indignation, and in a fiery resolution he called upon the Committee to decide whether it should rouse the eity to action and show who had the supremacy, or should acknowledge defeat by releasing all prisoners still in custody. "Why detain them here?" he asked. "Why expend our time and money on them, when we, the People, are afraid of the puny and insignificant powers whom we have placed in office?" His resolution was laid on the table, as was another that proposed an attempt at immediate recapture. Five men were appointed to investigate the events of the night; the chief of police was suspended from duty pending their report, and the meeting adjourned until the afternoon. At four o'clock the subcommittee was ready with its report, which was introduced by the following preamble:

The Committee having invited his Excellency the Governor of the State, his Honor the Mayor, Sheriff Hays, and Deputy Sheriff Caperton to meet them in the Executive Chambers, those gentlemen cordially assented, and being informed that the object of the Committee was to

60 Papers, 523-526. 
ascertain if their action in seizing and rescuing the prisoners was aided and abetted by any members of the Vigilance Committee they have provided the Committee with the statements as follows severally.' 61

This investigation illustrated more vividly than any other incident in the history of the Vigilance Committee the strange position in which it stood with the general public and with the constitutional representatives of the people. At midnight the Committee held two men as prisoners under sentence of death; before morning these men were seized in a raid conducted by the three highest officers of the state. city, and county ; and a few hours later all concerned (except the prisoners) sat around a council table in the very headquarters of the Vigilantes and discussed the event with the decorum befitting a court of law!

The committee of investigation found no evidence of corruption or of internal connivance in the escape, ${ }^{62}$ but it blamed the chief of police for want of necessary caution and energy, and censured those members "who were so derelict in duty as to inform the Governor of the intended action of the Committee, which rendered it imperative upon him to adopt the course he did." The report was accepted and Van Bokkelen was restored to his former position. It was resolved that the sentences of execution should be carried out as soon as Whittaker and McKenzie could be recaptured, and that in future any member guilty of divulging transactions of the Committee should be ignominiously expelled. ${ }^{63}$

On the very day after the rescue Hays allowed Ryckman to interview the prisoners. "Mr. Ryckman," said Whittaker, "I

61 Papers, 528. The evidence follows. It contains many allusions showing the arrangements of headquarters, and the customs of the Committee. The account in Popular Tribunals, I, 353-356, included other details supplied by the members.

62 Payran always attributed the reseue to treachery on the part of the guards (Carpenter's letter in Oakland Transcript, 1874, March 29, p. 1).

63 Papers, 524-525. 
hope you are not sorry that we made our escape." "You have not made your escape," was the inexorable reply. "You have been convicted, and you will be executed beyond a shadow of doubt. There is no power on earth that can save you."'64 Governor McDougal, however, was somewhat complacent over his easy victory, and he took occasion to issue another proclamation, which is reproduced upon the opposite page. This communication appeared in the city papers, even in those most friendly to the Committee, although its force was somewhat impaired by the close juxtaposition of the following:

\title{
A Card
}

San Francisco, August 20, 1851.

We, the undersigned, do hereby aver, that the present Governor, McDougal, asked to be introduced to the Executive Committee of the Committee of Vigilance which was allowed, and an hour fixed. The Governor, upon being introduced, stated that he approved the acts of the Committee, and that much good had taken place.65 He hoped that they would go on, and endeavor to act in concert with the authorities, and in case any Judge should be guilty of mal-administration, to hang him, and he would appoint others, \&c.

\author{
G. E. SCHENCK, \\ GEORGE J. OAKES, \\ IsAAC BLUXoMe, JR., \\ S. Payran.
}

64 Ryckman, MS Statement, 13.

65 "The Governor of the State, hearing of the condition of affairs [after the execution of Jenkins], issued, as was proper for him to do, a proclamation, warning all good citizens to desist from unlawful acts and from unlawful combinations. But upon examination of affairs, he was satisfied the work proposed by the Committee would really be beneficial to the publie interests, and that an active opposition would be harmful instead of useful, and decidedly agreed with the Executive that their work should go on, and that he would interpose no active opposition on the part of the state, so long as the operations of the Committee were confined to the sphere indicated, unless something then not foreseen should compel him to take a different position, of which he would give them due notice. Accordingly, throughout the existence or active operations of that Committee, the Governor properly maintained his attitude of nominal opposition, and the dignity of the state, but found no oceasion to take any active measures against us" (Coleman, MS Statement, 23-24). 


\section{PROCLAMATION!}

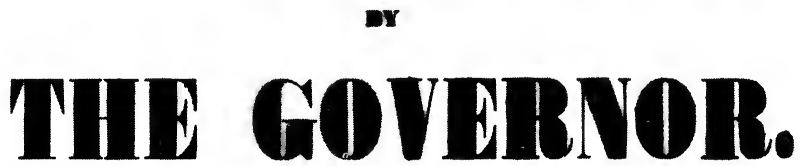

WHEREAS. an armed and organized body of the eitizens of San Franciseo County. bas, in defiance of the Constitution and Laws of this State, assamed to exereise the powers of the Courts of Criminat

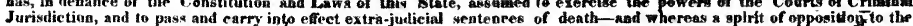
Officers of the Lass while enyaged th the exeeution of their duty, has been openly and publiely panifeated;

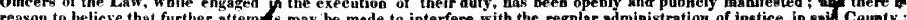
and especially to tahe frou the custody othe sherif eertain Prisoners now confined in the Gaol of said Con

Now therefore. I. JOHN McDOUG AL, Governor of the State of California, do hereby call upon all good citizens of said tounty to unite for the purpose of sustnining publie law and tranquillity, to aid the pablic officers in the discharke of their duty, and by all lawful means to diacountenance any and every atteupt which may be made to substitute the decpotic control of a self-constituted association unkaown and acting in defance of the laws, in the place of the regnarly organized government of the County. And hereby eall upos all public ofieers to be aetive, vigilant, and faithful in the performance of their trusts, and to resist to the atmost of their power, all efforts which may be made to aubvert the laws and trample on the Constitution.

And I hereby warn those who are disposed to resist the legal anthorities, that they canaot do ko, withont involving the community of which they are members in all the horrors of Civil War, subjectiog life, liberty and property to the most fearful sacrifices.

The Government is determined, at all hazards, to sustain the Constitution and Laws. public peace can only be secured. and publie liberty can only be maintained, hy a strict adherence tn that feeling of subordination to the law, and respect for its ministers, which have heretofore eharacterized the Ameriean People.

The attention of all citizens is requested to Sections 88 to 50 , of "An Act to regulate proceediags in Criminal eases."

It is earnestly hopgd that no necessity will arise calling for the execution of those provisions, and that the good nefise and ealm reffection of all good eitizens will induce then to refrain from committing ang acts calculated to destroy the peace and order of the commusity, and to bring the anthorities into oonflict with any portion of the People.

\section{NHO. MCDOOGAL,}

San Francisco, August $20 t h, 1851$.

Governor of Califormia.

Proclamation by Governor John MeDougal relative to the Committee of Vigilance, Angust 20, 1851. From the Bancroft Library. 

The records of the Committee contain but one more paper bearing on this case-the following curt order, to which is appended an equally curt report $:^{66}$

Capt. Cartwright:

You are hereby authorized to detail a guard such as you think proper, and arrest two Prisoners to-wit-Sam Whittaker \& R. Mackensie and bring them, into custody of the Committee of Vigilence.

Done by order of Executive Committee

August 22, A .D 1851.

Attest S. PaYRaN

[Signed] JaMes B HuIE

Sect'.

Chairman.

Executive $\mathrm{Com}^{\mathrm{e}}$ of Vigilance $\mathrm{Com}^{\mathrm{e}}$

S. Francisco Aug. 24./51

Agreeably to your orders above I detailed (30) Thirty men who proceeded in Three Divisons under the respective orders of Col G. W. White, Capt Calhoun \& Mr Oscar Smith \& in the short spaces of 5 minutes from the first charge the Prisoners above named were on their way to your Head Quarters-

Respy

[Signed] J W CARTwright

The story of that Sunday is worth telling in greater fullness. The reminiscences of the actors show that they plotted cunningly to outwit the triumphant authorities. ${ }^{67}$ In order to avoid any personal conflict with Jack Hays, George Schenck saw to it that the sheriff was invited to attend a bullfight at the Mission Dolores. Then, in advance of the proposed raid, Isaac Bluxome inspected the jail, ostensibly to see Berdue, who was lodged there awaiting a formal release from the sentence imposed after his conviction as the assailant of Jansen. The secretary's real errand was to discover whether a stand of muskets kept in the

66 Papers, 549. By an error in proof-reading, Huie's title as Chairman was omitted from the printed document. There are no minutes to explain why Payran was serving as secretary, but another order of the same date was signed by E. Gorham, as president pro tem (ibid., 541).

67 Details of the raid in the MS Statement of Ryckman, 13; Bluxome, 13-15; Schenck, 40-42; Farwell, 10; confirmed by the daily papers of August 25, and by Rev. Albert Williams, Pioneer Pastorate, 1879, pp. 117118. See also Popular Tribunals, I, 359-365. 
building was ready for emergency use. He accomplished this purpose by exhibiting his skill in the manual of arms to the old soldier, William Lambert, who acted as keeper, for he made excuses to pick up one gun after another during the drill, and thus ascertained that none was loaded.

When Sunday came, Captain Cartwright stationed parties of his guard of thirty near the front and rear entrances of the jail. The unsuspecting jailers even allowed a few of them to enter the building and attend a religious service which was being held in the unroofed court. A conspirator perched on Telegraph Hill commanded a view of the courtyard and watched for the signal that would indicate the best moment for attack. The Reverend Albert Williams exhorted his unpromising flock, while Captain Lambert lounged on guard, Caperton discussed his Sunday dimner, and Sheriff Hays enjoyed his holiday sports. Suddenly at half past two as the meeting drew to its close a signal was waved from within, transmitted by the observer on the hill, and answered from without. In a twinkling the Vigilantes inside pinioned Lambert and the guards, those without forced in the doors, seized Whittaker and McKenzie, carried them bodily to a waiting carriage, thrust them on to the seat, and held them down with cocked pistols at their heads. The driver lashed his horses to a gallop and dashed up Broadway to Stockton, along Stockton to Washington, thence through Dupont, Sacramento, Montgomery, and California streets, to the rooms of the Committee on Battery street. The Monumental bell began to tap out the alarm, and the streets filled with crowds that raced after the flying carriage and quickly packed the neighborhood around headquarters. On the box of that careening coach sat James R. Duff, who lived to become one of the last survivors of the Committee of $1851 .{ }^{68}$ Sixty-four years later he seemed to recall

$68 \mathrm{Mr}$. Duff's recollections of the day were printed in the San Franciseo Chronicle, 1915 , Oct. 3, Magazine p. 6. I had the pleasure of talking with him a few weeks later. 
every event of the day with photographic distinctness. It was not only its reckless daring that stamped the mad hour indelibly upon his memory. The shouting mob had caught in its swirl a frightened girl, just from the East, who recognized on the carriage her own brother-in-law, James T. Ryan, and marked the man beside him, and years later the gray-haired Vigilante depicted for me the fiercest episode of ' 51 as a somber background for the moment when he first attracted the attention of the woman who soon after became his wife.

But vengeance, not romance, possessed the minds of the committeemen on that Sunday afternoon when they rushed their captives back to their headquarters. The chambers had two second-story doorways on Battery Street, with projecting beams for the hoisting of freight. Seventeen minutes after the storming of the jail those doors were thrown open, ropes were reeved through the overhead blocks, and the two ends taken inside the room. In another instant the prisoners were pushed forward, with nooses around their necks, and almost at the same moment the ropes were tightened and the struggling wretches were launched into eternity. ${ }^{69}$ While the bodies were still hanging Sam Brannan addressed the crowd from the open doorway, informing them that the prisoners had confessed their guilt, had

69 Illustration, Annals, 562. An English traveler described the appalling silence and resolute mien with which the waiting thousands watched the sinister preparations. "They did not seem like men," he said, "but like judges sent by Osiris from the nether world, so steru, and implacable was their expression" (Jeremiah Lynch, A Senator of the Fifties, 101). Another writer said that brutal levity characterized the execution, and so shocked public sentiment that the popular approval of the Committee was greatly weakened, and contributions were withdrawn (Pictures of Pioneer Times, by William Grey [a pseudonym of W. F. White], 1881, p. 108). Contemporary accounts showed that McKenzie was in a pitiable state of panic, while Whittaker was calm and manly (see also R. M. Devens, Our First Century, 1880, p. 555). Ryckman said that Whittaker was "brave as Caesar,' and won his admiration so that he regretted the necessity for the execution. In the brief interval within headquarters the doomed man told Ryckman of a plot against his life, and the warning enabled the Vigilante to foil the would-be assassins (Ryckman, MS Statement, 14-15; Popular Tribunals, I, 364-365). 
acknowledged that they deserved death, and had affirmed that they would not have pursued the course which ended at the gallows had it not been for the weakness and corruption of some of the authorities. He stated that the members of the Committee were fully sensible of the solemnity of the occasion and of the fearful responsibility which the first law of nature, self-preservation, imposed upon them, but that they could not have acted other than they had without holding out a direct premium to crime. He trusted that the Committee would be supported by the citizens when it did right, and would receive their frowns when it did wrong. No innocent man need fear-it was no gratification to the Committee to be compelled to take the life of a fellow-being, and in no case would that be done unless the proof of guilt was beyond cavil.

The coroner held an inquest on the same day and summoned as witnesses George Mellus, W. H. Jones, Benjamin Reynolds, L. J. Bayles, J. B. Huie, and S. E. Woodworth, all members of the Committee. Their answers were guarded but not evasive, and the jury returned the following verdict: ${ }^{70}$

In accordance with the foregoing testimony, the jury, after deliberate consideration, have come to the conclusion and accordingly render their verdict that Samuel Whittaker and Robert McKenzie came to their death by being hanged by the neck, thereby producing strangulation, by the act of a body of citizens styling themselves the "Vigilance Committee of San Franciseo,' on the afternoon of Sunday, August 24th, instant, at about three o'clock, in front of the Vigilance Committee Rooms, on Battery Street, near California Street, from the second story thereof.

Although there was some severe censure of the execution ${ }^{71}$ most of the newspapers approved it, and blamed the courts for permitting the miscarriage of justice that evoked such interference on the part of private citizens. These strictures were

70 Herald, 1851, Aug. $25 \%$.

71 The Pacific, a religious paper friendly to the Committee, said that the act had forfeited the confidence of the community (Pacific, 1851, Sept. 5, 2/1). 
so severe that they moved Judge H. S. Brown, of the Court of Sessions, to resign his position on the ground that the attitude of the press was equivalent to an unjust impeachment of every judge in the San Francisco courts. ${ }^{72}$ In noting his resignation the Herald remarked that no one had particularly considered Judge Brown either for praise or censure, but it commended his example to Judges Bennett and Parsons; as for Judge Campbell, he had so won the confidence of the community that such a step on his part would only result in prompt re-election.

Judge Campbell allowed the matter to pass with a brief comment made to the grand jury on the day after the lynching. He said that it was not necessary for him to remark at length upon it; his views were still the same as they were when he had addressed the previous grand jury on the occasion of Stuart's execution. $^{73}$ By a curious coincidence, the same Monday found Campbell engaged in hearing evidence presented by members of the Committee to the effect that Stuart had assumed the guilt of the attack. on Jansen, and had completely exonerated Windred and Berdue. ${ }^{74}$ The latter was in court, eager to express his gratitude to the association that had already saved him from death and was then engaged in clearing him of the charge of robbery. When his discharge was ordered, Judge Campbell must have acknowledged, at least in secret, that the ends of justice had been served by the very men whom he had officially branded as murderers deserving of the severest punishment.

Learning that Berdue was penniless, the court suggested that a subscription should be raised for his benefit. Mr. Jansen offered to return the money taken from the prisoner at the time of his capture in February, and the members of the Committee arranged to collect additional funds. On September 16 Berdue

${ }^{72}$ Herald, 1851, Aug. $26 \%$. The resignation is reprinted in Popular Tribunals, I, 330 .

73 Herald, 1851, Aug. $26 \%$.

74 Herald, 1851, Aug. 26 \%2. 
signed an acknowledgment of $\$ 302$, given him by Isaac Bluxome, Jr., in the name of the Committee. ${ }^{75}$ A few days later he published in the papers the following card $:^{i 6}$

I have kindly to thank those gentlemen for what they have done for me; for certainly, through their vigilance and the kind providence of Almighty God, they succeeded in capturing the criminal for whom I have suffered so much.

75 Papers, 640.

76 California Courier, 1851, Sept. 24 2/2. The Alta, Oct. 11 2/2, stated that Berdue had lost his donation in an unfortunate mining venture, and his friends were trying to raise more. Two years later he unsuccessfully petitioned the legislature for an indemnity to the amount of $\$ 4000$ for injuries suffered during his imprisonment and trial (California Senate, Journal, 1853, Appendix, Doc. 37). 


\section{CHAPTER XIV}

\section{ADVENTURES IN CRIME}

The dealings of the Committee of Vigilance with Stuart's confederates have been related in a consecutive story in order to present a definite sequence of cause and effect which is lacking in the chronological arrangement of the printed documents.

While that story is still clearly in mind it may be interesting to linger over the records of this curious court, especially over the evidence that came from the lips of the prisoners themselves. A superficial perusal of the separate documents discloses little of the real human interest concealed within the terse and disconnected paragraphs. The members of the Executive Committee were not concerned with problems of criminal psychology; their literal transcriptions of sordid testimony and of brutal confessions were written down with the sole object of obtaining a knowledge of the criminal situation existing in their community.

In this purpose they were very successful, and the documents offer many striking illustrations of the local conditions we have discussed. ${ }^{1}$ We see in them how easy it was for criminals to escape punishment in California. A day's horseback ride could easily put them beyond the track of pursuit; if arrested, clever lawyers were ready to sustain them in perjury, to arrange defense from the testimony of their very confederates, and to distribute bribes to officials and jurymen. Even when the law had done its utmost, insecure prisons offered many opportunities of escape.

1 See Papers, Index, under the headings, Bail, Bribery, Courts of California, Jails, Murders, Perjury, Robberies. 
These documents give us also a hundred minute, instantaneous pictures of the underworld of San Francisco, and of the life that moved with stealthy footsteps through the chain of vicious lodging houses kept by convict landlords for the accommodation of convict guests. ${ }^{2}$ Such a place was the Uncle Sam when owned by the thief Jenkins and by his successors, Connolly and Thomas Burns. Such was McManus' Welcome, on North Beach, to which Burns removed when even the change of name to Shipman's Arms failed to make Jenkins' old stand a profitable investment.

The ex-convicts developed a happy faculty of christening their places with alluring names, and innocent, indeed, were the signs that ornamented the doorways of these wretched dens. Barnes, the tinman, kept the Cottage of Content; King, the barber, owned the Bird in Hand; Robert Ogden welcomed guests to the Live and Let Live; Goff, an ex-convict, owned the Panama House; Whittaker and McCormac, the Port Phillip; Mrs. Ryan and Mrs. Wilson, matrons from Sydney, presided respectively over the Rose Cottage and the Heart in Hand, but it does not appear that any poetic designation was attached to Mrs. Hogan's house, which was perhaps the most dangerous trysting place of all. From morning till night and from night till morning the bars and card rooms of these inns were open to their habitués. Even today the reader of the strange confessions may enter unchallenged and watch forgotten dramas of San Francisco lifeas much a part of history as are the stories of the mining camps and worth, as history, a moment of attention here.

Here is a simple tale entitled, "Dishonor Among Thieves." Characters: James Kelly, the fighting man; his friend Vyse, the bear hunter; other friends, among whom are Sam Whittaker, then the proprietor of the Port Phillip House, the latter's partner, Teddy McCormac, and Robert McKenzie; supernumeraries,

2 See Papers, Index, under "Lodging houses reported by the Committee as suspicious.', 
Osman, Old Jack, and King, the barber, owner of the Bird in Hand. Scene: a public house near the Mission Dolores, where Kelly has just been worsted in a prizefight with a man named McGee, and has been consoled with $\$ 900$ gate money, which now is in the keeping of his colleague, the bear hunter. While the defeated pugilist is in retirement Whittaker and McKenzie accost Vyse and ask for an opportunity to condole with his principal. There is some talking, some drinking. Vyse takes McKenzie into another room, and for a few minutes the money is left unguarded! The sympathetic friends appropriate it without delay and make a hasty exit, leaving McKenzie to comfort the "fighting man." A few hours later McKenzie finds his associates at the Bird in Hand, on Montgomery Street, and demands his share of the plunder. He is told, however, that "some one" has stolen $\$ 600$ on the way home, and $\$ 35$ apiece is the meager reward of the afternoon's adventure. Disappointment rankles in the breast of the defrauded McKenzie. When opportunity arises he discloses the whole affair to James Kelly himself. Swiftly the latter devises vengeance, pounces upon McCormac, who has attachable property in the Port Phillip House, and during an absence of the more astute Whittaker forces him by threats of imprisonment and lynching to give up possession of the place. The play ends with Kelly reimbursed, McCormac outwitted, and Whittaker, ousted from his own bar, betaking himself to the solace of Mrs. Hogan's lodging house. ${ }^{3}$

Another drama, "The Disappointed Locksmith," introduces Joseph Marks, sometime a member of the city police force, later a clerk of Colonel Stevenson, and finally discharged from that office. Angered by the loss of his position, he tempts the expert burglars George Adams and William Watkins to help him satisfy his grudge by robbing his former employer. Adams is cautious, suspicious; advises delay . Marks pleads for haste, since

\footnotetext{
3 Papers, 464-465, 469.
} 
his pockets are empty and he has neither food nor shelter. Adams, comfortably enjoying his British “tea," bestows largess upon him and instructs him how to take a soap impression of the key to Stevenson's place of business. Marks visits the office, accomplishes the errand, and slips the mold into his pocket, where it is ruined by the time he returns to his friends. Another trip to the office, another soap impression, another five dollars gratuity. The key is made, Mark's status as a trustworthy rascal is verified, and when the chosen night arrives a little group of four gathers in the shadows about the empty office building. Marks is posted as sentinel; the others disappear within. Lights flare up; there is a quick rush of armed men; Marks plays the rôle of informer; his companions, sullen and pinioned, are escorted to the city lockup. Marks, restored to the good graces of Colonel Stevenson as a detector of thieves, is made an assistant to the Committee of Vigilance in the effort to recapture Adams, who has speedily regained his freedom. ${ }^{4}$

Again, we have "A Matter of Compromise." The scene is laid in Monterey, the old capital of California, about the historic Custom House, which in December, 1850, was in charge of Dr. Andrew Randall. During his absence the building was entered and fourteen thousand dollars of his personal funds were stolen. Osman, Ryan, Briggs, and "Old Jack" Morgan were arrested, and a sum approximating Dr. Randall's loss was recovered from them. They gave bail and were set at large pending trial, to improve the interval by continuing their professional operations under the able direction of James Stuart. The theft of a safe in San Francisco resulted in the rearrest of Briggs and Morgan. The former, at least, did not wish to forfeit his heavy bail, so he escaped from prison in time to return to Monterey for trial. The case came up in April, and as the men were "too good and valuable to be locked up," Belcher Kay and Stuart, himself, superintended the defense.

4 Papers, 306, 318, 319, 344, 410-412. 
We have a glimpse of the court room, with the counsel on both sides, men whose names and faces were long familiar at the California bar; we see the jury, on whom bribe money has been lavished; we see Stuart, alias Carlisle, and Whittaker, also incognito, taking oath in the defense of their fellows; and we hear the foreman of the jury announce the expected disagreement. The case is too vexatious to risk another trial, so, on advice of the defendants' counsel, the efficient Stuart breaks open the jail. Exit prisoners, but a trifling matter of business remains. The money in dispute, over thirteen thousand dollars, has been placed in custody of the courts until its rightful ownership shall be established. Dr. Randall has demanded its restoration; Messrs. Osman, Ryan, Briggs, and Morgan, while still in confinement, have claimed it as theirs. Both parties have instituted civil suits for its recovery. But now, deciding to forego annoying litigation, they effect a friendly compromise, deduct the costs of the trial from the amount in question, and divide the balance. A delightful example of evenhanded justice! $!^{5}$

"The Sailor's Heirloom" shifts our attention to the little vessel James Caskie which lies offshore near Clark's Point, San Francisco, in October, 1850. James Stuart and three companions, hearing that money is in the captain's possession, swarm aboard in the dead of night, masked, armed, and ruthless. They encounter the skipper, who puts up a desperate fight, for he has not only gold but a wife to protect, and his only helper is a boy whom the desperadoes quickly overpower. The woman, with a strength born of terror, rushes to her husband's side with a cutlass, but is disarmed and reduced to such a state of abject fear that she brings out all the weapons and money on board

5 Alta, 1850, Dec. $19 \%$; 1851, April 21 22; Papers, 236 note 36, 371, 570. The charges of wholesale corruption in this case made by Stuart were indignantly denied. Whittaker appeared as a well dressed gentlemanly visitor from San Franciseo (Peckham, in San José Pioneer, 1877, Aug. 4, Scrapbook, pp. 33-34). See also the San Francisco Call, Feb. 5, 1893, p. 16. 
and thrusts them at the outlaws with pitiful appeals to spare her man, already half dead from a terrible beating. The chivalrous Stuart assures her that he will be glad to do as she asks if the captain will remain quiet. While ransacking the cabin the leader adds to his favors by again yielding to her pleas and leaving in its place a fine gold watch, the gift of a beloved mother; and he sternly quells the insubordination of his covetous crew by reminding them that they have made him master, and his orders must be obeyed. The captain and the boy are tied fast, and the pirates slip away into the darkness with a threat of worse to come if the woman utters a word within two hours. Her side of the story we do not know. Long before the two hours have elapsed Stuart and his pals have gained the shore and divided the plunder, which is less than $\$ 200$, as the captain had that day sent his funds away by an outgoing steamer. ${ }^{6}$

A longer drama might be built up about the Jansen affair. We are shown the plotters devising an attack and eager to rob a man who always kept English sovereigns in his safe for the special convenience of homeward-bound Australians. They concoct, at first, a clever scheme. ${ }^{7}$ Jansen is about to remove to a new store. His neighbor Whittaker learns that his funds are to be transported in a trunk placed on a cart and escorted by his clerk. When the guard seats himself upon the treasure chest he fails to notice that a lounger slips out the linchpin from the axle of the cart, nor does he suspect that footpads await the opportunity expected by the breakdown of the vehicle. But the joints of the wagon are stiff, the wheel remains in place, and the

${ }_{6}$ Papers, 228-229. Alta, 1850, Oct. 27 2/3; 29 2/2; Nov. 22 2\%. By a curious coincidence a physician (Samuel Merritt), who later became a member of the Committee of Vigilance, was near the scene of the Caskie robbery, and encountered a suspicious fugitive, whom he later recognized at headquarters as the prisoner Stuart (Oakland Tribune, 1884, Apr. 5 5/2).

7 The details of this plan were told by Whittaker (Papers, 470). He also described a plot that involved robbing the San Francisco Custom House (ibid., 244 note 43 ). 
gold is safely deposited in the new office. The conspirators refuse to accept defeat. So we see them again loitering outside Jansen's door on a chilly February night; Old Jack enters to ask for blankets, and lingers so long that Stuart follows impatiently, concealing a bludgeon beneath his long camlet cloak. We see the cruel blow, so heavy that the victim screams but an instant; the retreat with the treasure from the safe; the division of the spoils, \$196 to each man; and the placid reunion in Mrs. Hogan's barroom, after an incriminating watch had been tossed into the bay.

We see the same group gathered in the same place during the succeeding days, while the fate of Windred and Berdue hangs in the balance, and we know that their angry looks and gestures indicate their determination to burn the eity if capital punishment overtakes those guiltless prisoners. That revenge is abandoned, but when the legal trials result in conviction Whittaker resolves to right the injustice. He procures a key that will unlock the jail, and sends it to Windred by the latter's wife, or by Mrs. Hogan. Windred escapes and hides at the Mission until a safe passage can be engaged for Australia. On a certain night the runaway crouches in an alley near Clark's Point; Kitchen lies ready with his boat; Whittaker is directing affairs; Mrs. Windred and Mrs. Hogan are concealed close at hand, waiting to say good-bye. The policemen who are patroling the street seem equally oblivious of Windred and of two other fugitives, Adams and Jim Briggs, who are enjoying themselves in the neighborhood. When the coast is clear a pass word calls Windred from concealment; he snatches a moment with his wife, slips down into the boat, and is rowed away to the ship. Anxious days follow; Mrs. Windred, disguised as a man, calls regularly on Whittaker to learn if the vessel has sailed, and at last she too is smuggled on board. Still the departure is delayed, with 
constant danger of detection. Then comes the great fire of May 4, and on the fifth the ship clears away from the smouldering city, bearing two happy passengers who invoke blessings upon the head of Samuel Whittaker.s

Several pictures might be shown under the common title, "Baffled Villainy." One will suffice. It is night. Here is the office of Charles Minturn, on a wharf which stretches its slender length into the shadowy waters of the bay. A few oil lamps gleam in dancing spirals across the waves and make it possible to note a boat edging noiselessly along the piling until it comes to a mooring directly beneath the deserted building. Figures creep up a landing stage and enter the office, prepared to cut away the floor and lower the safe into the boat; McKenzie and Belcher Kay wait outside as lookouts. All goes well until an unwary interloper appears, a clerk or wharfinger returning for a forgotten paper. The lookouts signal the danger and dash off up the pier; the windows are thrown open; half a dozen forms hurtle through space into dark and friendly waters. In the bar of the Port Phillip House the swimmers meet again, furious with their lookouts because they have allowed them to run from one man, a weakness of which the leader, Stuart, seems heartily ashamed. The whole party is most soundly berated by George Adams, who, though excluded from the adventure, had loaned a kit of expensive tools on the promise of a generous share in the plunder. There is no plunder, and the tools are lost. ${ }^{9}$

Such were the everyday experiences related by the more adventurous men who fell into the hands of the Committee of Vigilance. Many of their obscure friends also gained distinction in the course of the protracted examinations, if not by sharing in deeds of daring, perhaps by the sheer force of some telling alias. Besides Dab and Jack Dandy and Jimmy from Town,

\footnotetext{
8 Papers, 233-234, 470-471, 478-479, and Index under "Jansen."

9 Papers, Index under "Minturn." Ryckman gave some details of the attempt (MS Statement, 6-7).
} 
whom we have met already, the archives of the Committee rescued from oblivion the names of Billy Sweet Cheese, Bungaraby Jack, and Moe the Jew; of Big Brummy, a man of mystery; of Tommy Round Head; of Slasher, the eutthroat, and of Peruvian Angel, whose tint may be inferred from Havana, the city of his nativity. By these names they exchanged greetings in the reeking saloons of Sydney Valley; by the same tokens they betrayed one another, as they strove to placate the Vigilantes with glib or halting confessions of crime.

It should not be overlooked that these intimate pictures of San Francisco life have a value quite apart from their criminal connection in their many references to local happenings and points of interest. North Beach and Clark's Point, Long Wharf and Cat Alley, the El Dorado gambling house, and the Old Adobe are mentioned as familiar scenes of everyday existence. Many officials are named, for praise or for blame; members of the police force are critically appraised; and even the eight variations used in writing the city's name are not without interest to the collector of bygone traditions. ${ }^{10}$

It is natural that queries should arise as to the reliability of this mass of confession and evidence. Can it be accepted at its face value, or must it be more or less discounted as a record of crime? Was there an opportunity for prisoners to consult one another, to prepare supporting falsehoods, and to protect themselves at the expense of others? And did they minimize or exaggerate their own misdeeds? There is no question that there was great opportunity for the prisoners of the Committee to prevaricate. There were minor discrepancies in the evidence presented by the various speakers, although there was little divergence that cannot be traced to the normal desire of each culprit to shift the heaviest blame to the shoulders of another. Stuart's confession was published in part on July 11,

10 Papers, Index under "San Francisco." 
and republished in full a week later. Since doubtless it was read by every one of his confederates, it was natural that all of them who fell into the hands of the Committee should unite in emphasizing his guilt and in palliating their own. But even in following that course subsequent confessions contradicted Stuart in few points, and Whittaker's almost equally important story confirmed and amplified it in several particulars.

Experience has shown that it is well to accept self-accusations with caution, especially those induced by threats or promises. In these accounts, however, when we turn to the accessible sources of verification, we find that the news items and the court reports of the San Francisco Herald and of the Alta California confirm the details of all the more important episodes related by the prisoners and the witnesses of the Committee. That is to say, the published facts as to time, place, method, and result, do not in any case conflict with the fuller statements submitted to the Committee of Vigilance. Those statements, therefore, must have been true at least in outline.

Although the work involved in ferreting out and dispersing the members of this particular gang constituted the major portion of the activities of the Committee, the accomplices of James Stuart were not the only objects of investigation. Other arrests were deemed expedient. It also became a common practice for citizens to take to headquarters any man accused of any kind of crime. During the weeks of July and August and early September there were many such individual cases considered in the reports of the Executive Committee, and some of them should be mentioned here.

While inspecting the haunts of the Sydney men the Committee came upon John Goff, a lodging house keeper, and such a close friend of undesirable citizens that his record was examined with attention. It was discovered that Goff had been 
transported for life on a charge of burglary, and had been permitted to leave the penal colonies only because of a conditional pardon, "effective in all parts of the world except the United Kingdom of Great Britain and Ireland." "11 While he was never convicted of overt crimes against the peace of the Commonwealth of California, his house was such a rendezvous for those who did violate the laws, and for policemen suspected of abetting them, that a sentence of banishment was pronounced against him. The Committee was aware of much public sympathy with the accused, and therefore published the entire evidence in the case in the daily papers. Nevertheless it still insisted upon the execution of the sentence, although Goff's time was extended more than once on account of the illness of his wife. It is probable that he left the city on his own vessel, the Veto, some time about the middle of August. ${ }^{12}$

One of the earliest appeals made to the Committee from without was a request from Lieutenant George H. Derby, of the Topographical Engineers, that the Vigilante police would apprehend one Samuel Church, who was a deserter from the army, a worthless scoundrel in general, and a blackguard in particular because of his theft of the aggrieved officer's favorite saddle horse. Lieutenant Derby, although a lover of stern discipline, possessed literary ability that made him famous, under the pseudonym of John Phoenix, as the author of popular humorous sketches; he was, moreover, a gifted letter writer, and he deluged the Committee with reports covering the case, urging it to hang the man at once as the only way to rid the state of a dangerous criminal. The evidence of witnesses summoned from a distance at considerable expense clearly established Church's guilt. The Committee, however, voted to hand him over to the military authorities in spite of the fact that a flogging would

11 See Herald, 1851, July $18 \% 4$.

12 See Papers, Index, under "'John Goff.', 
be the heaviest punishment likely to befall him. Lieutenant Derby protested not a little at such leniency, but he did not forget to express his thanks "as a citizen and as an officer of the army" for the work the society had done for the preservation of order in California. ${ }^{13}$

The action in the case of Church conformed with the principle of delivering prisoners to the constituted authorities whenever it seemed probable that the laws would accomplish the ends desired for the good of the community. The same course was pursued with Hamilton Taft, a confessed thief from Placer County, who was sent back to the scene of his crime together with his plunder of fifteen hundred dollars. A guard was appointed from the Committee, and two of his accusers assisted them, giving bonds of a thousand dollars that they would deliver the prisoner and his booty to the officials of the county. The papers drawn up and signed in this connection illustrate a constant tendency to clothe the irregular acts of this voluntary association with the dignity and formality of legitimate legal transactions. ${ }^{14}$ It is curious to see that the men who hanged Stuart without the shadow of authority, four days later demanded a precise and formal bond to insure from other private citizens the performance of a duty which, by rights, appertained solely to officers of the law. Certainly the chairman of the Committee of Vigilance of San Francisco was scarcely in a position to undertake a suit in the courts of his city, and the carefully indited instrument could have exercised no very great compulsion upon Benjamin Jenkins and David Howe, who put their names to the agreement.

Samuel Church was not the only deserter of whom the Committee took cognizance. Howard, another truant from the army, was returned to his commanding officer, and at least one run-

13 See Papers, 85, 107-109, 199-200.

14. Papers, 287-289. 
away sailor was restored to his ship. ${ }^{15}$ W. G. Hance had escaped from a prison in Panama, where he was under sentence of death for murder. Warned of his presence in San Francisco, the Committee arrested him and sent him back to his own country "on the ground that it would be contrary to equity that he should be punished by us in the absence of all proof, and for crimes committed beyond our jurisdiction." 16

Among the vessels inspected by the Committee was the Johnson or Johnston from Sydney. Her surgeon, Dr. Kennedy, was arrested by the chief of the water police on the charge of stabbing the captain, and was immediately turned over to the city authorities. ${ }^{17}$

More thorough investigations were made when there was evidence that crimes of violence arose from design and treachery rather than from bursts of sudden passion. For example: When Don Francisco Guerrero, a former Mexican magistrate, was thrown from his horse on the Mission Road and sustained fatal injuries that led to a rumor of foul play, the Committee lost not a moment in placing scouts all about the city in search of the suspected murderer, François Le Bras. He was soon arrested and was detained as a prisoner of the Committee, although he was produced at the inquest and was identified by the witnesses there present. The coroner's jury charged him with striking Guerrero on the head and thus causing his death. But the Committee refused to give him up, even in response to a writ of habeas corpus, until an exhaustive investigation, attended by

15 Papers, 596, 637, 638. The only record of the deserting sailor is found in the following notice from the Herald, 1851, June $26 \%$ :

"The Undersigned begs to return his sincere thanks to the Committee of Vigilance for the services rendered him last night in arresting a deserter from his vessel, and returning him on board. Bauginet,

Capt. of Belg. ship Louis, consigned to

E. Delessert, Ligeron \& Co."

16 Papers, 425, 608. The Herald, 1851, Nov. $18 \%$, reported that Hance was serving out his sentence in the chain gang in Carthagena.

17 Papers, 430. 
the French consul, had convinced the Executive Committee that the man was not guilty. After five days he was delivered to Sheriff Hays. In due time he was tried and acquitted. ${ }^{18}$

Another murder on the Mission Road engaged the attention of the Committee. Thomas Wheeler, a former servant of Colonel Frémont, suddenly disappeared and his body was found bearing marks of violence. Thereupon Mrs. Frémont's brother, Mr. William Carey Jones, turned to the Committee of Vigilance as the most effective detective agency in the city. This appeal is another indication of the general approval of Vigilante methods, for Mr. Jones was a law-abiding citizen of unquestioned standing who had come to California in 1849 as a special government agent for the investigation of land titles. Before his letter was received the Committee was seeking the murderers. A few hours after Wheeler's body was found Sam Brannan noticed two unprepossessing horsemen near the scene of the crime, and when they dashed off into the brush to avoid questions he summoned help and arrested them at the point of the pistol. Mr. Jones appeared at their trial, but their guilt was not established, and they were discharged after ten days. ${ }^{19}$

A curious instance, imperfectly explained by the records, was the case of four Chinese prisoners examined on July $4 .^{20}$ John Lipscom and Norman Assing, the latter an interpreter and a man of some importance in the small Oriental colony, influenced the Committee to arrest four other Chinese, two men and two women, on the charge of maintaining a disreputable resort. It had been decided to deport the prisoners when Selim E. Woodworth, president of the General Committee, appeared

18 Papers, 272, 275, 281, 291; Alta, 1851, July 14 2/4; 18 2/2; Nov. $162 / 4$. A. A. Green said that Le Bras, who was supposed to be simple-minded, had been used as a tool by land schemers who wished to get Guerrero out of the way (MS Statement, 80). See also Eldredge, San Francisco, II, 534.

19 See cases of W. L. Harding and John Olligin, Papers, 522, 542, 546, $578-581$.

20 Papers, 165, 170-172. 
in their behalf on the ground that he was a "Mandarin of the Celestial Empire, and Chinese Counsel,"' an expression which probably denoted some commercial relation with the Chinese companies engaged in the transportation of coolie immigrants. ${ }^{21}$ Woodworth characterized the action as a conspiracy to deprive the accused of their liberty, and upon his request they were set at liberty. The fact that Assing had made vain efforts in the city courts to obtain possession of a certain emancipated and imprudent young matron called Atoy, with the ostensible purpose of returning her to a deserted husband in China, suggested that he might have hoped for better success through an appeal to the Vigilance Committee, but as the names of the women are not given in the documents their identity was a matter of conjecture until it was confirmed by a paragraph in Holinski's La Californie, which narrated the incident, and attributed Atoy's arrest to the efforts of the Chinese colony to suppress their notorious country-women. ${ }^{22}$ Holinski wrote:

On fit entendre aux scrupuleux Chinois qu'il était impossible d'excepter miss Atoy de la tolérance accordée par la police de San-Francisco à mille femmes au moins, américaines, françaises, allemandes et espagnoles, dont la conduite n'est guère plus édifiants. La députation, quoique désappointée dans son but, se retira hautement édifiée de l'équité du tribunal des barbares, qui pèse dans la même balance et avec les mêmes poids les femmes de la ville, de quelque contrée qu'elles arrivent.

21 Frederick A. Woodworth, a brother of Selim, was mentioned as Chinese vice-consul, and agent for the "China Boys"' who participated in the memorial procession at the time of the death of President Polk (Alta, 1850, Aug. $281 / 1 ; 29$ 2/1). "The Honorable Mr. Woodworth, Chinese Mandarin in California," was mentioned in the Alta, 1851, March $6 \%$, and "Mr. Woodworth"' was again named as the agent for the Chinese immigrants in the Alta, May $12 \%$. Mr. F. A. Woodworth, of San Francisco, a son of the Vigilante, Selim E. Woodworth, told me that his father had no official relation with the Chinese government.

22 Holinski, La Californie, 119. Atoy was considered very pretty. She spoke English and often wore Oceidental dress. She was before the courts more than once for keeping a disorderly house (Alta, 1851, Mareh 6 2.2; $8 \%$; Nov. $9 \%$; Dec. $14 \% / 5$; Reminiscences of C. P. Duane, in San Francisco Examiner, 1881, Jan. 23 1/1). Norman As Sing was mentioned by James O'Mera in "The Chinese in Early Days," Overland Honthly, ser. 2, III (1884), 478 . 
For some reason that is not stated, the Vigilance Committee of Stockton sent to San Francisco a young man named Daniel Jenks, who had stolen a thousand dollars from a resident of Jacksonville. Papers forwarded with the prisoner showed that he had borne a good character up to the time of the robbery. In spite of the fact that a mass meeting in Jacksonville recommended a whipping, the committee which transmitted the evidence advised that merey should be shown "in consideration of the youth and previous good character of the accused, his bodily weakness, and the fact that this erime was in all probability his first offense." Jenks was quickly discharged without receiving any punishment at the hands of the Committee of San Francisco. ${ }^{23}$

False clues were sometimes followed with amusing consequences. One paper is solemnly endorsed as the record of the case of "Mary St. Clair against Hat \& Boots found at foot of Mission St." The "Hat \& Boots" were discovered weighted with bricks in the mud at low tide, and were so suggestive of murder that the Committee interrogated every livery man in town in quest of a carriage which had been seen to linger near the spot. The investigation showed that the water-soaked articles were indeed tokens of a crime, but of one that was already an old story. The carriage had been hired by two women who were inmates of the resort where Pollock had been killed on June 22 . His clothing poignantly reminded them of the tragedy of his death, and they had therefore attempted to afford it a decent sepulcher beneath the waters of the bay. ${ }^{24}$

Other minor cases were investigated by the Committee, but it is unnecessary to mention here all the people who were arrested, as a summary of Vigilance activity will appear in a later chapter.

The courts were still carefully watched during July and August. In one case the Committee was particularly interested - the trial of Charles Duane, a notorious bully and an unseru-

23 Papers, 510-517.

24 See supra, p. 242; Papers, 382-384; Alta, 1851, June 23 \%. 
pulous ward politician, who has already been introduced in these pages as an ally of Broderick at the time of Jenkins' execution. In March, 1851, Duane had been tried for shooting a man named Fayolle. The jury had disagreed and the case had not come up again until the last of June, when it was dismissed because the necessary witnesses had left town. About a month later Duane, abetted by Ira Cole, made an unprovoked attack on Frank Ball, a member of the Committee, alleging that the latter had acted offensively while serving on the jury which had tried him. For this assault he was arrested. Much feeling attended the subsequent trial, at which members of the Committee were excluded from jury service. Duane was convicted and sentenced to a year's imprisonment. While his lawyers were seeking to appeal the case Governor MeDougal issued a pardon, and refused to make public his reasons for taking such a step in the face of positive proof of guilt. ${ }^{25}$ The papers announced the pardon with great indignation, and the grand jury, which was then in session, went into court with the request that it be discharged, declaring that it was useless for jurymen to spend time and to risk the vengeance of criminals in seeking to convict felons who were so promptly set at liberty. ${ }^{26}$ Judge Campbell refused the request, but the incident clearly indicates the helplessness of the law-abiding citizens in the face of existing conditions. The Committee issued an order for Duane's arrest, but it was returned with the report that he was supposed to have left the state on the steamer for Panama. ${ }^{2 \tau}$ He thus escaped punishment at the hands of the Committee of 1851, although he was less fortunate in 1856, when he was banished from California in spite of his powerful political friends. ${ }^{28}$

25 Alta, 1851, March $232 / 3$; court reports March 25-27; June 27 ł; Papers, 96.

26 Alta, 1851, Sept. $10 \%$.

27 Papers, 590.

28 See Papers, Index under "Duane", also Index of Popular Tribunals. The case was frequently mentioned in the Herald and the Alta, July 22 to 
The Committee watched the progress of legal affairs not only to insist upon punishment of the guilty but also to defend the innocent. At the instance of Sheriff Hays an investigation was instituted into the case of John Williams, who was serving a sentence in the county jail under conviction of an assault with intent to kill. When the Committee decided that the act was one of justifiable self-defense it successfully petitioned the governor for the prisoner's release. ${ }^{29}$

This chapter was introduced by the statement that the members of the Committee of Vigilance had little interest in criminal psychology, but it should not close without remarking that the subject appealed to at least one observer of their activities. This was "Doctor" Collyer, known as the "Moddle artist man,", who exercised his talents in a museum of anatomy of questionable reputation. This enterprising phrenologist desired to earn an honest penny as a by-product of Vigilante justice, and advertised a lecture on the "Anatomy of Crime," which is further explained in the following communication $:^{31}$

To the President and Members of the Executive Committee of the Vigilance Committee of San Francisco:

Gentlemen: Tomorrow evening (Wednesday) I propose delivering a lecture on the "Anatomy of Crime," illustrated by the skulls of Jenkins, Stuart, McKenzie, and Whittaker.

Should you feel interested in the physiology and philosophy of the causes of mental action which prompted these men to pursue an evil course in life, I will be most happy for you to accept an invitation, which I now tender you, to form a part of my audience.

$$
\text { Yours, ete., }
$$

RoB. H. Collyer.

September 9, 1851.

It is a matter of regret that the press failed to report the success of this edifying entertainment.

Aug. 1, and again Sept. 5. Duane wrote some "Recollections", which ran in the Sunday edition of the San Francisco Examiner, 1881, Jan. 9; 16; 23; Feb. $6 ; 20 ; 27$; March $13 ; 20 ; 27$; April $3 ; 17$; May 8. They were absolutely unreliable, in so far as they dealt with the Vigilance Committee of 1851.

29 Papers, 216-218. 30 Papers, 49.

31 This letter is missing from the files, and is reprinted from Popular Tribunals, I, 392. The lecture was advertised in the Alta, 1851, Sept. $83 / 2$. 


\section{CHAPTER XV}

\section{POLITICS AND REORGANIZATION}

The deaths of Stuart, Whittaker, and McKenzie, the incarceration of Adams and Jimmy from Town, and the banishment or voluntary departure from the country of Kay, Duane, and half a dozen others, effectually disintegrated the Sydney gang that had so long terrorized the community, and resulted in a marked diminution of crimes of violence throughout the state. ${ }^{1}$ The attention of the Committee continued to be occupied with the men still in custody, who were chiefly minor offenders or immigrants under investigation. Twenty or thirty of these cases were noted in the records during the four weeks following the last execution, and decisions show that a little over half of the suspects were discharged and that the remainder were sent out of California.

As the consciousness of social security increased the question arose whether or not the Committee of Vigilance should continue to exercise an active supervision over public affairs. Some members felt that the excuse for their organization terminated with the relief of the emergency that had called them together $;^{2}$ some, notably Stephen Payran, thought that the association should continue unchanged for "all time," ${ }^{\prime 3}$ while a small group wished to prolong the influence of the leaders of the body by placing them in office at the approaching September election.

On Saturday, August 23, a "Meeting of Citizens" was held in the rooms of the Committee of Vigilance, and a committee was appointed to nominate candidates for the local offices. ${ }^{4}$

1 See the discussion of criminal conditions, infra, p. 388.

2 See resignation of E. M. Earl, Papers, 630.

3 Papers, 632. 4 Papers, 5 48. 
A second meeting took place on Monday evening, but there is no statement to show where the adjourned gathering was held. At that time a ticket was decided upon, and an address to the voters of the city was adopted. The latter was in the form of resolutions which declared that the one hope of civic regeneration lay in more general devotion to the ordinary duties of citizenship, and in the election of fit officials, irrespective of party affiliations. ${ }^{5}$ The communication was dignified and forceful, frank in its acknowledgment of social shortcomings in the past, but hopeful for better standards in the future. Although it was signed by fourteen members of the Committee, the society officially and publicly disavowed the action on the ground that political activity would be ruinous to the work for which it had been organized, ${ }^{6}$ and the further use of headquarters for any outside purpose was forbidden. In spite of this corporate attitude, members of the Committee, as individuals, pushed the campaign. The papers of the twenty-eighth published an indorsement of the ticket, and a call for a ratification meeting, signed by two hundred and three citizens, among whom were at least seventy-nine members of the Committee of Vigilance. On Angust 29 over fifteen hundred voters met and pledged themselves to support the non-partisan ticket, which presented nine candidates for the legislature, eleven for county offices, and twelve for township positions. An exact analysis of the personnel is difficult, as the official returns did not indicate the affiliations of the township nominees, but the Alta said that the ticket as a whole included eight Whigs, twelve Democrats, and twelve Independents. ${ }^{7}$ For the legislature and the county positions, the non-partisans made seven entirely independent nominations and indorsed three Whigs and ten Democrats. The Evening Picayune, a Whig paper, immediately charged that the whole

5 Alta, 1851, Aug. 26 2/6. An extract from the address is printed in the Appendix, infra, p. 470 .

6 Papers, 550-552. 7 Alta, 1851, Aug. $31 \%$. 
movement was a clever ruse on the part of the Democrats to use the Committee as a tool to regain the control they had lost in April. ${ }^{8}$ In spite of the fact that an effort had been made to put the Democratic party on record as opposed to the Committee, ${ }^{9}$ this charge was repeated as long as the campaign was under way, while it was as constantly contradicted by the Alta and the Herald.

One of the most important indorsements was that of the Democrat, Alexander Campbell, to succeed himself as judge of the County Court. The Vigilantes, whose indictment for murder he had urged upon the grand jury, staunchly supported him in the office where they had found him fearless and incorruptible. ${ }^{10}$

G. W. Ryckman made an interesting contribution to the history of this political effort. He said that on the day after the execution of Whittaker and McKenzie he had the following conversation with Jack Hays, who had anticipated renomination for the office of sheriff $:^{11}$

He said to me: "Ryckman, I am mortified to death. ... It destroys any hope I may have for a renomination, for I could not be elected; the people would frown upon what they would consider a neglect of duty." I said, "Colonel, don't be foolish. Seek the nomination. We will organize a Vigilance Committee ticket, put you on, and elect you by 1500 to 2000 majority." He took the hint, and accepted the nomination. We got up a Vigilance Committee ticket, put him on for Sheriff, and he was elected by 2000 [1826] majority.

The campaign for this non-partisan ticket was brief but spirited. When the official returns were announced it was shown that the Independents had controlled 1000 to 1300 votes out of

8 Picayune, 1851, Aug. 26-Sept. 4.

9 Resolutions to this effect had been published in the Herald, 1851, Aug. $5 \%$. See also Popular Tribunals, I, 322-323.

10 Judge Campbell, then in private practice, also opposed the Committee of ' 56 , and even left San Francisco at the time for temporary residence in the Hawaiian Islands (Shuck, Beneh and Bar in California, 125).

11 Ryckman, MS Statement, 16-17. 
a total of about 5700. ${ }^{12}$ Though none of the out-and-out Independent candidates was elected, the vote in the case of coalition candidates was sufficient to upset the previous Whig majority, and to elect all the Independent-Democrats, who ran about one thousand votes ahead of the regular Democratic ticket. The Independent-Whigs were also elected, and the figures proved that the party inaugurated at the headquarters of the Committee of Vigilance was able to exercise a decisive influence in city affairs. Jacob R. Snyder, a Democrat elected to the state senate, was an active member of the Committee, as was A. J. Ellis, a Whig who was sent to the assembly, and the two legislators resigned in November to take up their duties at the capital. ${ }^{13}$ Herman Wohler, a Democrat elected to the assembly, was a less prominent committeeman. P. A. Roach, of Monterey, also a member of the San Francisco Committee of Vigilance, was chosen for the senate at this same September election. Whatever may have been the subtle influences of the Democratic politicians, even the Picayune admitted that the Independents had selected the best candidates for indorsement. ${ }^{14}$

The gratifying result of the attempt to purify local politics raised sanguine expectations of improvement in local conditions. But a curious situation which arose in the municipal offices of San Francisco went far towards checking the efforts at reform. It will be remembered that under the terms of the new charter a Whig council had been elected in April, 1851. This body quickly won the confidence of the community by the commendable economy of its administration. ${ }^{15}$ There was a question,

12 Herald, 1851, Sept. 14. For the state offices, to which the Independents made no nomination, the Whigs polled a majority of 469 to 912 , and they liad a majority of 400 to 600 for local offices except where the rival Democrats were endorsed by the Independents.

13 Papers, 706.

14 Picayune, 1851, Aug. 30 \%.

15 See Annals, 348-350, Hittell, California, III, 408-409; contemporary papers, especially Alta, Aug. $27 \%$; $29 \%$; Sept. $5 \%$; Dec. $25 \%$; $26 \%$; Herald, Aug. $29 \% \frac{1}{4} ; 302 / 2$; Sept. $12 \% 2$; Dec. $25 \%$. The papers commended the old council, but Hittell said it nearly bankrupted the city. 
however, as to its legal term of office; the wording of the charter was ambiguous, and while some politicians claimed that a new council should be chosen in September others maintained that the existing body should hold over until September, 1852. The latter interpretation was adopted by the Whigs in office, and when September came they issued no call for elections for the city positions.

The Democrats, with nothing to lose, decided to put the matter to a test, and nominated a full ticket. The Independents, who desired no change in the city government, refrained from wasting any energy on a contest they deemed futile, although some party of obscure origin attempted to present a city ticket which included several members of the Committee of Vigilance. This was published in a single issue of the Herald, but seems to have been withdrawn after some of the nominees repudiated the movement. The only candidates considered at the polls were those on the Democratic ticket, who were elected by a light and uncontested vote. When they attempted to claim their positions the old officials refused to withdraw and the matter was taken to the courts. Late in December the case was decided against the incumbents, and they reluctantly retired in favor of the triumphant Democrats.

By this unexpected shifting of the local administration the Democratic machine acquired control of the city at the rery moment when the public conscience was aroused to the need of reform, and when the better element was effectively organized in a non-partisan campaign; for the independent vote had elected Democrats to some of the most important positions in the county, and the excitement of that open contest had entirely diverted public attention from the quiet movement for city positions by which skilful leaders sought to regain their former prestige. The new comptroller, James W. Stillman, was a member of the Committee of Vigilance, as were Caleb Hyatt and J. H. Blood, 
aldermen, and D. W. Lockwood and W. H. Crowell, assistant aldermen. None of them played any important part in the work of the association, and their connection with it is not noted in the newspapers that have been consulted in preparing this account of the election. It is unlikely that they were elected by the rotes of their fellow Vigilantes, or that they served as any effective check on an administration that soon became a target for charges of extravagance and corruption.

As the third month of the Committee's activities drew to a close it became apparent that its continued existence did not depend so much upon the personal convictions of individual members as upon their ability to defray the heavy expenses entailed by the work.

The constitution made no provision for financial needs, but we learn from the documents that each member was assessed five dollars a month for current expenses, and that fines were imposed for absence from duty. The reports of the sergeantat-arms show that 306 members paid initiation fees of five dollars before June 26. A month later a total of 550 initiation fees had been paid, while 80 were still due. In July 216 paid the monthly assessment and 336 were delinquent; $\$ 100$ was paid in fines. ${ }^{16}$

On July 5 a committee of five was appointed to hear the excuse of delinquent members, as about one hundred had never paid the initiation fee of five dollars, and $\$ 1025$ was due for fines. $^{17}$ At this time J. W. Salmon, the first treasurer, was obliged to resign because of ill health, and the position was filled by Eugene Delessert, who remained in office until April, 1852. When the funds were transferred the amount on hand was $\$ 800$, the debts of the association were $\$ 920$, and the estimated monthly expenses were $\$ 1500$. At the end of the month the finance committee reported that $\$ 400$ was due on initiation fees and $\$ 1680$

16 Papers, 764, and Index under "C. of V.-Finances."

17 Papers, 177, 205-206. 
on the monthly assessment of five dollars, and that in default of these payments the treasurer, Mr. Delessert, had advanced $\$ 500$ out of his own pocket. ${ }^{18}$ On this showing it was recommended that subcommittees, especially the water police, should exercise greater economy in their expenditures. A few days later plans were made to find less expensive rooms for headquarters, and the salary of the sergeant-at-arms was reduced from $\$ 200$ to $\$ 150$ a month. ${ }^{19}$

Frequent resolutions on the subject of delinquent members show the difficulty of collecting funds. At various times it was voted that the guard should question every one at the door and admit no one who had not paid up to date; that names of those in arrears should be read aloud in the meetings, and that delinquents should be assigned to guard duty at night. ${ }^{20} \mathrm{~A}$ collector was appointed on July 19, and an additional collector on August 8. The latter reported three days later that he had with great difficulty secured $\$ 200$ and could no longer continue in the position. $^{21}$

But the ordinary expenses of the Committee did not seriously threaten to bankrupt the organization; dues and fines were paid, even if with reluctance, and the support of the public was proved by frequent contributions. ${ }^{22}$ A far more serious embarrassment was imminent in the possibility of an adverse decision in the suit of Metcalf vs. Argenti et al., which came up for trial in the Supreme Court on August 16. Contrary to the advice of some of the members, especially of Stephen Payran, the Committee had assumed the expense of the defense, evidently with the expectation that the attorneys would volunteer their services. This

18 Papers, 377.

19 Papers, 443, 4.77.

20 Papers, 403, 440, 510.

21 Papers, 544.

22 Treasurer Salmon raised nearly $\$ 1000$ by outside subscriptions (Papers, 205, 752). 
hope was disappointed. The defendants' lawyers demanded compensation for their services, and thus created a serious situation in the face of the depleted treasury. ${ }^{23}$

The case aroused much interest and served as a test of public sentiment for and against the Committee. The prospective jurors were sharply questioned as to their sentiments towards the organization, and several plainly avowed their approval, while a few were as frankly antagonistic. ${ }^{24}$ Members of the searching party testified freely concerning their participation in the raid. Yet, in spite of the incontestable proof of violent trespass upon Metcalf's premises, and of the impassioned appeals of his counsel, the hearing resulted in a disagreement. ${ }^{25}$ The plaintiff immediately moved for a new trial and raised his claim for damages to $\$ 50,000$, thus forcing the Committee to expect increased expenses as the case progressed.

Certain passages in the press reports of the Argenti trial hint of occurrences within Vigilante headquarters that left no record in the archives. Metcalf's suit was first noticed in the documents on July 3, and the minutes of the General Meeting on the fifth record the passage of a resolution directing a subcommittee to call upon his lawyers, Lockwood, Tilford \& Randolph, and ask them to withdraw the complaint. This appeal proved

24 The Herald of Aug. 18 reported, among others, the following answers:

Question to F. Adams, not a member of the Committee: "Do you believe that the defendants as members of the Vigilance Committee have a right to enter and search a house without cause?" Answer: "I believe that they had a cause; I think the Vigilance Committee is right.", Set aside for cause.

J. Wilbur [Wilber]: "Am proud to say that I am able to present a character that entitles me to a membership of the Vigilance Committee.' Challenged peremptorily by plaintiff.

J. W. Young: "If I thought the law was wrong and the rules of the Committee right, I would rather lean to the latter.', Excused. Young was mentioned as a member of the Committee, but his name is not on the roll.

Marion MeNulty, not a member: "No self-constituted body has the right to act in opposition to the law."

23 Papers, 216, 290, 591, 598, 615.

25 The case was reported in the Herald, and the Alta, 1851, Aug. 17-25. The pleadings of Lockwood were published in pamphlet form and used as a campaign document in the September election (Herald, 1851, Sept. $1 \%$ ). 
a grave error in judgment, as it gave those gentlemen an opportunity to make an exceedingly sarcastic rejoinder, which was published with varying comment in several of the papers. ${ }^{26} \mathrm{~A}$ few days later it came to the knowledge of the Executive Committee that one of their number, John F. Spence, had spread a report that Stuart had implicated Mr. Tilford in his confession, and the president was immediately instructed to make official denial of the charge, an errand which Payran discharged in most courteous fashion. The retraction was a direct reflection on the gossip of Spence, whose attendance at the Executive meetings was thenceforth very irregular. ${ }^{27}$ It is quite possible that the rebuke rankled in his mind, for when he was on the witness stand at the trial he revealed a bit of inner history of the Committee by testifying that the motion to communicate with Metcalf's lawyers had never received the approval of a majority of the Committee, had been rejected at the General Meeting, and had only been passed later in the evening by a small number who reconvened after the dispersal of the others. ${ }^{28}$ Mr. Spence was immediately asked to tender his resignation, but he did not

26 Papers, 155-156, 177, 210. The following preamble appeared in some of the papers:

"To the 'Vigilance Committee'

San Francisco, July 7th, 1851.

Sundry fools or knaves, (perhaps both,) styling themselves 'The Vigilance Committee,' having caused to be transmitted to the firm of Lockwood, Tilford \& Randolph, a silly but impudent resolution, 'That a committee be appointed to wait on Messrs. Lockwood, Tilford \& Randolph, acting as counsel in the case of Metcalf v. Argenti, Atkins, and others, and they are hereby directed to request those gentlemen to withdraw the suit, and decline further proceedings in the matter touching the case.' As a member of that firm, my only answer to the aforesaid fools or knaves, (in addition to my 'verbal' response to the bearers of the resolution,) is, 'I do defy, deny, spurn, and scorn you.',

R. A. Lockwood.',

(Reprinted in the California Courier, 1851, July 9 \%2). The Picayune supported the lawyer's position (July $8 \%$ ), but the Herald strongly upheld the Committee (editorial of July 9 ).

27 Papers, 265-267, 434.

28 Herald, 1851, Aug. $19 \%$. 
comply with the request until the announcement of the independent political ticket gave him a pretext for a dignified withdrawal. ${ }^{29}$

The resolution of which Spence spoke is incorporated about midway in the proceedings of the evening of July 5, as if it had been adopted while the meeting was in full session, and a little later is recorded the more important resolution which claimed the right to search suspected premises. Relative to the latter, Stephen Payran testified that he had no knowledge at all of the action, and William Sharon deposed that there was decided opposition to its adoption. The resolution appeared in the daily papers subscribed "By order of the Committee of Vigilance, No. 67, Secretary." It is interesting to observe that in reply to questions on the witness stand Sharon disclaimed knowledge of the identity of "No. 67," and Payran calmly affirmed: "We have no secretary.", ${ }_{30}$ If the Herald quoted that statement correctly, Mr. Payran must have juggled with his conscience. Certainly his utterances cannot be defended on any ground known to the writer.

While considering this episode it may be remarked that two days after the passage of the contested resolutions the General Committee decided that a two-thirds vote should be required for the reconsideration of a measure once adopted. ${ }^{31}$ This ruling may have been prompted by the action of the small group which reversed the full vote in the matter of Metcalf's lawyers. The incident in itself and the sworn testimony at the trial lead one to speculate whether the secretary did not sometimes fail to record occasions that gave rise to significant differences of opinion.

There were other occurrences, very lightly emphasized in the minutes, which indicated that a certain amount of friction constantly accompanied the work of the Committee, and that it

29 Papers, 509, 552. 31 Papers, 204.

30 Herald, 1851, Aug. $19 \%$. 
was not only the hot temper of the first president that precipitated hard feeling. McDuffee, the sergeant-at-arms who had quarreled with Brannan in June, incurred the displeasure of the Executive Committee early in August, so that he was censured for some unrecorded official action. After a short period of probation, he finally resigned. ${ }^{32}$ Occasional complaints were registered against the character of members or against their insubordinate or overbearing behavior. ${ }^{33}$ One of the expeditions sent out after Whittaker was nearly wrecked because of internal dissension; convicts escaped from the inspected vessels on account of conflict between the guards. ${ }^{34}$ When the fate of George Adams was under discussion the divergent views were sharp and determined; and as soon as that matter was decided Colonel William C. Graham, a faithful attendant at the meetings of the Executive Committee, and its secretary for some months, tendered his resignation on the ground that he could no longer act in a body where a small minority had the rule. For some reason he reconsidered his action, then resigned again, but again continued his services until August 17, when he resigned once more, together with eight others, who complained that jealousy and petty interference with delegated powers were hampering their performance of important duties. ${ }^{35}$ That seems to have been the final exit of Mr. Graham, but the other eight immediately resumed their seats in the circle about the table in the Executive chamber. It was a few days after this that Sheriff Hays seized Whittaker and

32 Papers, 418, 571. See also infra, p. 367.

33 See Papers, Index under "C. of V.-Relations which indicated friction."

34 Papers, 414-417.

35 Papers, 427, 462, 498-500. The resignation was signed by Payran, Ryckman, Graham, J. B. Huie, Garwood, Schenck, Bluxome, Wadsworth, A. J. Ellis. There were earlier resignations that may or may not have been significant. John Buckler and Alexander Murray found that health forbade them to carry out the duties of the Committee (ibid., 153, 177); R. S. Watson and William T. Coleman had no time to continue in the Executive Committee (ibid., 217, 440). 
McKenzie from their passive guards, and it is doubtful if the suspicions of treachery that arose from the surrender were ever fully dispelled.

Whatever might have been the issues of this period, they received scant consideration in the records. Various reports indicate that routine business progressed as usual, but there are no minutes of Executive meetings from the date of the seizure of Whittaker and McKenzie until the middle of September, when the Committee of Vigilance was thoroughly reorganized. The recollections of the members ignored the lapse, and Bancroft did not explain it in Popular Tribunals.

It is probable that an unwritten law of the Committee prohibited resignations except for the most urgent cause, ${ }^{36}$ nevertheless several were tendered just at this time. Some who asked to withdraw gave no reason at all, or alleged business or domestic preoccupations, others expressed frank disapproval of the policies of the Committee. J. W. Salmon and H. D. Evans resigned without explanation on August 20; George Mellus resigned August 30, and on the same day Lloyd Minturn and C. S. Woods asked for long leaves of absence. ${ }^{37}$ It is evident that underlying these evidences of disaffection was an increasing difference of opinion over the future of the Committee of Vigilance, with a conviction on the part of a growing majority that some form of reorganization was imperative, since by this time conditions in the city showed signs of decided improvement. Stuart's gang was broken up, and by September 6 the Executive Committee was able to make reports and recommendations covering the disposition of every prisoner then in custody. ${ }^{38}$ It announced that many of the suspects ordered to leave California had consented to defray their own expenses back to Australia and showed themselves quite willing to depart in perfect satisfaction with the acts

36 See infra, p. 355.

37 Papers, 527, 577, and Index under "C. of V.-Resignations."

38 Papers, 591-598. 
of the Committee. The concluding sentences of the general report then transmitted read:

Our labours are now completed and so far peace, and security, have attended our efforts for the public good, we earnestly hope that the Blessing of Almighty God may rest upon us, may the cessation of our labours, be no cause on the part of the vicious, to renew their course of life to the injury of the people.

We trust that those in power at this time, and those who shall succeed them, by reason of the late election may so learn wisdom, that in the exercise of their representative duties, they may ease the weight from the shoulders of their constituents, and thereby honour their common Country and preserve their institutions unsullied.

It will now become you, to adopt some action for the future, to so base the present institution, that it may silently be a terror to all evil doers, and a rewarder of all that do well, that it may be a guardian spirit of the land.

Events proved that this recommendation embodied the conviction of a majority of the members. On September 9 the General Committee appointed a subcommittee to "make such suggestions or propositions as may be of interest to the association,' and to nominate a new Executive Committee of twentyfive. On the same day E. M. Earl asked to have his name stricken from the lists, as he believed the time had come to surrender power into the hands of the representatives recently elected by the people. ${ }^{39}$ On the eleventh James F. Curtis discovered that his business engagements would not allow the unremitting attention demanded by the duties devolving upon members of the Executive Committee. ${ }^{40}$ On the thirteenth Thomas McCahill, who had caused offense by remarks derogatory to the chief of police, acceded with "grate pleasure" to a request that he should withdraw from the Executive Committee. On the same day J. B. M. Crooks was incontinently expelled from the society when his bill for delinquent fees was returned with the crisp annotation "Says he will be damd before he pays." "11

\footnotetext{
39 Papers, 601, 630.

41 Papers, 621, 627, 631.

40 Papers, 630.
} 
Such occurrences were straws showing cross currents of opinions. Stephhen Payran was far more definite in the expression of his attitude, and he tendered his resignation from the Executive Committee as a protest against the proposed changes. He interpreted them as censure upon his personal conduct of affairs, and he stated at a later time that he had been informed that the dissolution of the association had been threatened because he was accused of exercising too absolute a power. ${ }^{42}$ In his note of resignation he took the opportunity to say:

I would love to see it [the.Committee], continue for all time, and firmly believe that if the Association could exist under its present order, it would tend to preserve the happy state of our City and State, and make it the abode of Safety, happiness and prosperity-

Dissolve it, or do anything that would serve to disorganize it, in its essentials, you will throw it open to abuses, never to be recovered fromAnarchy and confusion would soon reign in our midst.

In spite of his wounded feelings Payran did not insist upon the acceptance of his resignation; he continued to serve as president, and even formulated a plan for a modification of the work of the Committee, although there is no annotation to show that his scheme was ever submitted for discussion. ${ }^{43}$

By the fifteenth of September disposition had been made of every case before the Committee, and the prisoners' room at Vigilance headquarters was empty. ${ }^{44}$ On the evening of the sixteenth a General Meeting was held, the minutes for which are unfortunately lacking. At that meeting, however, was presented the report of the Committee on reorganization, which is incorporated in the minutes of September 17. It recommended the adjournment of the General Committee sine die, and the election of an Executive Committee of forty which should hold office for six months, should "watch with vigilance" the actions of

\footnotetext{
42 Papers, 631-632, 701.

43 Papers, 632-634.

44 Papers, 639; Herald, 1851, Sept. $18 \%$.
} 
public courts and officers, and should suggest desirable statutes for the improvement of criminal legislation. It was expressly stipulated that the Executive Committee should have no authority to make arrests, but that it should summon the General Committee in ease of any emergency, and act only under instruction therefrom; and the members were solemnly warned that the entire body of the associates and the community at large would hold them strictly accountable for the faithfulness with which they fulfilled this delegated task.

This report was adopted; the Executive Committee was elected as nominated, and the five members of the committee on reorganization were added to their number. Almost all the old and active members were retained, Brannan and Coleman were again included, and additions were made from the ranks of those who had taken an active part in the work of the General Committee. $^{45}$ $18 \%$.

45 Papers, 642-644. The meeting was reported in the Herald, Sept. 


\section{THE CLOSING MONTHS}

The new Executive Committee convened on September 17, and organized by electing Payran as president and Bluxome as secretary. ${ }^{1}$ The latter offered his resignation before long, as he could not afford the time necessary for the position, but he consented to remain in office when allowed a salary of $\$ 100$ a month. ${ }^{2} \mathrm{D}$. L. Oakley, the sergeant-at-arms, was also given an equal salary to take care of the rooms, to keep them open day and night, and to admit members "agreeably to the rules of the Association.",

On September 27 by-laws were adopted which defined the duties of the officers and provided for weekly meetings of the Executive Committee with a necessary quorum of nine attendants, and for special meetings of the General Committee upon the written request of any five members. ${ }^{*}$ The Alta spoke of the reorganization as an "adjournment" of the General Committee and congratulated the association on the accomplishments that permitted a cessation of activities. ${ }^{5}$ But the Evening Picayune did not attribute the step to improved conditions, but to the great expense attending the work and to the very general condemnation of the Committee expressed by the commercial papers of the eastern states. ${ }^{6}$ The editor thought that in spite of the appointment of the committee of forty-five it was unlikely that the association would be continued, owing to the danger in its methods. The Committee repudiated with vigor the insinuations

1 Papers, 645-646; revised list of members, 652.

2 Papers, 678.

3 Papers, 650.

5 Alta, 1851, Sept. $17 \%$.

4 Papers, 659-661.

${ }_{6}$ Picayune, 1851, Oct. $1 \%$. 
of the Picayune, and took occasion to print full and frequent notices of its meetings in the advertising columns of the daily press. $^{7}$

A week after the reorganization the Committee removed to smaller and less expensive quarters, ${ }^{8}$ which were described as follows in the Alta of November 3 :

The v. C. Rooms.-The rooms of the Vigilance Committee, situated on the corner of Sacramento and Battery streets, over Middleton \& Smiley's store, are handsomely furnished. The floor is carpeted. At one end is a handsome rostrum, containing an elegant chair for the President. In front of the desk hangs a small banner belonging to the Committee. Behind the President's chair is an elegant mirror. ${ }^{9}$ Down the centre of the room is a table containing books, an ornamental inkstand, \&c., \&c. At the eastern end, opposite the rostrum, the daily papers are to be found on file. The windows are neatly curtained; while hanging against the wall are pictures and maps. The large banner which was presented to the Committee by the ladies of Trinity Church, is rolled up and deposited in a small room adjoining the room for meetings; where are also the hand cuffs, chains and other paraphernalia of the Committee.

Before the month was over members of the Executive Committee began to chafe at the order which forbade them to make arrests. They therefore called a General Meeting for October 1, at which they recommended the restoration of the power of initiative in this respect. ${ }^{10}$ Apparently it was granted and was exercised on November 11 when Antonio Gonzales, who had engaged in a stabbing affray, was taken to headquarters. The committeeman who made the arrest stated that no police officer was present and that the bystanders requested him to take charge of the offender. ${ }^{11}$ Gonzales was immediately handed over to the authorities, and except for an obscure allusion to the "arrest of

\footnotetext{
7 See Papers, 673.

8 Papers, 651.

9 The mirror, found during the June fire, had been advertised without success (Papers, Voucher no. 70). The banners are mentioned infra, pp. 371,372 .

10 Papers, 671-673; Alta, 1851, Oct. $2 \%$.

11 Papers, 689-692. Noted in Alta, 1851, Nov. 12 \%3; Herald, Nov. $13 \%$.
} 
Handy, ", ${ }_{12}$ November 16 , no other prisoner seems to have been in the hands of the Committee until Charles Talbot was arrested on the charge of arson, November 25, 1852. ${ }^{13}$

The records for these fourteen months are far less interesting and picturesque than those for the earlier periods. From September 17,1851 , to March 17,1852 , twenty-five regular weekly meetings were held, with an average attendance of sixteen. ${ }^{1+}$ The meetings, therefore, were not neglected by the members, but the minutes indicate that they were devoted to routine business and to the effort to raise money, especially the sums needed to meet the expenses of the suits instituted by Peter Metcalf.

One of the first matters that engaged attention was a communication from the collector of the port, Thomas Butler King, to the effect that he had been informed by an American consul in France that the French government was preparing to send to California a shipload of emigrants, among whom might be a large number of desperadoes. The Committee at once appointed a delegation to wait upon the resident French consul, M. Dillon, and upon the representatives of Marizou \& Company, agents for the emigrant vessels, to make inquiries relative to the proposed expedition. These gentlemen assured the Committee that the colonists would include only persons of approved respectability. They promised to write to France to warn those interested in the venture to take every reasonable precaution and to advise them of the "existence of a powerful association styled the Committee of Vigilance, who have combined together for the purpose of ridding the community of all disreputable characters, and who have the determination and the power to carry out their views." ${ }^{15}$ This

12 Papers, 704. The Alta, 1851, Nov. $21 \%$, noted the arrest by the Committee of a suspected incendiary, who had been handed over to the recorder.

13 See infra, p. 354.

14 See Papers, Roll Call, Appendix C.

15 Papers, 651, 662-664. 
promise was faithfully performed and the responses they received appeared as follows in the papers of a later date: ${ }^{16}$

Messrs. Marziou \& Co.,

Paris, Nov. 20th, 1851.

San Francisco,

Gentlemen:

We have today seen Mr. Reyre, Government Commissioner, to whom we communicated the information received from you, relative to the action of the very honorable, the Committee of Vigilance, of your city. He has assured us that the solicitude of the American authorities would be completely satisfied through the proper diplomatic sources.

Among the emigrants there are no criminals... and we concur with you, in deeming the accession to your new State, of four or five thousand industrious operatives ... a subject of congratulation.

Havre, Nov. 26, 1851.

You may re-assure the members of the Committee of Vigilance, our emigrants are all honest people, emigrating voluntarily, and from whom testimonials of character are required before admission to the association. An official communication in regard to this subject will be made to the American Minister at Paris, for transmission to his government.

A thrill of the old-time excitement was experienced on October 15, when the Committee heard that Briggs and Osman, confederates of Stuart who had eluded arrest, had been seen in the city, and were supposed to be on board a vessel clearing for Australia. Since rich plunder was known to be in their possession, a pursuit was hastily organized, the tug Fire Fly pressed into service, and a dash made outside the Golden Gate. One or two vessels were overhauled, but the fugitives were not found, and when her bunkers were empty the Fire Fly returned to port. So concluded the last recorded expedition of the water police of the Committee of Vigilance. ${ }^{17}$

16 Alta, 1852, Feb. $10 \% 11$. The expedition was financed by the Sociéte du Lingot d'Or, which held a lottery on Nov. 16, 1851, and distributed as prizes the passage money for 5000 emigrants. See also Lévy, Les Français en Californie, 72-74.

17 Papers, 679, 710, 720, and Voucher no. 95. Among Bancroft's clippings is an undated serap (printed between Aug. 18 and Sept. 8, 1851), 
About the same time Andrew Goodwin appealed for help in recovering his niece, Mary Lye, who had been taken from him by people named Kohle, and placed in a house of ill fame at Marysville. ${ }^{18}$ The case was mentioned but briefly in the records of the Committee, but it was more fully reported in the newspapers. The Herald said:

Her aged uncle went several times to Marysville, and though very poor, expended upwards of $\$ 400$ in fruitless efforts, through the authorities and otherwise, to rescue the child. . . Almost heart-broken by his want of success, he . . . applied to the Vigilance Committee for relief. A member of that body [Stephen Payran] was alone deputed to proceed to Marysville and take the child from those who detained her. Having conferred... with the Marysville Vigilance Committee-a body that has been as efficient as any similar one in the State-accompanied by several of its members, he proceeded to the house and demanded the girl. Those who detained her were at first very boisterous and very menacing, but the threats were disregarded and the child was brought off and restored to her delighted relatives.

Many years later Mr. Payran recalled the incident with satisfaction. ${ }^{19}$ He said that he had been warned that the roughs of Marysville would try to prevent the rescue. Accordingly, after he had carried the child in safety to the hotel where he lodged, he took the other guests into his confidence, and fifteen or twenty miners instantly drew their revolvers and escorted her to the boat, where she was guarded until she arrived in San Francisco. The little story furnishes one note of tender pathos in all the dreary record of erime and punishment. Sketches by unskilled hands have delineated the executions of Stuart, Whittaker, and McKenzie, but no one has thought of picturing Stephen Payran, the enthusiast and idealist, as he braved the guns of the gamblers

reporting that at some time a hoax was perpetrated on the Committee by inducing it to pursue a vessel under the mistaken idea that Briggs was on board.

18 Papers, 676-768; Herald, 1851, Oct. 16 \%/, 17 2/1.

19 Carpenter's letter in Oakland Transcript, 1874, March 29 1/1. Ernest Kohle wrote a letter of protest, and asked compensation for his care of the child. His communication was "laid c.n the table" (Papers, 696). 
to restore a little girl to guardians who were too feeble and too poor to accomplish her rescue by their own efforts.

The incident was Payran's last participation in the work of the Committee. On October 27 he resigned again, "owing to the cares incident to my business, and the larger active service of our Committee being at an end, combined with other causes.",20 When requested to state his reasons more fully, he replied in a long letter that affords us valuable information on the condition of the Committee at the time. ${ }^{21}$ He pointed out that the large salaries of the sergeant-at-arms and the secretary increased the expenses of rent and incidentals to a minimum of $\$ 350$ a month "without a dollar in the treasury to meet them." He condemned the policy that made the Committee, rather than individuals, responsible for the costs of the suits instituted by Metcalf. That liability then exceeded $\$ 2500$, with the possibility of heavy damages if decision should be made for the plaintiff. He also alleged that the constitution and by-laws were so misinterpreted or misunderstood by the officers that the Committee was kept in ignorance of the truth and criminals were allowed to escape. Conscious of the criticism of his own use of authority, he said that he had usually refrained from taking the chair since his re-election in September, and now felt that the time had arrived for his final resignation. It was accepted, with suitable expressions of esteem and regret, and his name appears no more upon the records of the Committee, the office of the chairman being filled thereafter by the vice-presidents, G. W. Ryckman and S. E. Woodworth.

A curious reversal of the usual relations between the Committee of Vigilance and the authorities of San Francisco ocenrred late in October, in connection with an outbreak of public indignation against the eaptain and officers of the sloop Challenge as

20 Papers, 687-688.

21 Papers, 699-704. 
a result of charges of brutality during the voyage from New York. Crowds of angry sailors and longshoremen collected along the water front, demanding Captain Waterman and his mates, and threatening to lynch them as soon as they could be found. The excitement reached such a dangerous point on October 31 that the mayor ordered the bell of the Monumental Engine Company to be tapped as a signal to law-abiding citizens to assemble and disperse the mob. In obedience to the familiar summons the Vigilance Committee gathered at headquarters and sent to the chief executive an offer of any assistance he might require. The account of the affair in the Alta of November 1 said that the mayor "accepted the services of the Vigilantes, as a body of citizens, merely." The Herald reported that a strong detachment of the Committee appeared among the hundreds who responded to the call for help. Overawed by the reinforcements rallied about the authorities, and placated by promises of thorough investigation, the mob finally dispersed..$^{22}$ The Alta took occasion to say:

Where now are those who called the Committee a mob-who predicted that they would establish riot and ruin in our midst? Where are they who mourned over the ruins of the Constitution of the United States, the ruins of the laws, of the courts and of all legal forms?... Let the events answer. The Committee found society in a chaotic state... . They formed themselves together, conscious of the solemn responsibility which they were self-imposing. They seized upon culprits and promptly punished them ... crime shrank before them, and Order sprang from the chaos. Having restored security to the city, they yielded their power to the regularly constituted authorities, trusting that they would be enabled, unassisted, to keep off the floodings of crime. And now the Committee are found on the part of the authorities, upholding the law. And they will be found there until the courts can no longer afford us protection.

If the Vigilantes surprised their detractors by assisting the constituted authorities in the Waterman affair, the critic of

22 Farwell described the episode, and felt that it proved that the Committee opposed mob violence (MS Statement, 11-12). Captain Waterman surrendered himself as soon as it was safe. He was tried and fined, in February, 1852. 
today will be scarcely less surprised when he reads of a movement they were inaugurating at the very date of the riots on the water front. G. E. Schenck, who had left San Francisco a few weeks earlier, in his note of resignation urged his former associates to use their influence "for the establishment of schools, academies and seminarys of learning and virtue." ${ }_{23}$ Seminaries of learning and virtue would appear to be institutions incongruous with the administration of lynch law, and history does not record that the members of the Committee of Vigilance ever attempted to found them. They did, however, make a definite effort to carry out the spirit of Schenck's suggestion when they decided to establish a library as a contribution to the intellectual life of San Francisco. Mention of their action in this matter does not appear in the minutes or reports. It can be found, however, in the papers of the day and in the recollections of Isaac Bluxome, Jr., who said $:^{24}$

When the first committee was about to disband, we concluded that we would do something for the public at large. A man named Livingston suggested that we start a library for the public good, and Charles S. Eijenbraugh [Eigenbrodt] seconded the motion. I had a pretty good library for a private citizen of some five hundred volumes, which I contributed. Others did the same, and that is the foundation of the Mercantile Library of this eity. You will find my name in these books there, if not pasted over.

The Herald and the Alta of October 4, 1851, spoke of an effort to establish the San Francisco Library and Museum Company, and commended the plan proposed as the city had lost its only library in the May fire. It was stated that the proposition had come from a group of members of the Committee of Vigilance who desired to keep up the ties of companionship and who proposed to limit the membership of the library association to those who belonged to the Committee. This limitation was regretted by writers in both papers, and it was hinted that

23 Papers, 635.

24 Bluxome, MS Statement, 16. 
it would probably be removed before very long. Some donations were recorded from S. E. Woodward [Woodworth], Major Boyd, Captain W. A. Howard, and Mr. Shelton, the botanist. It was announced that the collection could be inspected in the room next to the Committee's headquarters, under the care of the Committee's librarian. Other donors, it seemed, were reluctant to place books in the inflammable structure, and waited until a fireproof building might be secured. ${ }^{25}$ The minutes of December 17 stated that fireproof accommodations were too expensive for the use of the Committee at that time. ${ }^{26}$ Late in November the California Institute was organized, with membership open to the public on the payment of moderate fees; rooms were secured on the south side of Pine Street, betwen Montgomery and Sansome; D. L. Oakley, of the Committee, acted as librarian; S. E. Woodworth was president; and the list of officers and directors was made up almost entirely from the roll of the Committee. ${ }^{27}$

There is no evidence that this library became an important factor in the life of San Francisco. If Bluxome's statement was correct, however, a substantial nucleus of books was transferred to the Mercantile Library, founded a year later. ${ }^{28}$ Had not the fire of 1906 swept away the collection of that association, search might now reveal that the earliest volumes in that historic library were donated by the men who armed themselves in 1851 to execute summary justice upon the murderers and incendiaries that threatened the peace of the community.

25 Alta, 1851, Nov. 22 2/2.

26 Papers, 713.

27 President, S. E. Woodworth; Vice-Presidents, G. W. Ryckman, A. C. Wakeman; Treasurer, Eugene Delessert; Recording Secretary, J. R. Dunglison; Corresponding Secretary, L. F. Zantzinger; Librarian, D. L. Oakley; Directors: G. M. Garwood, H. S. Gates, F. Argenti, F. C. Ewer, J. M. Swift, C. B. Lafitte, P. P. Hull, A. B. Stout, Henry Dreshfeldt, J. C. L. Wadsworth, Sam'l Taylor, J. S. Ellis, S. R. Gerry, D. J. Thomas, A. M. Macy, D. S. Turner, T. J. L. Smiley, L. W. Sloat, R. S. Lammot, A. J. Moulder (Herald, 1851, Nov. 30 2/4; Dec. $2 \frac{2}{4} ; 8 \% \frac{1}{4}$; Alta, Nov. $30 \% 2$; Dec. $8 \% \frac{4}{4}$ ). All were Vigilantes except Dunglison, Zantzinger, and Moulder.

28 The organization of the Mercantile Library was noted in the Herald, 1852, Dec. $172 / 1 ; 232 / 1 ; 242 / 2$. 
Metcalf's suit was ealled again in December, and the plaintifi then moved for a change of venue upon the following grounds: $:^{29}$

1st,-That an impartial jury cannot be had here, because the defendants are, or lately were, members of a numerous and powerful body, known as the Vigilance Committee, who have recognized the act charged upon the defendants as their own, and that the said Committee still exercises a controlling influence over the minds and actions of the people of this city, adverse to the cause of the affiant.

$2 d,-$ Because the said defendants and their associates through motives of fear or favor, and by means of their power and wealth, control the public press of this eity and county, and have instigated and prompted the same to attack this affiant without provocation and unjustly, but with the utmost bitterness and malice, so that the people of this city and county are filled with prejudice toward this affiant.

$3 d,-$ That the affiant is a poor laborer, and that defendants are rich property holders; and that affiant is an English immigrant, who reached here by way of Australia, and is therefore known as a "Sydney man," a class of the population of this city who have been proseribed and persecuted by these defendants.

The case was transferred to the jurisdiction of the District Court of Santa Clara and was tried immediately. The result was a verdict for the plaintiff, with damages of $\$ 201$, the lowest sum that would permit the jury to allow costs in his favor. ${ }^{30}$ Metcalf at once named Bluxome and others as defendants in another suit, which was tried in San Francisco and resulted in the nominal verdict of six cents for the plaintiff. The empty victory led to the dismissal of still other suits by which he sought to continue his action against the Vigilantes. ${ }^{31}$ Although many references show that these suits laid a heavy tax upon the

29 Alta, 1851, Dec. $13 \%$. In the issue of Dec. $22 \%$, the editor denied that the Committee exerted undue influence on the press, asserting that "the people who had the courage to sustain the Vigilance Committee, have the penetration to see through the film of shallow pretension which envelopes the cause." Angelina Duclos sued Metcalf for the recovery of the value of her alleged loss, and in the course of that suit Mr. Argenti was arrested on a charge of perjury, but was soon dismissed. Mme. Duclos ultimately abandoned her case (Herald, 1851, Dee. 31 2/4; 1852, Jan. $1 \%$; $12 \%$; 13 \%; ; Lockwood, The Vigilance Committee, 47 note).

30 Herald, and Alta, 1851, Dec. 8.

31 Papers, 731; Herald, 1852, Feb. $20 \% \frac{1}{;}$; Alta, May $8 \% 1$. 
Committee only one actual payment is recorded-a bill of costs amounting to fifty dollars. In June, 1852, a special subseription was collected for the fees of counsel employed for the defense. ${ }^{32}$

Throughout the winter of 1851 to 1852 the Committee continued to receive complaints concerning crimes committed in San Francisco and elsewhere. Most of them were filed without annotation, or were laid on the table. ${ }^{33}$ One was referred to the mayor of the eity. ${ }^{3 *}$ In a few instances investigation was made, as in the case of an attack on Captain Ellis, of the Callao, who was taken from his vessel by men impersonating Vigilantes, and compelled to promise them money in order to save himself from instant death. ${ }^{35}$

On October 22 a committee of five was appointed "to inquire into the acts of the various judges on the bench," but its members made no reports of any importance. ${ }^{36}$ In fact, the larger part of the attention of the Committee was occupied with the ever pressing question of financial ways and means.

A short time prior to the reorganization there had been a deficit of $\$ 1296.56 .^{37}$ By strenuous efforts this condition was improved. and on October 2 the Finance Committee reported that with a few exceptions all claims had been settled up to September 16 , and that a small balance remained on hand. ${ }^{38}$ This happy state of things did not long continue; the liabilities of the association soon again exceeded its assets.

On December 10 the city was divided into collection districts and canvassed for subscriptions by members of the Committee.

32 See Papers, 748, Voucher no. 63, and Index under "Metcalf.',

33 Papers, 696-699, 705, 706, 708-710, 719.

34 Papers, 708.

35 Papers, 713-716; Alta, 1851, Dec. 18 2/2; 19 2/2; 22 2/2; Picayune, Dec. $20 \% 3$; Holinski, La Californie, 129.

36 Papers, 680.

37 Papers, 767.

38 Papers, 675. This probably did not include expenses in the Metealf suit. Treasurer Delessert offered to advance $\$ 1000$ for two months, without interest, but it does not appear that the loan was accepted (ibid., 651-652, $702)$. 
Two of these collectors, George R. Ward and T. J. L. Smiley, received the thanks of the society, January 28 , for the three hundred dollars they had secured and for "their untiring efforts to rid the Committee of Vigilance from debt." ${ }_{39}$ An attempt was also made to raise money by the sale of engraved certificates of membership at five dollars each. The simple design showed some artistic skill. It bore several mottoes that expressed the sentiments of the members: "Fiat justitia ruat Cœlum." "Be just and fear not." "Self-Preservation the first law of nature." It showed, also, the scales of justice and the Lictor's rods. surmounted by the open eye that was always the favorite insignia of the Vigilantes.

The books of the treasurer report ninety dollars raised from the sale of these certificates before March, 1852. In that month it was voted to make the purchase of certificates compulsory, an action which resulted in the sale of seventeen more during the ensuing weeks. ${ }^{40}$

The news items of the daily papers and their reports of court proceedings showed a constant fluctuation in the amount of crime. The worst of the Sydney men had undoubtedly been driven away through the action of the Committee, and their disappearance was a blessing. Other undesirables soon departed for the gold fields of Australia. The Herald of September 21 remarked that the city was far less dangerous at night, and that there was no quarter where it was unsafe for a peaceable

39 Papers, 712, 722.

40 See Papers, Frontispiece, and pp. 711, 734, 762. The Alta, 1852, Jan. $23 \%$, described the certificate and said that its use indicated that the Committee would continue its vigilance as long as society was left at the mercy of criminals. The following notice appeared in the Herald, Jan. 21-28:

"Committee of Vigilance. The Members of the Committee of Vigilance of San Francisco, are hereby notified that their certificates of membership are now ready, and the Secretary will be in attendance, at the Chambers of the Committee, corner of Sacramento and Sansome, to deliver the same, every day, between the hours of 12 and 2 o'clock.

Per order of the Executive Committee, IsAac Bluxome, JR., Secy.', 
citizen to go about his business. ${ }^{41}$ On the next day the editor spoke with complacency of the increasing stability of society and of the influx from the East of families that intended to make their permanent home in California. In the issue of September 28 a long article signed by "Justice" defended the acts of the Committee against current attack in the Morning Post, likened its protest against inefficient laws to the historic protests of Revolutionary patriots, and asserted that crime and violence had almost disappeared as a result of its labors. The grand jury, reporting for the September term, corroborated this optimistic view and mentioned the marked diminution of crime. ${ }^{42}$ A few days later the Herald told of a daring burglary and a shocking murder, "perhaps due to temporary suspension of the police regulations of the Vigilance Committee." ${ }_{43}$ Not long after it admitted that there was a slight increase of crime in the city and state. ${ }^{44}$ By this time popular interest in humdrum trials had noticeably abated. Jury service was evaded so persistently that a sharp editorial in the Alta pointed out that such a shirking of the duties of citizenship would inevitably result in a revival of the activities of the Committee of Vigilance. ${ }^{45}$

Since the rainy winter months, as usual, drove to San Francisco many rough characters from the mining regions it was not strange that crimes increased during that season. The papers again had cause to complain of robberies, fires, and murders. It was feared that another criminal gang had been organized, and to add to the confusion seventeen desperate men escaped from the prison brig, where they were confined while working for a private contractor. $^{46}$ A correspondent in the Alta prophesied

41 Herald, 1851, Sept. $212 \%$.

42 Herald, 1851, Sept. $30 \% \frac{1}{4}$; Oct. $1 \%$.

43 Heral.d, 1851, Oct. $11 \%$. See also Oct. $14 \%$; Alta, Oct. $19 \%$.

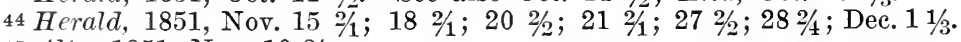
45 Alta, 1851, Nov. $10 \%$.

46 See supra, p. 290 ; and Alta, 1852, Jan. $21 \%$; $25 \% 1$; Herald, Jan. $292 \% 2$; Feb. $18 \% ; 28 \% ; 29 \%$. The existing dangers led to the formation of a special police force, paid by individuals, but under the control of the city authorities (Herald, March $2 \% 2$, April $19 \%$ ). 
that a continuation of existing conditions would necessitate "the same steps as were formerly taken by that much abused, but noble band of men, the Vigilance Committee, who devoted their time, money, and if need be their lives for the protection of society. ${ }_{47}$

In the meantime the Committee attempted little interference in public affairs. Its quiescence may have arisen from the fact that most of the tragedies in the city and in the state at large were attributed to sudden passion rather than to such deliberate intention as had signalized the operations of James Stuart and his confederates. ${ }^{48}$ But the members felt the necessity of continuing their association for the time being, and when on January 14,1852 . T. J. L. Smiley, one of the most faithful attendants, proposed an adjournment sine dir. the motion was laid on the table. ${ }^{49}$ On February 4 the office of sergeant-at-arms was abolished $;^{50}$ on March 13 it was voted to discontinue the salary of the secretary. ${ }^{51}$

March 17 was the end of the six-month term of the reorganized Executive Committee. Pursuant to a notice in the press over three hundred Vigilantes assembled at the old headquarters on Battery Street to elect new representatives. ${ }^{52}$ It was reported in the papers that the increase of crime in the city had roused the Committee to renewed activities; and the minutes and the new roll call showed that fresh interest was awakened. When the new Executive Committee met for organization ${ }^{53}$ G. W. Ryckman was elected president, S. E. Woodworth and Eugene

47 Alta, 1852, Jan. $252 / 1$.

48 Herald, 1852, Jan. $16 \%$; March $30 \%$. "Even when homicides were most frequent, the great majority of the people were secure in their lives and property; but the percentage of deaths was large among the gamblers, drunkards, holders of disputed land claims, thieves and borderers"' (J. S. Hittell, Resources of California, 32).

49 Papers, 720.

50 Papers, 724.

51 Papers, 733.

52 Papers, 732-735; Herald, 1852, Mareh 17 2.; 18 滈.

53 Papers, 738-740. 
Delessert vice-presidents, and G. R. Ward treasurer, Delessert having resigned that office in anticipation of a trip to Europe. ${ }^{5 t}$ Isaac Bluxome, Jr. continued to act as secretary, in spite of a resignation dated April 7.55 The Executive Committee attempted to maintain the habit of weekly meetings, but the minutes give evidence of no action of any importance although conditions in San Francisco grew steadily worse.

Early in May it was voted to renew the volunteer patrol of the city, ${ }^{56}$ and the following notice appeared in the Herald on several days from May 5 to 21 :

Vigilance Committee attention! At a special meeting of the Executive Committee, held at their Chambers last evening, the following recommendations were directed to be promulgated through the public prints:

All members of the "General Committee of Vigilance" are requested to assemble in the respective wards in which they reside, and form themselves into a "Night Patrol." From information received by the Executive Committee, they have every reason to believe that there yet exists within the limits of our city an organized band of thieves and incendiaries, who have within a few days past made several ineffectual attempts to fire the city, and the Executive Committee believe our strict observance of vigilance may prevent the evil by an early detection of the fire, should it be the result of accident or design.

Information of an important nature will be communicated to the members of the different Ward Committees, authorized to receive the same by the Executive Committee, which will continue always in session.

Selim E. Woodworth, Pres.

The Herald stated that the public was convinced of the existence of a band of miscreants, and that in consequence of information to that effect the General Committee of Vigilance would resume weekly meetings during May and June. ${ }^{57}$ Notices appeared in the papers, but minutes are preserved for only one meeting of the General Committee, on May 12, and for meetings of the Executive Committee on May 5, May 26, and Jume 30. ${ }^{58}$ The room for permanent headquarters was given up in May.

\footnotetext{
54 Papers, 734-735.

55 Papers, 742.

56 Papers, 746.

57 Herald, 1852, May 7 2\%; 12 2/1; Papers, 744 note.

58 Papers, 743-748.
} 
When the anniversary of the organization of the Committee drew near, it was suggested that the day, June 9, should be celebrated by a dinner. ${ }^{59}$ but no other mention of such a banquet was made in the records or in the reminiscences of the members.

As one reviews the year of strenuous work, of defiance of law, of popular approval, and of ever increasing financial burdens, one is inclined to invert a phrase dear to American orators, and to assert that if taxation without representation is tyranny, the experience of the San Francisco Committee of Vigilance goes far towards proving that representation without taxation is insolvency.

The last financial experiment of the Vigilantes accented with grotesque humor the straits to which they were reduced. On April 2 it was voted to arrange a dramatic benefit for the purpose of raising funds, three leading members, Selim E. Woodworth, Eugene Delessert, and W. A. Howard, being appointed a committee of arrangement. ${ }^{60}$ Several members of the theatrical profession immediately volunteered their services, among them Madame Eleanore, who was playing at the French Theatre, and the Committee returned its thanks in polite French for her kind offer. ${ }^{61}$ For unrecorded reasons the project was pushed no further, and we are fortunately spared the vision of the curtain of history descending upon the Committee of Vigilance amid the glitter of footlights and the clatter of perfunctory applause.

For the curtain is about to descend! The entries in the Minute Book of the Executive Committee close June 30. For several months there are no recorded activities, and it may be that the summer movement to the mines brought about a slight improvement in local affairs. Early in the fall the old apprehension of incendiaries recurred, and the editor of the Herald wrote for the warning of such outlaws: "The Vigilance 
Committee is not dead-it only sleeps, and woe to those whose rascality calls it into action again!' 62

The sleeping guardian roused itself to momentary vigor in November, when a meeting of the General Committee was called for the nineteenth, although no minutes have been preserved. ${ }^{63}$ On the twenty-sixth the Executive Committee met and elected officers, and even discussed hiring new headquarters, since the building occupied in the spring had been demolished. It was decided, however, to ask hospitality from the fire engine companies and to avoid the expense of permanent chambers. Minutes of that meeting are preserved in a rough draft, ${ }^{64}$ and with them is filed a brief memorandum of the examination of Charles Talbot. who had been arrested the day before by S. E. Woodworth on suspicion of arson, and who was probably released without delay. No later archives reveal the secret bonds that continued to unite the brotherhood of the Vigilantes, although every man in California knew that those bonds had not been severed. For a time the continued existence of the Committee was indicated by the publication of two brief notices which appeared at frequent intervals in the Herald and the Alta, from November 24, 1852, to January 20, 1853 :

Committee of Vigilance.-The eitizens of the eity of San Franciseo are requested to furnish to the Committee of Vigilance such information as they may have that will lead to the detection or arrest of any person that has committed, or attempted to commit the crimes of Arson, Burglary or Highway Robbery.

IsaAc Bluxone JR., Secretary.

\section{Committee of Vigilance.- $\$ 2,000$ Reward}

will be given by the Committee of Vigilance of the eity of San Franciseo for the arrest, with sufficient testimony for conviction, of any person setting fire to any building in San Francisco. By order of the Committee,

ISAAC Bluxome JR., Secretary. Selim E. Woodworth, President,

62 Herald, 1852, Oct. $282 / 2$.

63 Herald, 1852, Nov. $17 \%$; Papers, $748-749$ note. The meeting was called to adopt measures for the suppression of crime (Herald, Nov. $19 \%$ ).

64 Papers, 748-749. 
At some time after that date a further reorganization was effected, relieving from duty all of the members except a Committee of Thirteen, which was entrusted with the obligation of keeping alive the spirit of vigilance and of summoning the general body should the need arise. No press notices of this change and no further calls for meetings have come to the attention of the writer in searching through the files of the Herald and the Alta for the succeeding three years. ${ }^{65}$ The association of the Vigilantes never formally dissolved. Gerstäcker reported that the members had pledged themselves to a service of fifty years, and George E. Schenck wrote: "Once a Committeeman, always a Committeeman, according to the bylaws." ${ }_{66}$ In 1853 the organization silently disappeared from local attention, but it was the current conviction of the community that although the Committee of Vigilance was shrouded in silence and secrecy, it was prepared to re-establish its dreaded tribunal whenever a public emergency should move the people to summon it from obscurity. ${ }^{67}$

65 Tuthill said that sometime in 1853 there was published a call for a meeting of the Executive Committee (California, 461). Mention of a recent meeting was made in the Democratic State Journal, 1853, March 7 \%2; Alta, March $13 \%$.

66 F. W. C. Gerstäcker, Narrative of a Journey round the World, 1853, p. 253; Schenck, MS Statement, 52. "At the end it [the Committee] adjourned, to be called together on any occasion when it might be required', Ryckman, MS Statement, 20).

67 "The Vigilance Committee has long ceased to act, but the association has never formally dissolved. The original members are doubtless ready, if ever an occasion should require, again to assert the right of self-preservation, and the supremacy of natural law over defective civil rule" (Annals, 1855 , p. 587). "Crime, since the organization of the Committee, has decreased one half, and they have now ceased to make arrests, leaving all to the jurisdiction of the proper authorities. They, however, maintain their organization, and would, no doubt, act in case of emergency' California Illustrated [by Letts], 55). 


\section{PROBLEMS AND METHODS OF ADMINISTRATION}

The previous chapters have recounted the history of the Committee of Vigilance in its chronological development, reserving for special discussion various aspects of its work which require a grouping of episodes that were separated by intervals of time but related by logical connection. Certain useful summaries may be made from the records of the cases considered by the Committee, and from the receipt and expenditure of funds. Interesting deductions as to the spirit of the members may be formed by reviewing as a whole their relations to their prisoners, to each other, and to the general public. And finally, before the study is brought to a conclusion, it will be pertinent to ask what influences the work of the Committee may have exerted in San Francisco, in California, and in the country at large.

The relations that existed between the Committee and its prisoners are indicated not only by the general reports on the conduct of cases, but by brief allusions scattered through the minutes and miscellaneous papers. ${ }^{1}$

In the matter of providing for the physical necessities of those in confinement, the arrangements were very primitive. The inventories suggest that the prisoners' room was furnished with benches, straw mattresses, and blankets. ${ }^{2}$ No information is given of the accommodations provided for women prisoners, in spite of the fact that several women were detained for brief periods. $^{3}$ Mrs. Hogan was probably in custody for a few days,

1 See Papers. Index under "C. of V.-Relations with prisoners."

2 Papers, 654.

3 See Papers, 420, 502, 574-575. 
and so was Mrs. Robinson, charged with arson. On August 30 the wives of Robert Ogden and Joseph Turner were named among the prisoners. So was Jane Connolly, widow of the innkeeper, former friend of Jenkins and Burns, and later wife of one Martin Sanphy, who unkindly accused her of robbing him of twelve hundred dollars. Emma Jones, a Sydney immigrant, was held for deportation. But the personal experiences of the arrested women are unnoted alike in any of the records. in the papers of the day, or in the reminiscences of members.

The cost of maintaining the prisoners was a great burden on the overtaxed exchequer. One or two who had the means paid board while in confinement, but the others were fed at the expense of their jailers. Members of the Committees of 1851 and 1856 have told me that both Committees ordered the food of the prisoners from neighboring restaurants. The cash accounts for 1851 do not determine this point exactly, but they show that sums were expended for foodstuffs, such as cheese, crackers, and coffee, and also for refreshments purchased from hotels and eatinghouses. ${ }^{*}$ When all is said that can be gathered from the records. we simply know that the men under arrest were lodged and fed - their treatment was surely no worse, perhaps it was better than that accorded to prisoners in the city lockup. ${ }^{5}$

Nore definite information can be gained of the methods employed in the course of the criminal investigations and prosecutions. "It is the . . intention of this Committee of Vigilance to act in such a way as to obtain the sanction of this community for each and every one of the steps it takes.' So wrote Mr. James C. Ward on June 15, 1851, in a resolution which urged the Committee to act with circumspection in

4 See Papers, 442, 502, 625, 764, Appendix D, p. 824. I' discussed the subject of provisions with Mr. Duff, of the Committee of 1851, and Mr. E. P. Flint, of 1856.

5 It was ordered that the prisoners and their room should be scrubbed every week. A doctor attended cases of illness (Papers, 408, 409). 
proceeding against Burns and Hetherington. ${ }^{6}$ George Gibson, advising cantion in a different matter, declared that he felt "the awful character of our responsibilities." "7 The sentiments expressed thus early in the life of the Committee were never forgotten in the excitement of the days that followed. The execution of John Jenkins had been summary in the extreme, but after that night no action of any apparent importance was undertaken without painstaking investigation and deliberation. As in the cases of Burns and Hetherington, witnesses were summoned not only for the prosecution, but also at the request of the defense, and the thoroughness with which the Committee sought to sift evidence is proved by the preservation of verbatim statements made by nearly one hundred and fifty witnesses, and of written communications sent by many others. It is true that the technical evasions permitted by legal procedure were denied the prisoners of the Committee; no doubtful alibi was considered in their favor. But from the first it was the custom to confront the accused with the witnesses in his case, and it was one of the rules of the association that no sentence should be pronounced until he had appeared in person to plead in his own behalf. ${ }^{\mathrm{s}}$

The results of the policy of cautious investigation have been shown in the case of the Negro, Ben, whose false arraignment of Mrs. Robinson was so carefully sifted that it disclosed the plot designed to lead the Committee into extreme measures against a woman of open and well-known depravity. Again in the case of Church, the horse thief and deserter whose superior officer urged death as a just penalty for crimes against the public welfare, the Committee preferred to return their prisoner to the military authorities. The delivery to the authorities of Adams, Jimmy

${ }_{6}$ Papers, 43. The unsigned report is in Ward's handwriting.

- Papers, 61.

8 Papers, 197. 
from Town, and Hamilton Taft, and the discharge of Jenks, are further instances of the self-control that dominated the leaders of the Committee. The same quality is further illustrated by the vote to lay on the table a motion to seize and hang the incendiary Lewis if he should be convicted of arson in his legal trial. ${ }^{9}$

Justice to the Committee forces the acknowledgment of its habitual self-control, and of its inclination towards merey in doubtful cases. It was inevitable, however, that the methods necessary in the prosecution of its work entailed hardship, and in some cases real suffering upon the men who came under its suspicion. Read, for example, the complaint of the excitable Frenchman, Victor de Gray, an acquaintance of the Robinsons, who was "taken with violence and rudeness" and compelled to accompany the Committee as if a prisoner, was detained as a witness, and discharged only after his feelings and reputation were so damaged that he petitioned for a certificate that should exonerate him of suspicion, and for funds to enable him to depart from the scene of his humiliation. ${ }^{10}$

The case of Theodore Dahlgrén is another illustration of the misfortunes of an innocent man. On the accusation of Mr. Tennant, a dealer in nautical instruments, he was summoned to headquarters to clear himself of the charge of stealing a sextant. When he refused to obey, his personal property was seized and held as a sort of bail, and as soon as possible he himself was taken into custody. After a period of confinement he was honorably discharged and his property restored. although his acknowledgement of its return indicated that some articles were still missing. Dahlgrén's sensitive soul was torn with grief at these discreditable suspicions, and his letters were almost ludicrous in their hysterical protests. Yet the intentions of his jailers were so evidently fair, and their consideration of his case

9 Papers, 328.

10 Papers, 117, 177, 204, 210-212. 
was so impartial that after his release he sent them a friendly letter and printed in the papers the following tribute to their integrity : ${ }^{11}$

To the Public-I was recently ordered to appear before the Committee of Vigilance on the charge of being a "notorious thief and swindler." Said charge has been inquired into and I have been honorably released. I merely wish thus voluntarily to say that I admit to the fullest extent the propriety of their action in my case, and that their course towards me has been marked by perfect courtesy, impartiality, and kind feeling, and that although the fact of my having come within the cognizance of the "Committee of Vigilance" might probably injure me, yet I fully admit their right to act as they have done, and consider that all good citizens should aid them in their endeavors to ensure security of life and property. This is especially intended to reply to an inquiry made to me to know if I was desirous of prosecuting them for their course towards me. I thus reply.

Th. Dahlgren.

Another prisoner, William Wilson, was confined for a time under suspicions that are not definitely formulated in the records, and his friends feared for his health and for his reason under the strain and humiliation of his incarceration. ${ }^{12}$ And for many others who like Dahlgrén and Wilson were finally discharged, the days or weeks of detention in the poorly equipped prisoners' room must have engendered a mood of desperation. A glimpse of such a mood was given in letters which John Arentrue wrote in the hope of invoking help from friends whom he desired to call as witnesses. Arentrue, formerly a street commissioner in San Francisco, had been named by .Joseph Hetherington as an accomplice of Stuart. After that statement had appeared in the papers, he published an indignant denial of the charge and complained that he had been refused all opportunity to refute it before the Committee. ${ }^{13}$ He was later arrested by the Vigilantes

\footnotetext{
11 Herald, 1851, July 11 2\%1. See also Papers, Index under “'Dahlgrén.', 12 Papers, 587-588.

13 Alta, 1851, July $24 \% 1$. See also Papers, Index under “Arentrue.',
} 
on suspicion of murder, and while he acknowledged that he was "treated very handsomely by the gentlemen in whose hands" he had fallen, he complained that he had great difficulty in communicating with outside acquaintances, and was fearful of a conviction that might forfeit his life. It was always claimed by members of the Committee that prisoners were aided in securing whatever evidence they desired to present, and the large number of discharges justifies the inference that ample means were provided for defense. But the letters of Arentrue, at least, were not dispatched to their destination-perhaps because it was decided to relinquish him to the authorities for a trial where he would have the benefit of counsel.

The records show that ninety-one prisoners were under arrest by the Committee of Vigilance. It is probable that this number does not include all the immigrants forbidden to land in San Francisco, or all the petty offenders who were turned over to the authorities, ${ }^{14}$ although it is unlikely that any large number entirely escaped mention, either in the minutes or in the reports of subcommittees. It is possible to discover very exactly the indictments made against most of these ninety-one prisoners, to trace the course of their trials, and to determine their ultimate fate. Twenty-five were accused of being ex-convicts from Australia, thirty-one were charged with larceny of a more or less serious nature, nine with murder, five with keeping disreputable lodging houses, five with arson, three with horse stealing, and thirteen with a variety of crimes, from murderous assault to being, in general, a "bad man." 15 Against some there was an array of charges, as in the case of Stuart, who was exconvict, thief, and murderer, and who, for the purposes of this classification is listed only as murderer.

14 For example, a suspected murderer was arrested by the Committee and sent to Stockton, and a fugitive from the San Francisco jail was captured and returned (California Courier, 1851, July $19 \%$ ).

15 See Papers, "List of Prisoners,' Appendix E. 
Of these ninety-one prisoners, the Committee hanged four; whipped one; deported fourteen under direct supervision; ordered fourteen more to leave California at their own expense and on their own parole, with a threat of execution if they disobeyed $;{ }^{16}$ delivered fifteen to the authorities for legal trial; and discharged forty-one. The disposition made of two others is not noted, but they were probably discharged. As a matter of fact, punishment was enforced only upon those hanged, those deported under supervision, and upon the one thief who was whipped, a total of nineteen. It is not certain that all, or most, of the Australians ordered to leave California did so; on the other hand, there were others who departed hurriedly without risking discipline at the hands of the Vigilantes. ${ }^{17}$

In carrying out the sentences imposed by the Committee, it seems that due attention was paid to the ordinary dictates of humanity. The illness of Mrs. Goff, for instance, whose husband was under orders to leave California by a specified date, secured for her family an extension of time. ${ }^{18}$ Valuables found upon the persons of prisoners were guarded and restored at the time of departure, and business affairs were adjusted for several who were deported under supervision of the Committee. ${ }^{19}$ Food and blankets were provided for those whe were unable to purchase supplies for the voyage to Sydney. ${ }^{20}$

However one may be inclined to judge the actions of the Committee, the record of its dealings with prisoners is a most significant indication of the aims, methods, and temper of its

16 Coleman said that about thirty people were banished (MS Statement, 24 ), but Bluxome, speaking with apparent exaggeration, said: "I suppose we sent back... some three to five hundred at different times," (MS Statement, 15). The Herald, 1851, Oct. $17 \% 1$, stated that fifty-three had been sent away. There are bills for the passage of several (Papers, Voucher no. 5, p. 772 , and nos. 35,43$)$.

17 Papers, 84, 124, 132, 279.

18 Papers, 195.

19 See Papers, Index under '“Receipts for effects,' and supra, p. 232.

20 Papers, 338, 625. 
members. Arrogating to themselves, as they did, the power of life and death and the right to lay hands on any man or woman, they were far more merciful to the majority of their prisoners than the courts might have been if juries had strictly interpreted the existing statutes. Whipping could be inflicted for petty larceny, but of all the petty thieves that came before them the Vigilantes whipped but one. Grand larceny, highway robbery, and horse stealing were liable to capital punishment in the state of California. There was clear proof that certain prisoners of the Committee were guilty of such crimes, but with four exceptions they were turned over to the authorities and given a chance to fight for their lives in legal trials. ${ }^{21}$ Cutler said that vigilance committees almost invariably incline to ready conviction and severe punishments. ${ }^{22}$ As the Committee of 1851 discharged outright over forty-four per cent of its prisoners, its record deserves a place by itself in the annals of popular tribunals.

The records reporting the dealings of the Committee of Vigilance with its prisoners constitute the larger part of the seven hundred and fifty pages of the Minutes and Miscellaneous Papers. Another important source of information is to be found in the papers of the treasurers, which fill fifty more pages in the volume of documents. ${ }^{23}$ Some reference has been made to them in speaking of the financial difficulties of the organization. They will repay more extended study not only for their statistical value, but also for the light they throw on the methods of the Committee and on local conditions in San Francisco.

During the early days of the Committee the sergeant-at-arms collected and distributed funds without strict supervision from any ranking officer or committee. He kept a cashbook. of which only a fragment has been preserved. His vouchers. also. are far from complete, so that his accounts show an expenditure of 826

21 The outcome of some of the legal trials is noted in the Papers, 82522 Cutler, Lynch-Law, 135. 23 See Papers, 752-805. 
$\$ 575.58$ for which items eannot be assigned..$^{24}$ On and after June 19, 1851, he was directed to pay funds into the hands of the treasurer, and to contract no expenses without the sanction of the Finance Committee. ${ }^{25}$

The papers of the treasurers are in more satisfactory condition. J. W. Salmon presented a single report on July 7, 1851, when he turned his work over to Eugene Delessert, who acted as treasurer until April 1, 1852. Delessert kept all his papers in a file separate from that of the secretary. His accounts were based upon the items of one hundred and three receipted bills, which are now carefully arranged in bundles and numbered consecutively. As the numbering of these vouchers often ignored sequence of date for a classification by subject, it is the opinion of the writer that Delessert arranged them just prior to his resignation and then copied them in serial order into his cashbook. This theory is sustained by the uniformity of the handwriting in the book and by the fact that the footings of the pages were merely carried forward, without balances, until near the end of his term, when his successor, George R. Ward, audited the accounts. If such were his methods he risked inaccuracies that might have been avoided by more frequent balances, in fact a checking of his figures discloses an error of $\$ 100$ in the addition of one column of receipts, a possible duplication of entries for liquors, amounting to $\$ 58$, and another for the salary of the sergeant-at-arms, amounting to $\$ 280 .{ }^{26}$ George $R$. Ward approved the final accounts so that it is probable that they were understood at the time. It is only necessary to call attention to these features of the financial documents in order to caution the reader that their accuracy cannot be regarded as absolutely above question.

24 See Papers, 764, 765, 800-805. The fragment of McDuffee's eash book has not been printed.

25 Papers, 60, 91.

26 See Papers, 822 note. Delessert also made an error of one dollar in adding expenses, p. 757 . 
From April 5 to November 24, 1852, the book was continued in Mr. Ward's handwriting. The receipts there recorded amounted to only $\$ 310$ and the account was closed by some confused figures which apparently reported total receipts of $\$ 340$.

Taken as a whole, the pages of "Financial Accounts and Vouchers" show the care exercised to provide safeguards against irregularities and carelessness, for except in the earlier vouchers of McDuffee the approval of two or three members of the Finance Committee was signed across nearly every bill that might involve questions of accuracy or of expediency. In preparing the documents for publication it seemed advisable to make a classified analysis of expenses as a guide to any student who might care to note the prices current in California in 1851. That table appears in Appendix D of the Papers, but a summary will be interesting here since it gives a valuable clue to many of the activities of the Committee.

Classification of Expenses of the Committee of Vigilance

\begin{tabular}{|c|c|c|c|}
\hline & $\begin{array}{l}\text { June } 9 \text { to } \\
\text { Sept. } 17,1851\end{array}$ & $\begin{array}{c}\text { Sept. } 17,1851, \\
\text { to June } 17, \\
1852\end{array}$ & Total \\
\hline & $\$ 1,100.00$ & $\$ 425.00$ & $\$ 1,525.00$ \\
\hline Rent Salary: Sergeant-at-arms & 484.00 & $1,097.11$ & \\
\hline $\begin{array}{l}\text { Secretary } \\
\text { Porter }\end{array}$ & & 300.00 & 213811 \\
\hline \multirow{2}{*}{$\begin{array}{l}\text { Headquarters: Labor, equipment, } \\
\text { stationery, lights }\end{array}$} & 257.00 & & $2,135.11$ \\
\hline & $1,500.00$ & 414.84 & $1,914.84$ \\
\hline Advertising & 280.00 & 62.75 & 342.75 \\
\hline \multirow{2}{*}{ 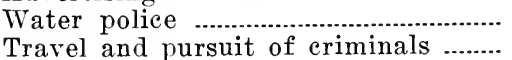 } & $1,317.24$ & 125.00 & $1,442.24$ \\
\hline & 848.25 & & 848.25 \\
\hline & 231.00 & & 231.00 \\
\hline Passage of convicts ............................... & $\begin{array}{l}425.00 \\
152.50\end{array}$ & & 425.00 \\
\hline 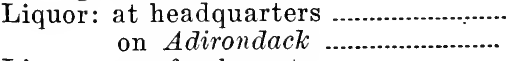 & 40.00 & & 192.50 \\
\hline \multirow{2}{*}{$\begin{array}{l}\text { Liquor or refreshments } \\
\text { Refreshments }\end{array}$} & 298.00 & & 298.00 \\
\hline & 132.71 & & 132.71 \\
\hline \multirow{2}{*}{$\begin{array}{l}\text { Cigars } \\
\text { Sundry }\end{array}$} & 19.50 & & 19.50 \\
\hline & 201.75 & 443.70 & 645.45 \\
\hline \multirow[t]{2}{*}{ 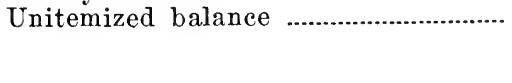 } & 520.58 & & 520.08 \\
\hline & & $\$ 2, \$ 68.40$ & $\$ 10,675.93$ \\
\hline
\end{tabular}


This segregation of expenses shows at a glance the cost of headquarters and of salaries. The vouchers for these groups of expenditures are indicated by number in the Appendix to the Papers. They show, for instance, that lumber sold at the rate of five and a half cents a foot, while carpenters' wages were $\$ 10$ a day. ${ }^{27}$ George, the porter or servant at headquarters, received only $\$ 100$ a month, with $\$ 3.50$ for extra days. At the termination of his engagement, when his pay was $\$ 137.50$ in arrears, he annotated his final receipt with the querulous complaint, "Paid me only 137 Dollars. " 28

The amount spent for advertising is a proof of the many notices issued through the Herald, the Alta, the Courier, the Picayune, and the Pacific Star; even the Morning Post, in spite of an unfriendly attitude, served as a medium of communication between the Committee and the public at large. The time and place of meetings were often matters of general knowledge, and the names of president and secretary were frequently subscribed to official notices.

Traveling expenses and the pursuit of criminals cost the Committee $\$ 848$. The itemized account of the expenses of one expedition included steamer fees and hotel bills for a party of three for several days, and showed charges surprisingly moderate for those early times. ${ }^{29}$

It is little wonder that the bills of the water police were paid under protest! A single statement presented by Captain Waterman, possibly for service following the fire of June 22, called for $\$ 479$. Another, in July, was for $\$ 192 .^{30}$ The total cost of boats and boatmen amounted to $\$ 1317$.

27 Papers, Voucher no. 27.

28 Papers, Voucher no. 54.

29 Papers, Voucher no. 10, p. 773. 86-88.

39 Papers, Vouchers no. 6, p. 770, no. 4, p. 771. See also Vouchers nos. 
One group of bills furnishes an interesting light on the morale of the Committee. During the early days of the association, while the sergeant-at-arms had a free hand, liquor to the amount of $\$ 150$ was purchased for headquarters. The committee that examined the passengers on board the Adirondack was furnished with gin and brandy that cost $\$ 40$ and eigars that cost $\$ 18 .^{31}$ On July 2 a resolution of the General Committee ruled that in future no spiritous liquor should be introduced into headquarters. Stimulants, if needed, were to be served only in the form of hot coffee. $^{32}$ After the adoption of this motion there was a bill for a case of claret and for three gallons of "alcohol." These contraband articles were bought by McDuffee on July 31. For some reason ignored in the records, the sergeant-at-arms was officially censured by vote of the Executive Committee a few days later, and was asked to tender his resignation. He was allowed to continue in office only after promising to "abstain in future from the faults complained of." He finally gave up his position on August 29. No further purchase of liquor appeared among the vouchers. ${ }^{33}$ Refreshments amounting to nearly $\$ 300$ were furnished from time to time by the Pioneer Club and the Oriental Hotel. A part of these charges may have been for drink, although the legitimate expense of feeding prisoners was undoubtedly large. We find, therefore, that in the first six weeks of its work the Committee expended over $\$ 200$ on liquor but made almost no official purchases of that kind after July 25 . It was a time when intoxicants were consumed in enormous quantities in California, but whatever may have been the personal habits of individual committeemen, the records show that dissipation was frowned upon by the Committee as a whole and that the convivial tendencies displayed by Mr. Andrew Jackson McDuffee were sternly checked by his fellow Vigilantes.

31 Papers, Vouchers nos. 14, 21, 57, 58, 111.

32 Papers, 339.

33 See Papers, Voucher no. 101, and pp. 418, 571. 
Of one thing we may be very sure: The hundreds of pages preserved in the archives of the Committee were not written by men habitually under the influence of liquor. Their very faults of composition, spelling, and punctuation show that they are not revised copies prepared for public inspection, and every hasty line gives evidence of the alert brain and the steady hand that directed the pen of the scribe. And this may be the place to emphasize the fact that these papers are clean-not only from the standpoint of a student of documents, but also from the standpoint of one who would judge the authors themselves by their reactions under such unusual circumstances. They dealt with the daily life of men and women who defied all restraints of decency, but the papers are never indecent. The few sentences expurgated before publication were consigned to oblivion only because their expressions were unnecessarily crude and startling in presenting certain facts that were fully established elsewhere. While it may have been necessary to check, by resolution, indecency of speech within the rooms, ${ }^{34}$ the most trivial scrap of official record shows that the writers were inspired with a sense of the dignity and importance of the work they had undertaken and had no desire to sully it with vulgarity of thought or word.

But little more need be said upon the subject of finances, for while the items of expenditure can be segregated with profit, the sources of the revenue can not be analyzed with exactness. Initiation fees, monthly dues, fines, and outside subscriptions are confused in their entry. An approximate classification, dependent upon the judgment of the compiler in interpreting the items, may be given as follows:

\section{Receipts of the Committee}

Initiation fees, dues and fines $\$ 6,296.38$

Subscriptions

Sale of certificates of membership

Sundry sources 
In addition to this was the $\$ 4700$ raised for the county jail. Therefore, if the analysis of receipts is approximately correct, total subscriptions donated in excess of standing assessments amounted to over $\$ 8000$. The fact that a great part of this sum came from the merchants of the city, many of whom were not members of the Committee, is an indication of the public support that was extended to the association. ${ }^{35}$

It was only the existence of such general approval that made it possible for the Committee to carry out its program of unauthorized interference with the established institutions of the state. It is very clear that from the moment when Jenkins' sentence was approved by the crowd assembled beneath the sand dune rostrum on Market and Bush streets, the Committee was convinced that its organization had achieved a position fairly representative of the mind of the community. That conviction was constantly fostered by the open commendation of the press. ${ }^{36}$ Many exact citations from the daily papers have been incorporated in this volume in order to associate with the initiative of the Committee the constant support received from the men outside its ranks. "We did not put them [the authorities] at defiance," said Ryckman. "It was the sound, sober sense of the people that recognized the Committee as just." ${ }_{37}$

35 See donation of Flint, Peabody and Company, and the facsimile of a list of subscribers, Papers, 527, 712 .

36 "With one single exception the entire press of this city, Sacramento, Stockton, Marysville and Sonora have justified and sustained the citizens, regarding their action as the result of painful, deplorable necessity' (Alta, 1851, June $16 \%$ \%). The exception was the Morning Post, an unimportant sheet, which ceased publication in November. The California correspondent of the New York Tribune thought the press of the state was so controlled by the advertising patronage of the merchants who led in the Committee, that disapproval would have been disastrous. The Alta indignantly denied the impeachment (Dec. $192 / 1$ ), but it may hare had some foundation, especially as the Herald was almost wrecked in 1856 by the withdrawal of advertising patronage in consequence of its disapproval of the reorganized committee (see infra, p. 410).

37 Ryckman, MS Statement, 9. 
This outspoken and widespread approval, coupled with the frankness with which the Committee announced its purposes and its personnel, formed a combination that actually gave the anomalous body a definite standing even in the eyes of the constituted authorities, and made possible those curious instances we have noted of coöperation between the lawful representatives of the people and the unlawful association that assumed power to supervise and override their proceedings. The governor of the state interfered only once in all the exciting events of 1851 . The mayor of the city interfered not at all, except at the summons of the governor, and both of these magistrates met the Vigilantes. in amicable conference, within the sacred precincts of the Executive Chamber. Sheriff Hays, as we have seen, was aided in his official exertions by the generous sum raised for the completion of the jail, and it does not appear that these cordial relations were affected by his varying success in the service of writs of habeas corpus, or by the seizure and the subsequent recapture of Whittaker and McKenzie. With punctilious formality President Payran would order his chief of police to hand over the body of a certain prisoner to the sheriff of the county, to take an acknowledgment of the transaction, and "herein fail not." With equal formality the sheriff or his deputy would accept the captive, and endorse on the order a receipt for the person named, from the hands of the "Chief of Police of the Vigilance Committee.", 38

Other sheriffs seem to have approved of the methods of the Committee, and two such officials sent to headquarters descriptions of escaped prisoners with the request that they should be captured if possible. The sheriff of Butte County characterized one man as such a pest to society that any assistance "your honourable and gentlemanly Committee can render, in retaking him will be highly appreciated by . . . this whole community." ${ }_{39}$ 
N. M. McKimmey, of Napa, was quite willing that the Committee should hang without ado a certain blond Dutch horse thief, a linguist of sorts, who wore a white fur hat and a large blue coat closely buttoned to the chin. ${ }^{40}$ Both of these fortunate rascals seem to have escaped detection in San Francisco for their names do not reappear in the annals of the Committee.

Officers of the army and the navy also coopperated with the officers of the Committee of Vigilance. ${ }^{41}$ The representatives of foreign nations gave the countenance of their presence on several occasions. ${ }^{42}$ More interesting still was the relation which existed between the Committee and the grand jury for the July term, on which served the eight Vigilantes who were charged by .Judge Campbell with the Spartan duty of bringing against themselves indictments for the murder of Stuart. This was the jury that requested from the Committee information in the case of $\mathrm{T}$. Belcher Kay, and visited headquarters to obtain it. ${ }^{43}$

But in all the history of the Committee there was no incident more significant of its place in the estimation of the people than was the gift of a large and handsome banner by the women belonging to Trinity Church. This flag was always considered one of the treasures of the Committee of 1851, and it was carried by the group of original members who participated in the great parade that marked the close of the activities of the Committee of $1856 .^{44}$ It was finally given to Mr. John S. Ellis, as a souvenir of his services in both Committees. It is now in the possession

\footnotetext{
40 Papers, 621-622.

41 The attitude of Lieutenant Derby has already been noted (supra, p. 316); the captain and officers of the revenue cutter Polk gave useful information more than once (Papers, 134, 136, 203, 207, 209), and there were friendly relations with the officers of the sloop of war Vincennes (ibid., 438, 440). S. F. Blunt and Lafayette Maynard, listed as officers in the Navy, were members of the Committee (C. of V., Constitution, 56).

42 The British consul, George Aiken, attended Stuart's examination, and the French consul that of Le Bras (Papers, 176, 275. See also supra p. 340$)$.

43 See supra, p. 283.

44 See infra, p. 403.
} 
of members of his family, having by great good fortune escaped the fate that destroyed so many relics of pioneer days, and its beauty, softened but unimpaired by the lapse of years, still offers tribute to the Vigilantes of $1851 .^{45}$

The banner was presented and accepted with appropriate remarks. The spokesman for the ladies stated that the gift was inspired by gratitude for the improved conditions brought about by the work of the Committee, and for the protection it afforded to the women who had formerly been distracted by constant fears of violence. He explained that the wreath of oak and fig and olive leaves that decorated one side of the banner was symbolic of the strength of the Committee of Vigilance and of the peace it had given to the homes of the city. The wreath of flowers on the reverse, enclosing the inscription of the donors, was emblematic of the gentler nature of the women who thus offered their thanks.

The response of the representatives of the Committee reiterated the principle that the radical action of the Vigilantes was justified by the necessity for self-preservation when the safety of their families demand some prompt and energetic action. It may be inferred that Payran wrote the sentences which read : ${ }^{46}$

We are naturally and instinctively a law loving and law abiding people, and have those principles, inherited from our fathers, too deeply rooted ever to be eradicated. But we have also inherited another great principle, or rather we have it inherent, one of the fundamental principles of nature, and that is the principle of self preservation, "which springs eternal in the human heart." ***

Our people submitted to repeated injuries and unheard of outrages, in the vain hope that the great majesty of the law would lend an ear to

45 The banner is now in the possession of Mr. Ashfield Ellis Stow, of San Francisco. Photographs are reproduced in the Papers, to face pp. 438, 439. A smaller banner was presented to the Committee by Messrs. Plum and Warner (Papers, 339).

46 From the Herald, 1851, August $12 \%$. Signed by Stephen Payran, Eugene Delessert, F. A. Woodworth, D. S. Turner, C. R. Bond and G. M. Garwood. Extracts from the presentation speech are printed in the Appendix, p. 471. 
their complaints and mete out impartial and even-handed justice. They submitted with patience until patience ceased to be a virtue, and their own safety and the safety of their families demanded some prompt and energetic action.

It was at this critical moment the Committee of Vigilance sprung, spontaneously as it were, into existence. The people from whom emanate all human laws, rose in their might, by common impulse, and resolved to carry out, themselves, the true spirit of the laws by which we are governed. In pursuance of their duties, the Committee have been ever sensible of the weight of responsibility they have assumed, the delicacy of their position before the world, and have endeavored always to be guided in their deliberations by a proper sense of reason and justice.

The addresses embody anew that spirit which we have already recognized as shaping American thoughts towards the conviction that "The People" might assume direct control of the government when the established order failed to function for the good of the community. It was the same spirit that inspired the announcement of the policy of search without warrant; that refused obedience to the writ of habeas corpus; that animated Stephen Payran when he wrote: "The people only can redress grievances," and again: "It is an old and popular doctrine, that it may be necessary to sacrifice the government to the people. but never the people to the government" ; that prompted the Committee of Sonora to say that in the existing dangers of society the people should resume the power they had delegated to incapable or unfaithful servants; that impelled Schenck to write: "Let them [officials] know that they are the servants of the people, and to them they must surrender their trust when not faithfully executed." 47 The logical process of this idea inevitably tended either towards anarchy or towards some modification of the social mechanism that would provide a lawful readjustment of the relations between "people" and "servants" in cases where friction was developed to an intolerable degree. But the Vigilantes of 1851 honestly thought they were defending their

47 For the citations, see Papers, 700, 373, 617, 635. 
sacred constitution from the machinations of a "corrupt minority.' '48

Approval of the Committee of Vigilance was not limited to San Francisco. Everywhere in California the courts were proving inefficient. Everywhere the miners still made their own laws for the regulation of claims, ${ }^{49}$ and settled many vexed questions in open meetings. Members of such communities constantly reverted to popular trials and punishments as they found themselves overrun with vicious and dangerous neighbors. Hangings and whippings and brandings, conflicts with sheriffs, and cruelty alike to innocent and guilty, had become all too common in the state. ${ }^{50}$ The precedent set in San Francisco was welcomed as a means of securing prompt punishment without the demoralizing accompaniments of irresponsible mobs and brutal vengeance.

A plan for a state-wide movement had been one of the early ideals of the San Francisco association, and the suggestion that other communities should organize for protection met with immediate response. On July 1 the editor of the Herald spoke with approval of the organization of committees in the interior

48 See Papers, 373, and Index under "C. of V.-Theory of Organization." Bluxome said: "There is a time when men should take the law into their own hands" (MS Statement, 10). A. M. Comstock, of the Committee of '56, said: "The community resolved itself back into its original rights, and took the law into its own hands'" (MS Vigilance CommitteesMiscellany, 37). The "right of insurrection", was defended in the Herald, 1851, August $112 \% 3$; Alta, June $14 \%$; Nov. $8 \% 1$; Nov. $15 \% 3$; Sacramento Union, Nov. $10 \% 2$. The grand jury of Marysville deprecated the evils that gave rise to the Committees of Vigilance, but felt that they could not be dispensed with (Alta, August $20 \%$ ).

49 See supra, p. 74. Referring to the miners' action in criminal affairs, Bancroft said that their courts were not wholly abrogated until after 1854 (Popular Tribunals, I, 436). See also his California Inter Pocula, 240; Borthwick, Three Years, 125, 154-156; Helper, Land of Gold, 151-153.

50 Ide wrote in December, 1851: "Last year the whole interior of Colusi [sic] County fell a prey to lawless maurauders and thieves, to suppress which 'lynch-law' was resorted to, to supply the defects of such systems of law as were, in the exigencies of the case, imported from, and alone applicable to, other communities-differing as widely from ours as light from darkness' (Biographical Sketch, 235). See also Carr, Pioneer Days, 134-135; Memoirs of Cornelius Cole, 86-91; Mrs. D. .B. Bates, Incidents on Land and Water, 1858, p. 121. 
towns ${ }^{51}$ by the end of the month Governor McDougal felt it necessary to issue his proclamation against a widespread Vigilante movement; and when in December Metcalf asked for a change of venue in his suit against committeemen and alleged that justice could not be expected in San Francisco, it was stated in reply that a change would be fruitless, as Vigilance Committees existed in nearly every county of California. ${ }^{52}$ There is no evidence that the relation between these scattered bodies was based on any closer bond than friendship and coöperation. At one time a suggestion was made that the San Francisco Committee should send delegates to organize Vigilantes throughout the state, but no resultant action was recorded, although a recommendation that subcommittees of correspondence should be established was adopted, at least by the Committee of Santa Clara. ${ }^{53}$

It was not surprising that the scheme of protective committees was approved in the old mining centers, where men were already accustomed to volunteer associations. Stockton, for instance, had attempted popular organization very early in its history. In the sumer of 1850 a "Vigilance Committee" of fifteen eitizens had been appointed to solicit from the state and military authorities assistance in preserving order. ${ }^{54}$ This was, perhaps, the first use of the specific name that became so familiar in 1851 , but it is not apparent that any success attended the effort. Allusion has already been made to the public demand for summary action when the band of horse thieves was discovered

51 "Other cities in the interior have imitated the example of San Franeisco, and have instituted Branch Vigilance Committees, who act in concert with the parent body. They have recently displayed the same energy and vigor that have characterized our own Association. It is probable that such branches will be established throughout all the settlements in the country, when by concert and correspondence, speedy justice will be sure to overtake the criminal, however rapid or remote his flight" (Herald, 1851, July $1 \% 1$ ).

52 Herald, 1851, Dec. $202 / 4$.

53 See Papers, 281, 283, 391, 527. $\quad 54$ Alta, 1850, July $19 \% 1$. 
in June, 1851, and of its contributing influence upon San Francisco affairs. Almost coincident with the formation of the San Francisco association, that is, on June 13, one hundred and serenty citizens of Stockton formed a volunteer patrol, which later developed into a Committee of Vigilance with regular officers. who corresponded with the Committee of San Francisco and joined with Sonora in the search for Whittaker and McKenzie. It was this body which transferred the thief, Jenks, to the Committee of San Francisco and recommended mercy, in spite of his evident guilt. ${ }^{55}$

One of the first communities to fall into line was the town of Marysville. A volume of minutes of a formal Committee of Vigilance is still preserved in the public library of that eity. ${ }^{56}$ The initial entry gave minutes for a meeting on June 24, which was an adjournment from an earlier gathering. Eleven more meetings were reported at intervals until August 26. The constitution as published in the Marysville Herald was signed by one hundred and twenty-seven persons and was almost identical with that of the San Francisco Committee. The minutes do not indicate, however, that an Executive Committee took the initiative. and all the gatherings were open to the entire membership. ${ }^{57}$ Permanent headquarters were leased and guards appointed, but no action of any particular interest was reported. The Committee of Marysville corresponded with that of San Francisco in regard to the Stuart-Berdue trials, transmitted information relative to various criminals, and assisted at the rescue of Mary Lye. In October a standing committee of ten was charged with the further conduct of affairs, and the general committee ceased

55 See supra, p. 320 ; Papers, Index under "C. of V. of Stockton"'; Popular Tribunals, I, 449-451.

56 Minutes of the Vigilance Committee of Marysville, 1851. Transeript obtained through the kindness of Dr. O. C. Coy.

57 An Executive Committee of five was appointed, July 19, to assist the president, and another on July 29, but their proceedings are not noted. 
operations. The daily papers spoke of temporary revivals of a Vigilance Committee in November, 1851, and in the spring of 1852. Bancroft said that the original organization, or its successors, continued activities for many years and participated in public affairs as late as January, $1858 .^{58}$

The citizens of Santa Clara, called together by a public notice, met on or about June 25, 1851, adopted resolutions endorsing the action of the San Francisco Committee of Vigilance and organized a local association. The San Francisco Herald, noting with great approval "that not a single citizen has yet refused to join," hoped for efficient coöperation between the societies of the interior towns. Several letters showed the warm support the smaller body offered to the San Francisco Committee, and one of them, dated "Vigilance Association Rooms," indicated that permanent headquarters were occupied in Santa Clara. One of the first acts was to furnish bail for a well-known thief, to make his temporary freedom the occasion of a whipping, and then to return him to the more lenient courts. At another time this Committee convicted an old man and his son of cattle stealing and sentenced both to corporal punishment. The father pleaded for mercy on account of his age and the son sturdily offered to bear a double share, an act of filial piety that moved the judges to remit the chastisement of the elder, although the dutiful son received his own allotted stripes. ${ }^{59}$

The Alta California of June 28 stated that a Committee of Vigilance had been formed in Sacramento, where two hundred and thirteen citizens had signed the roll of members. This organization coöperated with the San Francisco Committee in the search for Kay, and for Whittaker and McKenzie, but no other

58 See Popular Tribunals, I, 300, 454-456; History of Yuba County,

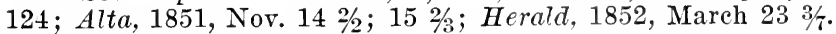

59 See Papers, Index under "C. of V. of Santa Clara"'; Popular Tribunals, I, 474-475; Herald, 1851, July $3 \frac{2}{3}$; Alta, August $30 \%$. 
record of its activities appears in the Papers. ${ }^{60}$ Early in July there was great excitement in Sacramento over a murderous assault made upon James Wilson, and a Vigilance Committee was organized to demand the punishment of the four men who attacked him. The reports of the affair make it appear that this body had impromptu officers chosen by the crowd, and it may have lacked organic connection with the permanent society started in June. However that may be, we learn that when the governor reprieved one of the highwaymen who had been legally convicted and sentenced to death, the bandit was hanged by popular action immediately after the lawful execution of two of his companions. On that occasion Joseph R. Beard, president of the permanent Vigilance Committee, was chairman of the citizens' committee in charge of the hanging. ${ }^{61}$

On June 28 the people of Sonora lynched a confessed thief, named Hill, and a day or two later a Vigilance Committee was privately organized. It immediately sent the San Francisco Committee a report of nine rogues implicated in Hill's confession, and at other times it transmitted useful information. Its members also gave cordial assistance to the San Francisco delegates who searched for Whittaker, and they passed resolutions condemning Governor McDougal's seizure of him and of his companion, McKenzie. The correspondence showed that regular officers directed the affairs of the organization and that letters were dated from the "Chamber" of the society. Lang's History of Tuolumne County gave some account of severe floggings administered by the Sonora Committee, and Bancroft mentioned other excessive punishments. But the local Directory boasted that the Committee refrained from all excesses and turned over

60 Papers, 392, 415.

61 See Papers, 366 note 2; History of Sacramento County, 125-126; Popular Tribunals, I, 441-448. The Sacramento Union, 1851, July 10, gave the officers chosen at the impromptu meeting on July 9. Bancroft gave the same names as if elected on June 25 , and made no distinction between a permanent and temporary organization. 
to the officers of the law the only man that came before them charged with a capital offense. ${ }^{62}$

Sometime in July a Committee was organized in Nevada City. In response to a request for a copy of the constitution of the San Francisco Committee Stephen Payran addressed to the new society a characteristic letter which set forth the aims and ideals of the Vigilance movement in the following grandiloquent terms : ${ }^{63}$

Our great aim, gentlemen, is to remove corruption from high places, to advance the safety and interest of our adopted state, to establish justice and virtue, without which our fall and ruin would be certain. ... It is an old and popular doctrine, that it may be necessary to sacrifice the government to the people, but never the people to the government. That your course may be marked with prudence and justice, may God grant. Do not permit vindictiveness to enter into your deliberations. Be calm and determined; swerve not to the right nor to the left, but go onward in your pursuit of right. Be of one mind, and carry your point. The might, majesty, and power of the people can overcome all impending evils; like the thunders of heaven it will shake to naught all corruptive influences, and drive its authors into oblivion. Let the motto of our fathers be ours to sustain and perpetuate-Virtue, Liberty. Let us show ourselves worthy of our origin, determined to sustain and support the blessed privileges bequeathed by them to us. The moment we render up one tittle of the sacred constitution under which we were born, and which cost so much to obtain, and permit a small and corrupt minority to prescribe, we lose our caste, and our boasted institution will become the laughing stock of the world.

Late in the fall the organization appointed an Executive Committee, modeled, we may presume, on the system adopted in San Francisco.

The genesis of the Committee of Mokelumne Hill was typical of the temper of the time. The settlement was a mining camp,

62 See Papers, Index under "C. of V. of Sonora", History of Tuolumne County [by Lang], 79-81; Heckendorn \& Wilson, Miners \& Business Men's Directory, 44; Popular Tribunals, I, 467-469; Sacramento Union, 1851 July

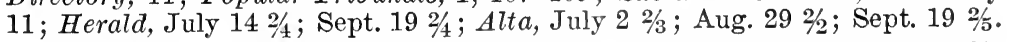
63 Papers, 373-374. See also Herald, 1851, July 29 2/2; Alta, Nov. 21 2/3. 
still primitive and crude, and dependent upon the county magistrates at Jackson for the restraint and punishment of criminals. But the county jail was so insecure and the county courts were so inefficient that the thugs of Mokelumne Hill had little cause to fear the law. Therefore the miners of that town approved the customs of ' 49 that lynched murderers red-handed. In July, 1851, one John Nelson was so sentenced to death. ${ }^{64}$ In November another murder was committed but the people were persuaded to leave the criminal in the hands of the sheriff at Jackson. ${ }^{65}$ A general jail delivery at Jackson on Christmas night did not increase confidence in the constituted authorities. A popular jury immediately assembled at Mokelumne to try a man named Campbell who had wantonly killed a Chileno on Christmas Day. The verdict was "guilty," but the crowd was influenced to vote for the transfer of Campbell to the authorities. His friends took advantage of the reprieve to appeal his case to a smaller meeting, which roted to discharge him unpunished. ${ }^{66}$

On December 28 the better element of the camp organized a Vigilance Committee, elected responsible officers, and requested a model constitution from San Francisco. The ensuing weeks were nearly free from crimes of violence. Late in March a murder was committed and the Committees of Mokelumne Hill and Stockton united in an unsuccessful pursuit. A series of daring robberies occurred about the same time. The offender was detected and forced to confess and the Committee decided to deal with him on the spot, as delivery to Jackson would inevitably end in his release or escape. He was accordingly sentenced to death, allowed the ministrations of a priest, and hanged the next day, with the full approval of the town. The Committee deplored the fact that the necessity existed for such extreme measures, but

\footnotetext{
64 Alta, 1851, July $7 \%$. I have found no record of the execution.

65 Alta, 1851, Nov. $32 / 4$.

66 Alta, 1851, Dec. 30 2/2; Herald, 1852, Jan. 2 2/4.
} 
announced that it would not disband until affairs promised better for the protection of society. Bancroft stated that the Committee of Mokelumne Hill subsequently reorganized to assist the regular courts and to oppose irresponsible mobs. ${ }^{67}$

Committees of Vigilance with formal organization and permanent officers existed in other communities. The San Francisco society sent its constitution to a Committee at San José and corresponded with a Committee at Wymans Ravine. ${ }^{68}$ In the autumn of 1851 "respectable citizens" of Scott's Valley, then in Klamath County, assured the Indian agent that if he would negotiate treaties with the natives they would punish all bad white men who might violate the provisions therein. In reporting this action the agent wrote $:^{69}$

I am utterly opposed to the jurisdiction of "Judge Lynch" in all ordinary cases; but until a military post is established on this exposed frontier, and society assumes a more settled, regular form, there seems to be no other course left for the protection of either person or property.

In 1853, when residents of Humboldt County protested against the issuance of school warrants that would depreciate the value of desirable farming land, they resolved : "io "That the Vigilance Committee be instructed to stop all further location of school warrants in Humboldt township."

The ways of the miners of 1852, at Scott's Bar. Shasta. County, were told in a picturesque story "founded on fact" published in the Overland Monthly. ${ }^{i 1}$ The theft of a large amount of gold dust led to the hasty formation of a Vigilance

67 Papers, 718, 730-732, 744-745 ; Popular Tribunals, I, 465-467 ; Borthwick, Three Years, 317-318; Alta, 1852, Jan. 5 2/4; Herald, March $24 \% 3$; $262 / 1$; April $42 / 4$.

68 Papers, 676, 708-709.

69 Redick McKee to C. E. Mix, Acting Commissioner of Indian Affairs, Oct. 28, 1851, Cong. Docs., Ser. No. 688, Doc. 4, p. 212.

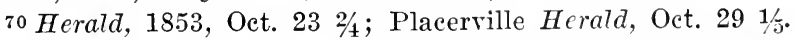

71 W. M. Turner, "How We Did It on Scott's Bar," Overland Monthly, XIV (1875), 377-381. 
Committee, the pursuit of the thief, his arrest, trial, confession, and corporal punishment. "It gave the Bar a rough name," said the pioneer raconteur, "an' there wasn't another robbery there as long as I can remember." He vouched for the authenticity of the copy of the warrant issued for the fugitive by the "old chief of the Vigilantes" at Humbug. It read as follows:

\section{State of California, County of Shaste Shaste Plains Township}

Vigelant Com Vs Dr Baid

To any constable of Shaste Plains Township this day complaint having Laid before me Vigelant Committee that the erime of felony has Ben commited and acusing the above named Dr Baid of the same therefore you are to arest the said Dr Baid and bring him before the people and to be delt with acording to their Judgment.

Yreka 1852

\section{A. Boles}

chairman of Commitee

There were popular tribunals in Southern California also during this period, ${ }^{72}$ but there was not a well defined movement towards the organization of permanent Committees of Vigilance. Conditions of life there were so distinctly different from those that developed about the mining centers of the North, that although they are an integral and important part of the progress of the state as a whole, it has not seemed necessary to enlarge upon them in studying the historical background of the Committee of San Francisco. Still, the courts in Southern California, like those in the North, failed to check crime. There were many robberies and murders and much trouble with lawless bands of Mexican bandits. ${ }^{73}$ In July, 1851, the citizens of Los Angeles organized a volunteer police force that served under the orders of the authorities. and Bancroft spoke of a Vigilance Committee that was

72 Rodman said there were few instances of lynch law in Southern California, Bench and Bar of Southern California, 45. Bancroft noted several instances, Popular Tribunals, I, 486-514.

73 The San Francisco Herald, 1851, Oct. $29 \%$, quoted the Los Angeles Star as saying that in the past fifteen months there had been forty-four homicides, and only one trial for murder in Los Angeles County. 
acting in the autumn of $1852 . .^{7 t}$ Two years later conditions in Los Angeles were so bad that the San Francisco Herald advised the citizens of that town to organize an effective Committee, to which the Los Angeles Star of November 30, 1854, made reply that such an association was unnecessary. ${ }^{75}$ Just at that time one David Brown was on trial for a murder that had nearly led to his lynching in October. He had then been saved by the efforts of the mayor, Stephen C. Foster, who quieted a mob by promising immediate justice in the courts. Brown was convicted and sentenced, but reprieved at the last minute. Mayor Foster promptly resigned his position, and on Jannary 12 led an indignant crowd that stormed the jail and hanged the murderer. A few days later Foster was re-elected to his former office. ${ }^{76}$

Other Committees of Vigilance besides those already mentioned were noted in the California papers between the rears 1851 and 1856. ${ }^{77}$ Bancroft repeated and supplemented these allusions, but the references were so brief and so disconnected that it is impossible to say whether the societies were permanent in character or were temporary associations formed to meet particular emergencies. It is possible that more extended research might uncover traces of others, but the facts already collected are sufficient to show that the Committees of Vigilance, as organized by responsible citizens, made a sincere effort to secure

74 Popular Tribunals, I, 489, 492.

75 Popular Tribunals, I, 493-494.

76 Popular Tribunals, I, 494-496; Newmark, Sixty Years, 139-141; History of Los Angeles County (1880), 78-79. Another convicted murderer, named Alvitre, was hanged at the same time.

77 Notices may be found of Committees at Barton's Bar, 1851 (Alta, Aug. $22 \%$ ) ; Natchez, 1851 (Alta, Nov. $15 \%$; Popular Tribunals, I, 456); Grass Valley, 1851 (Popular Tribunals, I, 456); Shasta, 1851 (Popular Tribunals, I, 457; Alta, Aug. 20 2\%) ; Columbia, 1851 (Popular Tribunals. I, 469-470); Santa Cruz, 1852, 1853 (Popular Tribunals, I, 477); Campo Seco, 1852 (Herald. Feb. 24 2/4) ; Jackson, 1852 (Alta, Mav 31 䏠); Oakland, 1852, 18.54 (Herald, 1852, Dee. $14 \%$; 1854, Aug. 24 \%); Nelson Creek, 1853-1854 (Illustrated History of Plumas, Lassen and Sierra Counties, 214-215); Mariposa, 1854 (Popular Tribunals, I, 467; Alta, March $18 \% \frac{7}{7}$; Herald, April $10 \%$ ); Coulterville, 1856 (Alta, April $29 \%$ ). 
the punishment of crime without the evils attendant upon lynchings by an irresponsible crowd. The danger and the horrors that were inevitable under mob rule were demonstrated by the tragedy that has passed into history as the "Downieville lynching," a tragedy which must form a part of any chronicle of the popular tribunals of California.

Downieville was a bustling, populous mining camp, where heavy-handed punishment was dreaded by the disorderly. ${ }^{78}$ In this town, on the evening of July 4, 1851, an intoxicated man named Cannon greatly affronted a Mexican woman known as Juanita, by bursting open the door of her house or tent and stumbling within. Cannon's friends declared the entrance was an accident. A resident acquainted with the facts said that it was the climax of unwelcome advances made to the woman, who was young, beautiful, passionate, and the faithful consort of a Mexican who may or may not have been her lawful husband. The aggressor returned the next day, ostensibly to apologize, but his excuses were received with indignation. A heated dispute followed and Juanita suddenly terminated the quarrel by stabbing the man with her dagger, while she furiously asserted that he had added the insult of spoken words to the insulting deed of the previous evening.

The wound was mortal, the dead man had many friends, and the sheriff of Yuba County was out of reach. A mob seized the murderer and her companion and improvised a court. There was no doubt whatever of the homicide-the girl acknowledged it with blazing eyes and protested that her traditions taught the protection of her honor, but as her defense was in Spanish it made little impression on her angry auditors. She was, however, not entirely lacking in champions. A physician appeared and begged for her life on the plea of approaching maternity, but a sceptical colleague brutally contradicted his statements. Cannon's

78 See Downie, Hunting for Gold, 145. 
friends were determined to secure her instant execution, and under their influence it was decided to hang her from the truss of a bridge that crossed the river close to the town.

Dressed in her gayest clothes Juanita walked towards her doom with the dignity of a princess. On the way another effort was made in her behalf. ${ }^{79}$ It is said that Stephen J. Field, former alcalde of Marysville, collected a little party of friends, halted the rabble, and made an almost irresistible appeal to the better nature of the men about him. While they hesitated between vengeance and chivalry, another Narysville lawyer, Samuel Spear, followed Field with a flood of invective. The cry for execution was revived, Field and his friends were overpowered, and the torrent swept on. Standing on an elevation beneath the gallows the girl waved back those who offered to lay hands upon her, spoke steadily and calmly for a few minutes, and declared that if by the American code she deserved to die she would pay that penalty without regret or apology. With her own hands she adjusted the rope, cried a brave "Adiós, Señors!" and swung lightly from the scaffold. An hour too late the sheriff arrived; within a week Downieville acknowledged the shame of the deed and the impromptu judge and jury were denounced for their responsibility. A Vigilance Committee was organized after this execution, ${ }^{80}$ but we have no records of its activities.

79 The effort at rescue was told by Senator Charles N. Felton, who had immediate information on the subject, although he was not an actual spectator (Grass Valley Union, 1917, Jan. 28, copied from an article by J. H. Wilkins, in the San Franciseo Bulletin). See also Downie, Hunting for Gold, 145-153; Royce, California, 368-374; Popular Tribunals, I, 587; Illustrated History of Plumas, Lassen and Sierra Counties, 445-447. The affair was condemned as disgraceful (Alta, 1851, July 14 \%). The newspaper index in the California State Library has the following entries under the "Downieville Hanging": Alta, 1851, July 9 \%; San Francisco Argo-

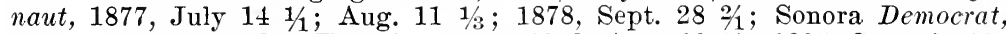
1877, July 28 1/5; San Franciseo Post, 1878, Aug. $101 / 6$; 1895, Sept. 21 \% ; Shuck, Bench and Bar of California, ed. of 1901, p. 273.

80 Papers, 360, 829. A later Committee was mentioned in Alta, 1854, May $24 \%$. 
The press of the state wrote of the Downieville tragedy as briefly as possible, but it stands to this day as the most terrible example in California of the deeds that are possible in a state of society in which the habitual failure of their legal safeguards has accustomed even decent men to regard lynch law as a legitimate expression of the law of self-preservation. ${ }^{81}$ The majority of the men in California did so regard lynch law in the decade of which we write. The emergencies of the transition period had forced it upon them as the sole restraint of criminals. A little later the impotence of their local courts had influenced them to continue the precedent and had finally resulted in the open demand for popular action that had been voiced by the press of the state. ${ }^{82}$

The Vigilance Committee of San Francisco and the allied organizations in the interior were not primarily responsible for the creation of this spirit. It had found previous expression in many crises of American life, and in every social group that braved anarchy and terrorism within that El Dorado whither the flag of the Union had failed to carry Federal, state, or local authority. It continued to express itself within those same groups when established authority still failed to give protection to life and property; it was abroad in San Francisco months before the Committee was organized; it asserted itself in unmistakable terms during the early days of June; and it threatened to break forth in riot and bloodshed at any moment of supreme tension.

What the Committee did ereate was an organization to combat the dual dangers that arose from inefficient administration on the one hand, and from mob vengeance on the other, by interposing

81 Juanita was not the only woman killed by a California mob. A Negress who set fire to a hospital near Stockton was whipped so severely that the punishment proved fatal, perhaps because she was soon to become a mother (Saint-Amant, Voyages 421; Popular Tribunals, 1, 522-523).

82 This point of view was frankly expressed in a letter from C. Hix, a justice of the peace, in Placer Times and Transcript, 1852, May 9. 
between those forces a small group of representative men who were willing to assume public responsibility for deliberate violation of the letter of the law, but who remained faithful to their personal interpretation of the spirit of the law and adopted methods so acceptable to their local communities that their verdicts superseded the vindictive clamor for stripes and death. ${ }^{83}$ Stripes and death they sometimes inflicted, but the records of the Committee of San Francisco, and the far less complete notices of the deeds of the out-of-town associations show that, with few exceptions, the men who formed these permanent and recognized associations accorded fair trials, imposed just punishments, and held themselves aloof from wanton cruelty.

83 In describing the development of popular juries in California, Hittell said: "It was what was known at first as lynch-law and afterwards as vigilance committee law' (California, II, 674). Coleman said that the Committee seized upon the forces of a mob, arrested them, and utilized their powers in regular form, systematically and coolly ("San Francisco Vigilance Committees," Century, XLIII [1891], 148). "La Comité de Vigilance est le Lynch Law régularisé, modifié, amélioré', (Holinski, La Californie, 128). "Vigilance Committee, Gesellschaft welche sich zur Aufrechterhaltung der bürgerlichen Ordnung gebildet und zu dem Zwecke häufig die Handhabung der Justiz, unter Anwendung des kürzesten Process-Verfahrens, selbst übernimmt', (Karl Rühl, Californien, 1867, p. 283). 


\section{CHAPTER XVIII}

\section{'51 TO '77}

Whatever may have been the ideals of the members of the Committee of Vigilance or the self-restraint imposed by their methods, we cannot intelligently appraise their work until we inquire whether or not the Committee exerted any abiding influence towards the restraint of crime and the improvement of society. In doing so we encounter an exceedingly difficult problem.

Owing to the lack of official criminal statistics, the contemporary newspapers furnish the only available source of information, and their accounts, at best, are incomplete and inadequate. Occasional statistics for San Francisco can be gathered from periodical reports of the recorder's court published in the Herald and in the Alta California. ${ }^{1}$ From the first of May, 1850, to the middle of July, 1851, a total of 3507 cases, an average of about 240 a month, were tried before the recorder. Statistics were also published from time to time covering the period from June 15 to December 31, 1851, with the exception of the month of October.

These give approximately 375 cases per month, showing that there was no improvement in the total number of arrests, though by far the larger number were for petty offenses and violation of license ordinances. During July, August, and September few cases were sufficiently serious to be referred to a higher court. The Herald of September 15 stated: "Crime has most sensibly diminished throughout the State, and no execution has taken place, either here or in the interior, since the sailing of the last steamer. . . For two months there has not been a murder, a burglary or a robbery with force committed in the city." Later

${ }_{1 \text { Herald, }} 1851$, July $172 / 3$; Aug. $152 / 2$; Sept. $152 / 3$; Alta, Oct. $82 / 2$; Dec. $92 / 5 ; 1852$, Jan. $32 / 5$. 
reports indicated that conditions were constantly changing. ${ }^{2}$ In April, 1852, the grand jury took a week's recess for lack of cases on the calendar, although the average of arrests, from January 1 to May 31, was 353 . In July, 1853, the grand jury found thirtythree indictments, a number considered low for a city of 50,000 inhabitants. In 1854 the arrests for April, May, and June averaged 400. In 1855 they were 509 for February and March.

Many generalizations have been made of the disorders occurring in California during this period, but accurate statistics have never been collected. It is said that at some time before 1855 the district attorney of San Francisco told a jury that during the previous four years there had been 1200 murders and only one legal execution in the city. ${ }^{3}$ I have been unable to find the original report of this speech, but the figures are often quoted as reliable. J. S. Hittell wrote that over a thousand homicides had bèen committed in San Francisco between 1849 and 1856, but he failed to give the sources of his information. ${ }^{4}$ T. H. Hittell cited the California Chronicle of December, 1855, as stating that in the state at large, during the preceding eleven months, five hundred and thirty-five homicides had occurred, and forty-nine hangings by mobs, but only seven legal executions. ${ }^{5}$

2 See Herald. 1852, April $26 \%$; June $62 / 2 ;$ Alta, 1853, July $31 \%$; Herald, 1854, May $42 \frac{4}{4}$; June $32 / 2$; July $7 \% 2$; 1855 , April $2 \%$. The report of the grand jury for November, 1853, lamented an increase of crime, and noted that while the county jail held forty prisoners in March, 1851, the number had been trebled in March, 1853 (Alta, Nov. 29 3/7).

3 See Helper, Land of Gold, 29, 253, 298; B. Brierly, Thoughts for the Crisis, 1856, p. 9; Popular Tribunals, I, 131. It was explained in the Phoenix, 1858, Feb. $141 / 3$, that about three years earlier, H. H. Byrne had spoken of 200 and the papers had misprinted the number as 1200 . The Phoenix was too scurrilous to deserve credence on any subject (see infra p. 402), and this paragraph may or may not contain a hint of truth. The single execution is described in Popular Tribunals, I, 135, 746-747.

4 J. S. Hittel, San Francisco, 243. The Herald, 1854, Sept. 9 2/4, spoke of 2000 murders which had taken place in the state since January, 1849 .

5 Hittell, California, III, 462. The Alta, 1856, Jan. $18 \%$, quoted, without contradiction, a statement in the New York Express, 1855, Dec. 12, to the effect that in the preceding ten months there had been 489 murders in California, 6 executions by sheriffs and 46 lynchings by mobs. See also infra, p. 397 note 30 . 
In the dearth of official summaries the following paragraph published in the Herald, April 14, 1852, becomes a matter of interest:

The idea is very generally entertained that the number of sudden deaths by accidents or violence is very great in this city. This, however, is incorrect, as the records show that but twenty-eight inquests have been held during the past eight months. For a eity so large this is quite a small number.

This brief report of the coroner covered the period from August, 1851, to March, 1852, during which the influence exerted by the Committee of Vigilance was a most stern reality. It showed an average of less than four deaths a month from accident and violence combined. If any reliance whatever can be placed on the figures quoted from other sources, it also indicated that the immediate result of the rule of the Vigilantes was a diminution of crime that deserves respectful attention.

The acceptance and repetition by contemporary writers of the current summaries of crime is conclusive evidence that the estimates were not at variance with the facts as to the existing conditions. Sinister as they are, they do not betray the darkest menace that overhung the state, for the youthful commonwealth had become a prey to despoilers far more dangerous than James Stuart and his accomplices or successors in crime. The latest plots were not hatched in the dens of Sydney Valley, but in the primaries, in the lobbies of the capitol, and in the halls of the national Congress. While business men were struggling with fires and floods, with unsettled land titles, with an unsound banking system, with feverish speculation and delirious panies, the political schemers from the Southern plantations and from Tammany Hall had not wasted a moment since the summer of ' 49 . It is no exaggeration to say that every interest in California except theirs trembled from hour to hour above quicksands of shifting fortune. Placer mining showed signs of speedy exhaustion, and quartz mining was still in the experimental stage; the 
agricultural methods familiar to farmers from the East were unsuited to the seasons of the Pacific Coast; and no great irrigation undertakings were possible while land titles were little more secure than a gambler's stake. The commercial markets, depleted on one day by a fire or by an unexpected demand, were glutted on the next by the arrival of laden clippers from New York, and the caprice of public auction was the only standard of prices. The value of real estate in the cities rose and fell beyond all power of anticipation. Manufacture was almost prohibited in a district that had developed no cheap or dependable supply of building material, fuel, or labor. ${ }^{6}$

The only stabilized asset in the state was official patronage, and the exploitation of a people absorbed in financial adventures and unambitious for political preferment. This exploitation was conducted with a persistency of purpose, a skill in organization, and an utter abandonment to corruption that turned party conventions into a farce, dominated elections by bands of shoulder strikers and repeaters, and invented ballot boxes that served the bosses exactly as his magic hat serves the stage magician. ${ }^{7}$ Amateur politicians were helpless in such hands. They passed ordinances to regulate gambling, drinking, and social disorder," built their jails, and even elected many incorruptible magistrates, but every sporadic effort at reform was frustrated by the intrigue that kept the tools of the bosses in the strategic positions of administration and finance.

The Vigilance Committees, though they had certainly contributed to the safety of particular communities, had nowhere

61854 and 1855 were years of disastrous failures. For financial and political conditions, see J. S. Hittell, San Francisco, 208-330; T. H. Hittell, California, III, 423-459; Bancroft, California, VI, chaps. 23-26; VII, chap. 8; Royce, Califarnia, 377-501.

T The "patent, double back action ballot box"' is described and illustrated in Popular Tribunals, II, 1-21.

8 San Francisco passed various ordinances framed to close saloons at midnight, to suppress houses of ill fame and to control gambling, but it was almost impossible to avoid unconstitutional provisions, or to secure convic tions. See, for instance, the Alta, 1854, March $10 \% 2$; April $6 \% 2$; May $3 \% 1$. 
succeeded in effecting any lasting reforms in local politics or in local courts. In most places their careers were brief, although the title, at first generally respected because of the character of the original Vigilantes, was often adopted by impromptu assemblies which formed hasty organizations to inflict impetuous punishments. But the men who led in the Committees of Vigilance constantly reappeared as leaders in other forms of civic activity. In San Francisco, for instance, they showed their continued interest in public affairs by constant service on the grand jury. As late as 1855 six former Vigilantes were on the grand jury in July, eight in the following November, three or more in January, 1856, and five in March. ${ }^{9}$ Often they acted as foremen, signing to the reports of these authorized bodies the same names they had fearlessly attached to the incriminating documents filed by "No. 67. Secretary." Thus they continued their protest against political graft and political lassitude, against supervisors who robbed the city, merchants who shirked service on trial juries, and jurors who acquitted prisoners in the face of direct evidence of guilt. One censorious foreigner who resided in the city in 1852 wrote that the grand jury was the only body in California which spoke its feelings and opinions fearlessly. ${ }^{10}$

By the spring of 1854 crime was again rife in San Francisco, burglaries had increased beyond all precedent, and in addition to the petty thieves, groups of determined squatters attempted to hold illegal possession of disputed tracts of land. To meet

9 Reports of grand juries, and lists of jurors may be found as follows: 18.51, Herald, August $1 \%$ \% $4 \%$; $5 \% \frac{2}{\text {; }}$; Sept. $10 \%$; $30 \%$; Oct. $2 \%$; Nov. $29 \%$; Dee. $3 \%$.

18.52, Alta, March $28 \%$; April $7 \%$; Herald, April $26 \%$; May $29 \%$; $30 \%$; Alta. Dec. $1 \% ; 10 \% ; 11$ (from elipping).

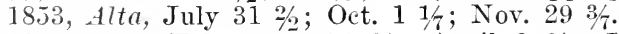

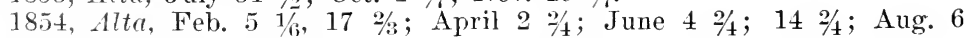
$2 / 4 ; 11 \% 2 ; 19 \%$; Oct. $1 \%$.

1855 , Herald, April $1 \%$; Alta, Ang. $1 \%$; Dee. 2 1/2.

1856, Alta, Feb. $2 \% \frac{4}{4}$; April $6 \%$.

10 California [by Huntley], II, 60. 
the menace of these lawless "settlers" and to check the armed conflicts that sometimes ensued, the landholders formed an "Association for the Protection of the Rights of Property, and the Maintenance of Order," adopted a formal organization, and appointed an executive committee of thirteen. About a thousand members enrolled and announced that their object was to sustain the law. They denied having any connection with the Committee of Vigilance, but many former Vigilantes were conspicuous in the meetings. ${ }^{11}$ The proceedings were generally confused and inharmonious, and the association disbanded without any notable achievement. The San Francisco Herald appeared to favor the movement, but the county judge, T. W. Freelon, took pains to warn the grand jury that rumors were abroad of a protective association of landowners which required prompt suppression. "San' Francisco has had one Vigilance Committee," he said. "It is past! and let the dead past bury its dead. It must have no other. Let there be Revolution or Law.",

The sentiments expressed by Judge Freelon were by this time gaining adherents throughout the state. The papers as a rule discouraged the continuance of Committees of Vigilance, and emphasized every hopeful symptom of increasing order. One pioneer of Placerville said that by the spring of 1853 "society commenced forming," and that the better element there concluded that promiscuous hanging should stop, organized a party to support the law, and in one instance held off an angry mob,

11 Current disorders and the need of better protection were noted in the Herald, 1854, May 4, \%1; May $23 \%$. On June 2 the editor said: "The Vigilance Committee was scarcely ever more necessary than at present.', The meetings of the Association were held June 5, 6, 7,9, and perhaps later (Herald, June $6 \% ; 8 \%$; $10 \%$; Annals $5+1$ ). The following former Vigilantes were prominent in the movement: C. R. Bond, C. L. Case, J. F. Curtis, J. P. Manrow, Dr. Samuel Merritt, H. M. Naglee, Jolın Parrot, John Perry, Jr., A. G. Randall, Michael Reese, William Sharon, S. Teschemacher, S. R. Throckmorton, D. S. Turner, J. P. Van Winkle, Ferdinand Vassault, J. C. Ward, Robert Wells, F. A. Woodworth, S. E. Woodworth, and possibly Louis Cohn [L. Cohen?] and J. C. George. A counter organization of

"Settlers"' was reported in the Herald, June $16 \%$.

12 Herald, 1854, June $14 \%$. 
rescued the suspected murderer, and escorted him to Coloma, where he was lawfully tried and executed. Thereafter there "was no more lynching in El Dorado County.", It is to be hoped that one county, at least, was so soon purged of disorder. In other parts of California lynchings still occurred. ${ }^{1+}$ The papers, however, reported them with increasing condemnation, and public disapproval was expressed with increasing vehemence. In the spring of 1854 the grand jury of Calaveras County indicted the men who had participated in the lynching of a horse thief, but the writer has been unable to discover that they were ever brought to trial. ${ }^{15}$ In January, 1855, there were several illegal executions in the mines, which prompted the editor of the Alta to write $:^{16}$

The Vigilance Committee had an influence from which California has not recovered to this day. Its influence for good was speedy; but because its immediate influence was good, its remote influence has been so many times the worse. Life and property were more safe during the days of the Vigilance Committee, and we do not design to find any fault with the members of it now. Those were trying times; and as the law failed to punish, many good men engaged in that which they could not be brought to look upon in ordinary times without abhorrence.

A few months later, after mobs in Amador County had made savage reprisals upon Mexicans because of the murder of an American, the residents of Butte City met in mass meeting to protest against such action on the part of a "purported Vigilance Committee." In reporting the episode the editor of the Alta California said: ${ }^{17}$ "The name of a Vigilance Committee should

13 Norton, Life and Adventures, 293.

14 For references on crininal conditions, see supra, p. 127 note 32 ; Bancroft, California, VII, 191-219; Popular Tribunals, I, 515-576; History of Nevada County, 115-117; Michael Kraszewski, Acts of the "Manilas"... at San Juan in 1866. 1878 (MS in the Bancroft Library).

15 Herald, 1854, April $22 \%$.

16 Alta, 1855, Jan. $27 \%$. Defense of that action, or a similar incident at Michigan City, was made in the Herald, Feb. $11 \%$.

17 Alta, 1855, Ang. $31 \%$ Earlier reference to this lynching was made in the Alta, Aug. $13 \% 1$. 
never be mentioned except as a terrible remedy employed in the past, when the impunity with which crime was committed led well meaning men to do what, on sound reasoning, cannot be justified." According to a later issue, society was "settling down, in spite of occasional lynchings; public gambling was disappearing; vice was restrained by law, and the Sabbath was more generally observed. ${ }^{18}$

The dangers that inevitably attended the prolonged activities of Vigilance Committees received attention from the grand jury of Tuolumne County in October, 1855. An interesting extract from its report is to be found among the documents printed in the Appendix. ${ }^{19}$ Not long thereafter a murderer was lynched at Columbia, Tuolumne County, and in editorial comment the Alta said : ${ }^{20}$ "There was a time when Lynch-law in California seemed to some extent justifiable, when San Francisco and the state were full of cut throats, who could not readily be punished in any other than a summary manner-but that time, if it ever existed, has long since passed away." Strong resolutions condemning the lynching were passed by residents of the vicinity, and the grand jury indicted eight of the men responsible, but no effective prosecution followed.

Study of the newspapers thus shows that public opinion more and more condemned the appeal to lynch law, although there were times of decided reaction. For example, when the San Franciseo grand jury for March, 1855, severely arraigned the powerful but secret forces that were corrupting the administration of the city, the editor of the Herald hailed the report as a reminder of the "good and vigorous days of the Vigilance Committee," and fervently ejaculated, "May such times come again, for we want them sadly.",21 The press, to be sure, took

18 See Alta, 1855, Oct. $21 \%$. Sunday closing, Aug. $9 \%$; Nov. $1 \%$ 19 See infra, p. 472.

20 Alta, 1855, Oct. $242 \%$; Dec. $17 \% 3$; Popular Tribunals, I, 548-553. 21 Herald, 1855, April $22 \% 1$. 
pains to mention every indication of increasing tranquility, but in spite of optimistic editorials there was constant disorder. ${ }^{22}$

The most wanton offenders were the underlings of the political bosses, for money and influence could protect any man, no matter how heinous his offense. In November. 1855, Charles Cora, a gambler, quarreled with William $\mathrm{H}$. Richardson and shot him on the streets of San Francisco. It was a cold-blooded murder, the dead man was the United States Marshal, but Cora was a protégé of the political machine, and every one knew that money and influence would be lavished to secure his acquittal. ${ }^{23}$

For three years the members of the Committee of Vigilance had hoped for protection and justice from their magistrates, and had refrained from open interference with the administration of the law, while the mysterious Committee of Thirteen guarded their secrets and kept alive the spirit of vigilance. One of the old Committee, however, was not silent; James King of William had started his Evening Bulletin before Richardson was shot, and had inaugurated in it a fearless and vehement crusade against the corruption that ruled the state. He struck from the shoulder, heavy blows that spared neither high nor low. After the murder of Richardson he spoke editorially of a rumor that the Committee of Vigilance might be reorganized. He deprecated taking that step, if it might in any way be avoided, but he most violently advocated hanging any sheriff or deputy who might treacherously allow the murderer to escape. ${ }^{24}$

It is very probable that a revival of the Committee was discussed at this time. Cora made affidavit that on the night of the shooting an association of citizens secretly met to consider his case and decided to hang him if he should be acquitted by a

22 "To walk the unfrequented streets in this eity, at a late hour of the night unarmed, is as dangerous as threading a forest infested by a war party of hostile Indians', (Alta, 1855, Oct. 4 2/1).

23 Alta, 1855, Nov. $19 \% 1$.

24 San Francisco Bulletin, 1855, Nov. $20 \% 1$; $22 \% 1$. 
jury $;^{25}$ and one talesman, James Davis, was excused from jury service when he testified that he had met with about a dozen others to consider whether the rules of the old Committee called for action in the existing emergency. ${ }^{26}$ The decision had been in the negative, but the Alta significantly asserted that San Francisco would watch the trial, and that if conviction proved possible lynch law would be "done away with." ${ }_{27}$

The trial was a farce that exhibited every mockery of justice possible in an American criminal court. Cora was jauntily defiant; his counsel were the most eloquent in the city; one juryman made public the fact that he had been offered a bribe by the defense; and every canon of decency was outraged by the attempt to influence the jury by a sentimental plea based on the devotion to the prisoner of the wealthiest and most notorious member of the San Francisco demimonde. When the result, as anticipated, was a disagreement, the Alta forgot its late abhorrence of popular tribunals and prophesied that lynch law would quickly be the desperate resort of a city where life could be protected only at the point of a pistol. ${ }^{28}$

While Cora complacently awaited retrial thirteen other men in San Francisco were under indictment for homicide with small prospect for their conviction, ${ }^{29}$ and murders were so common in the state that the attempt to record them was abandoned. ${ }^{30}$ James King of William, one time Vigilante, editor of the Bulletin and scourge of corruptionists, was himself fatally wounded on the afternoon of the fourteenth of May, 1856, by James P. Casey,

25 Alta, 1856, Jan. 43 . Sam Brannan was taken into custody as a general precaution against a public outbreak (Alta, Nov. $18 \% 2 ; 192 / 3$ ). For details see Popular Tribunals, II, 29-34; Hittell, California. III, 472. Long extracts from the papers of the day are given in F. M. Smith, editor, San Francisco Vigilance Committee of ''56, 1883.

26 Alta, 1856, Jan. 5 \%. J. Hawes Davis was member No. 216.

27 Alta, 1855, Dec. $8 \% 1$.

28 Alta, 1856, Jan. $17 \%$.

29 Alta, 1856, Jan. $21 \% 1$.

30 Alta, 1856, March $30 \% 1$. The violent deaths, including accident and murder, were estimated at 1400 yearly. 
a supervisor of the city, whose past record as a Sing Sing convict had been held up to public opprobrium by the militant reformer.

King's personal qualities had won him many admiring friends, while his outspoken arraignment of political iniquity had made him a popular leader and hero. The cowardly attack that laid him at death's door immediately invested him with the crown of a martyr. As if in answer to the shot the bell of the Monumental Engine Company sounded once more the well remembered call to action, and in less than an hour an infuriated multitude surged about the county jail, clamoring for the instant execution of the assassin. Our old acquaintances Charley Duane and Edward McGowan were already reinforcing the guard at the door. Detachments of the local military companies were rushed to the scene to hold the mob in check, but the men who hesitated before the rifles of the militia soon began to finger their own revolvers, and hysterical orators urged them to storm the building regardless of consequences. Shouts of approval interrupted the speakers, cries of anger and oaths of rage arose in a hideous pandemonium above the surging mass, while in all the city there was not a single representative of the law whose promise of justice could ring true, or carry an assurance of righteous retribution that might invoke patience.

Suddenly this tossing sea of heads reflected the ripples of a hidden current from its outer margin. Men swayed and turned and bent their faces to whisper, and lifted them again, sane and human, and cleansed from the blood lust of the brute. A brief message had passed from mouth to mouth, traversing the ranked thousands with incredible swiftness:

\section{"The Vigilance Committee has organized!"}

In less than five minutes the fearful tension was relaxed, ${ }^{31}$

31 The thrilling moment of announcement was described by W. O. Ayers in "Personal Recollections of the Vigilance Committee," Overland Monthly, ser. 2, VIII (1886), 166, and by J. D. B. Stillman in MS Vigilance Committees-Miscellany, 7-8. Hittell cited Ayer's reminiscences as an authoritative source (California, III, 482-488). 
for in the Vigilance Committee rested assurance of justice and righteous retribution, and the men of San Francisco, still gathering by thousands during all that tragic evening, waited and trusted in the promise of its speedy resurrection. The papers of the next day printed this notice:

The members of the Vigilance Committee, in good standing, will please meet at No. 1051/2 Sacramento Street, To-lay, Thursilay, 15 inst., at 9 A.M.

By order of the Committee of Thirteen.

San Francisco, May 14 [sic], 1856.

The archives of the Committee of 1851 make no mention of the Committee of Thirteen, which appears in history solely on this occasion. From the statements of various Vigilantes, especially those of William T. Coleman and George W. Frink, ${ }^{32}$ we learn that after various sporadic gatherings and much fruitless discussion Coleman was induced to take the initiative in reorganization, largely on account of his standing in the old Committee, and of his membership in the last representative group, the Committee of Thirteen. No other allusion to it oceurs in the manuscript recollections. Bancroft did not explain it, and inquiries now fail to discover its personnel or its proceedings.

The Committee of Thirteen remains to this day a shadowy and unnamed power, but that very secrecy was symbolic of the mysterious bonds that survived the lapse of years, for on the afternoon of May 14, 1856, the Committee of Vigilance of 1851 was no longer a corporeal organization. It was a name, and a

32 Frink arrived in San Francisco in June, 1852, and it is probable that he knew the old Committee only by reputation. He said that during the evening there was much confusion, and no definite action, but that Coleman and he finally went to the office of the Alta, where Coleman wrote out the notice. "He said, 'How shall we sign it?' I said: 'Put your name to it, as you are one of the thirteen of the old committee.' He said, 'No, put it one of the thirteen, as we disbanded under the name of the thirteen," (MS Statement, 4-5). Coleman's recollection coincided with this (MS Statement, 34), except for the modification of the signature to the form that appeared in the papers. As Coleman had lived in the East for two years prior to January, 1856 (MS Statement, 30; Phelps, Contemporary Biography, I, 272-280), it is permissible to infer that the Committee had disbanded before his departure. 
memory; it was a spiritual force that restrained the men of San Francisco from mob murder in the twilight of that evening and enlisted them by thousands under the oath of the Vigilantes during the days to come. ${ }^{33}$

The response to the printed call was instant and overwhelming. Old members hastened to the appointed place, and after a brief preliminary meeting threw open the doors for the reception of new registrants. Before midnight two thousand names were enrolled, headquarters were secured, an Executive Committee was selected, and the rank and file were grouped into military companies of one hundred men each. Coleman, who was by this time a merchant of wealth and prominence, reluctantly accepted the office of president, Bluxome was "Number 33, Secretary," and many other former workers were placed in offices of responsibility.

It has been necessary to touch lightly on five years of California's development in order to place the Committee of Vigilance of 1851 in its historical relation to the Committee of 1856 . The latter is usually designated the "Great Committee," and the work of the former is obscured by the more spectacular features of the larger association. Yet in spite of the silence that lay between the last notice of the Committee of ' 51 and the call that rallied the Committee of ' 56 , the organic unity of the two bodies is proved by many tokens: by the personnel of the leaders, ${ }^{34}$ by the adoption of the old constitution, ${ }^{35}$ by the membership certificate with its significant "Reorganized," and by the silver medal struck for the committeemen, which bears the old symbol,

${ }_{33} \mathrm{Mr}$. Charles B. Turrill, of San Francisco, has a photographic copy of the Oath of 1856. It reads: "I do solemnly swear to act with the Vigilance Committee and second and sustain [?] in full all their actions as expressed through their executive committee.',

34 Names of officers of 1856 are printed infra, p. 473.

35 Coleman said that the old constitution was adopted unanimously on the day of the ealled meeting, subject to revision at the leisure of the Executive (MS Statement, 41). See also Popular Tribunals, II, 111-113. 
the Watchful Eye of Vigilance, encircled by the legend "Organized 9th June, 1851. Reorganized 14th May, 1856.' ${ }_{36}$

The work of the Committe of 1856 is another story. Bancroft has told it in his own way in the second volume of Popular Tribunals; Royce has sketched it briefly, but well; and T. H. Hittell has given it at length with exact reference to contemporary newspapers and to the manuscript records, which were familiar to him as well as to Bancroft. ${ }^{37}$ The Committee was supported by the active membership of eight or nine thousand men, about three quarters of all the white citizens of San Francisco. $^{38}$ Barricades of sand bags were erected around its headquarters on Sansome Street below Front, and armed men stood there on guard, so that Fort Gunnybags became a citadel that defied both civil and military authorities. On the day that James King of William was borne to the grave the Committee hanged Casey, his assassin. and also Cora, who had killed William Richardson. A few weeks later it inflicted the same punishment on two other murderers. Philander Bruce and Joseph Hetherington. The latter had killed Dr. John Baldwin in a dispute over land titles, in August, 1853. On July 24. 1856, he also killed Dr. Andrew Randall, who had been robbed at Ionterey by the Stuart gang in 1850. The papers spoke of Hetherington as a "recipient of the old Vigilance Committee's attention," and Bancroft identified him with the witness of 1851. If that identification is correct, a strange fatality made the former collector of Monterey the victim of the very man who had been chief

36 See frontispiece.

37 Bancroft, Popular Tribunals, II; California, VI, 746-754; Tuthill, California, 432-524; Royce, California, 437-465; Hittell, California. III. 460-649; J. S. Hittell, San Francisco, 245-262 ; F. M. Smith, San Francisco Vigilance Committee of ' 56 ; The Tigilance Committee of 1856 [by James O'Meara], 1887.

$38 \mathrm{~J}$. S. Hittell placed the membership at 9000 out of a white male population of 12,000 (Resources of Califormia, ed. 1, p. 371). Bancroft said 8000 (California, VI, 747). 
informer against the gang that had despoiled him six years earlier. $^{39}$

These executions announced to the violent that money and influence and eloquent counsel might no longer be trusted to provide immunity from punishment. But the Committee did not stop there. Very early in its work it broke through the defense of seerecy that had baffled the investigations of grand juries. It laid its hands upon an incriminating ballot box that was still stuffed with forged ballots; it obtained confessions from the ward heelers who had done the bidding of the powerful and efficient bosses; then it announced its intention of cleansing the city from the plague of political corruption. It sent into exile over a score of the most valued tools of the machine. ${ }^{40}$ Among them were Charles Duane, who had evaded a like fate in 1851 . and Rube Nalony, who had been a committeeman in that year. ${ }^{41}$ Ned McGowan, also conspicuous upon the early black list, was forced to take refuge in flight. ${ }^{42}$ When David S. Terry, justice of the state supreme court, stabbed S. A. Hopkins as the latter

39 See Alta, 1856, July 25 2\%; Papers, 27 note 2; Hittell, California, III, 609-615; Popular Tribunals, Index under "Hetherington"'; Vigilance Committee of 1856 [by O'Meara], 31; Smith, San Francisco Vigilance Committee of '56, p. 75 ; San Francisco Call, 1893, Feb. 5 16/3. Various notices reported that Hetherington was an Englishman of wealth, had formerly lived in St. Louis, and had resided in California since 1849 or 1850 . Another rumor stated that in 1853 he had deserted a wife in Vermont, who intended to sue for his property (San Franciseo Bulletin, 1860, July 19 1/3).

40 A list of sentenees was given in Smith, San Francisco Vigilance Committee of ' 56 , pp. 82-83; reprinted in L. H. Woolley, California, 1849-1913, 1913, pp. 21-22.

41 Frink said that before the close of work some of the men who were fearful of arrest tried to join the Committee "to get under cover," and that Duane made such an application, but was refused (MS Statement, 21). For a note on Malony see supra, p. 198).

42 See his Narrative, 1857. In August, 1857, MeGowan started the publication of the Phoenix, a Sacramento newspaper that attacked the members and friends of the Committee without regard for truth or decency. After it was once prohibited in San Francisco, it was continued for a time under the title Ubiquitous. MeGowan was a familiar figure in San Franciseo until his death, Dec. 8,1893 . In his last illness William T. Coleman contributed towards his hospital expenses (San Francisco Examiner, 1893, June 4 2/5; 5 12\%; Chronicle, 1893, Dec. $95 / 1$ ). 
was arresting Malony, the Committee seized Terry, kept him in custody until Hopkins was out of danger, and liberated him only after the most bitter dissensions over his fate. ${ }^{43}$ G. W. Ryckman, who refused to join the reorganized Committee, said that it even contemplated the arrest of Broderick, ${ }^{44}$ but such a radical step was never taken.

The General Committee adjourned sine die August 18, 1856. Over six thousand men marched in the final parade, and the banner of 1851 led a company of one hundred and fifty members who represented the original organization. ${ }^{45}$ As a factor in California life the Committee long survived the formal adjournment, and Executive meetings continued as late as November, 1859. ${ }^{46}$

Nor was that all! The men of San Francisco had learned many lessons in civies since September, 1851, when they tried to purify their government by selecting for endorsement the better nominees of the regular political parties. Before they disbanded the Committee of ' 56 , they took the first steps towards the formation of an independent People's Party, which was recognized as the organ of the Vigilantes. In the fall election their ticket was first in the field; it was later endorsed by the new Republican party, and was overwhelmingly successful in November, when there was held perhaps the "first honest election that had taken place in the city." ${ }_{47}$ A permanent and efficient political organization was ereated that practically controlled the government of

43 See Trial of David S. Terry by the Committee of Vigilance, 1856; A. E. Wagstaff, Life of David S. Terry, 1892, pp. 97-136; also general references on the Committee.

44 Ryckman, MS Statement, 19-20; The Vigilance Committee of 1856 [by O'Meara], 55-56.

45 J. S. Hittell, San Francisco, 259; Popular Tribunals, II, 531-533. The Wide West, October, 1856, printed illustrations of the procession, but placed the number of old members at a somewhat lower figure. The banner was certainly carried although Ryckman said that it was never given to the Committee of ' 56 (MS Statement, 18).

46 Popular Tribunals, II, 541.

47 See Hittell, California, III, 636-665; J. S. Hittell, San Francisco, 262-266 ; Bancroft, California, VI, 770-772; Popular Tribunals, II, 639- 
San Francisco for more than ten years. Although many former committeemen served in various positions there was never any attempt to establish a distinctive Vigilante ring, and the People's Party was loyally supported by the better men among both Democrats and Republicans. Royce said that for years after the Committee of Vigilance of 1856 the people of San Francisco "boasted not without warrant, that they possessed, and for nearly a generation retained, the purest and soundest municipal government then known in any city of the size in the whole country. ${ }_{48}$

Charges have been made that the Committee of 1856 gave evidence of a sentiment that favored the political independence of the Pacific Coast. ${ }^{49}$ If that were so the spirit of secession was effectively checked and was never diverted toward affiliation with the cause of the Confederacy. Indeed, there has been some speculation of late as to whether the organization of the Committee of Vigilance was a conscious effort to oppose the influence of pro-slavery and secessionist Southerners. In studying the work of 1851 an effort has been made to collect any data that might indicate a latent partisanship in the sectional interests of the slavery discussions, but nothing of importance has come to light beyond the fact that in later years most of the leading committeemen, irrespective of parties, were loyal supporters of

663; Tuthill, California, 518-524; Davis, Political Conventions, 68-69, 73, 74, 79; Joseph Weed, "Vigilance Committees of San Franciseo,", Overland Monthly, XII (1874), 357; Woods, Lights and Shadows of Life on the Pacific Coast, 7, 45-48; MS Statements of Frink, 23; J. P. Manrow, 11-12; H. P. Coon, 6 et seq.; C. J. Dempster, 20.

48 Royce, “Provincialism,', Putnam's Magazine, VII (1909), 236. "This change [the purification of elections] was brought about by the organization of a Vigilance Committee, and they completely revolutionized the politics of the state" (Tinkham, History of Stockton, 245). The People's Party has even been charged with economy to the point of parsimony (J. P. Young, Journalism in California [1915], 33-35). The Consolidation Act of April 19, 1856, had prepared the way for more efficient local administration (California, Statutes, 1856, chap. 125).

49 See references supra, p. 102 note 36 ; Popular Tribunals, II, 371; Royce, California, 456; Life, Diary, and Letters of Oscar Lovell Shafter, 1915, p. 182; MS Statements of Coleman, 79-81; Dempster, 53-55; Green, 60. 
the Federal Union. The subject may assume greater significance if the archives of the Committee of 1856 become available for more thorough research. ${ }^{50}$ Generalizations relative to the influence of that body should be based on the original records rather than upon the accounts of secondary historians.

At the outbreak of the Civil War California was still a Democratic state with pro-slavery Southerners strongly intrenched in office. The contest for governor in 1861 was considered a matter of the most vital importance, for the advocates of secession hoped to strengthen their hold on local affairs, while the Republican party was determined to assume control. We must not linger over those exciting times, except to record that San Francisco, already purged of the Southern machine and eontrolled by the People's Party, was the strategic center of the whole campaign and polled nearly one fifth of the total vote cast for Leland Stanford.51 It was the fulcrum for the lever that wrenched the secessionists from their places of power. and the steel of that fulcrum had been forged by the hands of the Committee of Vigilance.

A valuable contribution to the history of this period is contained in a paper read before the Panama-Pacific Historical Congress of 1915 , by the late Horace Davis, who emphasized the value of loyal San Francisco in the state campaign of 1861, and told of the secret formation of a Home Guard to protect the polls

50 See infra, note in Bibliography on Archives of the Committee of Vigilance.

51 The vote is reported as follows, in the Annual Statistician, compiled by J. P. Mains, 1879, pp. 427-428:

Leland Stanford, Republican

State 56,036

San Francisco ........ 10,728

See also Hittell, California, IV, 290; Kennedy, Contest for California in 1861; Carr, Pioneer Days, 392-408; J. J. Earle, "Sentiment of the People of California with Respect to the Civil War,' American Historical Association, Report, 190\%, I, 123-135. It is said that about this time "an old hero of the Vigilante days' frustrated a plot to attack the arsenal at Benicia (R. T. Platt, "Oregon ... in the Civil War," Oregon Historical Society, Quarterly, IV (1903), 106-107). 
from corruption. ${ }^{52}$ Their muster book contains a list of about 1650 San Franciscans whose Union sentiments were so unqualified that they were ready to respond to a call for service under any sudden emergency. In the list are a few familiar Vigilante names. Selim E. Woodworth, George M. Garwood, James C. Ward, A. L. Tubbs, and Henry Wetherbee, all committeemen of 1851, took charge of five enlistment sheets. Oliver B. Crary, of 1856 , headed another, and other members of the later body may have been prominent in the Guard. None of the rolls shows any concerted action by members of ' 51 , except the one in charge of Woodworth. That was signed by several of his former associates, who formed the nucleus for a company of seventy-one in which ten of the first Committee were enrolled. ${ }^{53}$

In this connection it is interesting to read in the manuscript statement of Dr. H. P. Coon, a member of the Committee of 1856 , that previous to 1864 no line was drawn by the People's Party between Republican and Democratic nominees. In 1865, however, the nominating committee resolved to endorse only candidates who had voted for Lincoln and Johnson in the last presidential election. Dr. Coon felt that this action "was the end of the successful career of the Old People's Party at the ballotbox." " 54

The San Francisco Committee of 1856 did not attempt to establish any coördinated branches in the interior towns. ${ }^{55}$ For

52 Horace Davis, "The Home Guard of 1861," in Panama Pacific Historical Congress, The Pacific Ocean in History, 1917, pp. 363-372. Mr. Davis was a member of the Guard, and presented the muster book and sixtytwo enlistment sheets to the Bancroft Library.

53 S. E. Woodworth, F. E. [A. ?] Woodworth, J. C. Ward, T. A. Barry, C. R. Bond, G. W. Ryckman, W. A. Darling, G. M. Garwood, J. D. Farwell, $\mathrm{E}$ [dgar?] Wakeman. No attempt has been made to check the whole list for members of the Committee.

54 Coon, MS Statement, 27. Dempster said the Committee of '56 would have disbanded earlier if it had not been for the "pro-slavery chivalry" (MS Statement, 22).

55 Manrow, MS Statement, 10-11. Frink said that some men from out of town signed the rolls just to add their influence to the effort (MS Statement, 23). 
many years, however, sporadic Committees of Vigilance appeared in places where roughs and criminals congregated, and ejectment proceedings, more or less violent, often took place. Occasionally there was a lynching by a so-called Vigilance Committee, but in the absence of such records as exist for 1851 it is impossible to tell whether or not the organizations were any more responsible than angry mobs. ${ }^{56}$ They do not seem to have prolonged their existence beyond some passing emergency except in Truckee, where a committee known as the "601" effected desirable reforms in 1874 , and for more than a decade remained a name of menace to the desperadoes of the vicinity. ${ }^{57}$ Gradually the disorderly element in the state shrank to a more normal ratio, violence was more controlled, jails were made secure, popular tribunals ceased to usurp the functions of the criminal courts, and the number of lynchings dropped to two or three a year. ${ }^{58}$

There was a notable reunion of the San Francisco Vigilante personnel in 1877, when the city was in the throes of labor agitation and of anti-Chinese demonstrations which the authorities were impotent to control. There was such danger of incen-

${ }_{56} \mathrm{I}$ have not attempted extended research regarding later Committees of Vigilance, but have verified the following references in the Sacramento Union (Record Union after Sept. 1, 1875).

1860 , Sept. $201 / 7$, Protective League of Altaville, Angel's Camp, and vicinity; 1863, No. $263 / 2$, and 1870, Dec. 21 2/1, V. C. in Los Angeles (see also Popular Tribunals, I, 507, 511-512; Newmark, Sixty Years in Southern California, 204-210, 324, 420); 1873, Nov. $10 \%$ and Nov. $13 \%$, V. C. in Gilroy; 1873 , Dec. $123 / 3$ and Dee. $19 \%$, V. C. in Visalia (see also Popular Tribunals, I, 470-474); 1880, July $8 \%$ and 1884, March $274 / 3$, V. C. at Merced; 1882, Jan. $91 / 8$, rumor of a V. C. in Sonora; 1882, Oct. 2 $2 / 4$, V. C. in Yreka; 1884, Oct. 25 8/2, V. C. in Lundy; 1887, Sept. 5 1/4, V. C. in Jackson; 1888, Aug. 16 4/2, and 1889, July $131 / 1$, rumors of a V. C. in Fresno.

57 Popular Tribunals, I, 463-465. So far as I have ascertained, there was no execution by " 601 ," but one of their own members was accidentally shot in a raid on armed rowdies. The Committee was unsuccessful in quelling disturbances, according to the Sacramento Union, 1874, Dee. 16, 2/5; 19 $1 / 7$. It was condemned by the grand jury of Nevada County (ibid., 1875, Feb. $113 / 4)$. The same paper alluded to renewed activities at Truckee in the issue of 1876, Jan. $7 \% 1$; at Grass Valley (1885, Mareh $301 / 7$ ), and again at Truckee (1889, Aug. 17 4/3).

58 Statistics in Cutler, Lynch-Law, $18 t$. 
diary attacks against the coolie laundrymen and the docks of the Oriental steamers that the citizens assembled as in pioneer days and called upon the former president of the Vigilance Committee, William T. Coleman, to organize a Committee of Safety for the aid of the city forces. Within twenty-four hours over five thousand men had volunteered their services, funds were collected, headquarters were established, and by the orders of the President of the United States, the Secretary of War, and the Governor of California, ammunition and Federal forces were placed at Coleman's disposal. The ranks of the Committee were furnished with stout hickory pick handles, as emergency weapons, and firearms were held in reserve for extreme necessity. This "pick handle brigade" patrolled the city by day and night, suppressed incipient riots, prevented any disastrous conflagration, and demonstrated to the lawless that the slender equipment of the municipal police had behind it an effective army of well disciplined civilians. The pass word of the Committee was " ' 56 to '77,' and the spirit that had intimidated the criminals and the corrupt politicians of an earlier generation now overawed the hoodlums of the sand lots and re-established order within a few days. Then, as before, the swift mobilization of the man power of the city had prevented the horrors of mob conflicts, and again as before, when its work was accomplished the association quietly disappeared from public activity, though no one knew how long its leaders remained on guard against further disturbance. ${ }^{59}$

59 See San Francisco papers, 1877, July 24 et seq.; Popular Tribunals, II, 696 et seq.; Bancroft, Chronicles of the Builders, I, 349-379; Hittell, California, IV, 594-599 ; Coleman, "San Francisco Vigilance Committees,", Century, XLIII (1891), 145-148; Bryce, American Commonwealth, II, 432 ;

San Francisco Chronicle, 1896, Jan. $12 \% 1$. 


\section{CHAPTER XIX}

\section{LYNCH LAW AS A NATIONAL PROBLEM}

Such is the story of the San Francisco Committee of Vigilance: a brief, vivid, and significant episode in the history of the American people. Its significance, as Henry Morse Stephens said, will always be interpreted in accordance with the shifting interests of successive generations and the personal vision of successive historians.

The contemporary discussions that arose in 1851 have already been indicated in the references to press reports cited in previous chapters. Extracts from other comments in local and Eastern papers may be found in Popular Tribunals. ${ }^{1}$ Where objection to the work of the Committee was made, its basis was almost invariably impersonal argument relative to the danger of undermining the foundations of law and order, since there were few advocates particularly interested in the fate of the thieves and murderers summoned to the bar of the Committee.

When one tries to estimate the weight of commendation or condemnation made in a later period it is necessary to consider as one the two associations of ' 51 and '56. which were usually grouped together by friends and foes. An immediate difference in the attitude of the public is discernible after ' 56 . Then the Committee pitted itself against men of influence. It struck at the very existence of the powerful clique that controlled political patronage, and its menace to organized society was greatly enhanced in the eyes of some of its critics by its menace to their

1 Popular Tribunals, I, 402-426. Bancroft quoted less freely from the objectors, who were represented in San Francisco chiefly by the Morning Post, although many Eastern papers severely condemned the Committees. 
individual importance and prosperity. ${ }^{2}$ Current discussion in the papers was bitter and prejudiced on both sides: the Alta stoutly defended the course adopted by the Committee, the Herald nearly ruined itself by outspoken and violent objection. ${ }^{3}$ The views of the personal antagonists of the Vigilantes were vividly set forth in two anonymous pamphlets which described their work as illegal, brutal, vindictive, and under the control of many members who were as guilty of political corruption as were the men they prosecuted. ${ }^{4}$

Nore permanent value may be attached to the criticisms of contemporaries who were neither active members nor active traducers of the Committees. Bancroft in a sweeping generalization grouped their enemies as including "besides the lower. class of evil-minded persons, . . . all licentious judges, stabbing jurists, duelling editors and fighting lawyers." ${ }_{5}$ But opponents with higher standards should not be vilified or ignored. Peter Burnett viewed the movement as "incipient rebellion and a fatal precedent."6 Frank Marryat, whose observations deserve consideration, wrote that no one would defend the acts of the Committee and that they met with much opposition from the better

2 This difference between the opponents of the first and second Committees was emphasized by Dempster in his MS Statement, 27-28.

3 John Nugent was editor in 1851 and 1856 . He was so violently opposed to the reorganization of the Committee in 1856 that hundreds of patrons terminated their subscriptions, the auctioneers withdrew their advertisements, and the Herald was greatly reduced in size. It never recovered its lost prestige (see Popular Tribunals, II, 78-83, 217-223; Hittell, California, III, 489-492). It is said that the policy of approval adopted by the Alta was due in part to the desire to retain advertising patronage (San Francisco Call, 1868, Jan. 1 1/1).

4 Judges and Criminals... History of the Vigilance Committee of San Francisco, 1858, aseribed to Dr. Henry M. Gray; The Vigilance Committee of 1856 [by O'Meara]. The Narrative of Edward MeGowan should be mentioned with anti-Vigilante literature, as may be "The Lost Journals of a Pioneer" attributed to C. E. Montgomery a Southern lawyer of some prominence (Overland Monthly, ser. 2, VII (1886), 75-90, 173-181, 276-287).

5 Baneroft, California Inter Pocula, 589.

${ }_{6}$ Burnett, Recollections, 398. 
class of citizens, but he admitted, nevertheless, that San Francisco conditions were improved by their efforts. ${ }^{7}$ Judge John Currey said plainly that popular accusations exaggerated the corruption of the courts and that in spite of ballot box stuffing and organized crime, existing evils could have been corrected without resort to violence if the time and money devoted to the work of the Committee had been expended in a faithful performance of the legitimate duties of citizenship. ${ }^{8}$

The early historian, E. S. Capron, closed a brief and inaccurate report of the work of the Committee of 1851 by expressing sentiments akin to those of Judge Currey, asserting that its organization and actions were unjustifiable. ${ }^{9}$ William $\mathrm{F}$. White, who concealed his identity under the pseudonym of William Grey, made a violent attack upon the Vigilantes in his Picture of Pioneer Times in California. ${ }^{10}$ A more modern writer who strongly condemned the Committee of '56 was Isaac J. Wistar. He was an associate of Edward D. Baker, Casey's attorney during the trial for the murder of Richardson. ${ }^{11}$

On the other hand, a large number of the early Californians who had known the dangers of inefficient law and the protection of prompt, severe, but extra-legal punishment, maintained that the Committees of Vigilance accomplished an ultimate good and that some radical action was necessary to break the hold upon office which had been obtained by unserupulous politicians and their criminal adherents. The Rev. S. H. Willey said: "It looked then as if the immense preponderance of opinion in favor of the Committee was an effort to regain the reality of 'law and order,'

7 See Marryat, Mountains and Molehills, 227, 238, 390.

8 John Currey, Incidents in California, 1878, p. 16, MS in the Bancroft Library.

9 E. S. Capron, History of California, 1854, pp. 131, 161.

10 Picture of Pioneer Times, by William Grey [W. F. White], 108-114. The facts presented by this author are far from accurate.

11 I. J. Wistar, Autobiography, 1914, I, 313-316, 325--332. 
while those who stood by its forms were mainly those who had got those forms into their hands and used them to defeat justice." ${ }^{{ }_{12}}$

Some of the keenest criticisms on Californian conditions during the exciting period from 1851 to 1856 were written by Mrs. Eliza W. Farnham. She acknowledged the promptness and the usual justice of the popular tribunals as contrasted with the authorized courts, and the check they put upon criminals who had little cause to fear the law; she admitted that an era of apparent tranquility resulted from the rule of the Committee of Vigilance of 1851 ; but she felt that the improvement was superficial and was based upon a public opinion that desired order merely for temporary self-protection. "There is no deep stake in social welfare," she wrote, "and consequently no action that reaches its spring." She sustained her contention by citing the constant tendency to elevate the worst men to office where dishonesty could do even more damage than it could in better organized and more watchful communities. When the events of 1856 justified her anticipations of recurring violence, she followed them with eager interest, and although her concluding chapter was written before the adjournment of the Committee, she expressed her belief that the people of San Francisco and California were about to free themselves effectually from the open and dreadful corruption which had fastened upon their public affairs. ${ }^{13}$

H. H. Helper saw very little to admire in California, but he gave unhesitating praise to the Committees of Vigilance as the one means of enforcing order in communities which overwhelmingly reversed the normal American proportion of lawless and

12 S. H. Willey, Thirty Years in California, 1879, p. 49 et seq. He reported that the churches were fuller for four or five years after the uprising of '56. The editor of The Pacific, a pioneer religious weekly, asserted that with few exceptions the clergymen and church members approved the second Committee (The Pacific, 1856, Oct. 9 \%).

13 See Farnham, California In-doors and Out, 96, 318, 458-508. 
law-abiding citizens. ${ }^{14}$ Another statement of the views of those who sympathized with the Committee may be found in Alonzo Delano's Life on the Plains and among the Diggings. A brief excerpt may well be quoted here $:^{15}$

When the history of California shall be written, after time has mellowed the asperity of passing events, the occurrences of these days will form a singular... chapter.... In a country whose people are proverbial for their love of justice and order ... a condition of things existed, which threatened at one time to dissolve the social compact of the community ... organized bands of desperadoes and assassins... made the existing laws only an instrument to protect them in crime and high-handed villainy... the whole length and breadth of California was so beset with unprincipled men ... that, for the peace of society, a general revolution became necessary.... [When] it was found that under the administration of the law, the insecurity of life and property increased instead of diminished, the people became aroused to a sense of their own wrongs, and, convinced that there was no other mode of redress, they resolved to take the punishment of offenders into their own hands, and to do what the administrators of the law could not, or would not doprotect the honest part of the community from the depredations which were daily and hourly committed upon them.... This state of things could no longer be endured. Patience was no longer a virtue. Selfpreservation rentered it imperative that the first law of nature should be observed, and that unless some united effort was made, society must resolve itself into its primitive elements, and brute force become the only defence against aggression and violence.

It is interesting to notice that travelers from Europe. in spite of their more conventional traditions, expressed approval of the Committees of Vigilance. Writing of affairs in 1852, Borthwick said :" "Any one who lived in the mines of California at that time is bound gratefully to acknowledge that the feeling of security of life and person which he there enjoyed was due in a great measure to his knowledge of the fact that this admirable institution of Lynch-law was in full and active operation."

14 Helper, Land of Gold, 237-253. See also Harlan, California, 211.

15 Delano, Life on the Plains and among the Diggings, 363-365.

16 Borthwick, Three Years, 224-234. 
Ernest Seyd, another Englishman, said that the Committees were supported by the majority of the educated English, German and French immigrants. ${ }^{17}$

Saint-Amant, who made a most sympathetic analysis of the difficulties that accompanied the establishment of government in such unusual surroundings, paid tribute to the immense good accomplished by Vigilante methods. ${ }^{18}$ Auger also approved heartily, and wrote a spirited account of the executions in San Francisco in 1851, which, however, was not based on the experiences of an eyewitness. ${ }^{19}$ Ernest Frignet, giving another secondary report, eulogized both Committees as instruments that served the ultimate establishment of public order. ${ }^{20}$

"A Prussian Gentlemen," writing to the Alta, lauded the Committee of 1851 as an object lesson which compelled criminals to visualize the indignation of the law-abiding element. He held that it is "very necessary that society show itself in immediate concrete form, otherwise it is regarded as a mere abstract idea, which exerts too little influence on the stolid minds of brutish individuals.' ${ }_{21}$ The German traveler, Friedrich Gerstäcker, familiar with events in California through prior observation and contemporary correspondence, also praised the Committee of 1851, and wrote that it "honors the citizen to risk his own life and property that he may free town and state from such a curse, or, at least, check the continuance of such crimes. " 22

The later historians, Bancroft and Hittell, were staunch advocates of both Committees. Even Josiah Royce, who found

17 Ernest Seyd, California and Its Resources, 1858, pp. 23-24.

18 Saint-Amant, Voyages, 138, 408-411.

19 Auger, Voyage en California, 209-219.

20 Frignet, La Californie, 177-179, 196-202.

21 Alta, 1852, April $7 \% 1$.

22 Gerstäcker, Narrative of a Journey round the World, 253-255. See also commendation of Frank Lecouvreur, From East Prussia to the Golden Gate, 1906, pp. 183-193; Carl Meyer, Nach dem Sacramento, 1855, pp. 188-192. 
so much to condemn in the progress of society in California, called them the "expression of a pressing desire so to reform the social order that lynch law should no longer be necessary." and he said that what they accomplished was "not the direct destruction of a criminal class, but the conversion of honest men to a sensible and devout local patriotism." ${ }_{23}$

But it is fruitless to multiply the repetition of opinions either for or against the Committee of Vigilance of San Francisco, ${ }^{2+}$ since every estimate is so deeply colored by the personal temperament or the experiences of the writer. Yet it is interesting to observe that whether the various critics justify or condemn, whether they depict the Committee as productive of immediate good or immediate evil, they all agree that it was a product of basic defects in the local organization of society from which had arisen a pressing need for fundamental readjustment. In this judgment they were unquestionably correct, and here the commentators on California conditions have usually been content to pause. They have studied the Committee of Vigilance solely as a product of its local environment and described the situation from which it sprang as a ferment of political and social corruption peculiar to the time and place. Such a treatment is inadequate and misleading; just as the Committee must be related to the earlier episodes of frontier expansion, so also must it be related to later developments of American life.

For California did not present a unique and isolated example of defective social adjustment; while the state was emerging from

23 Royce, California, 407, 465.

$24 \mathrm{~A}$ few further references may be given. Cornelius Cole, who had little sympathy with lynch law, acknowledged that the San Francisco Committee of ' 56 contributed largely towards bringing about a condition where lynch law was no longer employed, and afforded "an example of good flowing from evil" (Memoirs, 119). Much the same opinion was expressed by Newmark (Sixty Years in Southern California, 141). H. K. Norton approved its results (Story of California, 254-257), as did Henry Robinson, ("Pioneer Days of California," Overland Monthly. VIII [1872]. 457-462). 
her period of storm and stress, and deferring more and more to the mandates of her constituted authorities, many of the conditions characteristic of her earlier youth were reappearing elsewhere. The individual histories of several states and the publications of their local historical associations are full of material that is closely akin to the reminiscences of the California Argonauts. In Indiana the lawful authorities were so incapable of restraining crime that the legislature of 1852 legalized the formation of private associations for the pursuit and arrest of horse thieves and gave the members the rights and privileges of constables. The experiment proved dangerous, for the volunteer posses were inclined to exceed their authority and inflict summary punishment on their captives. In spite of this tendency the statute remained in force, with modifications dating from 1865. ${ }^{25}$ Vigilance Committees to suppress crime were formed as well in Iowa in the decade of the fifties. They kept few records and their actions were often governed by sectional animosities, while their punishments were sometimes flagrantly cruel and unjust. ${ }^{26}$

During the years 1855 to 1870 gold rushes like that of 1849 sent prospectors by the thousands into Idaho, Montana, Eastern Washington, and Oregon. There, as in California, social necessities everywhere outran the tardy establishment of institutional administration. There, again, was the same intermingling of diverse races and of honesty and crime; the same atmosphere of seething excitement; the same need for local self-assertion in the absence of social control imposed from without. An excellent review of this general situation has been made by William J. Trimble in his Mining Advance into the Inland Empire. To one

25 See W. A. Rawles, Centralizing Tendencies in the Administration of Indiana, 1903, pp. 308-309.

26 The Annals of the Jackson County Historical Society of Iowa contain many reminiscences of the period of lynch law, especially I (1905), 30-34, 51-52; II (1906), 51-91 passim; III (1906), 28, 34-41, 68-75; IV (1907), 93-97. See also B. F. Gue, History of Iowa, 1903, I, 337-350; and supra, p. 74 note 23 . 
who approaches that volume after a detailed study of California problems, it is very interesting to read $:^{2 \tau}$

But whatever elements of population prevailed in one or the other place, there was one everywhere present, everywhere respected, everywhere vital-the Californian. To Fraser River, Cariboo, Kootenay; John Day, Boise, Alder Gulch, Helena, went the adopted sons of Californiayoungest begetter of colonies-carrying with them the methods, the customs, and the ideas of the mother region, and retaining for it not a little of love and veneration.

In the first critical months of the gold rush the territorial government of Washington exerted a nominal and attenuated authority from the seacoast to the Rocky Mountains. It entirely lacked the force needed to control the scattered and shifting camps, and the miners turned instinctively to the precedents set in California. Niners' meetings were summoned, miners' courts were formed, and civil and criminal matters were adjusted by popular decision. ${ }^{28}$ As had been the case in California, this simple and voluntary association was effective in safeguarding life and property in camps dominated by industrious and honest workmen, but it could not cope with organized and expert criminals.

A notorious gang of such criminals operated in 1862 and 1863 in the neighborhood of East Bannock, within the present limits of the state of Montana. Their secret leader was Henry Plummer. a shrewd, courageous man. who was popular in the camp as the trusted miners' sheriff, while at the same time he was using his position to direct and protect the movements of his confederates. The entire district was terrorized, over a hundred murders were committed, and the friends of the outlaws often controlled the miners' meetings that tried suspected prisoners. Finally, in December of 1863, a Vigilance Committee was formed by the citizens of Virginia City and its vicinity. The association

27 W. J. Trimble, Mining Advance into the Inland Empire, 1914, p. 141. 28 Ibid., 227-242. 
extended over a wide area, and in conformity with the San Francisco example, the various branches of the Committee had written pledges and by-laws, executive committees, and permanent, responsible officers, many of whom became respected leaders of civic affairs in the later era of order and tranquility. At the same time the organization differed in several important points from that of San Francisco. Its membership was absolutely secret. Its deliberations were also secret, and sentences were passed, in advance of arrest, upon men known to be affiliated with the desperadoes. Pursuit was then instituted and the death penalty was often inflicted as soon as the culprits were apprehended. Relentlessly the Vigilantes scoured their snow-swept wilderness and within a month Plummer and more than a score of his confederates were executed, other criminals took refuge in flight, and violence was checked. A pioneer who knew of this work from personal observation said of it : ${ }^{29}$

Of all the organizations for the irregular administration of justice that have marked the westward advance of American civilization, whether known as Moderators, Regulators, Vigilantes, or what not, the Vigilance Committee of Montana will be found to have been the most complete, most efficient, and most necessary of them all, and to have partaken of the character of a mob the least of any.

The territory of Montana was given separate organization in the spring of the next year, but the courts established their supremacy slowly, and the very judges themselves were sometimes content to let the Vigilantes go on for a time, as they could attend to criminal matters more cheaply, more quickly, and better than it could be done by the courts. The perplexing problems of frontier justice were discussed with unusual judgment and lucidity in two charges to the grand jury of

29 C. Barbour, “Two Vigilance Committees,', Overland Monthly, ser. 2, $\mathrm{X}$ (1887), 285-291. For detailed accounts of these Committees the reader is referred to T. J. Dimsdale, The Vigilantes of Montana, various editions, 1866-1915; N. P. Langford, Vigilante Days and Ways, 1890 (2 vols.), or 1912 (1 vol.) ; O. D. Wheeler, "Nathaniel Pitt Langford,' Minnesota State Historical Society, Collections, XV (1904-1914), 634-639. 
Madison County, Montana, delivered by Chief Justice H. L. Hosmer in 1864 and 1866 . Thoroughly conversant with conditions that existed prior to the organization of competent courts, Judge Hosmer gave unqualified approval to the severe measures adopted by the Vigilantes for the suppression of crime, and lamented the disorders that had resulted elsewhere from "the tardiness and moral obliquity of those Territories which have adopted a more lenient course." None the less, he pointed out with solemn warning the evils that would inevitably ensue if popular tribunals persisted in a country equipped for legal justice; but instead of berating the Committees of Montana for continuing their work, even after the courts had been established in the territory, he expressed the conviction that their members would gladly disband as soon as they saw that courts and juries met the demands of their frontier society, and he gravely queried whether the blame for each fresh outbreak of popular vengeance might not lie at the door of his own court, or rest upon the juries he impaneled. ${ }^{30}$

A later chief justice, Theodore Brantley, in reviewing the judicial history of Montana, wrote of the Committee of Vigilance $:^{31}$

Much casuistry may be indulged in as to the right and necessity of its doings. We must remember, however, that the arm of the law was not strong enough to extend to the people needed protection, and that, wherever it is a question, as it was then, whether peace and order shall prevail over crime and lawless spoliation, society may act in its own defense, by the use of whatever means may be necessary to preserve its life by protecting or insuring personal safety and individual rights. Necessity knows no law. Whatever wrongs or mistakes may have been committed by the men constituting this organization, its existence was justified by the necessities of the times, and the salutary results accomplished by it, must stand as its vindication.

30 See Montana Historical Society, Contributions, V (1904), 235-252; also L. E. Munson, 'Pioneer Life in Montana,' ibid., 200-234.

31 See Montana Historical Society, Contributions, IV (1903), 109-121, especially p. 112. Much valuable Vigilante material is preserved in that historical series, and particular reference may be made to II (1896), 254; III (1900), 290-295; VIII (1917), 99-104. 
Wherever the blame rested, it was corrected but slowly. Judge Brantley said that for many years public sentiment favored Vigilance Committees and seemed to oppose the infliction of the death penalty in all legal trials.

Trimble collected many references to Committees of Vigilance in Montana, Oregon, and Idaho. ${ }^{32}$ The majority began their work with a system approximating that of the Committee of San Francisco. Throughout this region, however, there was a greater tendency for the associations to degenerate into instruments of political ambition or of private animosity, and some of them fell under the well merited condemnation of the public that at first supported them.

An interesting development of the American trend towards extra-legal institutions took place in Louisiana in 1858 and 1859, but has received little attention from other than local historians. The events then enacted have been commemorated in an obscure volume by Alexandre Barde, ${ }^{33}$ a French journalist of the parish of Saint-Jean-Baptiste in the district of Attakapas. As settlements expanded after the American occupation, disorders incident to other frontiers appeared among the scattered villages: cattle thieves ravaged the unprotected grazing land; robbers and incendiaries terrorized the growing towns; and peaceful citizens met untimely deaths at the hands of desperate marauders.

32 Trimble, Mining Advance, 242-245. Bancroft made a very inadequate survey of these regions in Popular Tribunals, I, chap. III (see also his History of Nevada, Colorado and Wyoming, 1890, 738). Cutler made scant allusion to them in Lynch-Law. Material may be found in F. Fry, Fry's Traveler's Guide, 1865, pp. 241-245; W. M. Turner, "Pioneer Justice in Oregon,' Overland Monthly, XII (1874), 22t-230; T. M. Marquett, "'Effect of Early Legislation upon the Courts of Nebraska,', Nebraska State Historical Society, Proceedings and Collections, ser. 2, I (1894-1895), 104-105; Kansas State Historical Society, Transactions X (1907-1908), $125,131,146$; XI (1909-1910), 273; XIII (1913-1914), 261-262; J. E. Parker, "Pioneer Protection from Horse Thieves,' Annals of Iowa, ser. 3, VI (1903), 59-62; G. F. Shafer, "Early History of MeKenzie County,", North Dakota State Historical Society, Collections, IV (1913), 58-61.

${ }_{33}$ Alexandre Barde, Histoire des Comités de Vigilance aux Attakapas, 1861. See also H. L. Griffin, "Vigilance Committees of the Attakapas Country,' Mississippi Valley Historical Association, Proceedings, VIII (1914-1915), 146-159. 
One receives from the pages of Barde's Histoire des Comités de Vigilance the impression of a people and a society very dissimilar to the sturdy adventurers and the rugged communities of the Western pioneers. The land itself was a gentle and gracious domain, fringed with quiet bayous, shaded with noble forests, and responsive to cultivation. The colonists were typically French in life and thought. The little hamlets clustered about their simple churches, paid deference to their local curés, and enjoyed more worldly pleasures with Gallic gaiety and optimism. Their laws were excellent, their magistrates were honorable. But the people were without traditional attachment to the jury system of the American régime; the criminals among them were also of French descent, and the ties of blood were powerful! When clever advocates appealed to their volatile emotions they refused to convict men of their own race, and the guilty went unpunished.

As a result, the district of Attakapas became a haven for desperadoes and by 1859 their defiance of restraint became open and intolerable. Then, by a curious affiliation with the social precedents of their northern neighbors, the French population which had proved itself so inept in the duties and privileges of American citizenship adopted with vigor the American institution of organized and permanent Committees of Vigilance. One after another, a circle of neighboring parishes formed these Comités de Vigilance. They were instituted by men of position and respectability and were based, as were the associations in California, on written constitutions and regulations. Their historian, however, made little or no allusion to any imitation of California traditions. Suspects were ordered to leave the country; the defiant were whipped, and two or three murderers were executed.

Barde and his collaborators were personal friends of the Vigilantes and were in thorough sympathy with their work. The 
episodes, however, are substantiated by many citations from the contemporary press. As a source of history on the subject of popular tribunals the volume deserves a place with more familiar narratives ; but in using it one must be alert to detect indications of an underlying antipathy to the national movement for abolition as well as a determination to suppress crime. The constitution of the earliest Comité, that of Côte Gelée, gave as one of the objects of organization, "Surveillance rigoureuse des blanes suspects dans leurs rapports avec les hommes de couleur ou les esclaves d'une moralité donteuse." ${ }_{34}$ After inflicting several well deserved punishments on French outlaws of particular depravity, the Vigilantes shifted their attention to criminals who were emancipated Negroes, and to propagandists of liberation suspected of inciting the blacks to discontent and rebellion.

It is a curious circumstance in the development of our cosmopolitan people that the pages of this forgotten volume, written in an alien tongue by a foreign-born journalist, and descriptive of a society which lacked all Anglo-Saxon inheritances, should present with unexampled vividness the swift, subtle, and dangerous transformation of the popular tribunals such as had preserved order on the frontier, into intolerant associations determined to control public opinion and personal liberty of action by the threat of punishment and death. A similar transformation took place elsewhere in the South and Southwest during the years immediately before the Civil War. In Texas, for instance, so-called Vigilance Committees were in active operation against both criminals and abolitionists, while mob lynchings, without any semblance of unprejudiced trial, were constantly inflicted upon unpopular persons, both white and black. ${ }^{35}$

34 Barde, Histoire des Comités de Vigilance, 56.

35 See Cutler, Lynch-Law, 119-124; G. P. Garrison, Texas, 1903, 274-275; D. H. Hardy and I. S. Roberts, Historical Review of South-East Texas, 1910, I, 172-176, 385; J. F. Rippy, "Border Troubles along the Rio Grande," Southwestern Historical Quarterly, XXIII (1919), 103-104. 
Still further removed from the tribunals of the frontier, with their open trials and their public punishments, were the secret protective societies of the Southern whites during the unhappy days of Reconstruction, when the Knights of the White Camelia, the Ghouls of the Ku Klux Klan, and their confrères of similar societies, rode masked through the night and terrorized carpetbag official and incautious freedman with outrages that shocked the entire land. ${ }^{36}$ In that tumultuous period, amid the conflicts and the travail of a younger generation, there emerged such varied problems and relations that the exigencies and the traditions of the frontier were overshadowed by new phases of national development. Thereafter the West became year by year more populous, better policed, less afraid of high-handed violence, and less inclined to clamor for rigorous punishment of crime; while the South, demoralized and embittered by the devastation of the war and confronted by the new terror of emancipated and dangerous Negroes, demanded swift and summary retribution upon every colored delinquent, and its mobs inflicted both whipping and death with a recklessness and ferocity that knew no parallel in the annals of the Western pioneers. ${ }^{3 \pi}$

The end is not yet, for the records of every year of the twentieth century are stained with mob lynchings which for a moment horrify the entire country and are then quickly forgotten..$^{38}$

36 See J. C. Lester, and D. L. Wilson, $K u$ Klux Klan, ed. of 1905. A report on the $\mathrm{Ku}$ Klux Conspiracy in 13 volumes was made by a Congressional Committee, 1871-1872 (Cong. Docs., Ser. Nos. 1481-1496 or 15291541).

37 One of Cutler's charts shows that from 1882 to 1903, 1997 lynch executions occurred in the Southern states, and 363 in the Western, to which California contributed a quota of 31 (Lynch-Law, 181-185).

38 The study of lynching as an evidence of race hatred is particularly developed in Cutler's Lynch-Law, and in reports issued periodically by the Tuskegee Institute. The National Association for the Advancement of Colored People is also conducting a campaign to arouse public opinion. 
But why must these things be? The necessity for them is not inherent in the temper of the races from which our people have been amalgamated, nor in the forms of eivilization which they have evolved elsewhere. Those who have studied the subject seem to agree that lynching. as it is carried on in this country, is a demonstration of group anger that is not characteristic of other nations which have achieved a corresponding plane of social advancement. Other communities with comparable standards may be subject to riots. mob violence, and sanguinary revolutions, but in the ordinary course of non-revolutionary existence they do not decide the fate of suspected criminals by the verdicts of popular tribunals, nor execute men, with deliberate premeditation, in open defiance of all restraints of law and order.

Cutler stated categorically that at the time he wrote Europe as a whole was free from the practice of lynching except for certain customs prevalent among the peasants of Russia. ${ }^{39}$ Judge John D. Lawson said of the administration of English law: "For" seventy-five years, in England, Ireland, and Scotland, and in the colonies of the British Empire scattered all over the world, among peoples of all races and of all colors. no man's life has been taken by what we call Lynch Law." ${ }_{40}$ Similar assertions are often repeated by both English and American writers. ${ }^{41}$ so that, even if sporadic eases of lynching might be adduced in contradiction. it seems safe to assume that the accepted generalizations are indicative of a fundamental difference between a social organization where mob executions are practically unknown and

39 Cutler, Lynch-Lax. 3.

40 J. D. Lawson, "Technicalities in Procedure," Journal of Criminal Law, I (1910), 83-84.

41 As by William Roberts. "Administration of Justice in America," Fortnightly Reriew, new ser. LI (1892), 91-108; H. A. Forster, "Do Our Laws Protect Criminals? Why the United States Leads the World in the Relative Proportion of Murders, Lynchings and Other Felonies, and Why the Anglo-Saxon Countries Not under the American Flag Have the Least Proportion of Murders and Felonies, and Know No Lynehings,' American Law Revieu, LI (1917), 239-248, especially p. 243. 
another social organization where mob executions are of frequent occurrence.

Even upon the respective frontiers there is a contrast of methods and result. In spite of the circumstance that a pioneer chief justice of Montana acknowledged the necessity for popular tribunals on the American frontier, a student of comparative institutions must not ignore the fact that differing methods of social control have protected other frontiers from such disturbances as led in this country to the toleration of extra-legal punishment of crime.

In New South Wales, for example, the authorities in 1851 were confronted with the problem of preserving order among the thousands of miners who flocked to the newly discovered gold fields. They accomplished that tremendous task by a force of ten mounted troopers, under the command of a gold commissioner who had graduated from Oxford, was a colonist of experience, and had been a police magistrate of Parramatta. This corporal's guard of Englishmen actually 'kept the peace over their whole territory, devised equitable and acceptable regulations, received and transported incalculable treasure, settled disputes, and gave criminals prompt trials by jury. usually on the scene of their offenses. In one instance of organized resistance, reinforcements were sent to their assistance and the rioters dispersed, but mob law and lynching were unknown.42 There were occasions of serious disorder in Victoria and resistance to the collection of licenses. In Sydney, also. many crimes of violence occurred. The San Francisco papers of 1852 spoke of lynch law as "rampant" in the Victoria gold fields, ${ }^{43}$ and Bancroft said that a Vigilance Committee was contemplated in

42 See Rolf Bolderwood, "Genesis of Gold-Fields Law in Australia," Cornhill Magazine, new ser., III (1897), 612-623; A. L. Haydon, Trooper Police of Australia, 1911, especially chaps. 5, 6; Henrietta Huxley, "Gold Diggings at Bathurst," Nineteenth Century. XLV (1899), 962-972.

43 San Francisco Herald, 1852, May 29, 2/4, citations from the Sydney Herald of Feb. 23, and the Geelong Adertiser, without exact date. 
Sydney in 1853. ${ }^{44}$ But the English colonists adopted no practices that were really akin to the popular tribunals of the United States, and various writers plainly assert that such customs have never been tolerated in Australia. ${ }^{45}$

In the gold fields of British Columbia the authorities checked crime and prevented lynching, although the population was very much like that of contiguous territories of the United States in which was waged a long conflict with criminals before order could be established. Trimble's study of coëxistent conditions north and south of the national boundary showed that during the very days of the Vigilance Committees of Idaho and Montana, the courts of British Columbia were able to achieve prompt and exemplary punishment of crime and to afford adequate protection to life and property. Wherever the American miners found themselves on British soil they gladly acknowledged the efficiency of the constituted authorities and abandoned their wonted appeal to popular tribunals. The presiding judge of the British district bore witness that although the miners were dominated by California traditions, they "manifested a great desire to see justice fairly done, and great patience with the difficulties which the magistrates and the judiciary have had to contend with." And again: "There was on all sides a submission to authority, a recognition of the right, which, looking to the mixed nature of the population, and the very large predominance of the California element, I confess I had not expected to meet." ${ }_{46}$

Trimble's final contrast of the two systems was exceedingly interesting. He said : ${ }^{47}$

44 Popular Tribunals, I, 19.

45 As Edward Dowling, Australia and America in 1892, 1893, p. 58.

46 Trimble, Mining Advance, 154.

47 Ibid., 246-247. Directly in line with this summary of contrasting systems of frontier control is an address on the general subject of lynching by C. C. Butler, who holds that the conditions which provoke such acts of vengeance rarely exist under strong, centralized governments. He characterizes the situations which have incited the people of the United States to 
Reviewing in conclusion, the prominent features of the different governmental forms applied under the British and under the American auspices in the mining advance, we see, on the one hand, government concentrated largely in the hands of an efficient executive, who made laws and organized administration on summary methods; on the other, representative government, under hampering conditions, working tardily and painfully towards order, and meeting local or occasional reinforcement. Under the former society was from the first under control, and there was a tendency to restrain individuals for the benefit of society-a restraint at times verging to over repression; under the latter individualism was feebly controlled from above, but had to generate within itself forces of order, and it tended to undue license hurtful to society. The American system developed a country the more swiftly, the British the more safely. Under both systems strong men labored courageously and well to adjust forms of order to unorganized society.

adopt and continue popular tribunals, as "a part of the price we pay for the full measure of the liberty we enjoy,' but he insists that courage and intelligence may devise a cost less deadly, without forfeiting the prize of freedom, or adopting the methods of despotism ("Lynching," American Law Review, XLIV [1910], 200-220). 


\section{CHAPTER XX}

\section{IN RETROSPECT}

Lynch law in some of its later developments has been hastily reviewed in the preceding chapter, for the purpose of setting the local episode of the San Francisco Committee of Vigilance of 1851 in its proper place as an episode of the wider national life.

The Committee of Vigilance was a confession of failure! To that extent all who have considered it hold the same opinion. But the men who experienced for themselves the disordered days of its existence laid the failure upon unfaithful public servants who betrayed their trusts; students of a later period blamed the entire body politic which permitted power to pass into incompetent or unworthy hands; and the modern critics, grouping the episode with other manifestations of nation-wide recurrence, detect in it a failure of adjustment between the mechanism of social organization and the stress of complex and unusual conditions.

When we turn from the special field of California history in the days of the Vigilantes to the recent studies of our national institutions, we find that faults hitherto attributed to local incompetency and corruption are recognized as everywhere latent in our whole scheme of social control. ${ }^{1}$ Everywhere the dread of autocracy has resulted in the distribution of power among so many state officials that it is well-nigh impossible to hold particular individuals responsible for undesirable conditions. Every where the same distrust of centralized authority has been expressed in the loose construction of local organization. Everywhere the people must vote for many candidates whose qualifi-

1 See references supra, $7 / 8$; and Herbert Croly, Promise of American Life, 1909 , pp. $317-324$. 
cations are practically unknown. ${ }^{2}$ Everywhere the political machines are frequently able to place unworthy men in office. Everywhere the laws most obviously fail to restrain crime by prompt and effective punishment. ${ }^{3}$ Everywhere, also, there is the danger that the flagrant miscarriage of justice in the courts may be turned into an excuse for riot and lynching whenever the American good humor and optimism give way under the strain of conditions that suddenly become intolerable. ${ }^{4}$

Wherever may rest the heaviest responsibility for these acknowledged faults-whether in imperfect organization, or in defective standards of citizenship-we are forced to admit that the practices of our democracy fall far short of the ideals of our people.

It must not be thought. for an instant, that the nation is oblivious or indifferent to the dangers and defects which are

2 See A. M. Kales, Unpopular Government in the United States, 1914, pp. 25-44.

3 The student of early conditions in California should acquaint himself with these current discussions. Valuable keys are furnished by the Index to Legal Periodicals, published by the American Bar Association; Roseoe Pound, Bibliography of Procedural Reform, 1917. See especially W. H. Taft, "Administration of Criminal Law,', Yale Law Review, XV (1905), 1-17; Moorfield Story, Reform of Legal Procedure, 1911; W. L. Ransom, "The Organization of the Courts for the Better Administration of Justice,' Cornell Law Quarterly, II (1917), 186-201, 261-282; "Report of Committee on Criminal Procedure,' Journal of Criminal Law, III (1912), 566-591; Julius Goebel, Jr., "Prevalence of Crime in the United States, and Its Extent Compared with That in the Leading European States," ibid., III (1913), 754-769; H. E. Willis, "How Shall the People of the United States Reform Their Legal Procedure so as to Make It an Instrument of Justice?', ibid., VI (1915), 533-543; Roscoe Pound, "Causes of Dissatisfaction with the Administration of Justice," American Bar Association, Report, 1906, I, pp. 395-417.

4 In a vigorous address before the District and County Attorneys Assoeiation of Texas, H. W. Sumners held the faults of legal procedure directly responsible for lynching. "The instinct of protection," he said, "is deeply implanted. Men surrender the right to protect themselves and arenge their wrongs to the state upon conditions, implied if not expressed, that the state will protect them and punish those who do them injury. What if the state doesn't do it?', (American Law Review, XLIII [1909], 455-466). See also Butler, as eited, ibid., XLIV (1910), 200-220; Walter Clark, "True Remedy for Lynch Law,', ibid., XXVIII (1894), 801-807; Lawson, as cited, Journal of Criminal Law, I (1910), 63-85. 
asserting themselves with such frequency and boldness. Far from it! The daily papers, the popular periodicals, the professional journals consider them with the most serious attention, learned societies investigate them, national congresses meet to discuss them, schools of social scientists conduct experiments in reform. Some strive to elevate the moral standards of the average man to the point where he will be stimulated to a faithful discharge of all his eivic duties. Some seek to reduce the duties of citizenship to the point where the average man can faithfully discharge them without a ruinous sacrifice of his personal interests. Some would increase the power and the responsibility of the specialist and the expert, and some would fetter the hands of efficiency lest they serve the greed of private selfishness. Some are demanding that all questions of importance should be decided by the direct verdict of a majority of the sovereign people, and some are discussing the legitimate rights of the minority and asking what might be a workable definition of majority rule when for a moment the social group should consist of one honest traveler and two footpads. ${ }^{5}$

In California in 1849 and 1850 the strain to which the fabric of American life is always liable was raised to the $N^{\text {th }}$ power. There was no local background of American tradition, and there was an unusual admixture of aliens who were entirely unprepared for the privileges and the duties of self-government. Many of these were actively vicious or constitutionally lazy, and differed radically from the type of ambitious peasant who came from Europe to America with the expectation of returning honest labor for the rewards of prosperity. Even with the American majority wonted standards of citizenship were greatly

5 See L. A. Lawrence, Public Opinion and Popular Government, 1913, pp. 9-13. It is interesting to recall that Francis Lieber queried whether in defining liberty the emphasis should be laid on effectuating the will of the majority or on protecting the rights of the minority (On Civil Liberty and Self-Government, ed. of 1891, p. 31). 
affected by the absence of the normal restraints of domestic life, by the general anticipation of return to an Eastern home, and by the intense preoccupation in business of a highly speculative nature.

Owing to the confusion existing over land titles and the peculiar climatic conditions of the country, the people did not attach themselves to the soil, but fluctuated between the placers and the towns. with constant and rapid changes of residence, while the individual settlements had little chance to develop that stabilized public opinion which is the foundation of order under a democratic govermment. Nevertheless, in spite of the absence of such a constructive spirit within the social groups, and regardless of the fact that they were quite inexperienced in corporate life, the county communities were still entrusted with the heavy responsibilities involved in local autonomy, and the state was not equipped with any machinery whatever that conld restrain their eccentricities or correct their mistakes. ${ }^{6}$ The courts themselves were more or less subject to control by the local electorate, and they were at the same time bound and hampered by those rigid rules of technical procedure that had become an acknowledged evil in the administration of justice throughout the nation.

Many older communities entrenched within bulwarks of American tradition and enlightened in the duties of citizenship have capitulated to the demagogue and the perjurer. Who, then, can be surprised that the reckless stripling of the West, tolerant, sanguine, and self-absorbed, should have been worsted by the same insidions foes. And in truth the selfish and the lawless were not slow to avail themselves of every opportunity they detected in the situation. Adroit and ambitious politicians swiftly accomplished the organization of efficient machines which became permanent

${ }^{6}$ "Republicanism, here, may be literally said to have run mad, so ridiculously incapable is it of exercising control over the masses", (Pringle Sham, Ramblings in California [ca. 1860], 69). 
factors beneath the more shifting currents of commercial life. Expert criminals weighed the spoils of pillage against the eosts of trials, robbed and murdered as they pleased, and paid expert counsel to entangle the courts in such a maze of technicalities that conviction was impossible and the fear of punishment deterred no man from the indulgence of his predatory impulses.

Such influences, and many others, combined to emphasize every weakness inherent in the political system, to accentuate every disruptive force in the community, and to create a situation where the latent menace to the welfare of a group was quickly translated into an obvious menace to a large number of particular individuals.

These endangered individuals had been trained by all the emergencies of the tumultuous life about them to act quickly rather than cautiously, and to decide the most momentous issues of life and death by the light of their own judgment or the hasty vote of a small circle of associates. Unhesitating and intrepid action, prompted by absolute self-confidence, was the only key to suceess in California and from the moment the immigrant set foot within the state he seemed vitalized with a spirit that removed mountains in hand barrows, raised eities with the swiftness of magic, and conceived railroad projects that staggered the imagination of the nation. "To say that it was a period of intense excitement does not describe it," remarked one of the pioneers concerning the spirit of '49. "It was a raging, seething, red hot pandemonia, [sic] in which men struggled to accomplish their purpose in the shortest possible time." 7

Faced with the defiant triumph of lawlessness and crime, these men who had been schooled in audacity did not establish learned societies to analyze their social situation, nor summon a national congress to suggest remedies for their peril.

They experimented!

7 C. R. Street, "Crossing the Plains in '49,' in Associated Pioneers of the Territorial Days, Sixteenth Annual Meeting, 1891, p. 24. 
Their experiments, embodied in the Committee of Vigilance of 1851 , were based on a modification of the precedents of the unorganized frontier, and an application of the resultant methods to a society already organized and equipped with the machinery of representative government. They were, to say the least, crude and radical. They were destructive of personal liberty, they inflicted punishment without due process of law, yet they were tolerated by the community because of the general desire for effective protection, and the general recognition of the good sense and sincerity of the Vigilantes. ${ }^{8}$

In a curious fashion they suggest some of the modern attempts at political reform. Popular participation in the affairs of government, now legalized in certain matters by methods of initiative and referendum, was then illegally forced upon the judicial department of San Francisco by the action of the Committee and the assent of the community. The object now attained by the process of recall was then effected by the expedient of taking over the work of the police officers and magistrates who had failed to preserve order. An approximation to the fundamental idea of a commission form of government was developed in the various departments of the Executive Committee. with their subordination of responsibility to a few influential officers. A state-wide detective and police agency was instituted by the subcommittees for the pursuit and arrest of criminals. The Gordian knot of technicalities was severed by the admission of all evidence at its face value and the elimination of the privilege of appeal. Finally, the emancipation of municipal politics from party control was attempted when members of the Committee conducted an independent and effective campaign at the local election.

8 "Lynch law in some of its manifestations is a form of private initiative in the enforcement of law, where the ordinary official machinery for its enforcement has broken down or is manifestly inefficient, though this method of law enforcement is, of course, at the same time a violation of law" (Mathews, State Administration, 414). 
If we compare the work accomplished by the Committee of Vigilance of 1851 with the purpose that incited its formation, we are compelled to characterize it as successful. Under its stern rule the city was for a time delivered from the reign of violence and from the terror of incendiary fires, and the state was so swifty rid of the cutthroats and robbers of the Stuart gang that many other brigands took warning from the experiences of that outlaw brotherhood. All this was accomplished with few exhibitions of disorder or riot, and no man suffered at the hands of the Committee a punishment heavier than the law imposed for the crimes of which he had been proved guilty. The members of the Committee felt no shame in acknowledging their work while they still ranged themselves under the symbol of the Watchful Eye, nor in later years when they reviewed their services as Vigilantes, and the community which had welcomed their protection in time of need never repudiated their efforts after the emergency had passed.

Yet the Committee of Vigilance was a confession of failure. as is every political scandal, every parody of justice, every lynching throughout the country. It was not, necessarily, the failure of the people to use with honest endeavor the social tools within their grasp, but their failure to perfect the full equipment of tools required in their task of self-government. The realization of a similar failure is today stirring the whole nation to constructive criticism and to strenuous experimentation.

One of the vital and perplexing problems of the hour is the control of the constantly recurring mob clamor for illegal executions. Each act of lawless lynching is sternly condemned by the country at large, and is usually defended by local champions on the ground of special and urgent necessity. In discussing the subject it has been said : ${ }^{9}$

${ }^{9}$ Forster, as cited, American Law Review, LI (1917), 239-248. 
To understand popular tribunals and lynehings, the attitude of the vigilantes and their responsible supporters and neighbors is of more weight than that of the outlaws or the formal legalistic critics of the vigilantes who confine their activity to destructive criticism and make no attempt to remedy the underlying causes that have led to popular tribunals, popular justice or extra legal criminal justice in forty-four of our forty-nine continental states and territories.

It is doubtful if there exist any records in which the "attitude of the Vigilantes and their responsible supporters" can be more thoroughly studied than in the archives of the Committee of Vigilance, which in this volume have been given a concrete summary and a background of local history. The acts of that illegal tribunal were deliberate and cautious, they were quite removed from the influence of racial antagonism between black and white, and they made no sentimental appeal on the ground of punishing revolting crimes against women. Taken as a whole they present a series of episodes in which a well defined national tendency can be reviewed with extraordinary fullness and unbiased judgment.

It seems almost an injustice to associate even remotely the self-restrained members of the Committee of Vigilance with a blood-crazed mob that reverts to the vengeance of savages, and some of the differences between them are absolutely fundamental. It is unquestionably true that the precedents established by the San Francisco Committee of Vigilance have led other unorganized communities to interpose a quasi-representative and permanent body of responsible men between defiant outlaws and an outraged public, and to effect salutary punishment of crime with a minimum of disorder and cruelty. ${ }^{10}$ But it is equally true that

10 An interesting article by George Kennan entitled "A Russian Experiment in Self-Government," seems to invoke the very specters of the Vigilantes in an account of the "Amur California," in a No Man's Land of Manchurian gold fields. The placers were discovered in 1883 and were quickly thronged with cosmopolitan miners and escaped Siberian convicts. Pandemonium resulted, and after tentative experiments a popular organization was effected in February, 1885: organic laws were adopted, officials 
the very restraint of the members of the Committee of San Francisco, the wide scope of their work, and the tolerance accorded to them by a large and intelligent center of population have tended to endow with the dignity of an accepted national institution those emergency methods which the Vigilantes borrowed from revolutionary or pioneer communities. Even now their example is often cited by restive and irresponsible members of well established societies who in times of supposed crisis are moved to express hysterical racial antagonism or sporadic protest against the chronic shortcomings of their judicial system.

From whatever angle it may be viewed, the fact must be recognized that the work of the Committee of Vigilance was too spectacular to sink into oblivion, and that it still exercises a distinct influence upon the popular mind. It has therefore seemed important that its history should be presented in detail, based on the authentic records of its daily doings, stripped as far as might be possible of false glamour and false condemnation, and fairly related to the causes which engendered it.

The body of men who styled themselves the Committee of Vigilance of San Francisco were men who believed in the supremacy of law. Many of them had extemporized law when denied the ordinary protection of established society and had formulated law when the opportunity for self-organization arrived. They had appointed representatives to execute the law, after the manner of American citizens, and no survey of their work has yet proved that as citizens they consciously betrayed their city and state to violence and corruption. But when the laws they had ereated failed to protect them from the onslaughts

chosen, and the penalties of death and flogging were administered with rigor. Order was quickly enforced, and for nearly a year the isolated republic conducted its own affairs with marked suceess, but perished in a week before a hostile movement of the Chinese government, which saw with apprehension the introduction of unwelcome neighbors and customs upon its borderland (Atlantic Monthly, LXXX [1897], 494-507). 
of criminals, they put the immediate welfare of the community above their allegiance to the formulated laws, and did to the outlaws among them the things that seemed right in their own eyes.

That, as I understand it, was the spirit of the men who constituted the Committee of Vigilance. It is not a spirit which has been confined to a single decade of United States history, to a single section of the frontier, or even to the whole frontier region as distinguished from the areas of denser population. Of whatever vice or virtue it may be the outward and visible sign, it is a spirit which is still alive in the land, and with which reckoning must be made by those entrusted with the responsibilities of social leadership. It is capable of developing tremendous dynamic energy, and under provocation will assert itself with destructive ferocity unless restrained by physical force.

But the curbing of this spirit, which has manifested itself from the time of the Regulators to the yesterdays of 1920, is not so much a matter of heavy-handed restraint as of the elimination of provocation. The realization of the fact that such men as Stuart, Adams, and Jimmy from Town, time and again defied the people in their very courts created the impulse that moved Brannan and Bluxome and Coleman and Payran to teach those rascals a wholesome fear of the wrath of the community, and made the men of San Francisco listen with stern approval to the tapping of the Monumental bell. The realization of the fact that the most vicious criminal can today evade swift and certain punishment creates the impulse that now draws within the circle of lynchers men, and even women, whose lives are normally gentle and humane. If that conviction were destroyed, the will to lynch might remain as a social danger, but it would be so universally condemned by the better element of the people that both preventive and punitive measures might be adopted for its suppression. 
It is not the province of the historian of the Committee of Vigilance to prophesy what steps must be taken before the people may regard their political institutions as safeguards against corruption, and their courts as temples of justice rather than as sanctuaries for the fugitive from righteous punishment. In this Year of the Independence of the United States one hundred and forty-five the precedents of the past are not to be accepted as unerring guide posts towards the future development of American democracy. Old issues are swiftly sinking into oblivion, and new problems are arising that will test afresh the elasticity of our institutions and the temper of our people. But in spite of every failure of our political system, in spite of civic lassitude, in spite of standards of thought and action divergent from the past, in spite of commercial greed, of evasion of laws, of mob frenzy and brutal lynchings, one may say with confidence that our people still strive to carry on within the borders of their land the unending struggle between the constructive and destructure forces of society. For this reason no effort is wasted or ill-advised that seeks to set clearly before their minds the actions and reactions which transmute subtle and primary elements into the visible phenomena of their daily lives.

The Committee of Vigilance of 1851 was a phenomenon that has been visible and familiar to every reader of California history, but its vital significance has largely been obscured by its atmosphere of picturesque melodrama and its detachment from historical criticism. It was the confession of the failure of average men to control the unusually disruptive forces in their special community by the restraining influences of the form of government commonly practiced in the United States. It was also an experiment in correction, reflecting existing theories of popular sovereignty, and forecasting less explosive experiments of a later day. For a short time its influence in San Francisco and in California was undoubtedly productive of public quiet and 
safety. When another and more acute crisis arose in San Francisco in 1856, the framework of the Committee of 1851 formed the nucleus of a much larger body which brought under the discipline of its secret tribunal men of power and influence, and established practical and permanent political reforms. In other pioneer communities, as Colorado, Montana, and Nevada, the exercise of lynch law common to all the American frontier borrowed from the precedents set by the San Francisco Committee of Vigilance a decorum of procedure, and an element of restraint that prevented some of the worst evils incident to such an irresponsible code.

But with all this to its credit, the Committee of Vigilance was not a beacon light on the pathway of constructive reform; and as an experiment the real force of its lesson has been obscured, because the lawlessness and danger of its methods have diverted its critics from attention to the inherent weakness of organization that originally caused the breakdown of government in California. More than this-it must also be acknowledged that as an influence in American life surviving the emergencies of unprotected frontiers, the Committee, itself, became a menace to organized society, for the sincerity of the men who formed it, and the partial if temporary success of their efforts have diverted many of their admirers from a true valuation of the destructive measures which they employed. Yet in view of our own experiences in inefficiency, and our laborious and procrastinating efforts at improvement, it seems fair to place the emphasis of significance on the structural weakness and consequent breakdown of a social system rather than on the errors of those who experimented with readjustment.

Whatever might be the meed of praise or censure that the world should pass upon their deeds, the Vigilantes awaited the verdict unflinchingly, meeting with open faces the friends and foes upon their city streets, and setting their names to the records 
of their work, that men in other places and in other days might read and understand. 'They usurped power, but they exercised it without tyranny. They avenged crime, but they did so without cruelty. They disregarded the laws which had been formulated for the public good, but they felt themselves bound in solemn responsibility to the people who, behind those laws, represented to their minds the symbol of ultimate sovereignty.

To that self-imposed responsibility they were consistently faithful. They appealed unto the People. Let the People take warning from their errors, but give tribute to their sincerity and daring. 


\section{APPENDIX}

\section{BIOGRAPHICAL NOTES}

The following notes have been compiled from accessible sources, 1 with the purpose of showing the type of men who made up the rank and file of the Committee of Vigilance of 1851. Members of particular prominence are mentioned in the chapter on organization, and many more might be noted with interest and profit if the limits of this volume permitted. It would be a valuable addition to the archives of the Committee if relatives of Vigilantes would contribute biographical data to be filed with the original documents in the Bancroft Library.

The names are arranged in the order of signature to the constitution. A second number printed in brackets indicates a variation in the identification number used by the sergeant-at-arms (see supra, p. 192 note 10).

5. Of George J. Oakes we know little, except that he was a member of the firm of Endicott, Green and Oakes, was a foreman of the Empire Engine Company Number 1 (Broderick's), that he served on the Executive Committee until the date of his death, October 26 or 27, 1851, and that the Committee sent to his mother an eloquent letter of condolence which was probably the most gentle document indited "In behalf of the Committee of Vigilance of San Francisco.", The fire companies and the Vigilantes paraded at his funeral, and the rooms of the Committee were draped in mourning in deference to his memory (Papers, 681-686; Herald, 1851, Oct. 28-30).

9. James C. Ward, a former member of Stevenson's Regiment, served on the Executive Committee and sometimes filled the place of secretary or chairman. In 1854 he acted as president of the San Francisco and Mission Plank Road (Herald, April 27). At a later period he was a notary public, and became quite wealthy. Swasey said he was a man of education, and possessed some literary ability (Early Days, 272). In 1878 he published his "Recollections", in the San Francisco Argonaut. He died in Massachusetts in 1883 .

1 The Constitution and By-Laws of the Society of California Pioneers, as revised in 1912, has been followed for dates of arrival in California, and the California Blue Book for 1907 has furnished records of members of the state legislature. Other sources of information are mentioned in the text. 
12. The name of R. S. Watson, of Macondray and Company, made little impression on the archives of the Committee. Josiah Royce knew him in later years, and learned interesting details of the Jansen affair, of February, 1851, and of the inception of the Committee of Vigilance. Watson, under the pseudonym of "Justice," made the stirring suggestions in the Alta of June 8, that greatly promoted the organization of the Committee (see infra, p. 456, and Royce, California, 412-421). His ideals of duty may be inferred from the fact that he risked his life, on a stormy day, to deliver the anchor he had promised to a departing vessel (Knower, Adventures, 131).

14. Edward A. King, a sea eaptain, arrived in California in November, 1846. He was successively an agent for underwriters, a lumber dealer in Monterey in 1848, and harbor master of San Francisco in 1849. A copy of a table of arrivals made from his records for the Society of Pioneers furnishes valuable and unique statistics for the period of his administration (see supra, p. 123; Bancroft, California, IV, 700. The register of the Society of California Pioneers corrects Bancroft's date of arrival).

24 [20]. James T. Ryan was prominently identified with lumber interests in Humboldt County, where he was a partner of James R. Duff, Vigilante number $169 . \mathrm{He}$ served as a Democratic state senator, 1860 and 1861, and died at Vallejo, February 6, 1875 (Carr, Pioneer Days, 442; San Francisco Chronicle, 1915, Oct. 3, Magazine p. 6).

26 [22]. George H. Howard was a Democratic assemblyman, 1865-1866.

35 [31]. James F. Curtis, a native of Boston, and a "Territorial Pioneer" of 1850, was a partner of J. D. Farwell (see note on Farwell, number 89 ). He assisted in arresting the first prisoner of the Committee of Vigilance, served on the Executive Committee, and was active in the reorganization of 1856. Subsequently he was for two years chief of police in San Francisco. He became a brigadier general in the Federal army in the Civil War, and commanded the national guard of Idaho during the riots at the Coeur d'Aléne mines in 1892 (Alta California, 1858, November $7 \%$ $8 \%$; 11 \%/2; 1877, Aug. 27 1/5; Popular Tribunals, II, Index; G. E. French, "Coeur d'Aléne Riots," Overland Monthly, ser. 2, XXVI (1895), 32-40; biographical note, ibid, 109).

44 [40]. James C. L. Wadsworth was born in Litchfield, Connecticut, and came to California in 1847, as a sutler in Stevenson's Regiment. In 1848 and 1849 he worked in the southern mines, then established himself in business in Stockton and was elected second alcalde in the spring of 1849. Later he engaged in banking in San Francisco. He was a member of Broderick's fire company and was one of the first to suggest the formation of the Society of California Pioneers. Later he held important positions in Nevada mining companies, was appointed secretary to the State Board of Harbor Commissioners in California in 1883, and subsequently 
served as a commissioner of insurance. He was a staunch Democrat, a loyal Union man, and a prominent Mason. He dictated a brief statement which has a place in the Bancroft collections (Swasey, Early Days, 242-245; Alta, 1864, April 13 1/1; San Franciseo Call, 1883, March 22 3\%; ; 23 \%2).

55 [51]. Dr. Victor J. Fourgeaud was born in Charleston, South Carolina, February 1, 1816. He was educated in France and in South Carolina (Swasey, Early Days, 274). He undertook the overland trip in 1847, and had the courage to take with him his wife and child. He published several descriptions of California which may be called the first steps in the advertisement of the state (Eldredge, California, III, 181-182. Extracts reprinted in In Memoriam [of] Dr. Victor J. Fourgeaud, by the Society of California Pioneers). One of the earliest authoritative announcements of the discovery of gold was made in a long article on the advantages of California which he published in the California Star, April 1, 1848, but the author's eareer as a miner was quickly terminated by illness. He was conspicuous in the rising against the Hounds, but took no important part in the activities of the Committee of Vigilance, although his early membership gives interesting proof of the attitude towards the society of a quiet, scholarly man whose family was already in the eity. He was a Republican member of the state assembly in 1857. Obituary, Alta, 1875, Jan. $3 \%$

83 [79]. Jesse Seligman, was senior member of a firm of importers, and subsequently established a banking house (Colville's Directory, 1856; Eldredge, California, V, 446).

89 [85]. James D. Farwell and his partner, James F. Curtis (number 35) were merchants. They suffered in the fire of May, 1851, but were not ruined, because their store was built over the water, and in anticipation of such a catastrophe, they always kept lighters alongside, and so salvaged most of their stock before the building was destroyed. Farwell was not an important member of the Committee of ' 51 , but played a larger rôle in that of ' 56 , which he entered as a "sacred duty"' although conscious of the heavy responsibility assumed by such a defiance of established law (see his MS Statement; Popular Tribunals, Index).

92 [88]. Jacob Primer Leese was a representative of the old régime, as he arrived in California in 1833, was naturalized as a Mexican citizen, married a daughter of the Vallejo family, and was the father of Rosalía, the first white ehild born in Yerba Buena. He was alcalde of Sonoma in 1844-1845, acted as a sub-agent for Larkin in 1846, and was elected in 1847 as a member of the Sonoma town council. He was a bold man, but had little education and ultimately lost the fortune he had made in trade and mining, as well as that inherited by his wife (Bancroft, California, IV, 710-711; Annals, 171; Leese, "Reminiscences,'” Alta, 1865, March 30, p. 1).

107 [105]. Henry F. Teschemacher came to California from Boston in 1842. His work as a member of the Executive Committee was inconspicuous, 
but he became a man of wealth and sufficiently important in the eity to serve as president of the board of supervisors from 1859 to 1861, and as mayor, 1862 to 1863 . Much of his later life was spent in foreign travel. Baneroft found surprisingly little record of so prominent a pioneer (California, V, 745. See also, Swasey, Early Days, 270; Alta, 1863, July 2 1/3; obituary, San Francisco Chronicle, 1904, Nov. 29 13/2).

116 [115]. William H. Graham was a man of notable pugnacity. In January, 1851, he had fought a duel with William Walker, one of the editors of the Herald (Alta, Jan. $142 / 2$ ). For this he was tried and acquitted (Herald, Aug. $11 \%$ ). On July first the Herald printed in its advertising columns the following:

Card.-Old Alcalde's Building, west side of Portsmouth Square, July 1, 1851.

I hereby post and publish George Frank Lemon as a scoundrel, villain, liar and poltroon, and declare him to be out of the pale of gentlemen's society.

William H. Graham.

The issue of July 3 noted that the editor understood that Mr. Graham was doing very well, and though suffering much from his wounds was entirely out of danger. Later allusions showed that this encounter was a rather plebeian street fight that resulted in arrest for assault with intent to kill (Herald, July $26 \%$; Sept. $14 \%$ ). The ethics of the code were finally observed in a pistol duel at Benicia, where at the seventh round Graham satisfied his honor by slightly wounding his antagonist (Herald, Sept. $15 \%$ ). Fortunately the truculent gentleman developed no quarrel within the ranks of the Committee.

126 [125]. Owen P. Sutton was born in 1821 in the state of New York. He arrived in California in April, 1849, mined for a time, and then established himself in business in San Francisco. He was vice-president of the Democratic mass meeting held October 25, 1849. When his firm was burned out in the fire of May, 1851, their loss was estimated at $\$ 125,000$. From 1853 to 1858 he was an appraiser of the port, and in 1863 he was a member of the state assembly. He died September 1, 1881 (Annals, 236; San Franeisco Call, 1890, Sept. 8 3/4.

129 [128]. Alfred J. Ellis was born in New York in 1816. He came to San Francisco in April, 1847, after some years in New Zealand and the Pacific islands. He was a member of the popular legislative assembly in San Francisco in the spring of 1849 , took part in the trial of the Hounds, joined the California Guard, was elected to the ayuntamiento in August, and was a delegate to the eonstitutional convention. He was an active member of the Executive Committee of the Committee of Vigilance but resigned in November, 1851, as a sequel to his election to the legislature. In 1852 he received seventeen votes as a delegate to the presidential con- 
vention of the Whig party (Swasey, Early Days, 272; Davis, Political Conventions, 16; obituary, San Franciseo Call, 1883, July 30 3/8).

132 [131]. Captain Henry M. Naglee, a native of Philadelphia, was a graduate of the Military Academy at West Point. Although he was engaged in civil pursuits at the outbreak of the Mexican War, he came to California as a captain in Stevenson's Regiment, and distinguished himself in active service in Lower California. In January, 1849, he opened the first banking house in San Francisco, but was obliged to suspend payment in a financial panic, September, 1850. He took no active part in the business of the Committee until near the close of its existence. He received a commission as brigadier general of volunteers in the Civil War, and after his return to California at its close, made a great success in the culture of wine grapes, the manufacture of brandy, and the development of the agriculture of the Santa Clara Valley. In politics he was a Democrat (Swasey, Early Days, 219-229; Annals, 289; Love Life of Brig. Gen. Henry M. Naglee, 1867).

136 [135]. Alfred L. Tubbs was a member of the state senate, 18651868.

144 [142]. Thomas K. Battelle was of a different type. At the time of the first fire, December 24, 1849, his gambling saloon was destroyed, and while the eity was still blazing he rented another building, extinguished the flames that already threatened it, and opened for business without delay. In 1850 he was an assistant fire engineer in the volunteer department. During the term of the Committee of Vigilance he was proprietor of the Pioneer Club House and furnished refreshments, more or less spirituous in their composition, to his fellow Vigilantes (Annals, 617; Schenck, MS Statement, 49-50; notice of his departure from San Francisco, Alta, 1855, June 16 2/1).

155 [153]. J. Mead Huxley came to California in Stevenson's Regiment and again volunteered for military duty during the Civil War, when he served as a commissioned officer (Bancroft, California, III, 792).

157 [155]. Charles Minturn arrived in San Franciseo in October, 1849. He engaged in the commission business, was an alderman in 1850, and acted as agent for Sacramento steamers. An attempt to rob his office has been described on page 312 (Annals, 273; Kimball's Directory, 1850).

169 [167]. James R. Duff came from Boston around Cape Horn and arrived in San Francisco in July, 1849. Three days of hard work in the mines prostrated him with sunstroke, and he returned to San Franciseo and started business as a contractor and builder, forming a partnership with James T. Ryan (number 24). His interesting account of one of the most exciting episodes of ' 51 is incorporated in an earlier chapter (see supra, p. 300). So far as he could ascertain he was the last survivor of the Committee of 1851. He died at the age of ninety-two, on August 9, 1917 (Carr, Pioneer Days, 442; San Francisco Chronicle, 1915, Oct. 3, Magazine p. 6). 
170 [176]. James Dows arrived from New York in December, 1849, and established himself in a wholesale liquor business. It is said that his safe was robbed by the Sydney thieves of about $\$ 10,000$ before the organization of the Committee of Vigilance. He was a straightforward, sincere and capable man, and was blessed with a saving gift of humor. Coleman said that at one time the Committee was discussing the fate of a Mexican boy charged with theft, and each speaker was limited to a single period of five minutes. While the prisoner's life hung in the balance, Dows, who had already addressed the chair, gained the floor by a subterfuge and drawled out: "Gentlemen, I do not wish to fatigue you; I beg merely to say that it takes no longer to hang a man than to whip one." The resulting laugh cleared the atmosphere, and the culprit was released with a reprimand (MS Statement, 26-27). Dows did good service in both Committees, and suits were brought against him as a sequel to his actions in '56 (Popular Tribunals, I, 377-378; II, 127, 613-617).

172 [169]. John O. Earl, and his brother,

173 [170]. E. M. Earl, from New Jersey, were pioneers of 1849. Their business was burned out in the two fires that occurred in May, 1850 and 1851. Neither were conspicuous in ' 51 , but John was active in the reorganization of ' 56 . $\mathrm{He}$ was interested in the establishment of San Francisco schools, was a well-known Mason, and so loyal to the Union that he left the Democratic party and joined the Republican after the outbreak of the Civil War (Phelps, Contemporary Biography, II, 311-314).

176 [177]. George H. Blake was a Democratic assemblyman in 1853.

178 [176]. James Neall, Jr. arrived in May, 1849, and remained in San Francisco as a merchant. He dictated for Bancroft many interesting reminiscences of the early days and a most valuable account of the first steps in the formation of the Committee of Vigilance, although, strange to say, his name does not appear in the documents, except upon the roll of members (see infra, pp. 457-458).

188. Charles V. Gillespie, a native of New York, came with his wife to San Francisco in February, 1848, after seventeen years of voyaging between New York and China, and in Oriental waters. He took charge of the Leidesdorff estate shortly after his arrival, and in September, 1848, he served on a committee to petition Congress for a mint. Bancroft described him as a quiet, intellectual man, who did more important work in ' 56 than in the earlier organization. He dictated a statement for the Bancroft collection, but it touches very briefly on the work of '51 (Popular Tribunals, II, 130; Robinson, California and Its Gold Regions, Appendix, p. 126).

194. Andrew J. Grayson, from Louisiana, brought his wife and child to California in an overland wagon train of 1846 . He served as a lieutenant in Frémont's Mounted Riflemen, but was stationed in San Francisco during 
hostilities, and at their close he opened a stationery store in the town. He was one of the many unnamed participants in the work of the Committee. In later life he gained scientific renown as an ornithologist. Swasey spoke with admiration of his fine physique, abstemious habits and scholarly education. He died in Mazatlan in 1869 (Swasey, Early Days, 209-210; Bancroft, California, III, 76t).

193. F. C. Bennett may have been the Francis C. Bennett electerl one of the city assessors in May, 1850, and a Whig assemblyman, in the second legislature, 1851 (Annals, 273).

196. Jean Jacques Vioget, a Swiss, had been in California since 1837. He made the first survey of San Francisco. He was also a sailor and a hotel keeper of some skill, spoke several languages and loved music. He removed from San Francisco and was granted leave from the Committee in February, 1852 (Bancroft, California, V, 764).

199. George $H$. Hossefross was a pioneer of 1849 . He was elected to the Executive Committee towards the elose of activities in 1852, and renewed his connection with the association in 1856. He served as chief of the united San Francisco engine companies in 1852 and 1853 (Popular Tribunals, II, 474; Annals, 618; Alta, 1853, Sept. 14 \%3; Oct. $16 \% 2$; obituary, Alta, 1864, March 19-21; sketches, Argonaut, 1877, June 23 5/4; San Franciseo Call, 1890, Dec. 22 3\%3; Pendleton, Exempt Firemen, 10, portrait).

228. Cyrus Palmer was born in Maine in 1828. He arrived in San Francisco in August, 1849, and for three years was connected with the business of Macondray and Company, but later established with his brother an important foundry of their own. He aided in organizing the first fire company, was a Republican member of the assembly in 1857, 1858, and 1863, and was an officer of the Howard Street Presbyterian Church (Phelps, Contemporary Biography, II, 274-275).

243. E. V. Joice arrived in January, 1849 and was sufficiently prominent in the fall to serve as a vice-president of the Democratic mass meeting, October 25 (Annals, 236).

259. Dr. Galen Burdell arrived from New York in August, 1849, and attained a successful practice as the first scientific dentist in San Francisco (Eldredge, California, IV, 476, portrait).

268. Henry M. Gray, born in New York in 1821, was the son of a clergyman. He arrived in November, 1849, indulged in a brief experiment in mining, and then devoted himself to medicine in San Francisco, where he is said to have built up the largest practice in the eity. He was quickly identified witl the Whig party, served on the general and state central committees, was considered as a candidate for mayor in 1852, and was nominated but defeated for that office in the following year. He was a man of marked generosity and of cultured tastes, a connoisseur in music, literature and works of art, an eloquent speaker, a prominent Mason, anit the 
eighth president of the Society of California Pioneers. He died September 24, 1863 (Shuck, Representative Men, 479-493, portrait; San Francisco Call, 1890 , Sept. 8 3/4).

273. Timothy Guy Phelps, born in the state of New York in 1824, arrived in California in December, 1849. He mined for a time, and then entered the commission business in San Francisco. He became an important Republican politician, served several terms in the state senate and assembly, was a candidate for the nomination for governor in 1861, ran for that office, unsuccessfully, in 1875; was a member of Congress in 1861-1863, and collector of the port of San Francisco in 1869. He was a man of great wealth, and a regent of the State University at the time of his death, June 11, 1899 (Eldredge, California, IV, 156, portrait; Phelps, Contemporary Biography, II, 15-16).

283. Arthur M. Ebbets was born in New York in 1830, arrived in San Francisco in August, 1819, and made such an immediate success as a commission merchant, that in 1851 he established a branch house in New York. He served as county recorder in 1861, was supervisor in 1874, a director and president of the Mercantile Library, and a president of the Society of California Pioneers. He was active in supporting the Union during the Civil War (Swasey, Early Days, 297-301; San Francisco Call, 1890, Sept. $83 \% 8$.

287. At the age of thirty-two, William D. M. Howard was one of the most prominent, and one of the best loved men in California. He was a native of Boston, and had been identified with the commercial interests of the Pacific Coast since Jannary, 1839. After the gold discovery, the firm of Howard and Mellus, which had purchased the old property of the Hudson Bay Company, had the most extensive merchandise business in the state, but Howard retired from business in 1850. Although unambitious for political power, he was always interested in public affairs, and his name often appeared in connection with the earlier history of San Francisco. He promoted the establishment of schools, of the first orphan asylum, and of the fire department, donated the lot for a Presbyterian church, and urged and contributed to the improvement of city streets. He was influential in founding the California Guard, and was the first president of the Society of California Pioneers. On the Committee of Vigilance he did no recorded work but was appointed to one important subcommittee, and was placed on the Executive Committee in September, 1851. He never attended any Executive meetings, and his inability to do so served as an excuse for an early resignation. He died January 19, 1856 (Annals, 779-780, portrait; Swasey, Early Days, 151-155; Bancroft, California, III, 788-789; Davis, Sixty Fears, 314-327; Eldredge, California, II, 470, portrait; sketches, San Francisco Bulletin, 1897, April 3 12/2; San Francisco Call, 1890, Sept. 8 3/3; Pendleton, Exempt Firemen, 74-77, portrait). 
299. James S. Wethered, a pioneer of August, 1849, was a Whig assemblyman in the second legislature. He did inconspicuous, but faithful work in the ranks of the General Committee, and incidentally indulged in a harmless duel with Captain Schaeffer in September, 18.51. He was an inspector of customs in 1852, and became a brother-in-law of the Woodworths. He died January 14, 1900 (Swasey, Early Days, 217; Parker's Directory, 1852; Herald, 1851, Sept. $14 \%)$.

303. Henry Gerke was a German immigrant, who arrived in California August, 18+7. He later became a vineyardist in Tehama County (Bancroft, California, III, 755).

304. Francis Hoen was a member of the famous Swasey-Todd party which reached California in September, 1845. For a time he was employed by Sutter, then became a resident of Monterey and was there a candidate for treasurer in October, 1846. Later he kept a cigar store in San Francisco (Bancroft, California, III, 786; V, 295 note 5).

324. Mathew P. Burns was a well-known physician. He dictated a Statement for Bancroft.

331. Edward A. Suwerkrop was the Danish eonsul (Parker's Directory, $1852)$.

349. Samuel Fleishhacker had already placed his family name on the list of prominent merchants of San Francisco. He was an uncle of Hubert and Mortimer Fleishhacker.

361. Charles L. Wiggin reached California in August, 1849. He served as an assemblyman in the legislature, 1865 to 1866 .

403. William M. Lent arrived in April, 1849. He was a Democratic state senator in 1854 .

414. John P. Manrow arrived in April, 1849, and participated in the trial of the Hounds. He dictated reminiscences of the Committees of Vigilance for Bancroft, but they are not very valuable for the work of ' 51 .

437. Richard M. Jessup arrived in July, 1819. He was a Republican assemblyman in 1857.

440. John Middleton reached San Francisco in September, 1849, and in 1851 he was a member of a prosperous firm of auctioneers. He was a Democratic assemblyman in the legislature, 1867 to 1868 (Colville's Directory, 1856).

449. James M. Taylor arrived in July, 1849. He was an assemblyman in 1853 and 1859 , representing in turn the Whig and Republican parties.

466. William Sharon was born in Ohio in 1821, and practiced law in that state before he left for the gold fields in the summer of 1849. Quickly realizing the wonderful future that was before California, and anticipating speedy rail communication with the East, he devoted himself to real estate speculations in San Franciseo, and by 1862 his fortune was rated at $\$ 150,000$. He was an able member of the first council under the charter of 1850 , and 
inaugurated the first systematic and official survey of the eity archives. His later mining and banking undertakings form a well-known chapter in the financial history of California and Nevada, and have enrolled him among the millionaires of the Pacific Coast (Bancroft, Chronicles of the Builders, IV, 23-78, portrait).

501. John A. Sutter Jr. was the son of the famous pioneer of New Helvetia.

507. Dr. Samuel Merritt was born in Maine in 1822, and on the day after the fire of May, 1850, he sailed into San Franciseo Bay, the owner of a smart little brig, and of a eargo of merchandise which the devastated market quickly absorbed at a brilliant profit. He chartered his small vessel at $\$ 800$ a month, and began the practice of his profession equipped with an excellent education, a happy ability to make friends, and a letter of introduction and recommendation from his friend, Daniel Webster. He did little in the Committee of ' 51 , but was more active in that of ' 56 . He was elected as a supervisor in the reform of politics that ensued, and there served as chairman of the committee of finance which accomplished marvels of economy for the depleted city treasury. He declined the nomination for mayor in 1858, but accepted a similar position in Oakland in 1867, and long maintained a leading position in that eity. He was appointed a regent of the University of California in 1868. He died in 1891, and left a fortune that has endowed the great hospital in Oakland that bears his name (Phelps, Contemporary Biography, II, 92-100, portrait; obituary, San Francisco Examiner, 1890, Aug. 18 4/1).

509. Henry Wetherbee arrived in November, 1849, and in later years became one of the best known lumber manufacturers on the Coast.

530. Robert A. Parker was a native of Boston. He reached San Francisco in March, 1847, and became a member of the council elected in September of that year, and of the district legislature of 1849 . He was for a time one of the town's most ambitious merchants, and is said to have indulged in the spectacular amusement of "salting", Clay Street with two or three thousand dollars worth of coarse gold, just as the eastern passengers landed from the first steamer. The prospective Argonauts panned it out with delight and sent home jubilant reports of the abundance of the precious metal. It is not surprising to find that the generous and imaginative pioneer failed in his commercial undertakings, and fortunately his impulsive nature seems to have exerted no influence on the affairs of the Committee of Vigilance (Swasey, Early Days, 210-211).

573. Thomas J. L. Smiley was a native of Philadelphia and arrived in October, 1849. He was a partner of John Middleton (Number 440), and took an active interest in the affairs of the Committee after he was placed on the Executive Committee, in August. He was even more conspicuous in the reorganization in '56. Bancroft quoted a fellow Vigilante who called 
Smiley prompt in action, but talkative and excitable. His dictation is an interesting item of the Bancroft collection. He became a prominent broker, was first president of the California Stock and Exchange Board, and was also well known as a Republican politician (Popular Tribunals, II, 129-130; obituary, Alta, 1873, May $4 \frac{1}{1} 1$; records of the Society of California Pioneers).

580. Philip A. Roach reached California in August, 1849, and served as last alcalde and first mayor of Monterey. He was registered on the rolls of the Committee as a resident of the southern port, and tendered his resignation in August because of necessary absence from San Francisco. He served as a state senator in 1852, and distinguished himself by introducing a bill authorizing married women to conduct business as sole traders. $\mathrm{He}$ served again in 1853 and from 1873 to 1876, filled other important offices in subsequent years, and was long a successful leader of the Democratic party. He died April 27, 1889 (Bancroft, California, VI, 657 note; Upham, Notes, 497-500).

588. Beverley C. Sanders was a "Territorial Pioneer' of 1850 and became collector of the port of San Francisco in 1852. In the Committee he appears to have done little active work, but space must be allowed to repeat a Vigilante's anecdote of a later year when Sanders was sent to St. Petersburg by the Russian-American Commercial Company to secure the privilege of transporting ice from Sitka to San Francisco. With audacity characteristic of a handsome and dashing pioneer, Mr. Sanders introduced himself as a colonel, and wore an impressive and becoming uniform. He was once inconveniently asked to which department of the army he belonged, but he preserved his dignity by promptly responding: "To the Pacific, Madam!", (Hittell, California, III, 433).

598. Isaac M. Merrill was a Republican assemblyman in 1895 .

610. Henry Hiram Ellis was born in Maine in 1830, took to the sea, as had his family before him, and reached San Francisco in June, 1849. In California he experienced vicissitudes of mining life and was interested in shipping ventures. From 1855 to 1877 he was connected with the San Francisco police, became chief of the force, and left a fine record for efficiency. During the Civil War he held the position of deputy United States assistant provost-marshal (Phelps, Contemporary Biography, I, 379384, portrait; Alta, 1866, Feb. $41 / 1 ; 1871$, Jan. $131 \frac{1}{4} ; 1875$, Dee. $71 / 5$ ).

616. Herman Wohler was a German immigrant who reached California in February, 1848. He was elected a Democratic assemblyman in September, 1851, and served again in 1856. Baneroft said that he was famous as a musician (California, V, 779).

654. John Stoneacre Ellis, and his brother,

682. Augustus Van Horne Ellis, came from New York eity in 1819. They did no conspicuous work in 1851, although John was elected to the 
Executive Committee in March, 1852. He was more prominent in 1856, and was presented with the banners of the Committee as a token of esteem and affection. The name of Augustus appears once in a report of August 31, 1851, although it is so illegible that it was printed as "Hawthorne", Ellis on page 582 of the Papers. Both of the brothers served with distinction in the Civil War, and Augustus, a colonel, was killed at Gettysburg (data furnished by a niece, Mrs. Vanderlynn Stow, of San Francisco).

662. Daniel Cronin served as one of the secretaries of the Democratic mass meeting of October 25, 1849 (Annals, 236).

665. Jacob R. Snyder was born in Philadelphia, August 23, 1812. He was one of the Swasey-Todd party that crossed the plains and arrived in California in September, 1845. For a while he made shingles near Santa Cruz, then served as a major in the California Battalion, and was appointed surveyor general of the middle department of California during the administration of Colonel Mason. He was a delegate to the Constitutional Convention of 1849, and in 1850 became a banking associate of James King of William. His membership in the Committee was brief, as he resigned to take his seat as a Democratic senator, being one of four Vigilantes elected to the legislature in September, 1851. He remained in office for two terms, and also served as sub-treasurer of the United States mint, 1854 to 1860 . He was a fearless man, sturdy and independent, made a success of commercial life and retired in 1869 to a beautiful home in the Sonoma Valley. He died April 29, 1878 (Swasey, Early Days, 172-177; Eldredge, California, III, 310, portrait; Bancroft, California, V, 726; Willey, Transition Period, 117; San Francisco Call, 1890, Sept. 8 3/3). 


\title{
DOCUMENTARY APPENDIX
}

\author{
Handbill Issued in San Francisco, February 22, 1851 \\ Following the Attack on C. J. Jansen \\ Citizens of San Francisco
}

The series of murders and robberies that have been committed in this eity, without the least redress from the laws, seems to leave us entirely in a state of anarchy. "When thieves are left without control to rob and kill, then doth the honest traveller fear each bush a thief!' Law, it appears, is but a nonenity to be scoffed at; redress can be had for aggression but through the never failing remedy so admirably laid down in the code of Judge Lynch. Not that we should admire this process for redress, but that it seems to be inevitably necessary.

Are we to be robbed and assassinated in our domiciles, and the law to let our aggressors perambulate the streets merely because they have furnished straw bail? If so, let "each man be his own executioner." "Fie upon your laws!', They have no force.

All those who would rid our city of its robbers and murderers, will assemble on Sunday, at two o'clock, on the Plaza. (Alta California, 1851, Feb. 23, 2/2. See supra, p. 172.)

\section{The Popular Trial of Windred and Berdue, San Francisco, FEBruary 22, 1851}

\section{Described by William T. Coleman}

I said, “We don't want a mob; we will not have a mob! But let us organize as becomes men. Let it be done immediately, here, as a committee of citizens, and as a court, and coolly maintain the right, and insist upon it. These men can be tried in three hours time, and the truth known as clearly then as it ever can be. . . . The witnesses are all here. If any delays are allowed, they will probably be spirited away, as others have been heretofore, and justice cheated, and the high-handed outrages, lately so common, will be encouraged, continued and increased.', A loud response went up on every side. I then said, "All who are in favor of this motion, that we organize and take this business in our own hands immediately, will signify it by saying, Aye.', There was one unanimous shout and yell. . . . . I moved into the inner hall, which had been used I believe as a court room, and the mob moved with me. I mounted a chair, and asked that the assemblage should select a good citizen, one of the best men in the city, to act 
as Judge. Mr. Spence, an English merchant I think, was soon selected, and upon invitation, took the seat of the Judge. I then proposed that a jury be impaneled, to consist of a dozen of the best eitizens. I then proposed that counsel be selected, or that they might volunteer. For the prisoners, Hall McAllister, Calhoun Benham, and Judge Shattuck volunteered and were soon at the post. I asked for volunteers for the prosecution, and on all sides they cried out that I must conduct the prosecution. I asked if I must be alone, and they insisted, "Yes," that they were all with me. .... I then required that the prisoners be in the immediate charge of our friends, and it was responded to. As it had by this time grown to be about noon, I proposed that the mass of people should adjourn to their homes, get their mid-day meal, and come back to prepare for the work of the afternoon. ....

One purpose I had in the adjournment was to call upon some of the leading eitizens-Howard, Green, Brannan and others..... I wanted the co-operation of the oldest, best known and most valued citizens. I was very young, partly unknown, and did not want to make a misstep nor a mistake, and felt that the course, under the circumstances, was the better one. I believed that I could soon convince them of it, and I wanted to prevent any needless opposition, should such a thing be contemplated, and eatch any valuable suggestions that might be dropped. I drove to the residence of some, asked friends who flocked around me to see others, and had soon canvassed the subject with all I could reach. The result was that a number of those who had acted with the mayor heartily joined us and proceeded to the Court House. Others simply refrained, saying they were willing for the people, if they wished, to follow the course adopted in the morning. They pretty much all admitted the almost positive certainty of a mob and a mob execution, unless a better direction were given to our highly excited people, and that a fair trial in the way I proposed, though a hasty one, would be far preferable. (MS Statement, 7-10, passim. See supra, p. 174.)

\section{Organization of CRIMe in this State}

Extract from the San Francisco Herald, June 5, 1851

The recent detection of a band of marauders at Stockton, developing a brotherhood in crime extending throughout the entire country, and the watchfulness of the people, both there and in this city, gives promise that, with a united effort in every portion of the country infested by these scoundrels, we shall soon be rid of their depredations. . . . . It is full time some means were adopted to rid the country of this organization. The commencement should be made in this city, and the means are very simple. .... A committee of citizens should be appointed-those acquainted with them should be employed to point out these notorious characters-a vessel 
should be chartered and victualled, and every man known to the police to be implicated in crime, should be placed on board and sent out of the country. Hanging would have an excellent example unquestionably, but hanging one or two will not rid the community of the remainder. Let a general war be made on those scoundrels-quietly and without bloodshed let it be-but with the distinct intimation that should they ever return they will be summarily dealt with. We believe that to send them out of the country is the only effectual method of getting rid of those pests, and we trust the method will be adopted. (See supra, p. 184.)

\section{ExtraCt Fron the Strockton Journal}

Printed in the San Francisco Herald, June 10, 1851

\section{To the Public}

Citizens of Stockton: Without any war cry we already have an enemy in our country and in the midst of our town. The signal is Theft! Murder!! Fire!!! ....

Our laws are treated with contumely; our respectable citizens are supplanted by wholesale hordes of refuse from Sydney and other countries, who find how easily in California they can resume their old trades of robbery, plunder and incendiarism, and soon this golden country will be known only as the rendezvous for pirates by land and water.

Citizens! We are as yet strong enough to meet the enemy, and the remedy is with ourselves.

The laws are good for peaceful times, but not for such a state of tuımoil as the present. For such uncommon times, we should have equally stringent measures to meet them.

Citizens! in such an emergency you have to frame your own laws. The country is in danger and there is no time to wait.

The government and the people are one! Show that, if necessary, you can rule yourselves! All hope of justice is fallacious. Citizens of Stockton, our town is also included in the warfare. Fire, robbery, and murder are the order of the day. Wait not until it is too late, but call a meeting, appoint a commission and proclaim at once martial law, and lead the way.

All industrious men earn a living: the sick and infirm we are glad to help, but the thief, incendiary and murderer can expect no merey at our hands.

In martial law there are some few inconveniences, but the good citizen will not object to that which will assure his life and property, an the guilty being executed on the spot will prevent our prisons from filling, consequently the prisoners from escaping.

G. WALDO.

(See supra, p. 184.) 


\section{Propositions for Public Safety}

\section{Extract from Alta California, June 8, 1851}

Messrs. Editors-You are very well aware that the engrossing and absorbing topic at present, in this community .... is the insecurity of our lives and property, owing to our eity's being infested with the most desperate and determined and well organized band of villains with which any population was ever cursed. . . . . Desperate diseases require desperate remedies, and though the remedies I am about to suggest may not be strictly in accordance with the law, I believe the time has come when it is demonstrated that we must be a law unto ourselves, and there are enough good men and true who are ready to take hold and make root and branch work of this infernal system of crime which now stalks forth boldly in our midst. ....

I propose then, to establish a committee of safety, whose business it shall be to board, or cause to be boarded, every vessel coming in from Sydney, and inform the passengers that they will not be allowed to land, unless they can satisfy this committee that they are respectable and honest men ... . and let any one transgressing this order be shot down without merey. ....

The next remedy I would propose would be to appoint a committee of vigilance, say of twenty men, in each ward, whose duty it shall be to hunt ont these hardened villains .... and give them five days to leave the city, warning them at the same time that after that a war of extermination will be commenced against them. . . . It may be well to call a public meeting in the square, to organize and carry out these views. . . . Without this, or some similar plan, the evil cannot be remedied, and if there is not spirit enough amongst us to do it, why then in God's name let the eity be burned, and our streets flow with the blood of murdered men. I will do what I can to defend myself and take my chance with others, but I will not believe this is so, and trust that immediate public action will take place.

(Written by R. S. Watson. See supra, p. 184.)

JUSTICE.

\section{Crime in San Francisco}

Extract from the California Courier, June 10, 1851

It is clear to every man that San Francisco is partially in the hancis of Criminals, and that crime has reached a crisis where the fate of life and property are in imminent jeopardy. There is no alternative now left us but to lay aside business and direct our whole energies as a people to seek out the abodes of these villains and execute summary vengeance upon them. .... What now shall be done? Are we to continue to threaten, and nothing 
more?... Why stop, under the present unsafe and uncertain state of affairs, to have a thief, or one who attempts to fire the city, placed in the hands of law officers, from whose clutches they can, with ease, be relieved by false swearing, and the ingenuity of lawyers? or what is equally as certain, their escape from prison? Where the guilt of the criminal is clear and unquestionable, the first law of nature demands that they be instantly shot, hung, or burned alive. .... We must strike terror into their hearts.

Those who object to this summary and terrible mode of punishment, ought to recollect the men who were burned to death in the last fire. In thus punishing these criminals we may save the lives of hundreds of innocent beings. .... We can bear these things no longer. No man, since we became a eity, has been hung in San Francisco. Some fifty murders have been committed, but no murderer has suffered death for his crimes.

We ask again, what shall be done? We are in the midst of a revolution, and we should meet the emergencies of our condition with firm hearts and well-braced nerves. We have no time to talk about the defects of the lawsof the dangers which beset us; but we must act, and act at once-act as men do in revolutiouary times. . . . . We hope a meeting of the people will be called to-morrow afternoon, at 4 o'clock, in the Plaza, to organize a powerful force, and to establish some system of measures to rid this community of the criminals who infest it. . . . Men of San Franciseo, act, and act at once. (See supra, p. 185.)

The Ogranization of the Comaittee of Vigilance Described by the Members

Statement of James Neall, Jr.

On Sunday [June 8] ... George Oaks, [Oakes] .... in conversation with me, upon the perilous condition of society at that time, said we ought to take some steps to see if we could not change these things, and suggested that we should go up and have a talk with Sam Brannan, and we went up to Brannan's office, on the N. E. corner of Sansome \& Bush Sts. We there found Mr. Brannan and his elerk, and sat down and talker the matter [over]..... We discussed the subject, and .... concluded that something must be done, and it was suggested that each one of us should give Mr. Brannan's elerk, Mr. Wardwell, the names of such men as we could mention, whom we knew to be reliable, to invite them to meet us at 12 o'clock noon the next day, at the California Engine House . . . . to devise some means of protecting ourselves from the depredations of this hoard of ruffians, who seemed to have possession of the city. There was no such thing as doing anything with them before the Courts; that had been tried in vain. Notices were sent out to parties to the effect that they 
were nominated, each as chairman of. a committee for his neighborhood, to invite their fellow eitizens, good reliable men, to meet.... as above indicated.

In pursuance of that call, at 12 o'clock on Monday, there was a large gathering, so that the room was crowded. There they entered into a discussion upon the evils by which we were surrounded, and .... what the remedy should be .... and the meeting then adjourned, to assemble again that evening at the old Brannan building, on the N. W. corner of Sansome and Bush Sts. for the purpose of organization and settlement of a course of action. The adjourned meeting was held that evening, and a partial organization was effected, and they adjourned to meet on Tuesday evening at the same place. There they perfected the organization, and determined upon a method by which the society should be called together, in case of any disturbance, which was three taps of the bell on the California Engine House at the junction of Bush and Market Sts. The bell was not on the engine house but was on the ground. (MS Statement, 1-3.)

\section{Statement of William T. Coleman}

I had nothing more to do with public matters until I received one day a circular, signed, I think, by Col. J. D. Stevenson, asking me to meet a number of good eitizens of the place, the next evening, at the building of Mr. Samuel Brannan .... to consult on measures needed for the safety of life and property in the eity. This was on [Tuesday] the 10th of June, 1851. I was early at the building, and found a number of gentlemen there, probably thirty or forty already. An organization was formed, and the objects of the meeting stated, with a brief discussion. Articles had been already prepared for the mode of organization, and some thirty or forty names were enrolled, and it was styled the Committee of Vigilance of San Francisco, the avowed objects of the Committee being to vigilantly watch and pursue the outlaws and criminals who were infesting the city, and bring them to justice, through the regularly constituted courts, if that could be, through more summary and direct process, if must be. Each member pledged his word of honor, his life and fortune if need be, for the protection of his fellow members, for the protection of life and property of the citizens and of the community, and for purging the city of the bad characters who were making themselves odious in it. After arranging for concert of action, watchwords, and a signal to be used to call the members to the rendezvous .... and detailing officers for immediate duty, enrolling a number of members, all among the most respectable, substantial and wellknown citizens of the place, and the disposition of some needed business, the committee adjourned for the evening. (MS Statement, 17-18.) 


\section{Official Announcement of the Committee of Vigilance}

On June 13, 1851, the San Francisco Herald and the Alta California printed the constitution of the Committee of Vigilance, and also the following official announcement:

WHEREAS, the citizens of San Francisco convinced that there exists within its limits a band of robbers and incendiaries, who have several times burned and attempted to burn their eity, who nightly attack their persons and break into their buildings, destroy their quiet, jeopardize their lives and property, and generally disturb the natural order of society; And WHEREAS many of those taken by the police have succeeded in escaping from their prisons by carelessness, by connivance, or from want of proper means or force to secure their safe confinement, therefore be it

RESOLVED, That the citizens of this place be made aware that the Committee of Vigilance will be ever ready to receive information as to the whereabouts of any disorderly or suspicious person or persons, as well as the persons themselves when suspected of crime.

RESOLVED, That as it is the conviction of a large portion of our citizens, that there exists in this eity a nucleus of convicts and disorderly persons, around which cluster those who have so seriously disturbed the peace and affected the best interests of our city, such as are known to the police of the city or to the members of the Committee of Vigilance as felons by conduct or association, be notified to leave this port within five days from this date, and at the expiration of which they shall be compelled to depart, if they have not done so voluntarily within the time specified.

RESOLVED, That a Safety Committee of thirty persons be appointed, whose sacred duty it shall be to visit every vessel arriving with notorious or suspicious characters on board, and unless they can present to said committee evidences of good character and honesty, they shall be reshipped to the places from whence they came, and not be permitted to pollute our soil.

RESOLVED, That all good citizens be invited to join and assist the Committee of Vigilance in earrying out the above measures, so necessary for the perfect restoration of the peace, safety and good order of our community.

The names of the first hundred and eighty members were printed as signers of the constitution and announcement, and the communication continued:

The above, a portion of the Committee of Vigilance lately established in this city for the preservation of order, punishment of vice, and for the purpose of meteing [sic] out that justice so long withheld from criminals, unwilling that the names of a few of their associates should be selected by the Coroner's jury as the principal actors in the trial and execution of 
Jenkins, inform the public that they, with all the members of the Committee are equally responsible for the first act of justice that has been dealt to a criminal in San Francisco since California became a State of our Union.

Our fellow citizens, remembering the escape of Withers, Daniels and Adams; of Stuart, Windred and Watkins, and the tardy manner in which the incendiary Lewis is being brought to justice, will see the necessity of the stringent measures we have adopted.

This publication also informs those friendly to the eause that the Committee of Vigilance have nothing secret in their proceedings, but such matters as would tend to defeat the object for which we are associated, were they made public. (See supra, p. 216.)

\section{The Methods of the Committee of Vigilance}

The Executive Committee had all cases brought before them to dispose of. They had nothing to do with arrests, unless they were very efficient men, and could not be kept still. When any men were arrested and turned over to the Committee, they were tried by the Executive and such trials were as honest and impartial as ever a man had, and no man was convicted without an abundance of testimony, such as would convict any human being in any court of justice; only we could not allow any alibis to come in to screen these fellows. After the trial and conviction of the prisoner, the case was referred to the General Committee for its action, and the testimony was sent to them. They invariably confirmed the decisions of the Executive Committee, and it was impossible for them to do otherwise, in the face of such proofs as were offered.

The Committee was composed mostly of our best men; the salt of San Francisco joined us. Every thing was organized in a proper and unmistakable shape, so that every man had his duty to perform, and he had to report daily to the Committee, and if anything had transpired it was properly noted. Every man had his place, and there was a place for every man; there were no drones there. (G. W. Ryckman, MS Statement, 5. See supra, p. 222.)

\section{Handbill Calling for a Mass Meeting to Sustain Law and Order}

The people of the eity and county of San Francisco, republicans one and all, are called upon to choose now, ere it is too late, which they will serve-the law and order power of our eity, or the dictators and anarchists who have lately disgraced our city by their lawless and eriminal proceedings, and are yet endeavoring to assume unlimited and unlawful power in the punishment of criminals. Even now they are going from door to door, from eity to eity, soliciting desperate men to join their secret Committee, 
with a view to transfer the criminal jurisdiction from our legally constituted tribunals into their own irresponsible hands, thus subverting all government, all law, all justice, as made and provided by the United States and our own state constitution. Will ye, lovers of law, and order, and social compact, longer tolerate such men in their career of murder and subversion of the laws, among whom are those guilty of the very erimes they profess to punish? Shall it be said that our police is not of sufficient force to arrest these murderers, and our eity officials shall wink at their outrages, thus perjuring themselves? Shall we tolerate, in this enlightened age, a Danton, a Robespierre, or a Fouché, and all the paraphernalia of a secret inquisition for the suppression of our laws and criminal courts? Then to the rescue of law and order from the hands of a secret inquisition, every good citizen, and without further invitation turn out en masse to a public meeting to be holden on the plaza, Sunday next, June 22d, at three and a half o'clock, P. M., and there join in the general opposition to the acts and further operations of midnight murderers; and let the eivilized world know that we ean and will support law and order, and that our social compact shall be as much observed by the wealthy criminal, public robber, and law subverters, as by the lowly thief.

Many Citizens.

(Popular Tribunals, I, 321-322. See supra, p. 239.)

\section{REWARD FOR INCENDIARIES}

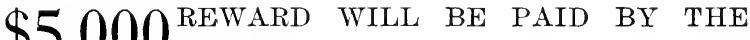 D., O00 Committee of Vigilance to any person} or persons who will place in its power any man against whom sufficient evidence can be brought to convict him of the erime of arson.

$\mathbf{F}^{\mathrm{L}}$ COMITAdo DE VIGILANCIA ha decidido, en L su sesion de anoche, que la soma de einco mil pesos seran pagados a la persona o personas por la aprension $y$ conviceion de un incendiario ante dicho Comitado.

I E COMITE DE SURVEILLANCE a decide, dans La seance d'hier soir, que cinq mille piastres seraient donnees a quiconque mettrait dans son pouroir avec temoinage suffisant pour la conviction de toute personne coupable du erime d'incendie.

DER SICHERHEITS COMITE in seiner sitzung ron gestern abend beschlossen fuer die auslieferung eines Brandstifters die summe von fuenf tausend dollars zul bezahlen.

(Reproduced exactly as printed in the California Courier, June 26, 1851. See supra, p. 245.) 


\section{Notice of the Committee of Vigilance, San Francisco Herald,} July 2, 1851'

Since the execution of Jenkins .... [the Committee] have increased their numbers, by voluntary enrollments, from one hundred to nearly five hundred. . . . . One hundred of these are always on duty, night and day, and all may be summoned at a moment's notice in case of need. . . . .

They have instituted a most elaborate and thorough investigation into the haunts and character of all suspicious persons.... and where the evidence is satisfactory that individuals live by plunder and rapine .... they have given them a warning to leave the city within five days. By this peaceful means the community has been rid of a great number of the vilest criminals that have infested it. Where obedience is refused to their mandate-as in the case of Hetherington-the Committee proceed in a body to enforce their sentence. They are not children to be trifled with, and the outlaws are now convinced of it.

They have made a number of arrests on suspicion of various crimes. Several have been discharged, no proof being found against them, and others have been found guilty as well of positive crimes brought home to them, as of general bad character, making them dangerous to the peace of the community. Several of those found guilty are now confined securely in the harbor, and arrangements have been made to ship them back to Sydney in a few days. One, a Mexican, was publicly lashed, and then expelled from the city. There are men still under examination for the commission of crime. The Committee are waiting for important witnesses that have been sent for in the interior. To expedite the ends of justice they spare no expense and are deterred by no difficulties. Witnesses will be sent for, when necessary to the fartherest corners of the State, and the committee will bear their expenses. Their arm is long as well as strong. In addition to all this they have offered a reward of $\$ 5000$ for the apprehension and conviction of any one guilty of the crime of arson. These admirable and sagacious means for the prevention of crime, and for the sure and speedy punishment of those caught in its commission, have instilled the hope in the breasts of our citizens that a brighter and better day is before them. The Courts, too, have been incited to unwonted exertions by the presence of this body in our midst, and have lately disposed of criminal cases with great promptness and energy.

Taking all these marked and tangible benefits into consideration, few will regret the past, and all must award the meed of praise to those who thus devote their time, labor and means for the good of the whole community. (See supra, p. 251.) 


\section{Proclamation of Mayor Brenham}

\section{To the Citizens of San Francisco}

We have arrived at an important erisis in the eivil and social condition and prospects of our city. A voluntary association of men has been formed, under peculiar bouds to each other, and assuming most extraordinary and irresponsible powers, and have undertaken to institute extra judicial proceedings in forms not known to the laws. This association claims and exereises the right to inflict penalties upon those adjudged by them guilty of erime, even to the penalty of death, and has publicly and boldly inflicted that penalty in two instances.

They claim and exercise the right of domiciliary visits, without any accountability, of a character not known under any other than Inquisitorial Governments. The great and sacred writ of habeas corpus has been rendered by them ineffectual, and the authority of the highest tribunal of the State disregarded. The circumstances in which the Authorities are placed, in consequence seem to demand of me... some action by which the views and purposes of the eity Government . . . may be indicated. . . .

In a community like ours, where the institutions of government have but just been established, any combinations of citizens.... whose proceedings are not controlled by law or subservient to the support of constituted authority, can have no other than an insurrectionary tendency .... and must, to an absolute certainty, inflict disgrace upon us . . . . and ruin the confidence which it is of first necessity to our prosperity to secure throughout the commercial world. With these views I feel impelled, by the strongest seuse of official duty .... to call upon all citizens to withdraw from such associations, and to unite in a common effort to support the laws, and to sustain a prompt and energetic administration of them in their proper application and action. In addition, I deem the present a proper occasion to announce .... that I shall not shrink from a prompt discharge of the duties . . . made imperative upon me. . . . . I have to call the attention of all citizens to the provisions of the "Act to regulate Proceedings in Criminal Cases," Chap. IV. I, however, appeal to the good sense and deliberate judgment of my fellow eitizens, to relieve me, and the other public functionaries of the eity, by their common submission to public order, from the necessity of any application of the requirements of that act.

Mayor's Office, July 11.

C. J. Brenham, Mayor.

(Alta California, July 14, 1851. See supra, p. 271.) 


\section{Extract from the Charge of Judge Alexander Campbell to the GRAND JURY}

\section{After the Execution of James Stuart}

The question has now arisen, whether the laws made by the constitutional authorities of the State are to be obeyed and executed, or whether secret societies are to frame and execute laws for the government of this county, and to exercise supreme power over the lives, liberty and property of our citizens. .... Are the people willing to throw away the safeguards which the experience of ages has proved necessary-to trample the laws and constitution under foot-to declare that law is inconsistent with liberty-and to place life, liberty, property and reputation at the mercy of a secret society? If such be the disposition of the people . . . it is time for every man who values his life, safety and honor, to shake the dust from his feet and seek out some new home, where he may hope to enjoy the blessings of liberty under the law. But if, on the other hand, we have not quite forgotten the principles upon which our government is formed-if we believe that the constitution and laws of our country should be reverenced and obeyed, and that public order and tranquility should be preserved;-if we believe that persons accused of crime should have an open, public and impartial trial by a fair jury of unprejudiced citizens, and should have a reasonable opportunity of making their defence, of employing counsel and summoning witnesses; if we believe that the good name and reputation of our citizens is to be protected from a secret scrutiny, where accusations are made under the influence of fear, by persons of questionable character;-if we believe that our houses are to be protected from unreasonable searches without color of authority, it is our solemn and bounden duty to take immediate and energetic measures for the suppression of the spirit of reckless violence which overrules the laws and sets the constitution at defiance.

When you first assembled, the Court called your attention to the unlawful execution of a man named Jenkins by an association of citizens. We considered that act was greatly palliated by the circumstances .... that the laws had been defective, and that perhaps there had been some laxity in their administration; that the county had no sufficient jail for the detention of prisoners; that crime had increased to a fearful extent, and that a portion of our citizens, deeming that the law afforded them no protection, had in that instance undertaken to execute what they conceived to be summary justice, in violation of the law, but with a sincere desire to advance the public interest. We further stated that the law had been amended in many respects, so as to secure the speedy trial and conviction of offenders . . . . that the county jail had been put in a proper condition for the safe keeping of prisoners, and we expressed the hope that no further attempt would be 
made to interfere with the legally organized tribunals of justice.... From the time of your assembling, the Court, the Grand Jury, and all the officers have been actively and constantly engaged in the performance of their duties. At the time when they were making every possible effort to dispose of the eriminal business of the county, and when the Court was in actual session and in the performance of its duties; an association of persons, of armed and organized men, have undertaken to trample on the constitution, defy the laws, and assume unlimited power over the lives of the community. There is no excuse or palliation for the deerl.... Every person who in any manner acted, aided, abetted or assisted in taking Stuart's life, or counselled or encouraged his death, is undoubtedly GuILTY OF MURDER. It is your sworn and solemn duty, which you cannot evade without perjuring yourselves, carefully and fully to investigate this matter, and to do your share towards bringing the guilty to punishment. Upon your fearless and faithful discharge of the trust confided to you, depenrls, in a great measure, the future peace, order and tranquility of the community. (Alta California, July 13, 1851. See supra, p. 272.)

\section{Extract from Editorial Comanent on Judge Campbell's Charge}

\section{California Courier, July 14, 1851}

No such committee could exist in any form in this city, if the whole body of the community did not consider that necessity and policy demanded it. The committee is composed of peace loving and orderly citizens-many of them are elders, deacons and conspicuous members of the Church. The are not composed of rowdies or blood thirsty men. . . . . We are not going to complain of Judge Campbell's charge-but we can tell him that the men who hung Stuart cannot be indicted, convicted and executer in California, while the records of the Courts show that some of our best eitizens have been shot down in cold blood, and that the murderers have been permitted entirely to run at large or to slip through their hands, unwhipped and unavenged of justice. These courts heretofore have manifested no holy horror at such deeds. We can say to the Coroner that although he may watch like a hawk the dead body of every villainous culprit executed by the people-so that he may summon a jury to take testimony to criminate the parties-his vigilance will amount to nothing-so long as he ean take his time with the corpses of unoffending men who are murdered in cold blood by notorious criminals. 


\section{Extract from the Report of the Grand Jury, San Francisco, August 2, 1851}

From the Herald, August 4, 1851

There is another subject to which our attention has been directed by the presiding Judge, in his able charge, which has occupied much of our time and serious consideration. It is well known that a large portion of our best and most worthy citizens have associated themselves together, and without the intervention of our legal and constituted tribunals, entered upon the investigation of criminal charges against several persons, and executed sentence of condemnation and death.

When we recall the provisions of the constitution of our government, which it is the bounden duty of every citizen to support and maintain"that no person shall be held to answer for a capital or otherwise infamous crime unless on a presentment or indictment of a grand jury . . . nor be deprived of life, liberty, or property, without due process of law' '--and find, also, the same provision and language in our State constitution, we feel convinced, doubly convinced while we believe the members of that association have been governed by no improper motives, that their proceedings are unlawful, and in violation of the fundamental law of the land. We fear, too, the powerful example of those proceedings may engender a spirit of insubordination, or afford a pretext to other individuals or associations, here or elsewhere in our State, who may not be governed by the same honest motive, or restrained by the same careful investigation of facts, for the perpetration of deeds of violence, which may lead to anarchy and abuses, dangerous to the lives and property of eitizens.

When we recall the delays and the inefficient, and we believe that with much truth it may be said, the corrupt administration of the law, the incapacity and indifference of those who are its sworn guardians and ministers; the frequent and unnecessary postponement of important trials in the District Court, the disregard of duty and impatience while attending to perform it manifested by some of our Judges having eriminal jurisdiction, the many notorious villains who have gone unwhipped of justice, lead us to believe that the members of that association have been governed by a feeling of opposition to the manner in which the law has been administered and those who have administered it, rather than a determination to disregard the law itself.

Under institutions so eminently popular as those under which we live, the power of correcting all these abuses is with the people themselves. If our officers are unfit for the stations they oceupy, if the laws are not faithfully executed, if an arraigned criminal procures his own friends to be placed on the jury that tries him, where is the fault and where the remedy? If those of our citizens who are most interested in having good and whole- 
some laws, and in seeing them purely administered, will not give sufficient attention to our elections to procure proper and sober legislators, judicial and other officers, and neglect to obey the mandates of our courts when summoned as jurors and witnesses, as has been too often the case, can they expect to see justice prevail? and is it not in the neglect of their duties in these important particulars they may find the true fountains from whence have sprung many of the evils we have suffered? The Grand Jurors, believing whilst they deplore their acts, that the association styling themselves the "Vigilant Committee", at a great sacrifice to themselves, have been influenced in their actions by no personal or private malice, but for the best interests of the whole, and at a time too when all other means of preventing erime and bringing criminals to deserved punishment had failed, here dismiss the matter as among those peculiar results of circumstances that sometimes startle communities, which they can neither justify or by a presentment effect any benefit to individuals or the county; and with the assurance that there is a determination on the part of all well disposed citizens to correct the abuses referred to by selecting proper officers to take the places of those who have violated their trusts, and by performing each his part in the administration of the laws. When this is done the axe will have been laid at the root of the tree-the proper remedy applied for the correction of the grievous evils our city and county have so long suffered, and there will be no necessity for the further action of that Committee. To them we are indebted for much valuable information and many important witnesses.

George Endicott, Foreman.

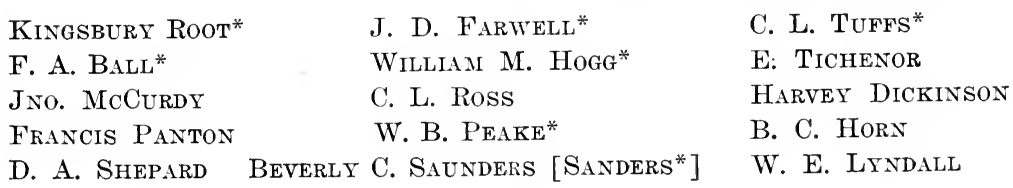

(The jurymen designated by $a *$ were members of the Committee of Vigilance. See supra, p. 273.)

\section{Proclamation of Governor McDougal}

Executive Department, Vallejo, July 21st, 1851

To the People of the State of California.

It has been represented to me that organizations of citizens, styling themselves "Vigilance Committees," have been formed in various portions of the State, and assume powers inconsistent with the existing laws, and serious apprehensions are entertained of collision between the constituted 
authorities and the citizens thus organized; and it becomes my duty to take some step by which so great a calamity may be averted. It is earnestly hoped that a few simple and practical suggestions may serve to secure this desirable end.

No security of life or property can be guaranteed except the constitution and laws are observed. Let these be forcibly dispensed with, their sacredness violated, and submission to their authority refused, and we are reduced to a state of anarchy more dangerous in its tendencies and probable results than the worst laws, under our system can possibly be, no matter how corruptly administered. We are just entering upon our career, our character is not yet formed, people from all climes and all countries are flocking to our shores, it then becomes us to take no unadvised step which shall retard our progress now or prejudice our elaims to a high and commanding stand hereafter. But more than this, we owe it to ourselves to impress upon the strangers who have settled amongst us, unacquainted with, and perhaps entertaining prejudices unfavorable to the practical operation of our peculiar institutions, that our government is a government of laws, and that though they may sometimes prove inadequate, sometimes operate oppressively, or be administered corruptly, the remedy is not in a destruction of the entire system, but is to be secured by a peaceful resort to those constitutional means which are wisely afforded to reform whatever abuses may exist, and correct whatever errors may have been committed.

The occurrences of the past three or four weeks, the apprehension of individuals within the jurisdiction of legally constituted tribunals, their trial, sentence, and execution without authority of law, by a voluntary association of citizens, who thus virtually place themselves above and beyond all law except that prescribed by and for themselves, will prove sufficiently prejudicial to our interests abroad, commercial and otherwise, if such organizations, assuming such unquestionably dangerous powers, were now dissolved, but if continued there is no calculating the extent of the injury which may result to us as a State. The dangerous tendencies, in other respects, of organizations of the character under consideration, the excitement produced in the public mind, consequent upon their action, resistance to the constituted authorities, which must almost inevitably result, and threatened collisions between themselves and officers of the law in the execution of their duties, cannot but be appreciated and deprecated by every right thinking and patriotic citizen of the State, and need not therefore be dwelt upon here. Whatever may have been the exigency heretofore existing, requiring, or supposed to require the adoption of extraordinary measures on the part of the citizen, it has now happily, in a great degree, passed, and such measures should, on this account, if on no other, be at once abandoned. Another eriminal code, with more efficient provisions, attaching adequate penalties to the commission of offenses, and directing 
a more prompt and effective administration of justice, has gone into operation. Courts are now enabled to try, sentence and execute as the offence deserves; safe and secure prison-houses are being provided, and the officers, there is reason to believe, are ready and anxious to discharge the high duty imposed upon them by the people.

I cannot do less therefore, than earnestly recommend to my fellow citizens everywhere throughout the State to aid in sustaining the law, for in this is our only real and permanent security. Associations may be organized, but they should be formed with the view to aid and assist the officers of the law in the execution of their duties, and act in concert with the eivil authorities to detect, arrest, and punish criminals. By pursuing this course, much good may, and undoubtedly will, be accomplished, and all the dangers which threaten unlawful assumptions of power, thus averted. Inefficiency will not then secure impunity to crimes, nor dangerous criminals be permitted to go unwhipt of justice. It is my sworn duty to see that the laws are executed, and I feel assured that all good citizens will cordially cooperate with me in its discharge.

(Alta California, July 23, 1851. See supra, p. 27t.)

JoHN McDougaL, Governor.

Affidavit and Warrant for the Seizure of Whittaker and McKenzie

State of California,

County of San Franciseo.

I, John McDougal, of the city of Vallejo, county of Solano, and State aforesaid, being duly sworn, depose and say, that I have good reason to believe and do believe that Samuel Whittaker and Robert MeKenzic are illegally held in eustody, confinement or restraint by a body of men styling themselves "The Vigilance Committee of the eity of San Francisco", and that there is good reason to believe that they will be carried out of the jurisdiction of this Court, or will suffer some irreparable injury before a compliance with a writ of habeas corpus can be enforeed. And further, says not.

JoHn McDougal.

Sworn to and subseribed before me, this 20th day of August, 18.51.

MYron NorTon

Ass't Justice of the Superior Court

City of San Francisco. 


\section{State of California, County of San Francisco.}

The People of the State of California to the Sheriff of said County, greeting :

Whereas it has been represented to me, an Associate Justice of the Superior Court of the city of San Francisco, upon oath, that Samuel Whittaker and Robert MeKenzie are restrained of their liberty by a body of men styling themselves the Vigilance Committee of the City of San Francisco, and that there is good reason to believe that said Whittaker and McKenzie will suffer irreparable injury before compliance with the writ of habeas corpus can be enforced-you are therefore commanded to take said Whittaker and McKenzie and forthwith bring them or either of them before me, at the Court House in San Francisco aforesaid, to be dealt with according to law.

Witness my hand and the seal of the said Court, this 20th day of August, 1851.

\section{MYron NoRTon, \\ Associate Justice of the Superior Court, City of San Francisco.}

On this was indorsed the Sheriff's return as follows:

I hereby certify that I received the within writ, at 3 o'clock A. M., and executed the same by taking the bodies of Samuel Whittaker and Robert McKenzie, and have them now in my custody.

August 20th, 1851.

JoHN C. HAYs, Sheriff.

(San Francisco Herald, August 21, 1851. See supra, p. 295.)

\section{Non-Partisan Address to the Voters of San Francisco}

TO THE PEOPLE OF THE CITY AND COUNTY OF SAN FRANCISCO

In view of the General Election, on the eve of which you now stand . . . . we, the undersigned, citizens of San Francisco, appeal to you, in the name of the common good of California, and would earnestly urge, that in casting your votes for suitable men to enact and administer laws, you will be careful to disregard all questions but such as relate to the general welfare.

In whatever light we may examine the present evils of society, every man must come to the conclusion that the primary error is in the people themselves. Trace the troubled waters of the community back to their source, and the explorer will find his journey terminate at the ballot box. There is where the fountain of evil found vent-not in the votes there given, so much as in the neglect of those who should have been there to select and elect proper men. ....

Herewith we present to your consideration and suffrages the names of certain gentlemen for the respective offices so soon to be filled as you may 
decide. In making the selection, we have cast aside every question but that of their fitness on the score of honesty and integrity of character, faithfulness to the interests of our eity and State, and mental qualifications for the position. We ask you to receive them as such. ....

Sweep clean the Augean stables of legislation; purify the ermine; show by your votes that honesty and virtue are at a premium in public estimation; and that hereafter no qualifications but those of integrity and capacity can pass current with the voters of this eity and State.... You have now the corrective in your own hands. The fate of California hangs trembling within your reach. You cannot neglect to act without criminal indifference; you cannot vote for any but honest and respectable men, without danger and disgrace.
J. L. BLOOD,
W. L. Bromley,
W. H. Jones,
H. M. NAGLeE,

JAMES KING OF' WMr.,

G. W. RYckMan,

S. L. DEWEY,

S. E. WOODWORTH,

W. D. M. HowARd,

JAS. B. HUIE,

Geo. M. GARWoOd, JAS. WADSWORTH, Jas. F. Curtis, W. A. Darling,

Nominating Committee.

(Alta California, August 27, 1851. All the signers were members of the Committee of Vigilance. See supra, p. 324.)

\section{Extract from a Speech Made at the Presentation of a Banner to the Committee of Vigilance}

Mr. Brooks, spokesman for the donors, said, in part:

This presentation is not a hasty movement. .... In the month of June .... the ladies of Trinity Parish .... resolved to express their full approbation of the acts of this Committee by the presentation of a banner. . . . .

The ornaments of the banner are intended to assist in expressing the confidence of the donors in this association, their reliance upon its strength and protection, and their confidence in the blessings which will flow from its existence and its action. On that side of the banner which bears the name of this association, the date of its organization and the purposes of its creation, the inscription is enclosed in a wreath of live oak, an emblem of their strength that defies the storms and tempests that howl and threaten around it. .... Entwined with this emblem on the one side is the fig. The emblem of home with all its pictures of quiet delight, of prosperity, ... . of happy faces and loving hearts. . . . .

On the other side the oak entwines with the olive.-Because from your strength comes peace..... Under the protection of your vigilance and strength, our rights, our lives, our persons and our property is safe from rapine and violence; but what is of far more importance, and what I feel from the bottom of my heart is, that in your banded strength, our dearest treasures, our wives and children find a safe and sure protection..... 
On the reverse of the banner which bears upon its more delicately tinted front the names of those who gave the banner, and the reason why it was given, a simple wreath of varied flowers encircles the inscription.....

This gift comes with peculiar appropriateness from the ladies. Ai the time that this society was organized our situation was very different from what it is at present.-It is true that the strong man with loaded revolvers in his pocket, and bowie knife concealed in his breast, might defy the attacks of the Syrlney convict and the refuse of all the world which infested our eity; but it was different with the weak and defenseless woman. She who sits patiently at home waiting for her husband's return from his businessin every noise about the house she fears the burglar and the robber. . . . If the husband is delayed beyond his usual time, a thousand fears, a thousand horrid visions of murder and outrage and violence come upon her heart, and fill her with anguish and dismay. Such was San Francisco-but now we live in peace; we sit beneath our vine and fig tree happy and secure, and woman's heart feels and this her gift expresses, her gratitude.

Gentlemen, accept this gift, and in all your actions, in all the assaults which may be made upon you by those who hate or those who fear or those who doubt, remember the motto which it bears, "do right and fear not," for in the end blessings will ever reward you for your laborious vigilance for the protection of our lives and property. (San Francisco Herald, August 12, 1851. See supra, p. 372.)

\section{Extract from a Report of the Grand Jury of Tuluumne County, California, October 9, 1855}

The Grand Jury would further report that there exists in their belief at the present time, or have recently existed in several of the camps of this county organized bodies of men who style themselves Vigilance Committees, or Committees of Public Safety. These committees were organized at first no doubt from a laudable desire to assist in the suppression of crime, which at a time not long since seemed to be committed almost with impunity in our midst. They were in the first instance, we believe, organized by many of the best citizens of the county-men who were actuated by no other motive than the detection of villainy and the punishment of crime. Many, if not all, of these citizens only designed to co-operate with the officers of the law, that the law might be more effectually executed and made more efficient in the preservation of life and the protection of property. But we regret the necessity we are under to state that irresponsible parties, men who under ordinary circumstances would not be considered safe repositories of power have crept in and under cover of these committees assumed the power of making arrests, and from what light we have before us have committed acts which should not be longer tolerated in our midst. 
In view of these facts the Grand Jury most earnestly recommend and urge that all good citizens throughout the county who were members of these committees or who countenanced their existence, will use all their influence in disbanding these organizations and thereby put a stop to all extra-judicial proceedings as have recently taken place. Justice and humanity demand that this course should be immediately adopted. (Archives of the County Clerk, Grand Jury Reports. See supra, p. 395.)

\section{Executive Comaitee of the Committee of Vigilance of 1856}

(Members of the Committee of 1851 are marked with $a^{*}$ )

President, W. T. Coleman*.

Vice-Presidents, C. J. Dempster, S. T. Thompson*, J. D. Farwell*, W. H. Tillinghast*, Lorenzo Hubbard, J. M. Taylor*, T. J. L. Smiley*, A. W. Bell, D. S. Turner*.

Secretary, Isaac Bluxome, Jr.*; Assistant Secretary, Charles Ludlow.

Treasurer, James Dows*; Assistant Treasurer, William Meyer*.

Grand Marshal, Charles Doane.

Sergeant-at-arms, Jerome Rice.

Chief of Police, Oscar Smith*; afterward, J. F. Curtis*.

Director of Police, A. M. Burns; afterward, W. C. B. Andrews.

Surgeon in Chief, Dr. R. B. Cole.

Executive Committee: W. T. Coleman*, T. J. L. Smiley*, James Dows*, J. P. Manrow*, S. T. Thompson*, W. T. Thompson*, R. B. Cole, J. S. Emery, N. O. Arrington, L. Bossange, Charles Doane, J. K. Osgood, R. M. Jessup*, J. H. Fish, M. J. Burke, C. L. Case*, F. W. Page, [C.] E. Grisar*, C. J. Dempster, J. D. Farwell*, O. B. Crary, W. H. Tillinghast*, William Arrington, E. P. Flint, W. T. Reynolds*, Eugene Delessert*, N. P. Hutchings, J. W. Brittan, W. H. Rogers, M. F. Truett, C. V. Gillespie*, Isaac Bluxome, Jr.*, H. S. Brown*, E. B. Goddard, E. Gorham*, G. R. Ward*, A. M. Burns. (Popular Tribunals, II, 113. Colville's San Francisco Directory for 1856 printed a list of officers, but the publisher tried to obliterate it by pasting a printed slip above the paragraphs.) 


\section{CLASSIFIED LIST OF MATERIAL}

This list includes the works which have been eited in the footnotes of this volume, with the addition of a few supplementary authorities of recognized importance. It contains, however, but a portion of the extensive literature relating to California, 1846 to 1860, and every student of the period must constantly refer to the excellent Bibliography compiled by Mr. Robert E. Cowan. The fullness of entry presented there is impossible here, but important bibliographical details have been noted as the author has thought necessary. Titles omitted by Cowan are given here with particular fullness, rare books are described more carefully than familiar authorities, and abbreviated titles are indicated by the conventional symbols. The number of pages is noted when a publication contains less than one hundred; also in the description of manuscripts and of some rare books.

For Californiana not included in the Bancroft Library reference is made to the following collections:

California State Library, Sacramento.

Henry E. Huntington Library, San Gabriel, California.

M. H. de Young Memorial Museum, Golden Gate Park, San Francisco.

Collection of Mr. Robert E. Cowan, San Francisco.

Collection of Mr. Charles B. Turrill, San Francisco.

Collection of Mr. Henry R. Wagner, Berkeley, California. 


\section{SCHEME OF CLASSIFICATION}

Public Documents

Congressional Documents

Miscellaneous Federal Documents

Bibliographies

\section{Californiana}

Newspapers

Series and Periodicals

State Documents

Local Official Documents

Local Histories and Directories

Contemporary Works, Published or Written 1844-1860

General Histories, Biographies, and Reminiscences, 1861 to date Manuscript Reminiscences in the Bancroft Library

Printed Works

The San Francisco Committees of Vigilance, 1851 and 1856

Archives of the Committee of 1851

Archives of the Committee of 1856

Manuscript Statements of Members in the Bancroft Library

Printed Accounts of the Committees

Committees of Vigilance elsewhere than in San Francisco

\section{Miscellaneous Works}

General Authorities

Series, Periodicals and Newspapers 


\section{PUBLIC DOCUMENTS}

\section{Congressional Docunents}

The Congressional reports relative to the occupation and military government of California appear in bewildering duplication. A useful analysis is made in the Index to Publications ... . Relating to Mexico, published by the War Department Library. Bancroft's footnotes, as cited supra, chapters one and two, generally cover exact reference to the official records. The subjects of the documents listed below are indicated in parentheses.

Serial

number

49329 Cong., 2 Sess., Sen. Doc. 1. (Reports of Sloat and Stockton. With President's Message of December 8, 1846.)

49929 Cong., 2 Sess., House Doc. 19. (Oceupation of Mexican Territory. With Message of December 22, 1846.)

50330 Cong., 1 Sess., Sen. Ex. Doc. 1. (Kearny's overland march. With Message of December 7, 1847.)

50730 Cong., 1 Sess., Sen. Ex. Doe. 33. (Court Martial of Frémont, 1847-1848.)

52030 Cong., 1 Sess., House Ex. Doe. 60. (Mexican War correspondence, 1846-1848.)

52130 Cong., 1 Sess., House Ex. Doc. 70. (New Mexico and California. With Message of July 24, 1848. 49 pp.)

53130 Cong., 2 Sess., Sen. Ex. Doc. 31. (Reports of Stockton.)

53730 Cong., 2 Sess., House Ex. Doc. 1. (Reports from California. With Message of December 5, 1848.)

54931 Cong., 1 Sess., Sen. Ex. Doc. 1 [pt. 1]. (Operations in California. With Message of December 4, 1849.)

55731 Cong., 1 Sess., Sen. Ex. Doc. 18. (See note on Ser. No. 573.)

55831 Cong., 1 Sess., Sen. Ex. Doc. 47. (P. T. Tyson, Geology . . . . of California, 1851.)

56131 Cong., 1 Sess., Sen. Ex. Doc. 52. (Correspondence of General Riley. With Message of May 22, 1850.)

57331 Cong., 1 Sess., House Ex. Doc. 17, 1850. (California and New Mexico. With Message of January 21, 1850. Cited in this volume in preference to Ser. No. 557, which contains practically the same material with some additions and omissions.) 


\section{Bibliography}

Serial

number

57731 Cong., 1 Sess., House Ex. Doc. 59. (T. B. King, Report on California, 1850.32 pp.)

58931 Cong., 2 Sess., Sen. Ex. Doc. 18. (W. C. Jones, Land Titles in California, 1851.)

68833 Cong., Special Sess., Sen. Doc. 4. (Indian agents in California. With Report of the Secretary of the Interior, March 17, 1853.)

82434 Cong., 1 Sess., Sen. Ex. Doc. 101. (Committee of Vigilance of 1856. With Message of August 6, 1856. $30 \mathrm{pp}$.

83534 Cong., 2 Sess., Sen. Mise. Doc. 1. (C of V., 1856. Printed with 34 Cong., 1 Sess., Sen. Misc. Doc. 82.1 p.)

88134 Cong., 3 Sess., Sen. Ex. Doc. 43. (C. of V., 1856. Report of the Secretary of War. 29 pp.)

124039 Cong., 1 Sess., Sen. Rep't. 105. (Occupation of mineral lands. 3 pp.)

128939 Cong., 2 Sess., House Ex. Doc. 29. (J. R. Browne, Report on mineral resources.)

129339 Cong., 2 Sess., House Ex. Doc. 92. (J. W. Taylor, Gold Mines east of the Rocky Mountains.)

1484-1496 42 Cong., 2 Sess., Sen. Rep't. 41, pts. 1-13. (Ku Klux Klan.)

197546 Cong., 3 Sess., House Ex. Doc. 47, pt. 4. (Thomas Donaldson, The Public Domain, 18s1).

214447 Cong., 2 Sess., House Misc. Doc. 42, pt. 14. (10th CensusMining laws).

587961 Cong., 3 Sess., Sen. Doc. 758. (Immigration Commission, Reports, vol. 39.)

658963 Cong., 2 Sess., Senate Doc. 608. (J. T. Hughes, Doniphan's Expedition; reprint of the edition copyrighted in 1847.)

Congressional Globe, 29-30 Cong. (1846-1849).

\section{Miscellaneous Federal Docunents}

United States. Statutes at Large. Boston and Washington, 1850.

United States. Presidents. A Compilation of the Messages and Papers of the Presidents, 1789-189\%. By James D. Richardson. Washington, 1899. 10 vols. (Also published as Cong. Docs., Ser. No. 3265, pts. 1-10, 1896-1899.) Cited as Richardson, Messages.

United States. War Department. Reports on the Law of Civil Government in Territory Subjcct to Military Occupation by the Military Forces of the United States .... By Charles E. Magoon. Ed. 2. Washington, 1902. Cited as Magoon, Reports. 


\title{
CALIFORNIANA
}

California material found in works of general history is listed under Californiana.

\begin{abstract}
BibliographiEs
Bancroft, Hubert Howe. "Authorities quoted in the History of California,' ' in his History of California, I, XXV-LXXXVIII.

The separate volumes of Bancroft's histories also contain valuable bibliographical guides. Citations in these pages are made from the full set of Works, which in some instances differ in date from the independent publications although the paging is identical. For a discussion of the authorship of the various volumes, see an article by William Alfred Morris, in the Oregon Historical Society, Quarterly, IV, 287-364 (December, 1903).
\end{abstract}

Bepler, Doris West. Descriptive Catalogue of Western Historioal Material in California Periodicals, 1854-1890. . . . 1920. 299 pp.

MS Thesis (M.A.), University of California Library.

California State Library. Card Index to California Newspapers. An invaluable guide to local history.

Chapman, Charles E. "The Literature of California History,' Southwestern Historical Quarterly, XXII, 318-352 (April, 1919).

Cowan, Robert Ernest. Bibliography of the History of California and the Pacific West, 1510-1906 .... San Francisco, 1914.

Full titles and descriptive notes of about 1000 books. An indispensable tool for the student of California history.

Dietz, Ambrose P. "'List of Books, Tracts, Pamphlets, and other Publications.... relating to California and .... to the adjoining States and Territories. From the earliest Period of Discovery to the Present Time...." in his Bibliotheca Californiae. A Descriptive Catalogue of Books in the State Library of California (2 vols. Sacramento, 1871), II, 687-789.

The first bibliography of California that appeared in book form.

Garoutte, Eudora. Study Outline of California History. Sacramento, 1920. 15 pp. (California State Library.)

Haferkorn, Henry E., compiler. The War with Mexico, 1846-1848; A Selcet Bibliography.... Washington Barracks, 1914. (Supplement no. 1, Professional Memoirs, VI, no. 26. Bibliographical Contributions, Bulletin no. 1.) 
Hunt, Rockwell D[ennis]. Pacific Slope History with Special Reference to California. Los Angeles, 1918. $25+30$ pp. MS syllabus of lectures, University of Southern California. In 2 pts.

Keith, Eliza D. "California Books from the Library of Capt. Isaiah W. Lees," in her Report of Historical Landmarks Committee of the Native Daughters [of the] Golden West [San Franciseo, 1902], 39-68.

Macdonald, Augustin S. List of Books, Californiana and the Pacific, in the Library of Augustin S. Macdonald. Oakland, 1903. 76 pp.

This valuable collection has been bought for the Huntington Library.

Taylor, Alexander S[mith]. Bibliografa Californica, 1510-1863. Printed in the Sacramento Union, June 25, 1863, March 13, 1866. Scrapbook, with preface by Henry K. Godilard, in the Bancroft Library.

Turner, Frederick Jackson. List of References on the History of the West. Revised ed. Cambridge, 1913.

United States. War Department Library. Index of Publications, Articles, and Maps Relating to Mexico, in the War Department Library. . . . . Washington, 1896. (Catalogue no. 3.)

\section{NEWSPAPERS}

Inclusive dates of publication are given as exactly as possible. These have most kindly been supplied by Mr. R. S. Kuykendall, of the University of California, who is preparing a volume entitled The Early History of the Newspaper Press in California. Valuable material may also be found in a "History of California Newspapers,' by E. C. Kemble, Sacramento Union, December 25, 1858, pp. 2-3, 6-8.

Democratic State Journal. February 5, 1852-June 24, 1858.

Grass Valley Union. October 28, 1864-date.

Marysville Herald. August 6, 1850-January 1, 1858.

Monterey Californian. Established August 15, 1846. After May 22, 1847, published in San Francisco. Continued as Califormia Star and Californian, November 18-December 23, 1848. See supra, p. 94 note 17.

Oakland Transcript. April 1, 1868-January 3, 1878.

Oakland Tribune. February 21, 1874-date.

Placer Times. Established in Sacramento April 28, 1849. Continued as Daily Placer Times and Transcript after June 16, 1851. Remored to San Francisco and published there until December 15, 1855.

Sacramento Bce. February 3, 1857-date.

Sacramento Transeript. Established April 1, 1850. Continued as Daily Plaeer Times and Transcript, June 16, 1851-December 15, 1855.

Sacramento Union. Established March 19, 1851. Continued as Sacramento Record Union, after September 1, 1875. 
San Francisco.* California Star. Established January 9, 1847. Continued as California Star and Californian, November 18-December 23, 1848. See supra, p. 37 note 40.

Alta California. January 4, 1849-1891. See supra, p. 94 note 17.

Pacific News. August 25, 1849-May (?), 1851.

Daily Herald. June 1, 1850-(?), 1863. See supra, p. 410 note 3.

California Daily Courier. July 1, 1850-January 5, 1852.

Evening Picayune. August 3, 1850-April (?), 1852.

Morning Post. May 24-November 15, 1851.

Pacific Star. June 25-September (?), 1851.

Sunday Dispatch. July 13, 1851-(?).

The Pacific. August 1, 1851-date.

Evening Bulletin. October 8, 1855-date.

Call. December 1, 1856-date.

Chronicle. January 16, 1865-date.

Examiner. June, 1865-date.

Argonaut. March 25, 1877-date.

Śan José Pioneer. January 13, 1877-December 29, 1883.

Sonora Herald. July 4, 1850-(?), 1859.

Sonora Union Democrat. July 1, 1854-date.

Stockton Journal. June (?), 1850-June (?), 1854.

Sydney (N. S. W.) Morning Herald. Issues from July to December, 1851, checked by correspondence.

\section{Series and Periodicals}

Academy of Pacific Coast History. Publications. Berkeley, 1910-date.

Associated Pioneers of the Territorial Days of California. Reports. New York and San Franciseo, 1875-.

California Historical Society. Papers. San Franeiseo, 1887-1893.

Historical Society of Southern California. Publications. Los Angeles, 1884-date.

Grizzly Bear. Los Angeles (ete.), 1907-date.

Hutchings' Illustrated California Magazine. 1856-1861.

Overland Monthly. San Francisco, 1868-date.

Pioncer Monthly. San Franciseo, 1854-1855.

Society of California Pioneers. Reports. San Francisco, 1850-.

Society of California Pioneers. Constitution and By-Laws . . . as Revised December, 1912... . List of Members since Its Organization. San Francisco, 1912.

University of California. Chronicle. Berkeley, 1898-date.

The Wide West. San Franciseo, March 17, 1854-July, 1858.

* Arranged by dates. 


\section{California State Documents}

California Arehives. Archives of California, "Unbound Documents, 18461850.' MS transcript in the Bancroft Library. $413 \mathrm{pp}$.

California. Laws of 1837, see Halleck, J. [i.e. H. W.], Translation and Digest, infra, p. 488. Another translation in Minutes... of the Legislative Assembly of ... San Francisco . . . 1849, pp. 249296.

California. Constitutional Convention, 1849. Report of the Debates in the Convention of California, on the Formation of the State Constitution, in September and October, 1849. By J. Ross Browne. Washington, 1850. Cited as Browne, Debates.

Californịa. Statutes, 1849-1850; 1851; 1852; 1856; 1865-1866.

California. Gcneral Laws, see Hittell, T. H., compiler, infra, p. 495.

California. Historical Survey Commission. Guide to the County Archives of California. By Owen C. Coy. Sacramento, 1919. Cited as Coy, Guide.

California. Penal Code, 1872.

California Blue Book or State Roster, 190\%. Sacramento, no date.

California Legislature. Journals, 1849-1850; 1851; 1853.

California Supreme Court. Reports. First, 1850-1851; annotated ed. of 1906 cited. (Ed. 2, 1872, lacks the Appendix.) Second, 1852; ed. of 1854 cited. Third, 1852-1853; ed. of 1868 cited. Fifth, 1855; ed. of 1870 cited. Fifteenth, 1860; ed. of 1861 cited.

\section{Local Official Docunents}

Colusa County. Minutes of the Court of Sessions for October, 1851. (See Coy, Guide, 132.)

Marysville. Archives of the County Clerk. Register of Suits before the First Alcalde of Marysville, Stephen J. Field, January to May, 1850. (See Coy, Guide, 609.)

Placerville. Archives of the County Clerk. Alcalde's Docket, 1849-1850. (See Coy, Guide, 158.)

San Francisco.* Arehives of the Recorder. General Index. Blotter $B$.

The Laws of the Town of San Hrancisco. San Francisco, 1847. 8 pp.

The date of an ordinance on the last page shows that the pamphlet was published after October 28, 1847. The copy in the Huntington Library is probably unique. (See Cowan, Bibliography, 200.)

\footnotetext{
* Arranged by dates.
} 
Minutes of the Proceedings of the Legislative Assembly of the District of San Francisco. From March 12th, 1849, to June 4th, 1849, and a Record of the Proceedings of the Ayuntamiento or Town Council . . . . From August 6th, 1849, until May 3d, 1850. With an Appendix Containing Official Communications.... with Extracts from Mexican Constitutions and Laws . . . . Published by order of the Board of Supervisors. San Francisco, 1860.

Reports of the Alcalde, Comptroller and Treasurer of San Francisco. San Franciseo, 1850. $36 \mathrm{pp}$.

Very rare (see Cowan, Bibliography, 203). California State Library. Proceedings of the Town Council of San Francisco, Upper California. San Francisco, 1849-1850.

Very rare (see Cowan, Bibliography, 202). California State Library. Manual of the Corporation of . . . San Francisco, Containing a Map ....the Charters....the Revised Ordinances; the General Repealing Ordinances; the Ordinances Still in Force, and Certain Laws Relating Particularly to .... San Francisco. San Franciseo, G. K. Fitch, 1852. $261 \mathrm{pp.}$

Excellent maps. Valuable compilation of ordinances, 1850-1852.

San Francisco Municipal Reports. 1862-63. San Francisco, 1863.

San Francisco officials, 1834-1863, pp. 284-297.

SAN José. Archives of the City Clerk.

Tuolunne County. Arehives of the County Clerk. Grand Jury Reports, 1855-1871. (See Coy, Guide, 576.)

\section{Local Histories and Directories}

Colusa County. Colusa County. . . . San Francisco. Elliott \& Moore, 1880.

Rogers, Justus H. Colusa County. . . . . Orland, Cal., 1891.

Contra Costa County. Illustrations of Contra Costa County. . . . . Oakland, Smith \& Elliott, [1878].

Eu Dorado County. Historical Souvenir of El Dorado County. . . . . Oakland, Paolo Sioli, 1883.

Jerrett, Herman Daniel. California's El Dorado Yesterday and Today. Sacramento, 1915.

Fresno County. History of Fresno County. . . . San Francisco, Wallace W. Elliott \& Co., 1882.

Los Angeles Countr. History of Los Angeles County . . . . [by John Albert Wilson]. Oakland, Thompson \& West, 1880. 
Marysville. Amy, George Sturtevant, and Amy, O., compilers. G. and $O$. Amy's Marysville Directory for the Year Commencing November 1, 1856..... Together with an Historical Sketch..... San Francisco, 1856.

Nevada Countr. Brown and Dallison's Nevada, Grass Valley and Rough and Ready Directory, for the Year Commencing January 1st, 1856. . . . . With an Historical Sketch of Nevada County, by A. A. Sargent. .... San Francisco, 1856.

California State Library.

Thompson, Hugh B. Directory of the City of Nevada and Grass Valley. ... [San Francisco], 1861.

Bean, Edwin F., compiler. Bean's History and Directory of Nevada County. . . . Nevada [City], 1867.

History of Nevada County . . . [ [by Harry Laurenz Wells]. Oakland. Thompson \& West, 1880.

Placer County. History of Placer County. . . . Oakland, Thompson \& West, 1882.

Plumas County. Illustrated History of Plumas, Lassen and Sierra Counties. ... San Francisco, Fariss \& Smith, 1882.

SaCRamento County. History of Sacramento County [edited by George F. Wright.] Oakland, Thompson \& West, 1880.

History of Sacramento County [edited by George F. Wright]. Oakland, Thompson \& West, 1880.

Royce, Josiah. '“The Squatter Riot of '50 in Sacramento,' Overland Monthly, ser. 2, VI, 225-246 (September, 1885). Reprinted in his Studies of Good and Evil, 1898.

Sacramento Illustrated. . . . Sacramento, Barber and Baker, 1855. 36 pp. California State Library.

San Francisco. Barry, T[heodore] A[ugustus], and Patten, B[enjamin] $\mathrm{A}[\mathrm{dam}]$. Men and Memories of San Francisco in the "Spring of '50.', San Francisco, 1873.

Brooks, B. S. "Alcalde Grants in the City of San Francisco," The Pioneer, I, II (1854). Five articles.

Brown, John $\mathrm{H}$ [enry]. Reminiscences and Incidents of "The Early Days', of San Francisco.... from 1845-1850. San Francisco [1886].

Committees of Vigilance, see infra, San Francisco Committee of Vigilance. 
Dwinelle, John W[hipple]. The Colonial History of the City of San Francisco, Being a Synthetic Argument in the District Court .... for Four Square Leagues of Land Claimed by That City. San Franeisco, 1863. Citations from ed. 3, San Francisco, 1866, which contains an Addenda of many important documents.

Eldredge, Zoeth Skinner. The Beginnings of San Francisco from . . . . 1774 to .... April 15, 1850. San Francisco, 1912. 2 vols.

Hittell, John S[hertzer]. A History of the City of San Francisco and Incidentally of the State of California. San Francisco, 1878.

Home Guard for the City and County of San Francisco. Roll Book. 1861. 67 pp. Also 62 muster rolls. MSS in the Baneroft Library.

Jones, William Carey. The "Pueblo Question"' Solved, in a Plain Statement of Facts and Law. San Francisco, 1860. 36 pp.

King, Edward A. "List of Passenger Arrivals at the Port of San Francisco for the Year 1849 [March 31-December 30]. Furnished by the Harbor Master, Edward A. King, and Supplemented by Research in the Papers,' in Society of California Pioneers, Twentyfourth Anniversary (San Francisco, 1874), 38-47.

Limantour, José Yves, defendant. The United vs.'José Y. Limantour. Transcript of Record. [San Francisco], [1857], 1858. 4 vols. Cover titles: I, U. S. Land Commission; II, U. S. District Court; III, Archive Exhibits; IV, Land Com[mission] Exhibits.

Moses, Bernard. Establishment of Municipal Government in San Francisco. Baltimore, 1889. 83 pp. (Johns Hopkins University, Studies in Historical and Political Science, VII, nos. 2-3.)

Palmer, John Williamson. "'Pioneer Days in San Francisco," Century Magazine, XLIII, 541-560 (February, 1892).

Pendleton, Harry C., publisher. The Exempt Firemen of San Francisco. .... Published by Authority of the Exempt Fire Company. San Francisco, 1900. Cover title: History of San Francisco Fire Department.

[Shuck, Oscar Tully, editor.] Sketches of Leading and Representative Men of San Francisco, see his Representative . . . Men, infra, p. 499.

Soulé, Frank, Gihon, John H., and Nisbet, James. The Annals of San Francisco; Containing a Summary of the History of . . . California, and a Complete History of .... Its Great City; to Which Are Added Biographical Memoirs of Some Prominent Citizens. San Francisco, 1855.

The chronological annals, compiled from contemporary newspapers, are an invaluable source of information. Cited as Annals. 
Taylor, Rev. William. Seven Years' Street Preaching in San Francisco. .... New York, 1857 [copyrighted 1856].

Turrill, Charles B. '“Life in San Francisco, 1856,' Overland Monthly, ser. 2, LXVIII, 495-502 (December, 1916).

Wheeler, Alfred. Land Titles in San Francisco.... San Francisco, 1852.

Williams, Rev. Albert. A Pioneer Pastorate and Times..... San Francisco, 1879.

Young, John P[hilip]. San Francisco. A History of the Pacific Coast Metropolis. San Francisco, [1912], 2 vols.

\section{San Francisco Directories}

Bogardus, [J. P.]. Bogardus' San Francisco, Sacramento City and Marysville Business Directory, for July, 1850. . . . [San Francisco, 1850] $8 \mathrm{pp}$.

Kimball, Charles P. San Francisco City Directory. September 1, 1850. San Francisco, 1850.

Two reprints. (See Cowan, Bibliography, 69).

Parker, James M., publisher. San Francisco Directory, for the Year 1852-53. . . . San Francisco, 1852.

A. W. Morgan \& Co.'s San Francisco City Directory. September, 1852. San Francisco, 1852.

Le Count \& Strong's San Francisco City Directory for the Year 1854. ..... San Francisco, 1854.

Colville, Samuel. Colville's San Francisco Directory. Volume I. For the Year commencing October, 1856. . . . San Francisco, 1856.

SAN Joaquin Countr. History of San Joaquin County ... . [by F. T. Gilbert]. Oakland, Thompson \& West, 1879.

SAN José. Hall, Frederic. The History of San José and Surroundings. .... San Francisco, 1871.

Stockton. Tinkham, George H[enry]. A History of Stockton. ..... Including a Sketch of San Joaquin County. . . . . San Francisco, 1880.

Tuolume County. Heckendorn \& Wilson. Miners \& Business Men's Directory. For the Year Commencing January 1st, 1856. Embracing a General Directory of the Citizens of Tuolumne, and Portions of Calaveras, Stanislaus and San Joaquin Counties. Together with the Mining Laws of Each District, a Description of the Different Camps, and Other Interesting Statistical Matter. Columbia, printed at the Clipper Office, $1856.104 \mathrm{pp}$.

Very rare. California State Library; Bancroft Library (copy imperfect).

[Lang, Herbert O.] A History of Tuolumne County..... Compiled from the Most Authentic Records. San Francisco, 1882. 
YUBA County. History of $Y$ uba County. . . . . [by William H. Chamberlain]. Oakland, Thompson \& West, 1879.

Contemporary Works, Published or Written 1844-1860

[Allsop, Thomas.] California and Its Gold Mines. . . . Edited by Robert Allsop. London, 1853.

Auger, Édouard. Voyage en Californie (1852-1853). Paris, 1854.

Bates, Mrs. D. B. Incidents on Land and Water, or Four Years on the Pacific Coast. . . . Boston, 1857.

Bigelow, John. Memoir of the Life and Public Services of John Charles Frémont. . . . New York, 1856.

Borthwick, J. D. Three Years in California. Edinburgh, 1857.

By an English artist. Attractive illustrations. Covers 1851-1854.

Brooks, J. Tyrwhitt, M. D. Four Months among the Gold-Finders in Alta California. ..... London, 1849. Citations from ed. 2. London, 1849.

Other editions printed in Paris and New York. The interesting diary of an English physician. Severely criticized in Gerstäcker, Narrative, 194.

Browne, J[ohn] Ross. Debates, see California Constitutional Convention, 1849 , supra, p. 481.

Bryant, Edwin. What I Saw in California: Being the Journal of a Tour ... across the Continent . . . and through California . . . 1846, 184\%. . . . New York, 1848.

By the second American alcalde of San Francisco. Many editions and translations.

Buffum, E[dward] Gould. Six Months in the Gold Mines: from a Journal of Three Years' Residence in Upper and Lower California. 18:4-8-9. Philadelphia, 1850.

The author was a lieutenant in Stevenson's Regiment.

California Illustrated. See Letts, J. M.

California: Its Gold and Its Inhabitants. See Huntley, H. V.

California: Its Past History; Its Present Position; Its Future Prospects. .... London, 1850. Engraved title page reads: The Emigrant's Guide to the Golden Land. . . . . 
Capron, E[lisha] S. History of California .... with a Journal of the Voyage from New York.... to San Francisco, and Back.... Boston, 1854.

Carson, J[ames] H. Early Recollections of the Mines, and a Descriptian of the Great Tulare Valley . . . . ed. 2. Stockton, 1852. $64 \mathrm{pp.}$

Cover title: Life in California. The first book printed in Stockton.

The first edition was a supplement to a "steamer number" of the San Joaquin Republican. Valuable observations of a practical miner. (See Hittell, California, III, 119.)

[Clappe, Mrs. Louise Amelia Knapp.] "California in 1851' ; "California in 1852.', By Shirley [pseudonym], The Pioneer, I-IV, 1854-1855. A reprint is now in press.

Clarke, A. B. Travels in Mexico and California .... a Journal. Boston, 1852.

Rare. California State Library.

Coke, Henry $\mathrm{J}[\mathrm{ohn}]$. A Ride over the Rocky Mountains to Oregon and California. With a Glance at Some of the Tropical Islands..... London, 1852.

Cover title: The Rocky Mountains to California. This English traveler deroted but one chapter to California. The English Catalogue notes an edition of 1851 .

Colton, Rev. Walter. Three Tears in California. New York, 1850. Events of 1846-1849. See supra, pp. 41-42.

Cutts, James Madison. The Conquest of California and New Mexico. . . . Philadelphia, 1847.

Delano, A[lonzo]. Life on the Plains and among the Diggings..... Auburn and Buffalo, 1854. Citations from New York ed. of 1857.

Under the nom de plume of "Old Block", this author wrote The Idle and Industrious Miner, Sacramento, 1854; Old Bloch's Sketch-Book, Sacramento, 1856; Pen Knife Sketches, Sacramento, 1853.

Delavan, James [proprietor of copyright]. Notes on California and the Placers. . . . By One Who Has Been There. New York, 1850.

Accurate and entertaining observations.

Dillon, Patrice. “'La Californie dans les derniers mois de 1849,' Revue des deux mondes, nouvelle periode, V, 193-219 (January 15, 1850).

By the French consul at San Francisco. 
Farnham, Eliza W[oodson (Burhans)]. California, In-doors and Out. . . . New York, 1856.

Keen observations, 1851-1856. Mrs. Farnham acquired notoriety by a project of bringing from the East a company of marriageable young women (see Hittell, California, III, 191; Ryan, Personal Adventures, II, 282-283; H. C. Clark, MS Statement, 1).

Frost, John. Frost's Pictorial History of California. . . . . Auburn, N. Y., 1850.

A popular but superficial history. Many editions.

Gerstäcker, Fredrich [i.e., Friedrich Wilhelm Christian]. Gerstäcker's Travels. . . . Translated from the German. London, 1854. California State Library.

Gerstäcker, Friedrich [Wilhelm Christian]. Gold! Ein Californisches Lebensbild. Jena, no date. Various editions. That cited is from the California State Library.

Gerstäcker, Friedrich [Wilhelm Christian]. Narrative of a Journey round the World. .... New York, 1853.

California State Library.

Golden Dreams and Leaden Realities, see Payson, George.

Grabowski, Stanislaus. Die Regulatoren von San Francisco. . . . Berlin, no date. 2 vols.

California State Library.

Listed in Heinsius, Allegemeines deutsches Bücher-Lexikon, XIII, 18571861, pt. 2, p. 168.

Halleck, J. [i.e., Henry Wagner]. Translation and Digest of Such Portions of the Mexican Laws of March 20th and May 23d, 183\%, as are supposed to be still in force and adapted to the present condition of California; with an Introduction and Notes, by J. Halleck, Attorney at Law, and W. E. P. Hartnell, Government Translator. San Francisco, 1849. $26 \mathrm{pp}$.

Very rare (see Cowan, Bibliography, 231-232). Huntington Library. Reprinted in Browne, Debates, Appendix, pp. XXIV-XL.

Helper, Hinton R[owan]. The Land of Gold. Reality versus Fiction. Baltimore, 1855.

Hittell, Theodore H[enry]. The Adventures of James Capen Adams, Mountaineer and Grizzly Bear Hunter, of California. San Francisco, 1860.

Holinski, Alexandre [Jean Joachim]. La Californie et les routes interocéaniques. Bruxelles, 1853. Citations from ed. 2, Bruxelles, 1853.

The author was a Lithuanian, and the British Museum Catalogue prints his name Holyuski. The title page of this book describes him as a "citoyen américain," and its contents show that he was an enthusiast for democracy. The work was prohibited in France (Lorenz, Catalogue général, II, 608). 
Hughes, John T[aylor]. Doniphan's Expedition; Containing an Account of the Conquest of New Mexico; General Kearney's [sic] Overland Expedition to California. . . . . Cincinnati, [copyrighted 1847].

Various editions, including Cong. Docs., Ser. No. 6589, Doc. 608. Citation from reprint edited by William Elsey Connelley, Topeka, 1907.

[Huntley, Sir Henry Vere.] California: Its Gold and Its Inhabitants. ... London, 1856. 2 vols.

Johnson, Theodore T[aylor]. Sights in the Gold Region, and Scenes by the Way. New York, 1849. Citations from ed. 3, with title: California and Oregon; or, Sights in the Gold Region, and Scenes by the Way. Philadelphia, 1851.

Jones, William Carey. Report on the Subject of Land Titles in California. .... Washington, 1851. (Cong. Docs., Ser. No. 589, Doc. 18.136 pp.)

Printed in part as Land Titles in California, Washington, 1850. $60 \mathrm{pp}$.

Kelly, William. An Excursion to California. . . . . With a Stroll through the Diggings and Ranches of That Country. London, 1851. 2 vols. A Stroll through the Diggings was published separately. London, 1852.

King, Thomas Butler. California: the Wonder of the Age.... New York, 1850. 34 pp. Reprint of his Report on California. (Cong. Docs., Ser. No. 577, Doc. 59).

Kingsley, Nelson. Diary of Nelson Kingsley, a California Argonaut of 1849 . Edited by Frederiek J. Teggart. Berkeley, 1914. (Academy of Pacific Coast History, Publications, III, no. 3.)

[Kip, Leonard.] The Volcano Diggings, a Tale of California Law. By a Member of the Bar. New York, 1851.

Not very interesting, but a reflection of local conditions. Huntington Library.

Lambertie, Ch[arles] de. Voyage pittoresque en Californie et au Chili. Paris, 1853.

[Letts, John M.] California Illustrated. . . . . New York, 1852.

Another edition has title: A Pictorial View of California. New York, 1853.

Lieber, Francis, compiler. California Scrap-Book, 1848-49.

A collection of clippings in the Bancroft Library.

Lyman, Albert. Journal of a Voyage to California, and Life in the Gold Diggings. . . . Hartford, Conn., 1852.

MeNeil, Samuel. McNcil's Travels in 1849, to, through and from the Gold Regions, in California. Columbus, 1850. 
Marryat, Frank [i.e., Samuel Francis]. Mountains and Molehills, or Recollections of a Burnt Journal. . . . . London, 1855.

By an English artist. Interesting illustrations. An inferior edition was published in New York in 1855.

Meyer, Carl. Nach dem Sacramento. . . . Aarau, 1855.

Montgomery, C. E. '“The Lost Journals of a Pioneer,'” Overland Monthly, ser. 2 , VII (1886), 75-90; 173-181; 276-287.

Mysteries and Miseries of San Francisco. . . . . New York, [1853].

Sensational fiction, with Belcher Kay as one of the characters. Huntington Library.

Notes on California and the Placers, see Delavan, James.

Nye, B. H. ' Extracts from Letters of a Nantucket Forty-niner,' History Teachers' Magazine, VI, 210-211 (September, 1915).

Palmer, J[ohn] W[illiamson], M.D. The New and the Old; or, California and India in Romantic Aspects. . . . . New York, 1859.

[Payson, George.] Golden Dreams and Leaden Realities. By Ralph Raven. .... New York, 1853.

$A$ "Pile," or a Glance at the Wealth of the Monied Men of San Francisco and Sacramento City. . . . . San Francisco, 1851. 15 pp.

Printed in New York, but bearing a San Francisco imprint.

Reid, Samuel C[hester], Jr. The Scouting Expeditions of McCulloch's Texas Rangers.... and Sketches of . . . Hays, McCulloch, and Walker. Philadelphia, 1847.

Robinson, Fayette. California and Its Gold Regions..... New York, 1849.

[Ryan, R. F.] "Judges and Criminals; or, Shadows of the Past." By Juris Consult, The Golden Era [1853-1854?]

A series of historical sketches of California from the Spanish occupation to 1849. Scrapbook in the Bancroft Library.

Ryan, William Redmond. Personal Adventures in Upper and Lower California, in 1848-9. . . . London, 1850. 2 vols.

By an English artist. Characteristic illustrations.

Saint-Amant, [Pierre Charles] de. Voyages en Californie et dans l'Oregon. Paris, 1854.

The author was French consul at Sacramento in 1851 (Popular Tribunals, I, 156). His observations are exceedingly interesting. A portion of his letters was published as Voyage en Californie 18501851, Paris, 1851.

Seyd, Ernest. California and Its Resources. . . . . London, 1858. 
Shaw, Pringle. Ramblings in California . . . the Five Years' Experience of a Gold Digger. Toronto [ca. 1860].

Shaw, William. Golden Dreams and Waking Realities. . . . . London, 1851. Shirley, pscudonym, see Clappe, Mrs. L. A. K.

Simpson, Henry I. Emigrant's Guide to the Gold Mines. Three Weeks in the Gold Mines, or Adventures with the Gold Diggers of California in August, 1848. . . . . New York, 1848. 30 pp.

The early date makes these observations interesting, but they must be received with caution.

Taylor, Bayard. Eldorado, or, Adventures in the Path of Empire.... New York, 1850. 2 vols.

Published in the same year in London, with illustrations by the author. Various reprints. See note, supra, p. 85.

Taylor, Rev. William. California Life Illustrated. . . . . New York, 1858. Turnbull, T[homas]. T. Turnbull's Travels from the United States across the Plains to California [1852]. Madison, 1914. Reprinted from the Wisconsin State Historical Society, Proceedings, 1913, pp. 151-225. Separate no. 158.

Tyson, James L[awrence], M.D. Diary of a Physician in California. . . . . New York, 1850.

Tyson, Philip T[homas]. Geology and Industrial Resources of California. .....Baltimore, 1851. Reprinted, with introduction and appendix from Cong. Docs., Ser. No. 558, Doe. 47.

The Volcano Diggings; a Tale of California Law, see Kip, Leonard.

Weston, S[ilas]. Life in the Mountains; or Four Months in the Mines of California. Providence [R. I.], 1854. $34 \mathrm{pp.}$

Ed. 2, revised, has title: Four Months in the Mines of California; or, Life in the Mountains. Providence, 1854. $46 \mathrm{pp}$.

Wierzbicki, F[elix] $\mathrm{P}$ [aul], M.D. California as It Is, and as It May Be, or, a Guide to the Gold Region. San Francisco, 1849. 60 pp.

Often described as the first book printed in San Francisco (see Holinski, La Californie, 113; Royce, California, 301). Cowan corrects this statement (Bibliography, 248). A second, enlarged edition, followed the same year. $76 \mathrm{pp}$.

Wilkes, Charles. Narrative of the United States Exploring Expedition. During the Years 1838, 1839, 1840, 1841, 1849. Philadelphia, 1844. 5 vols., and Atlas.

Wilson, R. A. "The Alcalde System of California," in First California Reports (1852), 559-582. Omitted from the edition of 1872.

Woods, Rev. Daniel B. Sixteen Months at the Gold Diggings. New York, 1851. 
Geňeral Histories, Biographies, and Reminiscences, 1861-date MANUSCRIPT REFERENCES OF PIONEERS IN THE BANCROFT LIBRARY

Clark, Hiram C. Statement of Historical Facts in Calif [ornia] from 1851 to $1865.1878 .12 \mathrm{pp}$.

Crosby, E[lisha] O. Statement of Events in Cal[ifornia]. 1878. 132 pp. Currey, John. Incidents in California. 1878. 16 pp.

Dally, Henry I. Narrative of His Life and Events in Cal[ifornia] since 1843. 1878. $95 \mathrm{pp}$.

Garniss, James R. Early Days of San Francisco. 1877. 32 pp.

Gwin, W[illia]m M. Memoirs on History of United States, Mexico, and California. 1878. 265 pp.

Hyde, George. Statement of Historical Facts in California. 1878. 26 pp. Kraszewski, Michael. Acts of the "Manilas." Lawlessness at San Juan in 1856. 1878. $17 \mathrm{pp}$.

Roach, Philip A. Statement of Historical Facts on California. 1878. $16 \mathrm{pp}$.

Sayward, Capt. W[illiam] T. Statement. Pioneer Reminiscences. [1877?] $34 \mathrm{pp}$.

Sutter, John Augustus. Personal Reminiscences. 1876. 206 pp.

For MS Reminiscences of Vigilantes see infra, p. 502.

PRINTED WORKS

Abbott, Carlisle S. Recollections of a California Pioneer. New York, 1917. Archer, Lawrence. "Oration,' in Society of California Pioneers, Twenty-seventh Anniversary (San Francisco, 1877), 7-16.

Bancroft, Hubert Howe. California Inter Pocula. San Francisco, 1888. (Works, XXXV.)

Bancroft, Hubert Howe. Chronicles of the Builders of the Commonwealth. San Francisco, 1891-1892. 7 vols. and Index.

Bancroft, Hubert Howe. History of California. San Francisco, 1884-1890. 7 rols. (Works, XVIII-XXIV).

Barker, Eugene C. 'California as the Cause of the Mexican War,' Texas Review, II, 213-221 (January, 1917).

Bell, Horace. Reminiscences of a Ranger; or, Early Times in Southern California. Los Angeles, 1881. 
Birkhimer, William E. Military Government and Martial Law. Ed. 3, revised. Kansas City, 1914 [copyrighted 1892].

[Black, Chauncey Forward, and Smith, Samuel B., editors.] Some Account of the Work of Stephen J. Field. . . . . With an Introductory Sketch by John Norton Pomeroy. [New York?], 1881.

Blackmar, Frank W[ilson]. Spanish Institutions of the Southwest. Baltimore, 1891. (Johns Hopkins University, Studies in Historical and Political Science. Extra Vol. X.)

Bolton, Herbert E[ugene]. "'The Admission of California," University of California, Chronicle, XV, 554-556 (October, 1913).

Bosqui, Edward. Memoirs. [San Francisco, 1904.]

Privately printed and very rare. (See Cowan, Bibliography, 22.)

Brace, Charles Loring. The New West: or, California in 1867-1868. New York, 1869.

Browne, J[ohn] Ross, and Taylor, James W. Reports upon the Mineral Resources of the United States [for 1866]. Washington, 1867.

Browne's report covered the area west of the Rocky Mountains. It was also published as Cong. Docs., Ser. No. 1289, Doc. 29. Taylor's, on the area to the east, appeared as Ser. No. 1293, Doc. 92.

Burnett, Peter H[ardeman]. Recollections and Opinions of an Old Pioneer. .... New York, 1880.

Carr, John. Pioneer Days in California. . . . E Eureka, Cal., 1891.

Clark, Francis D. The First Regiment of New York Volunteers, Commanded by Col. Jonathan D. Stevenson in the Mexican War..... New York, 1882. Cover title: Stevenson's Regiment in California, $1847-8$.

Cleland, Robert Glass. The Early Sentiment for the Annexation of California..... Austin, [1915]. Reprinted from the Southwestern Historical Quarterly, XVIII (July-October, 1914).

Cole, Cornelius. Memoirs of Cornelius Cole, Ex-Senator of the United States from California. New York, 1908.

Coman, Katharine. Economic Beginnings of the Far West.... New York, 1912. 2 vols.

Coy, Owen C. Guide, see California Historical Survey Commission, supra, p. 481.

Davis, Horace. '“The Home Guard of 1861,' in Panama-Pacific Historical Congress, The Pacific Ocean in History (New York, 1917), 363-372. 
Davis, John F. Historical Sketch of the Mining Law in California. Los Angeles, 1902. $83 \mathrm{pp}$. Reprinted from O. T. Shuck, History of the Bench and Bar of California, 1901.

Davis, William Heath. Sixty Years in California..... San Francisco, 1889.

Davis, Winfield J. History of Political Conventions in California, 18491892. Sacramento, 1893. (California State Library, Publications, no. 1.)

Degroot [De Groot], Henry. 'Six Months in '49,', Overland Monthly, XIV, 316-329 (April, 1872).

Dellenbaugh, Frederick S[amuel]. Frémont and '49.... New York, 1914.

Downie, William. Hunting for Gold. . . . San Francisco, 1893.

Dunbar, Edward E. The Romance of the Age; or, The Discovery of Gold in California. New York, 1867.

Duniway, Clyde A. "'Slavery in California after 1848,' American Historical Association, Annual Report, 1905, I, 243-248.

Earle, John Jewett. "Sentiment of the People of California with Respect to the Civil War,' American Historical Association, Annual Report, 190\%, I, 123-135.

Eldridge, Zoeth Skinner, editor. History of California. New York [copyrighted 1915]. 5 vols.

Ellison, Joseph. Sentiment in California for a Pacific Republic, 1943-1861. 1919. 111 pp. MS Thesis (M.A.), University of California Library.

Ellison, William Henry. The United States Indian Policy in California, 1846-1860. 1918. 434 pp. MS Thesis (Ph.D.), University of California Library.

Fankhauser, William C[harles]. A Financial History of California: Public Revenues, Debts, and Expenditures. Berkeley, 1913. (University of California, Publications in Economics, III, no. 2.)

Ferguson, Charles D. The Experiences of a Forty-niner during Thirty-four Years' Residence in California and Australia. Edited by Frederick T. Wallace. Cleveland, 1888. Cover title: A Third of a Century in the Gold Fields.

Field, Stephen J[ohnson]. Personal Reminiscences of Early Days in California. . . . No.place, [copyrighted 1880]. Citation from enlarged ed. [Washington, 1893]. 
Fitch, George Hamlin. ' How California Came into the Union,' Ccntury Magazine, XL, 775-792 (September, 1890).

Frémont, John Charles. Memoirs of My Life..... Vol. 1. Chicago, 1887. No more published.

Frignet, Ernest. La Californie. Histoire, organization politique et administrative, législation, description physique et géologique.... Paris, 1866.

An admirable study of local conditions. Lorenz, Catalogue général, cites an edition of 1865. Ed. 2 was published in 1867 .

Goodwin, Cardinal. Establishment of State Government in California, 1846-1850. New York, 1914.

Grey, William, pseudonym, see White, William Francis.

Guinn, J[ames] M[iller]. History of the State of California and Biographical Record of Sacramento Valley. . . . . Chicago, 1906.

One of a series of local histories with identical general introductions.

Harlan, Jacob Wright. California ' 46 to '88. San Francisco, 1888.

Haskins, C. W. The Argonauts of California. . . . . New York, 1890.

Lists some 35,000 names.

Hershiser, Beulah. "The Influence of Nevada on the National Mining Legislation of 1866,' Nevada Historical Society, Third Biennial, Report, 1911-1912, pp. 127-167.

Hittell, John S[hertzer]. The Resources of California. .... San Francisco, 1863. Ed. 6, rewritten, San Francisco, 1874.

Hittell, Theodore H[enry], compiler. General Laws of the State of California, from 1850 to 1864. San Francisco, 1865. 2 vols. Citations from ed. 2. San Francisco, 1870.

Hittell, Theodore H[enry]. History of California. San Francisco, 18851897. 4 vols.

Hull, Dorothy. "The Movement in Oregon for the Establishment of a Pacific Coast Republic,', Oregon Historical Society, Quarterly, XVII, 177-200 (September, 1916).

Hunt, Rockwell Dennis. Genesis of California's First Constitution (184649). Baltimore, 1895. (Johns Hopkins University, Studies in Historical and Political Science, XIII, no. 8.)

Hunt, Rockwell Dennis. '"Legal Status of California, 1846-49,' American Academy of Political and Social Science, Annals, XII, 387-40s (November, 1898). 
[Ide, Simeon.] Biographical Sketch of .... William B. Ide: with . . . Account of One of the Largest Emigrating Companies . . . and . . . . " The Virtual Conquest of California, in June, 1846, by the Bear Flag Party ....' [Claremont, N. H., 1880].

A part of this material was published separately as Who Conquered California? . . . . Claremont [1880]. See Cowan, Bibliography, 118.

Irvine, Leigh $\mathrm{H}$ [adley], editor. History of the New California; Its Resources and People. New York, 1905. 2 vols.

Jones, William Carey. "First Phase of the Conquest of California," California Historical Society, Papers, I, pt. I (1887), 61-94.

Kelsey, Rayner Wickersham. The United States Consulate in California. Berkeley, 1910. (Academy of Pacific Coast History, Publications, I, no. 5.)

Kennedy, Elijah R[obinson]. The Contest for California in 1861. . . . Boston, 1912.

Klein, Julius. The Making of the Treaty of Guadaloupe Hidalgo. . . . The James Bryce Historical Prize Essay for 1905. Berkeley, 1905. Reprinted from the University of California, Chronicle, VII, no. 4.

Knower, Daniel. The Adventures of a Forty-niner. . . . Albany, 1894. Cover title: The Days of the Forty-niners.

Landis, Jacob B. ' Life and Work of General John A. Sutter,' Lancaster County [Pennsylvania] Historical Society, Papers, XVII (1913), 279-300.

Lecouvreur, Frank [i.e., Theodor Maximilian Ferdinand Franz]. From East Prussia to the Golden Gate. . . . Edited . . . . by Mrs. Josephine Rosana Lecouvreur. . . . . New York, 1906.

Lévy, Daniel. Les Français en Californie. San Francisco, 1884.

Lippitt, Francis J. "'The California Boundary Question in 1849,' Century Magazine, XL, 794-795 (September, 1890).

Lynch, James. With Stevenson to California, 1846. No place [1896].

Lynch, Jeremiah. A Senator of the Fifties: David C. Broderick, of California. San Francisco, 1911.

McCall, A. J. The Grcat California Trail in 1849. Bath [New York], 1882.

California State Library.

McCall, A. J. Pick and Pan. Trip to the Diggings in 1849. . . . Bath [New York], 1883.

California State Library. 
McElroy, Robert MeNutt. The Winning of the Far West . . . 1829-1867. New York, 1914.

McKinstry, E[lisha] W. “Oration,' in Society of California Pioneers, Twenty-first Anniversary (San Franciseo, 1871), 5-19.

MeMurray, Orrin K. "Beginnings of the Community Property System in California. ....' Cälifornia Law Review, III, 359-380 (July, 1915).

Magoon, Charles E. Reports, see United States War Department, supra, p. 477 .

Mains, John P., compiler. Annual Statistician. $18 \% 9$ San Francisco [1879].

Merwin, Henry Childs. The Life of Bret Harte, with Some Account of the California Pioneers. Boston, 1911.

Naglee, Henry M[orris]. The Love Life of Brig. Gen. Henry M. Naglee, Consisting of a Correspondence on Love, War and Politics. [San Fraciseo], 1867.

This uninteresting volume, copyrighted by Mary L. Schell, was a woman's revenge for an alleged breach of promise of marriage.

Newmark, Harris. Sixty Years in Southern California, 1853-1913..... Edited by Maurice H. Newmark [and] Mareo R. Newmark. New York, 1916.

Norton, Henry K[ittredge]. The Story of California from the Earliest Days to the Present. Chicago, 1913.

Norton, L[ewis] A[delbert]. Life and Adventures of Col. L. A. Norton. .... Oakland, 1887.

O’Connor, R. C. “'David Colbert Broderick,', American Irish Historical Society, Journal, XIII (1914], 132-162.

O'Meara, James. Broderick and Gwin. . . . San Francisco, 1881.

O'Meara, James. “A Chapter of California History,' Overland Monthly, ser. 2, XIV, 625-630 (December, 1889).

Panama-Pacific Historical Congress. The Pacific Ocean in History. .... Edited by H. Morse Stephens.... [and] Herbert E. Bolton. New York, 1917.

Parsons, George Frederie. Life and Adventures of James W. Marshall, the Discoverer of Gold in California. Sacramento, 1870.

Patterson, Lawson B. Twelve Years in the Mines of California..... Cambridge [Mass.], 1862. 
Peckham, R[obert] F. Eventful Life. Scrapbook in the Bancroft Library. Extracts from the San José Pioneer, June 9-August 4, 1877.

Pérez Rosales, Vicente. Recuerdos del pasado, 1814-1860. Santiago de Chili, 1910. (Biblioteca de escritores de Chili, III.)

Phelps, Alonzo. Contemporary Biography of California's Representative Men..... San Francisco, 1881-1882. 2 vols.

Porter, Valentine Mott. General Stephen W. Kearny and the Conquest of California (1846-7). Los Angeles, 1911. Reprinted from Historical Society of Southern California, Annual Publications, VIII (1911), 95-127.

Revere, Joseph W[arren]. Keel and Saddle. Boston, 1872. Citations from ed. of 1873. California State Library.

Richman, Irving Berdine. California under Spain and Mexico, 1535-1847. Boston, 1911.

Ridge, John R[ollin]. Life and Adventures of Joaquin Murieta. . . . . Ed. 3, enlarged. San Franciseo, 1871. $81 \mathrm{pp}$.

Rives, George Lockhart. The United States and Mexico, 1821-1848. . . . New York, 1913. 2 vols.

Roberts, B[righam] $\mathrm{H}$ [enry]. The Mormon Battalion..... Salt Lake City, 1919.

Robertson, James R[ood]. From Alcalde to Mayor; a History of the Change from the Mexican to the American Local Institutions of California, 1908. $293 \mathrm{pp}$. MS Thesis (Ph.D.), University of California Library.

Robinson, Henry. “'Pioneer Days of California,' Overland Monthly, VIII, 457-462 (May, 1872).

Rodman, Willoughby. History of the Bench and Bar of Southern California. Introduction by W. J. Hunsaker. Los Angeles, 1909.

Royce, Josiah. California, from the Conquest in 1846 to the Second Vigilance Committee in San Francisco..... Boston, 1886. (American Commonwealths.)

Royce, Josiah. "Provincialism; Based upon a Study of Early Conditions in California,', Putnam's Magazine, VII, 232-240 (November, 1909).

Royce, Josiah. Race Questions, Provincialism, and Other American Problems. New York, 1908. 
Royce, Josiah. "'Squatter Riot,"' see supra, p. 483.

Scanland, J. M. “Joaquin Murrieta; California Fra Diavolo,'” Overland Monthly, ser. 2, XXVI, 530-539 (December, 1895).

Shafter, Oscar Lovell. Life Diary and Letters . . . . 1864, to . . . 1868. Edited.... by Flora Haines Loughead. .... San Francisco, 1915.

Shaw, D[avid] A[ugustus]. Eldorado; or, California as Seen by a Pioneer, 1850-1900. Los Angeles, 1900.

Sherman, William T[ecumseh]. Memoirs. . . . New York, 1875. 2 vols.

Shinn, Charles Howard. Land Laws of Mining Districts. Baltimore, 1884. (Johns Hopkins University, Studies in Historical and Political Science, II, no. 12.)

Shinn, Charles Howard. Mining Camps: A Study in American Frontier Government. New York, 1885.

Shinn, Charles Howard. "'Some California Documents," Magazine of American History, XXV, 394-402 (May, 1891).

Shuck, Oscar T[ully]. Bench and Bar in California. .... San Francisco, 1888. Citations from enlarged ed., San Francisco, 1889.

Shuck, Oscar T[ully], editor. History of the Bench and Bar of California. .... Los Angeles, 1901.

Entirely different from his Bench and Bar in California.

Shuck, Oscar T[ully], editor. Representative and Leading Men of the Pacific. .... San Francisco, 1870.

[Shuck, Oscar Tully, editor.] Sketches of Leading and Representative Men of San Francisco. London, New York and San Francisco, 1875.

A continuation of his Representative .... Men of the Pacific, pp. 7031082.

Smith, Justin H[arvey]. The War with Mexico. New York, 1919. 2 vols.

Street, Charles R. "Crossing the Plains in '49," in Associated Pioneers of the Territorial Days of California, Sixteenth Annual Meeting and Dinner. . . . (New York, 1891), 20-24.

Swasey, W[illiam] F. Early Days and Men of California. Oakland, 1891.

Thomas, David Yancey. A History of Military Government in Newly Acquired Territory of the United States. New York, 1904. (Columbia University, Studies in History, Economics and Public Law, $\mathrm{XX}$, no. 2.)

Tinkham, George H[enry]. California Men and Events ... 1769-1890. Stockton, 1915.

Very inaccurate. 
Tuthill, Franklin. History of California. San Francisco, 1866.

Tyler, Daniel. A Concise History of the Mormon Battalion in the Mexican War. . . . . [Salt Lake City], 1881.

Uphan, Samuel C. Notes of a Voyage to California. . . . Philadelphia, 1878. Cover title: Scenes in El Dorado in the Years 1849-'50.

Wagstaff, A[lexander], E., compiler and editor. Life of David S. Terry. .... San Francisco, 1892.

Waite, E. G. '“Pioneer Mining in California,'” Century Magazine, XLII, 127-141 (May, 1891).

Wakeman, Edgar. The Log of an Ancient Mariner. .... Written by himself and edited by his daughter. San Francisco, 1878.

Webster, Kimball. The Gold Seekers of '49. . . . . With an Introduction . . . by George Waldo Browne. Manchester, N. H., 1917.

Journal and reminiscences, 1849-1854.

Wheeler, Alfred. "'Oration," in Society of California Pioneers, Thirtysecond Anniversary (San Francisco, 1882), 7-28.

[White, William Francis.] A Picture of Pioneer Times in California. . . . . by William Grey [pseudonym]. San Francisco, 1881.

Willey, Rev. Samuel H[opkins]. The Transition Period of California, from a Province of Mexico in 1846 to a State of the American Union in 1850. San Franciseo, 1901.

Willey, Rev. Samuel H[opkins]. "Recollections of General Halleck as Secretary of State in Monterey, 1847-9,' Overland Monthly, IX, 9-17 (July, 1872).

Willey, Rev. S[amuel] H[opkins]. Thirty Years in California . . . 1849 to 1879. San Francisco, 1879.

Wistar, Isaac Jones. Autobiography, 1827-1905. Philadelphia, 1914. 2 vols.

Printed for private distribution. University of California Library.

Woods, Rev. James. Recollections of Pioneer Work in California. . . . San Francisco, 1878.

Woods, S[amuel] D. Lights and Shadows of Life on the Pacific Coast. New York [1910].

Woolley, L[ell] H[awley]. California, 1849-1913. . . . . Oakland, 1913.

Wright, Flora Alice. Richard Barnes Mason, Governor of California. 1919. 275 pp. MS Thesis (M.A.), University of California Library.

Yale, Gregory. Legal Titles to Mining Claims and Water Rights, in California, under the Mining Law of Congress, of July, 1866. San Francisco, 1867.

Young, John P. Journalism in California. . . . . San Francisco [1915]. 
The San Francisco Committees of Vigilance, 1851, 1856 ARCHIVES OF THE COMMITTEE OF 1851, IN THE BANCROFT LIBRARY

Constitution and List of Signers. Book of Names, Kept by the Sergeant-atarms. Printed as Papers of the San Francisco Committee of Vigilance of 1851. I. Edited by Porter Garnett. Berkeley, 1910. 69 pp. (Academy of Pacific Coast History, Publications, I, no. 7.)

List of Names Approved by the Committee on Qualification. Printed as) Papers, II. Edited by Porter Garnett. Berkeley, 1911. 19 pp. (Academy of Pacific Coast History, Publications, II, no. 2.)

Minutes and Miscellaneous Papers. Printed as Papers, III. Edited by Mary Floyd Williams. Berkeley, 1919. 905 pp. (Academy of Pacific Coast History, Publications, IV.) Cited as Papers.

Contents: Minute Book of the Executive Committee, September 17, 1851, to June 30, 1852. Cash Book of the Treasurer, July 1, 1851, to October 17, 1852. Roll Call of the Executive Committee, September 17, 1851, to March 13, 1852. Miscellaneous Minutes, Reports, Evidence, and Confessions. Financial Accounts and Vouchers.

Unprinted: Book of Fines of the Sergeant-at-Arms. Petty Cash Book of the Sergeant-at-Arms (fragment). Miscellaneous papers. (See Papers, III, 830-831.)

\section{ArChives of THE Consittee of 1856}

Both Bancroft and Hittell had access to the original archives of the Committee of 1856, but Bancroft was not allowed to retain them, and in 1914 he was unaware of their location. Correspondence with relatives of President Coleman and Secretary Bluxome has also failed to trace the documents. A number of the papers were obtained by Mr. A. S. Macdonald from a sealed room in a building in course of destruction in San Francisco's Chinatown, and were included in the Macdonald collection of Californiana purchased by Mr. Henry E. Huntington. The most interesting item is an Index to the Record of the Committee, made out under names of cases and witnesses, but the Record itself is missing. There are also unimportant papers relating to the cases of Judge Terry and Edward McGowan, some communications on ballot box stuffing, fragments of muster rolls, various subscription lists, vouchers, orders for membership certificates, and many complaints against the character of witnesses, and against men who had been admitted to membership in the Committee. The complaints show that vigorous efforts were made to expel undesirable members as fast as they could be discovered. A few letters relating to the Committee of 1856 are preserved in the Bancroft Library in the file that contains the papers of 1851. It is probable that the rest of the Archives were destroyed in the fire of 1906 . 


\section{Manuscript Statements of Members of the Committees IN THE BANCROFT LIBRARY}

Bluxome, Isaac, Jr., "33 Secretary." Statement. [1877?] 20 pp.

Cole, Dr. R. Beverly. Statement on Vigilance Committee in San Francisco. 1877. 22 pp. (1856 only.)

Coleman, William T[ell]. Statement. [1877?]. $174 \mathrm{pp}$.

Coon, H[enry] P., M.D. Annals of San Francisco. [1877?]. 31 pp. (1856 only.)

Crary, Oliver B. Statement on Vigilance Committees in San Francisco. 1877. 12 pp. (1856 only.)

Dempster, C[lancey] J. Vigilance Committee. [1877?]. 59 pp. (1856 only.)

Dows, James. Statement on Vigilance Committes in San Francisco. 1877. 12 pp.

Durkee, John L. Statement on Vigilance Committee in San Francisco. 8 pp. (1856 only.)

Farwell, James D. Vigilance Committees in San Francisco. 1878. 24 pp.

Frink, George W. Statement. Vigilance Committee. [1877?] 28 pp. (1856 only.)

Gillespie, Charles V. Vigilance Committee. 1875. 10 pp. (Chiefly 1856.) Manrow, John P[oole]. Statement on Vigilance Committees in San Francisco. 1878. $12 \mathrm{pp}$.

Neall, James, Jr. Statement. Vigilance Committee. [1877?]. 28 pp. (1851 only.)

Olney, James N. Statement. Vigilance Committee. [1877\%]. 36 pp. (1856 only.)

Ryckman, Gerritt W. Statement. Vigilance Committee. [1877?] 20 pp. (Chiefly 1851.)

Schenck, George E[verett]. Statement on the Vigilance Committee, 1856. 1877. 59 pp. (1851 and 1856.)

Smiley, Thomas J[oln] L[oud]. Statement on Vigilance Committees and Early Times in San Francisco. 1877. 24 pp.

Truett, Miers F. Statement on Vigilance Committees in San Francisco. 1871. 8 pp. (1856 only.)

Watkins, William B. Statement. Vigilance Committees in San Francisco. 1878. 24 pp. (1856 only.)

Vigilance Committees in San Francisco-Miscellany. 1877. 39 pp. Statements by Aaron M. Burns, J. D. B. Stillman, William H. Rogers, Hall MeAllister, Sylvester Woodbridge, James C. L. Wadsworth, Asa M. Bowen, A. M. Comstock. 


\section{PRINTED ACCOUNTS OF THE COMMITTEES*}

Ayres, W. O. "Personal Recollections of the Vigilance Committee," Overland Monthly, ser. 2, VIII, 160-176 (August, 1886). C. of V., 1856.

Bancroft, Hubert Howe. Popular Tribunals. San Francisco, 1877. 2 vols. (Works, XXXVI, XXXVII.)

The original edition gave such offense to some Californians that it was withdrawn, and another printed the same year, with modifications in the personal comments. Citations from ed. 2.

Bancroft, Hubert Howe. Chronicles of the Builders, I, 335-387.

Barbour, C. "'Two Vigilance Committees," Overland Monthly, ser. 2, X, 285-291 (September, 1887). Committee of '56 and Committee of Montana.

Brierly, Rev. B. Thoughts for the Crisis: a Discourse Delivered in the Washington St. Baptist Church, San Francisco, Cal., on the Sabbath Following the Assassination of James King of $\mathrm{Wm}$. by James P. Casey. San Francisco, 1856. 20 pp.

Carpenter, W. W. Letter describing Stephen Payran's work in 1851, Oakland Transcript, 1874, March 29 1/1. California State Library.

Carroll, W. [i.e., Conrad Wiegand]. Dr. Scott, the Vigilance Committee and the Church. A Lecture.... Delivered in Musical Hall, San Francisco, Oct. 12, 1856. San Francisco, 1856. 52 pp.

By a purported friend of the Committee. Too incoherent to be of value. Another item by Wiegand is listed on p. 507 .

Cary, Thomas G[reaves]. "The First San Francisco Vigilance Committee,' International Review, XI, 78-88 (July, 1881).

Cary, Thomas G[reaves]. "The San Francisco Committee of Vigilance," Atlantic Monthly, XL, 702-709 (December, 1877). C. of V., 1856.

Cary, Thomas Greaves. The Vigilance Committee of San Francisco, 1851: The Chinese in California: Clipper Ships and the China Trade. No date. $80 \mathrm{pp}$. MS in Harvard University Library.

The "City Guard.", A History of Company "B,' First Regiment Infantry, N.G.C., 1854-1896. San Franciseo, 1895. Cowan collection.

Material relating to the Committee of 1856 is given, pp. 224-228.

Coleman, William T[ell]. "San Francisco Vigilance Committees. By the Chairman of the Committees of 1851[?], 1856, and 1877,' Century Magazine, XLIII, 133-150 (November, 1891).

See also his reminiscences in San Francisco Call, 1884, April 14 1/1-3.

* No attempt has been made to list the many accounts of the Committees that occur in works of wider scope. 
Constitution and Addrress [sic] of the Committee of Vigilance of San Franciseo. San Francisco, 1856. 8 pp. Huntington Library. Also in Hutchings' California Magazine, I, 15-16, 38-41 (July, 1856).

Drury, P. Sheldon. The Startling and Thrilling Narrative of the Dark and Terrible Deeds of Henry Madison, and His Associate and Accomplice, Miss Ellen Stevens, Who Was Executed by the Vigilance Committee of San Francisco, on the 20th September Last. Cincinnati, [1857].

No such execution took place. Collection of R. E. Cowan (see his Bibliography, 73).

Estell, Gen. James M. Speech . . . Delivered in the House of Representatives, Sacramento City, Cal., . . . in Connection with the Vigilance Committee. No date, 1857. $13 \mathrm{pp}$.

A vituperative attack upon the personnel of the Committee of 1856 .

Evans, M. Discourse Pronounced by Rev. M. Evans, at the Funeral Obsequies of James King of William, in Grass Valley, Cal., May 22, 1856. ' Fiat Justitia Ruat Coelum.' Grass Valley, 1856. 17 pp. Collection of R. E. Cowan.

[Fargo, Frank F.] A True and Minute History of the Assassination of James King of Wm. and the Execution of Casey and Cora. San Francisco [1856]. $24 \mathrm{pp}$.

Compiled from articles in the Alta written by Fargo.

"Fort Gunnybags, the Old Stronghold of the Vigilance Committee. Shall It be Marked?', Overland Monthly, ser. 2, XXXI, 73-77 (January, 1898).

"Fort Gunnybags....", Overland Monthly, ser. 2, LXXII, 574-581 (December, 1918).

Gray, Henry M., see Judges and Criminals.

Green, Alfred A. Life and Adventures of a 47 -er in California. 1878. 86 pp. MS in the Bancroft Library.

The author was under arrest by the Committee of 1856 .

Hallidie, A. S. “'William T. Coleman,' Overland Monthly, ser. 2, XXIII, 71-75 (January, 1894).

Hunt, Rockwell D[ennis]. "'The Committees of Vigilance of California,", Overland Monthly, ser. 2, XLIX, 31-39 (January, 1907).

Hunt, T[imothy] Dwight. Sermon Suggested by the Execution of Jenkins in the Plaza by "the People" of San Francisco during the Night of the 10th of June, 1851. San Francisco, 1851. 26 pp. 
Judges and Criminals: Shadows of the Past. History of the Vigilance Committee of San Francisco, Cal. With the Names of its Officers. San Franciseo, 1858. $100 \mathrm{pp}$.

Ascribed to Henry M. Gray (see Cowan, Bibliography, 124). Opposed to the Committee of 1856 . Note similarity of title with that of the sketches by R. F. Ryan, supra, p. 490.

King, Charles J. "Reminiscences of Early Days in San Francisco," Overland Monthly, ser. 2, XI, 275-283 (March, 1888).

The Committee of 1856. By a son of James King of William. See also his contribution to Irvine, History of the New California, I, 83-101.

King, Joseph L. '“The Vigilance Committee of '56,' Overland Monthly, ser. 2, LXVIII, 509-520 (December, 1916).

By a son of James King of William.

Lockwood, R[ufus] A. The Vigilance Committee of San Francisco, Metcalf vs. Argenti et al. Speeches of R. A. Lockwood, Esq. San Francisco, 1852. 48 pp. Ed. 1, 1851, see supra, p. 330 note 25.

MeGowan, Edward. Narrative... Including a Full Account of the Author's Adventures and Perils, while Persecuted by the San Francisco Vigilance Committee of 1856. San Francisco, 1857.

"Edward MeGowan's Abenteuer," in German, appears in Wentzel \& Huefner's San Francisco Kalender, 187\%, pp. 1-25.

[O'Meara, James.] The Vigilance Committee of 1856. By a Pioneer California Journalist. San Francisco, 1887. $57 \mathrm{pp.}$

The cover title is dated 1890. Opposed to the Committee. See also his contribution to Irvine, History of the New California, I, 102-199.

O'Meara, James. “Admiral Farragut,', San Francisco Chronicle, 1881. July 10 1/1-2.

Reports a conference with a committee from the C. of V. of 18.56 .

Paul, Almarin B. "'The Vigilance Committee of '56," Overland Monthly, ser. 2, XXIV, 433-441; 529-542; 622-634 (October-December, 1891).

The Phoenix. A weekly anti-Vigilante sheet, published by Edward MeGowan in Sacramento, August 30, 1857, to February 14, 18.58. Its attacks were so indecent that newsboys were arrested for selling it in San Francisco, and to evade suppression the title was changed to Ubiquitous, under which it appeared from February 21 to June 20, 1858.

Pierce, Franklin. Message. August 6, 1856. 30 pp. (Cong. Docs., Ser. No. 824, Doc. 101.)

With correspondence relating to the "self-styled Vigilance Committee in California.', 
Rivors, - A Full and Authentic Account of the Murder of James King of Wm., Dr. Randall, Dr. Baldwin, West and Marion. The Execution of James P. Casey, Charles Cora, Philander Brace, and Joseph Hetherington, by the Vigilance Committee of San Francisco. . . . . Written by Rivors. Published by E. Darrow \& Brother, Rochester, 1857. $64 \mathrm{pp}$.

Collection of H. R. Wagner. Chiefly reprints of newspaper accounts. The first fifty pages elosely follow Fargo's True and Minute History.

Scott, Rev. [William Anderson]. A Discourse for the Times. Delivered in Calvary Church, Sunday, July 27, 1856. Education, and Not Punishment, the Truc Remedy for the Wrong-Doings and Disorders of Society. San Francisco, 1856. 8 pp.

In opposition to the Committee of Vigilance, although the organization was not directly mentioned.

Sherman, William T[ecumseh]. "Sherman and the San Francisco Vigilantes. Unpublished Letters . . . ' Century Magazine, XLIII, 296309 (December, 1891).

Sherman, William T[ecumseh]. “The Vigilance Committee of 1856," Overland Monthly, XII, 105-116 (February, 1874).

Correspondence between the Committee and General Sherman, who opposed the organization. Reprinted in San Francisco Chronicle, 1874, January $23 \% 1 / 4$.

Smith, Frank Meriweather, editor. San Francisco Vigilance Committee of '56, with Some Interesting Sketches of Events Succeeding 1846. San Francisco, 1883. $83 \mathrm{pp}$.

Friendly to the Committees of 1851 and 1856.

Soulé, Gihon and Nisbet, "The Vigilance Committee," in their Annals of San Francisco, (San Franciseo, 1855), pp. 562-687.

Texas Legislature. Resolution in relation to the restriction of the supremacy of the law in California, and in securing to Judge Terry a fair trial. 1 p. (Cong. Docs., Ser. No. 835, Doc. 1.)

Trial of David S. Terry by the Committee of Vigilance of San Francisco. San Francisco, 1856. $75 \mathrm{pp}$.

Transcript of the evidence. No comments.

United States. War Department. Report . . . . in relation to the proceedings of the Vigilance Committee in San Francisco, California. $29 \mathrm{pp}$. (Cong. Docs., Ser. No. 881, Doc. 43.)

Weed, Joseph. "Vigilance Committees of San Francisco," Overland Monthly, XII, 350-357 (April, 1874). 
Wheeler, C. B. Specch Delivered at the Sophomore Prize Debate of the Brothers in Unity of Yale College, January 14, 185\%.... Was the Formation of the San Francisco Vigilance Committee Jutifiable? $8 \mathrm{pp}$.

Collection of H. R. Wagner. Title page wanting.

The Wide West, June and October, 1856. Illustrations of scenes of 1856.

Wiegand, Conrad. To the People of San Francisco and Califormia as Citizens of the United States. [San Francisco, 1856.] 8 pp.

Relates to the Committee of Vigilance. Collection of R. E. Cowan. See also entry under Carroll, W., p. 503.

Willey, Rev. S[amuel] H[opkins]. "Personal Recollections of the Vigilance Committee,' Overland Monthly, ser. 2, VIII, 330-331 (September, 1886.)

Woolley, Lell Hawley. "'Pioneer Experiences in California,', Overland Monthly, ser. 2, LXIX, 66-78 (January, 1917).

Zabriskie, James C. Reply of James C. Zabriskie to a Committee of Citizens of Sacramento, in Reference to the Vigilance Committee and Democracy. Sacramento, $1856.8 \mathrm{pp}$.

Collection of H. R. Wagner. Approves the Committee.

Clippings from the contemporary papers on the Committee of 1851 were collected by Bancroft, and they are filed with the archives. Clippings on the Committee of 1856 were collected in a scrapbook made by Thomas B. Robinson, now in the Bancroft Library.

An interesting collection of pictorial letterheads, including illustrations of executions by both Committees, is preserve in the Memorial Museum in Golden Gate Park.

\section{Committees of Vigilance Elsewhere Than in San Francisco}

California, Shasta County. Turner, William M. "How We Did It on Scott's Bar,'' Overland Monthly, XIV, 377-381 (April, 1875).

California, Los Angeles. Committee of Vigilance, 1836. 13 pp. Vigilantes de Los Angeles.... 1836. 11 pp.

Two undated MSS in the Bancroft Library, describing the trial and execution of Gervacio Alipas and Rosario Villa for the murder of the latter's liusband. The Spanish MS is probably by Victor Prudon, president of the tribunal.

California, Marysville. Marysville Vigilance Committee. Minutes of the Vigilance Committee of Marysville. MS volume of $19 \mathrm{pp}$. in the Public Library of Marysville. 
CALifornia, Sonora. Layton, Grovenor I. Two Ycars in the Life of the Felon, Grovenor I. Layton, Who was Lynched by the Vigilance Committee at Sonora.... June 17, 1852. New Orleans, 1852. 40 pp. (See Cowan, Bibliography, 137.)

IowA. Jackson County Historical Society, Annals, I-IV, 1905-1907 (see supra, p. 416 note 26.)

Kansas. Kansas State Historical Society, Transactions, X-XIII, 19071914 (see supra, p. 420 note 32 ).

Louisiana. Barde, Alexandre. Histoire des Comités de Vigilance aux Attakapas. Saint-Jean-Baptiste (La.), 1861.

Griffin, H. L. "'The Vigilance Committees of the Attakapas Country ... .' Mississippi Valley Historical Association, Proceedings, VIII (1914-1915), 146-159. A review of Barde.

Montana and Vicinity. Dimsdale, Thomas J. The Vigilantes of Montana, or Popular Justice in the Rocky Mountains. . . . . Virginia City, 1866. Ed. 3 ; Butte, 1915.

Langford, Nathaniel Pitt. Vigilante Days and Ways; the Pioneers of the Rockies. Boston, 1890. 2 vols. New ed. Chicago, 1912. 1 vol.

Montana Historical Society. Contributions, II-VIII, 1896-1917 (see supra, p. 419 notes $30-31$ ).

Oregon. Turner, William M. “Pioneer Justice in Oregon," Overland Monthly, XII, 224-230 (March, 1874).

See also infra, under J. E. Cutler; George Kennan; J. C. Lester; T. M. Marquett; L. E. Munson; J. E. Parker; W. Y. Pemberton; G. F. Shafer; W. J. Trimble.

\section{MISCELLANEOUS WORKS}

General Authorities

Alden, George Henry. New Governments West of the Alleghanies before 1780..... Madison, 1897. (Bulletin of the University of Wisconsin. Historical Series, II, no. 1.)

Alden, George Henry. "'The State of Franklin,' American Historical Review, VIII, 271-289 (January, 1903).

American Association of Law Libraries. Index to Legal Periodicals. . . . Chicago, 1908 to date.

Ashe, Samuel A'Court. History of North Carolina. Vol. I. Greensboro, N. C., 1908.

Avery, Elroy McKendree. A History of the United States and Its People, from Their Earliest Records to the Present Time. Cleveland, 19041910. 7 vols. Index. Tarrytown, N. Y., 1915. 
Bancroft, Hubert Howe. History of Mexico. 1883-1888. 6 vols. (Works, IX-XIV.)

Bancroft, Hubert Howe. History of Nevada, Colorado, and Wyoming. . . . . San Franciseo, 1890. (Works, XXV.)

Bancroft, Hubert Howe. History of the North Mexican States and Texas. San Francisco, 1884-1889. 2 vols. (Works, XV-XVI.)

Bancroft, Hubert Howe. History of Oregon. San Francisco, 1886-1888. 2 vols. (Works, XXIX-XXX.)

Bancroft, Hubert Howe. Literary Industries. San Franciseo, 1890. (Works, XXXIX.)

Banta, David D. "The Criminal Code of the Northwest Territory," Indiana Magazine of History, IX, 234-236 (December, 1913).

Bassett, John S. “'The Regulators of North Carolina (1765-1771)," American Historical Association, Annual Report, 1894, pp. 141-212.

[Benton, Thomas Hart.] Thirty Years' View. . . . . New York, 1854-1856. 2 vols.

Black, Paul Walton. '“Attempted Lynehings in Iowa,' Annals of Iowa, ser. 3, XI, 260-285 (January, 1914).

Black, Paul Walton. ' Lynchings in Iowa,' Iowa Journal of History and Politics, X, 151-254 (April, 1912).

Bolderwood, Rolf. ' 'Genesis of Gold-Fields Law in Australia,' Cornhill Magazine, new ser., III, 612-623 (November, 1897).

Bolton, Herbert Eugene. "'The Obligation of Nevada Toward the Writing of Her Own History,' Nevada Historical Society, Third Biennial Report, 1911-1912, pp. 62-79.

Borgeaud, Charles. The Rise of Modern Democracy in Old and New England. Translated by Mrs. Birkbeck Hill, with a Preface by C. H. Firth. London, 1894.

Browning, Colin Arrott, M.D. England's Exiles; or, A View of a System of Instruction and Discipline, as Carried into Effect during the Toyage to the Penal Colonies of Austratia. London, 1842.

Bryce, James. The American Commonwealth. New York, 1914. 2 vols. (Ed. 1, 1888.)

Buchanan, James. Works.... Collected and edited by John Bassett Moore. Philadelphia, 1908-1911. 12 vols.

Burgess, John W[illiam]. The Middle Period, 1817-1858. New York, 1897. (The American History Series, IV.)

Butler, Charles C. "'Lynehing," American Law Review, XLIV, 200-220 (March-April, 1910).

Chapman, Charles Edward. History of Spain. . . . . New York, 1918. 
Clark, Walter. '“True Remedy for Lynch Law,' American Law Review, XXVIII, 801-807 (November-December, 1894).

Cleveland, Frederick A[lbert]. Organized Democracy; an Introduction to the Study of American Politics. New York, 1913. (American Citizen Series.)

Collins, Edward D. "Committees of Correspondence of the American Revolution,' American Historical Association, Annual Report, 1901, I, 245-271.

"County Government,' American Academy of Political and Social Science, Annals, XLVII (May, 1913. Whole no. 136).

"Criminal Procedure. Report of Committee E," Journal of the American Institute of Criminal Law and Criminology, III, 566-591 (November, 1912).

Croly, Herbert [David]. Promise of American Life. New York, 1909.

Cutler, James Elbert. Lynch-Law: an Investigation into the History of Lynching in the United States. New York, 1905.

The Cyclopedia of American Government. Edited by Andrew C. McLaughlin and Albert Bushnell Hart. New York, 1914. 3 vols.

Donaldson, Thomas [Corwin]. The Public Domain. Its History, with Statistics. . . . . Washington, 1881. (U. S. Public Land Commission, 1879-1880. Cong. Docs., Ser. No. 1975, Doc. 47, pt. 4.)

Devens, Richard M[iller]. Our First Century. .... Springfield, 1876. Citations from edition of 1880 .

Dowling, Edward. Australia and America in 1892: a Contrast. Sydney, 1893.

Published by authority of the New South Wales Commissioners for the World's Columbian Exposition, Chicago, 1893.

Duruy, Victor. History of Greece. . . . . Translated and edited by M. M. Ripley. . . . With an Introduction by J. P. Malaffy. . . . Boston, 1890. 4 vols. in 8 .

Esarey, Logan. History of Indiana. . . . . Indianapolis, 1915-1918. 2 vols.

Esarey, Logan. “'The Pioneer Aristocracy,' Indiana Magazine of History, XIII, 270-287 (September, 1917).

Fairlie, John A[rehibald]. Local Government in Counties, Towns and Villages. New York, 1906. (The American State Series.)

Foote, Henry Stuart. Texas and the Texans..... Philadelphia, 1841. 2 rols. 


\section{Bibliography}

Forster, Henry A. "Do Our Laws Protect Criminals? Why the United States Leads the World in the Relative Proportion of Murders, Lynchings and Other Felonies, and Why the Anglo-Saxon Countries Not under the American Flag Have the Least Proportion of Murders and Felonies, and Know No Lynchings,' American Law Review, LI, 239-248 (November, 1917).

French, George Edgar. “The Coeur d'Aléne Riots, 1892,' Overland Monthly, ser. 2, XXVI, 32-40 (December, 1895).

Fry, F. Fry's Traveler's Guide and Descriptive Journal of the Great Northwestern Territories. . . . Cincinnati, 1865.

Garrison, George P[ierce]. Texas; a Contest of Civilizations. Boston, 1903. (American Commonwealths.)

Garrison, George Pierce. Westward Extension, 1841-1850. New York, 1906. (The American Nation, XVII.)

Gilbertson, H[enry] S[timson]. The County, the "Dark Continent" of American Politics. New York, 1917.

Goebel, Julius, Jr. "Prevalence of Crime in the United States and Its Extent Compared with That in the Leading European States," Journal of the American Institute of Criminal Law and Criminology, III, 754-769 (January, 1913).

Goodnow, Frank J[ohnson]. Politics and Administration; a Study in Government. New York, 1900.

Gray, W[illiam] H[enry]. History of Oregon, 1792-1849. . . . . Portland, 1870 .

Gue, Benjamin F. History of Iowa From the Earliest Times To the Beginning of the Twentieth Century. New York [1903]. 4 rols.

Halleck, H[enry] W[ager]. International Law. New York, 1861.

Hardy, Dermot H., and Roberts, Ingham S., editors. Historical Review of South-East Texas. . . . Chicago, 1910. 2 vols.

Hart, Albert Bushnell. "Growth of American Theories of Popular Government,' American Political Science Review, I, 531-560 (August, $1907)$.

Hart, Albert Bushnell. National Ideals Historically Traced, 160\%-190\%. New York, 1907. (The American Nation, XXVI.)

Haydon, A[rthur] L[incoln]. The Trooper Police of Australia..... London, 1911.

Haywood, Marshall DeLancey. Governor William Tryon, and His Administration in the Province of North Carolina, 1r65-1ry1... . Raleigh, 1903. 
Henderson, Archibald. "The Origin of the Regulation in North Carolina,', American Historical Review, XXI, 320-332 (January, 1916).

Henderson, Archibald. Richard Henderson: the Authorship of the Cumberland Compact and the Founding of Nashville. [Nashville?], 1916. Reprinted from the Tennessee Historical Magazine, II,. 155-174 (September, 1916).

Hill, Robert Tudor. The Public Domain and Democracy. . . . . New York, 1910. (Columbia University, Studies in History, Economics and Public Law, XXXVIII, no. 1.)

Holst, Hermann [Eduard] von. Constitutional and Political History of the United States. . . . . Chicago, 1876-1892. 8 vols.

Howard, George E[lliott]. Introduction to the Local Constitutional History of the United States. Vol. I. Baltimore, 1889. (Johns Hopkins University, Studies in Historical and Political Science, extra Vol. IV.) No more published.

Hulbert, Archer Butler. "Richard.Henderson: the Founder of Transylvania," The Chatauquan, XXXVIII, 366-371 (December, 1903).

Hunt, Agnes. The Provincial Commitees of Safety of the American Revolution. [Cleveland], 1904.

Huxley, Henrietta. 'GGold Diggings at Bathurst in 1851," Nineteenth Century, XLV, 962-972 (June, 1899).

Johnson, Allen. "Genesis of Popular Soverignty," Iowa Journal of History and Politics, III, 3-19 (January, 1905).

Johnson, Allen. Stephen A. Douglas. New York, 1908.

Johnson, Brigham. "Frontier Life in Iowa in the Forties," Magazine of History, XVIII, 23-28 (January, 1914).

Kales, Albert M[artin]. Unpopular Government in the United States. Chicago [copyrighted 1914].

Kennan, George. "A Russian Experiment in Self-Government," Atlantic Monthly, LXXX, 494-507 (October, 1897).

Kipling, Rudyard. "With the Night Mail," in his Actions and Reactions (New York, 1909), 117-171.

Lavisse, Ernest, and Rambaud, Alfred. Histoire générale du IV siècle à nos jours. Paris, 1893-1901. 12 vols.

Lawson, John Davison. "'Technicalities in Procedure, Civil and Criminal," Journal of the American Institute of Criminal Law and Criminology, I, 63-85 (May, 1910).

Leake, James Miller. The Virginia Committee System and the American Revolution. Baltimore, 1917. (Johns Hopkins University, Studies in Historical and Political Science, XXXV, no. 1.) 
Lester, J[ohn] C., and Wilson, D. L. The $K u$ Klux Klan..... With Introduction and Notes by Walter L. Fleming. New York, 1905.

A smaller ed. was published at Nashville, 1884.

Lieber, Francis. On Civil Liberty and Self-Government. Philadelphia, 1853. Citations from ed. 3, Philadelphia, 1891.

Lindley, Curtis $\mathrm{H}[\mathrm{olbrook}]$. Treatise on the American Law Relating to Mines and Mineral Lands within the Public Land. . . . . Ed. 3. San Francisco, 1914. 3 vols.

Lobingier, Charles Sumner. The People's Law . . . a Study in the Evolution of Democracy and Direct Legislation...... With an Introduction by George Elliott Howard. New York, 1909.

Lowell, A[bbott] Lawrence. Public Opinion and Popular Goremment. New York, 1913.

Lyman, Horace S[umner], and others. History of Oregon.... New York, 1903. 4 vols.

“'The Lynch-Law Tree,' Green Bag, IV, 561-562 (December, 1892).

MeConnel, J[ohn] L[udlum]. Western Characteristics. . . . New York, 1853.

California State Library.

McCrady, Edward. History of South Carolina under the Royal Government, 1\%19-17r6. New York, 1899.

MeLaughlin, Andrew C. "Social Compact and Constitutional Construction,' American Historical Review, V, 467-490 (April, 1900).

McMaster, John Bach. History of the People of the United States from the Revolution to the Civil War. New York, 1883-1913. 8 vols.

Macy, Jesse. Institutional Beginnings in a Western State [Iowa]. Baltimore, 1884. (John Hopkins University, Studies in Historical and Social Science, II, no. 7.)

Magoon, Charles E[dward]. Reports, see United States. War Department, supra, p. 477.

Maine, Sir Henry Sumner. Dissertations on Early Law and Custom. . . . . New York, 1886.

Marquett, T. M. "The Effect of Early Legislation upon the Courts of Nebraska,' Nebraska State Historical Society, Proceedings and Collections, ser. 2, I (1894-1895), 103-118.

Marshall, Thomas Maitland, editor. Early Records of Gilpin County, Colorado, 1859-1861. Boulder, 1920. (University of Colorado, Collections, II. Mining Series I.)

Marshall, Thomas Maitland. "'The Miners' Laws of Colorado,' American Historical Review, XXV, 426-439 (April, 1920). 
Mathews, John Mabry. Principles of American State Administration. New York, 1917.

Matlews, Lois Kimball. "The Mayflower Compact and Its Descendants,' Mississippi Valley Historical Association, Proceedings, VI (19121913), 79-106.

Meigs, William M[ontgomery]. Life of Thomas Hart Benton. Philadelphia, 1904.

Merriam, C[harles] Edward. A History of American Political Theories. New York, 1903.

Merriman, Roger Bigelow. Rise of the Spanish Empire in the Old World and the New. New York, 1918. Vols. 1-2.

Munro, William Bennett, editor. The Initiative, Referendum and Recall. New York, 1912. (National Municipal League Series.)

Munson, Lyman E. "Pioneer Life in Montana,', Montana Historical Society, Contributions, V (1904), 200-234.

New Mexico Supreme Court. Reports. First, 1852-1879. Chicago, 1911.

North Carolina (Colony). The Colonial Records of North Carolina. Published . . . . by order of the General Assembly; collected and edited by William L. Saunders, Secretary of State. Raleigh, 1886-1890. 10 vols. Indexed in the Index to the Colonial and State Records, compiled by Stephen B. Weeks. Charlotte, 1909-1914. 4 vols.

Northcott, Clarence H[unter]. Australian Social Development. New York, 1918. (Columbia University, Studies in History, Economics and Pub. lic Law. LXXXI, no. 2. Whole no. 189.)

Oregon Archives . . . from the Earliest Attempt on the Part of the People to Form a Government, down to, and Inclusive of the Session of the Territorial Legislature, held in ... 1849.... By La Fayette Grover, Commissioner. Salem, 1853.

Huntington Library.

Osgood, Herbert L. "'The Political Ideas of the Puritans,' Political Science Quarterly, VI, 1-28 (March, 1891).

Paetow, Louis John. Guide to the Study of Medieval History. Berkeley, 1917.

Parker, James E. “Pioneer Protection from Horse Thieves,' Annals of Iowa, ser. 3, VI, 59-62 (April, 1903).

Paxson, Frederic Logan. The Last American Frontier. New York, 1910.

Pemberton, W. Y. “Montana's Pioneer Courts," Montana Historical Society, Contributions, VIII (1917), 99-104.

“'Petition for a Western State, 1780," Mississippi Valley Historical Review, I, 265-269 (September, 1914). 
Platt, Robert Treat. "'Oregon and Its Share in the Civil War," Oregon Historical Society, Quarterly, IV, 89-109 (June, 1903).

Polk, James K[nox]. The Diary of James $K$. Polk during His Presidency, 1845 to 1849 .... Edited . . . . by Milo Milton Quaife . . . . with an Introduction by Andrew Cunningham MeLaughlin. Chicago, 1910. 4 vols.

Pound, Roscoe. Bibliography of Procedural Reform. Chicago, 1917.

Pound, Roscoe. "Causes of Popular Dissatisfaction with the Administration of Justice,' American Bar Association, Annual Report, 1906, I, 395-417.

Price, Eliphalet. “Trial and Execution of Patrick O'Conner at the Dubuque Mines in the Summer of 1834,' Annals of Iova, III, 566574 (October, 1865).

Putnam, A[lbigence] W[aldo]. History of Middle Tennessee; or, Life and Times of Gen. James Robertson. Nashville, 1859.

Ramsay, David. History of South Carolina, from ....1670 to ... 1808. . . . Charleston, 1809. 2 vols.

Ramsey, J[ames] G[attys] M[cGregor]. The Annals of Tennessee to the End of the Eighteenth Century. . . . . Charleston, 1853.

Ransom, William L. "The Organization of the Courts for the Better Administration of Justice,' Cornell Law Quarterly, II, 186-201, 261282 (March, May, 1917).

Rawles, William A. Centralizing Tendencies in the Administration of Indiana. New York, 1903. (Columbia University, Studies in History, Economics and Public Law, XVII, no. 1.)

Rhodes, James Ford. History of the United States from the Compromise of 1850. . . . . New York, 1893-1904. 5 vols.

Richardson, James D. Messages and Papers of the Presidents, see United States Presidents, supra, p. 477.

Riley, Franklin L. "Transition from Spanish to American Rule in Mississippi,', Mississippi Historical Society, Publications, III (1900), 261-311.

Rippy, J[ames] Fred. "Border Troubles along the Rio Grande, 18481860,' Southwestern Historical Quarterly, XXIII, 91-111 (October, 1919).

Roberts, William. "The Administration of Justice in America," Fort. nightly Review, new ser., LI, 91-108 (January 1, 1892).

Robertson, James Rood. "Genesis of Popular Government in Oregon,", Oregon Historical Society, Quarterly, I, 1-59 (March, 1900). 
Roosevelt, Theodore. The Winning of the West. 4 vols. New York, 1889. 1896.

Ross, Edward Alsworth. Social Control; a Survey of the Foundations of Order. New York, 1901. (Citizen's Library of Economics, Polities and Sociology.)

Schouler, James. History of the United States of America, under the Constitution. Revised ed. New York [copyrighted 1880-1913]. 7 vols.

Scott, Leslie M. '“Pioneer Stimulus of Gold,' Oregon Historical Society, Quarterly, XVIII, 147-166 (September, 1917).

Shafer, George F. ' Early History of McKenzie County,' North Dakota State Historical Society, Collections, IV (1913), 41-61.

Shambaugh, Benjamin F[ranklin]. "Frontier Land Clubs or Claim Associations," American Historical Association, Annual Report, 1900, I, 67-84.

Shambaugh, Benjamin F[ranklin]. Constitution and Records of the Claim Association of Johnson County, Iowa. Iowa City, 1894.

See also his article in Iowa Historical Record, IX (1893), 414-420.

Smith, J[ames] Allen. Spirit of American Government. . . . . New York, 1912 [copyrighted 1907].

Smith, William Henry. A Political History of Slavery..... With an Introduction by Whitelaw Reid. New York, 1903. 2 vols.

Storey, Moorfield. Reform of Legal Procedure. New Haven, 1911. (William L. Storrs Lecture Series.)

Sumners, Hatton W. "Protection of the State against the Criminal ....' American Law Review, XLIII, 455-466 (May-June, 1909).

Taft, William $\mathrm{H}$ [oward]. "The Administration of Criminal Law," Yale Law Review, XV, 1-17 (November, 1905).

Taylor, Zachary. Letters .... from the Battle-Fields of the Mexican War. . . . Rochester, N. Y. 1908.

Texas (Republic of Texas). "Journal of the Permanent Council (October" 11-27, 1835),', Texas State Historical Association, Quarterly, VII, 250-278 (April, 1904); IX, 287-288 (April, 1906).

Thompson, J[oseph] W[esley]. United States Mining Statutes. Annotated. Washington, 1915. 2 vols. (United States Bureau of Mines, Bulletin 94, Law Serial 4.)

Thorndike, Lynn. History of Medieval Europe. New York. [Copyrighted 1917.]

Thorpe, Francis Newton. Constitutional History of the American People, 1776-1850. New York, 1898. 2 vols. 
Trimble, William J[oseph]. Mining Advance into the Inland Empire. . . . . Madison, 1914. (Bulletin of the University of Wisconsin, no. 638, History Series III, no. 2.)

Turner, Frederick Jackson. The Frontier in American History. New York, 1920.

Collects important articles hitherto accessible only in historical magazines.

Turner, Frederick Jackson. The Rise of the New West, 1819-1829. New York, 1906. (The American Nation, XIV.)

Turner, Frederick Jackson. " Western State-Making in the Revolutionary Era,' American Historical Review, I (1895-1896), 70-87, 251-269.

Twitchell, Ralph Emerson. History of the Military Occupation of the Territory of New Mexico from 1846 to 1851. . . . . Denver, 1909.

Watts-Dunton, Theodore. '“Bret Harte,' Athenaeum, May 24, 1902, pp. 658-659.

Weyl, Walter E[dward]. The New Democracy. . . . . New York, 1912.

Whately, Richard. Introductory Lectures on Political Economy. . . . With Remarks on Tithes and on Poor-Laws and on Penal Colonies. London, 1855. This is ed. 4, enlarged, of his Introductory Lectures. 1831.

Wheeler, John H[ill]. Historical Sketches of North Carolina, From 1584 to 1851. . . . Philadelphia, 1851. 2 vols. in 1.

White, Charles. Early Australian History. Convict Life in New South Wales and Van Diemen's Land. . . . . Bathurst, 1889.

Willis, Hugh Evander. "How Shall the People of the United States of America Reform Their Legal Procedure so as to Make It an Instrument of Justice?", Journal of the American Institute of Criminal Law and Criminology, VI, 533-545 (November, 1915).

Wilson, Woodrow. "'Issues of Reform,' in Munro, W. B., editor, Initiative, Referendum and Recall (New York, 1912), 69-91.

Winsor, Justin. The Westuard Movement. The Colonies and the Republic West of the Alleghanies, 1763-1798. . . . Boston, 1897.

Woodward, Walter Carleton. Rise and Early History of Political Parties in Oregon, 1840-1868. Portland, 1913.

Yoakum, Henderson K. History of Texas . . . to . . . 1846. New York, 1856 [copyrighted 1855]. 2 vols.

Young, John E. Law as an Expression of Community Ideals . . . ', Yale Law Journal, XXVII, 1-33 (November, 1917). 


\section{Series, Periodicals and Newspapers}

American Academy of Political and Social Science, Annals.

American Bar Association, Annual Reports.

American Historical Association, Annual Reports.

American Historical Review.

American Institute of Criminal Law and Criminology, Journal.

American Irish Historical Society, Journal.

American Law Review.

American Political Science Review.

Annals of Iowa.

Arkansas Historical Association, Publications.

Athenaeum.

Atlantic Monthly.

California Law Review.

Century Magazine.

Cornell Law Quarterly.

Cornhill Magazine.

Des Moines Register and Leader.

Fortnightly Review.

The Green Bag.

History Teachers' Magazine.

Indiana Magazine of History.

Iowa Journal of History and Politics.

Jackson County [Iowa] Historical Society, Annals.

Kansas State Historical Society, Transactions. Binder's title: Collections.

Lancaster County [Pennsylvania] Historical Society, Papers.

Magazine of American History.

Minnesota Historical Society, Collections.

Mississippi Valley Historical Association, Proceedings.

Mississippi Valley Historical Review.

Montana Historical Society, Contributions.

Nebraska State Historical Society, Proctedings and Collections.

Nevada Historical Society, Reports.

Niles Register.

Nineteenth Century.

North Dakota State Historical Society, Collections.

Oregon Historical Society, Quarterly.

Political Science Quarterly.

Revue des deux mondes.

Southwestern Historical Quarterly (formerly Texas State Historical Association, Quarterly).

Texas Review.

Yale Law Review. 


\section{INDEX}

Abolition (abolitionists): victims of popular tribunals, 74 note 23,422 . See also Slavery question.

Academy of Pacific Coast History: 3.

Adams, George, prisoner C. of V.: $247,251,275,276-277,287$, $290,307,308,311,312,358$.

Adams, Robert, Jr.: 14.

Adirondack, a vessel: 235 .

Aiken, George, see British consul.

Ainsworth, Thomas, prisoner C. of V.: $251,288$.

Alcalde, The: in Mexican administration of California, 24-27; small towns deprived of, by laws of $1837,25-26$; " alcalde system," a popular misnomer, 27 ; installed without distinetion as to size of town after. American occupation, 29-31, 38,40 ; jurisdiction and duties of, $40-42,44,47,51,58-60$, $80,110,117-119$; supervision of, by Mason, 44; despotism of, $37,48-49,52$ note 37,99 ; independent alcaldes elected in the mining camps, 70, 81-81, $89,101,117,147$; office discontinued after state organization, 147.

Alderson, William, prisoner C. of V.: 236 note 24.

Allsop, Thomas: eited, 142-143.

Almond, William B., judge of first instance: 111.

Alta California, a San Franciseo paper: 94 note 17, 168; proposed survey of eriminal resorts, 184, 228; confirmed statements in C. of $\mathrm{V}$. records, 314.

Alvarado, governor of California: 26.
Andrews, W. C. B., C. of V., 1856: 473.

Angel Island: searched for stolen goods, 236.

Angel's Camp, California: C. of V., 407 note 56.

Archer, Lawrence, cited, 84.

Arentrue, J. J.: prisoner C. of V., 267 note 49, 289-290, 360-361.

Argenti, Felix, $C$. of $\nabla .:$ biographical note, 198; mentioned, 188 note $3,240,346$ note 27 ; sued by Metcalf, 243-244, 329-331, $340,343,347,375$.

Army and Navy, U. S., coöperation of officers of, with C. of V.: 315,371 .

Arrington, N. O., C. of $V ., 1856$ : 473.

Arrington, William, $C$. of $V$., 1856: 473.

Arrowsmith, D. B., C. of V.: 208.

Arson: 239, 245, 340. See also San Franciseo-Fires.

Arthur, George, prisoner C. of V.: 288.

Assing, Norman: 318-319.

"Association for the Protection of the Rights of Property and the Maintenance of Order': 393. See also Land clubs; Land laws.

Atoy, a Chinese woman: 319.

Attakapas, district of Louisiana: Vigilance Committees organized by the French colonists in $18.59,420-422$.

Auburn, California: 146 note 25 . Auger, Edouard: cited, 168, 414 .

Austin, E. G.: 282.

Australia: comments of newspapers of, on acts of $\mathrm{C}$. of V., 241; efficient administration of justice on the frontier gold fields, 425-426. See also Convicts from Australia. 
Ayuntamiento (town council), in Mexican administration of California, 24-26, 30 note 16 ; in the American period, 49-50, 104; in San Francisco, 49, 97$98,112-113,163$.

Bail: forfeiture of, 152, 181 note 63.

Baker, E. D., lawyer : 411.

Ball, F. A., C. of V.: 467 .

Bancroft, H. H.: importance of his works on California history, 1 ; Popular Tribunals, 2, 5, 6; approval of C. of V., 414.

Bancroft Library: 1, 2, 221.

Banishment ordered by C. of V., 1851: 229, 232, 233, 286, 315, 362,402 ; by C. of V. 1856 , 199,402 .

Banners presented to C. of V.: by ladies of Trinity Church, 371$372,403,471$; by Plum and Warner, 372 note 45.

Bannock, Montana. See Plummer gang, Montana.

Barclay, William, prisoner C. of V.: 236 note 24.

Barde, Alexandre, Histoire des Comités d.e Vigilance: 420 422.

Barette, a vessel: 235 note 22 .

Barnes the tinman: 306 .

Barrett (Garrat), John: hanged for robbery, 156 note 49 .

Barry, P.: 107.

Barry, R. C.: 146 note 27.

Barry, T. A., C. of $V .: 406$ note 53.

Basquez, Theodore: hanged for horse stealing, 156 note 49 .

Bayles, L. J., C. of $V$.: 302.

Bear Flag revolt: 28.

Beard, J. R., president Sacramento C. of V.: 378 .

Beck, Henry, prisoner C. of V.: 228 note $1,251$.

Bell, A. W., C. of V.. 1856: 473.

Bells of the California and the Monumental engine companies, used by the C. of V.: 169, 206 note 51, 268, 289, 344, 398.
Bennett, F. C., C. of $V .: 164$ note 5,447 .

Benton, Senator T. H.: letter on organization of California, 90, 95, 96-97, 102 note 36.

Berdue, Thomas, from Sydney, mistaken for James Stuart, tried for his erimes, and saved by the C. of V.: Jansen attack, 171-175, 299, 453-454; Moore murder, 175-176, 257; exonerated, 303 ; subseription for, 303 ; published card of thanks, 304 .

Big Brummy, alias of Mat Hopwood.

"Bird in Hand," suspicious lodging house: 306,307 .

Blackburn,* William, alealde of Santa Cruz: 47.

Blackburn,* "Judge", William, $C$. of $V .: 188$ note 1.

Blake, G. H., C. of $V .: 446$.

Blood, J. H., C. of V.: 327, 471.

Blunt, S. F., C. of $V .: 371$ note 41.

Bluxome, Isaac, Jr., $C$. of $V$.: biographical note, 191-192; elected secretary, 209, 220, 338,352 ; “67, Secretary,' 1851,225 note 53,332 ; “ 33 , Secretary,' 1856, 189; mentioned, 2, 108 note 53, 267 note $49,269,298,299,333$ note 35 , 400, 473; MS Statement cited, 107 note 51, 202, 208 note 1 , 234,345 .

Boles, A.: 382 .

Bond, Charles R., C. of V.: 372 note 46,406 note 53 .

Bonner, - : 146 note 27.

Borthwick, J. D.: eited on C. of V., 413.

Bossange, L.: 473.

Boyd, Major: 346 .

Brannan, Samuel, $C$. of $V$.: biographical note, 189-190 ; president, 237; resignation, 260 ; re-election, 337 ; mentioned, 32 , 37,46 note $19,59,106,108$ note $53,173,178,187$ note 1 , 188 note $3,203,209,223,256$, $257,277,278,284,318$.

\footnotetext{
* I have been unable to identify the Vigilante with Alealde Blackburn.
} 
Brantley, Theodore: cited on Vigilance Committee of Montana, $419-420$.

Brenham, C. J., mayor of San Francisco: 176-177, 239, 244; proclamation against $\mathrm{C}$. of $\mathrm{V}$., 271,463 ; assisted in rescue of prisoners, $z \cdot 4,296$.

Brewer, Frank: murdered, 238.

Briggs, Jim : 275, 285, 308, 311, $3+1$.

Brinley, C. H., C. of $\mathrm{V} .: 188$ note 3.

British Columbia: efficient administration of justice in courts of, in frontier period, 426.

British consul (George Aiken): present at examination of Stuart, 258, 371 note 42.

British penal colonies, see Convicts from Australia.

Brittan, J. W., C. of $V ., 1856: 473$.

Broderick, David C.: 130-131, 153, $154,169,403$; opposed C. of T., 211, 215, 218, 220, 239 note $37,266$.

Bromley, W. L., C. of $F .: 471$.

Brown, David: hanged in Los Angeles, 383 .

Brown, Elam, alcalde, 59.

Brown, H. S., C. of $V ., 1856: 473$.

Brown, H. S., judge: 177 ; resigned as protest against C. of V.. 303.

Browne, William, C. of V.: 181 note 62.

Bruce, Philander: murderer, executed by C. of V., 18.56, $t 01$.

Bryant, Edwin, alcalde, San Francisco: 38 ; eited, $40-41$.

Bryant, Colonel J. J.: 141.

Bryce, James: cited, 1, 71.

Buchanan, James, secretary of state: status of California, $57,90,91,96$.

Buckler, John, Jr., C. of V.: 333 note 35 .

Bullfight, Mission Dolores, 1851: 299.

Bullett, Patrick \& Dow: lease to C. of T., 224.

Burdell, Dr. Galen, $C$. of $T .: 447$.

Burke, M. J., C. of $V$., 1856: 473 .
Burnett, P. H.: governor of California, 116, 128 note 36,138 . $1+1$ note 13 ; citer on defective administration of eriminal laws, 152 ; message to legislature, 153 ; resignation, 153 ; recommended death penalty for grand larceny, 154; disapproved C. of V., 410.

Burns, A. M., C. of V., 1856: 473.

Burns, James, alias Jimmy from Town, prisoner C. of V.: 275 , $276,288,290,358$.

Burns, Dr. M. P., C. of $\Gamma .: 238$, 449 .

Burns, Thomas, prisoner C. of V.: 228-232, 306 .

Butte City, California: protest against mob spirit, 394 .

Cahuenga, Treaty of: 34 .

California: under Nexico, 23-28 (see also Mexico, arlministration of California) ; American occupation, and military administration, 28-52 (see also Bear Flag, Frémont, Kearny, Mason, Sloat, Stockton); Mexican laws perpetuated, 29; Stockton's plan for eivil organization, 31, 37; discord with Kearny, 3t-35; Kearny warned against initiating permanent organization, 33-34; Mexican laws enforced by Kearny, 35-39, and by Mason, $40-52 ;$ status of California after Treaty of Guadalupe Hidalgo, 53-87; de facto government, 55-58, 90, 96-97 (see also Gold; Land laws; Mines); Governor Mason's situation, 59-61, 79-80; struggle for organization, 88-115 (see also Benton; Constitutional Convention; Settlers' theory ; Slavery question); independence broached, 38-39, 99, 100 note 30,102 note 36 ; public recorits, 111; admission to statehood, 13t-135; organization of state government, 116135; social and eriminal con- 
ditions, 136-151, 430-431; second legislature, 152-155; effect of California life on individuals, 157; slow development of community spirit, 158-159; California precedents followed elsewhere, 417-420, 435 note 10.

See also Committee of Vigilance; Convicts; Corruption; County system; Courts; Criminal conditions; Death penalty; Democratic party; Elections; Foreigners; Immigration; Indians; Jails; Jury trials; Local government; Lynch law; Mob spirit; Political parties; Popular tribunals ; Population; San Francisco; Whig party; and local history as given under names of places.

California Battalion of Mounted Riflemen: $30,36$.

California Courier: 168; comment on Stuart's execution, 273.

California Engine Company: 169, 206 note 51, 209.

California Guard: organized 1849, 107 note 51.

California Institute: organized, 346.

California Star: demanded civil organization, 37, 52 note 37.

California Star and Californian: proposed constitutional convention, 94-95.

Callao, a vessel:348.

Callaway, James: 14.

Cameo, a vessel: 280.

Campbell, Alexander, judge: 177; letter to Brannan, 237; opposed C. of V., 244, 272, 303; indorsed for re-election by C. of V., 325 ; copy of charge to the grand jury, 464, and editorial comment, 465 .

Campo Seco, California: 303 note 77.

Cannon, - : killed at Downieville, 384 .
Caperton, John: 247, 289, 295.

Capron, E. S.: cited on C. of V., 411.

Carlisle, James: alias of Stuart.

Carpenter, W. W.: cited, 202.

Carson, James: cited 70, 75.

Cartwright, Captain J. W., C. of $V .: 299,300$.

Case, C. L., C. of $V .: 181$ note 62 , 473.

Casey, J. P.: hanged by C. of V., $1856,397,401$.

Centralized government, American distrust of, 13, 117, 139, 428. See also County system; Local self-government.

Certificates of membership in C. of V.: $349,400$.

Challenge, a vessel: 343 .

Chief, a vessel: 234, 236 note 23.

Chilenos, in San Francisco: 126.

Chinese: prisoners of C. of V., 318-319; labor demonstrations against, 1877, 407-408.

Chinese Camp, California: 147 note 31.

Cholera, epidemic of: 121 note 15.

Church, Samuel, prisoner of C. of V.: $315-316,358$.

Civil government of California, sec California.

Civil Practice Act, 154.

Claim associations, 11. See also Association for the Protection of the Rights of Property; Land laws; Land titles.

Clappe, ${ }^{*}$ Louise A. K. (Shirley, pseudonym ) : letters from California, 6 .

Clark, H. K. W.: 219.

Clark, W. H., C. of V.: 237.

Clemens, S. C. (Mark Twain): cited, 197.

Clergyman called for condemned prisoners, see F. S. Mines.

Cole, Cornelius: cited on C. of V., 415 note 24.

Cole, Ira: opposed C. of V., 215, 220.

Cole, Dr. R. B., C. of V., 1856: 473.

* Mrs. Clappe was a native of New Jersey, not of New England, as is intimated in the Introduction. 
Coleman, W. T., C. of $V$. : biographical note, 190-191; mentioned, 17.4, 178, 189, 199, 209 note 7,211 ; resignation, 333 note 35 ; re-election, 337 ; member Committee of Thirteen, 399 ; president C. of V., 1856, 400 ; of Pick Handle Brigade, 408; MS Statement cited, 212, 261-263, 453, 458.

Collyer, — " "Dr.' ': 322.

Coloma, California: 184, 394.

Colton, Rev. Walter: alcalde of Monterey, 30, 37 note 40 ; diary cited, 41-42; introduced trial by jury, 45-46.

Columbia, California: C. of V., 383 note 77 ; lynching in, 395.

Committee of Vigilance of San Francisco, of 1851: preliminary influences, trial of the Hounds, 108; attack on Jansen and citizen patrol, 180181 ; arson by Lewis and widespread criminal disorders, 181 $185,454-457$; organization, 203-207, 457-458; name, 204; term defined, 387 note 83 .

Archives, 2-4, 6-7, 202, 221-222, 259, 332, 334, 368.

Constitution, etc.: 205-208, 237 ; published in newspapers, 216 , 459 ; copies sent to other Committees, 376-381; adopted by Committee of 1856,400 note 35. By-laws: 225-226, 278; orders in writing, 245; twothirds vote required for reconsideration, 332 ; reorganization, 338, 355 .

Executive Committee: appointed, 220 ; functions, 222,286 ; orders and reports in re Whittaker and McKenzie, 293, 299; lapse in minutes, 334; final report and recommendations, 334-335 ; resignations and dismissals, 335-336; election of enlarged new committee, 335, 336-337; authority to arrest restricted, 337, restored, 339 ; election of March, 1852, 351352 ; election in the fall of 1852, 354; Committee of Thirteen, $355,396,399$.

Finances: Committee on Finance, 223 ; assessments, fines, initiation fees, 328; difficulties, 329, $343,348,353$ (see also damage suit of Peter Metcalf); salary of secretary, 338,351 ; sale of certificates, 349 ; theatrical benefit suggested, 353 ; method of handling accounts, $363-366$; analysis of expenses, 365-367; liquor bills, 367-368; sources of revenue, 368 .

Headquarters: temporary, in Brannan's building, 224; permanent quarters, 224-225 ; removed to new quarters, 339; abandoned, 352, 354; cost of, 366 .

Members: biographical notes, 187-203, 441-452; identification numbers, 192 note 10 , 225; Vigilantes served on grand jury, 272, 392; majority loyal to Federal Union on slavery (secession) question, 404-405; members of. Committee of $1856,400,403,473$; join Home Guard, 406.

Pass word (countersign): 199, 209 note 4, 215, 295.

Police organization, 223, 267 note $50,270,278,352,370$, 433 ; water police, 223,236 , $237,242,329,341$; bills of 366 ; Chief of police, see J. L. Van Bokkelen; Sergeant-atarms, 223, 267 note 50, 329, $338,343,351,363$; see also A. J. MeDuffe, and D. L. Oakley.

Qualification Committee, 223.

Relation with authorities: coöperation of U. S. Revenue Department, 234, 371 note 41; C. of V. watched trials in San Francisco courts, 238, 289$290,320,322$; C. of V. prisoners handed over to eity au- 
thorities, 243, 288, 318, 339, receipts for their delivery, 289; right to search without warrant claimed, 243-245, 332; subseription for county jail, 246-249; attitude on writ of habeas corpus, 265, 266-267; pledged to sustain law, 287; investigation of Whittaker rescue, 296-298; the Waterman affair, 344; coöperation of Army and Navy officers, 315,371 ; of foreign consuls and county sheriffs, 370-371; relations to grand juries, 272, 283, 371, 392, 466-467.

Relations with general public: Publicity, given to constitution, 216,459 ; to meetings, etc., 251, 339, 352-354, 366 ; to cases, 275, 294, 314-315; sanction of the community desired and expressed, 212, 215$217,270,298$ note $65,302-303$, $357-358, \quad 369-374, \quad 398-399$, $462,465-467,471$; expressions of disapproval, 215-220, 239, 271-273, 301 note $69,303,325$, $330-331, \quad 460-461, \quad 463-465$, 467-469; reward offered for arson, 245, 354, 461; open letter to citizens of California, 249-250; help asked by reputable citizens, 318 ; non-partisan movement started by members of C. of V., 326-327; Vigilantes elected to legislature, 326; Metcalf case tested standing, 330 ; rescue of Mary Lye, 342 ; library established, 345-346; false impersonation of $\mathrm{C}$. of $\mathrm{V}$. in forged notices to leave San Francisco, 233, and in attack on Capt. Ellis, 348; Payran's statement of objects, 372-373; contemporary and historical appraisement, 2-7, 18-19, 386, 409$415,428,432-440$.

Relation with prisoners: clergymen called for condemned,
211, 228-233, 270, 334-335, 356-363; confessions of prisoners, 262-263, 291-293, 313314 ; witnesses summoned for defense, 230, 263 note 35 , 358; corporal punishment used but once, 242 ; business affairs of prisoners adjusted, 231; bond required for delivery of prisoners, 316 ; humane treatment, $356,357,362-363$; fair trials, 358; inevitable hardships, 359 ; testimony of a prisoner (Dahlgrén), as to fairness of treatment, 360 ; summary of cases, 361-362. See also names of prisoners: Adams; Ainsworth; Alderson; Arentrue; Arthur; Barelay; Beck; James Burns; Thomas Burns; Church; Jane Connolly; Dab; Dahlgrén; Earl; Samuel Gallagher; Richard Garland; Goff ; Gonzales; Hance; Hays; James Hetherington; Higgins; Mrs. Hogan; George Hopkins; Howard; Jenkins; Jenks; Thomas and Emma Jones; Kennedy; LeBras; McKenzie; Roach; Ben Robinson; Margaret Robinson; Scott; Stuart; Taft; Talbot; Joseph Turner; Whittaker; William Wilson, Wright.

Relations existing between members of the C. of V., friction in: 225,258 note $23,260,277$, 294,297 ; resignations: $333-$ 336,343 .

Committee of Vigilance of San Francisco, of 1856: organization, and relation to $\mathrm{C}$. of $\mathrm{V}$. of ' $51,400-401$; oath of, 400 note 33 ; story of, 401 ; executions by, 401, 402; efforts to purify local polities, 402 ; formation of non-partisan People's Party, 403-404; independence of California broached, 404; influence in struggle over secession, 404-406; relation to Pick Handle Brigade of 1877: 
407-408; opponents of C. of $\mathrm{V}$. of ' 56 more influential than those who opposed $\mathrm{C}$. of $\mathrm{V}$. of '51, 409-410; suits against committeemen, 199; archives, 405 ; certificates, 349,400 ; historical appraisement, 409-415; Executive Committee, 473.

Committees of Vigilance in California outside of San Francisco, 249-250, 374-386, 406-407. See also Angel's Camp; Barton's Bar; Campo Seco; Columbia; Coulterville; Downieville; Fresno; Gilroy; Grass Valley; Humbug; Humboldt County; Jackson; Los Angeles; Lundy; Mariposa; Marysville; Merced; Mokelumne Hill; Natchez; Nelson Creek; Nevada City; Oakland; Rougl and Ready; Sacramento; San José; Santa Clara; Scott's Bar; Scott's Valley; Shasta; Sonora; Stockton; Visalia; Yreka.

Committees of Vigilance outside of California: $41 \bar{\jmath}-423$; fostered by inefficient courts, 419 ; degenerated into organs of personal and political revenge, 422. See also Idaho; Iowa; Indiana; Louisiana; Lynch law; Mississippi; Montana; North and South Carolina; Uregon; Regulators; Texas ; Washington.

Committees of Vigilance and Safety in revolutionary period, 11-1.

Committees of Vigilance. See also Lynch law; Mob spirit; Popular tribunals.

Compact, social, see Contract, social; Mayflower.

Compromise of 1850: 134.

Comstock, A. M.: cited, 172 note 31.

Confessions, see C. of V., relations with prisoners.

Connolly, Mr. and Mrs., proprietors of "The Shipman's Arms',: 210, 229, 357.
Constitutional Convention: proposed, in 1847, 37 ; in Douglas bill, 91 ; by Governor Mason and California Star, 94-95; popular movement for, 95-97, date postponed, 97, 101-102; call for, by Governor Riley, 103, 104; election of delegates to, 109 ; work of, 113-115.

Contract, social: theory of, 9 ; influence of, on American frontier, 9-13; in California mining camps, 63-65, 68; in civil organization, 99,149 ; in formation of C. of V., 204, 373 . See also Local self-government; Centralized government.

Convicts from Australia, 61-72, 121-124, 179; ex-convicts used as voters by politicians, 140 note 11, 292; action against, by C. of T., 228-233, 251, 285. See also Immigration; James Stuart, and names of convicts : Alderson; Barclay; Barnes; Beck; Berdue; Thomas Burns; John Edwards; Captain Ellis; Garland; Goff; Higgins; James Hetherington(?); Mrs. Hogan (?) ; Hopkins (?); Jenkins; Thomas and Emma Jones; Kay ; King the barber; Kitchen; Long Charley ; Morgan; Ogden; Roach; Ryan; Joseph Turner; John Ward; Whittaker; Wright.

Coon, Dr. H. P., C. of $V ., 1856$ : cited, 406.

Cora, Charles: hanged by C. of V., 1856, 396-397, 401 .

Coroners' inquests, San Francisco: Jenkins, 214; Stuart, 271; Whittaker, 302 .

Corrales, José: hanged for horse stealing, 156 note 49 .

Corruption, political: 140, 143, $390-391,396-397,431,432$; attack upon, by Committee of $1856,402-403$.

"'Cottage of Content,', suspicious lodging house: 306 . 
Coulterville, California: C. of V., 383 note 77.

County attorney: office abolished, 178.

County jail of San Francisco: 169-170; escapes from, 247 ; subscription for building fund raised by C. of V., 246-249.

County system: organization in California, adopted, 117; its practical working out under local conditions, 139-144; size of county, 146. See also Centralized government; Local self-government.

Courts of California: under Mexican system, 24-25, 45 (see also Alcalde); no higher tribunals, 25; military, during American occupation, 44; proposed for mining regions, 60; miners' trials, 76-79, 150 ; corruption of, after statehood, 144 ; salaries insufficient, 144; Court of Sessions, 146, 154, 246; delays in judicial proceedings, 146147,218 ; defective administration of criminal laws in 1850, 152; District Court, 154; duties of district attorney, 178 . See also Bail; C. of V. of San Francisco, relation to authorities; Coroner's inquests ; Jury trials; Justice of the peace; Popular tribunals; San Franeisco - Courts - Grand Jury ; Sheriff; Writ of habeas corpus.

Crary, O. B., C. of $V ., 1856: 406$, 473.

Crescent City, a vessel, 232.

Crime (eriminal conditions): on American frontier, 13-17; in California, 59, 75-87, 129, 136, $146, \quad 150-152,228, \quad 305-323$, $392,397,454$; statistics of, 113 note 69,181 note 63,382 note $73,388-390$; decrease in, followed action of C. of V., 250, 288, 349-351. See also individual names under Conviets; Stuart gang.
Criminal Practice Act: 154.

Criminal resorts: survey of, 184, 228. See also Lodging houses considered suspicious.

Cronin, Daniel, $C$. of $V .: 452$.

Crooks, J. B. M., C. of $V .: 168$ note 19,200 note 37,335 .

Crowell, W. H., C. of V.: 328.

Crockstein, - 228 note 1 .

Crozier, R. G.: 177.

Curry, John, judge: cited on C. of V., 411.

Curtayne, W. M.: commended work of C. of V., 241 note 44.

Curtis, J. F., $C$. of $V$.: biographical note, 442 ; mentioned, 108 note 53,181 note $62,208,212,281$, $335,471,473$.

Cutler, J. E., Lynch Law: cited, 10 note $11,14-17,363,423-424$.

Dab the horse thief: 275,277 .

Dahlgrén, Theodore: prisoner C. of V., 240, 359; acknowledged fairness of his trial, 360 .

Dall, J. E., C. of $V .: 181$ note 62.

Darling, W. A., $C$. of $V$.: 406 note $53,471$.

Davis, Horace: eited, 405-406.

De facto government: 57, 58, 90, $96,99,135$.

De Groot, Henry: cited, 85 note 47.

Death penalty for grand lareeny: $154-155,210$; inflicted by $\mathrm{C}$. of V., see John Jenkins; Robert MeKenzie; James Stuart; Samuel Whittaker.

Delano, Alonzo: eited on C. of V., 413.

Delessert, Eugene, $C$. of $V$., treasurer: $200,328,329,346$ note $27,352,353,372$ note 46,364 , 473.

Democratic party: organization of, in California, 116 note 3,131 ; San Francisco elections of 1851, 176 note 43, 324-326, 327 ; election of $1856,403-$ 404 ; of 1861,405 . See also Broderick; Gwin.

Dempster, C. J., C. of $V$., 1856: 473. 
Derby, Lieut. G. H. (John Phoenix, pseudonym) : relation to C. of V., 315,371 note 41 .

Desertion of soldiers in the gold rush, 59, 61, 94 .

Dewey, S. L., C. of $V .: 471$.

Dickinson, Harvey: 467.

Dillon, Patrice, see French consul.

District attorney: small salaries, 144-145; duties, 178.

Doane, Charles, $C$. of $V ., 1856$ : 473.

Dodge, C. F.: 119.

Dodge and Company, of Foster's Bar: robbed, 352.

Dorr, Ralph, C. of V.: 173 note 33 .

Douglas, Senator S. A.: 80 note 37 ; bill for state organization of territory acquired from Mexico, 91-92, 97, 103.

Downieville lynching: 38t-386.

Dows, James, C. of V.: 268, 270 note $59,446,473$.

Drinking in California: 120-121; in C. of V., 367-368.

Dry Diggings, California: 138 note 5.

Duane, Charles: opposed C. of V., 22 ; criminal record, 321 ; exiled by C. of V., 1856, 402.

Dubuque's Mines, Iowa: popular tribunal at, 15.

Duclos, Angelina: 243-244, 347 note 29.

Duff, J. R., C. of $V .: 300,445$.

Dunglison, J. R.: 346 note 27.

Earl, David, C. of V.: 199.

Earl, E. M., $C$. of $V$.: 335, 446.

Earl, J. O., C. of $V .: 446$.

Ebbets, A. M., C. of $V .: 448$.

Echols, - $\longrightarrow$, sheriff at Auburn: murdered, 253.

Edwards, John: 251, 275, 285.

"'El Dorado," gambling hall of San Francisco: 313.

El Dorado County: citizens asked capital punishment for horse stealing, 154 ; lynching discontinued in, 394.
Eleanore, Madame, actress: 353.

Elections: in pre-state period, 31 , $37,40,43-44$; delegates to constitutional convention, 109 ; for state officers, 116; qualifications of electors, 140,141 ; character of candidates often unknown, 141, 142-146; corruption in, 391, 402; copy of non-partisan address, 1851 , 470. See also Political Parties; San Francisco-Government.

Elizabeth, a vessel: 235 .

Ellis, A. J., C. of $V .: 98$ note 25 , 106,108 note 51,108 note 53 , 173,188 note 2,188 note 3 , 326,333 note 35,348 ; biographical note, 444 .

Ellis, A. V. H., C. of $V$.: biographical note, 451 .

Ellis, H. H., C. of $V$.: biographical note, 451 .

Ellis, J. S., C. of $V .: 371$; biographical note, 451 .

Ellis, William, captain of the Callao, 348 .

Emery, J. S., C. of $\Gamma ., 1856: 473$.

Empire Engine Company: 130, 169.

Endicott, George: 467 .

England, popular tribunals in: 17.

Euphemia, San Francisco prison brig: 113 .

Eureka Engine Company: 169.

Evans, H. D., C. of V.: 334.

Evening Picayune, see San Francisco Evening Picayune.

Ewer, F. C., C. of $V .: 346$ note 27.

Farallon Islands: 236.

Farnham, Mrs. E. W.: cited, 412.

Farwell, J. D., C. of $V .: 272,406$ note 43; biographical note, 443 ; mentioned, 467,473 ; MS Statement, cited, 467,473 ; cited, 193 note 13, 208 note 2, 209.

Field, S. J.: alcalde of Marysville. $118-119$; tried to prevent Downieville lynching, 385.

Financial conditions in California. $1854-18.56: 391$. 
Fire Companies of San Francisco, see Broderick; California Engine Company; Empire Engine Company; Eureka Engine Company; Howard Engine Company; Monumental Engine Company; Protection Engine Company.

Fire Fly, a tug boat: 341 .

Fires, see Arson; San FranciscoFires.

Fish, J. H., $C$. of $V .$, 1856: 473.

Flag pole on San Francisco Plaza: $165,213$.

Fleishhacker, Samuel, $C$. of $\nabla$. : 449.

Flint, E. P., C. of $V ., 1856: 473$.

Folk moot: miners' meetings compared to, 72 .

Folsom, J. L.: 173 note 33 .

Foreigners (foreign miners): unpopular among the gold seekers, 61-62, 124-127; tax imposed on, 127; quarters of, in San Francisco, 166-167; C. of V. approved by many, 413.

Forged notices to leave San Francisco purporting to come from C. of V.: 232-233.

Fort Gunny Bags, 1856: 401.

Foster, S. C., mayor of Los Angeles: 383 .

Foster's Bar, California: 252, 257.

Fourgeaud, V. J., C. of V.: 108 note 53, 443.

France, confréres, 16-17; French immigrants expected in San Francisco, 340-341.

Franklin, State of: 11.

Frazier, James, miners' alcalde: 81.

Freelon, T. W., judge: 393.

Frémont, Captain J. C.: in California, 28, 30 ; governor, 3436 ; mentioned, 90,318 .

French, William, opposed C. of V., 239.

French consul (Patrice Dillon): present at examination of Le Bras, 317-318, 371 note 42 ; correspondence with C. of V., 340 .
Fresno, California, C. of V.: 407 note 56.

Frignet, Ernest: cited on C. of V., 414.

Frink, G. W., C. of V., 1856: cited, 399.

Frontier, The: in American democracy, $7,19,53-54$; the mining frontier of California, 64-87, differences from other frontiers, 66, 67, 136-137, 157, 287 ; individualism a characteristic of, 129, 158; mining frontier of Rocky Mountain area, 416-420; in the Australian gold fields, 425; in British Columbia, 426-427. See also Centralized government; Contract, social; Committee of Vigilance; Criminal conditions; Popular tribunals.

Gallagher, Edward, coroner of San Francisco: 214, 271 note 61 .

Gallagher, Samuel, prisoner C. of V.: 242.

Gambling: 121. See also the "El Dorado.",

Gang, criminal: $123,184,228,251$, 349,352 . See also Hounds; Plummer gang; Stuart gang.

Gardner, Richard: escape from San Francisco jail, 247.

Garland, Richard, prisoner C. of V.: 236 note 24.

Garnett, Porter, editor C. of V. Papers, Pts. I, II: 3.

Garrat, John, see John Barrett.

Garwood, G. M., $C$. of $V$.: 181 note 62,188 note 2,333 note 35,346 note 27,372 note 46 , $406,471$.

Gates, H. S., C. of V.: 346 note 27.

Geary, J. W., alcalde and mayor of San Francisco: 112-113, 163.

Geddes, Paul, alias Talbot $\mathrm{H}$. Green, see Talbot H. Green.

Gerke, Henry, $C$. of $V: 188$ note 1 , 449.

Germany, Vemgericht: 16.

Gerstäcker, Friedrich: cited, 126 note 28,179 note $58,355,414$. 
Gibson, George, $C$. of $V .: 358$.

Gibson, James: hanged for highway robbery, 155 note 49 .

Gillespie, Lieutenant A. H. : 28, 30.

Gillespie, C. V., C. of $\Gamma$.: cited, 108 note 53, 188 note 2, 188 note 3 ; biographical note, 446 ; mentioned, 473.

Gilroy, California: C. of V., 407 note 56.

Goddard, E. B., C. of $\Gamma$., 1856: 473.

Goff, John, prisoner C. of V.: 176 note 40,314-315, 362 .

Gold: discovery of in California, 54,59 ; the gold rush, 58-65; statistics, 66 note 1 ; organization in the mines, 66-87; gold rushes in Rocky Mountain area, 416, 426; in Australia, 425; in Manchuria, 435 note 10.

Goodwin, Andrew: 342.

Gorham, E., C. of $V$.: 181 note 62 , 473.

Graham, W. C., C. of $V .: 181$ note 62,333 .

Graham, W. H., C. of $\Gamma .: 444$.

Grand Jury: introduced at trial of Hounds, 107, 109; legal delays in early courts, 147 . See also references under grand juries of Marysville; Nevada County; San Francisco; Tuolumne County.

Grand larceny, punishable with death: $154-156,210$.

Grass Valley, California: C. of V., 383 note 77,407 mote 57 .

Grav, H. M., C. of $V .: 447$.

Gray, Victor de: complained of forcible seizure by the $\mathrm{C}$. of V., 359 .

Grayson, A. J., C. of $\Gamma$.: 98 note 25, 187 note $1,446$.

Green, T. H. (Paul Geddes) : 144, 173.

Grey, William, pseudonym of W. F. White.

Grisar, C. E., C. of $\Gamma$.: 473 .

Guadalupe Hidalgo, treaty of: 54 , 56.
Guerrero, Francisco: killed, 317.

Gwin, W. M. : assisted in trial of Hounds, 107 ; political career, 130-131.

Habeas corpus writ, see Writ of habeas corpus.

Haff, J. P., C. of $V .: 164$ note 5.

Haight, S. W., C. of $V .: 188$ note 3.

Hall, Richard, a suspect: 238.

Halleck, Lieutenant H. W.: secretary of state (California), $1847-1849,43,50 ;$ Digest of laws of $1837,43,110$; cited, 71.

Ham, R. S., miner's' alcalde: 81 .

Hammer, - Captain: resisted C. of $\mathrm{V}$. water police, 242.

Hampton, R. B., C. of $V .: 164$ note 5 .

Hance, W. G., escaped murderer: sent back to Panama by C. of V., 317.

Handbill: on appointment of George Hyde as alcalde of San Francisco, 38; on Jansen robbery 172, 173 note 35,453 ; calling mass meeting against C. of $\mathrm{T} ., 239,460$.

Hangtown, see Placerville.

Happy Valley, San Francisco: 166. Harlie, Major J. A.: 38.

Harris, Captain Isaac, from Sydney: rescued from mob by $\mathrm{C}$. of V., 239-241.

Hart, A. B.: cited, 71.

Hasson, J. C., C. of $V$.: 181 note 62.

Hat and Boots: investigated as a clue, 320 .

Hawes, Horace: 107.

Hays, J. C., sheriff of San Francisco: 141-142, 246, 295, 297, $299,322,325,470$.

Hays, IV. H., prisoner C. of V.: 267 note 49, 287.

Headquarters of $C$. of $V$. of San Francisco, see C. of V.-Headquarters.

"Heart and Hand,", suspicious lodging house: 306 . 
Hearne, V. W., sheriff of Santa Barbara: arrested Whittaker, 281.

Helper, H. H.: cited on C. of V., 412.

Henry, Patrick: cited on frontier associations, 14.

Herald, of San Francisco, see San Francisco Daily Herald.

Hetherington, James, prisoner C. of V.: 228-232.

Hetherington, Joseph: a witness against Stuart, 264, 280, 286, 291; perhaps executed by $\mathrm{C}$. of V., $1856,401$.

Higgins, Lawrence, prisoner C. of V.: 234 note 21.

Hinigan, Thomas, from Sydney: comments on Captain Harris affair, 241.

Hittell, T. H.: approval of Committees of Vigilance, 414 .

Hoag, Mr.: 219.

Hobart Town, Van Diemen's Land: 231.

Hobson, W. L., C. of $V$.: 108 note 51.

Hoen, Francis, $C$. of $V .: 449$.

Hogan, Mrs. Mary Ann, from Australia: companion of Stuart and Whittaker, 264, 280-281, 292-293, 306, 356.

Hogg, W. M., C. of V.: 467.

Holinski, Alexandre: eited, 126 note 28,319 .

Holst, Hermann von : cited, 115.

Home Guard of 1861: 405-406.

Hopkins, George: prisoner C. of T., 231.

Hopkins, S. A., C. of T., 1856: 403.

Hopwood, Mat: 275.

Horn, B. C.: 467.

Horse stealing: capital offense, $154-156$.

Hosmer, H. L.: eited on frontier problems and Vigilance Committees, 419 .

Hossefross, G. H., C. of V.: 447.

Hounds, The, rioters of San Francisco: 100; popular trial of, 105-109, 126 .

Howard, G. H., C. of $\Gamma .: 442$.
Howard, - a deserter: arrested by C. of V. and turned over to the army authorities, 316.

Howard, W. A., C. of $V .: 210,346$, 353.

Howard, W. D. M., $C$. of $V$. : biographical note, 448; mentioned, 49 note 26,107 note 51 , 108 note $53,173,187$ note 1 , 188 note 2,188 note 3,471 .

Howard Engine Company: 169.

Hubbard, Lorenzo, $C$. of $V$., 1856 : 473.

Hughes, William : 275, 285.

Huie, J. B., $C$. of $V .: 173$ note 33 , 188 note $3,299,302,333$ note 35,471 .

Humboldt County: C. of V., 381.

Hutchings, N. P., C. of $V ., 1856$ : 473.

Huxley, J. M., C. of $V .: 188$ note 1 , 445 .

Hyatt, Caleb, C. of V.: 327.

Hyde, George, alcalde of San Francisco: $38,48-49$.

Idaho: gold rush to, and frontier conditions, 416-417; Committees of Vigilance in, 420 .

Ide, W. B., justice of the peace: 146 note $25,156,374$ note 50 ; cited, 140-141.

Immigration, early problems of: British convicts from Australia, 121-124, 233 note 17 ; other foreigners, 124-127; legislation concerning, 122-123, 127; statutes against enforced by C. of V., 233 ; colonists from France, 340-341. See also Convicts; Foreigners.

Independence, a vessel, 237.

Independents, sec Non-partisan movements.

Indiana: political "Committees of Vigilance", in, 204 note 47 ; protective associations, 1852, 416.

Indians in California: difficulties with, 127-128.

Individualism: a frontier characteristic, $129,158$.

Initiative and referendum: principle of, in C. of V., 433. 
International law: its effect on administration of California, 29, $50,57$.

Iowa: Vigilance Committees in, 416.

Jack Dandy, alias of George Adams.

Jackson, Andrew, President: refused to interfere in $\mathrm{O}$ 'Conner case, 15 ; Jackson party in Indiana, 204 note 47 ; arrival in San Francisco noted in Papers, 235.

Jackson, California: C. of V., 380, 383 note 77,407 note 56 .

Jails (prisons): lack of, and insecurity of, 44-45, 63, 76, 77, 78,79 note $35,107,119,145$, 146 note $25,152,350,380$, 407 ; in San Francisco, 169; escapes from, 181 note 63 , 247, 380. Sce also Police; Prison ships; San Francisco county jail.

James, Colonel G. F.: 233.

James Caskie, a vessel: 309.

Jamestown, California: 81, 278.

Jansen, C. J.: attack on, 170, 180, 253, 263, 303, 310, 453 .

Jenkins, John, a thief hanged by C. of V.: 208-217, 229; execution followed by decrease in crime, 250.

Jenks, Daniel, prisoner C. of V.: $320,359$.

Jessup, R. M., C. of $V .:$ 449, 473.

Jewett, J. H., president Marysville C. of V.: 257.

Jimmy from Town, alias of James Burns.

John Potter, a vessel : 235.

Johnson, W. A., C. of V., 1856: quoted, 225 note 53.

Johnson (Johnston), a vessel: 317. Joice, E. V., $C$. of $V .: 447$.

Jones, E. P., C. of $V .: 49$ note 26.

Jones, Thomas, and Emma, prisoners C. of V.: 235, 236 note 24.

Jones, W. C.: cited, 129 note 40 ; requested assistance $\mathrm{C}$. of $\mathrm{V}$., 318.
Jones, W. H., C. of V.: 173 note 33 , 302,471 .

Joy, Captain Hartford, C. of $V$.: 257.

Juanita, lynched at Downieville: 381-386.

Jury trial: introduced in California, 45-47; practiced by miners, 75-86; volunteer firemen exempt from service, 169 ; jury service evaded, 159, 350; jury trials in Louisiana, 421.

Justice of the peace, in California: prior to $18.50,25-26,30$ note 17 ; limitation of authority, 1850,146 ; jurisdiction extended, 1851, 154 .

Kay, T. B., member of Stuart's gang: 238, 275, 282-284, 292, $308,312,371$.

Kearny, General S. W.: instructions on establishment of civil government in New Mexico and California, 31, 33-34; promulgated civil code for New Mexico, 32-33; administration in California, 34-39. See also California.

Kelly, James: 279, 306.

Kemble, E. C.: cited, 37 note 40 , 94.

Kennebec Hill, California: 138 note 5.

Kennedy, Dr., prisoner C. of V.: 317.

King, the barber, a convict: 306 , 307.

King, E. A., C. of $V .: 108$ note 51, 173 note 33,188 note 3,442 .

King, of William, James, C. of $\Gamma$.. 188 note 3,471 ; biographical note, 197 ; murdered, 397.

King, T. B., U. S. special agent to California: $93,103,109$; candidacy for U. S. Senate, 116 note 3,340 .

Kitchen, William, nember of Stuart's gang: 254, 275, 292, 311.

Knights of the White Camelia: 423. 
Ku Klux Klan: 423.

La Grange, Sacramento prison brig: 253.

Lambert, Capt. William, keeper of San Francisco county jail: 300 .

Lammot, R. S., C. of $V$.: 181 note 62.

Land clubs: 11. See also Land laws; Land titles; "Association for the Protection of the Rights of Property,' etc.

Land laws (titles): confused condition in California, 37, 49-51, 137-138, 152, 391, 431. See also Squatters.

Law, Common: adopted by California, 117.

Law books, lack of, 1846-1849: 40, $43,44,47$.

Laws of the Indies: 41.

Laws of 1837 (Mexican) : 25; English translation, 43, 56, 110. See also California; Mexico, administration of California.

Lawyers: rich rewards for in private practice and its effect on the securing of prosecuting attorneys, 144-145. See also E. G. Austin; Judge Alexander Campbell; T. W. Freelon; Hall McAllister; Edward MeGowan; Judge Levi Parsons; F. M. Pixley.

LeBras, François, prisoner C. of V.: 267 note $49,317$.

Leavenworth, T. M., alcalde of San Francisco: 98-100, 104, 105108.

Leese, J. P., C. of V.: 443.

Legislative Assembly of San Francisco, see San Francisco, legislative assembly.

Leidesdorff, W. A.: 38-39.

Lent, W. M., C. of $V$.: 449 .

Lewis, Benjamin: accused of arson, 181-185, 359 .

"Lex diggerorum" ": 70, 86.

Lippitt, F. J.: 106, 107.

Lipscom, John: 319.

Liquor used by the C. of V.: 226, 367-368.

Little Chile: 166 .
" Live and Let Live,' suspicious lodging house: 306 .

Local self-government: on American frontier, 9-13; in California mining eamps, 49, 68, 71, $73-74,83,89$; spirit of, in movement for civil organization, $96-109$; persistence of spirit after organization, 149150. See also Centralized government; Contract, social; County system.

Lockwood, D. W., C. of $V .: 328$.

Lockwood, R. A., lawyer: 330-331.

Lodging houses in San Franciseo, considered suspicious by C. of V.: 228, 306, 314. See also Henry Beck; "Bird in Hand"; "Cottage of Content"; "Heart and Hand"; Mrs. Hogan; "Live and Let Live"'; "McManus' Welcome"; "Panama House"; " Port Phillip House", "Rose Cottage"; "Shipman's Arms" ; "Uncle Sam.",

Long Charley: 275.

Long Wharf: $181,313$.

Lord Elden, a vessel: 235.

Los Angeles, California: ayuntamiento in, 26 ; capital in 1815 , 26: Committee of Vigilance of 1836,17 note 29 ; of 1852 , $382-383$; of 1856,407 note 56 ; volunteer police force, 1851, 382.

Louisiana: Committees of Vigilance. See Attakapas.

Ludlow, Charles, $C$. of $V$., 1856: 473.

Lundy, California: C. of V., 407 note 56.

Lye, Mary: abducted from guardians and rescued by $\mathrm{C}$. of V., 342.

"'Lynch Law" : origin of term, 14; development on American frontier, see Committee of Vigilance; Mob spirit; Popular tribunals; fostered by notorious failure of legal justice, $386-387,397,434-437$; grad- 
ually condemned by public opinion in California. 394395,407 ; practice of passes from West to South, 423; race hatred an impetus to, 423; a problem peculiar to the United States, 424-427, 434-437.

Lyndall, W. E.: 467.

McAllister, Hall: eited, 106-107, 174 note 37 ; testimony at Jenkins inquest, 215.

MeCahill, Thomas, $C$. of $V .: 181$ note $62,335$.

MeCarty, A. J., a policeman: 258, $27 \overline{5}$.

MeCormac, Teddy, member of Stuart's gang: 279, 306 .

MeCurdy, John : 467.

MeDougal, John, governor of California: $116,153,370$; proclamation in re Stuart execution, 273-274, 467-469; pardon of Duane, 321 ; proclamation against Vigilante movement, 375 ; seized Whittaker and McKenzie from C. of V., $29 \pm$ $298,469-470$; proclamation, 298.

MeDuffee, A. J., C. of $V$.: sergeantat-arms, 260, 333, 365, 367368.

MeGowan, Captain of the Polk: 234.

MeGowan, Edward, justice of the peace: opposed C. of V., 177, $398,402$.

MeIntire, R. C., a policeman: 258, 275.

McKenzie, Robert, prisoner C. of V.: 225, 227, 275, 278-279, $282,291,306,312$; reseued by authorities, recaptured and hanged, 293-302, 469.

MeKimmey, N. M., sheriff of Napa: 371.

MeLean, W. W., C. of V.: 200 note 37.

"'MeManus' Welcome,' suspicious lodging house: $229,306$.

Macondray, F. W.: 173 note 33, 180.
Mahony, Frank, C. of $V .: 181$ note 62.

Maloney, James R. (Rube), C. of V.: 183, 200, 289, 402; biographical note, 198-199.

Manchuria: popular tribunals in, 435 note 10.

Manrow, J. P., C. of V.: 449, 473.

Marey, W. L.: cited on status of California, 58.

Mariposa, California: C. of V., 383 note 77.

Markey, P., C. of $\Gamma .: 181$ note 62.

Marks, Joseph, member of Stuart's gang: 307.

Marmion, a vessel: 235 note 22.

Marryat, Frank; cited, 143, 410411.

Martin, W. F., C. of F.: 181 note 62.

Mary Catherine, a vessel: 235.

Marysville, California: organization, 118; C. of V., 250, 257, 376 ; approved by grand jury, 374 note 48.

Marziou \& Co.: 341-342.

Mason, Colonel R. B.: military governor of California, 35, 40-103, 128 ; letter relative to local organization, 94 .

Mathews, Lois K.: cited, 10 note 9, 207.

Mayflower compact: 9, 10, 207.

Maynard, Lafayette, $C$. of $V$.: 371 note 41.

Meiggs, Henry: 167 note 15.

Meiggs, J. C.: 167 note 15.

Mellus, George, $C$. of $\Gamma$.: 302, 334 .

Mereantile Library of San Franciseo: beginning of, 345,346 .

Merced, California: C. of V., 407 note 56.

Merrill, I. M., C. of $V .: 451$.

Merritt, Dr. Samuel, $C$. of $V .:$ biographical note, 450 ; mentioned, 256 note 12,261 note 32,310 note 6 .

Metcalf, Peter: damage suit against Argenti et al., 243$244,329-331,340,343,347-$ $348,375$.

Mexican land proprietors: injustice to, 139 . 
Mexico: administration of California, 23-27; laws of 1837,25 ; laws of 1843,26 ; laws of 1837 perpetuated after American occupation, 29-31, 35-36 ; 40-$47,51,57,103-104,110-111$, $114,118,163$. See also Alcalde; Ayuntamiento: California; Courts; Justice of the Peace; Pueblo.

Mexico, Santa Hermandad in: 17 note 29.

Meyer, William, C. of V.: 473.

Micheltorena: governor of California, 26.

Middleton, John, C. of V.: 164 note 5,188 note 3,449 .

Militia organization: 107 note 51.

Military courts under American occupation, 44.

Military organization, use of by Committee of Vigilance, 271 note 60.

Mines (mining region) of California: Pre-state period, equipment for social control lacking, $58-60,63$; status of miners, 67; average earnings, 68 note 6 ; self-organization of camps, 67-87; first code, 69 ; mining regulations, 71 note 14 ; control of crime (miners' trials), 76-89; California precedents on other frontiers, 416-420, 435 note 10 . After state organization, hardships, 121 ; ephemeral population, 138, 142 note 15; difficulties of early organization, 140-146; failure of courts to control crime, 147149,152 ; persistence of lynch law, 150-151, 374, 386, 389395, 407. See also California ; Contract, social; Gold ; Popular tribunals.

Mines, Rev. F. S., rector of Trinity Church: attended prisoners of C. of V., 211, 264 note 37, 268, 270.

Mining companies: 68 .

Minturn, Charles, $C$. of $V .: 164$ note 5,188 note $3,312,334$, 445 .
Mississippi: citizen committees in, 11 note 13.

Mob spirit manifested in the popular tribunals of California: 78, 148-151; trial of Berdue, 172175 ; of Lewis, 182 ; in connection with activity of $\mathrm{C}$. of V., 213-214, 219, 239-240, 242, 243, 284, 359; Waterman affair, 344 ; Downieville lynching, 384-387 ; King's assassination, 298 ; C. of V. organization a restraining influence, 386-387, 407; danger of, in American life, 423. See also Lynch law; Popular triunals.

Mokelumne Hill, California: 69; "Committee of Vigilance,", April, 1851, 204 note 47 ; C. of V., 379-381.

Mokelumne (River): jury trial on, 1849,84 .

Montana: gold rush to, 416 ; criminal conditions and Committee of Vigilance, 417-420.

Monterey, California: Mexican administrative district, 26; American occupation of, 2830 ; capital of California, 26, 35 ; first trial by jury, 46 ; constitutional convention at, 113 ; robbery of Custom House, 254, 308.

Monterey Californian: 37 note 40, 94 note 17.

Monumental Engine Company : 169, 206 note 51, 209, 268, 289.

Moore, Charles, of Winslow Bar: murdered by Stuart, 171, 252253.

Morgan, J. M., member of Stuart's gang: 228 note $1,275,285$, $307,308,311$.

Mormon Battalion: 32 .

Mormon Camp, California: 111 note 64 .

Mormons in California: 32, 46 note 19.

Morrison, R. M., judge: 177.

Motto of the C. of V.: 401. 
Muldoon, J. P., C. of $V .: 200$ note 37.

Mulligan, Billy : exiled by C. of V., $1856,199$.

Murderer's Bar, California : magistrates of, described, 143.

Murietta, Joaquin, bandit: 127 note 32.

Murray, Alexander, $C$. of $V .: 333$ note 35 .

Murray, James, $C$. of $V$.: 181 note 62.

Naglee, H. M., C. of V.: 107 note $51,445,471$.

Natchez, California: 383 note 77.

Neall, James, Jr., C. of $V .:$ biographical note, 446 ; cited, 75 note 24, 203, 207, 209 note 3,457 .

Nelson Creek, California: C. of V., 383 note 77.

Nevada City, California: C. of V., 379.

Nevada County: grand jury condemned Vigilance Committee of Truckee, 407 note 57.

New Helvetia, see Sutter's Fort.

New Mexico: American occupation of and Kearny's code, 31-33.

New South Wales: efficient administration of justice on the gold fields frontier, 425.

New York Volunteers, First Regiment, see Stevenson's Regiment.

Newmark, Harris: cited on C. of V., 415 note 24.

Newspapers: 37 note 40, 94 note 17.

Niantic, a vessel: 166 .

Non-partisan movements started by C. of V.: $1851,323-328,470$; People's Party, 1856, 403-406.

Norris, Thomas, $C$. of $V .: 200$ note 37.

North Beach, San Francisco: 166.
Norton, H. K.: cited on C. of V., 415 note 24.

Norton, Myron, judge: 107, 295, 469.

Noyce, J. P., a policeman: 215.

Oakes, J., C. of V.: 203, 209 note $3,298,441$.

Oakland: C. of V., 383 note 77 .

Oakley, D. L., C. of $V .: 338,346$.

O'Conner, Patrick: tried and executed by popular tribunal at Dubuque's mines, 15.

Ogden, Robert, nember of Stuart's gang: 251 .

Ohio, a vessel: 281 .

" Old Adobe', Custom House: 165, 213, 219, 313.

"Once a Committeeman, always a Committeeman' ': 199, 355.

Orator, a vessel: 232.

Old Jack, alias of J. M. Morgan.

Oregon: frontier organization in, 12; settlers joined gold rush to California, 61 ; opinion of President Taylor, 92; bitterness resulting from Indian massacres, 128; gold rushes to, 416; Committees of Vigilance, 420.

Oregon: brought news of admission, 13t-135.

Osman, Richard, member of Stuart's gang: 275, 285, 307, 308,341 .

Osgood, J. K., C. of $V ., 1856: 473$.

Page, F. W., C. of F., 1856: 473.

Palmer, Cyrus, C. of $\Gamma .: 447$.

"Panama House,' suspicious lodging house: 306 .

Panton, Francis, C. of $\mathrm{V} .: 467$.

Parker, R. A.. C. of $\Gamma$.: 49 note 26, 98 note 25,188 note 1,450 .

Parker, W. H., C. of $\Gamma$.: 200 note 37.

Parson, Levi, judge: 177-178, 182, 217. 
Passenger vessels from Sydney examined by C. of V.: 234-235.

Payne, Theodore: 173 note 33 .

Payran, Stephen, $C$. of $V$.: biographical note, 201-203; president of Executive Committee, 260-261, 331, 336, 338; resignation, 333 note $35,336,342$; letters, to Wakeman, 237, to Hays, 248-249, to Grass Valley C. of V., 379 ; rescue of Nary Lye, 342 ; mentioned, $223,286,293-294,296,298$, $323,329,332,372,373$.

Peake, W. B., C. of V.: 272, 467.

People's Adrocate (Sydney) : cited, 241 note 44.

People's Party, see Non-partisan movements.

Phelps, T. G., C. of $V .: 448$.

Phoenix, John, pseudonym of G. H. Derby.

Phoenix, a newspaper: 389 note 3 , 402 note 42.

Pick Handle Brigade, 1877: 408.

Pickett, C. E.: cited, 48 note 25; jury trial of, 83 .

Pixley, F. M.: city attorney of San Francisco, 177; defended Stuart, 253, 264, 265; charges against, in Stuart's confession, and his denial of, 266 .

Placerville (Hangtown, Dry Diggings), California: 78 .

Plank Road to the Mission, San Francisco: 167.

Planter, a vessel: 235.

Plaza (Portsmouth Square), San Francisco: 165, 213, 218.

Plum and Warner, Messrs., gift of banner to C. of V.: 372 note 45.

Plummer, Henry, Montana sheriff. and gang leader: 417-418.

Police. See C. of V. of San Francisco-Police; San FranciseoPolice.
Political parties (politicians) in California: 109, 116, 129-132, 403 ; Mexican war a dividing issue, 132; corruption in, 390, 391 ; cleansed by committee of 1856, 403-404. See also Broderick; Democratic party; Gwin; Non-partisan movements; Whigs.

Polk, J. K., President, and the establishment of government in New Mexico and California: 33, 55-56, 90-91, 92, 99.

Polk, U. S. revenue cutter: 234, 236, 371 note 41.

Pollock, Lewis: murdered, 242, 320.

Popular sovereignty, see Local selfgovernment.

Popular tribunals (lynch law): development of, on American frontier, 13-16; in other countries, 16-17, 424; in California, 17-19, 74-81; Governor Mason forced to approve, 80 ; weakness of, $85-86,89,93$; trial of the Hounds, 105-108; persistence after state organization, 149-151, 374-375, 407; trial of Berdue and Windred, 171-176. See also Committee of Vigilance; Frontier; Lynch law; Mob spirit.

Population of California: statisties, in 1847, 58 note 11 , in 1849,54 note 1,66 note 1 , in 1850, 131 note 47; ephemeral quality of , 137-138, 142 note 15, 431. See also San Francisco.

"Port Phillip house"': 279, 306, 312.

Portsmouth Square, see Plaza.

Preston, William: 14.

Prison ships: 113, 119 note 11,145 , 253.

Prisoners, see C. of V. of San Francisco-Relations with prisoners. 
Prisons, see Jails.

Proclamations against C. of V.: of Governor MeDougal, 273-274, $294,298,375,467-469$; of Mayor Brenham, 271, 463.

Protection Engine Company: 169.

Public improvements in California: impossible before state organization, 145 .

Pueblo organization in California: 25.

Qualification Committee, see C. of V. of San Francisco-Qualification Conmittee.

Race hatred, in America, an impetus to lynch law: 423 note 38 ; in California, see Foreigners.

Randall, Albert S., C. of $V .: 108$ note 51.

Randall, Dr. Andrew : robbed, 308 ; murdered, 401.

Ray, Benjamin: 173 note 33 .

Recall, process of, effected on California frontier: 433 ; by C. of V., 373, 433 .

Recorder, of a California city: powers of, 163 note 4.

Reed family: murder of, 80 .

Registration of voters, not required in 1850,140 .

Regulators of North and South Carolina: 10, 14.

Regulators, San Francisco Society of, see The Hounds.

Republican party: 403 .

Reynolds, Banjamin, $C$. of $V$.: 108 note 51, 108 note 53, 302.

Reynolds, W. T., $C$. of $V$.: 473 .

Rice, Jerome, C. of V., 1856: 473.

Richardson, W. H., U. S. marshall: murdered, 396.

Riley, General Bennet, governor of California: called constitutional convention, 101-104; administration, 110-116, 146 n.ote 25.

Roach, James, prisoner C. of V.: 236 note 24 .

Roach; P. A., C. of $V .: 326,451$.

Robbery, see Grand larceny.

Robert, J. H.: robbed, 238, 285.
Roberts, Samuel, leader of Hounds : 106.

Robinson, Ben (Negro Ben), prisoner C. of V.: 245-246, 358.

Robinson, Henry: eited on $\mathrm{C}$. of $\mathrm{V}$., 415 note 24 .

Robinson, Mrs. Margaret L., prisoner C. of V., see case of Ben Robinson.

Robinson (Heppard), William: lynched, 155 note $49,378$.

Rogers, W. H., C. of $V ., 1856: 473$.

Root, Kingsbury, $C$. of $V$.: 467.

Rosalind, a vessel: 235 note 22 .

Rose Bar, California: 70 .

"'Rose Cottage," suspicious lodging house: 306 .

Ross, C. L.: 467.

Rough and Rearly, California: appointment of "Committee of Vigilance and Safety,', 120 ; "State of,", 120 note 14.

Royce, Josiah: California, 5, 6; cited on miners' organizations, 72,74 note 22,78 , on antiforeign attitude of Californians, 126 , on election of unworthy officials, 144, on sanction of death penalty for grand larceny, 154-155, on People's Party, 404, on C. of V., 414-415.

Ryan, J. T., $C$. of $T$.: 301, 442 .

Ryan, Michael, member of Stuart 's gang: $232,275,308$.

Ryckman, G. W., C. of $\Gamma$.: biographical note, 194-19.5; mentioned, 286, 297-298, 333 note $35,343,346$ note $27,351,403$, 406 note 53, 471; MS Statement cited, 172 note 31,201 , 208 note 1, 211, 325, 369.

Sacramento: local organization attempted, 101, 119-120; squatters in, 138; prison brig purchased. 145; protest against erime, 184; C. of V., 250, 377378.

Sacramento, a vessel: 235 note 22. Saint-Amant: cited on California conditions, 137 : on Committees of Vigilance, $\$ 1 \pm$. 
Salaries: insufficient to attract competent officials, 142, 144-145, 152.

Salkmyer, Frederick: hanged for horse stealing, 155 note 49.

Salmon, J. W., C. of $V$. : treasurer, 328,365 ; resignation, 328 , 334 .

Sau Francisco: description of, 1851 , 163-185; population, 167 note 17.

Courts: first trial by jury, 46: statisties of erime, 1849,113 note 69 (see also Crime); conditions, 1851, 177-179; improvement in, after organization of C. of V., 288. See also Courts ; Lawyers.

Fires: 1849-1850, May, 164; 1851, 179, 181, 239; engine companies, 130 ; fire department, 168-169; firemen exempt from jury service, 169 ; rewards offered by C. of V. for incendiaries, 245, 261. See also Arson; California Engine Company; Monumental Engine Company.

Government: delegates elected to Stockton's legislative council, 37 ; protest against appointment of Hyde, 38 ; town council of $1847,48-49,97$; legislative assembly, 1849, 98-100, 104-105; elections of August, $1849,108,112$; incorporation, 163 ; city administration, 1850 , 164-165; charter of 1851, and election under, 176; election of September, 1851, 323-327; political corruption, 18551856, 396; election of 1856 (People's Party), 403. See also names of political parties.

Grand Jury: dismissed by Parsons, 182 ; report on condition of courts, June, 1851, 218; jury for July, 1851, 272-273, 283-284; relation to C. of V., 371,466 ; jury for September, 1851, asked to be discharged,
321 ; service of Vigilantes, $1851-1856,389$; reports of grand juries, 389 note 2.

Jail: 45 ; prison brig purchased, $145,169,181,247$; county jail, 246-249.

Otncials of City and County: Attorney (City), see Frank M. Pixley; Collector of the port, see T. B. King; Coroner, see Edward Gallagher and Coroner's inquests; Marshal, R. G. Crozier, 177; Mayor, see Charles J. Brenham, and J. W. Geary (alcalde); Port Warden, see T. B. Kay; Recorder (city magistrate), R. H. Waller, 177; Sheriff, see J. C. Hays, and deputy, John Caperton; Street Commissioner, see J. J. Arentrue.

Police: in 1847, 49 note 27 ; in 1849,113 ; in 1851,169 ; volunteer night patrol organized, 180, reorganized, 350 note 46 , 352 ; police failed to prevent lynching of Jenkins, 213-215; testimony in examination of Stuart, 258; assistance to criminals, 275 .

Streets: naming of, 113 ; expansion of territory, 165-167; nationalities represented in, 167 note 18 ; street lights installed, 168 note 19.

See also Committee of Vigilance of San Francisco; Flag pole; Happy Valley; Hounds ; Lodging houses; Old Adobe Custom House; Plank Road to the Mission; Plaza; Steam Paddy; Sydney Valley.

San Francisco Daily Herald: 168; advocated protective association, 182 ; approved C. of V., 1851, 217-218, 273; opposed C. of V., 1856, 410 .

San Franaisco Evening Bulletin, 198, 396.

San Francisco Evening Picayune, $168,324$. 
San Francisco Library and Museum Company: formed by C. of V., $345-346$.

San Franciseo Society of Regulators, see The Hounds.

San José, California: execution at, 80 ; movement for constitutional convention, 95 ; meeting of first state legislature at, 116 ; of the second, 152 ; C. of V., 381.

San Miguel: murder at, 80.

San Pasqual, battle of: 34 .

Sanders, B. C., C. of $V .: 451,467$,

Sandwich Islands: natives came to California, 61 .

Santa Anna: president of Mexico, 25-26.

Santa Clara, California: delegates elected to Stockton's council, 37 ; C. of V., 250, 375, 377.

Santa Cruz, California: C. of V., 383 note 77.

Sayward, W. T.: MS statement cited, 159 note 55.

Schenck, G. E., C. of $V$.: biographical note, 196 ; mentioned, 199, 208, 209, 212, 257, 290, $298,299,333$ note 35,355 ; MS Statement cited, 163 note 1, 171 note $31,174,179$ note $56,180,183,345$.

Schultz, J. G., C. of $V .: 279$.

Scotland, popular tribunals in : 17 .

Scott, Thomas, prisoner C. of V.: 231.

Scott's Valley, California: committee of citizens, 381 .

Search, without warrant, right to claimed by C. of V.: $243-245$, 332.

Secession, see Slavery.

Self-government, see Local selfgovernment.

Seligman, Jesse, C. of $V .: 443$.

Semple, Dr. Robert: 37 note 40 , 113.

"'Settlers' theory", regarding status of California after treaty of Guadalupe Hidalgo: 96-97.
Seyd, Ernest: cited on C. of V., 414.

Sharon, William, C. of V.: 164 note 5, 449 ; testimony in re right of search, 332 .

Shasta, California: C. of V., 383 note 77.

Shelton, Mr.: botanist, 346 .

Shepard, D. A., 467.

Sheriff, responsibility of : 150,151 note 33.

Sherman, General W. T.: assistant to Colonel Mason, 43; cited, 102.

Shinn, C. H., Mining Camps: 5-6, $70,72,78,155$.

"The Shipman's Arms', suspicious lodging house: 210 , 229,306 .

"'Shirley,' pseudonym of L. A. M. Clappe.

Shubrick, Commodore W. B., 35.

Sibley, A. H.: 173 note 33.

Sinclair, John, alcalde: 58, 60 .

Slavery question: effect of, on status of California, 54, 90, 132-134; prohibited in, 114, 245 ; views of Gwin and Broderick, 130 ; sentiment in California, 131-132; speculations on influence of, in the movement of establishing Vigilance Committees, 404; attitude of individual members, 404-405, 406 ; secession advocates beaten in elections of 1856,405 ; only Lincoln men endorsed by People's Party in election of 1865 , 406.

Sloat, Commodore J. D.: military oceupation of California, 2830.

Smiley, T. J. L., $C$. of $\nabla .: 286$, $349,351,450,473$; cited, 206 note 52 .

Smith, Oscar, C. of $V .: 473$.

Smith, General P. F.: cited, 85, 102 note $36,326,452$.

Snyder, J. R., C. of $V .: 59,187$ note $1,326,452$.

Social contract, see Contract, social. 
Society of California Pioneers: 187, 206 note 51.

Sonoma, California: Bear Flag revolt, 28 ; delegates elected to Stockton's council, 37 ; alcalde adopted laws of Missouri, 47 note 23 ; local organization attempted, 1849, 101.

Sonora, California: mining camp, organized, 1848,81 ; correspondence with alcalde, 111 note 64 ; town government adopted, 119 ; C. of V., 278-279, 373, $376,378-379,407$ note 56.

South, The: popular tribunals in, 421-423.

Southern California: social conditions differed from those of the north, 382 ; popular tribunals, 382-383.

"Southern Chivalry"': 132.

Spain, Santa Hermandad: 16.

Spear, Samuel: 385.

Spires, George, a suspect: 238.

Spofford, W. E.: 106.

Squatters (lawless settlers): 50, 137-138, 152, 393.

Stanford, Leland, governor: vote for, 405 .

Steam Paddy: 166.

Stephens, George: opposed C. of V., 239.

Stephens, H. M.: interest in California local history, 1-5.

Stevens, alias of James Stuart: 258.

Stevenson, Colonel J. D., C. of $V$.: 32,69 ; biographical note, 194 ; mentioned, 182,188 note 1,188 note $3,270$.

Stevenson's Regiment (New York Volunteers): 32, 39, 105, 106.

Stewart, Samuel, and William: killed Sheriff Echols, at Auburn, 253 note 5 .

Stilger, O. P., judge: 175, 252.

Stillman, J. W., $C$. of $V .: 327$.

Stockton, Commodore R. F.: governor of California, 30; his plan for eivil organization, $31,34,37,38$; discord with Kearny, 34-36.
Stockton, California: organization attempted, 119; aroused by horse thieves' depredations, 184; "Vigilance Committee," 1850,204 note 47 ; C. of V., $1851,320,375-376,380$.

Stockton Journal: advocated martial law, 1851, 184, 455.

Stout, A. B., C. of $V .: 188$ note 3.

Stuart, James, the leader of the Sydney convicts: robbery of Jansen, 170, 252 (see also Thomas Berdue); arrest, 227, 264 ; story of his career in California, 252-259, 308, 309, 311,312 ; personal description of, 255-256; identification, $257,258-259$; record incomplete in C. of V. archives, 259 ; contract as to confession, 231, 259 ; confession, 261-264; published in newspapers, 275, 314; connection with F. M. Pixley, 258-259, 264-266; conviction by C. of V., 268-269; popular approval of sentence, 270 ; execution, 270-271; coroner's inquest, 271 ; action of eity and state authorities, 271-274; his relation to Mrs. Hogan, 280.

Stuart gang: 238, 253, 274-303; adventures of, $305-322$; broken up by C. of V., 323 ; burning of eity plotted, 263, 311. See also Adams; Ainsworth ; Arentrue; Barnes the tinman; Beck; Briggs; James Burns; Long Charley; Dab; Darke; Duane; David Earl; John Edwards; Hays; Mrs. Hogan; Hopwood; Hughes; Kay; Kelly; King the barber; Kitchen; MeCarty; McCormac; MeIntire; MeKenzie; Marks; Morgan; Osman; Ryan; Switzer; Joseph Turner; Watkins; Welsh; Whittaker; Windred; Yates.

Sullivan, John, C. of V.: 199, 209; identification of Stuart, 257.

Sutter, J. A., California pioneer: $58,67,129$ note 38 . 
Sutter, J. A., Jr., C. of $V .: 450$.

Sutter's Fort: alcaldes at, 58, 60, 101 ; jury trial at, 83.

Sutton, O. P., C. of $V .: 444$.

Suwerkrop, E. A., C. of V.: 449.

Swift, J. M., C. of V.: 346 note 27.

Switzer, alias the Slasher: escape from jail, 247.

Sydney, Australia, immigrants, see Convicts.

"Sydney Coves," "Sydney Ducks',: 124.

Sydney Morning Herald: cited, 240.

Sydney People's Advocate: eited, 241 note 44.

Sydney Valley, San Francisco: $166,251,313$.

Taft, Hamilton, prisoner C. of V.: $316,359$.

Talbot, Charles: prisoner C. of V., 354 .

Tanner, George: hanged for grand larceny, 156 note 49 .

Taylor, Bayard: cited, 78, 85.

Taylor, J., of Marysville: 254.

Taylor, J. M., C. of V.: 449, 473.

Taylor, Zachary, President: Message on California and New Mexico, 43 ; opinion concerning California and Oregon, 92.

Terry, D. S., judge: arrest by C. of V. of 18.56, 402-403.

Teschemacher, H. J., C. of V.: 108 note 51,108 note $53,173,188$ note $3,443$.

Texas Committees of Vigilance (safety): 12, 422 .

Theatrical benefit, suggested for C. of V., 353 .

Thompson, John: hanged for highway robbery, 155 note 49 .

Thompson, S. T., C. of $V .: 473$.

Thompson, William, Jr.: indicted for perjury, 284. See also $\mathrm{T}$. B. Kay.

Thompson, W. T., C. of V.: 473 .

Tichenor, E., 467.

Tilford, Frank: 163, 331.

Tillinghast, W. H., C. of $V .: 107$ note $51,473$.
Timandra, a vessel: 240 .

Titan, a vessel : 235 note 22 .

Townsend, John: 38.

Transportation in California: facilities lacking, 139.

Treaty of Cahuenga: 34 .

Treaty of Guadalupe Hidalgo: 54, 56.

Trimble, W. J., Mining Advance into the Inland Empire: cited, 416-417, 426-427.

Trinity Church, San Francisco, see Banners presented to C. of V.; see also $\mathbf{k}$. S. Mines.

Truckee, California: "601", committee, 407, 407 note 57 .

Truett, M. F., C. of $V$., 1856: 473 .

Tubbs, A. L., C. of $V .: 406,445$.

Tuffs, Leonard, $C$. of $V .: 200,467$.

Tuolumne County : report of grand jury, 472.

Turner, D. S., C. of V.: 372 note $46,473$.

Turner, F. J.: cited on frontier institutions, 10-16.

Turner, Joseph : 275.

"Uncle Sam," suspicious lodging house: $210,229,306$.

Van Bokkelen, J. L., C. of $V .: 188$ note 2 ; biographical note, 198 ; chief of C. of V. police, 228, 238, 277, 295-297.

Van Diemen's Land: 229, 292.

Van Voorhies, William: 90, 96.

Van Winkle, P. W., C. of V.: 181 note 62.

Vassault, Ferdinand, C. of $T .: 188$ note 3.

Vermont, popular tribunals in: 15 note 22.

Teto, a ressel: 315 .

Vigilance Committees, see Committee of Vigilance.

Voiget, J. J., C. of $\mathrm{V}$. : 188 note 3 ; biographical note, 447.

Virgin, G. W.: robbery of, 208 .

Virginia, popular tribunals in : 14 15.

Virginia City: eitizens form Vigilance Committee, 417. 
Visalia, California: C. of V., 407 note 56.

Vyse, the bear hunter: 306 .

Wadsworth, J. C. L., C. of V.: 187 note 1, 209 note $7,220,281$, 333 note $35,442,471$.

Wakeman, A. C., C. of V.: 346.

Wakeman, Captain Edgar, C. of $T .:$ biographical note, 196 ; mentioned, 212, 224 note 48 , 236, 237, 406 note 53 .

Waldo, G.: proposed popular tribunals, 455.

Walker, R. J.: circular on California, $90-91$.

Walker, William, editor of San Francisco Herald: 177.

Waller, R. H., recorder of San Franciseo: 177.

Ward, Frank: 106.

Ward, G. R., $C$. of $\dot{V}$.: biographical note, 195 ; treasurer, 364 ; mentioned, 349, 352, 473 .

Ward, James C., C. of $V$. : biographical note, 441; mentioned, 107,108 note 51,108 note 53, 187 note 1,188 note 2, 188 note $3,216,357,406$, 406 note 53.

Ward, John, proprietor of suspicious lodging house: 228 note 1.

Ward, Sam: 106.

Wardwell, A., C. of V.: 203.

Washington, B. F., judge: 175 .

Washington: gold rushes to, and frontier conditions, 416.

" Watchful Eye of Vigilance,", symibol of C. of V.: 401.

Waterman, Captain: threatened with lynehing, 344 .

Watkins, Willian, thief: 307 ; escape from San Francisco jail, $247,290$.

Watson, R. S. ("Justice"), C. of $V .:$ biographical note, 442 ; organization of Committee proposed by, 184, 204, 456; mentioned, 257, 333 note 35 .

Watauga: frontier organization of, 10.
Webb, Hiram, C. of $V .: 108$ note 53.

Welling, C. H., C. of V.: 200 note 37.

Wells, Robert, $C$. of $V .: 188$ note 1 .

Welsh, Thomas: escape from San Franciseo jail, 247.

Weston, H. L., acknowledgment: 202 note 43.

Wetherbee, Henry, C. of V.: 406, 450.

Wethered, J. S., C. of $V .: 449$.

Wharves of San Franciseo: 113, 166.

Wheeler, Thomas: murdered, 318.

Whig, political party: organized, 131-132; San Francisco elections, 1851, 176, 324, 326-327.

Whipping: common frontier punishment: 14-15, 77; employed in California, 45, 77, 119, 155, $290,377,378,382,386$ note 81 ; inflicted by C. of V., 242 , 363.

White, W. F.: opposed C. of V., 411.

White Camelia, Knights of the: 423.

Whittaker, Samuel, a convict and leader in Stuart's gang: 254, $264,275,306,309,310,311$; voting of ex-convicts, 140 note 11; warning to Stuart, 254; search for, and seizure by $C$. of V., 279-281; confession, 291-293, 314; execution recommended, 293; rescued by authorities, $294-296,469$; recaptured and executed by $\mathrm{C}$. of V., 296-302; coroner's inquest, 302 ; public approval and disapproval of Committee's action, 301-303.

Wiggin, C. L., C. of V.: 449.

Wilber (Wilbur), James, $C$. of $\nabla$.: 330 note 24.

Willey, Rev. S. H.: cited on C. of V., 411-412.

Williams, Edwards C.: miners' alcalde, 1848,81 ; mentioned, 166. 
Williams, John, a state prisoner: pardoned on petition of C. of V., 322.

Willow Bar, California: 111 note 64.

Wilmot proviso: 55 .

Wilson, James: hanged for horse stealing, 155 note 49.

Wilson, Joseph: trial of, 156.

Wilson, William: prisoner C. of V., 360.

Windred, Robert: popular trial of, for Jansen robbery, 171-175, 453-454; legal trial and conviction, 171 ; escape, 247,311 : exonerated by testimony of members of C. of V., 303 .

Wistar, I. J.: cited on C. of V., 41.1 .

Witnesses in courts: difficult to procure at time of trial, 152 , $289,290,321$; nembers of C. of $V$. as, $302,303,330-332$.

Wohler, Herman, $C$. of $V$.: 326 , 4.51.

Woods, C. S., C. of V.: 334.

Woods Creek, California: 69.
Woodworth, Frederick A., C. of $V$.: biographical note, 193-194; mentioned, 237, 319 note 21, 372 note 46,406 note 53 .

Woodworth, Selim E., C. of $T_{\text {.: }}$ biographical note, 192-194; mentioned, 216, 223, 258, 302, $319,343,346,351,353,406$, 471 ; president General Committee, 260; vice-presilent, 343,351 .

Wright, Alexander, prisoner C. of V.: 236 note 24.

Writ of habeas corpus (or of arrest): resisted by C. of V., 26.5-268; case of Stuart, 265267 ; report on use and abuse of, 267 ; successfully served in case of Whittaker and $\mathrm{Mc}$ Kenzie, 294-295, 469.

Wyman's Ravine, California: C. of V., 381 .

Yates, Thomas, alias Wood: arrested by S. F. city police, 238 .

Yerba Buena, see San Francisco.

Yreka, 382, 407 note 56 .

Zantzinger, L. F., 346 note 27. 





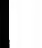
$x^{2}$ 
